Wendy Martin Rios

\title{
Vacinas de DNA codificando antígenos de glioblastoma e proteínas imunomoduladoras: construção e avaliação da imunogenicidade
}

Tese De Doutorado

\begin{abstract}
Tese apresentada à Faculdade de Medicina de Ribeirão Preto da Universidade de São Paulo para obtenção do Título de Doutor em Ciências. Área de concentração: Imunologia Básica e Aplicada.
\end{abstract}

Orientador: Prof. Dr. Celio Lopes Silva

Ribeirão Preto 
AUTORIZO A REPRODUÇÃO E DIVULGAÇÃO TOTAL OU PARCIAL DESTE TRABALHO, POR QUALQUER MEIO CONVENCIONAL OU ELETRÔNICO, PARA FINS DE ESTUDO E PESQUISA, DESDE QUE CITADA A FONTE.

\section{FICHA CATALOGRÁFICA}

Preparada pela Biblioteca Central do Campus Administrativo de Ribeirão Preto / USP

\section{Rios, Wendy Martin}

Vacinas de DNA codificando antígenos de glioblastoma e proteínas imunomoduladoras: construção e avaliação da imunogenicidade. Ribeirão Preto, 2013.

260 p.: il. ; $30 \mathrm{~cm}$

Tese de Doutorado, apresentada a Faculdade de Medicina de Ribeirão Preto/USP. Área de concentração: Imunologia Básica e Aplicada.

Orientador: Silva, Celio Lopes.

1. Glioblastoma. 2. Imunoterapia. 3. Vacina de DNA. 4. Antígenos de glioblastoma. 5. Glicoproteína D. 6. Proteínas de choque térmico. 6. IFN- $\gamma$. 7. IL-10. 
Nome: RIOS, Wendy Martin.

Título: Vacinas de DNA codificando antígenos de glioblastoma e proteínas imunomoduladoras: construção e avaliação da imunogenicidade.

Tese apresentada ao Programa de pós-graduação em imunologia básica aplicada da Faculdade de Medicina de Ribeirão Preto da Universidade de São Paulo para a obtenção do título de doutor em ciências.

Aprovado em:

\section{Banca Examinadora}

Prof. Dr. Celio Lopes Silva

Instituição: Universidade de São Paulo, Faculdade de Medicina de Ribeirão Preto.

Julgamento: Assinatura:

Prof. Dr. Sandro Gomes Soares

Instituição: Universidade de São Paulo, Faculdade de Medicina de Ribeirão Preto. Julgamento: Assinatura:

Profa. Dra. Isabel Kinney Ferreira de Miranda Santos

Instituição: Universidade de São Paulo, Faculdade de Medicina de Ribeirão Preto. Julgamento: Assinatura:

Prof. Dr. Luis Carlos de Souza Ferreira

Instituição: Universidade de São Paulo, Instituto de Ciências Biomédicas.

Julgamento: Assinatura:

\section{Prof. Dr. Anderson Miyoshi}

Instituição: Universidade Federal de Minas Gerais, Instituto de Ciências Biológicas. Julgamento: Assinatura: 


\section{Dedicatória}

À minha Mãe Maria das Graças Martin, exemplo de amor, coragem, dedicação, bondade e perseverança; com você aprendi o que realmente importa nessa vida...

À minha metade Fernando José Gisoldi por todo carinho, dedicação, ajuda, companheirismo, compreensão e amor, as palavras não são suficientes para expressar minha gratidão...

Ao meu irmão André Martin Rios pela amizade e amor...

Ainda agradeço a vocês pelo amor, ajuda e compreensão durante o desenvolvimento deste trabalho!

"Ser profundamente amado por alguém nos dá força; amar alguém profundamente nos dá coragem". (Lao-Tse)

Dedico também à todas as pessoas que um dia possam se beneficiar com os resultados obtidos neste trabalho. 


\section{Agradecimentos}

Ao meu orientador professor Dr. Celio Lopes Silva pela oportunidade, orientação e confiança. Agradeço também por me apoiar na continuidade do Doutorado mesmo depois de me tornar funcionária;

À Jeanne pela orientação durante todo o desenvovimento deste trabalho, desde o Projeto inicial até a elaboração da Tese. Em especial, gostaria de agradecer pela grande amizade e pelos ensinamentos de vida que vou levar comigo para sempre;

Aos professores Dr. Sandro Gomes Soares, Dra. Isabel Kinney Ferreira de Miranda Santos, Dr. Luis Carlos de Souza Ferreira e Dr. Anderson Miyoshi, membros da banca, pela disponibilidade, orientação e ensinamentos;

Às professoras Dra. Arlete A. M. Coelho-Castelo e Dra. Vânia Luiza Deperon Bonato por abrirem as portas dos seus laboratórios para a realização de parte do meu trabalho;

À minha família do Laboratório de Vacinas Gênicas: Aninha, Frederico, Iza, Priscila, Rodrigo e Rogério, por toda ajuda, aprendizado e amizade. Juntos pudemos compartilhar momentos únicos e inesquecíveis. Em especial, quero agradecer a Aninha e Iza, com quem sempre pude contar e aprender, agradeço ainda pelos conselhos, compreensão e momentos de intensa ajuda e amizade.

À todos os Queridos Amigos do Laboratório da Dra. Vânia e Dra. Arlete, por toda colaboração e amizade, sem esquecer dos que já saíram do laboratório e dos que estão chegando com muita disposição em ajudar. Quero agradecer em especial a Ana Flávia pela intensa ajuda, amizade e cumplicidade;

À equipe de profissionais da empresa Farmacore pelos experimentos realizados;

À Denise Morais por todos os ensinamentos e pela ajuda em todos os momentos;

À Denise Brufato pelo apoio técnico na aquisição dos experimentos de citometria;

Às minhas Amigas Amanda, Elyara, Fernanda Rocha, Juliana Issa, Juliana Giantomassi, Luana, Luciana, Marininha e Patrícia Assis pela amizade, cumplicidade, confiança e pelo ombro amigo; 
Aos Amigos da Farmacore, especialmente a Rosiane e Idalete pela ajuda durante o desenvolvimento de parte dos experimentos e pela grande amizade;

Ao Amigo Eduardo Dantas por todo auxílio, ajuda, disposição e amizade;

À todos os colegas, docentes e a secretária Ana Cristine do Programa de PósGraduação em Imunologia Básica e Aplicada pelo aprendizado, auxílio e amizade;

À FAPESP, FAEPA e CNPq pelo auxílio financeiro;

Aos meus Amigos Angélica, Junior, Thacia e Flávio e às minhas Eternas Amigas Samantha e Thaís pela convivência, amizade, apoio e confiança;

À minha nova e Eterna Família, Patrícia, Leandro, Lucas e Beatriz pelo amor, carinho e grande amizade. Meus dias são mais especiais pela presença de vocês na minha vida;

Aos meus tios Dolores e Pepe pelo amor e todo auxílio;

Aos familiares do meu marido: Idalina, Toninho, Fernanda, Didio, Gabriel, James, Elis, Letícia, Vinícius, Vô Walide e Vó Cida que sempre estiveram por perto como minha família.

"Cada pessoa que passa em nossa vida, passa sozinha, é que cada pessoa é única e nenhuma substitui a outra! Cada pessoa que passa em nossa vida, passa sozinha e não nos deixa só, porque deixa um pouco de si e leva um pouco de nós. Essa é a mais bela responsabilidade da vida e a prova de que as pessoas não se encontram por acaso". (Charles Chaplin) 
"Julgue seu sucesso pelas coisas que você teve que renunciar para conseguir". (Dalai Lama) 


\section{RESUMO}

RIOS, W. M. Vacinas de DNA codificando antígenos de glioblastoma e proteínas imunomoduladoras: construção e avaliação da imunogenicidade. 2013. 260 p. Tese (Doutorado) - Faculdade de Medicina de Ribeirão Preto, Universidade de São Paulo, Ribeirão Preto, 2013.

O glioblastoma (GBM) é o tumor cerebral primário mais comum e o mais grave tumor de células da glia. O GBM é um tumor astrocítico de grau IV caracterizado pela proliferação descontrolada, infiltrado difuso, tendência à necrose, angiogênese, resistência a apoptose e grande heterogeneidade genética. Apesar da terapia abranger a remoção cirúrgica máxima, a radioterapia e a quimioterapia, o tumor torna-se resistente à drogas utilizadas no tratamento levando o paciente a recorrência e morte em menos de 15 meses após o diagnóstico. Uma alternativa para o tratamento do GBM é a imunoterapia, a qual é capaz de estimular o sistema imunológico do próprio paciente a gerar uma resposta específica e duradoura que pode proteger contra a recorrência da doença. Uma dessas alternativas envolve o uso de vacinas de DNA codificando antígenos tumorais e proteínas imunomoduladoras capazes de ativar eficientemente linfócitos B e T específicos aos antígenos presentes no tumor. Nesse contexto, o objetivo do presente trabalho foi construir vacinas de DNA utilizando-se os genes dos antígenos EGFRvIII, cERBB2, MAGE e GLEA de GBM e os genes das proteínas imunomoduladoras hsp65, hsp70, gp96 e gD e avaliar suas respectivas imunogenicidades. Os genes foram avaliados in silico, sintetizados in vitro e utilizados na construção das vacinas de DNA. Ferramentas de biologia molecular e o vetor pVAX foram utilizados para obtenção das vacinas. Elas foram caracterizadas por sequenciamento e western blot e utilizadas na imunização de camundongos C57BL/6. As imunizações foram realizadas com três doses em intervalos de 12 dias combinando um antígeno tumoral e uma proteína imunomoduladora na forma de vacina de DNA. A imunogenicidade foi avaliada 20 dias após a última dose. Os ensaios ex vivo foram realizados com o soro dos animais imunizados para dosagem de anticorpos específicos contra os antígenos tumorais e com as células do baço que foram reestimuladas com as proteínas EGFRvIII, cERBB2, MAGE e GLEA para identificar a presença de células específicas aos antígenos tumorais. Como resultado, a vacina pVAXgDGLEA foi a única capaz de induzir anticorpos do subtipo IgG2a anti-GLEA. As vacinas pVAXgDGLEA, pVAXgDEGFRvIII e pVAXgDMAGE foram capazes de ativar células específicas aos antígenos que após o re-estímulo responderam rapidamente com produção de IFN- $\gamma$ e IL-10. A proteína imunomoduladora $\mathrm{gD}$ foi, portanto, capaz de ajudar na indução de um padrão de resposta Th1, específica aos antígenos de GBM, importante no combate ao tumor e a IL-10 pode favorecer e/ou balancear a resposta no cérebro que deve ser eficaz, mas não exacerbada. 


\section{ABSTRACT}

RIOS, W. M. DNA vaccines codifying glioblastoma antigens and immunomodulating proteins: construction and immunogenicity evaluation. 2013. 260 p. Tese (Doutorado) Faculdade de Medicina de Ribeirão Preto, Universidade de São Paulo, Ribeirão Preto, 2013.

Glioblastoma multiforme (GBM) is the most common form of primary brain cancer and the most severe tumour affecting glia cells. GBM is a grade IV astrocytoma known by uncontrolled proliferation, diffused infiltrate, necrosis tendency, angiogenesis, apoptosis resistance and a wide genetic heterogeneity. The standard of care consists of maximal surgical resection, followed by a combination of radiation and chemotherapy. Despite that, tumour becomes resistant to drugs used to treatment, and the patient experiences recurrence followed by death in less than 15 months after diagnosis. An alternative in GBM treatment could be immunotherapy which aims to stimulate patient's immunological system in order to obtain a specific and long-term response that can protect against recurrence. One of these alternatives involves the use of DNA vaccines codifying tumoral antigens and immunomodulatory proteins that can effectively activate tumour antigen specific $\mathrm{B}$ and $\mathrm{T}$ lymphocytes. In this context, the objective of this work was the construction of DNA vaccines using GBM antigen genes (EGFRvIII, cERBB2, MAGE e GLEA) and immunomodulatory proteins (hsp65, hsp70, gp96 e gD), followed by their immunogenicity evaluation. Genes were evaluated in silico, synthesized in vitro and used in DNA vaccines construction. Molecular biology tools and the pVAX vector were used to obtain the vaccine. They were characterized by sequencing, western blot and were used in the immunization of C57BL/6 mice. Immunizations were performed in 3 doses of a DNA vaccine combining a tumoral antigen and an immunomodulatory protein at each 12 days. Immunogenicity was evaluated 20 days after the last dose. The ex vivo assays were performed with the serum of immunized animals for antibody evaluation and spleen cells were stimulated with EGFRvIII, cERBB2, MAGE e GLEA proteins to assess tumoral antigen specific cells. The pVAXgDGLEA vaccine was the only able to induce IgG2a subtype anti-GLEA antibodies. Vaccines pVAXgDGLEA, pVAXgDEGFRvIII e pVAXgDMAGE were able to activate antigen-specific cells that produced IFN- $\gamma$ e IL-10 quickly after reestimulation. The gD immunomodulatory protein was able to induce a Th1 immune response, specific to GBM antigens, which is important in tumor combat while IL-10 could favor and/or balance the response in brain, which should be effective but not exacerbated. 


\section{SUMÁRIO}

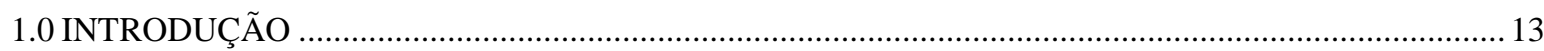

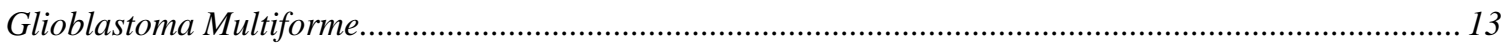

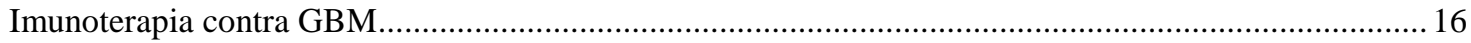

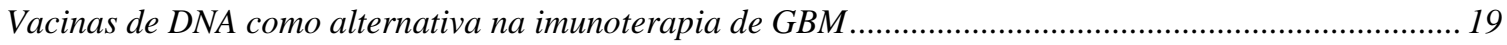

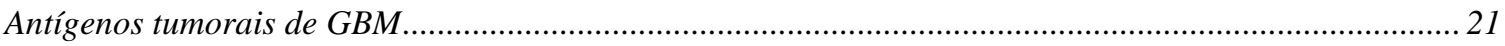

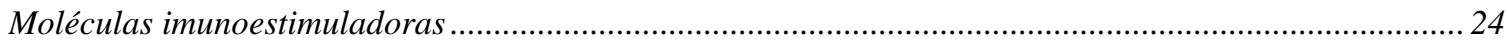

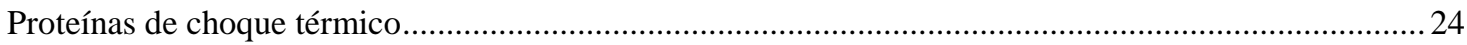

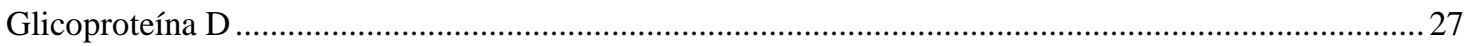

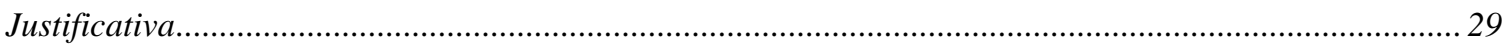

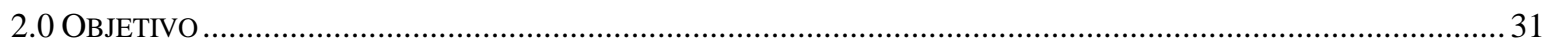

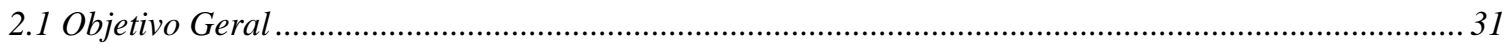

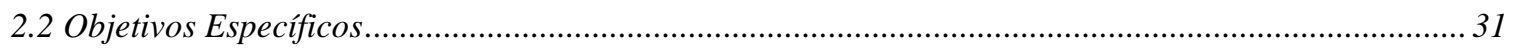

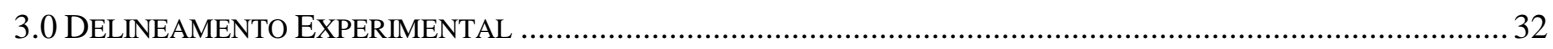

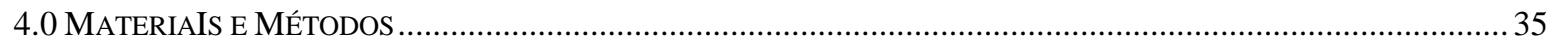

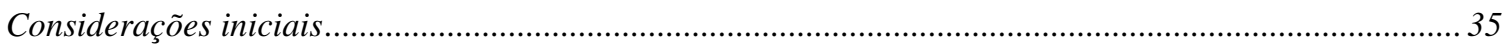

4.1 Análise in silico da sequência de aminoácidos e nucleotídeos dos genes EGFRvIII, cERBB2, MAGE-3,

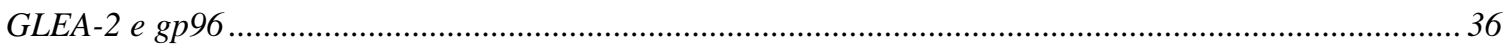

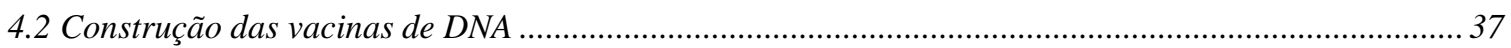

4.2.1 Clonagem dos fragmentos gDEGFRvIII, gDcERBB2, gDMAGE e gDGLEA e do gene gp96 no

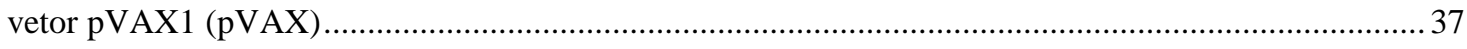

4.2.1.1 Clivagem dos fragmentos gDEGFRvIII, gDcERBB2, gDMAGE, gDGLEA-2 e gp96...........38

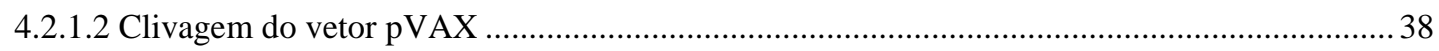

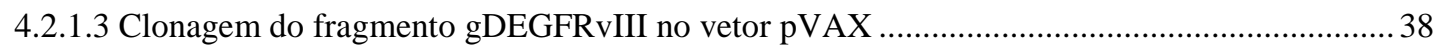

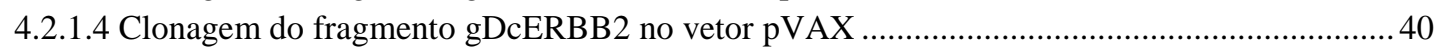

4.2.1.5 Clonagem do fragmento gDMAGE no vetor pVAX............................................................. 41

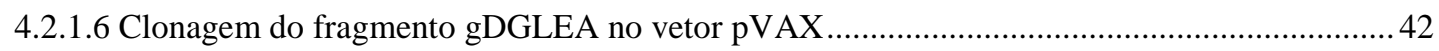

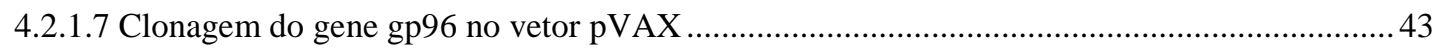

4.2.2 Clonagem dos genes EGFRvIII, cERBB2, MAGE, GLEA e hsp70 no vetor pVAX....................... 44

4.2.2.1 Amplificação e clivagem dos genes EGFRvIII, cERBB2, MAGE, GLEA e hsp70 ................. 44

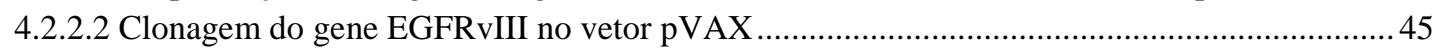

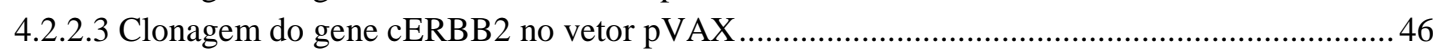

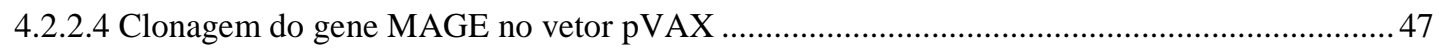

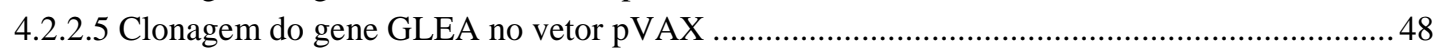

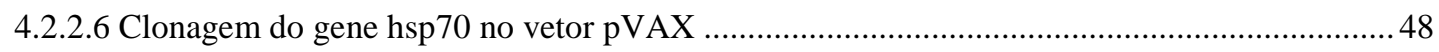

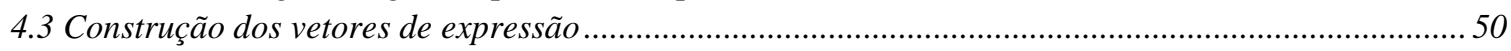

4.3.1 Clonagem dos genes EGFRvIII, cERBB2, MAGE, GLEA e hsp70 no vetor pET28a (pET) ..........50

4.3.1.1 Amplificação e clivagem dos genes EGFRvIII, cERBB2, MAGE, GLEA e hsp70 .................50

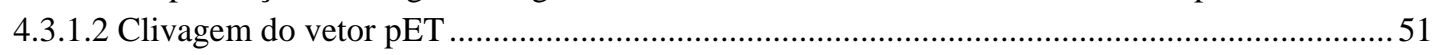

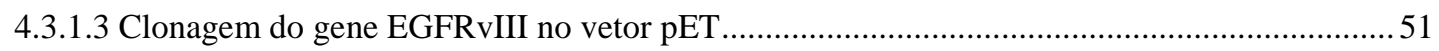

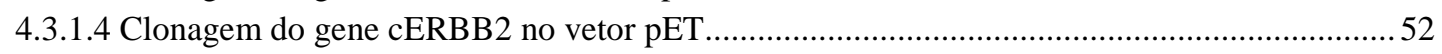

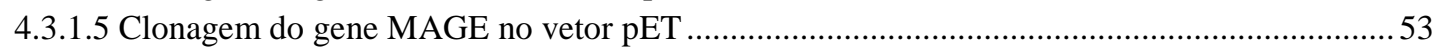

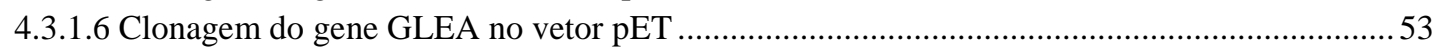

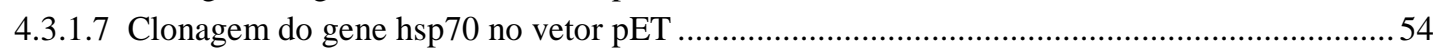

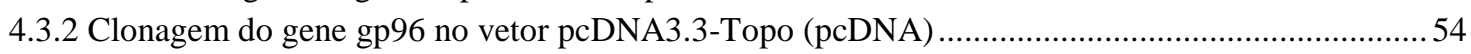

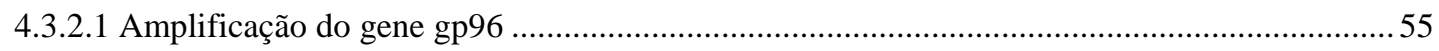

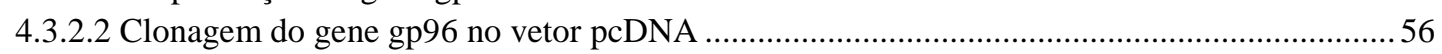

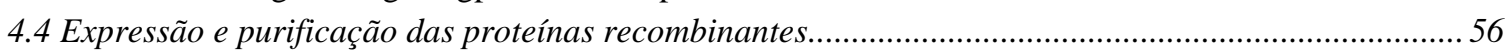

4.4.1 Expressão e purificação das proteínas EGFRvIII, cERBB2, MAGE, GLEA e Hsp70 em E. coli .. 56

4.4.1.1 Expressão e purificação das proteínas EGFRvIII e cERBB2 ………………………………....57

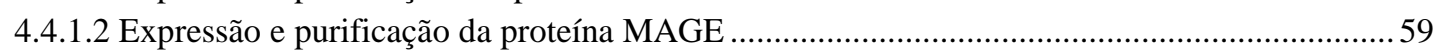

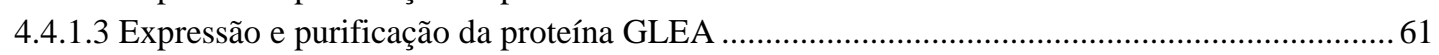




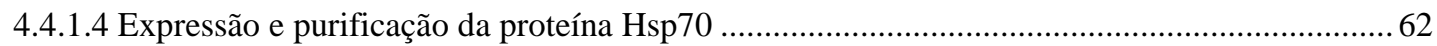

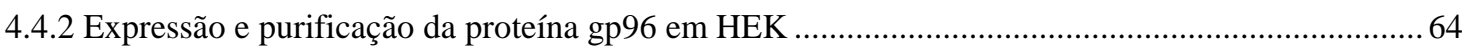

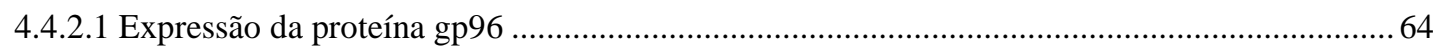

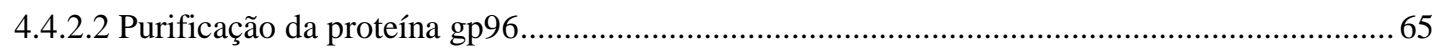

4.5 Produção de anticorpos policlonais contra as proteínas recombinantes.................................................66

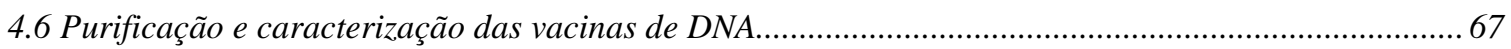

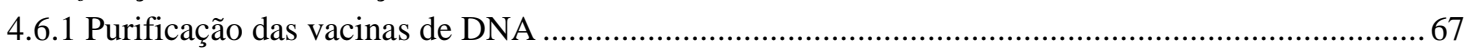

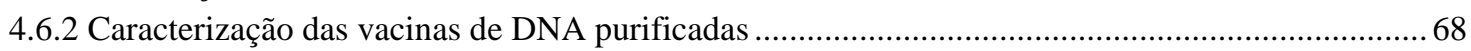

4.6.2.1 Análise de restrição e dosagem de endotoxinas nas vacinas de DNA.......................................6 68

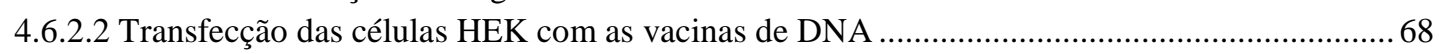

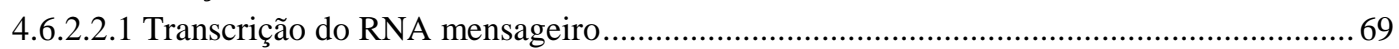

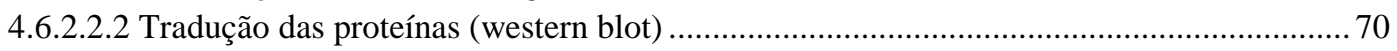

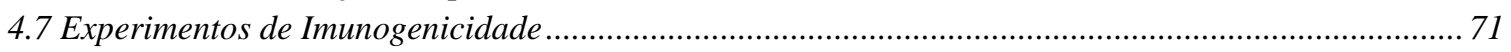

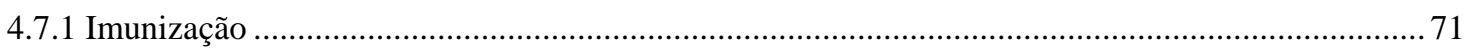

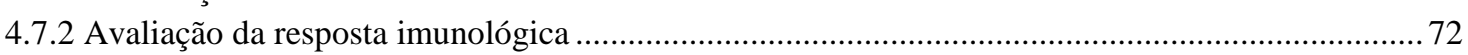

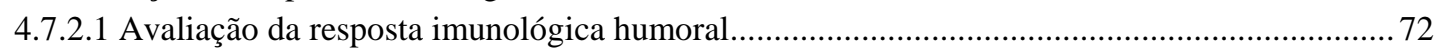

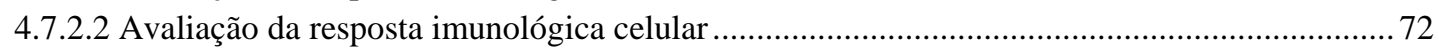

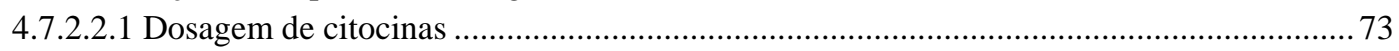

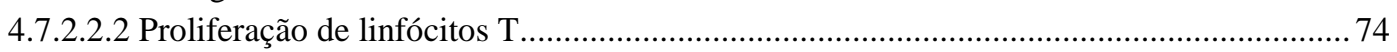

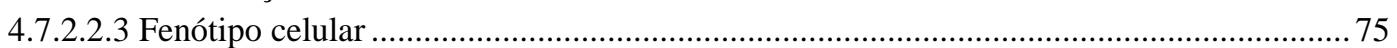

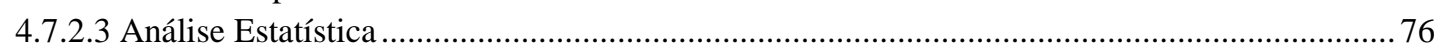

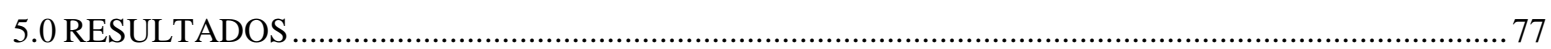

5.1 Analise in silico da sequência de aminoácidos dos genes EGFRvIII, cERBB2, MAGE, GLEA e gp96.77

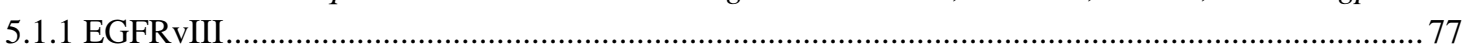

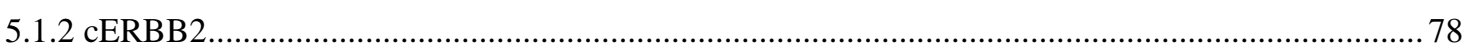

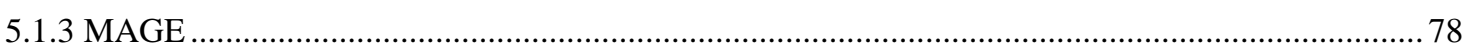

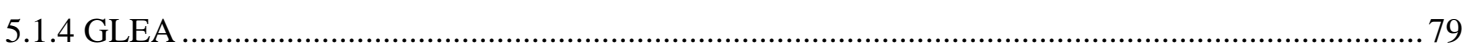

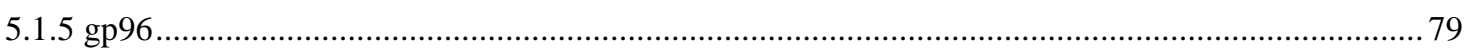

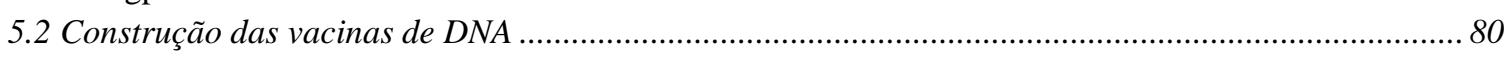

5.2.1 Clonagem dos fragmentos gDEGFRvIII, gDcERBB2, gDMAGE e gDGLEA e do gene gp96 no

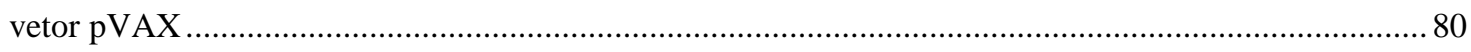

5.2.1.1 Clivagem dos fragmentos gDEGFRvIII, gDcERBB2, gDMAGE, gDGLEA-2 e gp96............ 80

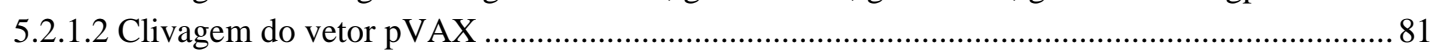

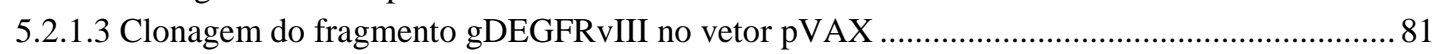

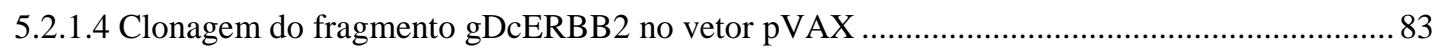

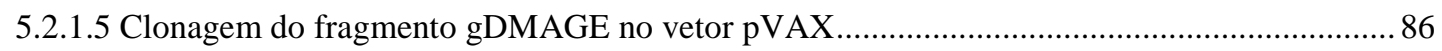

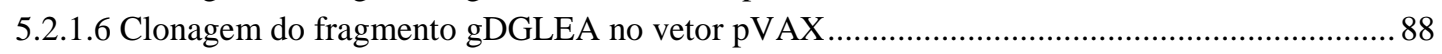

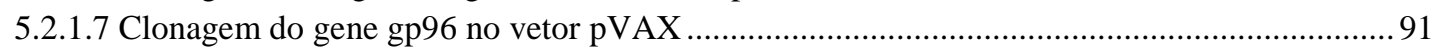

5.2.2 Clonagem dos genes EGFRvIII, cERBB2, MAGE, GLEA e hsp70 no vetor pVAX.......................93

5.2.2.1 Amplificação e clivagem dos genes EGFRvIII, cERBB2, MAGE, GLEA e hsp70 …............. 93

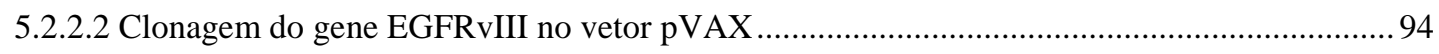

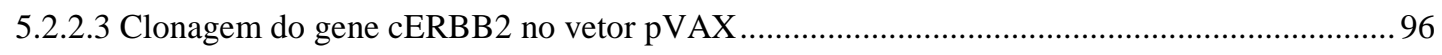

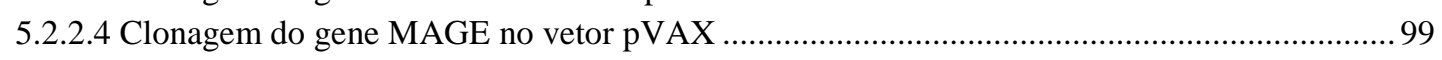

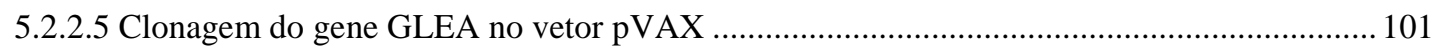

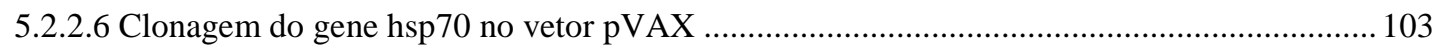

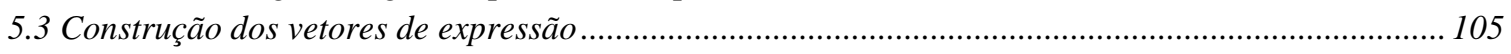

5.3.1 Clonagem dos genes EGFRIII, cERBB2, MAGE, GLEA e hsp70 no vetor pET ……………...... 105

5.3.1.1 Amplificação e clivagem dos genes EGFRvIII, cERBB2, MAGE, GLEA e hsp70 ............... 105

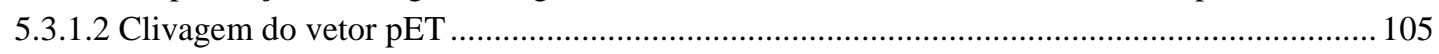

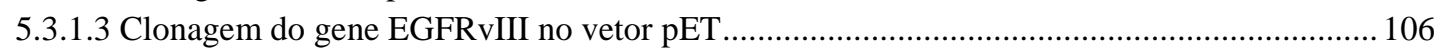

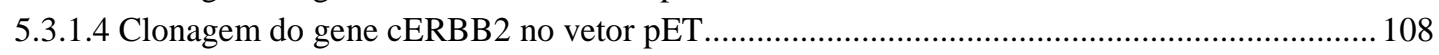

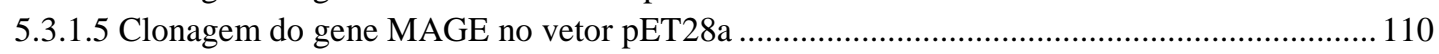


5.3.1.6 Clonagem do gene GLEA no vetor pET .....

5.3.1.7 Clonagem do gene hsp70 no vetor pET ......................................................................... 113

5.3.2 Clonagem do gene gp96 no vetor pcDNA3.3 ........................................................................ 115

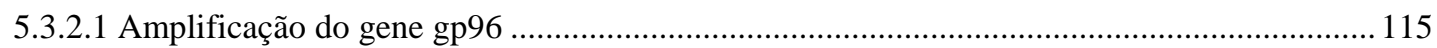

5.3.2.2 Clonagem do gene gp96 no vetor pcDNA ..................................................................... 115

5.4 Expressão e purificação das proteínas recombinantes......................................................................... 117

5.4.1 Expressão e purificação das proteínas EGFRvIII, cERBB2, MAGE, GLEA e Hsp70 produzidas em

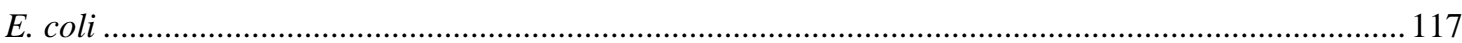

5.4.1.1 Expressão e purificação das proteínas EGFRvIII e cERBB2 ................................................ 117

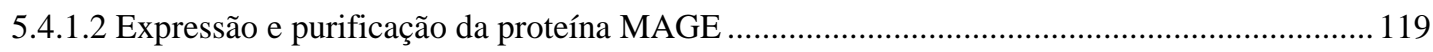

5.4.1.3 Expressão e purificação da proteína GLEA …........................................................................ 121

5.4.1.4 Expressão e purificação da proteína Hsp70 ............................................................................ 122

5.4.2 Expressão e purificação da proteína gp96 em células HEK .......................................................... 122

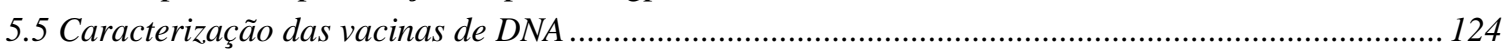

5.5.1 Análise de restrição e dosagem de endotoxinas nas vacinas de DNA ........................................... 124

5.5.2 Transfecção das células HEK com as vacinas de DNA.......................................................... 125

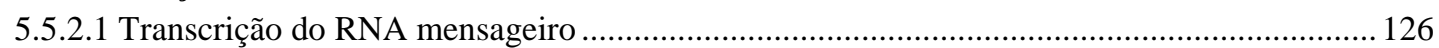

5.5.2.2 Tradução das proteínas (western blot) ................................................................................ 127

5.6 Experimentos de Imunogenicidade ................................................................................................ 128

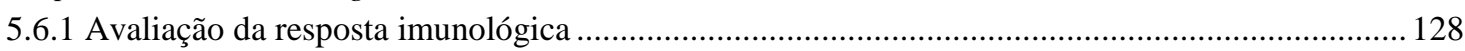

5.6.1.1 Avaliação da resposta imunológica humoral (primeiro protocolo) ..................................... 129

5.6.1.2 Avaliação da resposta imunológica celular (primeiro protocolo) ...................................... 131

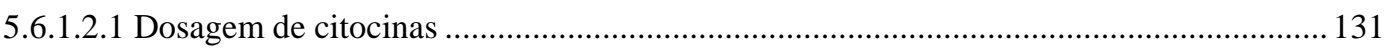

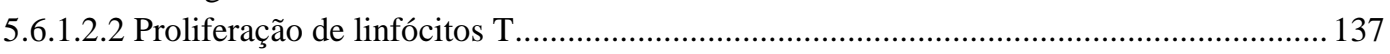

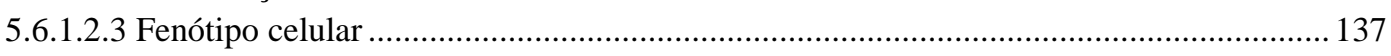

5.6.1.1 Avaliação da resposta imunológica humoral (segundo protocolo) ........................................ 140

5.6.1.2 Avaliação da resposta imunológica celular (segundo protocolo) ......................................... 142

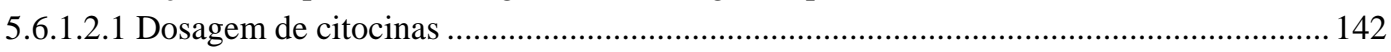

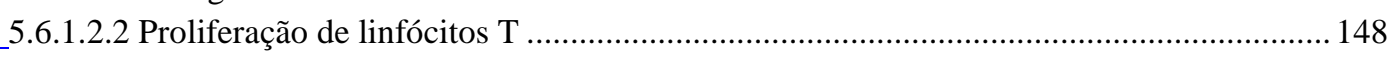

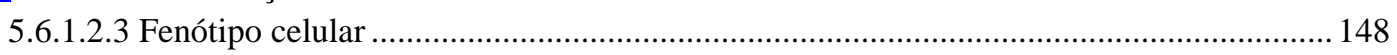

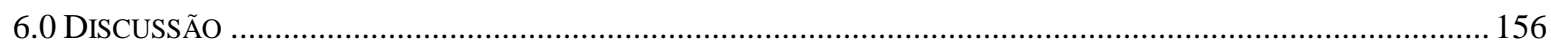

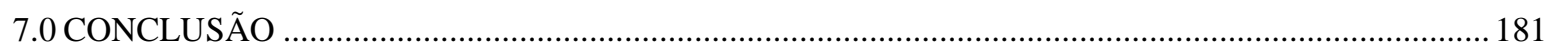

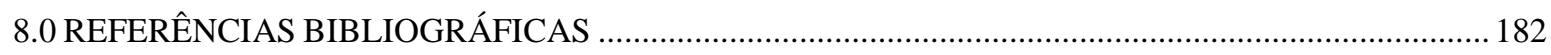

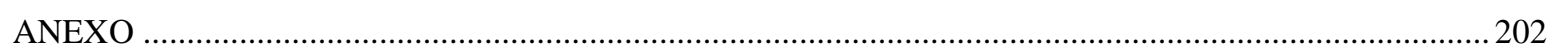

Anexo 1.0 - Clonagem dos genes EGFRvIII, cERBB2, MAGE, GLEA e gp96 no vetor pKLAC ................ 202

Anexo 2.0 - Expressão da proteína gp96 em K. lactis e purificação ..................................................... 216

Anexo 3.0 - Clonagem dos genes EGFRvIII, cERBB2, MAGE e GLEA no vetor pcDNA3.3 .................... 221

Anexo 4.0 - Expressão das proteínas EGFRvIII, cERBB2, MAGE e GLEA em HEK............................... 228

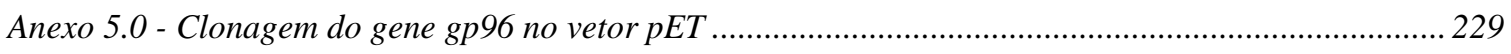

Anexo 6.0 - Expressão da proteína gp96 em E. coli ..............................................................................233

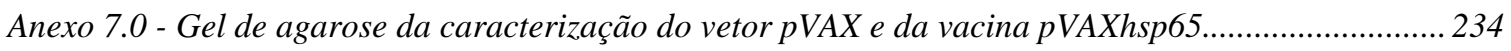

Anexo 8.0 - Caracterização da vacina pVAXhsp65 por western blot. ................................................... 234

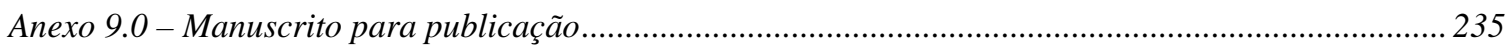




\subsection{INTRODUÇÃO}

\section{Glioblastoma Multiforme}

Os tumores do sistema nervoso central (SNC) abrangem neoplasias que surgem no próprio tecido cerebral (tumores cerebrais primários) e aquelas que envolvem o cérebro como um sítio de metástase (tumores cerebrais secundários). Os tumores cerebrais primários incluem tumores do parênquima cerebral, das meninges, dos nervos cranianos e de outras estruturas intracranianas (Schiff e Batchelor, 2010). O parênquima do SNC consiste de neurônios e células da glia. Estas providenciam suporte e proteção aos neurônios e, ao contrário destes, não conduzem impulso nervoso. Existem três tipos de células da glia no SNC: astrócitos, oligodendrócitos, e as células ependimais (Bailey, 2012). Os tumores cerebrais originados a partir das células da glia são chamados de gliomas e eles representam mais de $80 \%$ de todos os tumores cerebrais primários (Schiff e Batchelor, 2010).

Os gliomas podem ser, dessa forma, segundo a classificação da Organização Mundial da Saúde (WHO, World Health Organization): tumores astrocíticos, oligodendrogliais, oligoastrocíticos e ependimais. Esse mesmo sistema de classificação ainda reconhece três tipos de tumores astrocíticos de acordo com a histopatologia do tumor: astrocitomas (astrocitoma pilocítico - grau I e astrocitoma difuso - grau II); astrocitomas anaplástico (grau III) e glioblastoma (glioblastoma multiforme ou GBM) (Wen e Kesari, 2008). O GBM é um tumor astrocítico de grau IV, a mais alta classificação para um astrocitoma, devido ao crescimento rápido e a capacidade de invasão aos tecidos adjacentes (Kesari, 2011).

O GBM é o tumor cerebral primário mais comum e é o mais grave tumor de células da glia (Behin et al., 2003; Stupp et al., 2005; Henson, 2006; Johnson e Sampson, 2010). Esse tumor representa 25\% de todos os tumores do SNC (ORGANIZATION WWH, 1992; ENCR, 2001) e é responsável por mais mortes a cada ano do que o melanoma maligno (UNITED STATES CANCER STATISTICS). A incidência tende a ser maior nos países desenvolvidos; no entanto, a baixa incidência em outras regiões pode ser devido a um registro inadequado (Brandes et al., 2008). Esse tumor é 1,5 vezes mais comum em homens (ORGANIZATION WWH, 1992; ENCR, 2001) e aproximadamente 60\% dos pacientes com GBM têm idade entre 55 e 74 anos (Brandes et al., 2008).

O GBM é caracterizado por uma proliferação celular descontrolada, infiltrado difuso, tendência à necrose, angiogênese, resistência a apoptose e grande heterogeneidade genética (Furnari et al., 2007). Esse tumor pode ser primário quando surge sem existência prévia de 
outra lesão, o que representa mais de $90 \%$ dos casos. Pode ocorrer, ainda, pela progressão de um astrocitoma de baixo-grau ou de um astrocitoma anaplástico; o que geralmente ocorre em pacientes mais jovens (Ohgaki e Kleihues, 2007).

Ferramentas para a triagem e diagnóstico do GBM, antes da manifestação clínica, ainda são inexistentes (Kesari, 2011). Apesar da terapia agressiva, com remoção cirúrgica máxima, radioterapia e quimioterapia (Sul e Fine, 2010), o prognóstico permanece muito ruim, com taxa média de sobrevivência de menos de 15 meses após o diagnóstico (Johnson e Sampson, 2010; Vauleon et al., 2010). Além disso, esse tumor é resistente ao tratamento, sendo, portanto, fatal (Sul e Fine, 2010). Embora alguns avanços tenham sido obtidos nos últimos anos, o tratamento permanece paliativo para a maioria dos pacientes e a cura parece ilusória (Kesari, 2011).

Entre os desafios no tratamento do GBM estão três fatores principais: a heterogeneidade tumoral que torna os tratamentos incapazes de atingir todas as células tumorais; a resistência das células-tronco cancerígenas (CSCs, cancer stem cells) ao tratamento; e o microambiente tumoral imunossupressor (Kesari, 2011). Células de um GBM individual podem diferir em sua morfologia, genética e comportamento biológico (Furnari et al., 2007; Bonavia et al., 2011). Essa heterogeneidade também ocorre entre os GBMs e é um desafio ao tratamento, pois algumas células dentro do tumor podem responder a uma determinada terapia enquanto outras não (Kesari, 2011), assim como alguns pacientes podem responder e outros não. A heterogeneidade pode surgir de uma evolução clonal, que gera, portanto, células resistentes à pressão seletiva (ao tratamento) que continuam a sofrer mutações (Bonavia et al., 2011). A diversidade também pode surgir das CSCs que se dividem indefinidamente gerando células heterogeneamente diferenciadas (Bonavia et al., 2011). Além disso, sabe-se que essas células são resistentes às drogas servindo como um reservatório para a recorrência (Bonavia et al., 2011).

Em 2005, um estudo de Stupp e colaboradores definiu o tratamento padrão, após remoção do tumor, com radioterapia e quimioterapia oral com Temodal. Essa terapia melhorou a sobrevida e o tempo sem progressão tumoral quando comparada a radioterapia sozinha. No entanto, como citado anteriormente, a heterogeneidade tumoral dificulta o tratamento e com o temodal não é diferente, vários pacientes não são beneficiados com a utilização desse quimioterápico. 
O temodal é um agente alquilante que provoca metilação no DNA (deoxyribonucleic acid) levando as células tumorais à morte por apoptose. Entretanto, algumas células conseguem reparar esse dano no DNA pela expressão da proteína MGMT (O-6-metilguanina metiltransferase) e, como consequência, tornam-se resistentes ao tratamento. A expressão dessa enzima é controlada pela metilação do seu promotor gênico. Como a hipometilação do DNA é uma característica comum a vários tumores malignos (Belanich et al., 1996; Hegi et al., 2005), essa enzima, na maioria das vezes, está ativa nas células tumorais, o que promove resistência à terapia. Um estudo mostra, que de 206 pacientes com GBM, apenas 46 foram beneficiados com a quimioterapia com temodal. Isso ocorreu, pois apenas estes pacientes apresentavam metilação do promotor gênico da enzima MGMT o que impediu a sua produção (Hegi et al., 2005).

Diversas evidências também demonstram a dificuldade no tratamento de pacientes com GBM por causa do microambiente tumoral que contribui para o crescimento e progressão da neoplasia (Kesari, 2011). O GBM apresenta antígenos associados ao tumor que podem ser reconhecidos pelo sistema imunológico, no entanto a profunda imunossupressão presente nos pacientes prejudica essa resposta (Kesari, 2011). Um estudo recente de Wei e colaboradores (2010) demonstrou que as células tumorais provocam imunossupressão tanto pelo contato célula-célula como pela secreção de moléculas. Essa imunossupressão é caracterizada pela inibição da atividade e proliferação dos linfócitos $\mathrm{T}$, pela apoptose dessas células e pela indução de células T reguladoras (Treg).

Moléculas imunossupressoras que tornam o microambiente tumoral desfavorável às respostas do sistema imunológico tais como prostaglandina E2 (PGE-2), TGF- $\beta$ (transforming growth factor $\beta$ ) e IL-10 (interleucina 10) são altamente expressas no GBM (Rolle, Sengupta e Lesniak, 2010; Heimberger e Sampson, 2011). Rodrigues e colaboradores (2010) demonstraram que IL-10, TGF- $\beta$ e B7-H1 (PD-L1, programmed cell death ligand) são produzidas por monócitos humanos normais após exposição a células de GBM. Outros estudos indicam que essas moléculas são mais expressas pelas CSCs (CD133 ${ }^{+}$) no glioma e que a alta expressão delas está relacionada ao pior prognóstico (Anido et al., 2010; Qiu et al., 2011). Além disso, tem sido demonstrado um aumento na frequência de células $\mathrm{CD}^{+} \mathrm{CD} 25^{+}$foxp $3^{+}$(Treg) no infiltrado tumoral (El Andaloussi e Lesniak, 2006). Uma terapia efetiva, então, precisa superar as propriedades tumorigênicas do microambiente do GBM (Jackson et al., 2011) e eliminar a população de células tumorais antigenicamente diversa (Phillips et al., 2006). 


\section{Imunoterapia contra GBM}

Uma alternativa no tratamento do GBM, que vêm sendo realizada em combinação com as terapias convencionais, é a imunoterapia que usa as propriedades do sistema imunológico para combater o tumor (Johnson e Sampson, 2010). Esta é uma terapia particularmente atrativa pela capacidade de gerar uma resposta específica e imunovigilância a longo prazo (Jackson et al., 2011), capazes de proteger o paciente de uma recorrência e/ou metástase (Eschenburg et al., 2010). No entanto, a imunoterapia também precisa superar o microambiente imunossupressor, identificar antígenos tumorais e gerar uma forte resposta imunológica contra as células tumorais (Brennan et al., 2009; Jackson et al., 2011; Kesari, 2011).

Outra dificuldade enfrentada pela imunoterapia e outras terapias (que não são locais) para tumores do SNC é a característica desse sistema de ser um sítio imunoprivilegiado por causa da barreira hemato-encefálica (Pachter, De Vries e Fabry, 2003). No entanto, essa teoria vem sendo revisada e discutida. Pesquisadores demonstraram que a microglia (Yang et al., 2010), os macrófagos e as células dendríticas (DCs, dendritic cells) (Serot et al., 1997; Hussain e Heimberger, 2005) atuam como células apresentadoras de antígenos (APCs, antigen presentation cells) no SNC. Além disso, os antígenos conseguem ser drenados para os linfonodos nasais e cervicais pelo fluido cerebroespinhal onde conseguem ativar células $\mathrm{T}$ naive (Weller, Engelhardt e Phillips, 1996; Goldmann et al., 2006) e, células T ativadas expressam integrinas $(\alpha 4 \beta 7)$ que as direcionam para o SNC (Calzascia et al., 2005) onde atuam exercendo suas funções efetoras auxiliares ou citotóxicas (Quattrocchi et al., 1999).

Em pacientes com GBM, a barreira hemato-encefálica parece ser desorganizada com estrutura assimétrica dos capilares cerebrais e disfunção das junções entre as células endoteliais (Davies, 2002; Rascher et al., 2002; Mrass e Weninger, 2006). No entanto, foi demonstrado que em modelo murino de glioma, células $\mathrm{T} \mathrm{CD}^{+}$chegam ao cérebro, proliferam e aumentam a expressão de IFN- $\gamma$ (interferon $\gamma$ ) e granzima B. Além disso, essas células expressam integrina $\alpha 4 \beta 7$ que as retêm no SNC (Masson et al., 2007). Mittelbronn e colaboradores (2007) demonstraram em vários GBM analisados a expressão da molécula CD8 e Barcia e colaboradores (2009) encontraram células T $\mathrm{CD}^{+}$que expressam granzimas localizadas preferencialmente próximas aos vasos no parênquima cerebral de quatro GBMs. Dessa forma, é possível observar que um infiltrado de células T está presente em gliomas, sugerindo que as reações imunológicas ocorrem nos tumores cerebrais primários; no entanto, elas são ineficientes, pois a ocorrência da doença é inevitável (Vauleon et al., 2010). 
Apesar da dificuldade de tratar um tumor altamente heterogêneo e com características imunossupressoras, a imunoterapia tem sido bastante utilizada em vários estudos clínicos. As pesquisas têm sido realizadas com o intuito de modular a produção de citocinas no microambiente tumoral e de destruir as células tumorais pela utilização de células autólogas ativadas ex vivo (imunoterapia passiva) ou pela ativação do sistema imunológico do indivíduo (imunoterapia ativa).

A modulação das citocinas no ambiente tumoral, que consiste no bloqueio ou provimento dessas moléculas, é uma das estratégias da imunoterapia passiva que tem demonstrado resultados promissores (Jackson et al., 2011). O bloqueio na produção do TGF- $\beta$ em modelos pré-clínicos, utilizando-se o oligonucleotídeo antisense Trabedersen, tem resultado em diminuição da proliferação, inibição da migração tumoral e aumento da resposta antitumoral in vitro (Jackson et al., 2011). Um estudo clínico de fase IIb com o Trabedersen demonstrou uma tendência de aumento na taxa de sobrevida de pacientes jovens com GBM (Bogdahn et al., 2011). A inibição da síntese do TGF- $\beta$ juntamente com a radioterapia, também seria prudente, uma vez que a expressão dessa citocina é aumentada pela radiação (Ehrhart et al., 1997; Tabatabai et al., 2006; Barcellos-Hoff et al., 2009). Além do bloqueio do TGF- $\beta$, a administração de citocinas recombinantes também tem sido testada em ensaios clínicos, como IL-2 (Colombo et al., 2005), IFNs (Allen et al., 1991; Färkkilä et al., 1994; Buckner et al., 1995), IL-12 (Kikuchi et al., 2004) e GM-CSF (granulocyte and macrophagecolony stimulating factor) (Butowski, 2010) demonstrando resultados promissores.

Já a terapia utilizando células $\mathrm{T}$ efetoras envolve a transferência de células T CD8 ${ }^{+}$ citotóxicas (CTLs, cytotoxic T lymphocytes) autólogas que são obtidas a partir de células mononucleares de sangue periférico (PBMCs, peripheral blood mononuclear cells) ou células $\mathrm{T}$ do próprio tumor estimuladas com antígenos tumorais e/ou citocinas ex vivo (Jackson et al., 2011). Tsurushima e colaboradores (1999) demonstraram que células T policlonais ativadas com IL-2 proporcionaram completa regressão tumoral em dois pacientes com grau III da doença por 5 anos e uma parcial regressão em um terceiro paciente. Já um estudo utilizando células T obtidas de linfonodo de pacientes com GBM que tinham sido vacinados com células tumorais irradiadas resultou em três regressões tumorais parciais (Plautz et al., 2000).

Apesar dos resultados obtidos com a imunoterapia passiva serem promissores (modulação de citocinas e utilização de células autólogas ativadas), trata-se de uma estratégia cara e com riscos. As citocinas e células ativadas administradas podem alcançar outros locais que não o cérebro provocando uma inflamação indesejada. Somando-se a isso, o uso de medicamentos (corticosteroides) no tratamento do GBM pode provocar profunda diminuição 
nos linfócitos periféricos (Gustafson et al., 2010) interferindo na obtenção de células efetoras utilizadas na transferência adotiva (Vauleon et al., 2010). Diante disso, e levando em consideração que a imunoterapia pode ser uma alternativa aditiva ao tratamento padrão, a estimulação da resposta de células $\mathrm{T}$ específicas a antígenos tumorais no próprio indivíduo (imunoterapia ativa) pode ser uma opção mais viável.

Dentre as novas estratégias de imunoterapia ativa para GBM destacam-se as vacinas de células tumorais autólogas (ATC, autologous tumour cells), de DCs associadas a antígenos tumorais, de proteínas solúveis e de peptídeos sintéticos (Sul e Fine, 2010; Vauleon et al., 2010). Todas essas abordagens têm como objetivo induzir uma resposta imunológica específica aos antígenos tumorais que possa destruir as células do tumor e consequentemente proteger o paciente.

Estudos clínicos com DCs estão entre as imunoterapias mais estudadas em GBM (Vauleon et al., 2010), visto que essas células são APCs profissionais que quando ativadas de forma correta são capazes de ativar eficientemente a resposta imunológica adaptativa ( $\mathrm{Yu}$ et $a l ., 2001)$. A obtenção dessas células, na maioria das vezes, é realizada a partir de monócitos periféricos; a ativação é realizada com diferentes citocinas e a origem do antígeno é diversa: lisado tumoral, peptídeos ou RNA mensageiro de ATC ou peptídeos sintéticos. As vacinas são, ainda, administradas via intradérmica ou subcutânea, e em menor proporção intracerebral (Vauleon et al., 2010). Em alguns casos, junto com a vacina são administradas citocinas recombinantes (Vauleon et al., 2010). Os resultados de alguns desses estudos demonstraram efeitos benéficos para alguns pacientes, particularmente aqueles com tumores pequenos. Nesses pacientes foi observada indução de resposta imunológica detectada pelo desenvolvimento de hipersensibilidade do tipo tardia (DTH, delayed-type hypersensitivity), pelo infiltrado de linfócitos $\mathrm{T}$ no tumor e pela resposta antitumoral de células $\mathrm{T}$ obtidas do PBMC (Liau et al., 2000; Ardon et al., 2010).

Outra estratégia bastante utilizada na imunoterapia de GBM é a vacinação utilizando peptídeos capazes de se ligar a moléculas do complexo principal de histocompatibilidade de classe I (MHC, major histocompatibility complex) e ativar a resposta de células T citotóxicas contra o tumor. Esses fragmentos proteicos são associados a moléculas adjuvantes capazes de ativar a resposta imunológica inata (Yamanaka, 2008). Yajima e colaboradores (2005) demonstraram, em um estudo clínico, utilizando uma vacinação personalizada com até 4 peptídeos, em 21 pacientes com glioma maligno, aumento da resposta celular e humoral específicas a pelo menos um peptídeo em 50\% dos indivíduos. A sobrevida média dos 
pacientes com GBM nesse estudo foi de 622 dias. Outro grupo também demonstrou a ativação da resposta imunológica humoral e celular, bem como o aumento na sobrevida de 7,1 para 12 meses, em pacientes vacinados via intradérmica com o peptídeo PEPvIII, derivado da proteína EGFRvIII (variante III do receptor factor growth epidermal), conjugado à proteína carreadora KLH (keyhole limpet hemocyanin) e administrado junto com GM-CSF (Heimberger et al., 2006; Choi et al., 2009).

Apesar dos resultados promissores, a variabilidade de resposta usando qualquer uma das estratégias é, ainda, muito grande. Definir um tipo de imunoterapia com DCs ainda se apresenta como algo complexo devido às diferentes variáveis utilizadas em cada estudo. Além disso, o processo de obtenção/diferenciação dessas células é complexo, demorado e caro. Os peptídeos, por sua vez, têm como desvantagens serem específicos para alguns GBMs e apresentam a necessidade de serem identificados como epitopos de células T. Embora a vacinação personalizada com peptídeos específicos para cada GBM possa ser a vacinação do futuro, ainda é necessária a utilização de antígenos presentes na maioria das células desse tumor e entre GBMs de diferentes pacientes.

\section{Vacinas de DNA como alternativa na imunoterapia de GBM}

A imunoterapia utilizando vacinas de DNA, apesar de ainda não ser utilizada no tratamento de GBM, é uma estratégia interessante pela capacidade de ativar as diferentes células da resposta imunológica adaptativa contra a célula tumoral. Essas vacinas são capazes de ativar células $\mathrm{T} \mathrm{CD}^{+}$citotóxicas; células $\mathrm{B}$, com consequente produção de anticorpos, capazes de mediarem citotoxicidade celular e células T CD4 ${ }^{+}$(Ulmer et al., 1993; Corr et al., 1996; Ulmer et al., 1996; Liu, 2003). A resposta efetora das células T CD4 ${ }^{+}$consiste no auxílio da ativação dos linfócitos $\mathrm{T}_{\mathrm{CD}}{ }^{+}$, das células $\mathrm{B}$ e de macrófagos e eosinófilos produtores de óxido nítrico e superóxidos, moléculas capazes de provocar dano tumoral (Hung et al., 1998).

Além de ativar as respostas imunológicas celular e humoral, as vacinas de DNA apresentam outras vantagens como estratégia vacinal: sua produção é relativamente simples, apresentam grande estabilidade, constituem-se em fonte estável e persistente do antígeno (Gurunathan, Klinman e Seder, 2000; Kutzler e Weiner, 2008) e podem ser administradas por várias rotas (Wolff et al., 1990; Raz et al., 1996). As vacinas de DNA também apresentam efeito adjuvante inerente, devido à presença de sequências CpG não metiladas (Krieg et al., 1998). Essas sequências são ligantes do TLR-9 (toll like receptor 9) e induzem produção de 
IL-12 em monócitos e DCs (Hemmi et al., 2000). Elas podem, ainda, ativar outras vias independentes de TLRs que induzem a produção de interferons (Ishii et al., 2006; Takaoka et al., 2007).

Várias pesquisas também já demonstraram que os riscos utilizando vacinas de DNA são limitados. Os estudos mostram indução efetiva de imunidade específica sem efeitos colaterais de integração do plasmídio no genoma ou produção de anticorpos anti-DNA (Ledwith et al., 2000; Manam et al., 2000; Schalk et al., 2006). Trabalhos do nosso grupo também já demonstraram segurança utilizando essa estratégia vacinal. A vacina DNAhsp65, utilizada por nós e que expressa a Hsp65 de Mycobacterium leprae foi bem tolerada, não desencadeou auto-imunidade (Santos-Junior et al., 2005; Lima, 2006; Santos Júnior et al., 2007) e tolerância (Pelizon et al., 2007) e não houve evidências de integração no genoma (Coelho-Castelo et al., 2006).

Diante disso, durante os últimos anos, vários trabalhos vêm sendo realizados com vacinas de DNA em modelos animais demonstrando resposta imunológica específica contra antígenos associados a tumores com consequente imunidade tumoral (Kim et al., 1998; Steitz et al., 2000; Pupa et al., 2001). Esses resultados encorajaram estudos clínicos com vacina de DNA para tratar vários tipos de tumores: melanoma, câncer colorretal, câncer de pulmão, próstata, mama e ovário (Weide et al., 2008). Em um dos primeiros trabalhos publicados, pacientes com carcinoma colorretal tratados com injeções intramusculares de uma vacina de DNA codificando um antígeno tumoral, apresentaram resposta linfoproliferativa contra esse antígeno (Conry et al., 2002). Pacientes com melanoma em estágio IV, tratados com uma vacina de DNA intranodal codificando um antígeno tumoral, tiveram resposta de linfócitos $\mathrm{T}$ citotóxicos, e embora nenhuma regressão tenha sido observada, a sobrevida média dos pacientes aumentou, principalmente naqueles que desenvolveram resposta imunológica (Tagawa et al., 2003).

Os resultados, apesar de promissores, revelaram uma resposta imunológica fraca contra o tumor. Desta forma, vários estudos começaram a ser realizados combinando a vacina de DNA com moléculas adjuvantes ou com sistemas de entrega/liberação capazes de ajudar na ativação da resposta imunológica. Pavlenkoe colaboradores (2004) demonstraram que a vacinação de pacientes com câncer de próstata, com uma vacina de DNA codificando o antígeno tumoral PSA (protate-specific antigen) juntamente com as citocinas IL-2 e GM-CSF desencadearam respostas humoral e celular contra o antígeno e regressão tumoral. Dois outros 
estudos em pacientes com o mesmo tipo tumoral, um deles usando DNA que codifica o antígeno PSMA (protate-specific membrane antigen) e co-estimulação com a molécula CD86 (cluster of differentiation 86) (Mincheff et al., 2000) e no outro, utilizando-se eletroporação (Low et al., 2009) foi observado o desenvolvimento de resposta celular contra o antígeno em metade dos pacientes e uma resposta aumentada em 24 vezes durante 18 meses, respectivamente.

As vantagens dessa estratégia e os resultados promissores tornam as vacinas de DNA uma ferramenta muito atrativa. O grande desafio é realmente torná-las mais imunogênicas, e nesse sentido é possível combinar as vacinas de DNA com moléculas adjuvantes, como citocinas, co-estimuladores e proteínas imunomoduladoras e/ou utilizar sistemas de entrega/liberação controlada que favoreçam a imunogenicidade, como foi citado anteriormente. Uma das vantagens dessa estratégia é que genes de vários antígenos podem ser usados e combinados com os genes de proteínas adjuvantes em uma única vacina de DNA. Entretanto, esse tipo de imunoterapia, assim como qualquer outra, apresenta dois desafios: a escolha dos antígenos tumorais contra os quais a resposta imunológica será gerada, e a escolha da abordagem a ser utilizada na estimulação do sistema imunológico, de forma a quebrar a imunossupressão que existe no ambiente tumoral para gerar uma resposta eficaz contra o tumor.

\section{Antígenos tumorais de GBM}

Como as células tumorais surgem de células normais, elas apresentam em sua maioria as mesmas proteínas de um tecido normal do qual elas derivam. Dessa forma, há duas barreiras que precisam ser transpostas com relação à escolha de antígenos tumorais a serem utilizados na imunoterapia: a necessidade de quebra da tolerância a antígenos próprios, e a possibilidade de indução de autoimunidade. Esses são grandes desafios no desenvolvimento de qualquer imunoterapia ativa que necessita superar a tolerância a antígenos próprios para gerar uma resposta imunológica antitumoral sem causar um problema autoimune indesejado (Pardoll, 1999).

Considerando o sítio onde ocorrerá a resposta imunológica, o SNC, esse é um ponto ainda mais importante, uma vez que a quebra na tolerância para combater o tumor pode, diferentemente de outros tecidos, gerar uma autoimunidade potencialmente fatal. Para evitar toxicidade no SNC, o ideal seria selecionar antígenos presentes apenas no tumor que fossem reconhecidos com alta especificidade pelo sistema imunológico (Johnson e Sampson, 2010), 
além de gerar uma resposta moderada para evitar danos nos tecidos adjacentes. Assim, a resposta seria gerada apenas contra o tumor, sem efeitos nas células normais adjacentes, evitando o problema da quebra de tolerância e consequentemente da autoimunidade.

No entanto, não é fácil encontrar vários antígenos específicos do tumor, o que tem levado à ampla utilização, em estudos clínicos, de antígenos preferencialmente expressos no tecido tumoral; antígenos mutados ou modificados, derivados de proteínas próprias e os superexpressos no tumor (Gilboa, 1999). Alguns pesquisadores demonstraram em uma série de 47 GBMs a superexpressão de quatro moléculas que induzem reações imunológicas: IL13R 2 (IL13 receptor $\alpha$ 2), EGFRvIII, gp100 e TRP2 (tyrosinase-related protein-2) (Saikali et al., 2007). Vários outros antígenos associados com GBM têm sido descritos como EphA2 (ephrintype-A receptor 2), survivina, WT1 (wilms tumor protein), SOX2, SOX11, MAGE (melanoma-associated antigen), AIM2 (absent in melanoma 2) e SART1 (Okada et al., 2009).

Entre esses antígenos, o EGFR parece um alvo interessante, pois seu gene está amplificado em aproximadamente 50\% dos GBM e é superexpresso em mais de $90 \%$ desses tumores (Ekstrand et al., 1991; Jaros et al., 1992). O gene EGFR codifica uma glicoproteína de membrana de $170 \mathrm{kDa}$ que possui um domínio de ligação extracelular e uma porção intracelular com função de tirosina quinase (Stoscheck e King, 1986). A ativação desse receptor conduz à proliferação e manutenção da sobrevivência celular (Carpenter e Cohen, 1990). O EGFRvIII é a variante melhor caracterizada desse receptor e primeiramente encontrada em GBM. Essa isoforma independe da interação com seu ligante, sendo, portanto, constitutivamente ativa (Batra et al., 1995) e está associada à tumorigenicidade pelo aumento da proliferação celular e inibição da apoptose (Nishikawa et al., 1994).

O EGFRvIII apresenta deleção dos aminoácidos 6 ao 273, o que resulta na união de aminoácidos inicialmente distantes na molécula ao redor de um novo resíduo de glicina (Bigner et al., 1990; Humphrey et al., 1990). Como essa variante não é expressa por células normais, o epitopo formado da junção de duas porções distantes é tumor específico (PEPvIII) (Humphrey et al., 1990). Dessa forma, alguns estudos clínicos têm sido desenvolvidos com esse peptídeo. Um estudo clínico com DCs pulsadas com o PEPvIII conjugado com KLH demonstrou melhor sobrevida em 12 pacientes com GBM (Sampson et al., 2008). Outro estudo, de fase II, conduzido sem DCs, somente com o PEPvIII-KLH e GM-CSF em 18 pacientes diagnosticados com GBM mostrou aumento na sobrevida sem progressão do tumor de 6,3 para 14,2 meses (Heimberger et al., 2006). 
Outro receptor do fator de crescimento epidermal que pode estar associado ao risco de desenvolvimento de GBM, sendo, portanto, interessante de ser estudado, é o cERBB2 (Andersson et al., 2010). Essa molécula não apresenta domínio de ligação a um ligante, mas se liga fortemente a outro receptor da família formando um heterodímero capaz de aumentar a atividade de tirosina quinase. Já foi demonstrado em um estudo com gliomas que a proteína cERBB2 está presente principalmente em tumores cerebrais de grau III e IV (Andersson et al., 2004).

Os gliomas compartilham propriedades biológicas com os melanomas devido à mesma origem embrionária dos melanócitos e células da glia. Desta forma, alguns antígenos, como os da família MAGE podem ser compartilhados entre esses tumores. Os genes dessa família são expressos em muitos tumores e na linhagem germinativa, mas são silenciados nos tecidos normais (Chomez et al., 2001) o que os torna interessante como alvos. Chi e colaboradores (1997) demonstraram a presença de RNA mensageiro dos genes MAGE-1 e MAGE-3 em 38 e 33\% dos GBMs analisados, mas não em tecido normal. Outro membro da família, MAGEE1, também apresentou maior expressão em GBM (Sasaki et al., 2001) e as proteínas MAGE 1 e 4 também foram detectadas em 86 e 36\%, respectivamente, dos gliomas analisados (Kuramoto, 1997). Zhang e colaboradores (2003) reportaram o reconhecimento por células T $\mathrm{CD}^{+}$de um peptídeo da proteína MAGE-3 em pacientes com melanoma, indicando que essa molécula é capaz de induzir resposta imunológica celular importante no combate ao tumor.

Além dos receptores do fator de crescimento epidermal e das proteínas MAGE serem alvos interessantes na terapia contra GBM, um antígeno não citado anteriormente, expresso também apenas no tecido tumoral e específico de gliomas é o GLEA-2 (gliomaexpressed antigen2) (Fischer et al., 2001). Esse antígeno foi identificado em uma biblioteca de cDNA de GBM, na qual o produto dos genes expressos em Escherichia coli (E. coli) foram avaliados frente ao soro de vários pacientes com GBM (Fischer et al., 2001). Anticorpos antiGLEA foram encontrados em 43\% dos pacientes (Fischer et al., 2001) e um aumento da sororeatividade contra essa proteína foi observado após radioterapia em pacientes com GBM (Heisel et al., 2008). Os autores não determinaram porque aconteceu esse aumento, mas acreditam que a destruição celular com consequente liberação da proteína GLEA pode ser um dos fatores para esse aumento na resposta imunológica humoral.

A heterogeneidade antigênica presente nas células de um GBM acaba sugerindo como primordial a utilização de mais de um antígeno na imunoterapia. Dessa forma, esses quatro antígenos descritos anteriormente constituem interessantes objetos de estudo para uma 
futura utilização na terapia. Além da heterogeneidade, estudos clínicos utilizando apenas um antígeno como o EGFRvIII têm esbarrado em outra dificuldade presente em células tumorais: a mudança no perfil antigênico que ocorre nos tumores após uma pressão seletiva (imunoedição) (Dunn, Old e Schreiber, 2004). De fato, dados não publicados de um estudo clínico demonstraram que GBM recorrente de 20 em 23 pacientes que tinham sido inicialmente vacinados com um peptídeo derivado da proteína EGFRvIII não expressavam mais essa molécula (Rolle, Sengupta e Lesniak, 2010).

A imunoedição é uma característica que o tumor apresenta de mudar seu perfil de expressão antigênico, essa é mais uma forma de escapar da resposta imunológica (Jackson et al., 2011) e é uma propriedade comum entre os tumores. Essa característica realmente dificulta a escolha do antígeno, por isso muitas vezes uma alternativa é estudar mais de um antígeno como alvo. Essa alternativa é ainda mais importante quando nos deparamos com, talvez, a maior dificuldade no tratamento do GBM que é a incapacidade de adaptar uma terapia para os diferentes indivíduos. O perfil de expressão antigênica como já foi citado anteriormente é diferente não só entre as células que compõem o mesmo GBM, mas também entre GBM de diferentes indivíduos.

\section{Moléculas imunoestimuladoras}

A escolha dos antígenos para combater o tumor altamente heterogêneo é realmente um grande desafio, mas uma imunoterapia efetiva não depende só deles. É necessário, também, ativar eficientemente a resposta imunológica, de forma a superar a profunda imunossupressão no microambiente do GBM (Jackson et al., 2011; Kesari, 2011) para conseguir combater o tumor. Dessa forma, como discutido anteriormente, a maioria das imunoterapias tem sido realizada com antígenos combinados a moléculas adjuvantes que auxiliam o desenvolvimento da resposta imunológica por serem capazes de ativar as células da imunidade inata bem como auxiliar a captura, processamento e apresentação antigênica (Guy, 2007). Além das citocinas e moléculas co-estimuladoras já citadas previamente, trabalhos também vêm sendo realizados com as proteínas de choque térmico (HSPs, heat shock proteins) e a glicoproteína $\mathrm{D}(\mathrm{gD})$ do envoltório celular do vírus herpes humano tipo-1 (HSV-1) como adjuvantes na imunoterapia contra o câncer.

\section{Proteínas de choque térmico}

As HSPs são as principais proteínas envolvidas em proteger a estrutura e interações de outras proteínas (Lindquist e Craig, 1988; Mayer e Bukau, 2005). Elas são intrínsecas às 
células, apresentam-se de forma conservada e são altamente expressas em situações de estresse térmico (Lindquist e Craig, 1988; Mayer e Bukau, 2005). Elas são divididas em famílias de acordo com o tamanho, Hsp27, Hsp60, Hsp70 e Hsp90. Podem, ainda, ser divididas em dois grandes grupos de acordo com a localização celular: no citoplasma/núcleo Hsp27, 60 e 70; e no retículo endoplasmático - Hsp90 (Wei e Hendershot, 1996; Kampinga et al., 2009).

Desde a descoberta dessas proteínas, um número crescente de funções vem sendo descritas, e, entre elas, funções imunológicas. Estas funções começaram a surgir na década de 80, quando foi observado que HSPs isoladas de células cancerígenas eram compostas por um complexo formado com peptídeos tumorais que eram capazes de induzir imunidade contra o tumor (Udono e Srivastava, 1993; Tamura et al., 1997). Os estudos iniciais foram realizados com a Hsp gp96, mas resultados similares foram obtidos com Hsp70 (Udono e Srivastava, 1993; Tamura et al., 1997). A imunogenicidade desses complexos foi atribuída à capacidade das HSPs, capturadas pelas APCs, transportar os peptídeos ligados a elas para o citoplasma dessas células com consequente ativação de células T CD8 ${ }^{+}$(Srivastava e Maki, 1991; Srivastava, 2005; Murshid, Gong e Calderwood, 2010). Hoje se sabe que as proteínas Hsp70, gp96 e outras HSPs dessas famílias apresentam sítios de interação com peptídeos (Bukau e Horwich, 1998), protegem essas moléculas da degradação por endopeptidases e carregam um grande repertório de peptídeos para serem apresentados pelas APCs de forma cruzada aos linfócitos T CD8 ${ }^{+}$(Kunisawa e Shastri, 2006; Lev et al., 2008).

As HSPs, então, interagem com receptores de superfície de APCs e são internalizadas; entretanto, a interação com receptores de superfície também pode resultar na sinalização e ativação de células do sistema imunológico. Ainda não está claro se os processos de captura e sinalização são realizados por um ou mais receptores (Calderwood et al., 2007; JockheckClark et al., 2010). Receptores SRs (scavenger receptors) parecem estar envolvidos na ligação com HSPs e iniciação dos processos envolvidos na apresentação cruzada (Thériault, Adachi e Calderwood, 2006; Murshid, Gong e Calderwood, 2010). A Hsp70 também interage com lectinas do tipo-c presente em células natural killers (NKs) (Thériault, Adachi e Calderwood, 2006) e com o receptor CD40 responsável pela maturação de APCs e indução da produção de citocinas (Becker, Hartl e Wieland, 2002). Massa e colaboradores (2005) demonstraram que a Hsp70 murina induziu a maturação de DCs na presença de células NKs (Massa, Melani e Colombo, 2005). Alguns estudos ainda sugerem a interação das HSPs com o receptor CD91 presente em macrófagos e DCs (Basu et al., 2001; Binder e Srivastava, 
2004; Jockheck-Clark et al., 2010) e muitos outros revelam a interação de HSPs de varias espécies com receptores TLR desencadeando maturação de DCs com consequente indução de moléculas co-estimuladoras e ativação de células T (Vabulas et al., 2002; Vabulas e Wagner, 2005; Reis E Sousa, 2006; Souza, 2011).

Devido a suas propriedades, as HSPs vêm sendo estudadas em vários trabalhos préclínicos e clínicos na forma de complexos HSP-peptídeo e em vacinas de DNA. Pesquisadores mostraram que a administração de vacinas de DNA codificando a oncoproteína E7 e a gp96 resultaram em respostas humoral e celular mais efetiva do que a vacina E7 administrada sozinha em camundongos C57BL/6 (Bolhassani et al., 2008). Outro trabalho usando a proteína E7 juntamente com a Hsp70 em uma vacina de DNA demonstrou resposta imunológica capaz de promover a redução tumoral em camundongos (Farzanehpour et al., 2013). Wang e colaboradores (2009) também mostraram que a imunização de camundongos com uma vacina de DNA que codificava a proteína MAGE-3 em fusão com Hsp70 em uma forma secretada induziu respostas celular e humoral e inibição do crescimento tumoral. Esses estudos indicam que a imunização com antígenos tumorais e HSPs pode ter um efeito sinergístico no imunoterapia de tumores.

Um estudo clínico de Fase I/II realizado pelo nosso grupo em pacientes terminais com carcinoma epidermóide de cabeça e pescoço com a vacina DNAhsp65 mostrou que, além de ser bem tolerada apresentando apenas pequenos efeitos colaterais, ela foi capaz de induzir uma resposta parcial de 4 pacientes, com dois sobrevivendo por mais de 3 anos (Michaluart et al., 2008). As HSPs também têm sido utilizadas como vacinas proteicas em estudos clínicos de vários tumores como melanoma metastático, carcinoma colorretal, leucemia mieloide crônica, carcinoma renal e GBM (Belli et al., 2002; Rivoltini et al., 2003). Os resultados demonstram que o tratamento é seguro e está associado a um aumento na sobrevida dos pacientes (Belli et al., 2002; Rivoltini et al., 2003).

Parsa e colaboradores (2007) realizaram um estudo em pacientes com GBM recorrente e demonstraram que sete de oito indivíduos tratados com um complexo peptídeos-HSP tiveram a sobrevida aumentada para 10,5 meses quando comparados ao controle com 6,5 meses. A continuação desse estudo demonstrou que os pacientes apresentam resposta imunológica inata eficiente e células $\mathrm{T} \mathrm{CD} 8^{+}$produtoras de IFN- $\gamma$ após re-estimulação, e a sobrevida média também aumentou para 324 dias com 4 pacientes vivos há mais de 1 ano 
(Jackson et al., 2011). Essas proteínas podem, dessa forma, constituir ferramentas úteis na quebra da imunossupressão, auxiliando na resposta imunológica inata e específica.

\section{Glicoproteína D}

A gD é uma glicoproteína presente no envelope do HSV-1 envolvida na infecção; a interação dela com seu receptor ajuda na fusão do vírus com a célula hospedeira (Carfí et al., 2001; Connolly et al., 2003). A gD apresenta uma porção extracelular com três sítios de ligação a oligossacarídeos e um grampo na porção N-terminal composto de 37 resíduos de aminoácidos responsáveis pela interação ao HVEM (HVEM, herpes vírus entry mediator) (Carfí et al., 2001; Connolly et al., 2003) expresso em muitas células do sistema imunológico incluindo células T (Montgomery et al., 1996).

O HSV-1 infecta facilmente macrófagos e DCs prejudicando a apresentação de antígenos (Pollara et al., 2004). No entanto, no início da infecção, a interação da gD com o

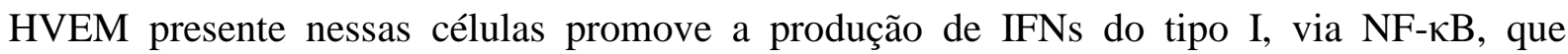
estimulam outras DCs a produzirem IL-12 (Medici et al., 2003; Pollara et al., 2004). Dessa forma, uma resposta Th1 é montada no combate ao vírus.

O HVEM é uma molécula da superfamília dos receptores de TNF (tumor necrosis factor), primeiramente descrito como um ligante da gD (Montgomery et al., 1996), que pode transmitir sinais estimuladores ou inibidores dependendo do ligante. O HVEM apresenta na sua porção extracelular quatro domínios repetidos ricos em cisteína (CRD, cysteine-rich domain) (Bodmer, Schneider e Tschopp, 2002) e pode interagir pelos CRD2 e CRD3 com a molécula LIGHT presente nas células T (Rooney et al., 2000). Essa interação promove sinais co-estimulatórios na célula $\mathrm{T}$ conduzindo a proliferação e produção de citocinas (Tamada et al., 2000). Devido ao HVEM ser um membro da família dos TNFRs, seus efeitos

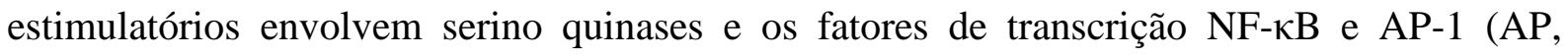
adapter protein) que promovem a expressão de proteínas envolvidas na sobrevivência celular e de moléculas pro-inflamatórias (Marsters et al., 1997; Locksley, Killeen e Lenardo, 2001).

O HVEM pode também interagir com o BTLA (BTLA, B- and T-lymphocyte attenuator) pelo CRD1 (Sedy et al., 2005), havendo fosforilação de um resíduo de tirosina no imunorreceptor do BTLA que recruta fosfatases responsáveis pela inibição da proliferação das células T (Gavrieli et al., 2003; Gonzalez et al., 2005; Sedy et al., 2005). O BTLA, além de ser expresso em células $\mathrm{T}$ ativadas e anérgicas, também está presente em células $\mathrm{B}$ e em menor quantidade nas DCs e macrófagos (Watanabe et al., 2003; Hurchla et al., 2005). 
Alguns autores descrevem o BTLA como um inibidor constitutivo por ser expresso juntamente com HVEM em células T naive (Hurchla et al., 2005).

Mais recentemente também foi demonstrado por Cai e colaboradores (2008) que a proteína CD160, membro da superfamília das imunoglobulinas, presente em células T CD ${ }^{+}$, NKT e NK (Anumanthan et al., 1998; Maeda et al., 2005), é mais um ligante do receptor HVEM. Além dessa interação, os autores mostraram que o CD160 é expresso por células T $\mathrm{CD}^{+}$ativadas e com fenótipo de memória e que a ligação com o HVEM, no mesmo sítio de interação com o BTLA, inibe a proliferação desses linfócitos e produção de citocinas. $\mathrm{O}$ CD160 e BTLA não interferem na interação LIGHT-HVEM, no entanto, esta interação melhora a ligação do HVEM com os outros receptores e esse caminho inibitório CD160BTLA-HVEM parece dominar sobre o efeito estimulador da molécula LIGHT (Cai et al., 2008). A rede CD160-BTLA-HVEM parece, portanto, um grande alvo para terapia, pois afeta as respostas imunólogicas como a ação de células de memória, importante no desenvolvimento de vacinas (Krieg et al., 2007; Kaye, 2008).

A gD interage com HVEM no CRD1 se sobrepondo ao sítio de interação HVEMBTLA (Carfí et al., 2001). Ela compete com o BTLA pelo sítio de interação, podendo assim, prejudicar o caminho inibitório HVEM-BTLA, sem prejudicar a interação do receptor HVEM com o co-estimulador LIGHT que reconhece os domínios CRD2 e CRD3 (Cheung et al., 2005). A quebra no equilíbrio LIGHT-HVEM-BTLA pode ser um mecanismo pelo qual o vírus do herpes modula a imunidade sem levar à forte patogenicidade (Cheung et al., 2005). Diante dessa quebra do equilíbrio LIGHT-HVEM-BTLA (e possivelmente agora incluindo o CD160 que interage com o HVEM no mesmo local que o BTLA) provocado pela gD e da

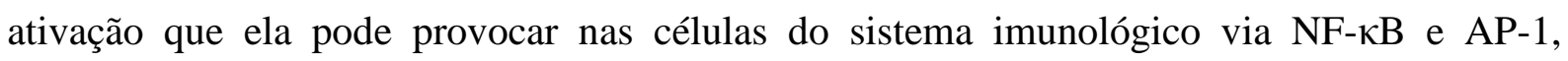
trabalhos vêm mostrando que vacinas de DNA baseadas na fusão de proteínas à gD parecem exibir uma forte atividade imunomoduladora.

A construção de uma vacina de DNA expressando uma proteína híbrida constituída pela gD fusionada a $\mathrm{CfaB}$ (subunidade estrutural da fimbria CFA/1) de ETEC (E. coli enterotoxigênica) resultou em um aumento na intensidade e longevidade da resposta de anticorpos contra $\mathrm{CfaB}$ em camundongos imunizados (Lásaro et al., 2003). Além dessa vacina, construções semelhantes utilizando o gene que codifica a gD fusionado aos genes das oncoproteínas E5, E6 e E7 do HPV-16 (human papilloma vírus-16) desencadearam resultados igualmente positivos (Lasaro et al., 2005; Lasaro et al., 2008; Diniz et al., 2010). 
Camundongos vacinados com estas preparações apresentaram um aumento na ativação de células $\mathrm{T} \mathrm{CD}^{+}$específicas, que resultou em proteção profilática e terapêutica em animais desafiados com células tumorais.

Mais recentemente um trabalho do nosso grupo fusionou a proteína gD com os epitopos da proteína Hsp65 em uma estratégia de vacina de DNA para a tuberculose. Esse estudo demonstrou eficiente resposta imunológica humoral e celular. As vacinas construídas induziram anticorpos do subtipo IgG2a epitopo-específicos, aumento na população de células $\mathrm{T} \mathrm{CD}^{+}$e $\mathrm{T} \mathrm{CD}^{+}$e indução de células produtoras de IFN- $\gamma$ quando utilizadas em camundongos (Rios, 2009).

Os efeitos imunomoduladores da gD, aumentando a imunogenicidade dos antígenos fusionados a ela, parecem estar relacionados à sua interação com o receptor HVEM ativando diferentes células do sistema imunológico, bem como prejudicando o caminho inibitório HVEM-BTLA (Lasaro et al., 2008; Lasaro et al., 2011) (e agora possivelmente HVEMCD160). Segundo Lasaro e colaboradores (2008) a fusão de proteínas com a gD não prejudica sua interação com o receptor HVEM, nem a interação HVEM-LIGHT. Esse mesmo grupo de pesquisadores (2011) demonstraram que a indução de células T CD ${ }^{+} \mathrm{IFN}-\gamma^{+}$específicas para a proteína E7 do HPV-16 em camundongos vacinados com AdgDE7 (Adenovirus-gD-E7) é mediada pela gD e dependente da interação dessa proteína com seu receptor HVEM. Dessa forma, vacinas de DNA baseadas na expressão de antígenos tumorais fusionados a gD podem representar uma estratégia vacinal com grande potencial terapêutico contra tumores.

\section{Justificativa}

É evidente que existem muitas dificuldades a serem transpostas no tratamento de indivíduos com GBM, como: a heterogeneidade molecular e genética, o microambiente imunossupressor e a imunoedição tumoral. No entanto, pelo fato deste tumor ser um dos mais agressivos e com um dos piores prognósticos, qualquer avanço pode ser altamente significativo para os pacientes com GBM. A imunoterapia ativa parece ser uma alternativa viável se pensarmos que ela pode estimular o sistema imunológico a responder e pode proteger o indivíduo de uma recorrência. Com essa terapia é possível selecionar alguns antígenos, o que evita o problema da autoimunidade quando se utiliza célula tumoral total ou lisado proteico tumoral, uma vez que essas fontes de antígenos contêm muitas proteínas compartilhadas com as células normais. 
Além disso, moléculas capazes de ativar eficientemente a imunidade inata podem ser utilizadas juntamente com os antígenos para ajudar a gerar uma resposta específica contra o tumor. Como descrito acima, as HSPs e a gD estimulam o sistema imunológico por meio da interação com células da imunidade inata, como as DCs. As HSPs podem ainda complexar-se a peptídeos ajudando no processamento e apresentação antigênica e a gD pode bloquear vias inibitórias da ativação de células T. Dessa forma, seria interessante utilizar, em uma única abordagem, vacinas de DNA expressando antígenos tumorais e HSPs ou a gD para estimular o sistema imunológico a "produzir" células $\mathrm{T}$ e anticorpos específicos para os antígenos tumorais capazes de combater o tumor. Como novas abordagens terapêuticas são continuamente investigadas para o tratamento de tumores malignos e, dentre elas, a imunoterapia representa uma forma de crescente relevância, essa estratégia pode ser promissora na imunoterapia do GBM, que é o mais comum e letal tumor cerebral. 


\subsection{OBJETIVO}

\subsection{Objetivo Geral}

Construir e avaliar a imunogenicidade de vacinas de DNA utilizando genes de antígenos de GBM e de proteínas imunomoduladoras.

\subsection{Objetivos Específicos}

»Analisar as sequências de nucleotídeos e de aminoácidos dos antígenos tumorais de GBM e das proteínas imunomoduladoras para montagem da estratégia de construção dos vetores recombinantes e dos oligonucleotídeos que serão utilizados nesse trabalho;

» Sintezar os genes dos antígenos tumorais de GBM, EGFRvIII, cERBB2, MAGE-3 e GLEA2 e das proteínas imunomoduladoras, gD, gp96 e Hsp70;

»Clonar os antígenos no vetor vacinal pVAX1 fusionados a gD;

» Clonar os antígenos no pVAX1 sem fusão;

»Clonar os genes que codificam as proteínas imunomoduladoras gp96 e Hsp70 no pVAX1;

» Caracterizar in vitro as vacinas construídas (transfecção de células e avaliação da expressão das proteínas e antígenos);

»Clonar todos os genes, exceto o da $\mathrm{gD}$, em vetor de expressão;

» Expressar e purificar os antígenos e as proteínas gp96 e Hsp70;

» Produzir anticorpos contra os antígenos e as proteínas gp96 e Hsp70;

»Avaliar a imunogenicidade, em camundongos, das vacinas construídas, utilizando a vacina de DNA contendo o antígeno tumoral sozinho ou em combinação com uma proteína imunomoduladora. 


\subsection{DELINEAMENTO EXPERIMENTAL}

\section{$\underline{\text { Análise dos genes }}$}

Genes EGFRvIII, cERBB2,

MAGE, GLEA, gp96 e gD

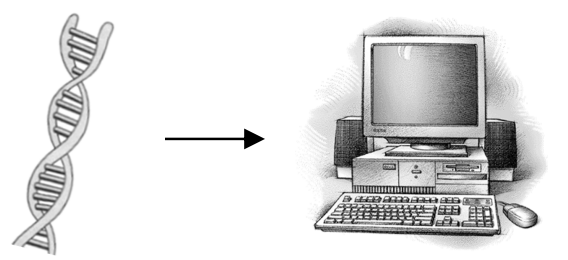

Analisados in silico e modificados
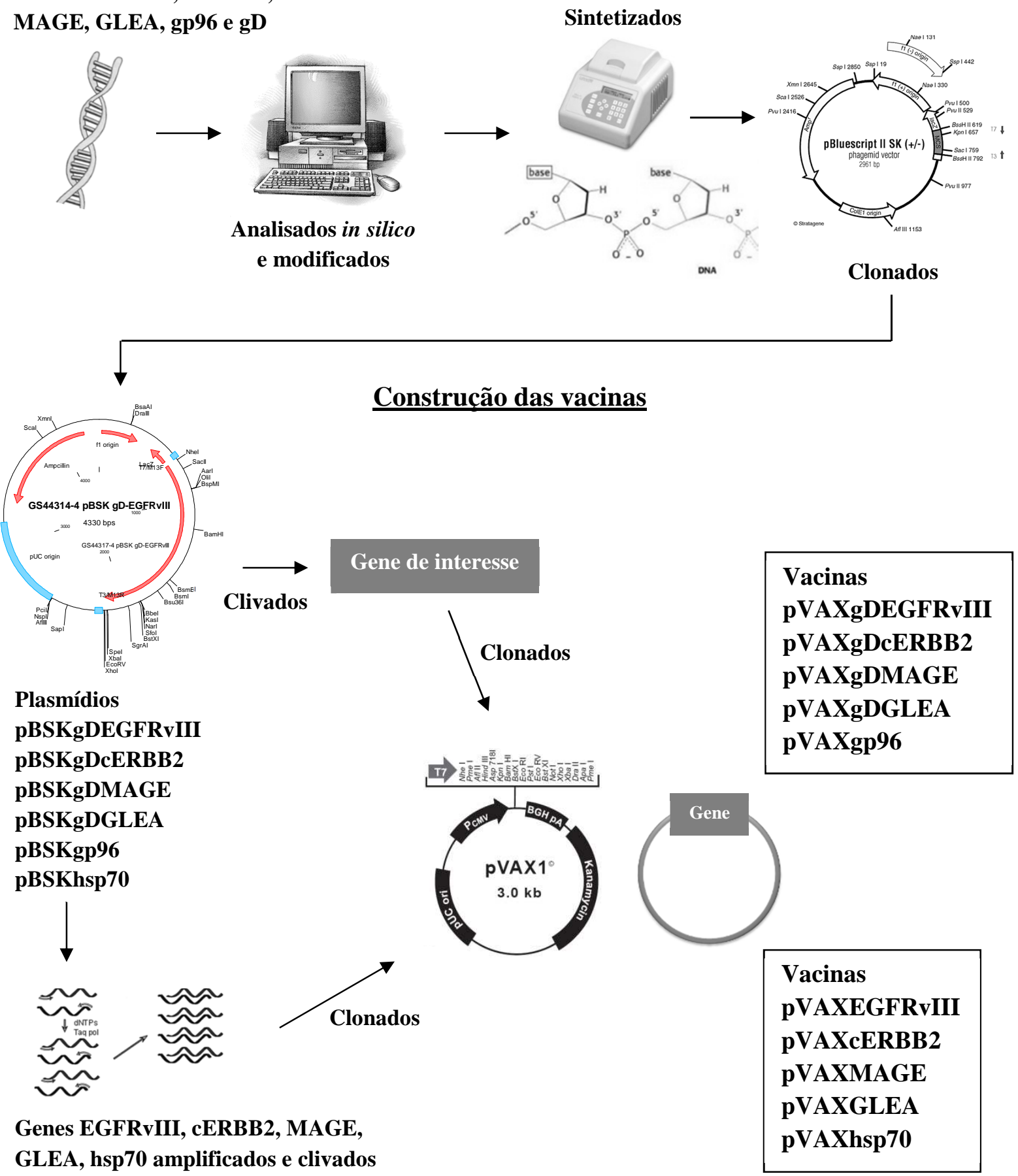

GLEA, hsp70 amplificados e clivados 


\section{Construcão dos vetores de expressão}

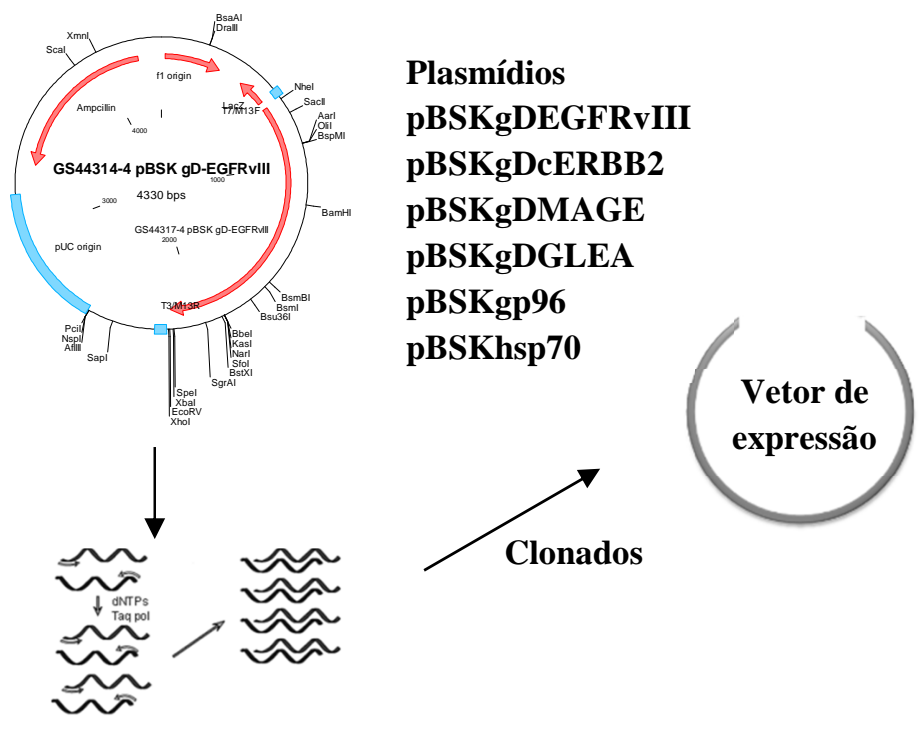

Genes EGFRvIII, cERBB2, MAGE, GLEA, gp96 e hsp70 amplificados e clivados
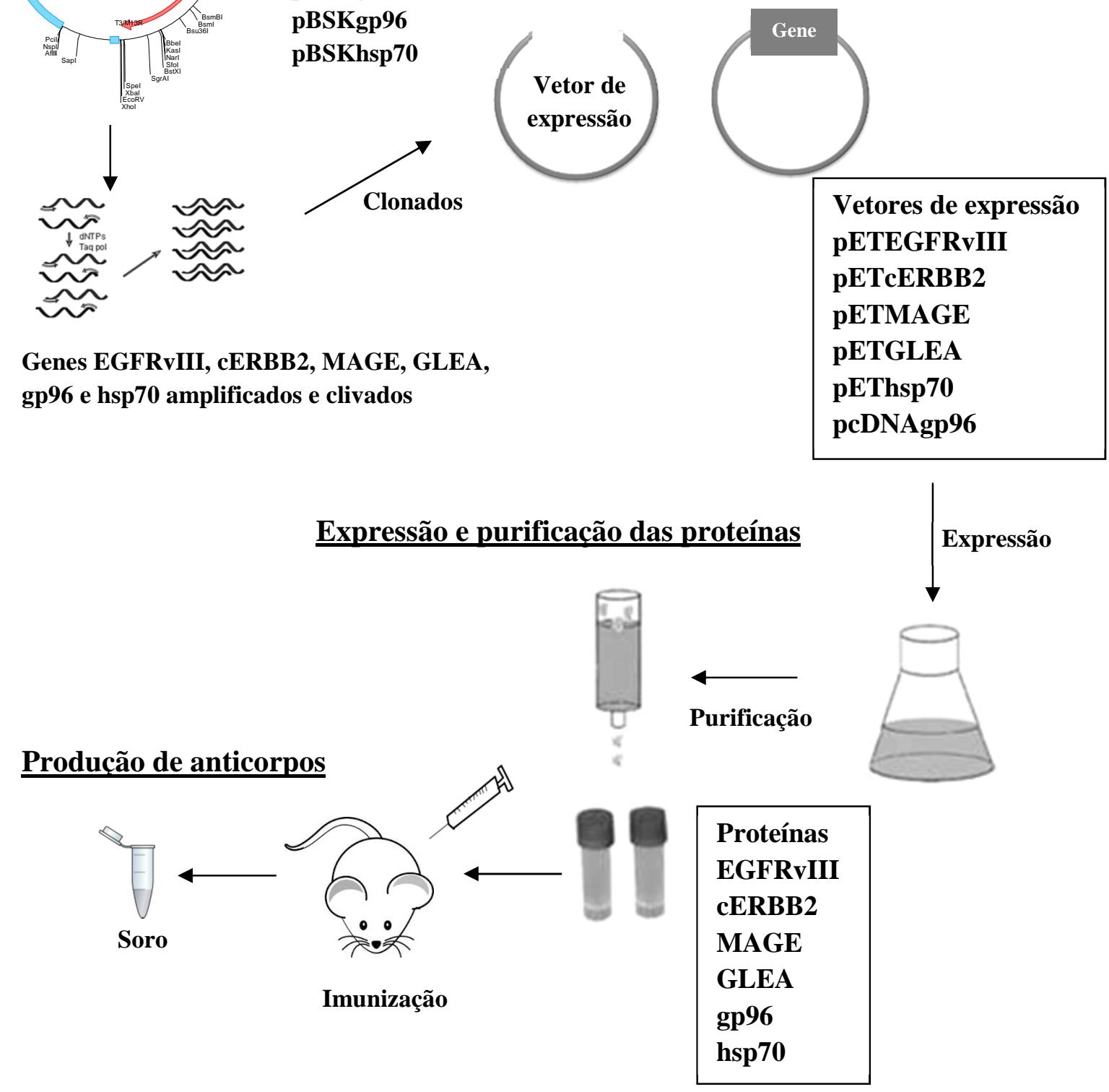


\section{Caracterizacão das vacinas}

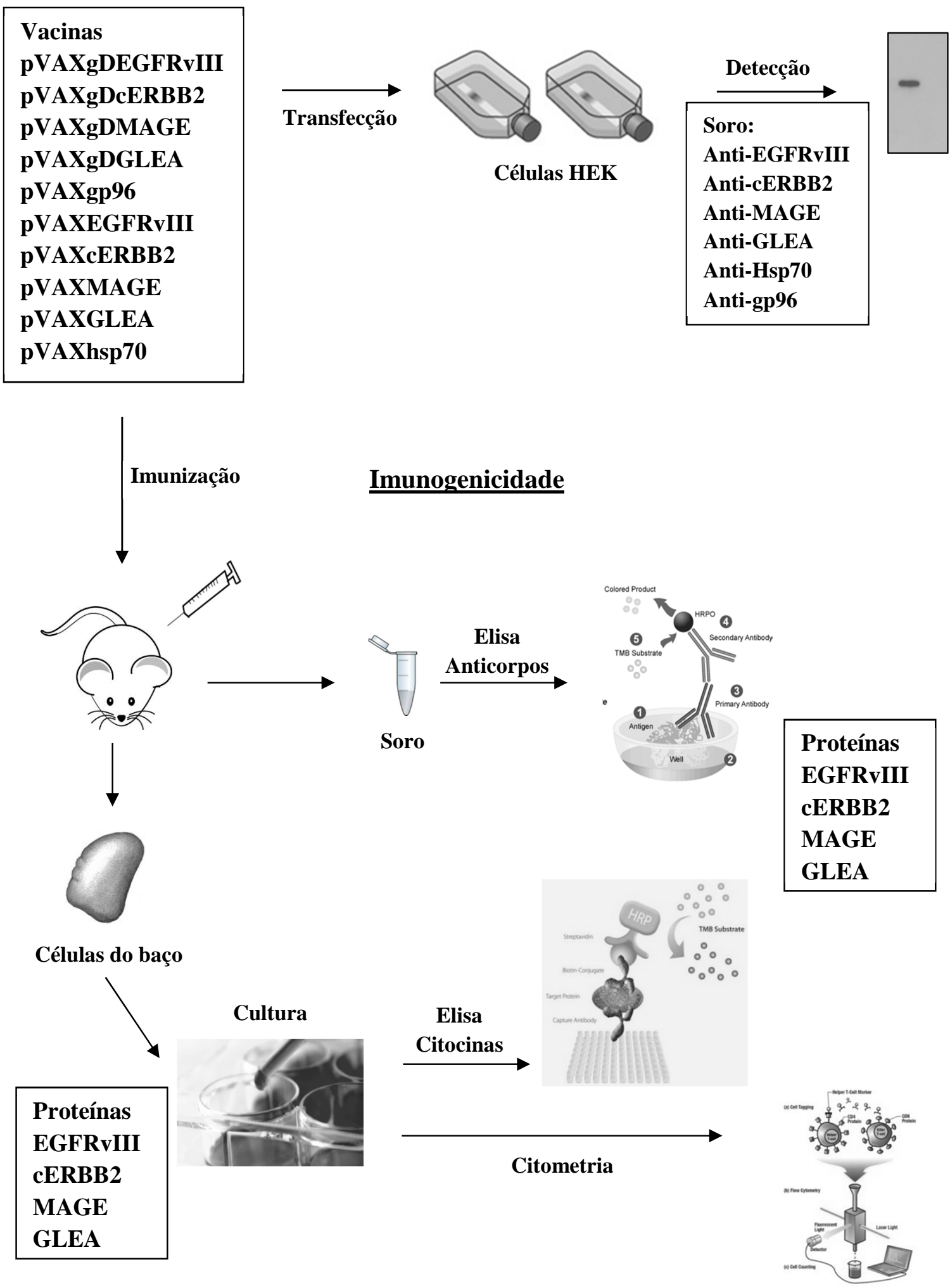




\subsection{MATERIAIS E MÉTODOS}

\section{Considerações iniciais}

» Todas as reações realizadas nesse trabalho, quando necessário, foram completadas com água Milli-Q estéril;

» O termociclador utilizado no decorrer desse trabalho foi MJ Research (PTC-100 ${ }^{\mathrm{TM}}$ );

» Todas as quantificações plasmidiais e dos fragmentos de DNA utilizados durante a construção das vacinas foram feitas em gel de agarose 1\% (Invitrogen);

» As purificações plasmidiais foram realizadas por lise alcalina com SDS (Duodecil Sulfato de Sódio) (Sambrook, 1989);

» As transformações em bactérias foram feitas pelo método de choque térmico (Sambrook, 1989) e plaqueadas em meio sólido-LB ágar (USB), contendo o antibiótico apropriado;

»As bactérias competentes foram preparadas com cloreto de cálcio segundo Sambrook e colaboradores (1989);

» Os antibióticos utilizados foram ampicilina $(100 \mathrm{mg} / \mathrm{mL}$ ) (ARISTON) e canamicina $(50 \mathrm{mg} / \mathrm{mL})$ (Gibco-BRL, USA) nas concentrações finais de $100 \mu \mathrm{g} / \mathrm{mL}$ e $50 \mu \mathrm{g} / \mathrm{mL}$ respectivamente;

»As Reações em Cadeia da Polimerase (PCRs) realizadas nas construções plasmidiais seguiram em sua maioria o programa denominado VAC: $94^{\circ} \mathrm{C}-5^{\prime}, 24$ ciclos de $94^{\circ} \mathrm{C}-1$ ' (desnaturação), $48^{\circ} \mathrm{C}-1^{\prime}$ (anelamento ou temperatura de melting-TM), $72^{\circ} \mathrm{C}-1$ ' (extensão), finalizando com $72^{\circ} \mathrm{C}-10^{\prime}$. As variações dentro desse programa foram na temperatura de anelamento (dependente do oligonucleotídeo utilizado) e tempo de extensão (dependente do tamanho do fragmento a ser amplificado) e foram citadas no decorrer dos materiais e métodos;

» As amostras analisadas em gel de agarose foram acrescidas de tampão da amostra 6X (0,25\% azul de bromofenol; $40 \%$ de sacarose em água) de forma a ficar em uma concentração final de $1 \mathrm{X}$ e submetidas à eletroforese em tampão TAE (Tris-acetato 40mM; EDTA 1mM $\mathrm{pH} 8,3$ ), voltagem $50-60 \mathrm{~V}$. O gel foi corado com $0,5 \mathrm{mg} / \mathrm{mL}$ de brometo de etídio (GibcoBRL, USA) ou $S_{Y B R}{ }^{\circledR}$ gold (Invitrogen) e a visualização dos fragmentos foi feita em luz ultravioleta nos aparelhos Image Master VDS (Pharmacia Biotech, NJ, USA) ou MiniBIS Pro (DNR Bio-Imaging Systems). 
» Todas as reações de sequenciamento realizadas nesse trabalho foram feitas no Centro de Estudo do Genoma Humano-USP/São Paulo utilizando-se o sequenciador ABI 3730 DNA Analyser (Applied Biosystems) e BigDye® Terminator v3.1 Cycle Sequencing Kit.

\subsection{Análise in silico da sequência de aminoácidos e nucleotídeos dos genes EGFRvIII, cERBB2, MAGE-3, GLEA-2 e gp96}

A sequência de aminoácidos (aas) de todas as proteínas foi analisada in silico utilizando-se os programas SignalP 3.0 Server e NetNGlyc 1.0 Server para avaliar à presença de peptídeo sinal e sítios de N-glicosilação, respectivamente. O peptídeo sinal e sítios de Nglicosilação foram retirados e mutados, respectivamente, quando presentes, devido ao sistema de expressão escolhido para produzir as proteínas (inicialmente levedura Kluyveromyces lactis - K. lactis). Essas modificações realizadas na sequência de aminoácidos das proteínas foram passadas para a sequência de nucleotídeos e, ainda in silico, a sequência de nucleotídeos dos genes EGFRvIII, cERBB2, MAGE-3 e GLEA-2 foi inserida no interior da sequência gênica da $\mathrm{gD}$, uma das moléculas imunomoduladoras utilizada nesse trabalho. A inserção dentro da $\mathrm{gD}$ foi realizada entre os sítios $P v u \mathrm{II}$ e $A p a \mathrm{I}$ com a retirada da porção central da gD, 642pb (214 aas, do aa 54 ao 267). Como os genes EGFRvIII e cERBB2 são muito grandes e é conhecido que fragmentos de até 300 aas não interferem com a função da $\mathrm{gD}$ (Watson et al., 1982), foram utilizados apenas os 900 pares de bases (pb) iniciais dessas moléculas para a construção dos vetores. Após essa inserção, os fragmentos gDEGFRvIII, gDcERBB2, gDMAGE-3 e gDGLEA-2 e o gene gp96 foram avaliados quanto a presença de sítios de clivagem em seu interior pelo programa NEBcutter V2.0 (New England BioLabs) para inserção desses sítios de forma correta no início e final dos genes e nos oligonucleotídeos (que foram usados nas amplificações) para realização das construções.

Observação: para facilitar a nomenclatura, os genes MAGE-3 e GLEA-2 foram referidos como MAGE e GLEA. 


\subsection{Construção das vacinas de DNA}

\subsubsection{Clonagem dos fragmentos gDEGFRvIII, gDcERBB2, gDMAGE e gDGLEA e do} gene gp96 no vetor pVAX1 (pVAX)

Os fragmentos gDEGFRvIII, gDcERBB2, gDMAGE e gDGLEA e o gene gp96 foram sintetizados in vitro pela empresa Epoch Biolabs e clonados no vetor pBluescript II SK (pBSK) gerando os plasmídios pBSKgDEGFRvIII, pBSKgDcERBB2, pBSKgDMAGE, pBSKgDGLEA e pBSKgp96 (Figura 1). Os plasmídios foram transformados em E. coli Top10 (Invitrogen). Em seguida, as colônias transformadas foram crescidas em meio LB Broth e submetidas à extração do plasmídio por lise alcalina. Após a extração, os plasmídios pBSKgDEGFRvIII, pBSKgDcERBB2, pBSKgDMAGE, pBSKgDGLEA e pBSKgp96 foram clivados com as enzimas NheI e XbaI (FastDigest-Fermentas) cujos sítios foram inseridos no início e final dos fragmentos (gDEGFRvIII, gDcERBB2, gDMAGE, gDGLEA e gp96), respectivamente. Os fragmentos foram, então, purificados e clonados no vetor pVAX para obtenção das vacinas de DNA.
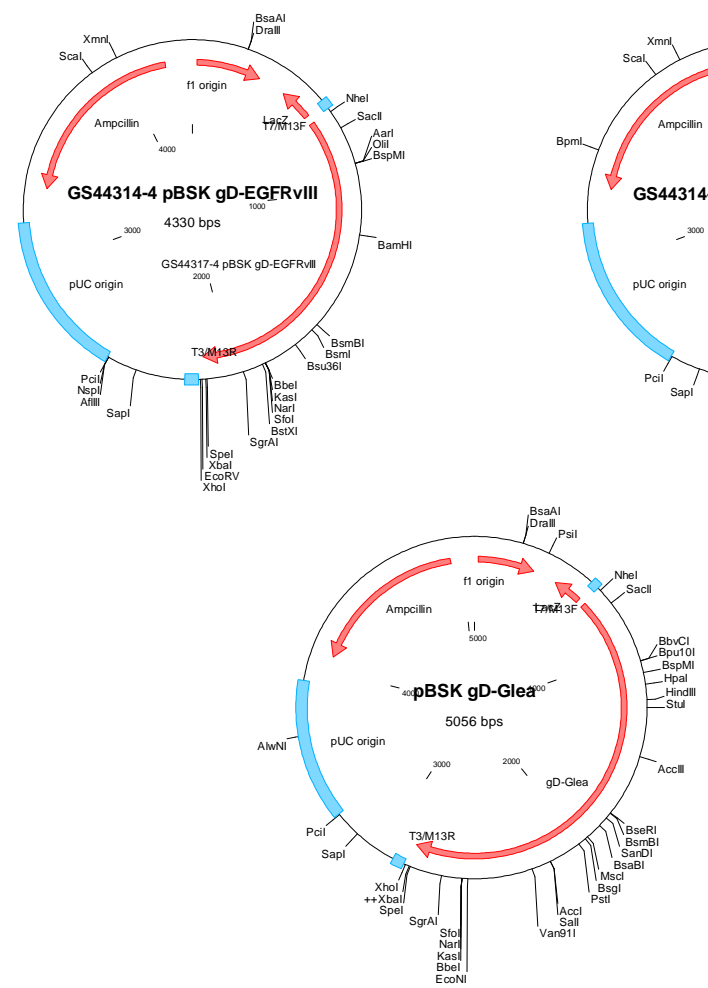
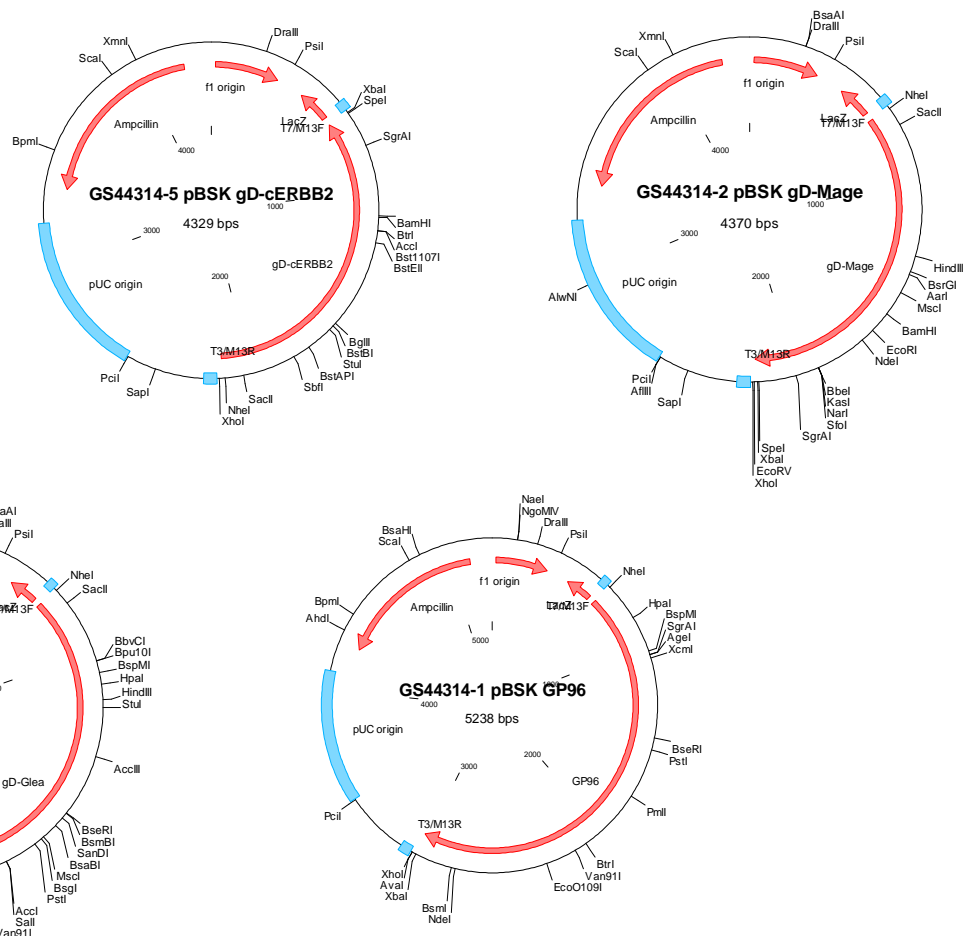

Figura 1: Plasmídios pBluescript II SK contendo as sequências de interesse. Plasmídios construídos pela Epoch Biolabs com os fragmentos de interesse. 
4.2.1.1 Clivagem dos fragmentos gDEGFRvIII, gDcERBB2, gDMAGE, gDGLEA-2 e gp96

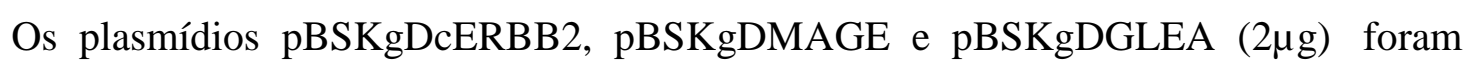
clivados com 2 unidades das enzimas NheI e XbaI juntamente com tampão FastDigest $1 \mathrm{X}$ por aproximadamente 16 horas (overnight) a $37^{\circ} \mathrm{C}$ em um volume final de $60 \mu \mathrm{L}$. Os plasmídios pBSKgDEGFRvIII e pBSKgp96 $(3 \mu \mathrm{g})$ foram clivados com 3 unidades das enzimas NheI e XbaI juntamente com tampão $1 \mathrm{X}$ a $37^{\circ} \mathrm{C}$, overnight em um volume final de $80 \mu \mathrm{L}$ e $70 \mu \mathrm{L}$, respectivamente. As reações de digestão foram analisadas em gel de agarose $1 \%$ e os fragmentos foram purificados utilizando-se o Wizard SV Gel and PCR Clean-Up System (Promega).

\subsubsection{Clivagem do vetor $p V A X$}

$\mathrm{O}$ vetor pVAX (Figura 2), usado no desenvolvimento de vacinas de DNA, foi digerido $(17 \mu \mathrm{g})$ com 2 unidades das enzimas NheI e XbaI, tampão $1 \mathrm{X}$ em um volume final de $70 \mu \mathrm{L}$ a $37^{\circ} \mathrm{C}$ por 4 horas. A digestão foi analisada em gel de agarose $1 \%$ e o vetor foi purificado

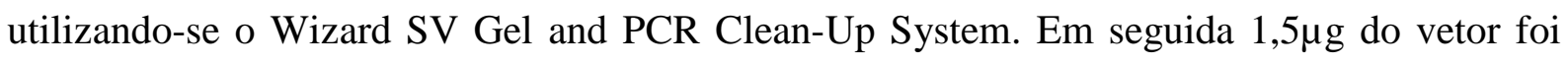
desfosforilado pela adição de 0,3 unidades da enzima CIAP (Promega) em uma reação mantida a $30^{\circ} \mathrm{C}$ por 30 minutos, novamente foi adicionado 0,3 unidades de CIAP seguindo o mesmo protocolo. O vetor desfosforilado foi purificado utilizando-se o Wizard SV Gel and PCR Clean-Up System. Esse procedimento foi necessário para evitar que durante a ligação com o inserto o plasmídio religue sem o fragmento de interesse.

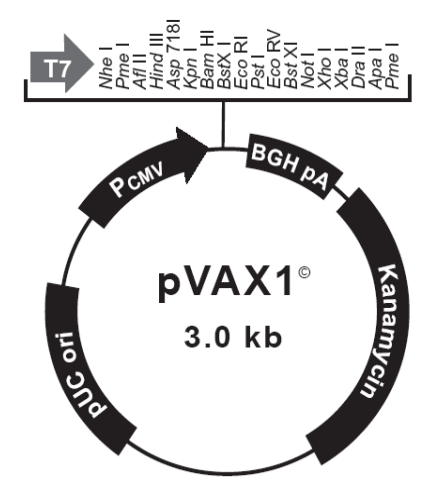

Figura 2: Plasmídio pVAX1. Vetor utilizado nas construções vacinais.

\subsubsection{Clonagem do fragmento gDEGFRvIII no vetor $p$ VAX}

O fragmento gDEGFRvIII clivado com as enzimas NheI e XbaI, obtido como descrito no item 4.2.1.1, foi clonado no plasmídio pVAX, clivado com as mesmas enzimas (item 
4.2.1.2), pela reação de ligação, feita a aproximadamente $25^{\circ} \mathrm{C}$ (temperatura ambiente) por 1 hora, utilizando-se 150ng do inserto gDEGFRvIII, 60ng do vetor pVAX, tampão da enzima $1 \mathrm{X}$ e 0,5 unidade da T4 DNA ligase (Invitrogen) em um volume final de $10 \mu \mathrm{L}$. Todo volume da ligação foi utilizado na transformação de células de E. coli Top10 competentes que foram plaqueadas em meio LB ágar suplementado com canamicina. O vetor $\mathrm{pVAX}$ apresenta gene de resistência a esse antibiótico, dessa forma, realiza-se uma primeira seleção, garantindo que apenas bactérias transformadas com esse vetor cresçam no meio de seleção utilizado.

A seleção do plasmídio recombinante pVAXgDEGFRvIII foi feita, em seguida, realizando uma PCR de colônias, que consiste em uma reação de amplificação utilizando-se como molde uma mistura de água + bactérias, essa mistura foi feita picando-se uma colônia com um palito de dente estéril, dissolvendo-a em água e fervendo por 5 minutos. Na seleção do plasmídio recombinante pVAXgDEGFRvIII foram selecionadas 13 colônias que foram palitadas separadamente e diluídas em $20 \mu \mathrm{L}$ de água estéril. Para a reação utilizou-se, então, $5 \mu \mathrm{L}$ da mistura de água + bactérias como molde, $0,1 \mu \mathrm{M}$ de cada oligonucleotídeo $\left(\mathrm{T} 7 \mathrm{p}^{* *} \mathrm{e}\right.$ EGFRvIII_Rseq**), 0,2mM de cada deoxirribonucleotídeo (dNTPs) (Invitrogen), tampão 1X, $1,5 \mathrm{mM}$ de $\mathrm{MgCl}_{2}$ e 1 unidade da enzima Taq DNA polimerase (Fermentas) em um volume final de $20 \mu \mathrm{L}$ (programa VAC).

\section{T7 promoter (T7p): 5' TAATACGACTCACTATAGGG 3'}

\section{EGFRvIII_Rseq: 5' TCTAGGTTCTCAAAGGCATG 3'}

**O oligonucleotídeo T7p hibridiza no vetor pVAX e o EGFRvIII_Rseq no interior do gene EGFRvIII. Dessa forma, foi possível avaliar a presença e direção do fragmento gDEGFRvIII no interior desse vetor uma vez que ele (assim como os demais fragmentos) pode ser ligado na direção correta ou invertida devido aos sítios NheI e XbaI serem coesivos.

O produto da PCR foi analisado em gel de agarose $1 \%$ e a partir desse resultado foi realizada a extração dos plasmídios das colônias que apresentaram banda de amplificação do tamanho esperado. Esses plasmídios foram submetidos a uma reação de clivagem: 400ng de cada plasmídio foram digeridos com 0,5 unidade das enzimas NheI e XbaI, tampão FastDigest $1 \mathrm{X}$ em uma reação final de $20 \mu \mathrm{L}$, overnight a $37^{\circ} \mathrm{C}$. A digestão foi analisada em gel de agarose $1 \%$. 
A partir dos resultados obtidos com a PCR e a análise de restrição, um clone que apresentava o plasmídio recombinante pVAXgDEGFRvIII foi analisado por sequenciamento utilizando-se os oligonucleotídeos T7p e BGH** para confirmação da clonagem.

\section{BGH: 5 'TAGAAGGCACAGTCGAGG 3'}

**O oligonucleotídeo BGH anela no vetor $\mathrm{pVAX}$.

\subsubsection{Clonagem do fragmento gDcERBB2 no vetor $p V A X$}

O fragmento gDcERBB2 clivado com as enzimas NheI e XbaI, obtido como descrito no item 4.2.1.1, foi clonado no plasmídio pVAX, clivado com as mesmas enzimas (item 4.2.1.2), pela reação de ligação feita a temperatura ambiente por 1 hora, utilizando-se 160ng do inserto gDcERBB2, 60ng do vetor pVAX, tampão da enzima $1 \mathrm{X}$ e 0,5 unidade da T4 DNA ligase em um volume final de $10 \mu \mathrm{L}$. Todo volume da ligação foi utilizado na transformação de células de E. coli Top10 competentes que foram plaqueadas em meio LB ágar suplementado com canamicina.

A seleção do plasmídio recombinante pVAXgDcERBB2 foi feita realizando uma PCR de colônias com 6 grupos contendo 5 colônias cada (nesse caso, 5 colônias foram diluídas na mesma água estéril). As bactérias foram diluídas em $50 \mu \mathrm{L}$ de água estéril, fervidas e utilizadas $(5 \mu \mathrm{L})$ como molde, juntamente com $0,1 \mu \mathrm{M}$ de cada oligonucleotídeo (T7p e RgDApa**), 0,2mM de cada dNTPs, tampão $1 \mathrm{X}, 1,5 \mathrm{mM}$ de $\mathrm{MgCl}_{2}$ e 1 unidade da enzima Taq DNA polimerase em um volume final de $20 \mu \mathrm{L}$ (programa VAC).

\section{RgDApa: 5' TGCGTGGCGTTGGGGGTCTC 3'}

**O oligonucleotídeo RgDApa hibridiza no interior da gD (logo após o gene inserido) sendo possível avaliar a presença e direção do fragmento gDcERBB2.

O produto da PCR foi analisado em gel de agarose $1 \%$ e a partir desse resultado foi realizada uma nova PCR com 5 plasmídios já extraídos de um dos grupos que apresentou banda de amplificação do tamanho esperado. Na reação foi utilizado 40ng de cada plasmídio como molde juntamente com 0,1 $\mu \mathrm{M}$ de cada oligonucleotídeo (T7p e RgDApa), 0,2mM de cada dNTPs, tampão $1 \mathrm{X}, 1,5 \mathrm{mM}$ de $\mathrm{MgCl}_{2}$ e 1 unidade da enzima Taq DNA polimerase em um volume final de $20 \mu \mathrm{L}$ (programa VAC). 
A partir dos resultados obtidos com as PCRs, um clone que apresentava o plasmídio recombinante pVAXgDcERBB2 foi analisado por sequenciamento utilizando-se os oligonucleotídeos T7p e BGH para confirmação da clonagem.

\subsubsection{Clonagem do fragmento gDMAGE no vetor $p V A X$}

O fragmento gDMAGE clivado com as enzimas NheI e XbaI, obtido como descrito no item 4.2.1.1, foi clonado no plasmídio pVAX, clivado com as mesmas enzimas (item 4.2.1.2), pela reação de ligação feita a temperatura ambiente por 1 hora, utilizando-se 160ng do inserto gDMAGE, 60ng do vetor pVAX, tampão da enzima 1X e 0,5 unidade da T4 DNA ligase em um volume final de $10 \mu \mathrm{L}$. Todo volume da ligação foi utilizado na transformação de células de E. coli Top10 competentes que foram plaqueadas em meio LB ágar suplementado com canamicina.

A seleção do plasmídio recombinante pVAXgDMAGE foi feita realizando duas PCRs de colônias com 6 grupos contendo 5 colônias cada. As bactérias foram diluídas em $50 \mu \mathrm{L}$ de água estéril e para cada reação utilizou-se $5 \mu \mathrm{L}$ da mistura de água + bactérias como molde, 0,1 $\mu \mathrm{M}$ de cada oligonucleotídeo (T7p e MAGE_Rseq** ou T7p e RgDApa), 0,2mM de cada dNTPs, tampão $1 \mathrm{X}, 1,5 \mathrm{mM}$ de $\mathrm{MgCl}_{2}$ e 1 unidade da enzima Taq DNA polimerase em um volume final de $20 \mu \mathrm{L}$ (programa VAC).

MAGE_Rseq: 5' AAAGACCAGCTGCAAGGAAC 3',

**O oligonucleotídeo MAGE_Rseq anela no interior do gene MAGE sendo possível avaliar a presença e direção do fragmento gDMAGE.

O produto das PCRs foram analisados em gel de agarose $1 \%$ e a partir desses resultados foi realizada a extração de 5 plasmídios de um dos grupos que apresentou banda de amplificação do tamanho esperado. Esses plasmídios foram submetidos a uma reação de clivagem: 320ng de cada plasmídio foram digeridos com 0,5 unidade das enzimas PmeI** (Fermentas) e HindIII** (Invitrogen), tampão OneforAll 1X (Pharmacia Biotech) em uma reação final de $20 \mu \mathrm{L}$ a $37^{\circ} \mathrm{C}$, overnight. A digestão foi analisada em gel de agarose $1 \%$.

**A enzima PmeI cliva dentro do vetor pVAX e a HindIII no interior do fragmento gDMAGE sendo possível avaliar a presença e direção do fragmento de interesse. 
A partir dos resultados obtidos com a PCR e a análise de restrição, um clone que apresentava o plasmídio recombinante pVAXgDMAGE foi analisado por sequenciamento utilizando-se os oligonucleotídeos, MAGE_Rseq, T7p e BGH para confirmação da clonagem.

\subsubsection{Clonagem do fragmento gDGLEA no vetor $p V A X$}

O fragmento gDGLEA clivado com as enzimas NheI e Xbal, obtido como descrito no item 4.2.1.1, foi clonado no plasmídio pVAX, clivado com as mesmas enzimas (item 4.2.1.2), pela reação de ligação realizada a temperatura ambiente por 1 hora utilizando-se 160ng do inserto gDGLEA, 60ng do vetor pVAX, tampão da enzima 1X e 0,5 unidade da T4 DNA ligase em um volume final de $10 \mu \mathrm{L}$. Todo volume da ligação foi utilizado na transformação de células de E. coli Top10 competentes que foram plaqueadas em meio LB ágar suplementado com canamicina.

A seleção do plasmídio recombinante pVAXgDGLEA foi feita realizando uma PCR de 13 colônias individuais. As bactérias foram diluídas em água estéril, fervidas e, em seguida, utilizadas $(5 \mu \mathrm{L})$ como molde na reação com $0,1 \mu \mathrm{M}$ de cada oligonucleotídeo (T7p e GLEA_2Rseq**), 0,2mM de cada dNTPs, tampão $1 \mathrm{X}, 1,5 \mathrm{mM}$ de $\mathrm{MgCl}_{2}$ e 1 unidade da enzima Taq DNA polimerase em um volume final de $20 \mu \mathrm{L}$ (programa VAC, com TM de $50^{\circ}$ e extensão de 2 minutos).

\section{GLEA_2Rseq: 5' TTCTTTAAACTTCTCTCG 3'}

**O oligonucleotídeo GLEA_2Rseq hibridiza no interior do gene GLEA sendo possível avaliar a presença e direção do fragmento gDGLEA.

O produto da PCR foi analisado em gel de agarose $1 \%$ e a partir desse resultado foi realizada a extração de 7 plasmídios que apresentaram banda de amplificação do tamanho esperado. Esses plasmídios foram submetidos a uma reação de clivagem: 750ng de cada plasmídio foram digeridos com 0,5 unidade das enzimas PmeI e HindIII**, tampão OneforAll $1 \mathrm{X}$ em uma reação final de $20 \mu \mathrm{L}$ a $37^{\circ} \mathrm{C}$, overnight. A digestão foi analisada em gel de agarose $1 \%$.

**A enzima HindIII também cliva o interior do fragmento gDGLEA sendo possível avaliar a presença e direção do fragmento de interesse.

A partir dos resultados obtidos com a PCR e a análise de restrição, um clone que apresentava o plasmídio recombinante pVAXgDGLEA foi analisado por sequenciamento 
utilizando-se os oligonucleotídeos T7p, GLEA_1Sseq**, GLEA_2Rseq, GLEA_3Sseq** e BGH para confirmação da clonagem.

\section{GLEA_1Sseq: 5' AAAGATCAGAATATTGTGG 3' \\ GLEA_3Sseq: 5', AATACTCGGAAAACACTGAC 3'}

**Os oligonucleotídeos GLEA_1Sseq e GLEA_3Sseq anelam no interior do gene GLEA.

\subsubsection{Clonagem do gene gp96 no vetor $p V A X$}

O fragmento gp96 clivado com as enzimas NheI e XbaI, obtido como descrito no item 4.2.1.1, foi clonado no plasmídio pVAX, clivado com as mesmas enzimas (item 4.2.1.2), pela reação de ligação, feita a temperatura ambiente por 1 hora, utilizando-se 150ng do inserto gp96, 60ng do vetor pVAX, tampão da enzima 1X e 0,5 unidade da T4 DNA ligase em um volume final de $10 \mu \mathrm{L}$. Todo volume da ligação foi utilizado na transformação de células de $E$. coli Top10 competentes que foram plaqueadas em meio LB ágar suplementado com canamicina.

A seleção do plasmídio recombinante pVAXgp96 foi feita realizando uma PCR de colônias com 5 grupos contendo 5 colônias cada. As bactérias foram diluídas em $50 \mu \mathrm{L}$ de água estéril, fervidas e utilizadas $(5 \mu \mathrm{L})$ como molde, juntamente com $0,1 \mu \mathrm{M}$ de cada oligonucleotídeo (T7p e gp96_2Rseq**), 0,2mM de cada dNTPs, tampão 1X, 1,5mM de $\mathrm{MgCl}_{2}$ e 1 unidade da enzima Taq DNA polimerase em um volume final de $20 \mu \mathrm{L}$ (programa VAC).

\section{Gp96_2Rseq: 5' ACTGGCCATCTTCCTGTGC 3'}

**O oligonucleotídeo gp96_2Rseq hibridiza no interior do gene gp96 sendo possível avaliar a presença e direção do fragmento gp96.

O produto da PCR foi analisado em gel de agarose $1 \%$ e a partir desse resultado foi realizada a extração de 5 plasmídios de um dos grupos que apresentou banda de amplificação do tamanho esperado. Esses plasmídios foram submetidos a uma reação de clivagem: 480ng de cada plasmídio foram digeridos com 0,5 unidade das enzimas PmeI e NdeI** (Fermentas), OneforAll $1 \mathrm{X}$ em uma reação final de $20 \mu \mathrm{L}$ a $37^{\circ} \mathrm{C}$, overnight. A digestão foi analisada em gel de agarose $1 \%$.

**A enzima NdeI cliva no interior do gene gp96 sendo possível avaliar a presença e direção do fragmento gp96. 
A partir dos resultados obtidos com a PCR e a análise de restrição, um clone que apresentava o plasmídio recombinante pVAXgp96 foi analisado por sequenciamento utilizando-se os oligonucleotídeos T7p, gp96_1Sseq**, gp96_3Sseq**,gp96_4Sseq** e BGH para confirmação da clonagem.

Gp96_1Sseq: 5' AAACCTTGGTACCATAGC 3'

Gp96_3Sseq: 5' ACTGTCTGGGACTGGGAAC 3'

Gp96_4Sseq: 5' TGAAGACCACTCGCAACG 3'

**Todos os oligonucleotídeos gp96_seq anelam no interior do gene gp96.

\subsubsection{Clonagem dos genes EGFRvIII, cERBB2, MAGE, GLEA e hsp70 no vetor pVAX}

Os plasmídios pBSKgDEGFRvIII, pBSKgDcERBB2, pBSKgDMAGE, pBSKgDGLEA e pBSKhsp70 (cedido gentilmente pela empresa Farmacore Biotechnology Ltd.) também foram utilizados para amplificação dos genes EGFRvIII, cERBB2, MAGE, GLEA e hsp70 para posterior clonagem no vetor pVAX e obtenção das vacinas de DNA. Os genes EGFRvIII, cERBB2, MAGE e GLEA foram clonados sem a presença do gene que codifica a proteína imunomoduladora $\mathrm{gD}$ para posteriormente serem utilizados em combinação com as outras proteínas imunomoduladoras, gp96 e Hsp70.

\subsubsection{Amplificação e clivagem dos genes EGFRvIII, cERBB2, MAGE, GLEA e hsp70}

Os genes EGFRvIII, cERBB2, MAGE, GLEA e hsp70 foram amplificados para a clonagem no vetor pVAX utilizando-se como molde os plasmídios pBSKgDEGFRvIII, pBSKgDcERBB2, pBSKgDMAGE, pBSKgDGLEA e pBSKhsp70 e os seguintes iniciadores:

EGFRpVAX_S:

5'TACTAGCTAGCACCATGCTGGAGGAAAAGAAAGGTAATTATGTGGTGACAGATCACG3'

EGFRpVAX_R: 5'ATTCTAGATCAGCAGTGGGGGCCGTC 3'

ERBB2pVAX_S: 5'TACTAGCTAGCACCATGAAGCTGCGGCTCCC 3'

ERBB2pVAX_R: 5'ATTCTAGATCACCGCTGTGTTCCATC 3'

MAGEpVAX_S: 5'TACTAGCTAGCACCATGCCTCTTGAGCAGAG 3'

MAGEpVAX_R: 5'ATTCTAGATCACTCTTCCCCCTCTC 3'

GLEApVAX_S: 5'TACTAGCTAGCACCATGACAAAGCATCCACC 3'

GLEAPVAX_R: 5'ATTCTAGATCACTTCTTTGGCTTCAC 3'

Hsp70pVAX_S: 5'TACTAGCTAGCACCATGGCCAAAGCCGCGGCGATC 3' 


\section{Hsp70pVAX_R: 5'ATTCTAGATCAATCCACCTCCTCAATG 3'}

Nos oligonucleotídeos sense (S) foram incluídos um sítio de ancoragem (em cinza), o sítio da enzima NheI (região sublinhada), a sequência Kozac (ACCATG) (Kozak, 1990) e a porção inicial do gene (aproximadamente 18 bases, com exceção do EGFRvIII, 40 bases) e nos oligonucleotídeos antisense ou reverse (R) foram inseridos a porção final do gene, um stop códon (em negrito), o sítio da enzima XbaI (região sublinhada) e um sítio de ancoragem (em cinza).

Na reação de amplificação, além dos $0,1 \mu \mathrm{M}$ de cada oligonucleotídeo foi utilizado 100-150ng do molde, 0,2mM de cada dNTPs, tampão $1 \mathrm{X}$ e 5 unidades da enzima High fidelity (Fermentas); a reação foi feita em $100 \mu \mathrm{L}$ finais utilizando o programa VAC (1 minuto de extensão para a amplificação dos genes EGFRvIII, cERBB2 e MAGE e 2 minutos para a amplificação do gene GLEA e hsp70). Os produtos das amplificações foram analisados em gel de agarose $1 \%$ e purificados utilizando-se o Wizard SV Gel and PCR Clean-Up System.

Os genes EGFRvIII, cERBB2, MAGE, GLEA e hsp70 após purificação foram clivados com as enzimas NheI e XbaI, EGFRvIII: 1,5 $\mu \mathrm{g}$ do gene foi clivado com 3 unidades de cada enzima, juntamente com tampão $1 \mathrm{X}$ em um volume final de $60 \mu \mathrm{L}$, overnight a $37^{\circ} \mathrm{C}$; cERBB2, MAGE, GLEA e hsp70: 2,4 $\mu$ g de cada gene foram clivados com 4 unidades de cada enzima, nas mesmas condições anteriores. Os fragmentos clivados foram diretamente purificados utilizando-se o Wizard SV Gel and PCR Clean-Up System.

\subsubsection{Clonagem do gene EGFRvIII no vetor $p$ VAX}

O fragmento EGFRvIII clivado com as enzimas NheI e XbaI, como descrito no item anterior, foi clonado no plasmídio pVAX, clivado com as mesmas enzimas (item 4.2.1.2), pela reação de ligação feita a temperatura ambiente por 1 hora, utilizando-se 150ng do inserto EGFRvIII, 60ng do vetor pVAX, tampão da enzima 1X e 0,5 unidade da T4 DNA ligase em um volume final de $10 \mu \mathrm{L}$. Todo volume da ligação foi utilizado na transformação de células de E. coli Top10 competentes que foram plaqueadas em meio LB ágar suplementado com canamicina.

A seleção do plasmídio recombinante pVAXEGFRvIII foi feita realizando uma PCR de 13 colônias individuais diluídas em $20 \mu \mathrm{L}$ de água estéril. Na reação utilizou-se $5 \mu \mathrm{L}$ da mistura de água + bactérias como molde, $0,1 \mu \mathrm{M}$ de cada oligonucleotídeo (T7p e 
EGFRvIII_Rseq), 0,2mM de cada dNTPs, tampão $1 \mathrm{X}, 1,5 \mathrm{mM}$ de $\mathrm{MgCl}_{2}$ e 1 unidade da enzima Taq DNA polimerase em um volume final de $20 \mu \mathrm{L}$ (programa VAC).

O produto da PCR foi analisado em gel de agarose $1 \%$ e a partir desse resultado foi realizada a extração dos plasmídios das colônias que apresentaram banda de amplificação do tamanho esperado. Esses plasmídios foram submetidos a uma reação de clivagem, na qual 400ng de cada plasmídio foram digeridos com 0,5 unidade das enzimas NheI e XbaI, tampão FastDigest $1 \mathrm{X}$ em uma reação final de $20 \mu \mathrm{L}$, overnight a $37^{\circ} \mathrm{C}$. A digestão foi analisada em gel de agarose $1 \%$.

A partir dos resultados obtidos com a PCR e a análise de restrição, um clone que apresentava o plasmídio recombinante pVAXEGFRvIII foi analisado por sequenciamento utilizando-se os oligonucleotídeos T7p e BGH para confirmação da clonagem.

\subsubsection{Clonagem do gene cERBB2 no vetor $p V A X$}

O fragmento cERBB2 clivado com as enzimas NheI e XbaI, obtido como descrito no item 4.2.2.1, foi clonado no plasmídio pVAX, clivado com as mesmas enzimas (item 4.2.1.2), pela reação de ligação feita a temperatura ambiente por 1 hora, utilizando-se 160ng do inserto cERBB2, 60ng do vetor pVAX, tampão da enzima 1X e 0,5 unidade da T4 DNA ligase em um volume final de $10 \mu \mathrm{L}$. Todo volume da ligação foi utilizado na transformação de células de E. coli Top10 competentes que foram plaqueadas em meio LB ágar suplementado com canamicina.

A seleção do plasmídio recombinante pVAXcERBB2 foi feita realizando uma PCR de colônias com 5 grupos contendo 5 colônias cada. As colônias foram diluídas em $50 \mu \mathrm{L}$ de água estéril, fervidas e utilizadas $(5 \mu \mathrm{L})$ como molde, juntamente com $0,1 \mu \mathrm{M}$ de cada oligonucleotídeo (T7p e cERBB2_Rseq**), 0,2mM de cada dNTPs, tampão 1X, 1,5mM de $\mathrm{MgCl}_{2}$ e 1 unidade da enzima Taq DNA polimerase em um volume final de $20 \mu \mathrm{L}$ (programa $\mathrm{VAC})$.

\section{cERBB2_Rseq: 5' TCTATCAGTGTGAGAGCCAG 3'}

**O oligonucleotídeo cERBB2_Rseq hibridiza no interior do gene cERBB2 sendo possível avaliar a presença e direção do gene no interior do vetor.

O produto da PCR foi analisado em gel de agarose $1 \%$ e a partir desse resultado foi realizada a extração de 5 plasmídios de um dos grupos que apresentou banda de amplificação 
do tamanho esperado. Esses plasmídios foram submetidos à outra PCR realizada com 60ng de cada plasmídio como molde, $0,1 \mu \mathrm{M}$ de cada oligonucleotídeo (T7p e cERBB2_Rseq), 0,2mM de cada dNTPs, tampão $1 \mathrm{X}, 1,5 \mathrm{mM}$ de $\mathrm{MgCl}_{2}$ e 1 unidade da enzima Taq DNA polimerase em um volume final de $20 \mu \mathrm{L}$ (programa VAC). A PCR foi analisada em gel de agarose $1 \%$.

A partir dos resultados obtidos com as PCRs, um clone que apresentava o plasmídio recombinante pVAXcERBB2 foi analisado por sequenciamento utilizando-se os oligonucleotídeos T7p e BGH para confirmação da clonagem.

\subsubsection{Clonagem do gene MAGE no vetor $p V A X$}

O fragmento MAGE clivado com as enzimas NheI e XbaI, obtido como descrito no item 4.2.2.1, foi clonado no plasmídio pVAX, clivado com as mesmas enzimas (item 4.2.1.2), pela reação de ligação feita a temperatura ambiente por 1 hora, utilizando-se 160ng do inserto MAGE, 120ng do vetor pVAX, tampão da enzima 1X e 0,5 unidade da T4 DNA ligase em um volume final de $10 \mu \mathrm{L}$. Todo volume da ligação foi utilizado na transformação de células de E. coli Top10 competentes que foram plaqueadas em meio LB ágar suplementado com canamicina.

A seleção do plasmídio recombinante pVAXMAGE foi feita realizando uma PCR de colônias com 5 grupos contendo 5 colônias cada. As colônias foram diluídas em $50 \mu \mathrm{L}$ de água estéril e a reação realizada com $5 \mu \mathrm{L}$ da mistura de água + bactérias como molde, $0,1 \mu \mathrm{M}$ de cada oligonucleotídeo (T7p e MAGE_Rseq), 0,2mM de cada dNTPs, tampão 1X, 1,5mM de $\mathrm{MgCl}_{2}$ e 1 unidade da enzima Taq DNA polimerase em um volume final de $20 \mu \mathrm{L}$ (programa VAC).

O produto da PCR foi analisado em gel de agarose $1 \%$ e a partir desse resultado foi realizada a extração de 5 plasmídios de um dos grupos que apresentou banda de amplificação do tamanho esperado. Esses plasmídios foram submetidos à outra PCR e uma reação de clivagem. A PCR foi realizada com $60 \mathrm{ng}$ de cada plasmídio como molde, $0,1 \mu \mathrm{M}$ de cada oligonucleotídeo (T7p e MAGE_Rseq), 0,2mM de cada dNTPs, tampão 1X, 1,5mM de $\mathrm{MgCl}_{2}$ e 1 unidade da enzima Taq DNA polimerase em um volume final de $20 \mu \mathrm{L}$ (programa VAC). A clivagem foi feita com 480ng de cada plasmídio, 0,5 unidade da enzima ApaI**, tampão B $1 X$ (Fermentas) em uma reação final de $20 \mu \mathrm{L}$ a $37^{\circ} \mathrm{C}$ por 6 horas. A digestão e a PCR foram analisadas em gel de agarose $1 \%$.

**A enzima ApaI cliva no interior do vetor pVAX e no gene MAGE sendo possível avaliar a 
presença e direção do fragmento no interior do vetor.

A partir dos resultados obtidos com a PCR e a análise de restrição, um clone que apresentava o plasmídio recombinante pVAXMAGE foi analisado por sequenciamento utilizando-se os oligonucleotídeos T7p e BGH para confirmação da clonagem.

\subsubsection{Clonagem do gene GLEA no vetor $p V A X$}

O fragmento GLEA clivado com as enzimas NheI e Xbal, obtido como descrito no item 4.2.2.1, foi clonado no plasmídio pVAX, clivado com as mesmas enzimas (item 4.2.1.2), pela reação de ligação feita a temperatura ambiente por 1 hora, utilizando-se 160ng do inserto GLEA, 60ng do vetor pVAX, tampão da enzima 1X e 0,5 unidade da T4 DNA ligase em um volume final de $10 \mu \mathrm{L}$. Todo volume da ligação foi utilizado na transformação de células de $E$. coli Top10 competentes que foram plaqueadas em meio LB ágar suplementado com canamicina.

A seleção do plasmídio recombinante pVAXGLEA foi feita realizando uma PCR de colônias com 5 grupos contendo 5 colônias cada. As colônias foram diluídas em $50 \mu \mathrm{L}$ de água estéril e a reação realizada com $5 \mu \mathrm{L}$ da mistura de água + bactérias como molde, $0,1 \mu \mathrm{M}$ de cada oligonucleotídeo (T7p e GLEA_2Rseq), 0,2mM de cada dNTPs, tampão 1X, 1,5mM de $\mathrm{MgCl}_{2}$ e 1 unidade da enzima Taq DNA polimerase em um volume final de $20 \mu \mathrm{L}$ (programa VAC).

O produto da PCR foi analisado em gel de agarose $1 \%$ e a partir desse resultado foi realizada a extração de 5 plasmídios de um dos grupos que apresentou banda de amplificação do tamanho esperado. Esses plasmídios foram submetidos à outra PCR realizada com 60ng de cada plasmídio como molde, $0,1 \mu \mathrm{M}$ de cada oligonucleotídeo (T7p e GLEA_2Rseq), 0,2mM de cada dNTPs, tampão $1 \mathrm{X}, 1,5 \mathrm{mM}$ de $\mathrm{MgCl}_{2}$ e 1 unidade da enzima Taq DNA polimerase em um volume final de $20 \mu \mathrm{L}$ (programa VAC). A PCR foi analisada em gel de agarose $1 \%$.

A partir dos resultados obtidos com as PCRs, um clone que apresentava o plasmídio recombinante pVAXGLEA foi analisado por sequenciamento utilizando-se os oligonucleotídeos T7p, Glea_1Sseq e BGH para confirmação da clonagem.

\subsubsection{Clonagem do gene hsp70 no vetor pVAX}

O gene hsp70 clivado com as enzimas NheI e Xbal, obtido como descrito no item 4.2.2.1, foi clonado no plasmídio pVAX, clivado com as mesmas enzimas (item 4.2.1.2), pela reação de ligação feita a temperatura ambiente por 1 hora, utilizando-se 160ng do inserto 
hsp70, 60ng do vetor pVAX, tampão da enzima 1X e 0,5 unidade da T4 DNA ligase em um volume final de $10 \mu \mathrm{L}$. Todo volume da ligação foi utilizado na transformação de células de $E$. coli Top10 competentes que foram plaqueadas em meio LB ágar suplementado com canamicina.

A seleção do plasmídio recombinante pVAXhsp70 foi feita realizando uma PCR de colônias com 5 grupos contendo 5 colônias cada. As colônias foram diluídas em $50 \mu \mathrm{L}$ de água estéril, fervidas e utilizadas $(5 \mu \mathrm{L})$ como molde, juntamente com $0,1 \mu \mathrm{M}$ de cada oligonucleotídeo (T7p e Hsp70_2Rseq**), 0,2mM de cada dNTPs, tampão 1X, 1,5mM de $\mathrm{MgCl}_{2}$ e 1 unidade da enzima Taq DNA polimerase em um volume final de $20 \mu \mathrm{L}$ (programa VAC).

\section{Hsp70_2Rseq: 5' AGCCCCGCGATCACACCC 3'}

**O oligonucleotídeo Hsp70_2Rseq hibridiza no interior do gene hsp70 sendo possível avaliar a presença e direção do fragmento no interior do vetor.

O produto da PCR foi analisado em gel de agarose $1 \%$ e a partir desse resultado foi realizada a extração de 5 plasmídios de um dos grupos que apresentou banda de amplificação do tamanho esperado. Esses plasmídios foram submetidos à outra PCR realizada com 60ng de cada plasmídio como molde, $0,1 \mu \mathrm{M}$ de cada oligonucleotídeo (T7p e Hsp70_2Rseq), 0,2mM de cada dNTPs, tampão $1 \mathrm{X}, 1,5 \mathrm{mM}$ de $\mathrm{MgCl}_{2}$ e 1 unidade da enzima Taq DNA polimerase em um volume final de $20 \mu \mathrm{L}$ (programa VAC). A PCR foi analisada em gel de agarose $1 \%$.

A partir dos resultados obtidos com as PCRs, um clone que apresentava o plasmídio recombinante pVAXhsp70 foi analisado por sequenciamento utilizando-se os oligonucleotídeos T7p, Hsp70_1SSeq** e BGH para confirmação da clonagem.

\section{Hsp70_1Sseq: 5' CTACCCGGTGACCAACGC 3'}

**O oligonucleotídeo Hsp70_1Sseq hibridiza no interior do gene hsp70. 


\subsection{Construção dos vetores de expressão}

4.3.1 Clonagem dos genes EGFRvIII, cERBB2, MAGE, GLEA e hsp70 no vetor pET28a $\underline{(\mathbf{p E T})}$

Os plasmídios pBSKgDEGFRvIII, pBSKgDcERBB2, pBSKgDMAGE, pBSKgDGLEA e pBSKhsp70 também foram utilizados para amplificação dos genes EGFRvIII, cERBB2, MAGE, GLEA e hsp70 para clonagem no vetor pET (Novagen). Esse vetor é usado na expressão de genes de interesse em $E$. coli apresentando nas suas porções N e C-terminal códons que codificam uma cauda de histidina importante na identificação e purificação das proteínas expressas nesse sistema.

\subsubsection{Amplificação e clivagem dos genes EGFRvIII, cERBB2, MAGE, GLEA e hsp70}

Os genes EGFRvIII, cERBB2, MAGE, GLEA e hsp70 foram amplificados para a clonagem no vetor pET utilizando-se como molde os plasmídios pBSKgDEGFRvIII, pBSKgDcERBB2, pBSKgDMAGE, pBSKgDGLEA e pBSKhsp70 e os seguintes iniciadores:

EGFRpET28a_S:5'TACTAGCTAGCATGCTGGAGGAAAAGAAAG 3'

EGFRpET28a_R: 5'GATCTCGAGTCAGCAGTGGGGGCCGTC 3'

ERBB2pET28a_S: 5'TACTAGCTAGCATGAAGCTGCGGCTCCC 3'

ERBB2pET28a_R: 5'GATCTCGAGTCACCGCTGTGTTCCATCCTC 3'

MAGEpET28a_S: 5'TACTAGCTAGCATGCCTCTTGAGCAGAG 3'

MAGEpET28a_R: 5'GATCTCGAGTCACTCTTCCCCCTCTCTC 3'

GLEApET28a_S: 5'TACTAGCTAGCATGACAAAGCATCCACC 3'

GLEApET28a_R: 5'GATCTCGAGTCACTTCTTTGGCTTCAC 3'

Hsp70pET28a_S: 5'TACTAGCTAGCATGGCCAAAGCCGCGGCGATC 3'

Hsp70pET28a_R: 5'GATCTCGAGTCAATCCACCTCCTCAATG 3'

Nos oligonucleotídeos $\mathrm{S}$ foram incluídos um sítio de ancoragem (em cinza), o sítio da enzima NheI (região sublinhada) e a porção inicial do gene (aproximadamente 18 bases) e nos oligonucleotídeos $\mathrm{R}$ foram inseridos a porção final do gene, um stop códon (em negrito), o sítio da enzima XhoI (região sublinhada) e um sítio de ancoragem (em cinza).

$\mathrm{Na}$ reação de amplificação, além dos $0,1 \mu \mathrm{M}$ de cada oligonucleotídeo foi utilizado 100-150ng do molde, 0,2mM de cada dNTPs, tampão $1 \mathrm{X}$ e 5 unidade da enzima High fidelity; a reação foi feita em 100 $\mu \mathrm{L}$ finais utilizando o programa VAC (1 minuto de extensão para a amplificação dos gene EGFRvIII e 2 minutos para a amplificação dos genes GLEA e 
hsp70). Os produtos das amplificações foram analisados em gel de agarose $1 \%$ e purificados utilizando-se o Wizard SV Gel and PCR Clean-Up System.

Os genes EGFRvIII, GLEA e hsp70 após purificação foram clivados com as enzimas NheI e XhoI (Fermentas): 2,4 $\mu$ g de cada gene foram clivados com 4 unidades de cada enzima, juntamente com tampão FastDigest $1 \mathrm{X}$ em um volume final de $60-70 \mu \mathrm{L}$, overnight a $37^{\circ} \mathrm{C}$. Os fragmentos clivados foram diretamente purificados utilizando-se o Wizard SV Gel and PCR Clean-Up System.

OBS.: A amplificação e clivagem dos genes cERBB2 e MAGE foram realizadas pela empresa Farmacore Biotechnology Ltd..

\subsubsection{Clivagem do vetor $p E T$}

$\mathrm{O}$ vetor pET (Figura 3) foi digerido $(3 \mu \mathrm{g})$ com 4 unidades das enzimas NheI e XhoI, juntamente com tampão $1 \mathrm{X}$ em um volume final de $80 \mu \mathrm{L}$ a $37^{\circ} \mathrm{C}$ por 5 horas. A digestão foi analisada em gel de agarose $1 \%$ e o vetor foi purificado utilizando-se o Wizard SV Gel and PCR Clean-Up System.

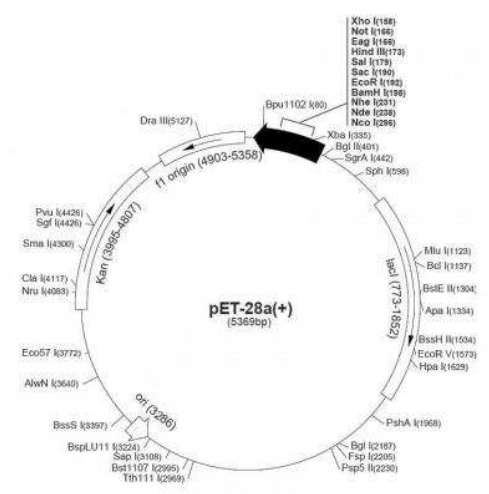

Figura 3: Plasmídio pET28a. Vetor utilizado nas construções dos vetores de expressão.

\subsubsection{Clonagem do gene EGFRvIII no vetor pET}

O fragmento EGFRvIII clivado com as enzimas NheI e XhoI, obtido como descrito no item 4.3.1.1, foi clonado no plasmídio pET, clivado com as mesmas enzimas (item 4.3.1.2), pela reação de ligação, feita a temperatura ambiente por 1 hora, utilizando-se 80ng do inserto EGFRvIII, 50ng do vetor pET, tampão da enzima $1 \mathrm{X}$ e 0,5 unidade da T4 DNA ligase em um volume final de $10 \mu \mathrm{L}$. Todo volume da ligação foi utilizado na transformação de células de $E$. coli Top10 competentes que foram plaqueadas em meio LB ágar suplementado com 
canamicina.

A seleção do plasmídio recombinante pETEGFR foi feita realizando uma PCR de 13 colônias individuais diluídas em $20 \mu \mathrm{L}$ de água estéril. A reação foi realizada com $5 \mu \mathrm{L}$ da mistura de água + bactérias como molde, $0,1 \mu \mathrm{M}$ de cada oligonucleotídeo (T7p** e EGFRvIII_Rseq), 0,2mM de cada dNTPs, tampão $1 \mathrm{X}, 1,5 \mathrm{mM}$ de $\mathrm{MgCl}_{2}$ e 1 unidade da enzima Taq DNA polimerase em um volume final de $20 \mu \mathrm{L}$ (programa VAC).

**O oligonucleotídeo T7p hibridiza no vetor pET sendo possível avaliar a presença do fragmento EGFRvIII no interior desse plasmídio.

O produto da PCR foi analisado em gel de agarose $1 \%$ e a partir desse resultado foi realizada a extração dos plasmídios das colônias que apresentaram banda de amplificação do tamanho esperado. Esses plasmídios foram submetidos a uma reação de clivagem: 240ng de cada plasmídio foram digeridos com 0,5 unidade das enzimas NheI e XhoI, tampão $1 \mathrm{X}$ em uma reação final de $20 \mu \mathrm{L}$, overnight a $37^{\circ} \mathrm{C}$. A digestão foi analisada em gel de agarose $1 \%$.

A partir dos resultados obtidos com a PCR e a análise de restrição, um clone que apresentava o plasmídio recombinante pETEGFRvIII foi analisado por sequenciamento utilizando-se os oligonucleotídeos T7p e T7t** para confirmação da clonagem.

T7 terminator (T7t): 5' GCTAGTTATTGCTCAGCGG 3'

**O oligonucleotídeo $\mathrm{T} 7 \mathrm{t}$ também anela no interior do vetor $\mathrm{pET}$.

\subsubsection{Clonagem do gene cERBB2 no vetor $\mathrm{PET}$}

A clonagem do gene cERBB2 no vetor pET foi realizada pela empresa Farmacore Biotechnology Ltd. utilizando-se o molde e os oligonucleotídeos citados no item 4.3.1.1.

A seleção do plasmídio recombinante pETcERBB2 foi feita realizando a extração de plasmídios de 5 colônias que foram submetidos a digestão (400ng) com 0,5 unidade da enzima $X b a I^{* *}$, tampão $1 \mathrm{X}$ em uma reação final de $15 \mu \mathrm{L}$, overnight a $37^{\circ} \mathrm{C}$. A digestão foi analisada em gel de agarose $1 \%$ e a partir desse resultado foi realizada nova digestão do plasmídio selecionado como recombinante (400ng) com 0,5 unidade das enzimas NheI e XhoI, tampão $1 \mathrm{X}$ em uma reação final de $20 \mu \mathrm{L}$, overnight a $37^{\circ} \mathrm{C}$.

**A enzima XbaI cliva no interior do plasmídio, linearizando o vetor. 
A partir dos resultados obtidos com as clivagens, um clone que apresentava o plasmídio recombinante pETcERBB2 foi analisado por sequenciamento utilizando-se os oligonucleotídeos T7p e T7t para confirmação da clonagem.

\subsubsection{Clonagem do gene MAGE no vetor pET}

A clonagem do gene MAGE no vetor pET e a seleção do plasmídio recombinante foram realizadas pela empresa Farmacore Biotechnology Ltd. utilizando-se o molde e os oligonucleotídeos citados no item 4.3.1.1. O clone que apresentava o plasmídio pETMAGE foi analisado por sequenciamento utilizando-se os oligonucleotídeos $\mathrm{T} 7 \mathrm{p}$ e $\mathrm{T} 7 \mathrm{t}$ para confirmação da clonagem.

\subsubsection{Clonagem do gene GLEA no vetor pET}

O fragmento GLEA clivado com as enzimas NheI e XhoI, como descrito no item 4.3.1.1, foi clonado no plasmídio pET, clivado com as mesmas enzimas (item 4.3.1.2), pela reação de ligação feita a temperatura ambiente por 1 hora, utilizando-se 100 ng do inserto GLEA, 50ng do vetor pET, tampão da enzima $1 \mathrm{X}$ e 0,5 unidade da T4 DNA ligase em um volume final de $10 \mu \mathrm{L}$. Todo volume da ligação foi utilizado na transformação de células de $E$. coli Top10 competentes que foram plaqueadas em meio LB ágar suplementado com canamicina.

A seleção do plasmídio recombinante pETGLEA foi feita realizando uma PCR de colônias com 8 grupos contendo 5 colônias cada. As colônias foram diluídas em $50 \mu \mathrm{L}$ de água estéril e a reação realizada com $5 \mu \mathrm{L}$ da mistura de água + bactérias como molde, $0,1 \mu \mathrm{M}$ de cada oligonucleotídeo (T7p e GLEA_2Rseq), 0,2mM de cada dNTPs, tampão 1X, 1,5mM de $\mathrm{MgCl}_{2}$ e 1 unidade da enzima Taq DNA polimerase em um volume final de $20 \mu \mathrm{L}$ (programa VAC).

O produto da PCR foi analisado em gel de agarose $1 \%$ e a partir desse resultado foi realizada a extração de 5 plasmídios de um dos grupos que apresentou banda de amplificação do tamanho esperado. Esses plasmídios foram submetidos a uma reação de clivagem: 360ng de cada plasmídio foram digeridos com 0,5 unidade das enzimas NheI e XhoI, tampão $1 \mathrm{X}$ em uma reação final de $20 \mu \mathrm{L}$ a $37^{\circ} \mathrm{C}$ por 3 horas e 30 minutos. A digestão foi analisada em gel de agarose $1 \%$. 
A partir dos resultados obtidos com a PCR e com a análise de restrição, um clone que apresentava o plasmídio recombinante pETGLEA foi analisado por sequenciamento utilizando-se os oligonucleotídeos T7p, Glea_1SSeq e T7t para confirmação da clonagem.

\subsubsection{Clonagem do gene hsp70 no vetor $\mathrm{pET}$}

O fragmento hsp70 clivado com as enzimas NheI e Xhol, como descrito no item 4.3.1.1, foi clonado no plasmídio pET, clivado com as mesmas enzimas (item 4.3.1.2), pela reação de ligação, feita a temperatura ambiente por 1 hora, utilizando-se 150ng do inserto hsp70, 50ng do vetor pET, tampão da enzima 1X e 0,5 unidade da T4 DNA ligase em um volume final de $10 \mu \mathrm{L}$. Todo volume da ligação foi utilizado na transformação de células de $E$. coli Top10 competentes que foram plaqueadas em meio LB ágar suplementado com canamicina.

A seleção do plasmídio recombinante pEThsp70 foi feita realizando uma PCR de colônias com 8 grupos contendo 5 colônias cada. As bactérias foram diluídas em $50 \mu \mathrm{L}$ de água estéril e a reação realizada com $5 \mu \mathrm{L}$ da mistura de água + bactérias como molde, $0,1 \mu \mathrm{M}$ de cada oligonucleotídeo (T7p e Hsp70_2RSeq), 0,2mM de cada dNTPs, tampão 1X, 1,5mM de $\mathrm{MgCl}_{2}$ e 1 unidade da enzima Taq DNA polimerase em um volume final de $20 \mu \mathrm{L}$ (programa VAC).

O produto da PCR foi analisado em gel de agarose $1 \%$ e a partir desse resultado foi realizada a extração de 5 plasmídios de um dos grupos que apresentou banda de amplificação do tamanho esperado. Esses plasmídios foram submetidos a uma reação de clivagem: 360ng de cada plasmídio foram digeridos com 0,5 unidade das enzimas NheI e XhoI, tampão $1 \mathrm{X}$ em uma reação final de $20 \mu \mathrm{L}$ a $37^{\circ} \mathrm{C}$ por 3 horas e 30 minutos. A digestão foi analisada em gel de agarose $1 \%$.

A partir dos resultados obtidos com a PCR e a análise de restrição, um clone que apresentava o plasmídio recombinante pEThsp70 foi analisado por sequenciamento utilizando-se os oligonucleotídeos T7p, Hsp70_1Sseq e T7t para confirmação da clonagem.

\subsubsection{Clonagem do gene gp96 no vetor pcDNA3.3-Topo (pcDNA)}

O gene gp96 foi clonado no vetor pcDNA (Invitrogen) (Figura 4) para expressão da proteína gp96 em células de mamíferos HEK293 (human embrionic kidney) (HEK). 


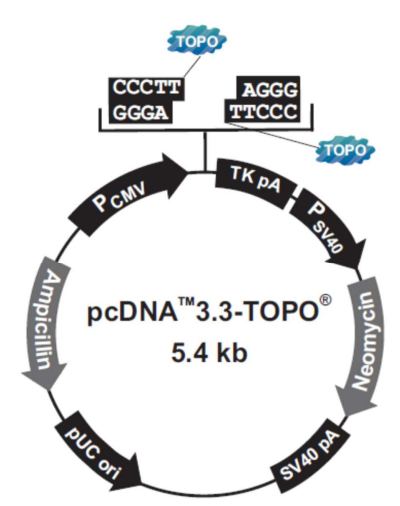

Figura 4: Plasmídio pcDNA3.3-Topo. Vetor utilizado na construção do vetor de expressão pcDNAgp96.

\subsubsection{Amplificação do gene gp96}

O gene gp96 foi amplificado para a clonagem no vetor pcDNA utilizando-se como molde o plasmídio pETgp96 (Anexo 5) e os iniciadores, T7p e Gp96pET28a_R. A amplificação com o oligonucleotídeo T7p que anela no plasmídio pET determina a amplificação de uma porção desse vetor, contendo a cauda de histidina, juntamente com o gene gp96. O oligonucleotídeo Gp96pET28a_R apresenta a porção final do gene e um stop códon (em negrito).

\section{Gp96pET28a_R: 5'GATCTCGAGTCACAATTCATCTTTTTCAGC 3'}

$\mathrm{Na}$ reação de amplificação, além dos $0,1 \mu \mathrm{M}$ de cada oligonucleotídeo foi utilizado 100ng do molde, 0,2mM de cada dNTPs, tampão $1 \mathrm{X}$ e 5 unidade da enzima High fidelity; a reação foi feita em $100 \mu \mathrm{L}$ finais utilizando o programa VAC (2'30" de extensão e TM de $50^{\circ} \mathrm{C}$ ). Após a amplificação, 2,5 unidades da enzima Taq DNA polimerase foi adicionada e a reação incubada a $72^{\circ} \mathrm{C}$ por 10 minutos para adição de adenina nas extremidades do fragmento amplificado. O produto da amplificação foi analisado em gel de agarose $1 \%$.

O fragmento foi clonado diretamente no vetor pcDNA segundo as instruções do pcDNA ${ }^{\text {TM}} 3.3-$ Topo® ${ }^{\circledR}$ TA Cloning Kit (Invitrogen). Na reação de ligação utilizou-se $4 \mu \mathrm{L}$ da reação de amplificação, $0,5 \mu \mathrm{L}$ do vetor pcDNA, $1 \mu \mathrm{L}$ da solução salina (disponibilizada pelo kit) em um volume final de $6 \mu \mathrm{L}$. Essa reação foi incubada por 30 minutos a temperatura ambiente e utilizada na transformação de células de $E$. coli Top10 competentes que foram plaqueadas em meio LB ágar suplementado com ampicilina. 


\subsubsection{Clonagem do gene gp96 no vetor pcDNA}

Após a transformação, a seleção do plasmídio recombinante pcDNAgp96 foi feita realizando uma PCR de 10 colônias individuais diluídas em $20 \mu \mathrm{L}$ de água estéril. A reação foi realizada com $5 \mu \mathrm{L}$ da mistura de água + bactérias como molde, $0,1 \mu \mathrm{M}$ de cada oligonucleotídeo (T7p e gp96pET28a_R), 0,2mM de cada dNTPs, tampão 1X, 1,5mM de $\mathrm{MgCl}_{2}$ e 1 unidade da enzima Taq DNA polimerase em um volume final de $20 \mu \mathrm{L}$ (programa VAC, TM $50^{\circ} \mathrm{C}$ e extensão de 2'30', ).

O produto da PCR foi analisado em gel de agarose $1 \%$ e a partir desse resultado foi realizada a extração de 6 plasmídios das colônias que apresentaram banda de amplificação do tamanho esperado. Uma nova PCR com os plasmídios já extraídos foi realizada como a citada acima, no entanto, foi utilizado $75 \mathrm{ng}$ de cada plasmídio como molde, os oligonucleotídeos CMV sense (CMV)** e Gp96pET28a_R.

CMV: 5'-CGCAAATGGGCGGTAGGCGTG-3'

**O oligonucleotídeo CMV hibridiza no plasmídio pcDNA sendo possível identificar a presença e direção do gene.

A partir dos resultados obtidos com as PCRs, um clone que apresentava o plasmídio recombinante pcDNAgp96 foi analisado por sequenciamento utilizando-se os oligonucleotídeos CMV, gp96_1Sseq, gp96_3Sseq e TK poli A reverse (TK)** para confirmação da clonagem.

TK: 5'-CTTCCGTGTTTCAGTTAGC-3'

**O oligonucleotídeo TK também hibridiza no plasmídio pcDNA.

\subsection{Expressão e purificação das proteínas recombinantes}

\subsubsection{Expressão e purificação das proteínas EGFRvIII, cERBB2, MAGE, GLEA e} Hsp70 em E. coli

Os genes que codificam as proteínas EGFRvIII, cERBB2, MAGE, GLEA e Hsp70 foram clonadas no vetor pET para expressão em sistema procarioto utilizando-se E. coli. A utilização desse vetor garante a expressão das proteínas em fusão com uma cauda de histidina, importante na purificação dessas moléculas por cromatografia de afinidade. 


\subsubsection{Expressão e purificação das proteínas EGFRvIII e cERBB2}

As construções pETEGFRvIII e pETcERBB2 foram utilizadas na transformação de células competentes E. coli BL21 (DE3) (BL21) (Invitrogen) utilizadas na expressão das proteínas EGFRvIII e cERBB2. Uma colônia de células E. coli BL21 transformada com pETEGFRvIII e uma transformada com pETcERBB2 foram separadamente coletadas (com auxílio de alças descartáveis) e inoculadas, cada uma, em um pré-inóculo de $5 \mathrm{~mL}$ de LB líquido suplementado com canamicina. Para ambas as construções os procedimentos descritos na expressão e purificação foram os mesmos. O pré-inóculo foi incubado sob agitação de 200rpm, a $37^{\circ} \mathrm{C}$, overnight e, em seguida, diluído 1:50 em 50mL de LB líquido suplementado com canamicina. As células foram crescidas nas mesmas condições até uma densidade óptica (DO) de aproximadamente 0,6 (fase logarítmica do crescimento), em uma absorbância de $600 \mathrm{~nm}$ medida em espectrofotômetro B572 (Micronal S.A.). Uma nova diluição foi realizada de 1:33 em 800mL de LB líquido e as células foram crescidas novamente até a DO de 0,6; outra condição de pré-inóculo foi feita com $10 \mathrm{~mL}$ de LB líquido e uma colônia, o crescimento foi de 6 horas a $37^{\circ} \mathrm{C}, 200 \mathrm{rpm}$, seguido de uma diluição 1:50 em 400mL de LB líquido, essa cultura também foi crescida até uma DO de 0,6. Em ambas as condições, as bactérias foram induzidas com 0,5mM de IPTG (isopropil- $\beta$-D-tiogalactosídeo) (Invitrogen), a $30^{\circ} \mathrm{C}$, overnight, sob agitação de 200rpm para a expressão da proteína recombinante de interesse. Amostras de $1 \mathrm{~mL}$ foram retiradas antes e após a indução. Esse material foi centrifugado 2 minutos a $15800 \mathrm{~g}$ em uma centrifuga 5402 (Eppendorf), sendo o sobrenadante descartado e a parte celular armazenada para análise em SDS-PAGE a 10\% (Eletroforese desnaturante em gel de poliacrilamida contendo duodecil sulfato de sódio) (Laemmli, 1970).

Após a indução overnight, a cultura foi recolhida em frascos apropriados e centrifugada 18 minutos, $6650 \mathrm{~g}$ a $4^{\circ} \mathrm{C}$ (J2-HS, Beckman). O sobrenadante (meio de cultura) foi descartado e as células ressuspendidas em $50 \mathrm{~mL}$ de tampão de sonicação A $(0,02 \mathrm{M}$ de tampão fosfato de sódio, $0,5 \mathrm{M}$ de $\mathrm{NaCl}, 0,02 \mathrm{M}$ de imidazol e inibidor de protease - Complete [Roche], pH 7,4) (6-8mL para cada grama de precipitado). Em seguida, as células foram submetidas a sonicação alternada - 6 repetições de 30 segundos com intervalo de 1 minuto (potência 60) - em um desruptor de célula ultra-sônico (Unique). O lisado foi centrifugado por 20 minutos a $4^{\circ} \mathrm{C}, 20000 \mathrm{~g}$ (Avanti ${ }^{\mathrm{TM}} 30$ Centrifuge, Beckman) e o sobrenadante (sobrenadante 1) e precipitado foram separados. O precipitado foi ressuspendido em $35 \mathrm{~mL}$ de tampão de sonicação A1 (0,02M de tampão fosfato de sódio, $0,5 \mathrm{M}$ de $\mathrm{NaCl}, 0,02 \mathrm{M}$ de imidazol, $8 \mathrm{M}$ de ureia e inibidor de protease - Complete [Roche], $\mathrm{pH} 7,4)(6-8 \mathrm{~mL}$ para cada 
grama de precipitado) e sonicado novamente nas mesmas condições. Nova centrifugação foi realizada para separar sobrenadante (sobrenadante 2) e precipitado. Frações dos sobrenadantes e do sedimento foram analisadas em SDS-PAGE para testes da solubilidade da proteína.

A análise em SDS-PAGE foi feita utilizando-se as amostras da cultura não induzida, induzida, sobrenadantes após a lise e uma pequena parte do sedimento nos quais foram adicionados água e tampão da amostra 5 vezes concentrado (5X) (Tris-HCl a 200mM, pH 6,8, SDS a 360mM, glicerol a 41,6\%, azul de bromofenol a 0,05\% e 2-mercaptoetanol a 12,5\%), todas as amostras foram fervidas por 5 minutos e aplicadas no gel $(20 \mu \mathrm{L})$ (Tampão de corrida-Tris-base a $125 \mathrm{mM}$, glicina a $960 \mathrm{mM}$ e SDS a $170 \mathrm{mM}, \mathrm{pH} 8,3$ ), a eletroforese foi realizada a $50 \mathrm{~V}$ por 30 minutos seguida de 2 horas a $100 \mathrm{~V}$.

A purificação das proteínas EGFRvIII e cERBB2 foi realizada por cromatografia de afinidade utilizando-se uma coluna montada com $4 \mathrm{~mL}$ de resina NiSepharose (GE HealthCare). A cauda de histidina expressa em fusão com as proteínas de interesse apresenta afinidade ao níquel imobilizado na resina. A purificação foi realizada com o sobrenadante 2 que foi submetido inicialmente a centrifugação por 15 minutos, à 2500g (Centrifuga CT6000R, CIENTEC), $4^{\circ} \mathrm{C}$ para retirada de precipitados. Antes da purificação a resina foi tratada com $\mathrm{NaOH}$ a $1 \mathrm{M}$, overnight (passou-se 6 volumes de coluna - $\mathrm{VC}$ - de $\mathrm{NaOH}$ na coluna e em seguida completou-a com esse reagente; o $\mathrm{NaOH}$ é utilizado para retirada de lipopolissacarídeo - LPS ou endotoxina). Após esse intervalo de tempo, a resina foi lavada com 10VC de água milliQ, carregada com $1 \mathrm{VC}$ de sulfato de níquel a $0,1 \mathrm{M}$ e lavada novamente com 10VC de água.

A coluna foi equilibrada com $7 \mathrm{VC}$ de tampão de equilíbrio/lavagem $\mathrm{A}(0,02 \mathrm{M}$ de tampão fosfato de sódio, $0,5 \mathrm{M}$ de $\mathrm{NaCl}, 0,05 \mathrm{M}$ de imidazol, $8 \mathrm{M}$ de ureia, $\mathrm{pH} 7,4)$. Em seguida, todo o volume de sobrenadante 2 foi aplicado na coluna e a fração não ligada foi coletada. A coluna foi lavada posteriormente com $15 \mathrm{VC}$ de tampão de equilíbrio/lavagem A que também foi recolhido junto com a fração anterior. As proteínas presas à resina pela cauda de histidina foram eluídas (10VC) utilizando-se alta concentração de imidazol que compete pela interação com o níquel (tampão de eluição A - 0,02M de tampão fosfato de sódio, 0,5M de $\mathrm{NaCl}, 0,5 \mathrm{M}$ de imidazol, $8 \mathrm{M}$ de ureia, $\mathrm{pH} 7,4$ ). Todas as frações coletadas durante a purificação foram submetidas a eletroforese: foram separados $20 \mu \mathrm{L}$ de cada fração, adicionado $5 \mu \mathrm{L}$ de tampão da amostra $5 \mathrm{X}$, fervido por 5 minutos e analisadas em SDS- 
PAGE. As frações recuperadas após a passagem do sobrenadante e da lavagem foram chamadas de eluato/lavagem e as obtidas após a passagem de imidazol, eluições. As frações eluato/lavagem foram repurificadas.

As frações contendo a proteína de interesse foram dialisadas utilizando-se uma membrana Snake Skin® Pleated Dialysis Tubing 3500MWCO (Pierce-Perbio) e tampão fosfato com menor concentração de sal, $0,3 \mathrm{M}$ de $\mathrm{NaCl}$ e quantidades decrescentes de ureia e (8M, 6M, 4M, 2M - cada um por 2 horas; $1 \mathrm{M}$, overnight; 0M, por 8 horas). Outras diálises também foram feitas utilizando-se diretamente tampão fosfato com menos sal e sem ureia e utilizando-se PBS (137mM de $\mathrm{NaCl}, 2,7 \mathrm{mM}$ de $\mathrm{KCl}, 8,1 \mathrm{mM}$ de $\mathrm{Na}_{2} \mathrm{HPO}_{4}$ e $1,5 \mathrm{mM}$ de $\mathrm{KH}_{2} \mathrm{PO}_{4}, \mathrm{pH} 7,2$ ). As frações contendo as proteínas foram colocadas dentro da membrana que ficou mergulhada no tampão de diálise.

Após a diálise, como as proteínas precipitam, elas foram centrifugadas por 15 minutos a $2500 \mathrm{~g}, 4^{\circ} \mathrm{C}$ e separadas em sobrenadante e precipitado. O sobrenadante foi quantificado pelo ensaio de Bradford (Bradford, 1976), utilizando-se o corante Coomassie Plus ${ }^{\mathrm{TM}}$ Protein Assay Reagent (Pierce) e a leitura feita em espectrofotômetro de placa ( $\mu$ Quant Bio-Tek Instruments Inc.). As frações após diálise e quantificação foram concentradas utilizando-se vivaspin 20 - 5kDaMWCO (GE Healthcare) e analisadas em SDS-PAGE seguindo os mesmos procedimentos das frações coletadas na purificação.

As proteínas também foram doseadas com relação a presença de LPS uma vez que elas são produzidas em bactérias gram-negativas que apresentam essa molécula na constituição de sua parede celular. A quantidade de endotoxinas foi determinada utilizando-se o QCL-100 LAL kit (Cambrex), teste cromogênico do lisado de amebócito de Limulus polyphemus (LAL).

OBS.: Todo material utilizado na purificação de todas as proteínas era livre de LPS (Endofree).

\subsubsection{Expressão e purificação da proteína $M A G E$}

A construção pETMAGE foi utilizada na transformação de células competentes $E$. coli Rosetta (DE3) (Rosetta) utilizadas na expressão da proteína MAGE. Uma colônia de células E. coli Rosetta transformada com pETMAGE foi coletada e inoculada em um pré-inóculo de $5 \mathrm{~mL}$ de LB líquido suplementado com canamicina. O pré-inóculo foi incubado sob agitação de $200 \mathrm{rpm}$, a $37^{\circ} \mathrm{C}$, overnight e, em seguida, diluído 1:100 em 400mL de LB líquido 
suplementado com canamicina. As células foram crescidas nas mesmas condições até uma DO de aproximadamente 0,6 em uma absorbância de 600nm. As bactérias foram induzidas com $0,5 \mathrm{mM}$ de IPTG, a $37^{\circ} \mathrm{C}$ por 4 horas, sob agitação de 200 rpm para a expressão da proteína recombinante de interesse. Amostras de $1 \mathrm{~mL}$ foram retiradas antes e após a indução. Esse material foi centrifugado 2 minutos a $15800 \mathrm{~g}$, sendo o sobrenadante descartado e a parte celular armazenada para análise em SDS-PAGE a 10\%.

Após a indução por $4 \mathrm{~h}$, a cultura foi recolhida em frascos apropriados e centrifugada 18 minutos, $6650 \mathrm{~g}$ a $4^{\circ} \mathrm{C}$. O sobrenadante foi descartado e as células ressuspendidas em tampão de sonicação $\mathrm{B}\left(0,05 \mathrm{M}\right.$ de $\mathrm{NaH}_{2} \mathrm{PO}_{4}, 0,12 \mathrm{M}$ de $\mathrm{NaCl}$ e inibidor de protease Complete [Roche], pH 7,0) (6mL para cada grama de precipitado). Em seguida, as células foram submetidas à sonicação alternada como descrito acima. O lisado foi centrifugado por 20 minutos a $4^{\circ} \mathrm{C}, 20000 \mathrm{~g}$ e o sobrenadante (sobrenadante 1 ) e precipitado foram separados. $\mathrm{O}$ precipitado foi ressuspendido em tampão de sonicação $\mathrm{B} 1\left[0,05 \mathrm{M}\right.$ de $\mathrm{NaH}_{2} \mathrm{PO}_{4}, 0,12 \mathrm{M}$ de $\mathrm{NaCl}, 8 \mathrm{M}$ de ureia e inibidor de protease - Complete (Roche), $\mathrm{pH} 7,0]$ (6mL para cada grama de precipitado) e sonicado novamente nas mesmas condições. Nova centrifugação foi realizada para separar sobrenadante (sobrenadante 2) e precipitado. Frações dos sobrenadantes e do sedimento foram analisadas em SDS-PAGE para testes da solubilidade da proteína. A análise em SDS-PAGE foi feita utilizando-se as amostras da cultura não induzida, induzida, sobrenadantes após a lise e uma pequena parte do sedimento conforme descrito para as proteínas EGFRvIII e cERBB2.

A purificação da proteína MAGE foi realizada por cromatografia de afinidade, utilizando-se uma coluna com resina NiSepharose e o sobrenadante 1. Como descrito para as proteínas EGFRvIII e cERBB2, a resina foi tratada com $\mathrm{NaOH}$ e imobilizada com sulfato de níquel.

A coluna foi equilibrada com $5 \mathrm{VC}$ de tampão de sonicação $\mathrm{B}$, em seguida, todo o volume do sobrenadante 1 foi aplicado na coluna e a fração não ligada foi coletada. A coluna foi lavada posteriormente com $10 \mathrm{VC}$ de tampão lavagem $\mathrm{B}\left(0,05 \mathrm{M}\right.$ de $\mathrm{NaH}_{2} \mathrm{PO}_{4}, 0,12 \mathrm{M}$ de $\mathrm{NaCl}$ e 0,05M de imidazol, $\mathrm{pH} 7,0$ ) que também foi recolhido junto com a fração anterior. As proteínas presas a resina foram eluídas $(5 \mathrm{VC})$ utilizando-se alta concentração de imidazol (tampão de eluição $\mathrm{B}-0,05 \mathrm{M}$ de $\mathrm{NaH}_{2} \mathrm{PO}_{4}, 0,12 \mathrm{M}$ de $\mathrm{NaCl}$ e $0,5 \mathrm{M}$ de imidazol, pH 7,0). Todas as frações coletadas durante a purificação foram submetidas à eletroforese conforme descrito para as proteínas EGFRvIII e cERBB2. 
As frações contendo a proteína de interesse foram dialisadas utilizando-se a membrana Snake Skin ${ }^{\circledR}$ Pleated Dialysis Tubing 3500MWCO e PBS, a diálise foi feita contra 1 litro de PBS por 6 horas, seguido de mais 18 horas com novo PBS. Após a diálise, a proteína foi quantificada pelo ensaio de Bradford, concentrada em vivaspin 20 - 5kDaMWCO e analisada em SDS-PAGE. A quantidade de endotoxinas bacterianas foi determinada pelo teste cromogênico LAL.

\subsubsection{Expressão e purificação da proteína GLEA}

A construção pETGLEA foi utilizada na transformação de células competentes $E$. coli Rosetta utilizadas na expressão da proteína GLEA. Uma colônia de células E. coli Rosetta transformada com pETGLEA foi coletada e inoculada em um pré-inóculo de $10 \mathrm{~mL}$ de Terrific Brouth (TB) (24g de extrato de levedura, $12 \mathrm{~g}$ de peptona, 0,05M de $\mathrm{K}_{2} \mathrm{HPO}_{4}, 0,016 \mathrm{M}$ de $\mathrm{KH}_{2} \mathrm{PO}_{4}$ e $0,043 \mathrm{M}$ de glicerol) suplementado com canamicina. O pré-inóculo foi incubado sob agitação de $200 \mathrm{rpm}$, a $37^{\circ} \mathrm{C}$, overnight e, em seguida, diluído 1:100 em 400mL de TB suplementado com canamicina. As células foram crescidas nas mesmas condições até uma DO de aproximadamente 0,6 em uma absorbância de $600 \mathrm{~nm}$. As bactérias foram induzidas com $0,2 \mathrm{mM}$ de IPTG, a $37^{\circ} \mathrm{C}$ por 4 horas, sob agitação de $200 \mathrm{rpm}$ para a expressão da proteína recombinante de interesse. Amostras de $1 \mathrm{~mL}$ foram retiradas antes e após a indução. Esse material foi centrifugado 2 minutos a $15800 \mathrm{~g}$, sendo o sobrenadante descartado e a parte celular armazenada para análise em SDS-PAGE a $10 \%$.

Após a indução por 4h, a cultura foi recolhida em frascos apropriados e centrifugada 18 minutos, $6650 \mathrm{~g}$ a $4^{\circ} \mathrm{C}$. O sobrenadante foi descartado e as células ressuspendidas em tampão de sonicação B (6mL para cada grama de precipitado). Em seguida, as células foram submetidas a sonicação alternada como descrito anteriormente. O lisado foi centrifugado por 20 minutos a $4^{\circ} \mathrm{C}, 20000 \mathrm{~g}$ e o sobrenadante (sobrenadante 1) e precipitado foram separados. O precipitado foi ressuspendido em tampão de sonicação B1 $(6 \mathrm{~mL}$ para cada grama de precipitado) e centrifugados para separar sobrenadante (sobrenadante 2) e precipitado (o precipitado foi ressuspendido mais duas vezes em tampão B1 e centrifugado gerando mais dois sobrenadantes, 3 e 4). Frações dos sobrenadantes e do sedimento foram analisadas em SDS-PAGE para testes da solubilidade da proteína. A análise em SDS-PAGE foi feita utilizando-se as amostras da cultura não induzida, induzida, sobrenadantes após a lise e uma pequena parte do sedimento conforme descrito para as proteínas EGFRvIII e cERBB2. 
A purificação da proteína GLEA foi realizada por cromatografia de afinidade, utilizando-se uma coluna com resina NiSepharose e os sobrenadantes 2, 3 e 4 juntos. Como descrito para as proteínas EGFRvIII e cERBB2, a resina foi tratada com $\mathrm{NaOH}$ e imobilizada com sulfato de níquel.

A coluna foi equilibrada com $5 \mathrm{VC}$ de tampão de sonicação B1. Em seguida, todo o volume dos sobrenadantes foi aplicado na coluna e a fração não ligada foi coletada. A coluna foi lavada posteriormente com $10 \mathrm{VC}$ de tampão de lavagem $\mathrm{B} 1\left(0,05 \mathrm{M}\right.$ de $\mathrm{NaH}_{2} \mathrm{PO}_{4}, 0,12 \mathrm{M}$ de $\mathrm{NaCl}, 8 \mathrm{M}$ de ureia e 0,05M de imidazol, $\mathrm{pH} 7,0$ ) que também foi recolhido. As proteínas presas à resina foram eluídas (5VC) utilizando-se alta concentração de imidazol [tampão de eluição B1 (0,05M de $\mathrm{NaH}_{2} \mathrm{PO}_{4}, 0,12 \mathrm{M}$ de $\mathrm{NaCl}, 8 \mathrm{M}$ de ureia e 0,5M de imidazol, $\mathrm{pH}$ 7,0)]. Todas as frações coletadas durante a purificação foram submetidas a eletroforese conforme descrito para as proteínas EGFRvIII e cERBB2. As frações eluato e lavagem foram repurificadas pelo mesmo procedimento devido a presença de proteína.

As frações contendo a proteína de interesse foram dialisadas utilizando-se um Dialysis Tubing Celllose (12000MWCO) (Sigma-Aldrich) e PBS, a diálise foi feita contra 1 litro de PBS por 6 horas, seguido de mais 18 horas com novo PBS. Após a diálise, como a proteína precipita, ela foi centrifugada por 15 minutos a $2500 \mathrm{~g}, 4^{\circ} \mathrm{C}$ e separada em sobrenadante e precipitado. O sobrenadante foi quantificado pelo ensaio de Bradford e a quantidade de endotoxinas bacterianas determinada pelo teste cromogênico LAL.

\subsubsection{Expressão e purificação da proteína Hsp70}

A construção pEThsp70 foi utilizada na transformação de células competentes $E$. coli Rosetta utilizadas na expressão da proteína Hsp70. Uma colônia de células E. coli Rosetta transformada com pEThsp70 foi coletada e inoculada em um pré-inóculo de $5 \mathrm{~mL}$ de TB suplementado com canamicina. O pré-inóculo foi incubado sob agitação de $200 \mathrm{rpm}$, a $37^{\circ} \mathrm{C}$, overnight e, em seguida, diluído 1:1000 em 400mL de TB suplementado com canamicina. As células foram crescidas nas mesmas condições até uma DO de aproximadamente 0,6 em uma absorbância de $600 \mathrm{~nm}$. As bactérias foram induzidas com $0,2 \mathrm{mM}$ de IPTG, a $30^{\circ} \mathrm{C}$, overnight, sob agitação de 200rpm para a expressão da proteína recombinante de interesse. Amostras de $1 \mathrm{~mL}$ foram retiradas antes e após a indução. Esse material foi centrifugado 2 minutos a $15800 \mathrm{~g}$, sendo o sobrenadante descartado e a parte celular armazenada para análise em SDSPAGE a $10 \%$.

Após a indução, a cultura foi recolhida em frascos apropriados e centrifugada 18 
minutos, $6650 \mathrm{~g} \mathrm{a} 4^{\circ} \mathrm{C}$. O sobrenadante foi descartado e as células ressuspendidas em tampão de sonicação B (2,5mL para cada grama de precipitado). Em seguida, as células foram submetidas a sonicação alternada - 15 repetições de 1 minuto com intervalo de 30 segundos (potência 30) - em um sonicador Vibra cell ${ }^{\mathrm{TM}}$ (Sonic \& Materials Inc.). O lisado foi centrifugado por 20 minutos a $4^{\circ} \mathrm{C}, 20000 \mathrm{~g}$ e o sobrenadante (sobrenadante 1) e precipitado foram separados. O precipitado foi ressuspendido novamente em tampão de sonicação B1 (2,5mL para cada grama de precipitado), sonicado (10 repetições conforme descrito acima) e centrifugados para separar sobrenadante (sobrenadante 2) e precipitado. Frações dos sobrenadantes e do sedimento foram analisadas em SDS-PAGE para testes da solubilidade da proteína. A análise em SDS-PAGE foi feita utilizando-se as amostras da cultura não induzida, induzida, sobrenadantes após a lise e uma pequena parte do sedimento conforme descrito para as proteínas EGFRvIII e cERBB2.

A purificação da proteína Hsp70 foi realizada por cromatografia de afinidade, utilizando-se uma coluna com resina NiSepharose e os sobrenadantes 1 e 2. Como descrito para as proteínas EGFRvIII e cERBB2, a resina foi tratada com $\mathrm{NaOH}$ e imobilizada com sulfato de níquel.

A coluna foi equilibrada com $5 \mathrm{VC}$ de tampão de sonicação B. Em seguida, o sobrenadante foi aplicado na coluna e a fração não ligada foi coletada. A coluna foi lavada posteriormente com 10VC de tampão de lavagem B que também foi recolhido. As proteínas presas a resina foram eluídas (5VC) utilizando-se alta concentração de imidazol [tampões de eluição $\mathrm{C}\left(0,05 \mathrm{M}\right.$ de $\mathrm{NaH}_{2} \mathrm{PO}_{4}, 0,12 \mathrm{M}$ de $\mathrm{NaCl}, 0,15 \mathrm{M}$ de imidazol, $\left.\mathrm{pH} 7,0\right)$ e $\mathrm{D}(0,05 \mathrm{M}$ de $\mathrm{NaH}_{2} \mathrm{PO}_{4}, 0,12 \mathrm{M}$ de $\mathrm{NaCl}, 0,25 \mathrm{M}$ de imidazol, $\left.\left.\mathrm{pH} 7,0\right)\right]$. Todas as frações coletadas durante a purificação foram submetidas a eletroforese conforme descrito para as proteínas EGFRvIII e cERBB2.

As frações contendo a proteína de interesse foram dialisadas utilizando-se um Dialysis Tubing Celllose e PBS, a diálise foi feita contra 1 litro de PBS, overnight, seguido de 8 horas com novo PBS e mais 16 horas com novo PBS. Após a diálise, as proteínas foram quantificadas pelo ensaio de Bradford e a quantidade de endotoxinas bacterianas determinada pelo teste cromogênico LAL. As proteínas Hsp70 com altos níveis de endotoxinas foram lavadas com PBS utilizando-se filtro vivaspin 20 - 30kDaMWCO (GE Healthcare), foi realizado 8 ciclos de 30 minutos, a $2500 \mathrm{~g}, 4^{\circ} \mathrm{C}$, sempre completando o volume para $20 \mathrm{~mL}$ com PBS. 


\subsubsection{Expressão e purificacão da proteína gp96 em HEK}

O gene que codifica a proteína gp96 foi clonado no vetor pcDNA para expressão dessa proteína em células eucarióticas HEK. Após expressão, a proteína foi purificada por cromatografia de afinidade.

\subsubsection{Expressão da proteína gp96}

O vetor pcDNAgp96 foi utilizado na transfecção de células HEK para expressão da proteína gp96. Células HEK foram cultivadas inicialmente em garrafas T150 (TPP, Techno Plastic Products) na forma aderente com meio DMEM (Gibco), 10\% de SBF (Soro Bovino Fetal) (Gibco), 1\% de estreptomicina/penicilina (100unidades $/ \mathrm{mL}$ de penicilina e $100 \mu \mathrm{g} / \mathrm{mL}$ de estreptomicina) (Gibco) (DMEM-C) a $37^{\circ} \mathrm{C}, 5 \%$ de $\mathrm{CO}_{2}\left(\mathrm{CO}_{2}\right.$ Water Jacketed Incubator Nuaire). Posteriormente, essas células foram transferidas para um spinner de 700mL (Tchne) na concentração de $3,5 \times 10^{5}$ células/mL de meio Ex-Cell ${ }^{\circledR} 293$ Serum-Free Medium (Sigma) com $1 \%$ de estreptomicina/penicilina e livre de SBF. A cultura foi mantida sob agitação de 80rpm em MCS-104-S biological Stirrer (Tchne) a $37^{\circ} \mathrm{C}, 5 \%$ de $\mathrm{CO}_{2}$ por 6 dias, sendo avaliadas em número e viabilidade diariamente e complementadas com meio de cultura e antibiótico de forma a permanecerem com concentração entre 3,5 - 6,5×10 células $/ \mathrm{mL}$ e respeitando o limite de volume do spinner. Após 6 dias de cultura, as células foram coletadas por centrifugação a $461 \mathrm{~g}, 10$ minutos, $4^{\circ} \mathrm{C}$ (Centrifuga CT-6000R), ressuspendidas em meio

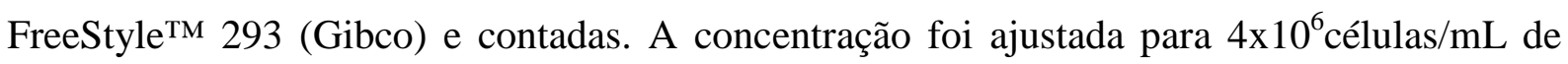
meio Freestyle e as células mantidas em cultura no spinner por 2 horas antes da transfecção (as células são ajustadas para a concentração e volume final desejados - no caso $50 \mathrm{~mL}$, no entanto, o volume durante a adaptação de duas horas é 0,9 do volume total $-45 \mathrm{~mL}$, para depois ser completado com o volume da transfecção - 5mL). Após 2 horas as células foram

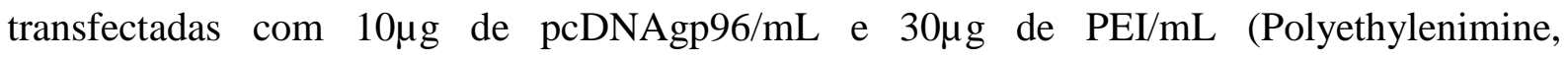
Polisciences) da seguinte forma: 0,1 do volume final de cultura $(5 \mathrm{~mL})$ foi dividido em duas frações para o preparo do DNA e PEI, a fração 1 foi feita com 500 $\mu$ g pcDNAgp96 juntamente com $5 \mu \mathrm{g}$ de pGFP $(1 \%), 150 \mathrm{mM}$ de $\mathrm{NaCl}$ e água, quando necessário para completar o volume; a fração 2 foi feita com $1500 \mu$ g de PEI, $150 \mathrm{mM}$ de $\mathrm{NaCl}$ e água, se necessário; a fração 2 (PEI) foi adicionada a 1 (DNA) e incubada por 20 minutos a temperatura ambiente. O complexo DNA:PEI foi adicionado as células e após 4 horas de cultura foi feito uma diluição de 4 vezes com meio Ex-Cell e antibiótico de forma que a cultura ficasse com concentração de $1 \times 10^{6}$ células/mL. Após 96 horas de cultura, as células foram coletadas por centrifugação a $461 \mathrm{~g}, 10$ minutos, $4^{\circ} \mathrm{C}$, ressuspendidas em PBS $(10 \mathrm{~mL})$ e congeladas. 
O plasmídio pGFP, pGreen Lantern.gcc (cedido gentilmente pelo Prof. Dario Simões Zamboni) apresenta o gene que codifica a proteína GFP (green fluorescent protein) e foi utilizado para controlar a eficiência da transfecção. No dia seguinte a transfecção, as células foram contadas e observadas em microscópio de fluorescência Aristoplan (Leica).

OBS.: um primeiro experimento teste foi realizado seguindo protocolo semelhante ao realizado acima, no entanto, a quantidade de células, volume de transfecção e proporção

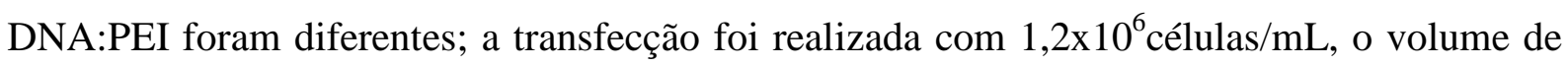
transfecção foi de $25 \mathrm{~mL}$, completado depois para um volume de $50 \mathrm{~mL}$ e a quantidade de DNA e PEI foram $1 \mu \mathrm{g} / \mathrm{mL}$ e $2 \mu \mathrm{g} / \mathrm{mL}$; além disso, as células foram transferidas das garrafas para o spinner no dia da transfecção; as células foram coletadas após 72 horas de transfecção e ressunpendidas em $5 \mathrm{~mL}$ PBS.

\subsubsection{Purificação da proteína gp96}

As células congeladas em PBS foram descongeladas a $37^{\circ} \mathrm{C}$, congeladas em nitrogênio líquido e descongeladas novamente para promover a lise celular. Em seguida, a suspensão foi centrifugada a $2500 \mathrm{~g}$ por 10 minutos, $4^{\circ} \mathrm{C}$ (Centrifuga CT-6000R) e o sobrenadante (1) e precipitado separados. O precipitado foi ressuspendido em tampão de sonicação B1 $(5 \mathrm{~mL})$, centrifugado a $23000 \mathrm{~g}$, por 25 minutos $4^{\circ} \mathrm{C}$ (Avanti ${ }^{\mathrm{TM}} 30$ Centrifuge) e o sobrenadante (2) e precipitado separados. Frações dos sobrenadantes e precipitado foram avaliadas em SDSPAGE.

A purificação da proteína gp96 foi realizada por cromatografia de afinidade, utilizando-se uma coluna com resina NiSepharose e o sobrenadante 1. Como descrito para as proteínas EGFRvIII e cERBB2, a resina foi tratada com $\mathrm{NaOH}$ e imobilizada com sulfato de níquel.

A coluna foi equilibrada com 5VC de PBS (tampão em que a proteína estava). Em seguida, o sobrenadante foi aplicado na coluna e a fração não ligada foi coletada. A coluna foi lavada posteriormente com 10VC de tampão de lavagem B que também foi recolhido. As proteínas presas a resina foram eluídas $(5 \mathrm{VC})$ utilizando-se alta concentração de imidazol (tampão de eluição B). Todas as frações coletadas durante a purificação foram submetidas à eletroforese conforme descrito para as proteínas EGFRvIII e cERBB2.

A fração contendo a proteína de interesse foi dialisada utilizando-se um Dialysis Tubing Celllose e PBS, a diálise foi feita contra 500mL de PBS, overnight, seguida de 8 horas com novo PBS. Após a diálise, as proteínas foram quantificadas pelo ensaio de Bradford e a 
quantidade de endotoxinas bacterianas determinada pelo teste cromogênico LAL. Frações contendo a proteína precipitada foram inicialmente centrifugadas por 15 minutos a $2500 \mathrm{~g}$, $4^{\circ} \mathrm{C}$ e separada em precipitado e sobrenadante para depois ser caracterizada como descrito acima.

OBS.: a purificação realizada a partir do primeiro experimento (teste) foi realizada segundo o protocolo acima, no entanto, foi feita com os dois sobrenadantes, 1 (PBS) e 2 (com ureia), sendo a purificação do sobrenadante 2 com tampões de sonicação, lavagem e eluição B1 contendo ureia; a proteína purificada foi dialisada e concentrada diretamente em vivaspin 500 - 5kDaMWCO (GE Healthcare).

\subsection{Produção de anticorpos policlonais contra as proteínas recombinantes}

As proteínas recombinantes, EGFRvIII, cERBB2, GLEA, Hsp70 e gp96, produzidas conforme descrito no item 4.4, foram utilizadas na imunização de camundongos BALB/c para a produção de anticorpos policlonais. Para isso, camundongos isogênicos da linhagem BALB/c (fêmeas), provenientes do Biotério de Animais Isogênicos da Faculdade de Medicina de Ribeirão Preto-USP, foram utilizados nos ensaios de imunização, segundo os princípios éticos adotado pelo Colégio Brasileiro de Experimentação Animal (COBEA) e condições estabelecidas pelo nosso grupo. Os animais foram mantidos em isoladores de animais, com temperatura, umidade, fluxo de ar e ciclo de luz claro/escuro controlado, com livre acesso a água e ração.

Os animais ( $n=2$ ou 3) receberam as proteínas por via subcutânea em regime vacinal

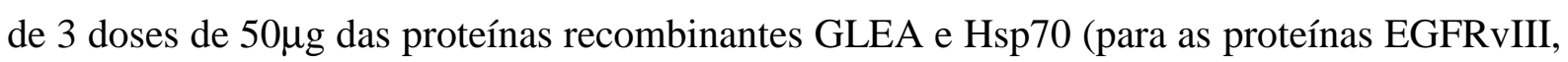
cERBB2 e gp96 foram utilizados frações insolúveis, os precipitados) juntamente com adjuvante incompleto de Freud (AIF) (Gibco BRL) obedecendo um intervalo de 12 dias entre cada dose e coleta do soro 20 dias após a última dose. O AIF foi preparado, de acordo com as instruções do fabricante, homogeneizando-se a proteína diluída em salina (Cloreto de sódio 0,9\% - Samtec Biotecnologia) e o adjuvante numa proporção de 1:1 (volume) até a aquisição de uma emulsão homogênea e consistente.

Após 20 dias da última imunização, os animais foram sacrificados por deslocamento cervical e em seguida, foi realizada punção cardíaca para retirada do sangue do animal. $\mathrm{O}$ sangue foi incubado por 1 hora a temperatura ambiente e centrifugado por 10 minutos a 
$1300 \mathrm{~g}$ (Eppendorf 5402). Após centrifugação, o soro foi coletado, armazenado a $-20^{\circ} \mathrm{C}$ e posteriormente utilizado na caracterização das vacinas. Os soros contendo os anticorpos policlonais contra as proteínas recombinantes foram usados na detecção dessas proteínas expressas pelas vacinas de DNA (item 4.6.3).

OBS.: o anticorpo anti-MAGE foi fornecido pela Empresa Farmacore Biotechnology Ltd..

\subsection{Purificação e caracterização das vacinas de DNA}

\subsubsection{Purificacão das vacinas de DNA}

As vacinas pVAXgDEGFRvIII, pVAXgDcERBB2, pVAXgDMAGE, pVAXgDGLEA, pVAXgp96, pVAXEGFRvIII, pVAXcERBB2, pVAXMAGE, pVAXGLEA e pVAXhsp70 foram purificadas por cromatografia de troca iônica, utilizando-se o kit comercial Qiagen Giga Plasmid Purification, EndoFree (Qiagen Inc., Santa Clarita, CA, USA.).

Bactérias E. coli Top 10 foram transformadas com cada plasmídio e plaqueadas em meio LB ágar suplementado com canamicina. Após a transformação, escolheu-se uma colônia que foi inoculada em 5,0mL de meio LB líquido suplementado com canamicina e incubada durante 8 horas, $200 \mathrm{rpm}$ a $37^{\circ} \mathrm{C}$ (Incubador shaker innova 44, New Brunswick, Edison, New Jersey, USA). Em seguida, essa cultura foi diluída 1/1000 em 2,5L de LB líquido, contendo canamicina, e incubada novamente a $37^{\circ} \mathrm{C}$ sob agitação (200rpm), overnight. Após esse período, o material foi centrifugado a $6650 \mathrm{~g}$ por 15 minutos a $4^{\circ} \mathrm{C}$, o sobrenadante desprezado e cerca de 7 gramas do precipitado foi ressuspendido em $125 \mathrm{~mL}$ de tampão P1 (Tris-HCl 50mM pH 8,0; EDTA 10mM e RNAse $100 \mu \mathrm{g} / \mathrm{ml}$ ). Logo após, foram adicionados $125 \mathrm{~mL}$ de tampão P2 (NaOH 200mM; SDS1\%), feita uma homogeneização e incubação de 5 minutos, em seguida, adicionou-se $125 \mathrm{~mL}$ do tampão $\mathrm{P} 3$ (acetato de potássio 3,0M pH 5,5). O material foi filtrado e mantido no gelo por 30 minutos após adição de tampão para remoção de endotoxinas.

O filtrado foi aplicado em uma coluna de sefarose previamente equilibrada com tampão QBT (NaCl 750mM; MOPS 50mM pH 7,0; etanol 15\% e Triton X-100 0,15 \%). Após a aplicação do filtrado, a resina foi lavada com 600mL de tampão QC (NaCl 1,0M; MOPS $50 \mathrm{mM} \mathrm{pH} \mathrm{7,0;} \mathrm{etanol} 15 \%$ ) e o DNA plasmidial foi eluído com 100mL de tampão QN (NaCl 1,25M; MOPS 50mM pH 7,0; etanol $15 \%$ ). O DNA eluído foi precipitado com isopropanol, 
centrifugado a $15000 \mathrm{~g}$ por 30 minutos, $4^{\circ} \mathrm{C}$ (Avanti ${ }^{\mathrm{TM}} 30$ Centrifuge), lavado com etanol $70 \%$ e centrifugado novamente por 10 minutos. Por fim, o sedimento foi ressuspendido em cerca de 1,0mL de água estéril livre de endotoxinas.

\subsubsection{Caracterizacão das vacinas de DNA purificadas}

\subsubsection{Análise de restrição e dosagem de endotoxinas nas vacinas de DNA}

Após a purificação das diferentes construções vacinais, foi realizada a quantificação, a clivagem e a avaliação da presença de LPS nos produtos purificados. A quantificação dos plasmídios foi realizada em espectrofotômetro nos comprimentos de onda de 260 a $280 \mathrm{~nm}$ utilizando-se o aparelho Nanodrop $1000^{\mathrm{TM}}$ (Thermo). A quantidade de endotoxinas bacterianas foi determinada pelo teste cromogênico LAL. A clivagem de todas as vacinas pVAXgDEGFRvIII, pVAXgDcERBB2, pVAXgDMAGE, pVAXgDGLEA, pVAXgp96, pVAXEGFRvIII, pVAXcERBB2, pVAXMAGE, pVAXGLEA e pVAXhsp70 foi realizada com a enzima NheI. Aproximadamente $1 \mu \mathrm{g}$ de cada plasmídio separadamente foi incubado a $37^{\circ} \mathrm{C}$ por 5 horas com $0,5 \mu \mathrm{L}$ da enzima NheI juntamente com seu tampão na concentração $1 \mathrm{X}$, em $20 \mu \mathrm{L}$ finais. Em seguida, o produto da digestão de cada amostra foi submetido a eletroforese em gel de agarose $1 \%$.

\subsubsection{Transfecção das células HEK com as vacinas de DNA}

Para detecção da transcrição e tradução das proteínas codificadas pelas vacinas de DNA, células HEK foram transfectadas pela utilização de cloreto de cálcio com as diferentes construções vacinais, pVAXgDEGFRvIII, pVAXgDcERBB2, pVAXgDMAGE, pVAXgDGLEA, pVAXgp96, pVAXEGFRvIII, pVAXcERBB2, pVAXMAGE, pVAXGLEA, pVAXhsp70, bem como, com os vetores pVAX e pVAXgD.

Aproximadamente $2 \times 10^{5}$ células ressuspendidas em DMEM-C foram adicionadas em cada poço da placa de 24 (Corning) e incubadas por 24 horas a $37^{\circ} \mathrm{C}, 5 \%$ de $\mathrm{CO}_{2}$ (as células podem ser incubadas por mais tempo para atingirem uma confluência de aproximadamente $70 \%)$. A transfecção foi realizada após as 24 horas de incubação pela adição em cada poço de $500 \mathrm{ng}$ de DNA, $54 \mu \mathrm{L}$ de água estéril, $6 \mu \mathrm{L}$ de cloreto de cálcio a $2,5 \mathrm{M}$ estéril e $60 \mu \mathrm{L}$ de HEBS $2 \mathrm{X}\left(\mathrm{NaCl}\right.$ a $0,28 \mathrm{M}$, Hepes a $0,05 \mathrm{M}$ e $\mathrm{Na}_{2} \mathrm{HPO}_{4}$ a $\left.1,5 \mathrm{mM}, \mathrm{pH} 7,05\right)$ segundo o seguinte protocolo (para cada poço): em um tubo de 1,5mL foram adicionados a água e o DNA e homogeneizado, em seguida, o $\mathrm{CaCl}_{2}$ a $2,5 \mathrm{M}$ foi adicionado a mistura de água e DNA e realizada nova homogeneização; em um outro tubo de $1,5 \mathrm{~mL}$ contendo $60 \mu \mathrm{L}$ de HEBS $2 \mathrm{X}$ foi 
adicionado a mistura de água, DNA e $\mathrm{CaCl}_{2}$, a solução foi homogeneizada, incubada a temperatura ambiente por 20 minutos e adicionada ao poço de cultura, a placa foi levemente movimentada para homogeneizar e incubada em estufa, a $37^{\circ} \mathrm{C}$ por 24 horas.

A transfecção foi realizada com todas as construções vacinais e a presença do RNA mensageiro e da proteína codificada por elas foram avaliados após 24 horas de transfecção. Como controle do experimento de transfecção além dos vetores pVAX e pVAXgD foi utilizado o plasmídio pGFP para visualização da transfecção em microscópio de fluorescência (Leica DMI 4000B).

\subsection{Transcricão do RNA mensageiro}

Após 24 horas de cultura, o meio foi retirado, as células lavadas com PBS e adicionado $500 \mu \mathrm{L}$ de Trizol (Invitrogen). As células foram homogeneizadas, coletadas em tubo de $1,5 \mathrm{~mL}$ e congeladas a $-70^{\circ} \mathrm{C}$. No dia da extração do RNA adicionou-se $100 \mu \mathrm{L}$ de clorofórmio ao trizol descongelado, as células foram agitadas por 15 segundos e incubadas por 3 minutos a temperatura ambiente. A suspensão celular foi, então, centrifugada a $12000 \mathrm{~g}$, por 15 minutos a $4^{\circ} \mathrm{C}$ (Eppendorf 5402), para recuperação da fase aquosa, na qual foi adicionado $250 \mu \mathrm{L}$ de isopropanol. As amostras foram, em seguida, homogeneizadas levemente e incubadas por 10 minutos a temperatura ambiente para precipitação do RNA. Após esse intervalo de tempo, as amostras foram centrifugadas $12000 \mathrm{~g}$ por 10 minutos a $4^{\circ} \mathrm{C}$, o sobrenadante foi descartado e $500 \mu \mathrm{L}$ de etanol a $75 \%$ adicionado. O precipitado foi resuspendido, centrifugado a $7500 \mathrm{~g}$, por 5 minutos a $4^{\circ} \mathrm{C}$ e o sobrenadante descartado; após secagem de aproximadamente 1 hora, o RNA foi ressuspendido em água, incubado a $42^{\circ} \mathrm{C}$ por 10 minutos, congelados e quantificados no dia seguinte no aparelho nanodrop.

Após a extração e quantificação do RNA, $1 \mu \mathrm{g}$ foi tratado com 1 unidade de DNAse I (Fermentas) e tampão (10X DNAse buffer), em um volume final de $10 \mu \mathrm{L}$ (completado com água ultrapure - Invitogen), por 30 minutos a $37^{\circ} \mathrm{C}$. Após esse período, a enzima foi inativada com $5 \mathrm{mM}$ de EDTA (Fermentas), por 10 minutos a $65^{\circ} \mathrm{C}$.

A produção do cDNA, de cada RNA obtido das células transfectadas com as distintas construções vacinais, foi realizada incubando-se os $11 \mu \mathrm{L}$ da reação acima juntamente com 100picomol de oligo dT (Invitrogen) por 5 minutos a $70^{\circ} \mathrm{C}$ e 5 minutos a $4^{\circ} \mathrm{C}$. Após esse período, foram adicionados buffer $(1 \mathrm{X}), \mathrm{MgCl}_{2}(3 \mathrm{mM})$, dNTPs $(0,5 \mathrm{mM})$ e transcriptase $(1 \mu \mathrm{L})$ (ImProm II - Promega) em um volume final de $20 \mu \mathrm{L}$. As amostras foram incubadas por 5 minutos a $25^{\circ} \mathrm{C}, 60$ minutos a $42^{\circ} \mathrm{C}$ e 15 minutos a $70^{\circ} \mathrm{C}$. 
A detecção dos transcritos codificados pelas vacinas foi realizada por PCR utilizandose o programa VAC e $2 \mu \mathrm{L}$ do cDNA, $0,4 \mu \mathrm{M}$ de cada oligonucleotídeo**, $0,2 \mathrm{mM}$ de cada dNTPs, tampão da enzima $1 \mathrm{X}, 1,5 \mathrm{mM}$ de $\mathrm{MgCl}_{2}$ e 1 unidade da enzima Taq DNA polimerase, em um volume final de $20 \mu \mathrm{L}$. O produto da PCR foi analisado em gel de agarose a $1 \%$.

**Os oligonucleotídeos utilizados para detectar os transcritos de todas as construções vacinais foram T7p e o Rseq de cada gene, que hibridizam no interior da plasmídio e no gene respectivamente. $\mathrm{O}$ controle do experimento foi realizado com os oligonucleotídeos específicos do gene constitutivo GAPDH (glyceraldehyde-3-phosphate dehydrogenase).

\section{GAPDH sense 5' ACCCACTCCTCCACCTTTG 3'}

\section{GAPDH antisense 5' CTCTTGTGCTCTTGCTGG 3'}

\subsection{Traducão das proteínas (western blot)}

Após 24 horas de cultura, o meio foi retirado e as células lavadas 2 vezes com PBS $(500 \mu \mathrm{L})$. Foi adicionado $100 \mu \mathrm{L}$ de tampão RIPA modificado (Tris a 50mM, pH 8,0, NaCl a 150mM, SDS a 0,1\%, IgePal 1\%, coquetel de inibidores-Complete, EDTA free-Roche) para lise das células. As células foram homogeneizadas no tampão de lise e coletadas. Todas as amostras $(20 \mu \mathrm{L})$ foram completadas com $5 \mu \mathrm{L}$ de tampão da amostra $5 \mathrm{X}$, fervidas por 5 minutos e submetidas à eletroforese em gel a $10 \%$.

Após a eletroforese, as proteínas foram transferidas para uma membrana de nitrocelulose (Life Technologies) por 1,5 hora a 100V (Tampão de transferência-Tris-base a $22,7 \mathrm{mM}$, glicina a $61 \mathrm{mM}$, metanol a $18,3 \%, \mathrm{pH} 8,3$ ), em seguida, a membrana foi incubada com tampão de bloqueio [PBS, 2\% de BSA-Albumina Bovina (INLAB), 0,05\% de Tween 20] por 2 horas a temperatura ambiente, lavada (PBS, 0,05\% de Tween 20 - PBS-T) e incubada com os anticorpos específicos para as proteínas de interesse [soro anti-proteínas recombinantes diluídos 1:1000 (soro de camundongos imunizados, item 4.5), anticorpo antigD diluído 1:20000 (cedido gentilmente pelo Professor Luis Carlos de Souza Ferreira ICBII/USP - São Paulo) e anticorpo anti-grp94 (Sigma) diluído 1:2000] em tampão bloqueio, a $4^{\circ} \mathrm{C}$, overnight. A membrana foi, então, novamente lavada e incubada com o anticorpo de cabra contra IgG de camundongo marcado com peroxidase (Molecular Probes) diluído 1:5000, por 1 hora a temperatura ambiente e revelada com peróxido de hidrogênio e DAB (Vector Peroxydase Substrate Kit). 


\subsection{Experimentos de Imunogenicidade}

\subsubsection{Imunizacão}

Todas as vacinas construídas, após caracterização, foram usadas na imunização de camundongos para avaliação da imunogenicidade desencadeadas por elas. Camundongos isogênicos da linhagem C57BL/6 (fêmeas), com 7-8 semanas de idade, provenientes do Biotério citado anteriormente, foram utilizados nos ensaios de imunização, segundo os princípios éticos adotado pelo COBEA. As imunizações foram realizadas pela inoculação nos músculos quadríceps (direito e esquerdo) em regime vacinal de 3 doses de $100 \mu \mathrm{g}$ de DNA/dose, obedecendo um intervalo de 12 dias entre cada dose e avaliação dos resultados 20 dias após a última dose. Foram realizados dois protocolos em duplicata com o número de animais variando entre 4 e 8 por grupo.

\section{Primeiro protocolo}

O primeiro protocolo foi realizado apenas com um antígeno tumoral (GLEA) e com todas as proteínas imunomoduladoras, para determinar qual dessas moléculas seria mais eficiente na indução da resposta imunológica específica contra o antígeno tumoral. Os animais foram divididos em grupos e imunizados com as seguintes vacinas: pVAX / pVAXGLEA / pVAXgDGLEA / pVAXGLEA + pVAXhsp65 / pVAXGLEA + pVAXhsp70 / pVAXGLEA + pVAXgp96.

OBS.: No primeiro experimento desse protocolo foram incluídos os grupos pVAX + pVAXGLEA e pVAX + pVAXgDGLEA como controles, pois os grupos imunizados com pVAXGLEA + pVAXHsps receberam maior quantidade do vetor pVAX. Nos dois experimentos desse protocolo foi utilizada a vacina pVAXhsp65, desenvolvida pelo nosso grupo, em combinação com o plasmídio pVAXGLEA.

\section{Segundo protocolo}

O segundo protocolo foi realizado com os outros antígenos tumorais (EGFRvIII, cERBB2 e MAGE) e apenas com as proteínas gD e Hsp70. Os animais foram divididos em grupos e imunizados com as seguintes vacinas: pVAX / pVAXEGFR / pVAXgDEGFR / pVAXEGFR + pVAXhsp70 / pVAXcERBB2 / pVAXgDcERBB2 / pVAXcERBB2 + pVAXhsp70 / pVAXMAGE / pVAXgDMAGE / pVAXMAGE + pVAXhsp70. 
Os animais durante todo protocolo experimental foram mantidos em isoladores de animais, com temperatura, umidade, fluxo de ar e ciclo de luz claro/escuro controlados, com livre acesso a água e ração.

\section{$\underline{\text { 4.7.2 Avaliacão da resposta imunológica }}$}

\subsubsection{Avaliação da resposta imunológica humoral}

A resposta imunológica humoral foi avaliada pela detecção de anticorpos IgG1 e IgG2a específicos contra as proteínas recombinantes EGFRvIII, cERBB2, MAGE e GLEA (produzidas em E. coli - item 4.4), por ELISA, nas amostras de soro pré-imune (coletados antes das imunizações) e soros coletados 20 dias após a última imunização através do plexoretro orbital. Placas de 96 poços de poliestireno (Maxisorp Nunc-Immuno Plates, USA) foram sensibilizadas com $100 \mu \mathrm{L} /$ poço da solução de proteína (EGFRvIII, cERBB2, MAGE ou GLEA) diluídas em tampão de ligação (15mM de $\mathrm{Na}_{2} \mathrm{CO}_{3}$ e $35 \mathrm{mM}$ de $\mathrm{NaHCO}_{3}$, pH 9,6) em uma concentração final de $5 \mu \mathrm{g} / \mathrm{mL}$. As placas foram incubadas a $4{ }^{\circ} \mathrm{C}$, overnight e posteriormente lavadas com PBS-T e bloqueadas com $200 \mu \mathrm{L} /$ poço de uma solução de PBS contendo $10 \%$ de SBF e $0,05 \%$ de Tween 20 (solução de bloqueio). Após incubação por 1 hora, a $37^{\circ} \mathrm{C}$, as placas foram novamente lavadas e adicionou-se $100 \mu \mathrm{L}$ /poço dos soros, diluídos 1:10, 1:100, e 1:1000, em solução de bloqueio. As placas foram incubadas por 2 horas, a $37^{\circ} \mathrm{C}$, e após lavagem das mesmas, foi realizada incubação por 1 hora, a $37^{\circ} \mathrm{C}$, com anticorpo monoclonal anti-IgG1 (A85-1) ou anti-IgG2a (R19-15) conjugados com biotina (BD Bioscience), adicionando-se 100 $\mathrm{L}$ /poço do anticorpo diluído 1:1000 em solução de bloqueio. Após procedimento de lavagem, foi adicionada $100 \mu \mathrm{L} /$ poço da solução de avidinabiotina-peroxidase (Vectastain $\mathrm{ABC}$ kit, Vector), sendo incubada por 30 minutos a temperatura ambiente protegida da luz. As placas foram reveladas pela adição de $100 \mu \mathrm{L} /$ poço de TMB (3,3', 5,5' tetramethylbenzidine, BD Bioscience) e a reação foi interrompida pela adição de $50 \mu \mathrm{L} /$ poço de ácido sulfúrico a $16 \%$ após 30 minutos de revelação. A leitura da absorbância foi realizada em espectrofotômetro de placa VERSA max microplate reader (Molecular Devices) a 490 e 570nm.

\subsubsection{Avaliação da resposta imunológica celular}

Vinte dias após a última imunização, os animais foram sacrificados por deslocamento cervical. O baço de cada animal foi retirado assepticamente e incubado em $2 \mathrm{~mL}$ de meio 
RPMI-1640 incompleto (Sigma-Aldrich) separadamente. Em seguida, o órgão foi macerado entre um pedaço de organza com o auxílio do embolo de uma seringa e o macerado foi centrifugado a $461 \mathrm{~g}$, por 5 minutos a $4^{\circ} \mathrm{C}$ (Centrifuga CT-6000R). O sobrenadante foi descartado e o sedimento tratado com $2 \mathrm{~mL}$ de tampão de lise ACK $\left(0,15 \mathrm{M}\right.$ de $\mathrm{NH}_{4} \mathrm{Cl}, 10 \mathrm{mM}$ de $\mathrm{KHCO}_{3}$ e $0,1 \mathrm{mM}$ de EDTA, pH 7,3), por 2 minutos a $4^{\circ} \mathrm{C}$ para lise das hemácias. À suspensão foi acrescentado $10 \mathrm{~mL}$ de PBS sendo, em seguida, centrifugada a $461 \mathrm{~g}$, por 5 minutos a $4^{\circ} \mathrm{C}$. O sobrenadante foi descartado e o sedimento ressuspendido em $1 \mathrm{~mL}$ de RPMI completo (RPMI incompleto acrescido de 10\% de SBF, $1 \%$ de estreptomicina/penicilina, $30 \mu \mathrm{g} / \mathrm{mL}$ de polimixina-P-4932, Sigma, $10 \mu \mathrm{g} / \mathrm{mL}$ de Gentamicina-Gibco e $50 \mu \mathrm{M}$ de 2mercaptoetanol-Sigma) (RPMI-C). As células foram contadas em câmara de Neubauer (Boeco) e ajustadas para uma concentração final de $5 \times 10^{6}$ células/mL em RPMI-C. A resposta imunológica celular foi avaliada após uma estimulação secundária dessas células com as proteínas específicas de cada grupo experimental [proteínas recombinantes EGFRvIII, cERBB2, MAGE e GLEA (produzidas em E. coli - item 4.4)]. A avaliação consistiu da dosagem de citocinas no sobrenadante celular por ELISA e na caracterização fenotípica das células estimuladas.

\subsection{Dosagem de citocinas}

Para dosagem de citocinas, parte da suspensão celular obtida no item 4.7.2.2 foi distribuída em placas de 24 poços $\left(5 \times 10^{6}\right.$ células $/ \mathrm{mL} /$ poço $)$, estimulada ex vivo com meio

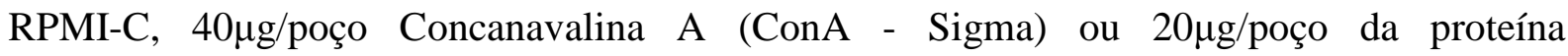
recombinante específica de cada grupo experimental (EGFRvIII, cERBB2, MAGE ou GLEA) e incubadas a $37^{\circ} \mathrm{C}, 5 \%$ de $\mathrm{CO}_{2}$.

Após 48 horas de cultura, as placas foram centrifugadas a $453 \mathrm{~g}$, por 5 minutos (Centrifuge 5810R, Eppendorf) e o sobrenadante coletado e avaliado quanto à presença de IFN- $\gamma$, IL-12, IL-2, IL-5, IL-10 e IL-6, por ELISA. Placas de 96 poços de poliestireno foram sensibilizadas com $100 \mu \mathrm{L}$ da solução de anticorpo monoclonal purificado específico para a citocina de interesse (BD Bioscience), diluído em tampão de ligação $\left(\mathrm{Na}_{2} \mathrm{HPO}_{4}\right.$ a $0,1 \mathrm{M}, \mathrm{pH}$ 9,0), em uma concentração final de $1 \mu \mathrm{g} / \mathrm{mL}$ (para IL-10, $2 \mu \mathrm{g} / \mathrm{mL}$ ). As placas foram incubadas a $4^{\circ} \mathrm{C}$, overnight e após sucessivas lavagens com solução PBS-T, foram incubadas com $200 \mu \mathrm{L}$ /poço da solução de bloqueio, constituída de PBS contendo $10 \%$ de SBF por 1-2 horas, a temperatura ambiente. As placas foram novamente lavadas e as amostras (sobrenadante) foram adicionadas, $100 \mu \mathrm{L} /$ poço juntamente com a curva padrão da citocina recombinante, 
diluída em tampão de bloqueio com $0,05 \%$ de Tween 20 , e incubada overnight a $4{ }^{\circ} \mathrm{C}$. Após lavagem, foi feita incubação por 1 hora, a temperatura ambiente, com anticorpo monoclonal conjugado com biotina específico para a citocina de interesse (BD Bioscience), adicionandose $100 \mu \mathrm{L} /$ poço do anticorpo diluído em tampão de bloqueio com 0,05\% de Tween 20 em uma concentração final de $0,5 \mu \mathrm{g} / \mathrm{mL}$ (para $\mathrm{IL}-10,1 \mu \mathrm{g} / \mathrm{mL}$ ). Após lavagem, adicionou-se $100 \mu \mathrm{L} /$ poço de solução de avidina-biotina-peroxidase diluída em tampão de bloqueio com 0,05\% de Tween 20 (1:1000, exceto IFN- $\gamma, 1: 500$ e IL-2, 1:2000) e incubou-se as placas por 30 minutos a temperatura ambiente protegida da luz. As placas foram reveladas pela adição de TMB após novo procedimento de lavagem. A reação foi interrompida pela adição de $50 \mu \mathrm{L} /$ poço de ácido sulfúrico $16 \%$ após 30 minutos de revelação. A leitura da absorbância foi realizada em espectrofotômetro de placa a 490 e 570nm. A determinação das concentrações das citocinas foi feita por interpolação dos resultados de absorbância obtidos nas amostras em relação aos da curva padrão utilizando-se o programa SoftMaxPro 5.4.

\begin{tabular}{lcc}
\hline & Anticorpo Purificado & Anticorpo Biotinilado \\
\hline IFN- $\boldsymbol{\gamma}$ - Clone & R4-6A2 & XGM1.2 \\
\hline Isotipo & Rat IgG1 & Rat IgG1 \\
\hline IL-10 - Clone & JES5-2A5 & SXC-1 \\
\hline Isotipo & Rat IgG1 & Rat IgM \\
\hline IL-5 - Clone & TRFK5 & TRFK4 \\
\hline Isotipo & Rat IgG1 & Rat IgG2a \\
\hline IL-12 - Clone & $9 \mathrm{~A} 5$ & C17.8 \\
Isotipo & Rat IgG2b & Rat IgG2a \\
IL-2 - Clone & JES6-1A12 & JES6-5H4 \\
\hline Isotipo & Rat IgG2a & Rat IgG2b \\
\hline IL-6 - Clone & MP5-20F3 & MP5-32C11 $^{-}$Rat IgG \\
Isotipo & Rat IgG & Ra \\
\hline
\end{tabular}

\subsection{Proliferação de linfócitos $T$}

Parte da suspensão celular obtida no item 4.7.2.2 foi distribuída em placas de 96 poços fundo U (1-2x10 células/poço em $100 \mu \mathrm{L})$ (Corning) e estimuladas ex vivo com $100 \mu \mathrm{L}$ de meio, 8 ou $16 \mu \mathrm{g} /$ poço de ConA e 4 ou $8 \mu \mathrm{g} /$ poço das proteína recombinante específica de cada grupo experimental [EGFRvIII, cERBB2, MAGE ou GLEA (produzidas em E. coli - item 4.4)] em poços separados e incubadas a $37^{\circ} \mathrm{C}, 5 \%$ de $\mathrm{CO}_{2}$. Após 24 horas de cultura as placas foram centrifugadas a $453 \mathrm{~g}$, por 5 minutos e o sobrenadante coletado e avaliado quanto à presença de IL-2 (fator de crescimento para os linfócitos T) por ELISA conforme descrito acima. 


\subsection{Fenótipo celular}

As células em cultura nos itens 4.7.2.2.1 e 4.7.2.2.2 foram avaliadas quanto aos marcadores de superfície celular CD4, CD8, CD44 e CD62L por citometria de fluxo. Após coleta do sobrenadante, as células foram lavadas com $200 \mu \mathrm{L}$ de PBS e centrifugadas a $320 \mathrm{~g}$, por 10 minutos a $4^{\circ} \mathrm{C}$ (Eppendorf 5402) (para as células na placa de 96) (as células na placa de 24 poços foram coletadas com $1 \mathrm{~mL}$ de PBS em eppendorf, centrifugadas e passadas para uma placa de 96 poços). O sobrenadante foi descartado, o sedimento ressuspendido em $50 \mu \mathrm{L}$ de tampão bloqueio (1:1 de PBS/2\%SBF e Fcblock - sobrenadane de cultura do clone 2,4G2PharMingen) e incubado por 30 minutos a $4{ }^{\circ} \mathrm{C}$. A solução de anticorpos $(5 \mu \mathrm{L}$ de tampão PBS/2\%SBF mais o volume de cada anticorpo conforme titulação/poço) foi adicionada e nova incubação de 30 minutos a $4^{\circ} \mathrm{C}$ no escuro foi realizada. As células foram lavadas com $200 \mu \mathrm{L}$ de $\mathrm{PBS} / 2 \% \mathrm{SBF}$ e centrifugadas a $320 \mathrm{~g}$, por 10 minutos a $4^{\circ} \mathrm{C}$. O sobrenadante foi descartado, as células lavadas novamente com $200 \mu \mathrm{L}$ de PBS e o sedimento ressuspendido em $100 \mu \mathrm{L}$ de PBS contendo $0,1 \%$ de formaldeído. As amostras foram adquiridas em aparelho FACSCantoII (BD Bioscience), coletando-se 50.000 eventos por amostra. Um tubo apenas com células, um com os isotipos controles e outros com cada marcação separada foram utilizados em todos os experimentos para o ajuste das fluorescências. Anticorpos utilizados:

\begin{tabular}{|c|c|c|}
\hline & Clone & Isotipo \\
\hline CD4-FITC & RM4-5 & IgG2aк Rat \\
\hline CD8-PE & $53-6.7$ & IgG2aк Rat \\
\hline CD44-PeCy5 & IM7 & IgG2bк Rat \\
\hline CD62L-APC & MEL-14 & IgG2aк Rat \\
\hline CD4-PE & RM4-5 & IgG2aк Rat \\
\hline CD8-Percp & $53-6.7$ & IgG2aк Rat \\
\hline CD62L-FITC & MEL-14 & IgG2aк Rat \\
\hline CD44-APC & IM7 & IgG2aк Rat \\
\hline
\end{tabular}

FITC - isotiocianato de fluoresceína, PE - ficoeritrina, PeCy5 - ficoeritrina Cy-chrome, APC - allophycocyanin e Percp - Peridinin chlorophyll.

Em dois de três experimentos de fenotipagem celular as células foram coletadas e lavadas com PBS, conforme descrito acima, ressuspendidas em 100-120 $\mu \mathrm{L}$ de PBS/4\% formol, incubadas por 11 minutos a $4^{\circ} \mathrm{C}$, acrescidas de $1-1,5 \mathrm{~mL}$ de PBS e armazenadas a $4^{\circ} \mathrm{C}$ por 4-5 dias. Após esse período, as células foram marcadas segundo protocolo descrito acima. 


\subsubsection{Análise Estatística}

Os resultados foram avaliados comparando-se a média dos valores encontrados por análise de variância (ANOVA) seguida de um pós-teste (Teste de Tukey). Foram considerados estatisticamente significantes resultados com $\mathrm{p}<0,05$. Valores que estavam acima do valor da média mais duas vezes o desvio padrão foram excluídos das análises, assim como valores abaixo do valor da média menos duas vezes o desvio padrão. 


\subsection{RESULTADOS}

5.1 Analise in silico da sequência de aminoácidos dos genes EGFRvIII, cERBB2, MAGE, GLEA e gp96

Conforme descrito nos materiais e métodos, a sequência de aminoácidos de todas as proteínas foi analisada in silico utilizando-se os programas SignalP 3.0 Server e NetNGlyc 1.0 Server para avaliar à presença de peptídeo sinal e sítios de N-glicosilação, respectivamente. O peptídeo sinal e sítios de N-glicosilação foram retirados e mutados, respectivamente, quando presentes, devido ao sistema de expressão inicialmente escolhido para produzir as proteínas de interesse (levedura K. lactis).

\subsubsection{EGFRvIII}

O gene EGFR ou ERBB1 (N_005228) possui uma fase aberta de leitura (ORF Open Reading Frame) de 3630pb e codifica uma proteína de 1210 aas (P_005219). A proteína nativa apresenta 1186 aas devido à ausência do peptídeo sinal. A isoforma EGFRvIII é uma variante da proteína nativa, não apresenta os aas 6 a 273 e possui uma glicina na junção entre os aas 7 e 274. Neste trabalho foram utilizados apenas os 900pb iniciais do gene EGFRvIII que codifica uma proteína de 300 aas, pois é conhecido que fragmentos de até 300 aas não interferem com a função da $\mathrm{gD}$ (Watson et al., 1982). A análise da sequência de aminoácidos da proteína EGFRvIII realizada com o programa SignalP 3.0 Server demonstrou ausência de peptídeo sinal, mas, conforme predito pelo programa NetNGlyc 1.0 Server, a sequência apresentava seis sítios de $\mathrm{N}$-glicosilação (em destaque) representados pela sequência: asparagina $(\mathrm{N})$ - qualquer aminoácido $(\mathrm{X})$ - Treonina $(\mathrm{T})$ ou Serina $(\mathrm{S})$, na qual o aminoácido asparagina é glicosilado.

Sequência dos 300 aas iniciais da proteína EGFRvIII, em destaque os sítios de N-glicosilação:

LEEKKGNYVVTDHGSCVRACGADSYEMEEDGVRKCKKCEGPCRKVCNGIGIGEFKDSLSINATNIKHFKNCTSIS GDLHILPVAFRGDSFTHTPPLDPQELDILKTVKEITGFLLIQAWPENRTDLHAFENLEI IRGRTKQHGQF SLAVV SLNITSLGLRSLKEISDGDVIISGNKNLCYANTINWKKLFGTSGQKTKI ISNRGENSCKATGQVCHALCSPEGCW GPEPRDCVSCRNVSRGRECVDKCNLLEGEPREFVENSECIQCHPECLPQAMNITCTGRGPDNCIQCAHYIDGPHC

A asparagina foi trocada em todos os sítios pela glutamina (Q) que é um aminoácido de mesma característica, polar neutro. A sequência de nucleotídeos foi alterada para não haver tradução da asparagina e sim de uma glutamina. Esse procedimento foi adotado para os outros genes que apresentavam sítios de N-glicosilação. Após a modificação na sequência de nucleotídeos, os 900pb iniciais do gene EGFRvIII foram inseridos no interior da sequência de nucleotídeos da $\mathrm{gD}$, cuja porção central, entre dois sítios de enzimas (PvuII e Apal) foi 
retirada. Esse procedimento também foi adotado para os genes cERBB2, MAGE e GLEA. Após essa junção, o fragmento gDEGFRvIII foi avaliado quanto a presença de sítios de clivagem em seu interior pelo programa NEBcutter V2.0. Foram inseridos no início do fragmento gDEGFRvIII o sítio de clivagem para a enzima NheI (GCTAGC), um sítio de ancoragem (TACTA) para essa enzima e a sequência Kozac (ACCATG); no final do gene já havia o stop códon (TAG) próprio da $\mathrm{gD}$, sendo inserido apenas o sítio da enzima XbaI (TCTAGA) e um sítio de ancoragem (AT). As enzimas escolhidas não apresentavam sítios de clivagem no interior do gene. Todos os outros genes foram analisados e modificados da mesma forma. Após as modificações, o fragmento gDEGFRvIII foi sintetizado pela empresa Epoch Biolabs e clonado no vetor pBSK.

\subsection{2 cERBB2}

O gene cERBB2 (NM_001005862.1) possui uma ORF de 3675pb e codifica uma proteína de 1225 aas (NP_001005862.1). Nesse trabalho foram utilizados apenas os 900pb iniciais do gene que codifica uma proteína de 300 aas. A análise da sequência de aminoácidos da proteína cERBB2 demonstrou ausência de peptídeo sinal e presença de quatro sítios de Nglicosilação.

Sequência dos 300 aas iniciais da proteína cERBB2, em destaque os sítios de N-glicosilação:

MKLRLPASPETHLDMLRHLYQGCQVVQGNLELTYLPTNASLSFLQDIQEVQGYVLIAHNQVRQVPLQRLRIVRGT QLFEDNYALAVLDNGDPLNNTTPVTGASPGGLRELQLRSLTEILKGGVLIQRNPQLCYQDTILWKDIFHKNNQLA LTLIDTNRSRACHPCSPMCKGSRCWGESSEDCQSLTRTVCAGGCARCKGPLPTDCCHEQCAAGCTGPKHSDCLAC LHFNHSGICELHCPALVTYNTDTFESMPNPEGRYTFGASCVTACPYNYLSTDVGSCTLVCPLHNQEVTAEDGTQR

A sequência de nucleotídeos foi alterada, inserida no interior da sequência de nucleotídeos da gD e avaliada quanto à presença de sítios de clivagem em seu interior conforme descrito para o fragmento gDEGFRvIII. Foram inseridos no fragmento gDcERBB2 as mesmas modificações descritas para o gDEGFRvIII. As enzimas escolhidas não apresentavam sítios de clivagem no interior do gene e após as modificações, o fragmento gDcERBB2 foi sintetizado pela empresa Epoch Biolabs e clonado no vetor pBSK.

\subsubsection{MAGE}

O gene MAGE (NM_005362.3) possui uma ORF de 945pb e codifica uma proteína de 314 aas (NP_005353.1). A análise da sequência de aminoácidos da proteína MAGE demonstrou a ausência de peptídeo sinal e sítios de N-glicosilação.

Sequência dos 314 aas da proteína MAGE, ausência de sítios de N-glicosilação: 
MPLEQRSOHCKPEEGLEARGEALGLVGAQAPATEEQEAASSSSTLVEVTLGEVPAAESPDPPQSPQGASSLPTTM NYPLWSQSYEDSSNQEEEGP STFPDLESEFQAALSRKVAELVHFLLLKYRAREPVTKAEMLGSVVGNWQYFFPVI FSKASSSLQLVFGIELMEVDP IGHLY IFATCLGLSYDGLLGDNQIMP KAGLII IVLAI IAREGDCAPEEKIWEEL SVLEVFEGREDSILGDPKKLLTQHFVQENYLEYRQVPGSDPACYEFLWGPRALVETSYVKVLHHMVKISGGPHIS YPPLHEWVLREGEE

Após todas as análises, a sequência de nucleotídeos do gene MAGE foi inserida no interior da $\mathrm{gD}$ e avaliada quanto a presença de sítios de clivagem em seu interior conforme descrito para o fragmento gDEGFRvIII. Foram inseridos no fragmento gDMAGE as mesmas modificações descritas para o gDEGFRvIII. As enzimas escolhidas não apresentavam sítios de clivagem no interior do gene e após as modificações, o fragmento gDMAGE foi sintetizado pela empresa Epoch Biolabs e clonados no vetor pBSK.

\subsubsection{GLEA}

O gene GLEA (AF258787) possui uma ORF de 1629pb e codifica uma proteína de 543 aas ( $\underline{\mathrm{AAG} 49888}$ ). A análise da sequência de aminoácidos da proteína GLEA demonstrou ausência de peptídeo sinal, no entanto, evidenciou quatro sítios de N-glicosilações.

Sequência dos 543 aas da proteína GLEA, em destaque os sítios de N-glicosilação:

MTKHPPNRRGISFEVGAQLEARDRLKNWYPAHIEDIDYEEGKVLIHFKRWNHRYDEWFCWDSPYLRPLEKIQLRK EGLHEEDGSSEFQINEQVLACWSDCRFYPAKVTAVNKDGTYTVKFYDGVVQTVKHIHVKAFSKDQNIVGNARPKE TDHKSLSSSPDKREKFKEQRKATVNVKKDKEDKPLKTEKRPKQPDKEGKLICSEKGKVSEKSLPKNEKEDQGNIS GNDREYSGDAQVDKKPENDIVKSPQENLREPKRKRGRPP SIAPTAVDSNSQTLQPITLELRRRKISKGCEVPLKR PRLDKNSSQEKSKNYSENTDKDLSRRRSSRLSTNGTHEILDPDLVVSDLVDTDPLQDTLSSTKESEEGQLKSALE AGQVSSALTCHSFGDGSGAAGLELNCP SMGENTMKTEPTSPLVELQEISTVEVTNTFKKTDDFGSSNAPAVDLDH KFRCKVVDCLKFFRKAKLLHYHMKYF HGMEKSLEPEESPGKRHVQTRGP SASDKPSQETLTRKRVFASSPTTKDK EKNKEKKFKEFVRVKPKK

A sequência de nucleotídeos foi alterada, inserida no interior da sequência de nucleotídeos da gD e avaliada quanto a presença de sítios de clivagem em seu interior conforme descrito para o fragmento gDEGFRvIII. Foram inseridos no fragmento gDGLEA as mesmas modificações descritas para o gDEGFRvIII. As enzimas escolhidas não apresentavam sítios de clivagem no interior do gene e após as modificações, o fragmento gDGLEA2 foi sintetizado pela empresa Epoch Biolabs e clonado no vetor pBSK.

\section{$\underline{5.1 .5 \mathrm{gp} 96}$}

O gene gp96 (NM_003299) possui uma ORF de 2409pb e codifica uma proteína de 803 aas (ㅍ_003290). A análise da sequência de aminoácidos da proteína gp96 demonstrou a presença de peptídeo sinal e cinco sítios de N-glicosilação. 
Sequência dos 803 aas da proteína gp96, em destaque o peptídeo sinal e os sítios de Nglicosilação:

MRALWVLGLCCVLLTFGSVRADDEVDVDGTVEEDLGKSREGSRTDDEVVQREEEAIQLDGLNASQIRELREKSEK FAFQAEVNRMMKLI INSLYKNKE IFLRELISNASDALDKIRLISLTDENALSGNEELTVKIKCDKEKNLLHVTDT GVGMTREELVKNLGTIAKSGTSEFLNKMTEAQEDGQSTSELIGQF GVGFYSAFLVADKVIVTSKHNNDTOHIWES DSNEF SVIADPRGNTLGRGTT ITLVLKEEASDYLELDTIKNLVKKYSOF INFP IYVWSSKTETVEEPMEEEEAAK EEKEESDDEAAVEEEEEEKKPKTKKVEKTVWDWELMNDIKP IWQRP SKEVEEDEYKAFYKSF SKESDDPMAY IHF TAEGEVTFKS ILFVPTSAPRGLFDEYGSKKSDYIKLYVRRVF ITDDFHDMMPKYLNFVKGVVDSDDLPLNVSRET LQQHKLLKVIRKKLVRKTLDMIKKIADDKYNDTFWKEFGTNIKLGVIEDHSNRTRLAKLLRFQSSHHPTDITSLD QYVERMKEKQDKIYFMAGSSRKEAESSPFVERLLKKGYEVIYLTEPVDEYCIQALPEFDGKRFQNVAKEGVKFDE SEKTKESREAVEKEFEPLLNWMKDKALKDKIEKAVVSQRLTESPCALVASQYGWSGNMERIMKAQAYQTGKDIST NYYASQKKTFEINPRHPLIRDMLRRIKEDEDDKTVLDLAVVLFETATLRSGYLLPDTKAYGDRIERMLRLSLNID PDAKVEEEPEEEPEETAEDTTEDTEQDEDEEMDVGTDEEEETAKESTAEKDEL

Além da retirada do peptídeo sinal e da alteração nos sítios de $\mathrm{N}$-glicosilação, foram inseridos no início do gene gp96 o sítio de ancoragem, o sítio de clivagem para a enzima NheI e a sequência Kozac. No final do gene está o stop códon próprio do gene gp96 e foram inseridos o sítio da enzima XbaI e o sítio de ancoragem. As enzimas escolhidas não apresentavam sítios de clivagem no interior do gene e após as modificações, o gene gp96 foi sintetizado pela empresa Epoch Biolabs e clonado no vetor pBSK. Esse gene não foi inserido no interior da $\mathrm{gD}$, pois ambos os genes (gp96 e $\mathrm{gD}$ ) codificam proteínas imunomoduladoras.

\subsection{Construção das vacinas de DNA}

5.2.1 Clonagem dos fragmentos gDEGFRvIII, gDcERBB2, gDMAGE e gDGLEA e do gene gp96 no vetor $\mathrm{pVAX}$

5.2.1.1 Clivagem dos fragmentos gDEGFRvIII, gDcERBB2, gDMAGE, gDGLEA-2 e gp96

Os vetores pBSKgDEGFRvIII, pBSKgDcERBB2, pBSKgDMAGE, pBSKgDGLEA e pBSKgp96 foram clivados com as enzimas NheI e XbaI para obtenção dos fragmentos gDEGFRvIII, gDcERBB2, gDMAGE e gDGLEA e gp96 (Figura 5). 


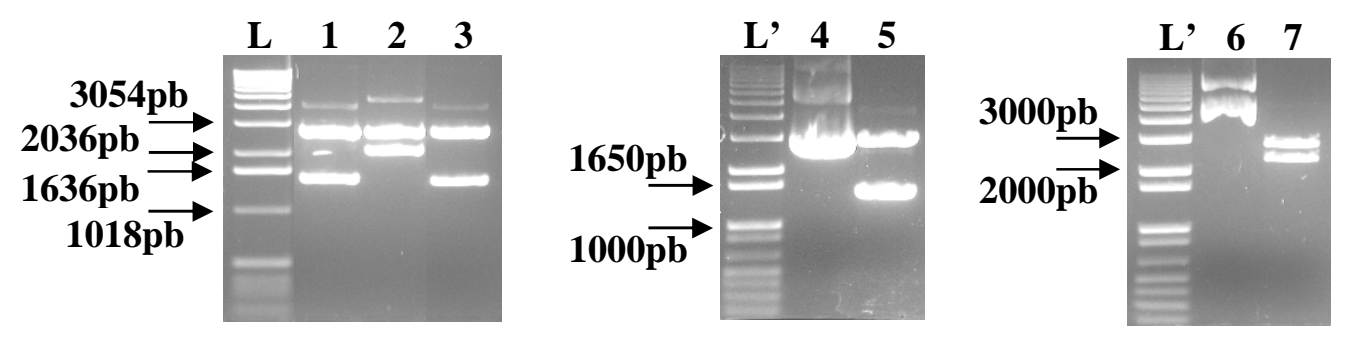

Figura 5: Clivagem dos plasmídios pBSKgDEGFRvIII, pBSKgDcERBB2, pBSKgDMAGE, pBSKgDGLEA e pBSKgp96. L e L'-marcadores de peso molecular (Invitrogen-1 Kb DNA Ladder e $1 \mathrm{~Kb}$ Plus DNA Ladder, respectivamente), 1-pBSKgDMAGE, 2-pBSKgDGLEA, 3-pBSKgDcERBB2, 5pBSKgDEGFRvIII e 7-pBSKgp96 clivados com as enzimas NheI e XbaI; 4-pBSKgDEGFRvIII não digerido e 6pBSKgp96 não digerido.

Todos os plasmídios liberaram os fragmentos de tamanhos esperados: gDMAGE com 1494pb; gDGLEA com 2181pb; gDEGFRvIII e gDcERBB2 com 1452pb e gp96 com $2361 \mathrm{pb}$. Os fragmentos foram purificados do gel de agarose para posterior clonagem no vetor pVAX.

\subsubsection{Clivagem do vetor $p V A X$}

$\mathrm{O}$ vetor $\mathrm{pVAX}$ foi clivado com as mesmas enzimas, NheI e $\mathrm{XbaI}$, e analisado em gel de agarose $1 \%$ (Figura 6).

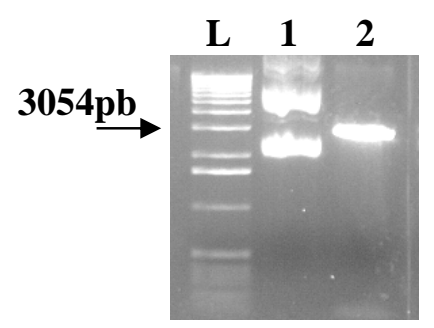

Figura 6: Clivagem do vetor pVAX. L-marcador $1 \mathrm{~Kb}, 1-\mathrm{pVAX}$ não digerido e 2-pVAX clivado com as enzimas NheI e XbaI.

$\mathrm{O}$ vetor pVAX clivado foi identificado pela presença de uma única banda no tamanho de 3000pb. Após a clivagem as três conformações do plasmídio são perdidas ficando todas abertas em um único fragmento. O plasmídio foi purificado, desfosforilado, purificado novamente para posterior ligação com os fragmentos obtidos no item 5.2.1.1.

\subsubsection{Clonagem do fragmento gDEGFRvIII no vetor $p$ VAX}

O fragmento gDEGFRvIII foi clonado no plasmídio $\mathrm{pVAX}$ por meio de uma reação de ligação, cujo produto foi posteriormente transformado em células E. coli Top10. A seleção do plasmídio recombinante pVAXgDEGFRvIII foi feita inicialmente pela PCR de 13 colônias individuais (nomeadas de 14 a 26). A reação foi realizada com os oligonucleotídeos T7p e 
EGFRvIII_Rseq, que indicam a presença e direção do fragmento gDEGFRvIII no interior do pVAX (Figura 7).
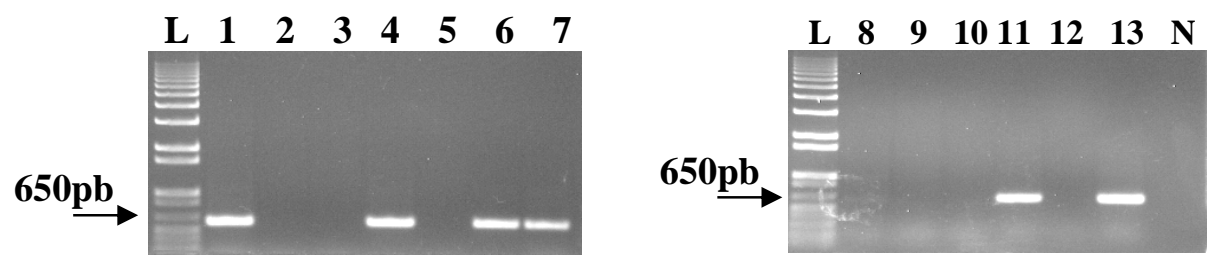

Figura 7: PCR de colônia da ligação pVAX + gDEGFRvIII. PCR de 13 colônias da ligação pVAX + gDEGFRvIII com os oligonucleotídeos T7p e EGFRvIII_Rseq. L-marcador 1Kb Plus, 1 ao 13-PCR das 13 colônias (nomeadas de 14 a 26) e N-negativo.

As colônias 14, 17, 19, 20, 24 e 26 apresentaram o fragmento gDEGFRvIII na direção correta demonstrado no gel pelo fragmento de aproximadamente 650pb (tamanho esperado de 598pb). A partir do resultado acima, foram realizadas a extração e clivagem dos cinco primeiros plasmídios com as enzimas NheI e XbaI. A digestão foi analisada em gel de agarose $1 \%$ (Figura 8):

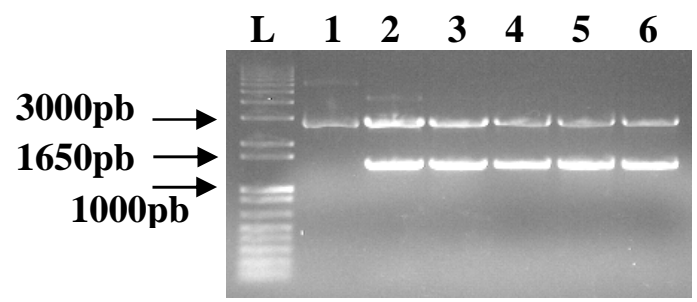

Figura 8: Clivagem dos plasmídios pVAXgDEGFRvIII. Clivagem dos clones pVAXgDEGFRvIII com as enzimas NheI e XbaI. L-marcador 1Kb Plus, 1-pVAXgDEGFRvIII_14 não digerido e 2 ao 6-clones pVAXgDEGFRvIII_14, 17, 19, 20 e 24 digeridos.

Todos os cinco clones pVAXgDEGFRvIII apresentaram fragmento próximo a 1650pb após a clivagem, indicando a presença do fragmento gDEGFRvIII (1452pb) no interior do pVAX. A partir dos resultados obtidos com a PCR e a análise de restrição, o plasmídio recombinante pVAXgDEGFRvIII_14 foi analisado por sequenciamento utilizando-se os oligonucleotídeos T7p e BGH para confirmação da clonagem (Figura 9). 


\begin{tabular}{|c|c|c|c|c|c|c|c|c|c|c|c|c|c|c|}
\hline $\mathrm{A}$ & 1 & 10 & 20 & 30 & 40 & 50 & 60 & 70 & 80 & 90 & 100 & 110 & 120 & 130 \\
\hline \multirow[t]{2}{*}{$\begin{array}{r}\text { gDEGFRuIII_C } \\
\text { pYAXgDEGFRUIIIC_I7P } \\
\text { Consensus }\end{array}$} & \multicolumn{14}{|c|}{ 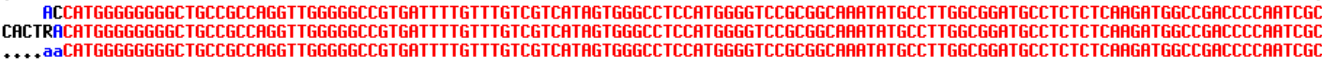 } \\
\hline & 131 & 140 & 150 & 160 & 170 & 180 & 190 & 200 & 210 & 220 & 230 & 240 & 250 & 260 \\
\hline \multirow[t]{2}{*}{$\begin{array}{r}\text { gDEGFRuIII_C } \\
\text { PYAXgDEGFRUIII_C_I7p } \\
\text { Consensus }\end{array}$} & \multicolumn{14}{|c|}{ 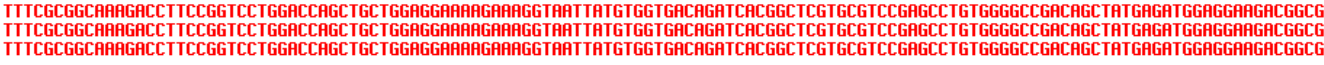 } \\
\hline & 261 & 270 & 280 & 290 & 300 & 310 & 320 & 330 & 340 & 350 & 360 & 370 & 380 & 390 \\
\hline \multirow[t]{2}{*}{$\begin{array}{r}\text { gDEGFRuIII_C } \\
\text { PUAXgDEGFRuIII_C_T7p } \\
\text { Consensus }\end{array}$} & \multicolumn{14}{|c|}{ 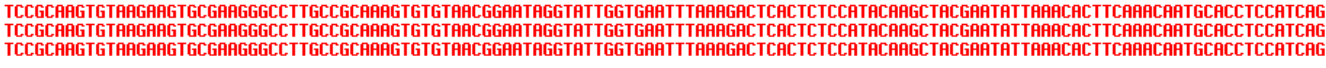 } \\
\hline & 391 & 400 & 410 & 420 & 430 & 440 & 450 & 460 & 470 & 480 & 490 & 500 & 510 & 520 \\
\hline \multirow[t]{2}{*}{$\begin{array}{r}\text { gDEGFRuIII_C } \\
\text { pvAXgDEGFRuII_C_I7p } \\
\text { Consensus }\end{array}$} & \multicolumn{14}{|c|}{ 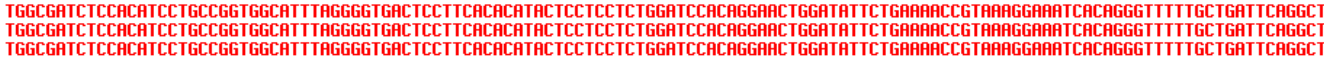 } \\
\hline & 521 & 530 & 540 & 550 & 560 & 570 & 580 & 590 & 600 & 610 & 620 & 630 & 640 & 650 \\
\hline \multirow[t]{2}{*}{$\begin{array}{r}\text { gDEGFRuIII_C } \\
\text { PUAXgDEGFRuIII_C_T7p } \\
\text { Consensus }\end{array}$} & \multicolumn{14}{|c|}{ 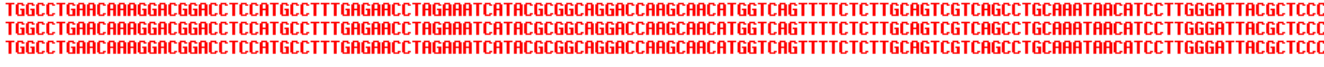 } \\
\hline & 651 & 660 & 670 & 680 & 690 & 700 & 710 & 720 & 730 & 740 & 750 & 760 & 770 & 780 \\
\hline $\begin{array}{r}\text { gDEGFRvIII_C } \\
\text { pYAXgDEGFRuIII_C_I7p } \\
\text { Consensus }\end{array}$ & & & & & & & & & & & & & & \\
\hline
\end{tabular}

\begin{tabular}{|c|c|c|c|c|c|c|c|c|c|c|c|c|c|c|}
\hline B & 651 & 660 & 670 & 680 & 690 & 700 & 710 & 720 & 730 & 740 & 750 & 760 & 770 & \\
\hline $\begin{array}{l}\text { gDEGFRuIII_C } \\
\text { pYAXgDEGFRIII_C_BGH } \\
\text { Consensus }\end{array}$ & \multicolumn{14}{|c|}{ 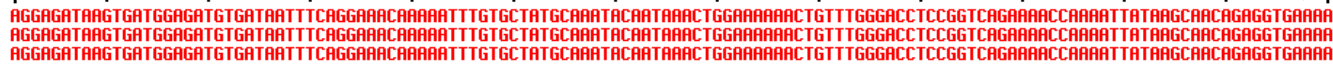 } \\
\hline $\begin{array}{r}\text { gDEGFRuIII_C } \\
\text { pYHXgDEGFRIII_C_BGH } \\
\text { Consensus }\end{array}$ & \multicolumn{14}{|c|}{ 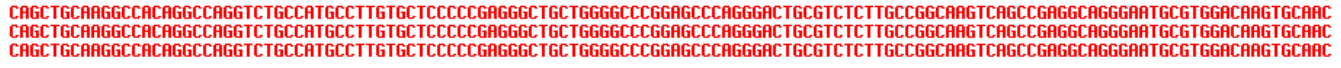 } \\
\hline & 911 & 920 & 930 & 940 & 950 & 960 & 970 & 980 & 990 & 1000 & 1010 & 1020 & 1030 & \\
\hline & 1041 & 1050 & 1060 & 1070 & 1080 & 1090 & 1100 & 1110 & 1120 & 1130 & 1140 & 1150 & 1160 & \\
\hline $\begin{array}{r}\text { gDEGFRuIII_C } \\
\text { pYHXgDEGFuIII_C_BGH } \\
\text { Consensus }\end{array}$ & \multicolumn{14}{|c|}{ 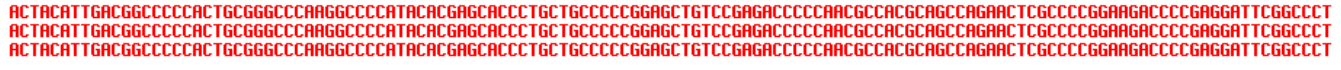 } \\
\hline & 1171 & 1180 & 1190 & 1200 & 1210 & 1220 & 1230 & 1240 & 1250 & 1260 & 1270 & 1280 & 1290 & \\
\hline $\begin{array}{r}\text { gDEGFRuIII_C } \\
\text { pUAXgDEGFRIII__BGH } \\
\text { Consensus }\end{array}$ & \multicolumn{14}{|c|}{ 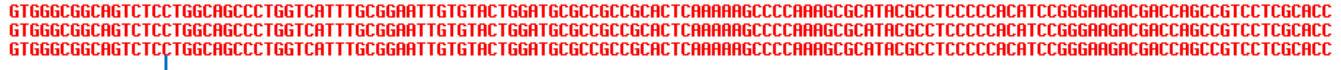 } \\
\hline & 1431 & 1440 & 1450 & 145a6e & & & & & & & & & & \\
\hline $\begin{array}{l}\text { gDEGFRuIII_C } \\
\text { pYAXgDEGFRvIII_C_BGG } \\
\text { Consensus }\end{array}$ & $\begin{array}{l}\text { AGCCC } \\
\text { AGCCO } \\
\text { AGCCO }\end{array}$ & & GTCT & CCGTAC & & & & & & & & & & \\
\hline
\end{tabular}

Figura 9: Sequenciamento do clone pVAXgDEGFRvIII_14. Alinhamento da sequência gDEGFRvIII com o clone pVAXgDEGFRvIII_14 sequenciado com o primer T7p (A) e BGH (B); em destaque (setas), o códon de iniciação da tradução da proteína gDEGFRvIII, o início da sequência que não é encontrada no sequenciamento anterior e o códon de terminação da tradução.

O sequenciamento confirmou a clonagem e a análise do eletroferograma (registro gráfico do sequenciamento) confirmou a possibilidade da presença do $\mathrm{T}$ no final. Como a sequência gDEGFRvIII foi sintetizada in vitro e não amplificada, não houve dúvidas quanto a presença do nucleotídeo, indicando a sequência correta do fragmento clonado.

\subsubsection{Clonagem do fragmento gDcERBB2 no vetor $p V A X$}

$\mathrm{O}$ fragmento gDcERBB2 foi clonado no plasmídio pVAX por meio de uma reação de ligação, cujo produto foi posteriormente transformado em células E. coli Top10. A seleção do 
plasmídio recombinante pVAXgDcERBB2 foi feita inicialmente pela PCR de 6 grupos contendo 5 colônias (nomeados de 13 a 18). A reação foi realizada com os oligonucleotídeos T7p e RgDApa (Figura 10), que indicam a presença e direção do fragmento gDcERBB2 no interior do pVAX.

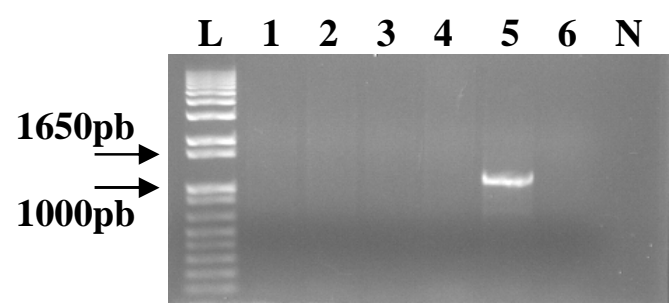

Figura 10: PCR de colônia da ligação pVAX + gDcERBB2. PCR de 6 grupos com cinco colônias da ligação pVAX + gDcERBB2 com os oligonucleotídeos T7p e RgDApa. L-marcador 1Kb Plus, 1 ao 6-PCR dos 6 grupos (nomeados de 13 a 18) e N-negativo.

O grupo 17 apresentou banda de amplificação entre 1000-1650pb (tamanho esperado de $1168 \mathrm{pb}$ ) indicando a presença do fragmento gDcERBB2 na direção correta. A partir do resultado acima, foi realizada uma nova PCR com os plasmídios das cinco colônias do grupo 17 extraídos (nomeados de 6 a 10). A reação foi realizada com os mesmos oligonucleotídeos e foi avaliada em gel de agarose $1 \%$ (Figura 11):

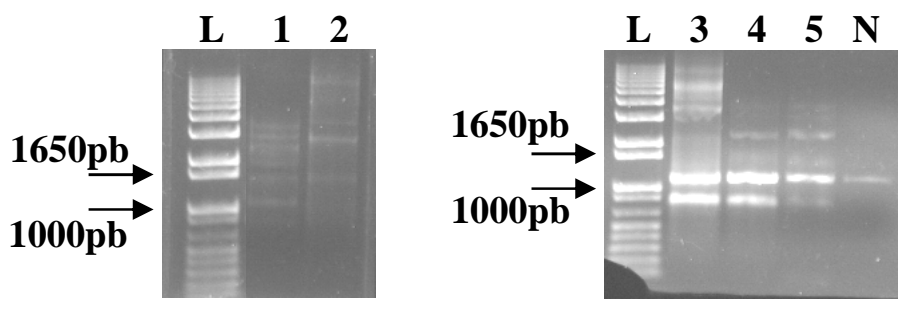

Figura 11: PCR dos plasmídios da ligação pVAX + gDcERBB2. PCR de 5 plasmídios da ligação pVAX + gDcERBB2 com os oligonucleotídeos T7p e RgDApa. L-marcador $1 \mathrm{~Kb}$ Plus, 1 ao 5-PCR dos 5 plasmídios (nomeados de 6 a 10) e N-negativo.

Os clones pVAXgDcERBB2_8, 9 e 10 apresentaram fragmento entre 1000-1650pb (tamanho esperado de 1168pb) indicando a presença do fragmento gDcERBB2 na direção correta no interior do pVAX. Os três clones também apresentaram um fragmento próximo a $850 \mathrm{pb}$, podendo indicar uma amplificação inespecífica.

A partir dos resultados obtidos com as PCRs, o plasmídio recombinante pVAXgDcERBB2_8 foi analisado por sequenciamento utilizando-se os oligonucleotídeos T7p e BGH para confirmação da clonagem (Figura 12). 


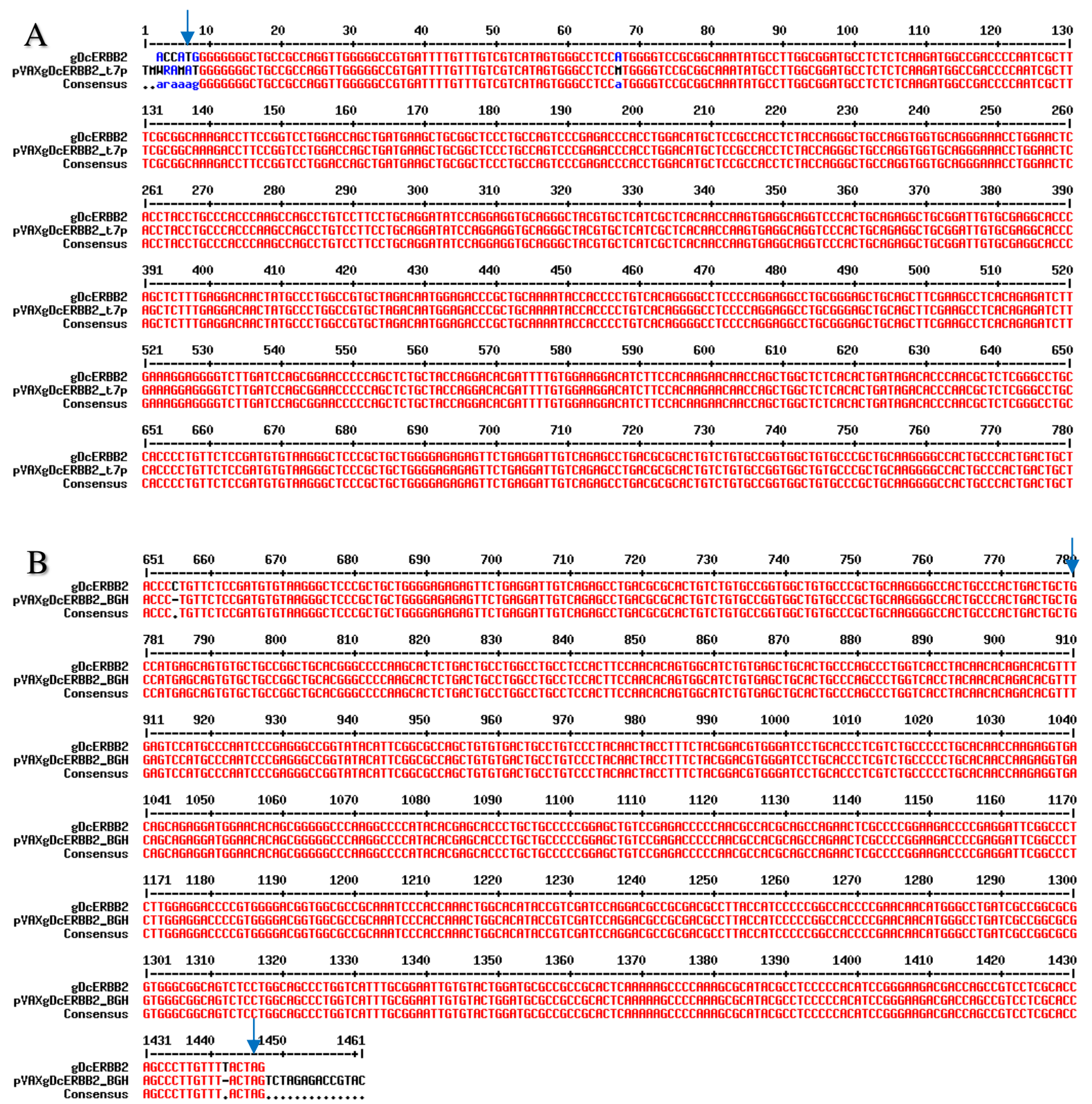

Figura 12: Sequenciamento do clone pVAXgDcERBB2_8. Alinhamento da sequência gDcERBB2 com o clone pVAXgDcERBB2_8 sequenciado com os oligonucleotídeos T7p (A) e BGH (B); em destaque (setas), o códon de iniciação da tradução da proteína gDcERBB2, o início da sequência que não é encontrada no sequenciamento anterior e o códon de terminação da tradução.

O sequenciamento confirmou a clonagem e a análise do eletroferograma confirmou a presença do ATG no início do gene, a base indicada como um M é um A e novamente existe a possibilidade da presença do T no final. Um novo sequenciamento foi realizado com o BGH, mas a presença do $\mathrm{T}$ novamente foi questionável, assim como na sequência pVAXgDEGFRvIII (Figura 9). Apesar da presença do $\mathrm{T}$ ser questionável pelo sequenciamento, como esses genes foram clivados de um fragmento sintetizado não houve dúvidas quanto à presença do nucleotídeo. 


\subsubsection{Clonagem do fragmento gDMAGE no vetor $p V A X$}

O fragmento gDMAGE foi clonado no plasmídio $\mathrm{pVAX}$ por meio de uma reação de ligação, cujo produto foi posteriormente transformado em células E. coli Top10. A seleção do plasmídio recombinante pVAXgDMAGE foi feita inicialmente pela PCR de 6 grupos contendo 5 colônias cada. A reação foi realizada com os oligonucleotídeos T7p e MAGE_Rseq (Figura 13) ou T7p e RgDApa (Figura 14), que indicam a presença e direção do fragmento gDMAGE no interior do pVAX.

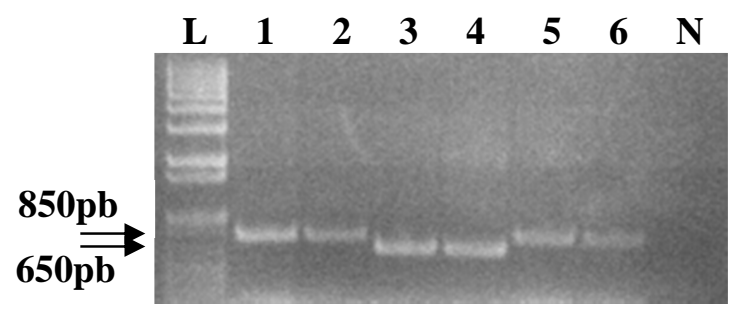

Figura 13: PCR de colônia da ligação pVAX + gDMAGE. PCR de 6 grupos de colônias da ligação pVAX + gDMAGE com os oligonucleotídeos T7p e MAGE_Rseq. L-marcador 1Kb, 1 ao 6-PCR dos 6 grupos e Nnegativo.

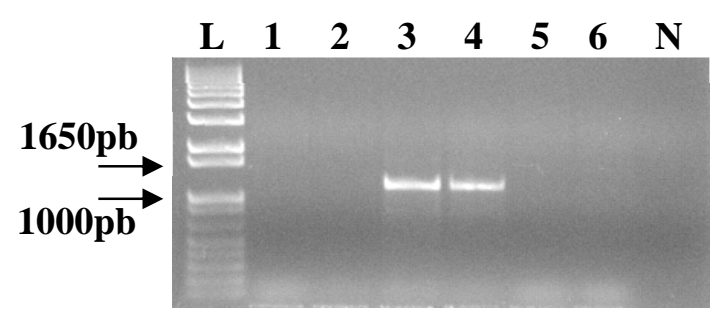

Figura 14: PCR de colônia da ligação pVAX + gDMAGE. PCR de 6 grupos de colônias da ligação pVAX + gDMAGE com os oligonucleotídeos T7p e RgDApa. L-marcador 1Kb Plus, 1 ao 6-PCR dos 6 grupos e Nnegativo.

Os grupos 1, 2, 5 e 6 apresentaram uma banda de amplificação de aproximadamente $850 \mathrm{pb}$ enquanto os grupos 3 e 4, uma banda próxima de $650 \mathrm{pb}$ quando usados os oligonucleotídeos T7p e MAGE_Rseq (tamanho esperado de 686pb) (Figura 13). Na amplificação com T7p e RgDApa apenas os grupos 3 e 4 apresentaram banda de amplificação entre 1000-1650pb (tamanho esperado de 1210pb) indicando a presença do fragmento gDMAGE na direção correta. A partir dos resultados acima, foram realizadas a extração e clivagem dos cinco plasmídios do grupo 3 com as enzimas PmeI e HindIII. A digestão foi analisada em gel de agarose $1 \%$ (Figura 15): 


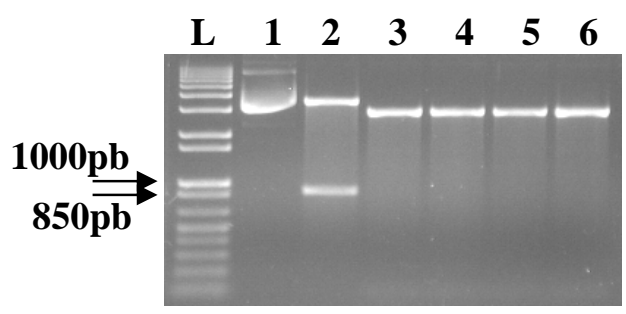

Figura 15: Clivagem dos plasmídios pVAXgDMAGE. Clivagem dos clones pVAXgDMAGE com as enzimas PmeI e HindIII. L-marcador $1 \mathrm{~Kb}$ Plus, 1-plasmídio não digerido e 2 ao 6-clones pVAXgDMAGE_1 a 5 digeridos.

Apenas o clone pVAXgDMAGE_1 apresentou fragmento entre 850-1000pb (tamanho esperado de $884 \mathrm{pb}$ ) após a clivagem, indicando a presença do fragmento gDMAGE na direção correta no interior do pVAX. Os outros clones não liberaram fragmentos, apresentando apenas uma banda de aproximadamente 3000pb que é o tamanho do plasmídio pVAX.

A partir dos resultados obtidos com as PCRs e a análise de restrição, o plasmídio recombinante pVAXgDMAGE_1 foi analisado por sequenciamento utilizando-se os oligonucleotídeos MAGE_Rseq, T7p e BGH para confirmação da clonagem (Figura 16).

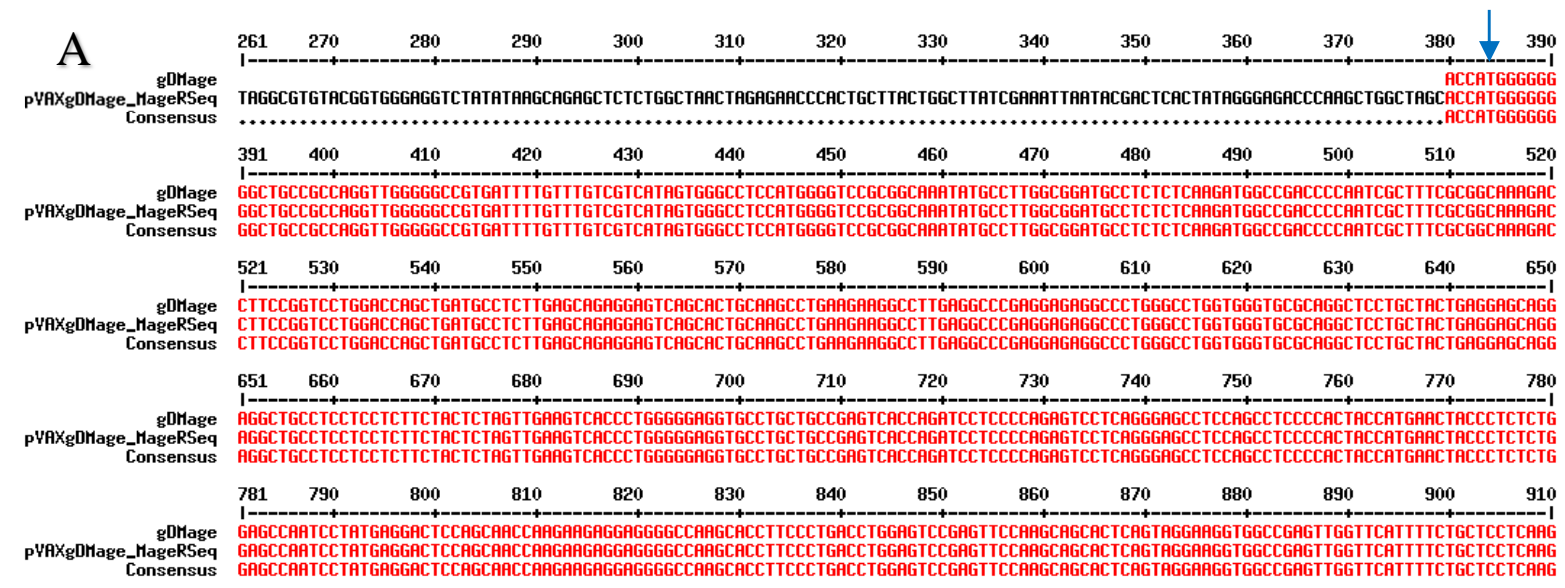

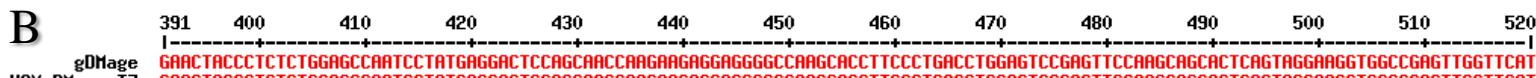

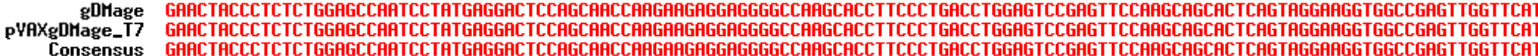

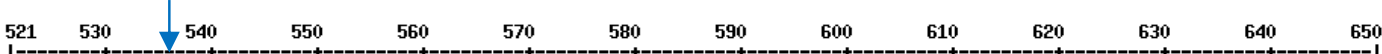

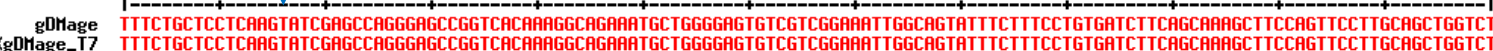
pyaxgDHage_T7
Consensus

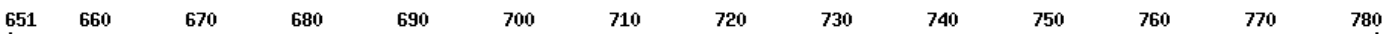

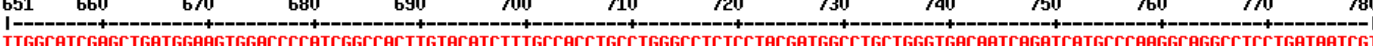

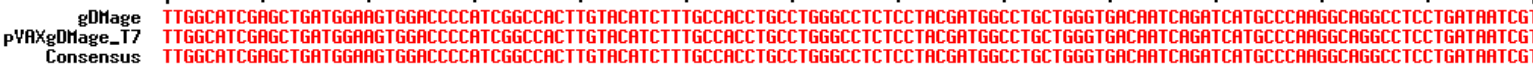




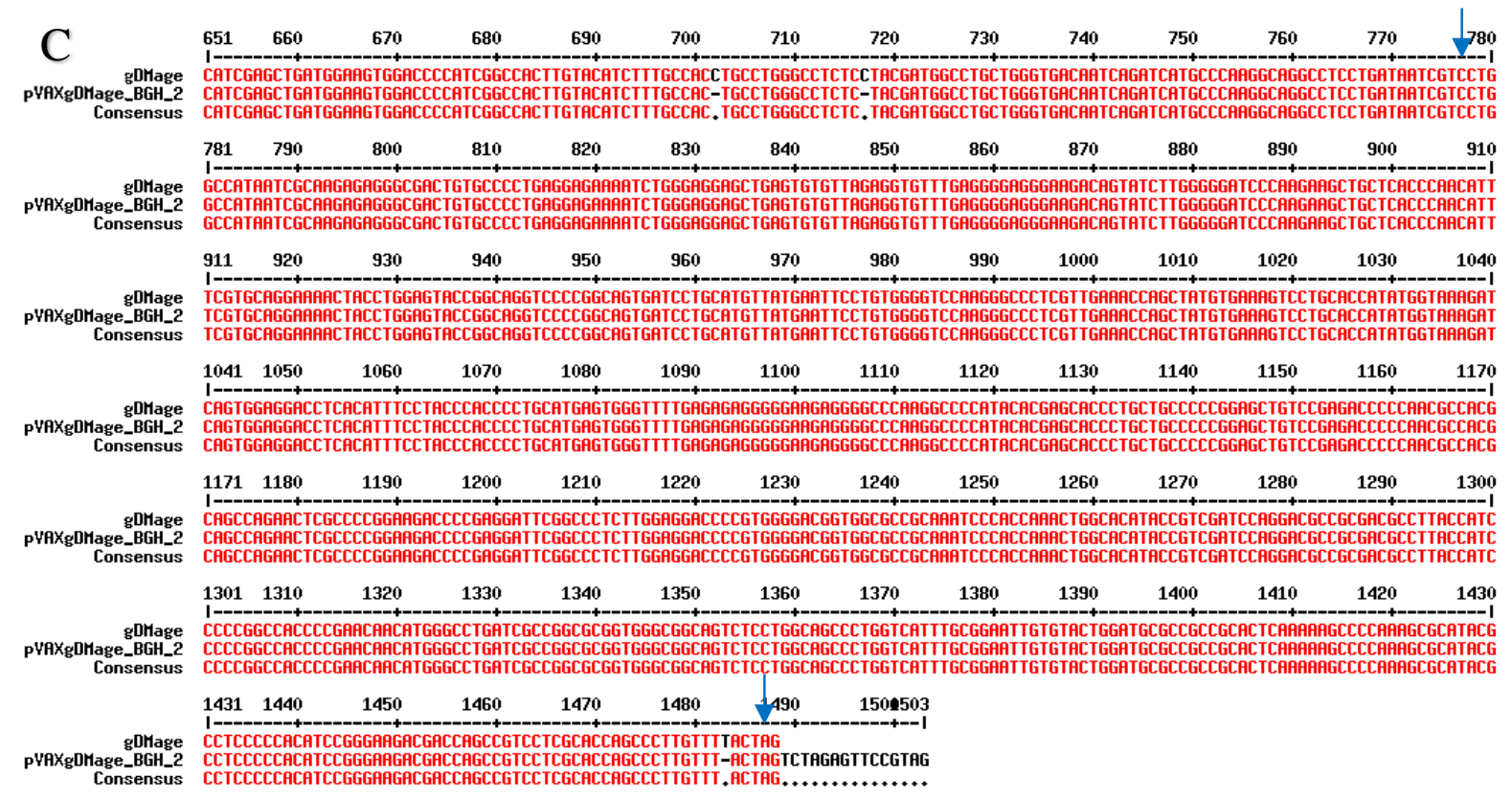

Figura 16: Sequenciamento do clone pVAXgDMAGE_1. Alinhamento da sequência gDMAGE com o clone pVAXgDMAGE_1 sequenciado com os oligonucleotídeos MAGE_Rseq (A), T7p (B) e BGH (C); em destaque (setas), o códon de iniciação da tradução da proteína gDMAGE, o início da sequência que não é encontrada no sequenciamento anterior e o códon de terminação da tradução.

O sequenciamento confirmou a clonagem e a análise do eletroferograma demonstrou a possibilidade da presença do T no final, assim como nos sequenciamentos anteriores. Essa é uma região comum a todas as construções com $\mathrm{gD}$, pois é o final desse gene e deve ser uma porção sujeita a problemas de sequenciamento.

\subsubsection{Clonagem do fragmento gDGLEA no vetor $p V A X$}

$\mathrm{O}$ fragmento gDGLEA foi clonado no plasmídio $\mathrm{pVAX}$ por meio de uma reação de ligação, cujo produto foi posteriormente transformado em células E. coli Top10. A seleção do plasmídio recombinante pVAXgDGLEA foi feita inicialmente pela PCR de 13 colônias. A reação foi realizada com os oligonucleotídeos T7p e Glea_2Rseq (Figura 17), que indicam a presença e direção do fragmento gDGLEA no interior do pVAX.
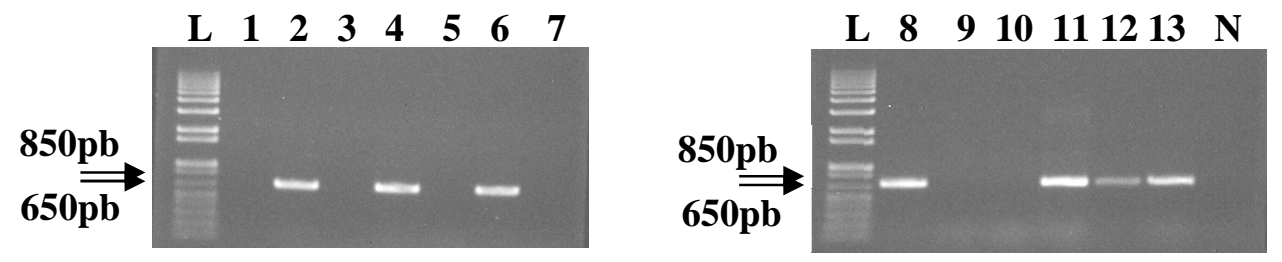

Figura 17: PCR de colônia da ligação pVAX + gDGLEA. PCR de 13 colônias da ligação pVAX + gDGLEA com os oligonucleotídeos T7p e Glea_2Rseq. L-marcador 1Kb Plus, 1 ao 13-PCR das 13 colônias e N-negativo. 
As colônias 2, 4, 6, 8, 11, 12 e 13 apresentaram uma banda de amplificação entre 650$850 \mathrm{pb}$ (tamanho esperado de 704pb) indicando a presença do fragmento gDGLEA na direção correta. A partir do resultado acima, foram realizadas a extração e clivagem dos sete plasmídios com as enzimas PmeI e HindIII. A digestão foi analisada em gel de agarose $1 \%$ (Figura 18):

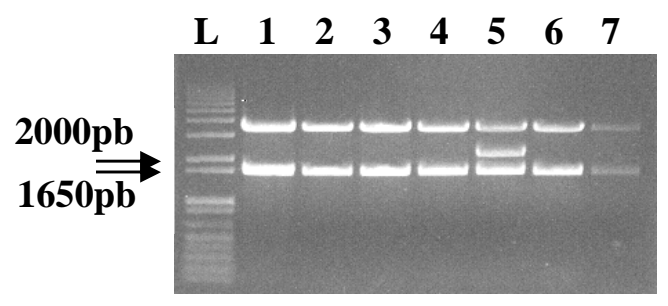

Figura 18: Clivagem dos plasmídios pVAXgDGLEA. Clivagem dos clones pVAXgDGLEA com as enzimas PmeI e HindIII. L-marcador $1 \mathrm{~Kb}$ Plus e 1 ao 7-clones pVAXgDGLEA_2, 4, 6, 8, 11, 12 e 13 digeridos.

Os clones pVAXgDGLEA_2, 4, 6, 8, 12 e 13 apresentaram fragmento próximo a 1650 (tamanho esperado de 1628pb) após a clivagem, indicando a presença do fragmento gDGLEA na direção correta no interior do pVAX. O clone 11 liberou um fragmento próximo a 1650pb e outro próximo a $2000 \mathrm{pb}$, podendo indicar a presença de mais de um inserto.

A partir dos resultados obtidos com a PCR e a análise de restrição, o plasmídio recombinante pVAXgDGLEA_4 foi analisado por sequenciamento utilizando-se os oligonucleotídeos T7p, GLEA_1Sseq, GLEA_2Rseq, GLEA_3Sseq e BGH para confirmação da clonagem (Figura 19).

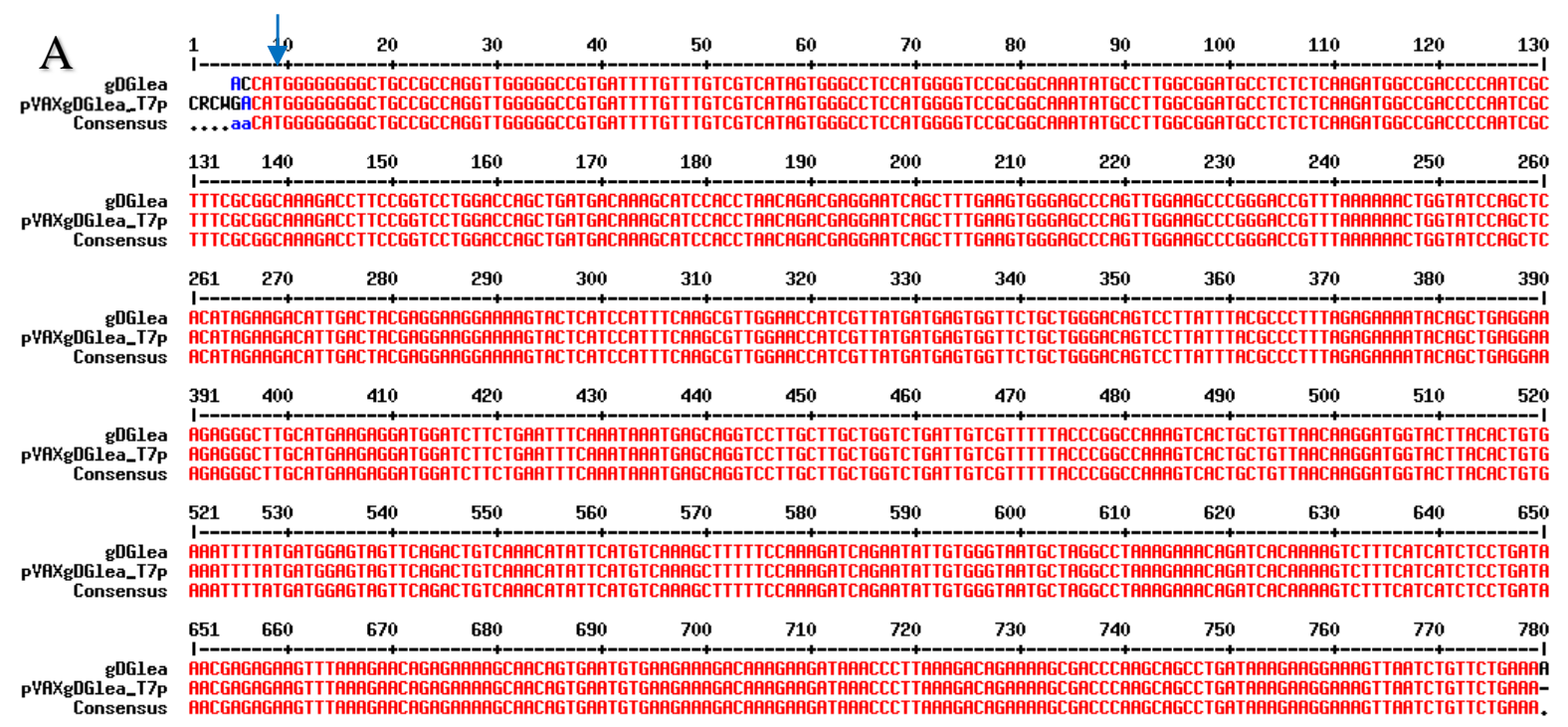




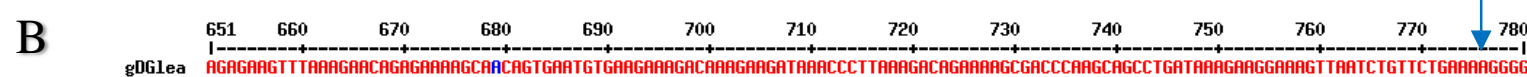

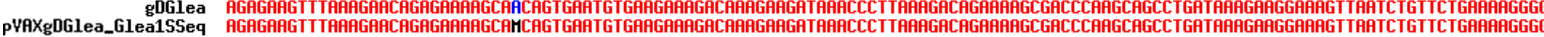

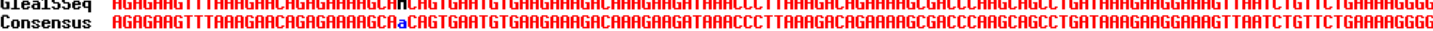

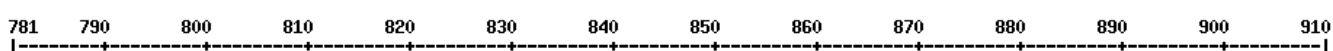

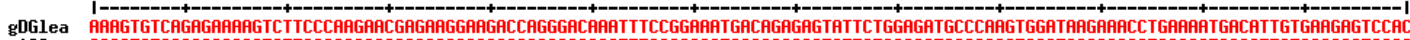

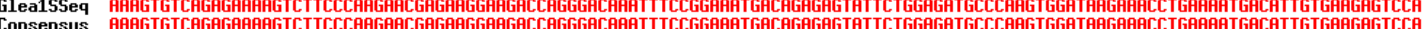

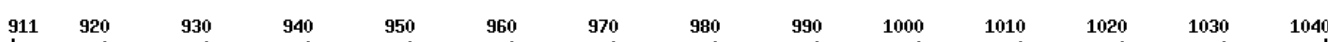

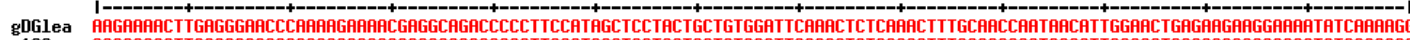
Consensus

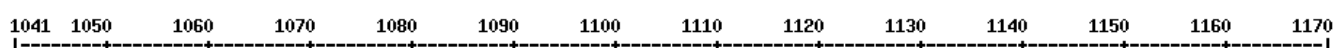

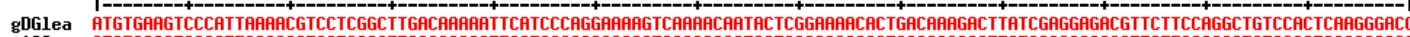

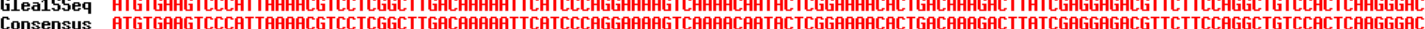

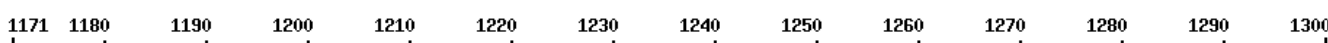

\begin{tabular}{|c|c|c|c|c|c|c|c|c|c|c|c|c|c|c|}
\hline & 301 & 1310 & 1320 & 1330 & 1340 & 1350 & 1360 & 1370 & 1380 & 1390 & 1400 & 1410 & 1420 & 1430 \\
\hline $\begin{array}{r}\text { gDGlea } \\
\text { pYAXgDGlea_Glea3SSeq } \\
\text { Consensus }\end{array}$ & \multicolumn{14}{|c|}{ 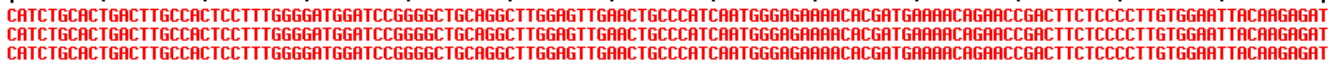 } \\
\hline & 1431 & 1440 & 1450 & 1460 & 1470 & 1480 & 1490 & 1500 & 1510 & 1520 & 1530 & 1540 & 1550 & 1560 \\
\hline $\begin{array}{r}\text { gDGlea } \\
\text { pVPXgDGlea_Glea3SSeq } \\
\text { Consensus }\end{array}$ & \multicolumn{14}{|c|}{ 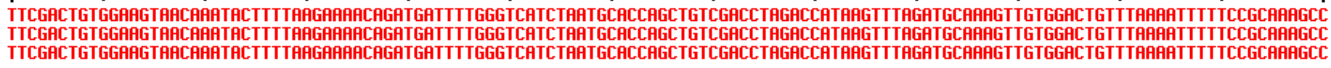 } \\
\hline & 1561 & 1570 & 1580 & 1590 & 1600 & 1610 & 1620 & 1630 & 1640 & 1650 & 1660 & 1670 & 1680 & 1690 \\
\hline $\begin{array}{r}\text { gDGlea } \\
\text { PYAXgDGlea_Glea3SSeq } \\
\text { Consensus }\end{array}$ & \multicolumn{14}{|c|}{ 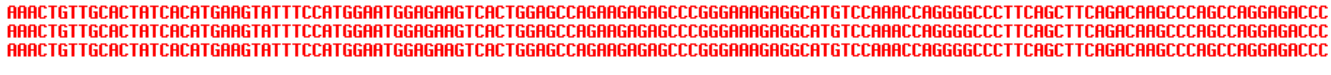 } \\
\hline & 1691 & 1700 & 1710 & 1720 & 1730 & 1740 & 1750 & 1760 & 1770 & 1780 & 1790 & 1800 & 1810 & 18 \\
\hline $\begin{array}{r}\text { gDGlea } \\
\text { pYAXgDGlea_Glea3SSeq } \\
\text { Consensus }\end{array}$ & & & & & & & & & & & & & & \\
\hline
\end{tabular}

\begin{tabular}{|c|c|c|c|c|c|c|c|c|c|c|c|c|c|c|}
\hline & 1691 & 1700 & 1710 & 1720 & 1730 & 1740 & 1750 & 1760 & 1770 & 1780 & 1790 & 1800 & 1810 & 1820 \\
\hline $\begin{array}{r}\text { gDGlea } \\
\text { PYAXgDlea_BGH } \\
\text { Consensus }\end{array}$ & \multicolumn{14}{|c|}{ 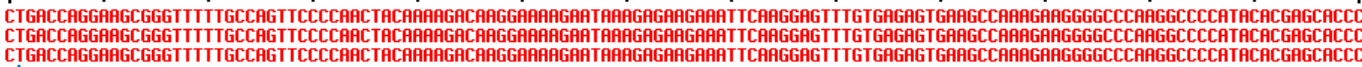 } \\
\hline & 1821 & 1830 & 1840 & 1850 & 1860 & 1870 & 1880 & 1890 & 1900 & 1910 & 1920 & 1930 & 1940 & 1950 \\
\hline $\begin{array}{r}\text { gDGlea } \\
\text { PYAXgDGlea_BGH } \\
\text { Consensus }\end{array}$ & \\
\hline & 1951 & 1960 & 1970 & 1980 & 1990 & 2000 & 2010 & 2020 & 2030 & 2040 & 2050 & 2060 & 2070 & 2080 \\
\hline
\end{tabular}

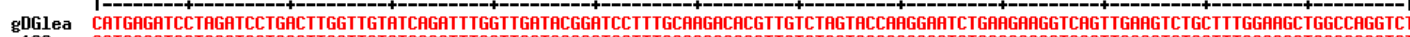

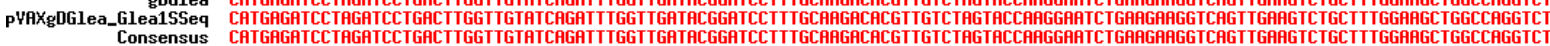

gyaxgDGlea_BGH ATGCGCCGCCGCACTCARAPAGCCCCAAHGCGCATACGCCTCCCCCACATCCGGGARGACGACCAGCCGTCCTCGCACCAGCCCTTGTITTHCTAG

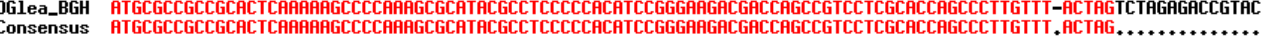

E $\quad \begin{array}{rrrrrrrrrrrrrr}391 & 400 & 410 & 420 & 430 & 440 & 450 & 460 & 470 & 480 & 490 & 500 & 510 & 520\end{array}$

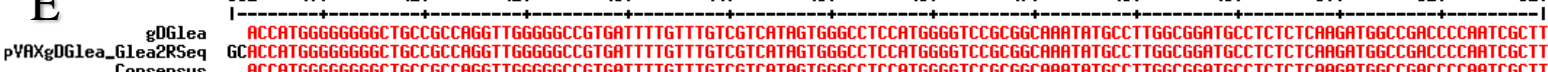

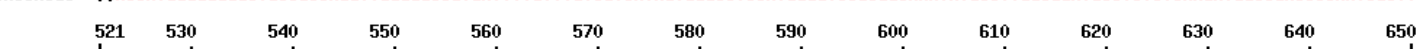
gDGlea
PVAXgDGlea_Glea2RSeq

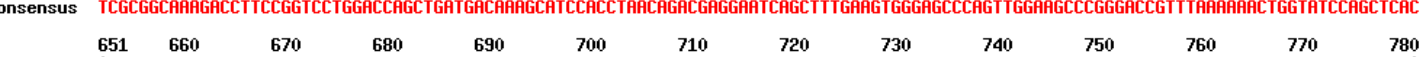

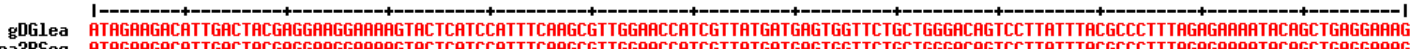

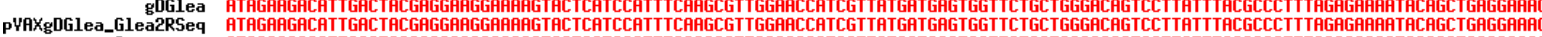

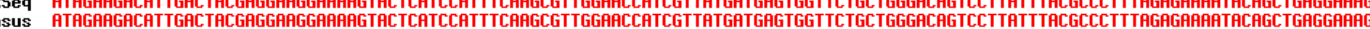

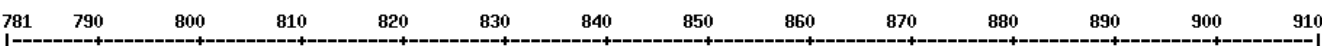

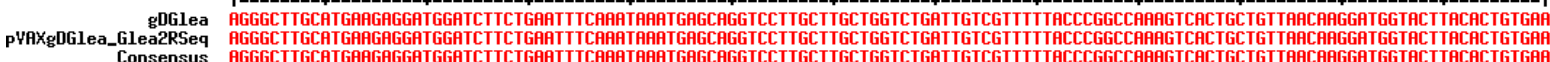

Figura 19: Sequenciamento do clone pVAXgDGLEA_4. Alinhamento da sequência gDGLEA com o clone pVAXgDGLEA_4 sequenciado com os oligonucleotídeos T7p (A), GLEA_1Sseq (B), GLEA_3Sseq (C), BGH (D) e GLEA_2Rseq (E); em destaque (setas), o códon de iniciação da tradução da proteína gDGLEA, o início da sequência que não é encontrada no sequenciamento anterior e o códon de terminação da tradução. $\mathrm{O}$ sequenciamento com GLEA_2Rseq confirmou a sequência correta do início do gene gDGLEA. 
O sequenciamento confirmou a clonagem e mostrou que a vacina pVAXgDGLEA apresentava sequência correta, apesar do mesmo problema com a base $\mathrm{T}$ no final.

\subsubsection{Clonagem do gene gp96 no vetor $p V A X$}

O fragmento gp96 foi clonado no plasmídio pVAX por meio de uma reação de ligação, cujo produto foi posteriormente transformado em células E. coli Top10. A seleção do plasmídio recombinante pVAXgp96 foi feita inicialmente pela PCR de 5 grupos contendo 5 colônias cada. A reação foi realizada com os oligonucleotídeos T7p e gp96_Rseq que indica a presença e direção do fragmento gp96 no interior do pVAX (Figura 20).

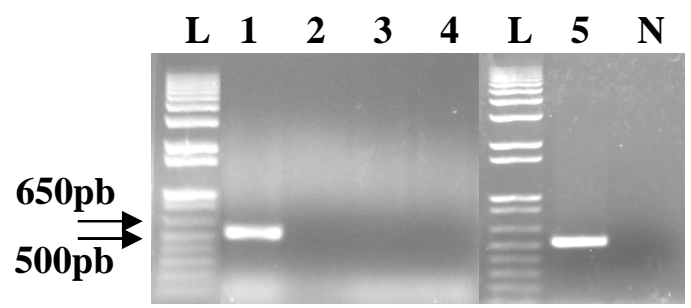

Figura 20: PCR de colônia da ligação pVAX + gp96. PCR de 5 grupos de colônias da ligação pVAX + gp96 com os oligonucleotídeos T7p e gp96_Rseq. L-marcador 1Kb Plus, 1 ao 5-PCR dos 5 grupos e N-negativo.

Os grupos 1 e 5 apresentaram uma banda de amplificação de aproximadamente 500pb (tamanho esperado de 540pb) indicando a presença do fragmento gp96 na direção correta. A partir do resultado acima, foram realizadas a extração e clivagem com as enzimas PmeI e NdeI dos cinco plasmídios do grupo 1 (nomeados de 21 a 25). A digestão foi analisada em gel de agarose 1\% (Figura 21):

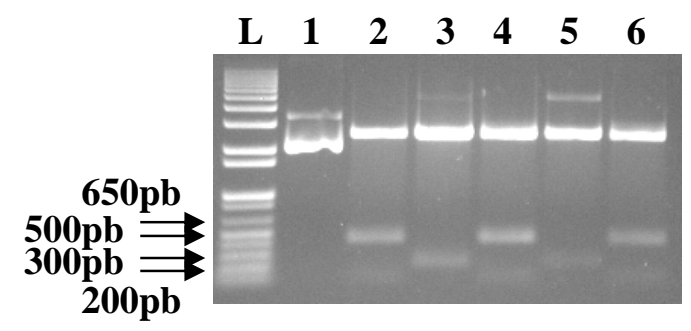

Figura 21: Clivagem dos plasmídios pVAXgp96. Clivagem dos clones pVAXgp96 com as enzimas PmeI e NdeI. L-marcador $1 \mathrm{~Kb}$ Plus, 1-plasmídio não digerido e 2 ao 6-clones pVAXgp96 digeridos (nomeados de 21 a 25).

Os clones pVAXgp96_22 e 24 apresentaram fragmentos entre 300-200pb e 2000$3000 \mathrm{pb}$ (tamanhos esperados, 224, 2563 e 2548pb) após a clivagem, indicando a presença do fragmento gp96 na direção correta no interior do pVAX. Os outros clones parecem ter o fragmento gp96 na direção invertida por causa dos fragmentos entre 500-650pb e 2000$3000 \mathrm{pb}$ (tamanhos, 642, 2161 e 2552pb). 
A partir dos resultados obtidos com a PCR e a análise de restrição, o plasmídio recombinante pVAXgp96_22 foi analisado por sequenciamento utilizando-se os oligonucleotídeos T7p, gp95_1Sseq, gp96_3Sseq, gp96_4Sseq e BGH para confirmação da clonagem (Figura 22).

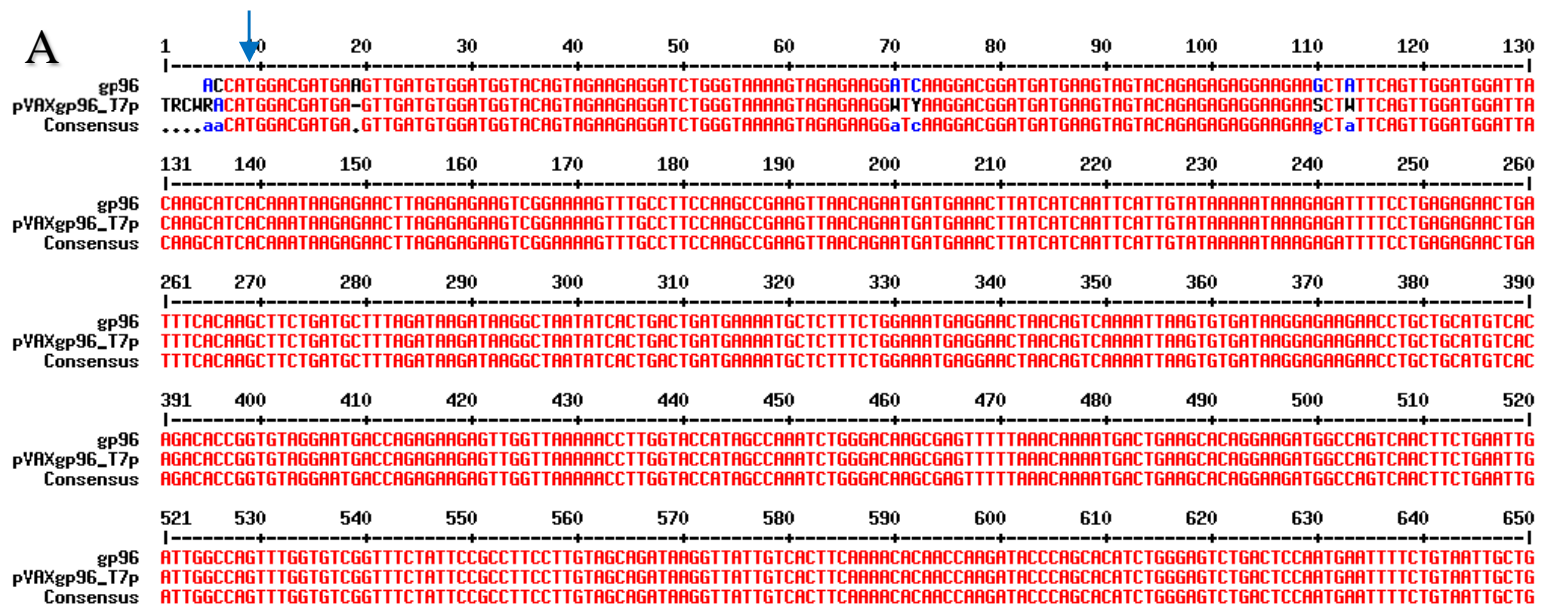

B gp96
pYAXgp96_gp96/15Seq
Consensus$$
52
$$

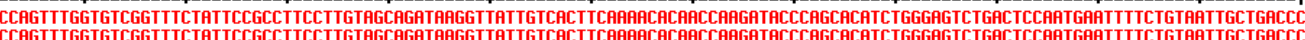

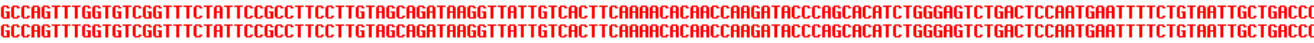

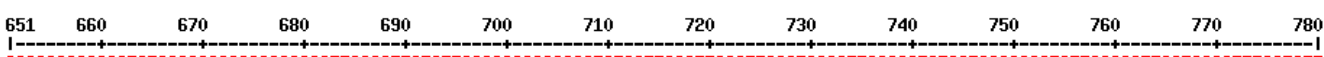

pYAXgp96_gp96/1SP96

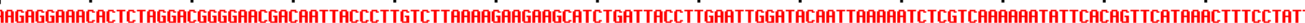

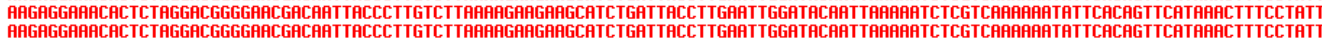

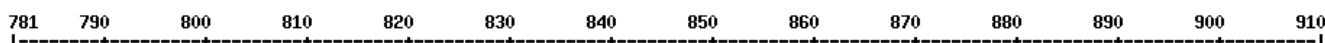

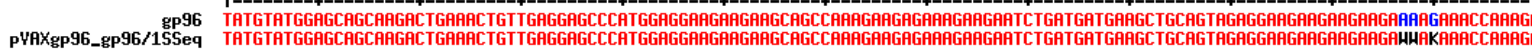

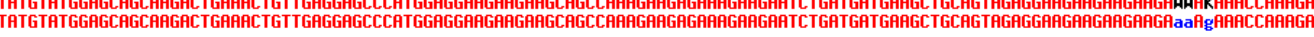
94095
$960 \quad 970 \quad 980$
$990 \quad 1000$
$1010 \quad 1020 \quad 1030$

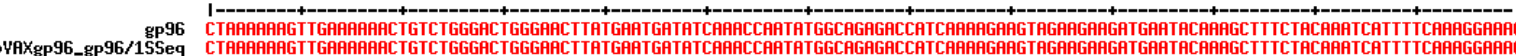

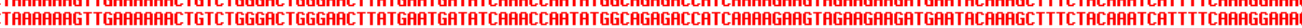

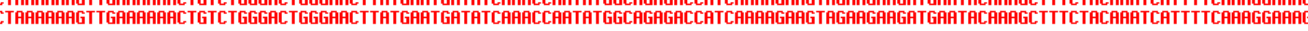

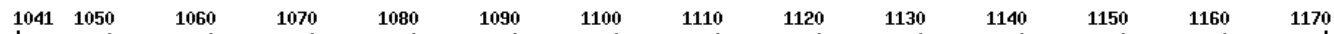

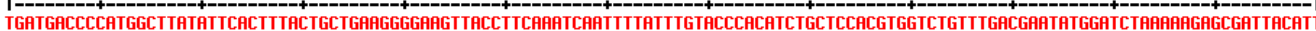

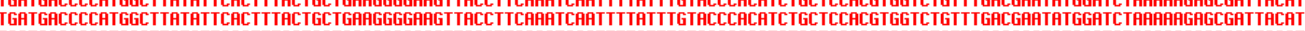

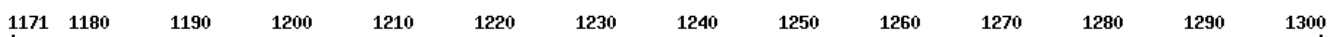

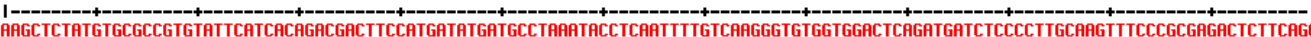

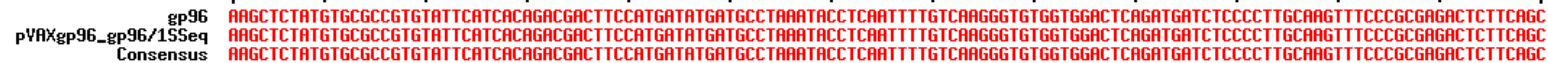

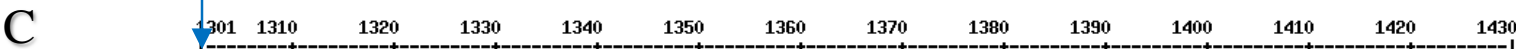

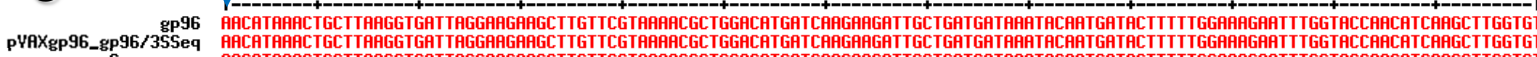

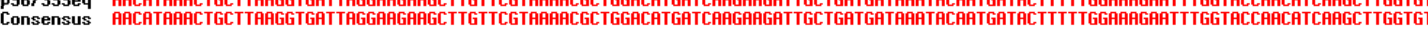

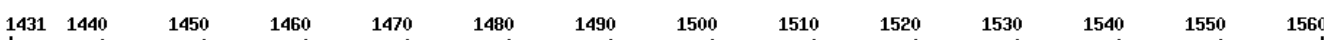

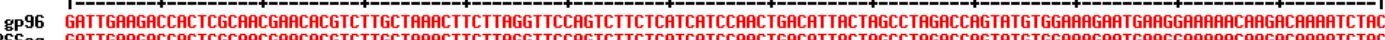

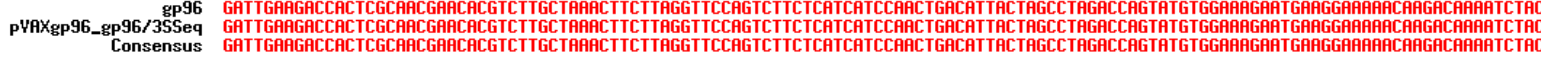

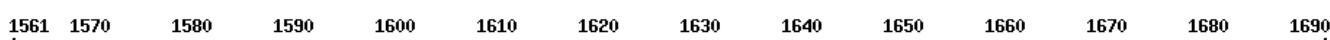

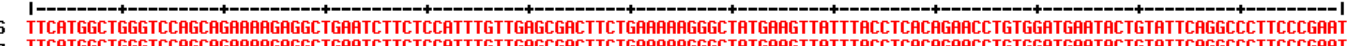

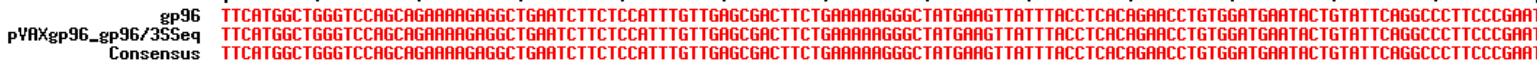




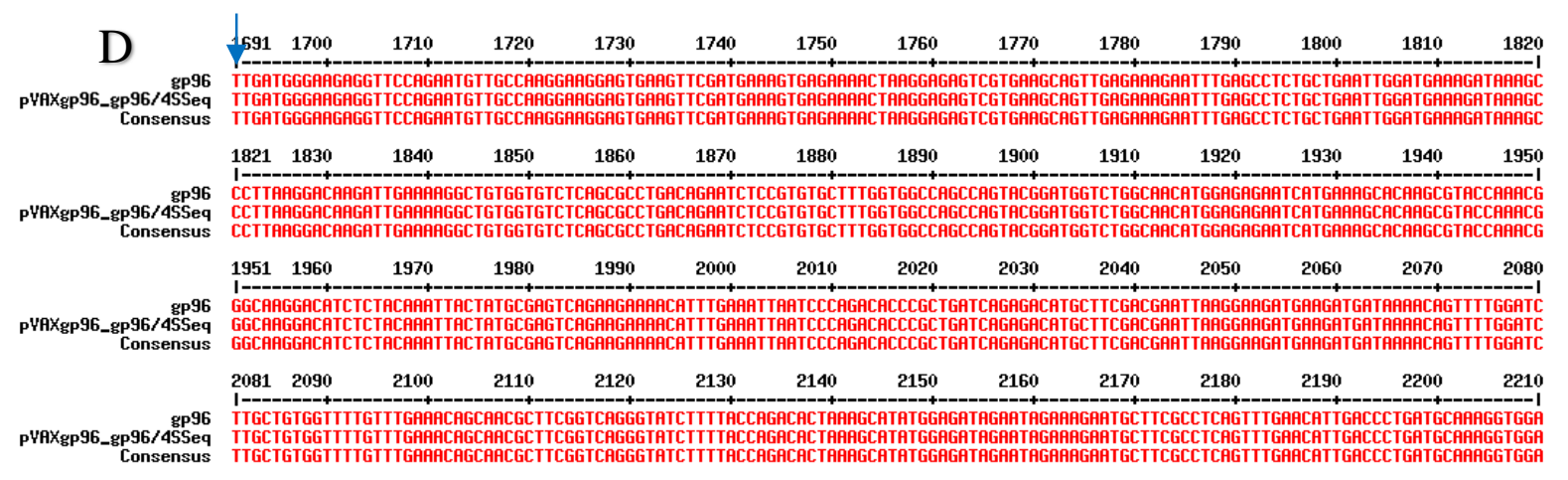

$\mathrm{E}$

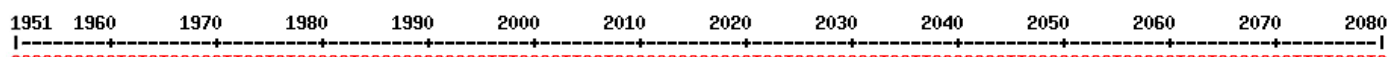

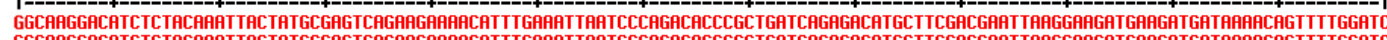

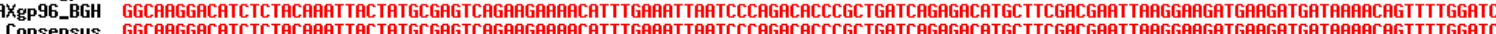

Consensus GGCARGGACHCTCTACAAR $2100 \quad 2130 \quad 2140 \quad 2150 \quad 2160 \quad 2170 \quad 2180 \quad 2190$

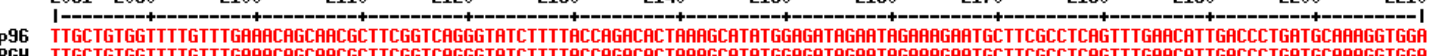
PYAXgp96_BGH
Consensus

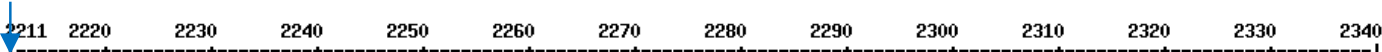

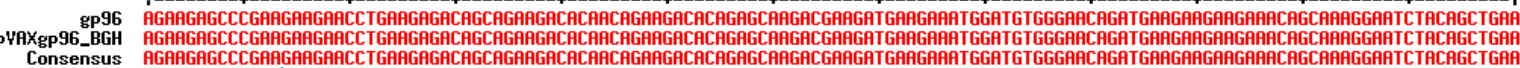

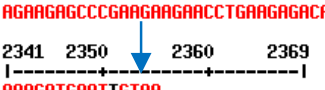

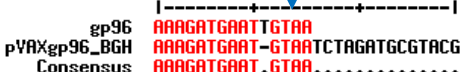

Figura 22: Sequenciamento do clone pVAXgp96_22. Alinhamento da sequência gp96 com o clone pVAXgp96_22 sequenciado com os oligonucleotídeos T7p (A), gp96_1Sseq (B), gp96_3Sseq (C), gp96_4Sseq (D) e BGH (E), em destaque (setas) o códon de iniciação da tradução da proteína gp96, o início da sequência que não é encontrada no sequenciamento anterior e o códon de terminação da tradução.

O sequenciamento confirmou a clonagem e a análise do eletroferograma esclareceu que todos os erros estavam corretos. Um sequenciamento com gp96_2Rseq também foi realizado para visualização do início do gene, no entanto, o alinhamento não ficou compatível, levando a conclusão de que o oligonucleotídeo pode hibridizar em um local inespecífico.

\subsubsection{Clonagem dos genes EGFRvIII, cERBB2, MAGE, GLEA e hsp70 no vetor pVAX}

\subsubsection{Amplificação e clivagem dos genes EGFRvIII, cERBB2, MAGE, GLEA e hsp70}

Os genes EGFRvIII, cERBB2, MAGE, GLEA e hsp70 foram amplificados usando oligonucleotídeos específicos para cada gene, para a posterior clivagem e clonagem direta no vetor $\mathrm{pVAX}$ sem a sequência que codifica a proteína $\mathrm{gD}$. As amplificações foram avaliadas em gel de agarose 1\% (Figura 23): 

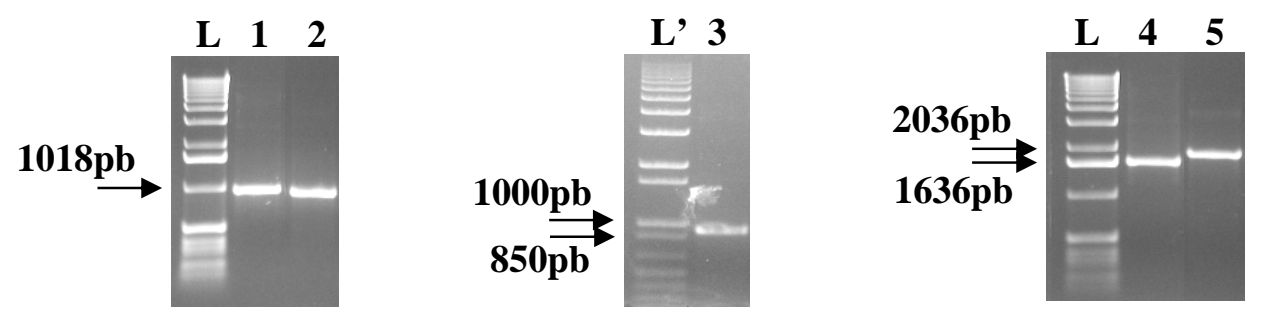

Figura 23: Amplificação dos genes EGFRvIII, cERBB2, MAGE, GLEA e hsp70 para clonagem no vetor pVAX. L e L'-marcador $1 \mathrm{~Kb}$ e $1 \mathrm{~Kb}$ Plus, respectivamente, 1-MAGE, 2-cERBB2, 3-EGFRvIII, 4-GLEA e 5hsp70.

Os cinco genes, MAGE, cERBB2, EGFRvIII, GLEA e hsp70 foram amplificados de forma correta revelando bandas de $967 \mathrm{pb}, 928 \mathrm{pb}, 925 \mathrm{pb}, 1654 \mathrm{pb}$ e $1948 \mathrm{pb}$, respectivamente. Esses genes foram posteriormente clivados com as enzimas NheI e XbaI e clonados no vetor pVAX clivado com as mesmas enzimas (item 5.2.1.2).

\subsubsection{Clonagem do gene EGFRvIII no vetor pVAX}

O fragmento EGFRvIII foi clonado no plasmídio pVAX por meio de uma reação de ligação, cujo produto foi posteriormente transformado em células $E$. coli Top10. A seleção do plasmídio recombinante pVAXEGFRvIII foi feita inicialmente pela PCR de 13 colônias individuais. A reação foi realizada com os oligonucleotídeos T7p e EGFRvIII_Rseq, que indicam a presença e direção do fragmento EGFRvIII no interior do pVAX (Figura 24).
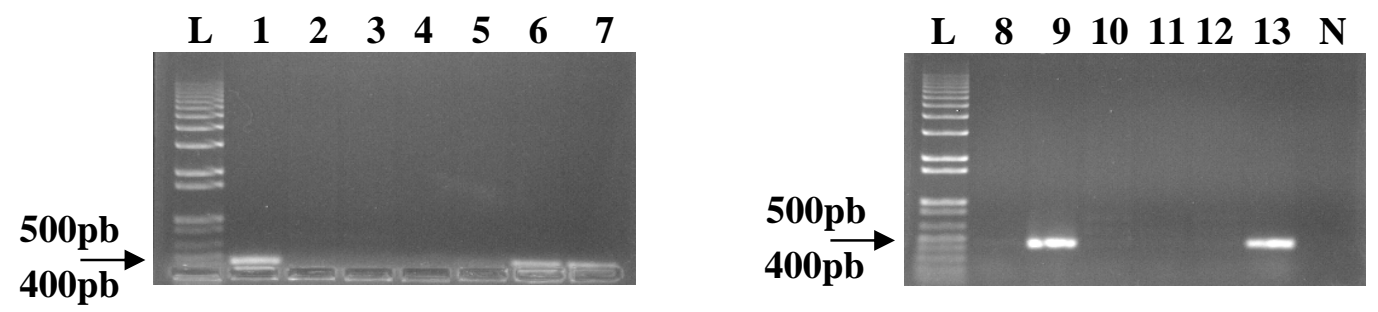

Figura 24: PCR de colônia da ligação pVAX + EGFRvIII. PCR das 13 colônias da ligação pVAX + EGFRvIII com os oligonucleotídeos T7p e EGFRvIII_Rseq. L-marcador 1Kb Plus, 1 ao 10-PCR dos 10 grupos e $\mathrm{N}$-negativo.

As colônias 1, 6, 7, 9 e 13 apresentaram o fragmento EGFRvIII na direção correta demonstrado no gel pelo fragmento de aproximadamente 500pb (tamanho esperado de 442pb). A partir do resultado acima, foram realizadas a extração e clivagem dos cinco plasmídios com as enzimas NheI e XbaI. A digestão foi analisada em gel de agarose $1 \%$ (Figura 25): 


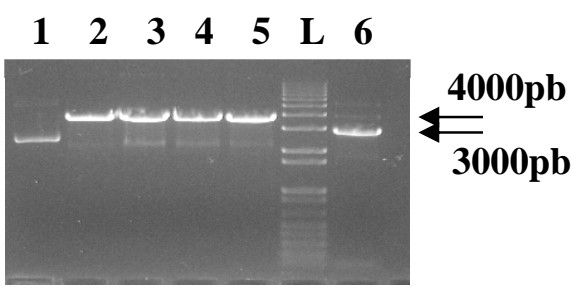

Figura 25: Clivagem dos plasmídios pVAXEGFRvIII. Clivagem dos clones pVAXEGFRvIII com as enzimas NheI e XbaI. L-marcador 1Kb Plus, 2 ao 6-clones pVAXEGFRvIII_1, 6, 7, 9 e 13 digeridos e 1pVAXgDEGFRvIII_1 não digerido.

Os clones pVAXEGFRvIII_1, 6, 7 e 9 apresentaram fragmento próximo a 4000pb após a clivagem, indicando que apenas linearizaram sem liberar o fragmento EGFRvIII, no entanto, esse tamanho indica a presença desse fragmento no interior do pVAX (tamanho esperado de 3818pb). O clone pVAXEGFRvIII_13 apresentou fragmento próximo a 3000pb após a clivagem indicando a presença apenas do plasmídio.

A partir dos resultados obtidos com a PCR e a análise de restrição, o plasmídio recombinante pVAXEGFRvIII_7 foi analisado por sequenciamento utilizando-se os oligonucleotídeos T7p e BGH para confirmação da clonagem (Figura 26).

\begin{tabular}{|c|c|c|c|c|c|c|c|c|c|c|c|c|c|c|}
\hline$A$ & 1 & $t_{0}$ & 20 & 30 & 40 & 50 & 60 & 70 & 80 & 90 & 100 & 110 & 120 & 130 \\
\hline \multirow[t]{2}{*}{$\begin{array}{r}\text { EGFRuIII_C } \\
\text { pYAXEGFRuII_C_t7p } \\
\text { Consensus }\end{array}$} & \multicolumn{14}{|c|}{ 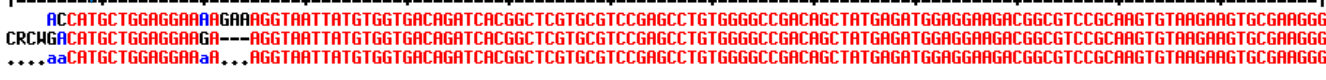 } \\
\hline & 131 & 140 & 150 & 160 & 170 & 180 & 190 & 200 & 210 & 220 & 230 & 240 & 250 & 260 \\
\hline \multirow[t]{2}{*}{$\begin{array}{r}\text { EGFRuIII_C } \\
\text { PYAXEGFRvIII_C_t7p } \\
\text { Consensus }\end{array}$} & \multicolumn{14}{|c|}{ 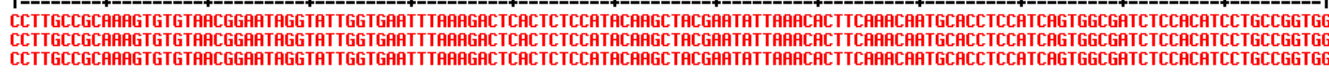 } \\
\hline & 261 & 270 & 280 & 290 & 300 & 310 & 320 & 330 & 340 & 350 & 360 & 370 & 380 & 390 \\
\hline \multirow[t]{2}{*}{$\begin{array}{r}\text { EGFRuIII_C } \\
\text { PYAXEGFRuIII_C_t7p } \\
\text { Consensus }\end{array}$} & \multicolumn{14}{|c|}{ 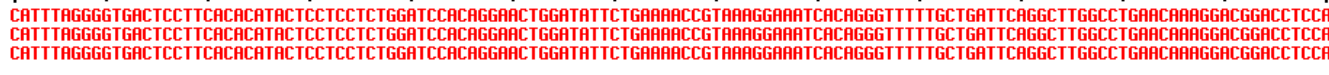 } \\
\hline & 391 & 400 & 410 & 420 & 430 & 440 & 450 & 460 & 470 & 480 & 490 & 500 & 510 & 520 \\
\hline \multirow[t]{2}{*}{$\begin{array}{r}\text { EGFRuIII_C } \\
\text { PVAXEGFRuIII_C_t7p } \\
\text { Consensus }\end{array}$} & \multicolumn{14}{|c|}{ 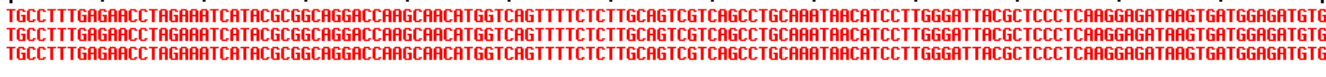 } \\
\hline & 521 & 530 & 540 & 550 & 560 & 570 & 580 & 590 & 600 & 610 & 620 & 630 & 640 & 650 \\
\hline \multirow[t]{2}{*}{$\begin{array}{r}\text { EGFRuIII_C } \\
\text { PUAXEGFRuIII_C_t7p } \\
\text { Consensus }\end{array}$} & \multicolumn{14}{|c|}{ 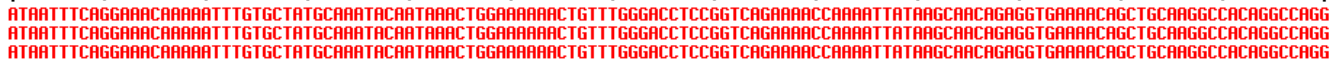 } \\
\hline & 651 & 660 & 670 & 680 & 690 & 700 & 710 & 720 & 730 & 740 & 750 & 760 & 770 & 780 \\
\hline $\begin{array}{r}\text { EGFRuIII_C } \\
\text { pyAXEGFRuIII_C_t7p } \\
\text { Consensus }\end{array}$ & & & & & & & & & & & & & & \\
\hline
\end{tabular}




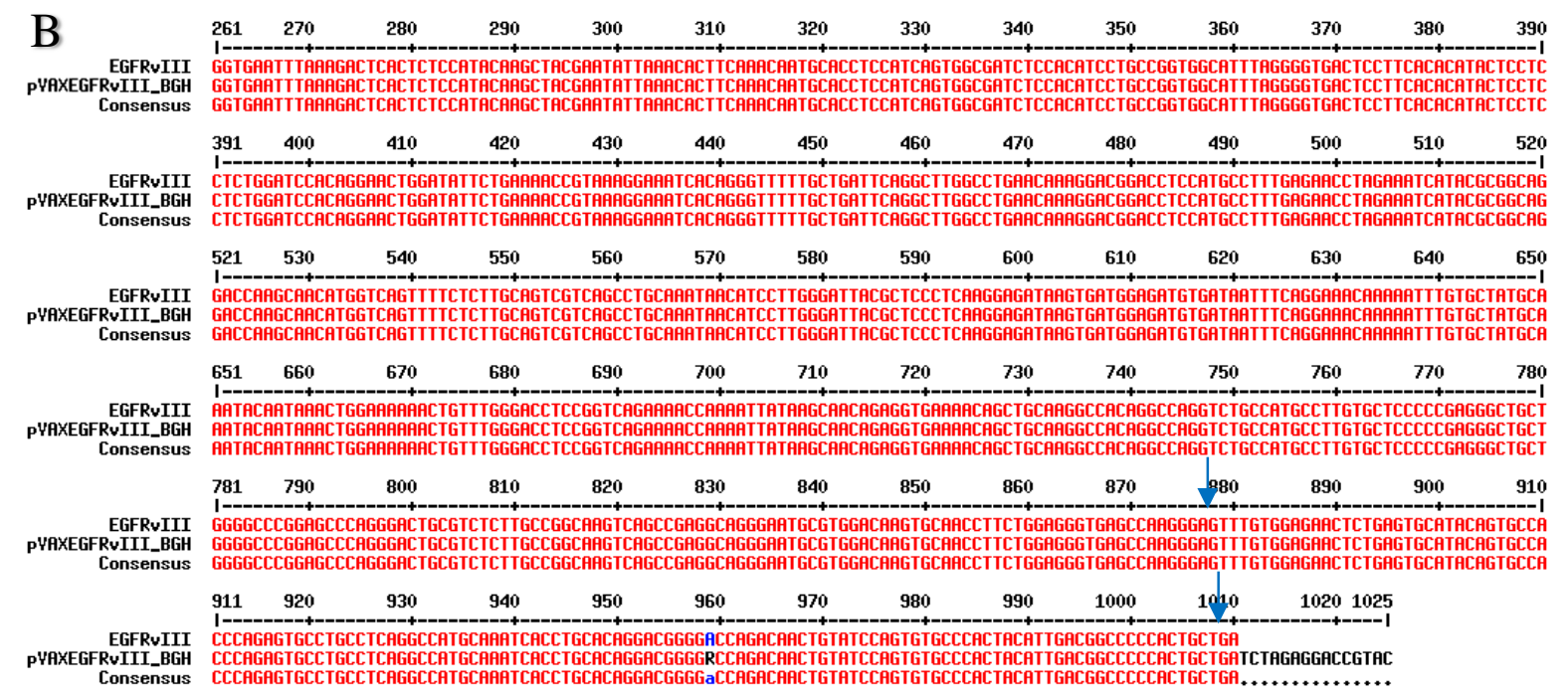

Figura 26: Sequenciamento do clone pVAXEGFRvIII_7. Alinhamento da sequência EGFRvIII com o clone pVAXEGFRvIII_7 sequenciado com o primer T7p (A) e BGH (B); em destaque (setas), o códon de iniciação, o início da sequência que não é encontrada no sequenciamento anterior e o códon de terminação da tradução da proteína EGFR.

O sequenciamento confirmou a clonagem e a análise do eletroferograma de dois sequenciamentos realizados com T7p demonstrou a ausência do GAA, mas confirmou que o $\mathrm{R}$ é um A. A ausência do GAA, promoveu um erro no início do gene, a perda de uma trinca de bases (e consequentemente de um aminoácido) e a mudança da próxima trinca, mas não mudou a ordem de leitura da proteína após o erro. A sequência correta seria metionina, leucina, ácido glutâmico, acido glutâmico, lisina, lisina, glicina; a sequência modificada pela ausência do GAA é metionina, leucina, ácido glutâmico, acido glutâmico, acido glutâmico, glicina.

\subsubsection{Clonagem do gene cERBB2 no vetor $p V A X$}

O fragmento cERBB2 foi clonado no plasmídio pVAX por meio de uma reação de ligação, cujo produto foi posteriormente transformado em células E. coli Top10. A seleção do plasmídio recombinante pVAXcERBB2 foi feita pela PCR de 5 grupos contendo 5 colônias cada (nomeados de 11 a 15). A reação foi realizada com os oligonucleotídeos T7p e cERBB2_Rseq, que indicam a presença e direção do fragmento cERBB2 no interior do pVAX (Figura 27). 

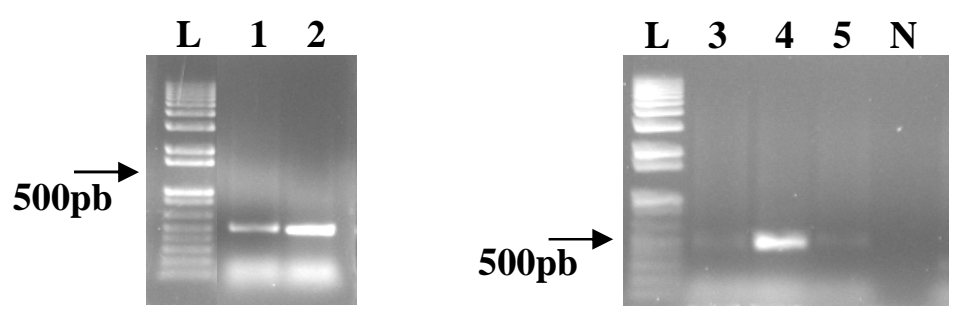

Figura 27: PCR de colônia da ligação pVAX + cERBB2. PCR de 5 grupos de colônias da ligação pVAX + cERBB2 com os oligonucleotídeos T7p e cERBB2_Rseq. L-marcador 1Kb Plus, 1 ao 5-PCR dos 5 grupos (nomeados de 11 a 15) e N-negativo.

Os grupos 11, 12 e 14 apresentaram uma banda de amplificação de aproximadamente $500 \mathrm{pb}$ (tamanho esperado de 505pb). A partir do resultado acima, foi realizada a extração dos cinco plasmídios do grupo 12 (nomeados de 11 a 15) que foram submetidos a análise por PCR utilizando-se novamente os oligonucleotídeos T7p e cERBB2_Rseq (Figura 28).

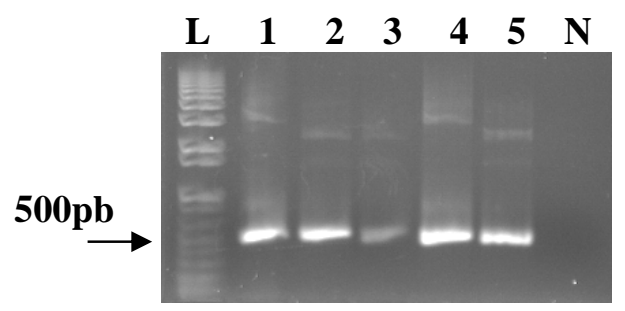

Figura 28: PCR dos plasmídios pVAXcERBB2. PCR dos 5 plasmídios pVAXcERBB2 com os oligonucleotídeos T7p e cERBB2_Rseq. L-marcador 1Kb Plus, 1 ao 5-PCR dos clones pVAXcERBB2_11 a 15 e N-negativo.

Todos os clones pVAXcERBB2 apresentaram fragmento de aproximadamente 500pb quando amplificados com os oligonucleotídeos T7p e cERBB2_Rseq (tamanho esperado de $505 \mathrm{pb}$ ), indicando a presença do inserto cERBB2 na direção correta no interior do pVAX.

A partir do resultado obtido com as PCRs, o plasmídio recombinante pVAXcERBB2_11 foi analisado por sequenciamento utilizando-se os oligonucleotídeos T7p e BGH para confirmação da clonagem (Figura 29). 


\begin{tabular}{|c|c|c|c|c|c|c|c|c|c|c|c|c|c|c|}
\hline$A$ & & $1_{+}^{10}$ & 20 & 30 & 40 & 50 & 60 & 70 & 80 & 90 & 100 & 110 & 120 & 30 \\
\hline $\begin{array}{r}\text { CERBB2 } \\
\text { PYAXCERBB2_I7 } \\
\text { Consensus }\end{array}$ & \multicolumn{14}{|c|}{ 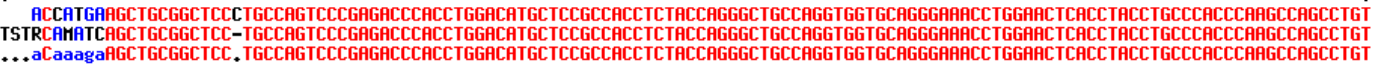 } \\
\hline & 131 & 140 & 150 & 160 & 170 & 180 & 190 & 200 & 210 & 220 & 230 & 240 & 250 & 260 \\
\hline $\begin{array}{r}\text { CERBB2 } \\
\text { AXCERBB2_I7 } \\
\text { Consensus }\end{array}$ & \multicolumn{14}{|c|}{ 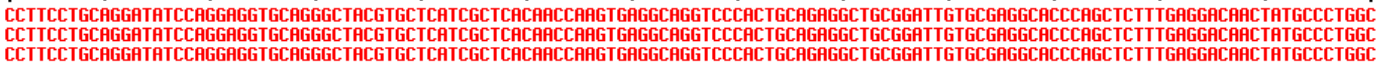 } \\
\hline & 261 & 270 & 280 & 290 & 300 & 310 & 320 & 330 & 340 & 350 & 360 & 370 & 380 & 390 \\
\hline $\begin{array}{r}\text { CERBB2 } \\
\text { 1XCERBB2_I7 } \\
\text { Consensus }\end{array}$ & \multicolumn{14}{|c|}{ 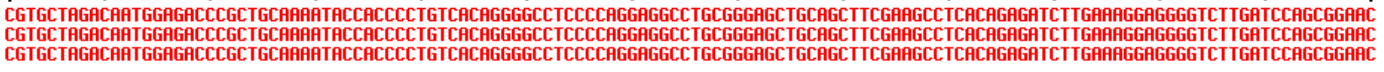 } \\
\hline & 391 & 400 & 410 & 420 & 430 & 440 & 450 & 460 & 470 & 480 & 490 & 500 & 510 & 520 \\
\hline $\begin{array}{r}\text { CERBB2 } \\
\text { IXCERBD_I7 } \\
\text { Consensus }\end{array}$ & \multicolumn{14}{|c|}{ 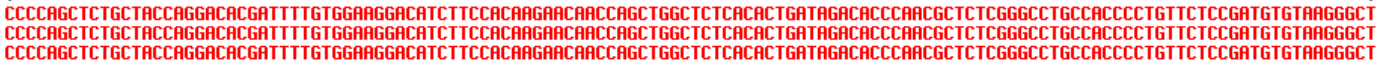 } \\
\hline & 521 & 530 & 540 & 550 & 560 & 570 & 580 & 590 & 600 & 610 & 620 & 630 & 640 & 650 \\
\hline $\begin{array}{c}\text { CERBB2 } \\
\text { IXCERBR2_T7 } \\
\text { Consensus }\end{array}$ & \multicolumn{14}{|c|}{ 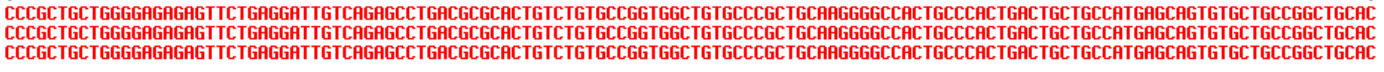 } \\
\hline & 651 & 660 & 670 & 680 & 690 & 700 & 710 & 720 & 730 & 740 & 750 & 760 & 770 & 80 \\
\hline
\end{tabular}

\begin{tabular}{|c|c|c|c|c|c|c|c|c|c|c|c|c|c|c|}
\hline B & 1 & 10 & 20 & 30 & 40 & 50 & 60 & 70 & 80 & 90 & 100 & 110 & 120 & \\
\hline $\begin{array}{r}\text { CERBB2 } \\
\text { PYAXCERBB2BGH } \\
\text { Consensus }\end{array}$ & \multicolumn{14}{|c|}{ 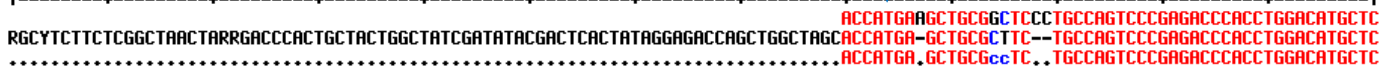 } \\
\hline & 131 & 140 & 150 & 160 & 170 & 180 & 190 & 200 & 210 & 220 & 230 & 240 & 250 & 26 \\
\hline $\begin{array}{r}\text { CERBB2 } \\
\text { AXcERBB2_BGH } \\
\text { Consensus }\end{array}$ & \multicolumn{14}{|c|}{ 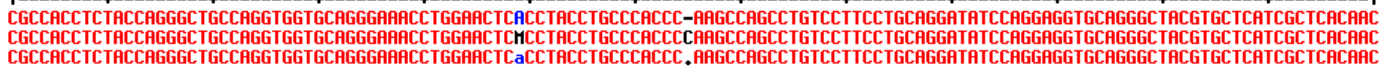 } \\
\hline & 261 & 270 & 280 & 290 & 300 & 310 & 320 & 330 & 340 & 350 & 360 & 370 & 380 & \\
\hline $\begin{array}{r}\text { CERBB2 } \\
\text { AXcERBB2_BGH } \\
\text { Consensus }\end{array}$ & \multicolumn{14}{|c|}{ 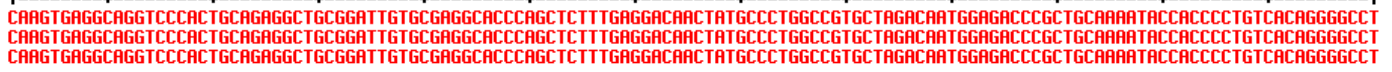 } \\
\hline & 391 & 400 & 410 & 420 & 430 & 440 & 450 & 460 & 470 & 480 & 490 & 500 & 510 & 52 \\
\hline $\begin{array}{r}\text { CERBB2 } \\
\text { XCERBB2_BGH } \\
\text { Consensus }\end{array}$ & \multicolumn{14}{|c|}{ 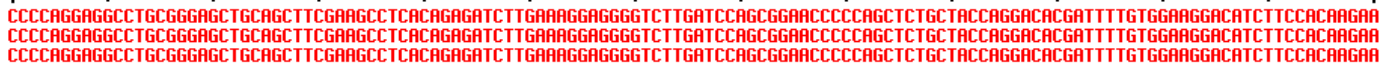 } \\
\hline & 1 & 530 & 540 & 550 & 560 & 570 & 580 & 590 & 600 & $\mathbf{6 1 0}$ & 620 & 630 & 640 & \\
\hline $\begin{array}{r}\text { CERBB2 } \\
\text { XCERBB2_BGH } \\
\text { Consensus }\end{array}$ & \multicolumn{14}{|c|}{ 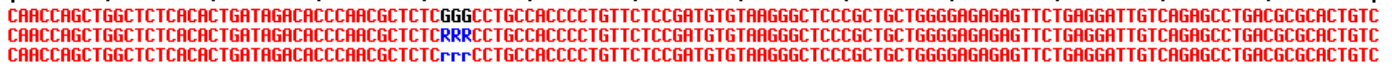 } \\
\hline & 651 & 660 & 670 & 680 & 690 & 700 & 710 & 720 & 730 & 740 & 750 & 760 & 770 & \\
\hline $\begin{array}{r}\text { CERBB2 } \\
\text { AXcERBB2_BGH } \\
\text { Consensus }\end{array}$ & \multicolumn{14}{|c|}{ 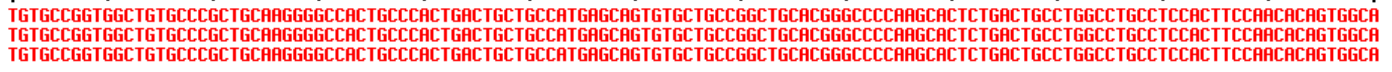 } \\
\hline & 781 & 790 & 800 & 810 & 820 & 830 & 840 & 850 & 860 & 870 & $\mathbf{8 8 0}$ & 890 & 900 & 91 \\
\hline $\begin{array}{r}\text { CERBB2 } \\
\text { AXcERBB2_BGH } \\
\text { Consensus }\end{array}$ & \multicolumn{14}{|c|}{ 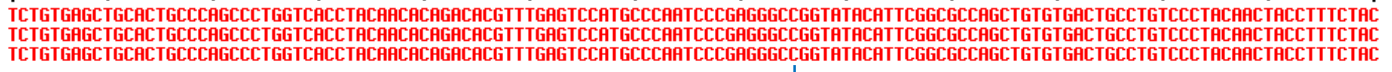 } \\
\hline & 911 & 920 & $\mathbf{9 3 0}$ & 940 & 950 & 960 & 970 & 980 & 990 & 1001 & & & & \\
\hline
\end{tabular}

Figura 29: Sequenciamento do clone pVAXcERBB2_11. Alinhamento da sequência cERBB2 com o clone pVAXcERBB2_11 sequenciado com os oligonucleotídeos T7p (A) e BGH (B); em destaque (setas), o códon de iniciação e terminação da tradução da proteína cERBB2.

O sequenciamento com os dois oligonucleotídeos confirmou a clonagem e, juntamente com a análise do eletroferograma, demonstrou a sequência correta do pVAXcERBB2_11, pois os erros encontrados em um sequenciamento foram esclarecidos no outro ou no eletroferograma. 


\subsubsection{Clonagem do gene MAGE no vetor $p V A X$}

O fragmento MAGE foi clonado no plasmídio pVAX por meio de uma reação de ligação, cujo produto foi posteriormente transformado em células E. coli Top10. A seleção do plasmídio recombinante pVAXMAGE foi feita inicialmente pela PCR de 5 grupos contendo 5 colônias cada. A reação foi realizada com os oligonucleotídeos T7p e MAGE_Rseq, que indicam a presença e direção do fragmento MAGE no interior do pVAX (Figura 30).

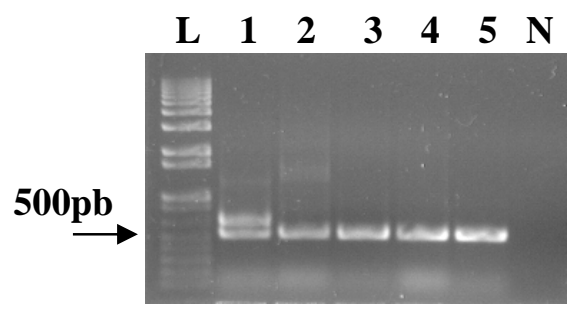

Figura 30: PCR de colônia da ligação pVAX + MAGE. PCR de 5 grupos de colônias da ligação pVAX + MAGE com os oligonucleotídeos T7p e MAGE_Rseq. L-marcador 1Kb Plus, 1 ao 5-PCR dos 5 grupos e Nnegativo.

Todos os grupos apresentaram banda de amplificação de aproximadamente 500pb (tamanho esperado de 527pb). A partir do resultado acima, foi realizada a extração dos cinco plasmídios do grupo 5 que foram submetidos a análise por PCR e digestão. A PCR foi realizada novamente com os oligonucleotídeos T7p e MAGE_Rseq (Figura 31) e a clivagem com a enzima ApaI (Figura 32).

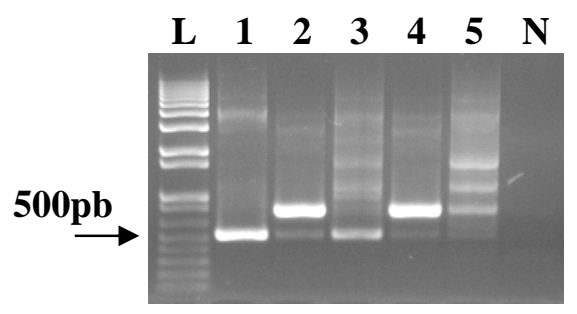

Figura 31: PCR dos plasmídios pVAXMAGE. PCR dos 5 plasmídios pVAXMAGE com os oligonucleotídeos T7p e MAGE_Rseq. L-marcador 1Kb Plus, 1 ao 5-PCR dos clones pVAXMAGE_1 a 5 e N-negativo.

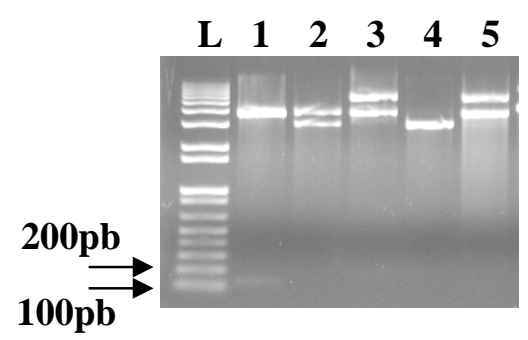

Figura 32: Clivagem dos plasmídios pVAXMAGE. Clivagem dos clones pVAXMAGE com a enzima ApaI. L-marcador 1Kb Plus e 1 ao 5-clones pVAXMAGE_1 a 5 digeridos.

Os clones pVAXMAGE_1 e 3 apresentaram fragmento de aproximadamente 500pb quando amplificados com os oligonucleotídeos T7p e MAGE_Rseq (tamanho esperado de 
$527 \mathrm{pb}$ ) (Figura 31), indicando a presença do inserto na posição correta. No entanto, apenas o clone pVAXMAGE_1 apresentou fragmento entre 100-200pb após a clivagem com ApaI (tamanho esperado de 125pb) (Figura 32) que confirmou a presença do fragmento MAGE na direção correta no interior do pVAX.

A partir dos resultados obtidos com a PCR e a análise de restrição, o plasmídio recombinante pVAXMAGE_1 foi analisado por sequenciamento utilizando-se os oligonucleotídeos T7p e BGH para confirmação da clonagem (Figura 33).

\begin{tabular}{|c|c|c|c|c|c|c|c|c|c|c|c|c|c|c|}
\hline A & 1 & 10 & 20 & 30 & 40 & 50 & 60 & 70 & 80 & 90 & 100 & 110 & 120 & 130 \\
\hline \multirow[t]{2}{*}{$\begin{array}{r}\text { Mage } \\
\text { pypXMage_T7 } \\
\text { Consensus }\end{array}$} & \multicolumn{14}{|c|}{ 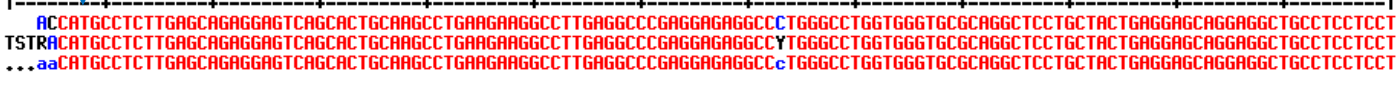 } \\
\hline & 131 & 140 & 150 & 160 & 170 & 180 & 190 & 200 & 210 & 220 & 230 & 240 & 250 & 260 \\
\hline \multirow[t]{2}{*}{$\begin{array}{r}\text { Mage } \\
\text { PYAXMage_T7 } \\
\text { Consensus }\end{array}$} & \multicolumn{14}{|c|}{ 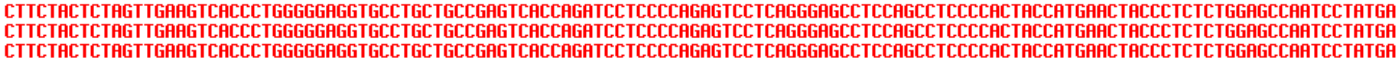 } \\
\hline & 261 & 270 & 280 & 290 & 300 & 310 & 320 & 330 & 340 & 350 & 360 & 370 & 380 & 390 \\
\hline $\begin{array}{r}\text { Mage } \\
\text { pyAXMage_T7 } \\
\text { Consensus }\end{array}$ & \multicolumn{14}{|c|}{ 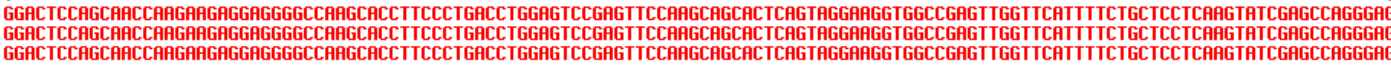 } \\
\hline & 391 & 400 & 410 & 420 & 430 & 440 & 450 & 460 & 470 & 480 & 490 & 500 & 510 & 520 \\
\hline $\begin{array}{r}\text { Mage } \\
\text { PUAXMage_t7 } \\
\text { Consensus }\end{array}$ & \multicolumn{14}{|c|}{ 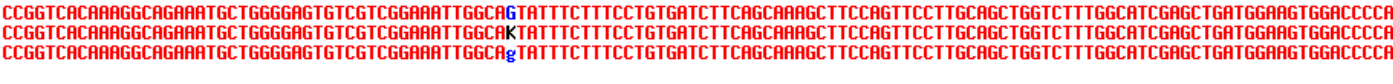 } \\
\hline & 521 & 530 & 540 & 550 & 560 & 570 & 580 & 590 & 600 & 610 & 620 & 630 & 640 & 650 \\
\hline $\begin{array}{r}\text { Mage } \\
\text { PYhXMage_T7 } \\
\text { Consensus }\end{array}$ & \multicolumn{14}{|c|}{ 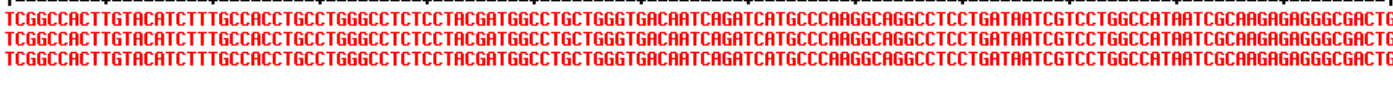 } \\
\hline & 651 & 660 & 670 & 680 & 690 & 700 & 710 & 720 & 730 & 740 & 750 & 760 & 770 & 780 \\
\hline $\begin{array}{r}\text { Mage } \\
\text { püXXage_I7 } \\
\text { Consensus }\end{array}$ & $\begin{array}{l}\text { TECC } \\
\text { TGCC }\end{array}$ & & & & & & & & & & & & $\begin{array}{l}\text { ACTA } \\
\text { ACTA }\end{array}$ & $\begin{array}{l}\text { GTAC } \\
\text { GTAC }\end{array}$ \\
\hline
\end{tabular}

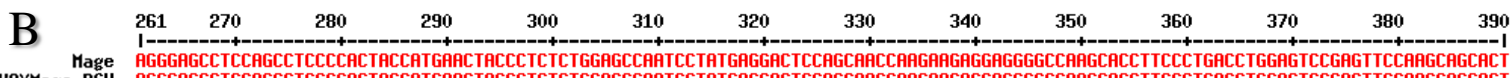

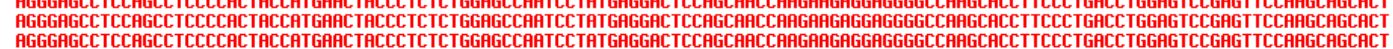

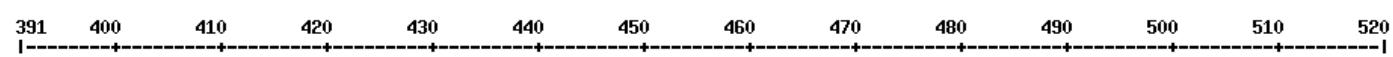

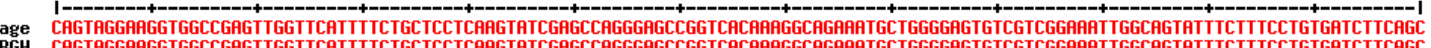

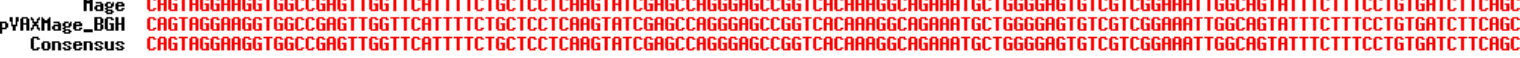

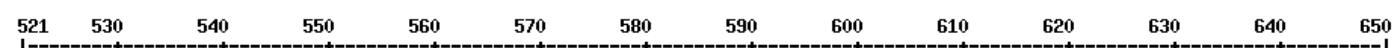

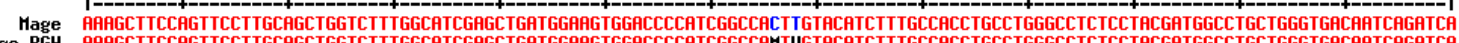

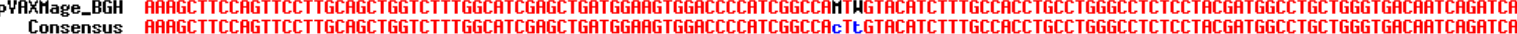

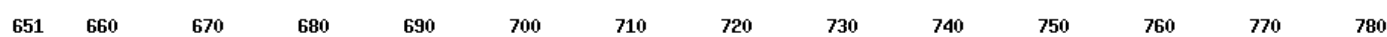

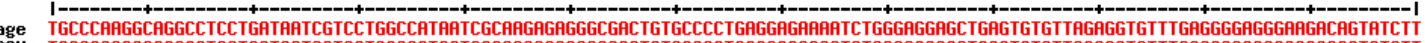

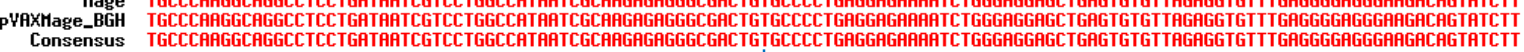

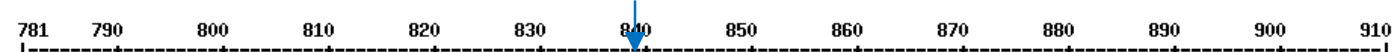

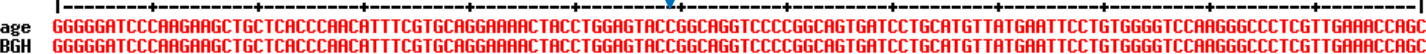

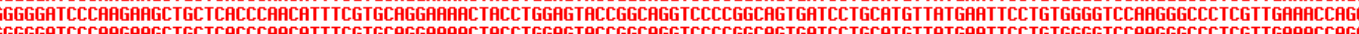

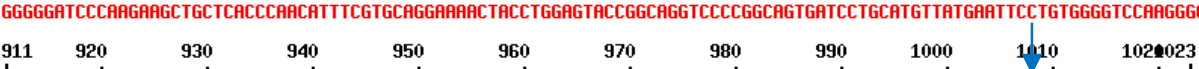

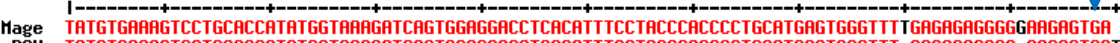

pqaXMage_BG TATGTGARAGTCCTGCACCATATGGTARAGATCAGTGGAGGACCTCACATTTCCTACCCACCCCTGCATGAGTGGGTIT-GAGAGGGGGG-AAGAGTGATCTAGAgCCCGTAC

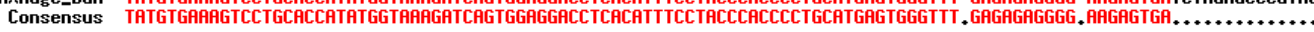

Figura 33: Sequenciamento do clone pVAXMAGE_1. Alinhamento da sequência MAGE com o clone pVAXMAGE_1 sequenciado com os oligonucleotídeos T7p (A) e BGH (B); em destaque (setas), os códons de iniciação da tradução da proteína MAGE, o início da sequência que não é encontrada no sequenciamento anterior e o códon de terminação da tradução. 
O sequenciamento confirmou a clonagem e, juntamente com a análise do eletroferograma, esclareceu os erros que foram, então, corrigidos analisando o sequenciamento com o outro oligonucleotídeo ou pelo eletroferograma.

\subsubsection{Clonagem do gene GLEA no vetor $p V A X$}

O fragmento GLEA foi clonado no plasmídio pVAX por meio de uma reação de ligação, cujo produto foi posteriormente transformado em células E. coli Top10. A seleção do plasmídio recombinante pVAXGLEA foi feita pela PCR de 5 grupos contendo 5 colônias cada. A reação foi realizada com os oligonucleotídeos T7p e GLEA_2Rseq, que indicam a presença e direção do fragmento GLEA no interior do pVAX (Figura 34).
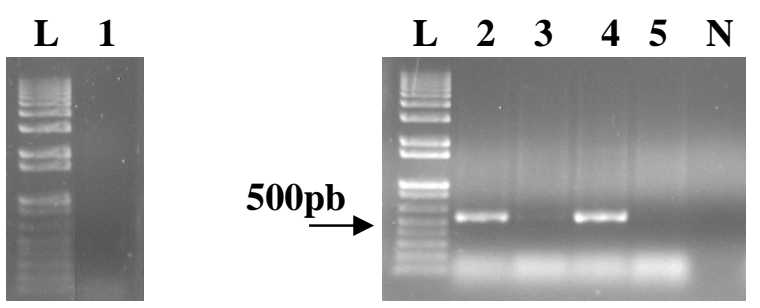

Figura 34: PCR de colônia da ligação pVAX + GLEA. PCR de 5 grupos de colônias da ligação pVAX + GLEA com os oligonucleotídeos T7p e GLEA_2Rseq. L-marcador 1Kb Plus, 1 ao 5-PCR dos 5 grupos e Nnegativo.

Os grupos 2 e 4 apresentaram uma banda de amplificação de aproximadamente 500pb (tamanho esperado de 545pb). A partir do resultado acima, foi realizada a extração dos cinco plasmídios do grupo 2 (nomeados de 6 a 10) que foram submetidos a análise por PCR utilizando-se novamente os oligonucleotídeos T7p e GLEA_2Rseq (Figura 35).
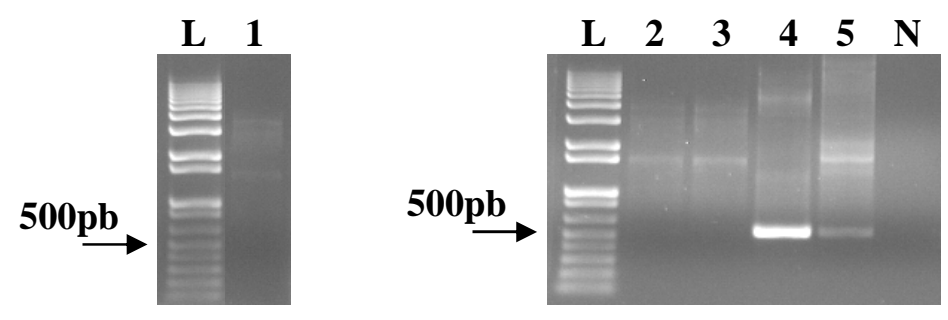

Figura 35: PCR dos plasmídios pVAXGLEA. PCR dos 5 plasmídios pVAXGLEA com os oligonucleotídeos T7p e GLEA_2Rseq. L-marcador 1Kb Plus, 1 ao 5-PCR dos clones pVAXGLEA_6 ao 10 e N-negativo.

Os clones pVAXGLEA_9 e 10 apresentaram fragmento de aproximadamente 500pb quando amplificados com os oligonucleotídeos T7p e GLEA_2Rseq (tamanho esperado de $527 \mathrm{pb}$ ), indicando a presença do inserto GLEA na direção correta no interior do pVAX.

A partir dos resultados obtidos com as PCRs, o plasmídio recombinante pVAXGLEA_9 foi analisado por sequenciamento utilizando-se os oligonucleotídeos T7p, Glea1Sseq e BGH para confirmação da clonagem (Figura 36). 


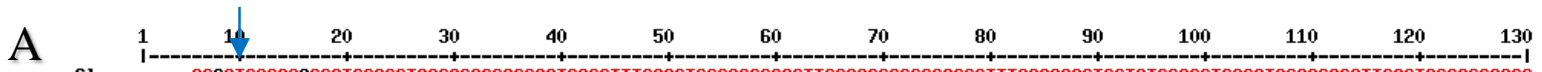

Glea

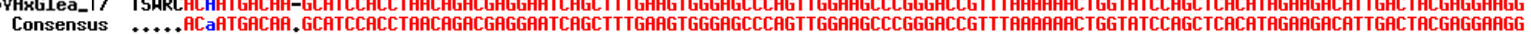

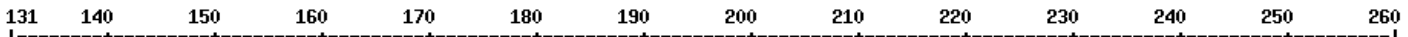

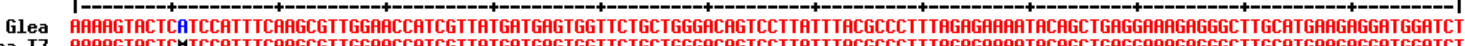

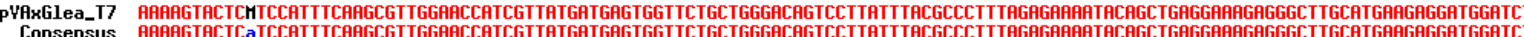

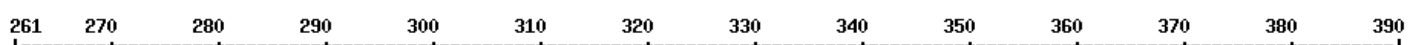

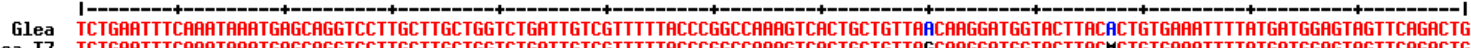

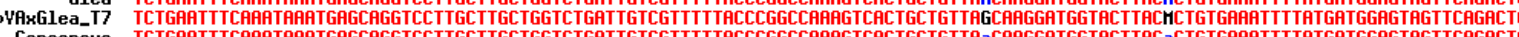

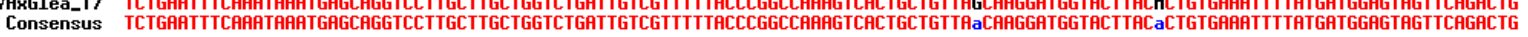

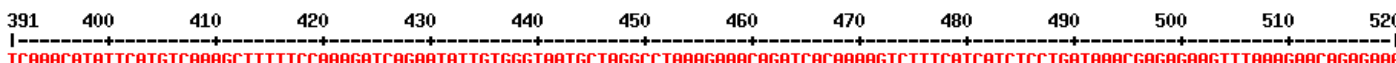

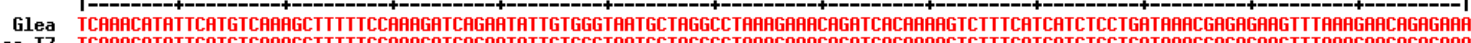
pyAxGlea_T7
Consensus

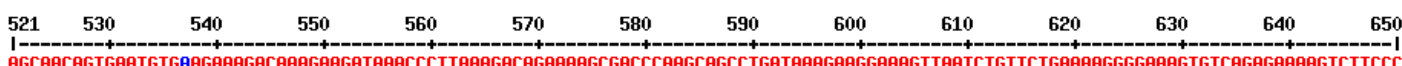

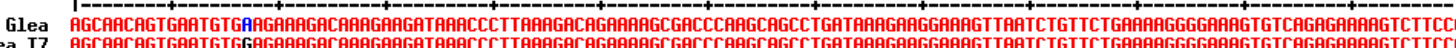

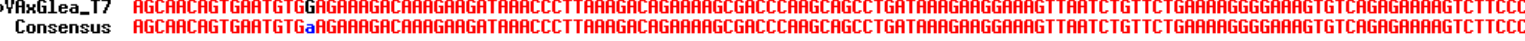

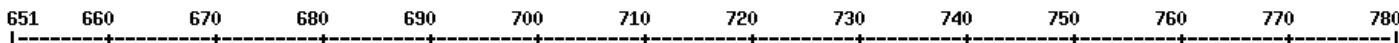

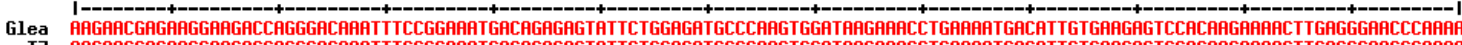
PVAxGlea_I7
Consensus

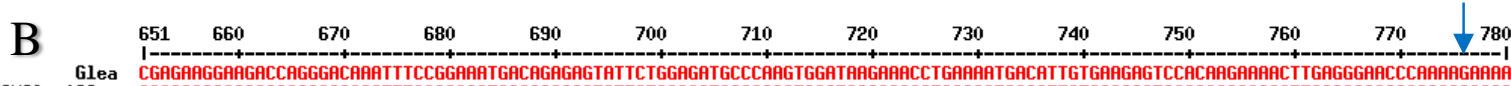
vyAXGlea1sSeq CGAGAGGAGG

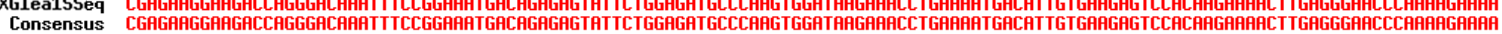
$781 \quad 790$
$810 \quad 820$
$830 \quad 840 \quad 850$
860
870
$\mathbf{8 8 0}$
890
$900 \quad 910$

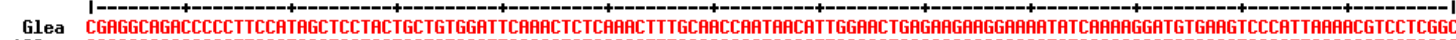

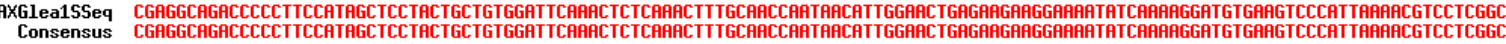

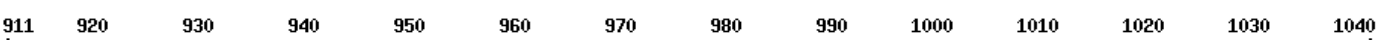

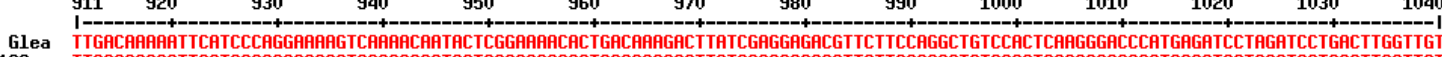

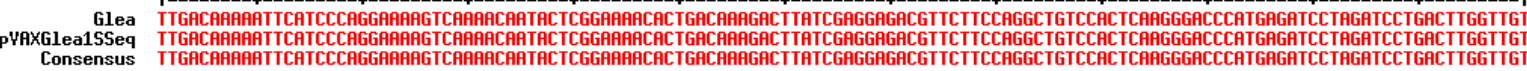

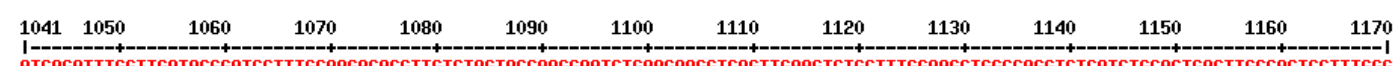

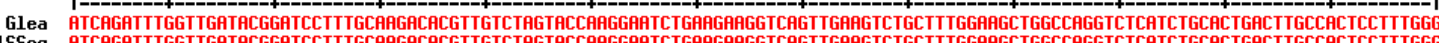

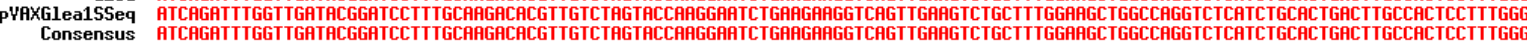

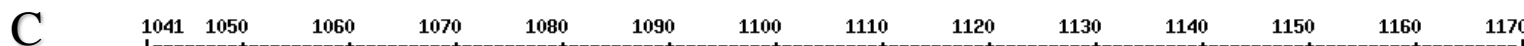

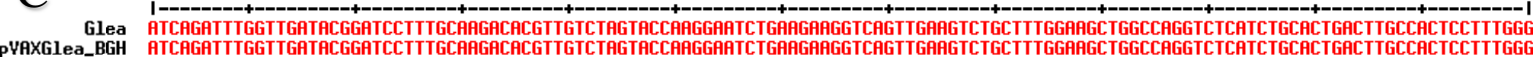
PHAXGlea_BGH
Consensus

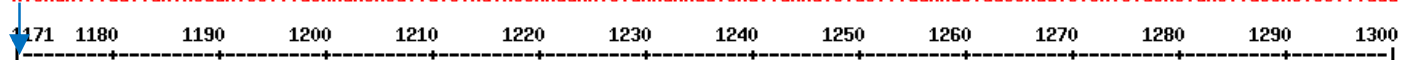

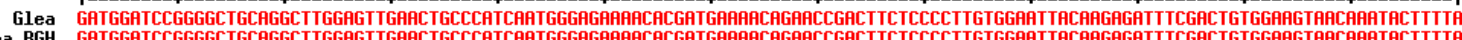

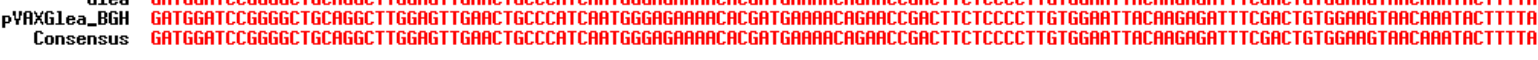

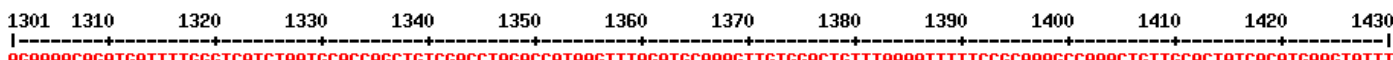

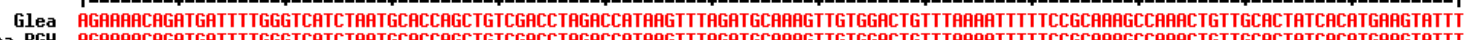
pyAXGlea_BGH
Consensus $1431 \quad 1440 \quad 1450 \quad 1460 \quad 1470 \quad 1480 \quad 1490 \quad 1500 \quad 1510 \quad 1520 \quad 1530 \quad 1540 \quad 1550 \quad 1560$

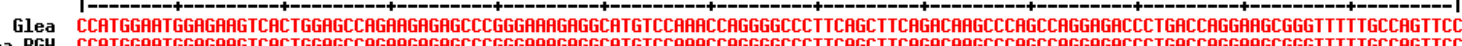
pVAXGlea_BGH
Consensus

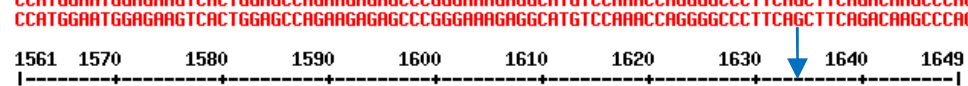

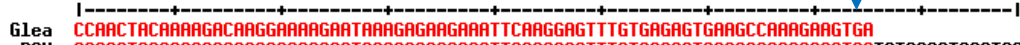

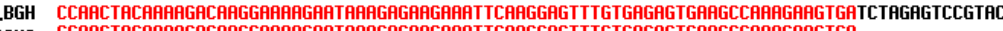

Figura 36: Sequenciamento do clone pVAXGLEA_9. Alinhamento da sequência GLEA com o clone pVAXGLEA_9 sequenciado com os oligonucleotídeos T7p (A), Glea1Sseq (B) e BGH (C); em destaque (setas), o códon de iniciação da tradução da proteína GLEA, o início da sequência que não é encontrada no sequenciamento anterior e o códon de terminação.

O sequenciamento confirmou a clonagem e a análise do eletroferograma confirmou a sequência correta. 


\subsubsection{Clonagem do gene hsp70 no vetor $p V A X$}

O fragmento hsp70 foi clonado no plasmídio pVAX por meio de uma reação de ligação, cujo produto foi posteriormente transformado em células E. coli Top10. A seleção do plasmídio recombinante pVAXhsp70 foi feita pela PCR de 5 grupos contendo 5 colônias cada (nomeados de 16 a 20). A reação foi realizada com os oligonucleotídeos T7p e Hsp70_2Rseq, que indicam a presença e direção do fragmento hsp70 no interior do pVAX (Figura 37).
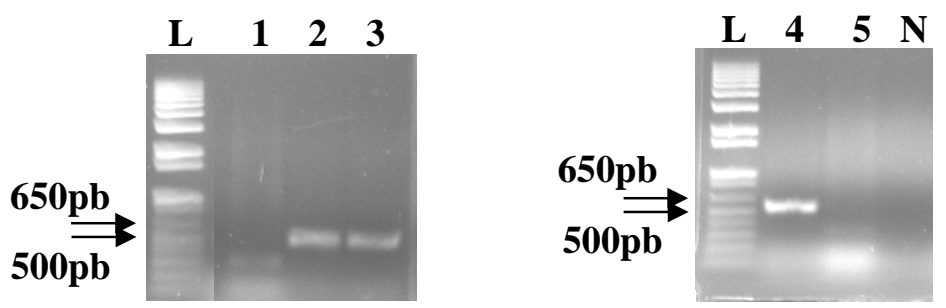

Figura 37: PCR de colônia da ligação pVAX + hsp70. PCR de 5 grupos de colônias da ligação pVAX + hsp70 com os oligonucleotídeos T7p e hsp70_Rseq. L-marcador 1Kb Plus, 1 ao 5-PCR dos 5 grupos (nomeados de 16 a 20) e N-negativo.

Os grupos 17, 18 e 19 apresentaram uma banda de amplificação entre 500-650pb (tamanho esperado de $541 \mathrm{pb}$ ). A partir do resultado acima, foi realizada a extração dos cinco plasmídios do grupo 19 (nomeados de 16 a 20) que foram submetidos a análise por PCR utilizando-se novamente os oligonucleotídeos T7p e hsp70_Rseq (Figura 38).
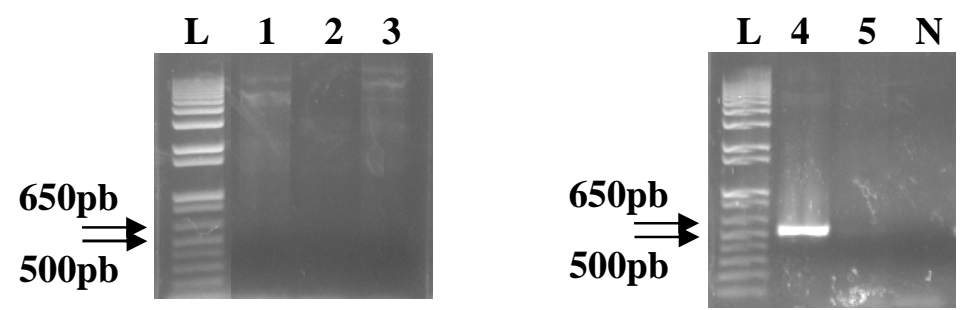

Figura 38: PCR dos plasmídios pVAXhsp70. PCR dos 5 plasmídios pVAXhsp70 com os oligonucleotídeos T7p e hsp70_Rseq. L-marcador 1Kb Plus, 1 ao 5-PCR dos clones pVAXhsp70_16 ao 20 e N-negativo.

Apenas o clone pVAXhsp70_19 apresentou fragmento entre 500-650pb quando amplificado com os oligonucleotídeos T7p e hsp70_Rseq, indicando a presença do inserto hsp70 na direção correta no interior do pVAX.

A partir dos resultados obtidos com as PCRs, o plasmídio recombinante pVAXhsp70_19 foi analisado por sequenciamento utilizando-se os oligonucleotídeos T7p, hsp70_1Sseq e BGH para confirmação da clonagem (Figura 39). 


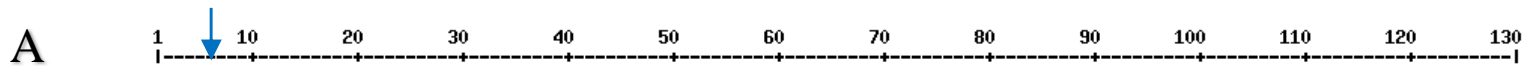

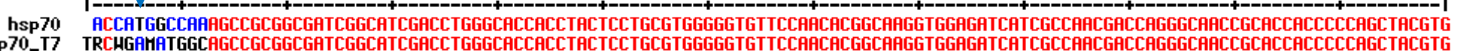

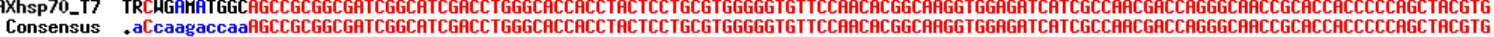

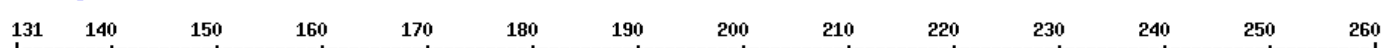

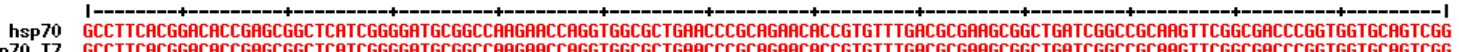

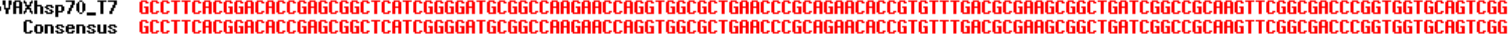

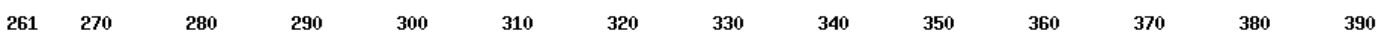

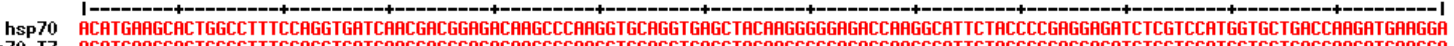

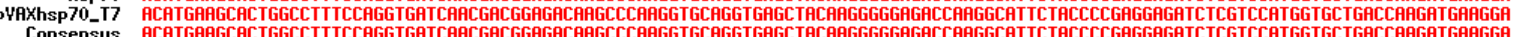

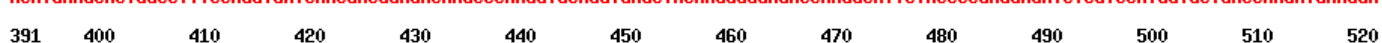

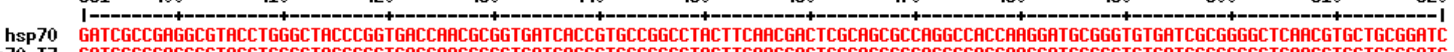
GATCGCCGAGGCGTACCTGGGCTACCCGGTGACCAACGCGGTGATCACCGTGCCGGCCTACTTCAACGACTCGCAGCGCCAGGCCACCAAGGATGCGGGTGTGATCGCGGGGCTCAACGTGCTGCGGATC

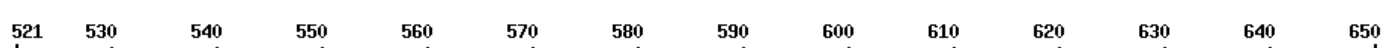

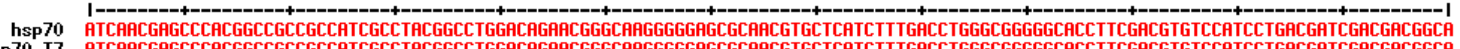

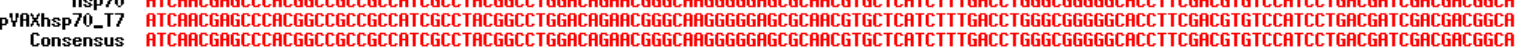

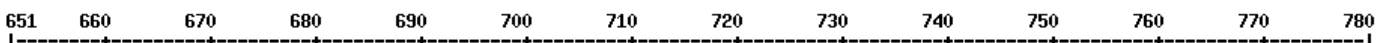

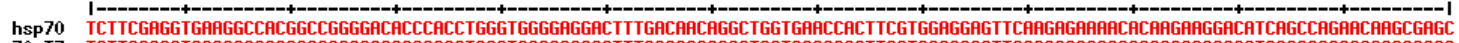
pyAXhsp70_T7
Consensus

B

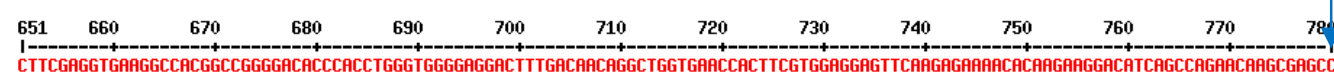

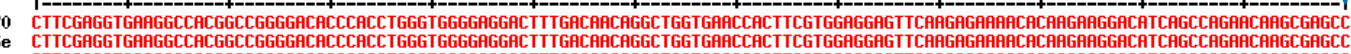

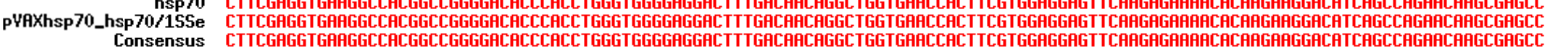

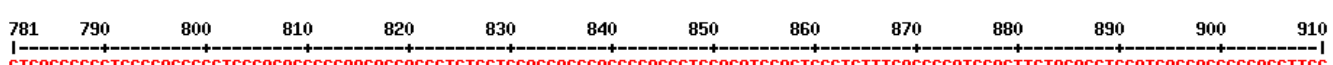

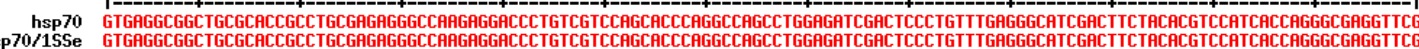
hsp70/15Se
Consensus

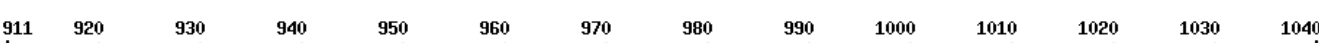

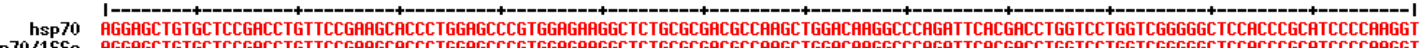

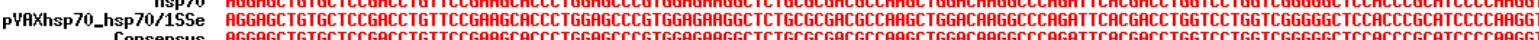

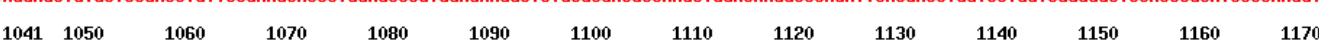
I-AGGARGCTGCTGCAGGACTTCTTCAACGGGCGCGACCTGAACAAGAGCATCAACCCCGACGAGGCTGTGGCCTACGGGGCGGCGGTGCAGGCGGCCATCCTGATGGGGGACARGTCCGAGAACGTGCAG pyaXhsp70_hsp70/15Se GCAGAAGCTGCTGCAGGACTTCTICAACGGGCGCGACCTGAACAAGAGCATCAACCCCGACGAGGCTGTGGCCTACGGGGCGGCGGTGCAG-CGGCCATCCTGATGGGGGACAAGTCCGAGARCGTGCAG Consensus GCAGAFGCTGCTGCAGGACTTCTTCAACGGGCGCGACCTGAACAAGAGCATCAACCCCGACGAGGCTGTGGCCTACGGGGCGGCGGTGCAG.CGGCCATCCTGATGGGGGACAFGTCCGAGAFCGTGCAG

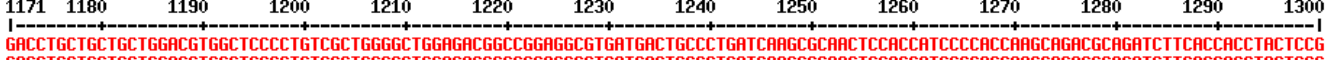

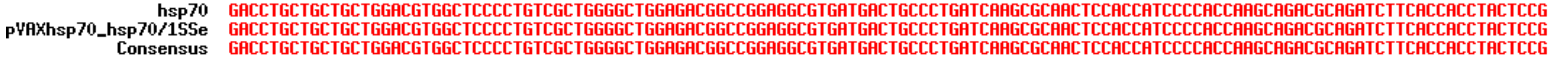

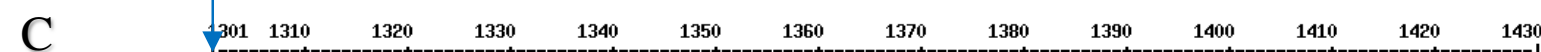

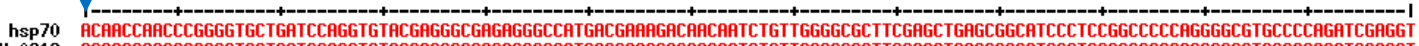
D_BGH_0313 ACAACCAACCCGGGGTGCTGATCCAGGTGTACGAGGGGGAGGGGGCCATGACGAAAGGACAACAATCTGTTGGGGCGCTTCGAGCTGAGCGGCATCCCTCCGGCCCCCAGGGGCGTGCCCCAGATCGAGG

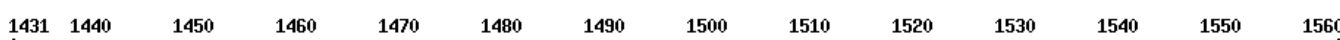

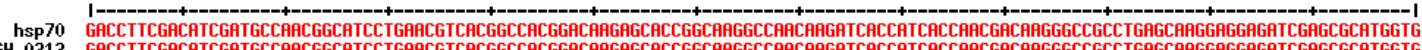

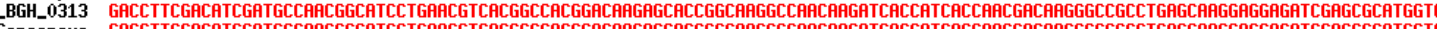

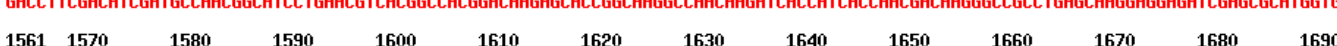

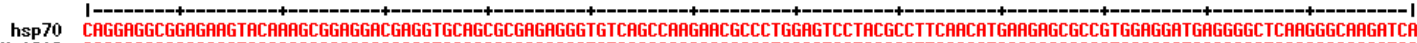

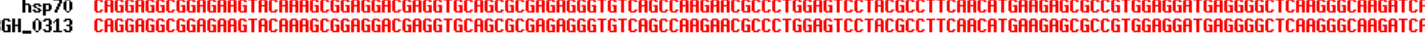

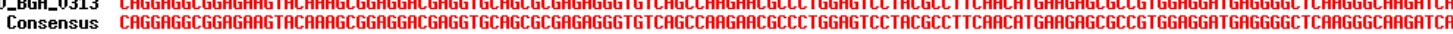

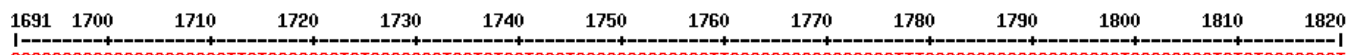

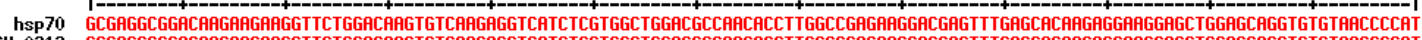

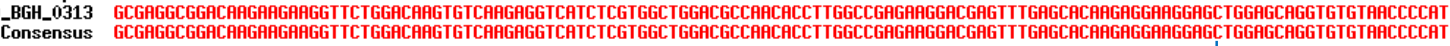

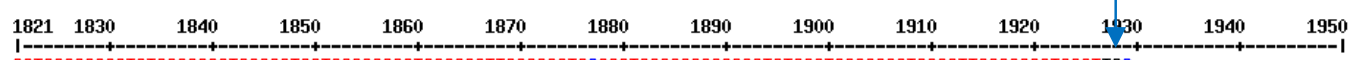

hsp70 CATCAGCGGACTGTACCAGGGTGCCGGTGGTCCCGGGCCTGGCGGCTTCGGGGCTCAGGGTCCCARGGGAGGGTCTGGGTCAGGCCCTACCATTGAGGAGGTGGATTGA

CATCAGCGGACTGTACCAGGGTGCCGGTGGTCCCGGGCCTGGCGGCTTCGGGGCTCRGGGTCCCAAGGGGGGGTCTGGGTCAGGCCCTACCATTGAGGGAGGTGGATGATCTAGAGACGTACACTGGTGTT

Figura 39: Sequenciamento do clone pVAXhsp70_19. Alinhamento da sequência hsp70 com o clone pVAXhsp70_19 sequenciado com os oligonucleotídeos T7p (A), hsp70_1Sseq (B) e BGH (C); em destaque (setas), o códon de iniciação da tradução da proteína Hsp70, o início da sequência que não é encontrada no sequenciamento anterior e o códon de terminação da tradução.

O sequenciamento confirmou a clonagem, mas o início do gene ficou ruim com o oligonucleotídeo T7p, foram realizados novos sequenciamentos com T7p e Hsp70_2RSeq que 
confirmaram a presença do ATG, no entanto, o sequenciamento do início do gene continuou ruim, o Hsp70_2Rseq parece anelar em uma região inespecífica do gene. A análise do eletroferograma indicou que o R é um A, mas o final do gene deixou dúvidas quanto ao stop códon, mesmo após repetições do sequenciamento com BGH e com um oligonucleotídeo que hibridiza no interior do gene.

\subsection{Construção dos vetores de expressão}

\subsubsection{Clonagem dos genes EGFRIII, cERBB2, MAGE, GLEA e hsp70 no vetor pET}

\subsubsection{Amplificação e clivagem dos genes EGFRvIII, cERBB2, MAGE, GLEA e hsp70}

Os genes EGFRvIII, GLEA e hsp70 foram amplificados usando oligonucleotídeos específicos para cada gene, para a posterior clivagem e clonagem no vetor pET. As amplificações foram avaliadas em gel de agarose $1 \%$ (Figura 40):

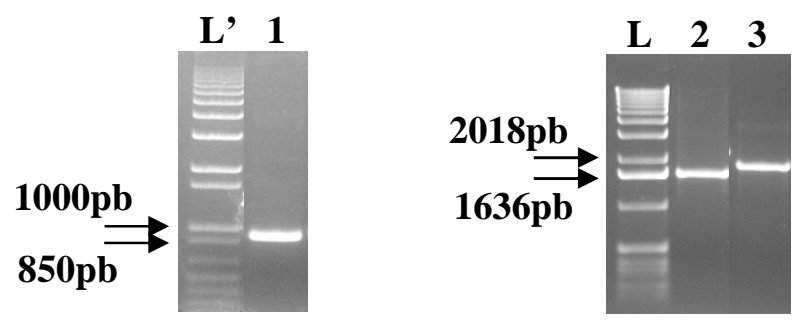

Figura 40: Amplificação dos genes EGFRvIII, GLEA e hsp70 para clonagem no vetor pET. L, L'-marcador $1 \mathrm{~Kb}$ e $1 \mathrm{~Kb}$ Plus, respectivamente, 1-EGFRvIII, 2-GLEA e 3-hsp70.

Todos os genes foram amplificados de forma correta revelando bandas de tamanhos esperados: EGFRvIII, 926pb; GLEA, 1652pb e hsp70, 1946pb. Esses genes foram clivados com as enzimas NheI e XhoI para a clonagem no vetor pET clivado com as mesmas enzimas.

OBS.: A amplificação e clivagem dos genes cERBB2 e MAGE foram realizadas pela empresa Farmacore Biotechnology Ltd..

\subsubsection{Clivagem do vetor $\mathrm{pET}$}

$\mathrm{O}$ vetor pET foi clivado com as enzimas NheI e XhoI e analisado em gel de agarose $1 \%$ (Figura 41): 


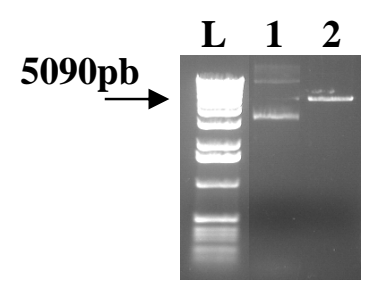

Figura 41: Clivagem do vetor pET. L-marcador $1 \mathrm{~Kb}, 1-\mathrm{pET}$ não digerido e 2-pET clivado com as enzimas NheI e XhoI.

O vetor pET clivado com NheI e XhoI foi visualizado por uma única banda que indica seu tamanho de 5292pb. O plasmídio foi purificado e ligado aos genes EGFRvIII, GLEA e hsp70.

\subsubsection{Clonagem do gene EGFRvIII no vetor pET}

O fragmento EGFRvIII foi clonado no plasmídio pET por meio de uma reação de ligação, cujo produto foi posteriormente transformado em células E. coli Top10. A seleção do plasmídio recombinante pETEGFRvIII foi feita inicialmente pela PCR de 13 colônias individuais (nomeadas de 27 a 39). A reação foi realizada com os oligonucleotídeos T7p e EGFRvIII_Rseq (Figura 42).
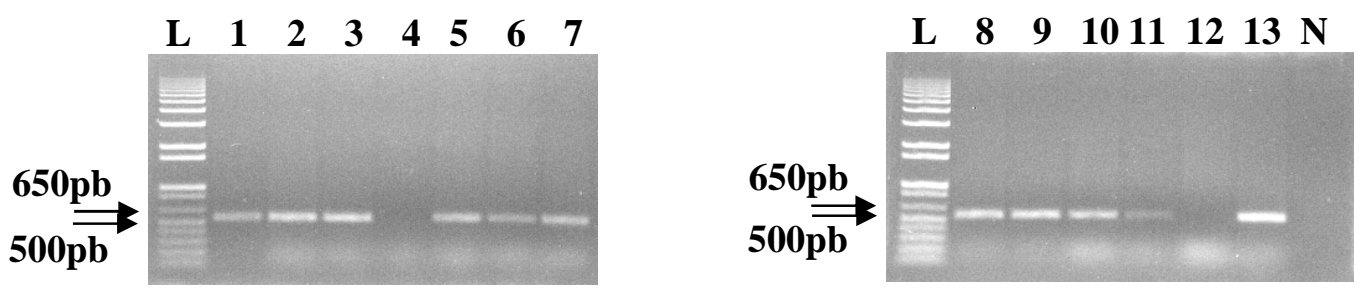

Figura 42: PCR de colônia da ligação pET + EGFRvIII. PCR de 13 colônias da ligação pET + EGFRvIII com os oligonucleotídeos T7p e EGFRvIII_Rseq. L-marcador 1Kb Plus, 1 ao 13-PCR das 13 colônias (nomeadas de 27 a 39) e N-negativo.

As colônias pETEGFRvIII_27, 28, 29, 31, 32, 33, 34, 35, 36 e 39 apresentaram fragmento entre 500 e $650 \mathrm{pb}$ (tamanho esperado de $557 \mathrm{pb}$ ). A partir do resultado acima, foram realizadas a extração e clivagem de cinco plasmídios $(27,28,29,31$ e 32) com as enzimas NheI e XhoI. A digestão foi analisada em gel de agarose 1\% (Figura 43): 


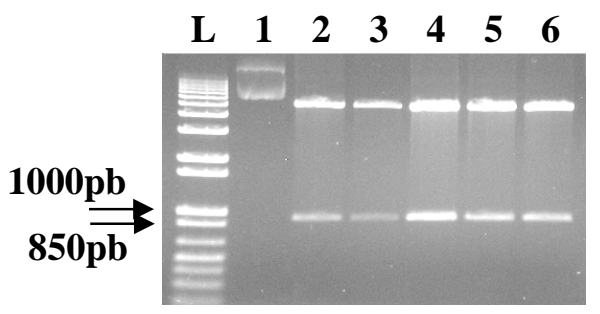

Figura 43: Clivagem dos plasmídios pETEGFRvIII. Clivagem dos clones pETEGFRvIII com as enzimas NheI e XhoI. L-marcador $1 \mathrm{~Kb}$ Plus, 2 ao 6-clones pETEGFRvIII_27, 28, 29, 31 e 32 digeridos e 1pETEGFRvIII_27 não digerido.

Todos os clones pETEGFRvIII apresentaram fragmento entre 850-1000pb (tamanho esperado de $912 \mathrm{pb}$ ) após a clivagem, indicando a presença do fragmento EGFRvIII no interior do $\mathrm{pET}$.

A partir dos resultados obtidos com a PCR e a análise de restrição, o plasmídio recombinante pETEGFRvIII_29 foi analisado por sequenciamento utilizando-se os oligonucleotídeos T7p e T7t para confirmação da clonagem (Figura 44).

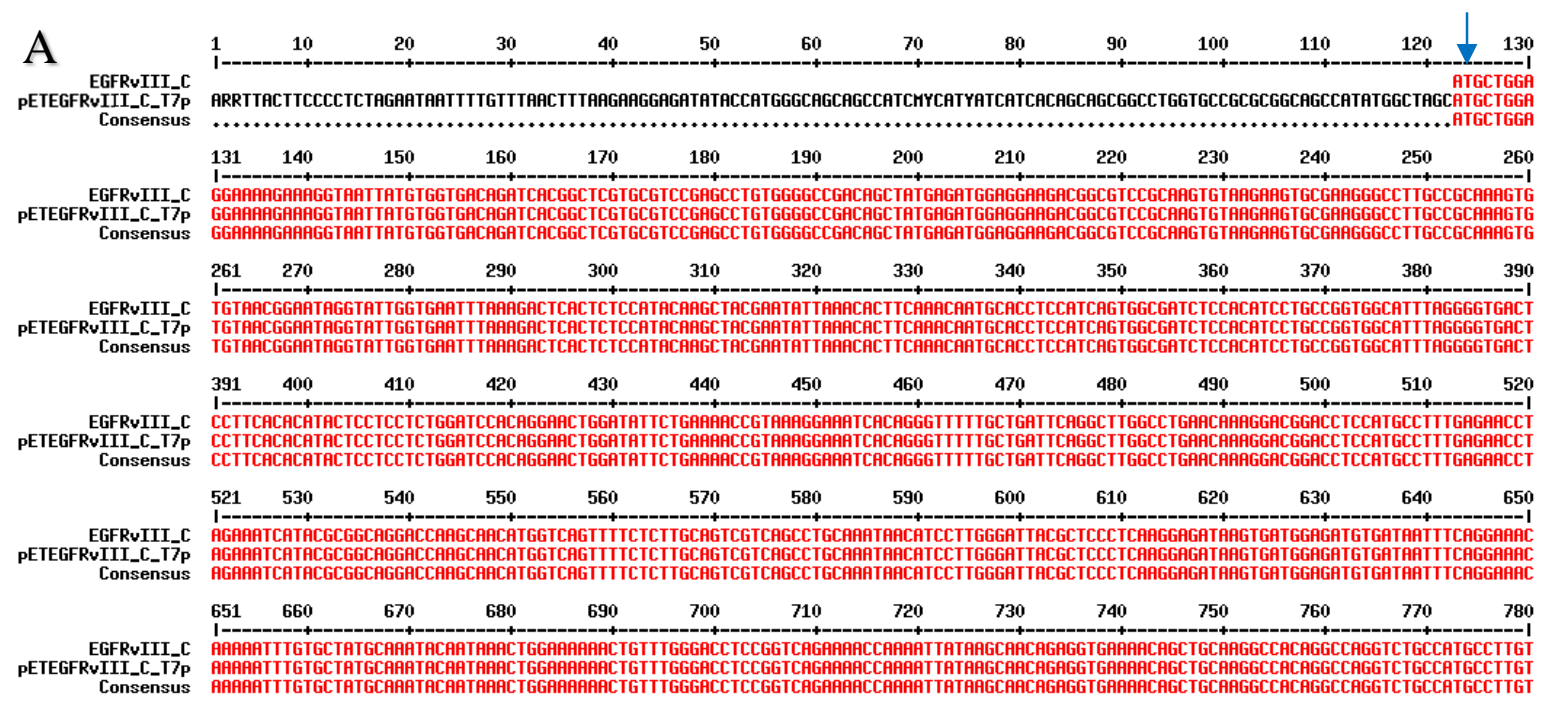




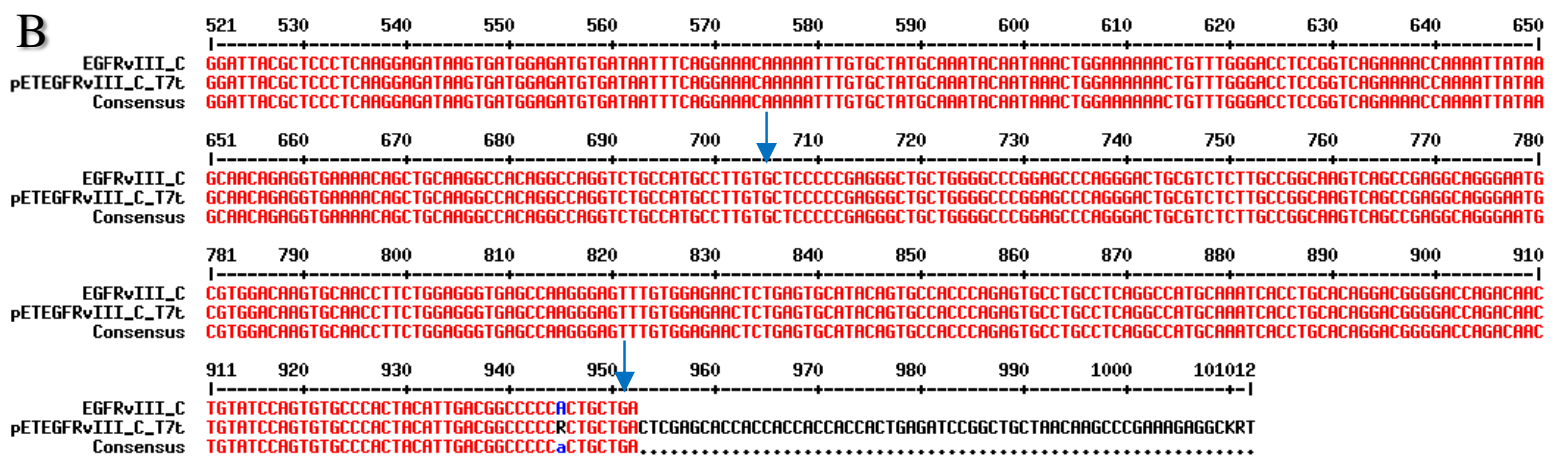

Figura 44: Sequenciamento do clone pETEGFRvIII_29: Alinhamento da sequência EGFRvIII com o clone pETEGFRvIII_29 sequenciado com o primer T7p (A) e T7t (B); em destaque (seta), o códon de iniciação da tradução da proteína EGFRvIII, o inicio da sequencia que não é encontrada no sequenciamento anterior e o códon de terminação da tradução.

O sequenciamento com os dois oligonucleotídeos confirmou a clonagem e, juntamente com a análise do eletroferograma, demonstrou a sequência correta do pETEGFRvIII_29.

\subsubsection{Clonagem do gene cERBB2 no vetor $p E T$}

A clonagem do gene cERBB2 no vetor pET foi realizada pela empresa Farmacore Biotechnology Ltd. e a seleção do plasmídio recombinante pETcERBB2 foi realizada pela clivagem de cinco plasmídios extraídos de colônias da transformação da ligação pETcERBB2 (nomeados 14, 15, 20, 21 e 26). A digestão foi realizada com a enzima XbaI e analisada em gel de agarose $1 \%$ (Figura 45):

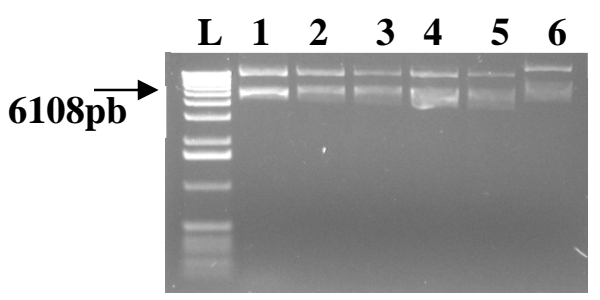

Figura 45: Clivagem dos plasmídios pETcERBB2. Clivagem dos clones pETcERBB2 com a enzima XbaI. Lmarcador 1Kb, 2 ao 6-clones pETcERBB2_14, 15, 20, 21 e 26 digeridos e 1-pET clivado com a mesma enzima.

Em todos os clones a digestão não foi completa ou mesmo pode não ter acontecido. Os plasmídios pETcERBB2_14, 15, 20 e 21 apresentaram bandas muito semelhantes ao vetor pET digerido, no entanto, o clone pETcERBB2_26 (tamanho esperado de 6205pb) apresentou fragmentos maiores, podendo ser um recombinante. Para confirmar esse resultado o clone foi novamente digerido, no entanto, com as enzimas NheI e XhoI (Figura 46). 


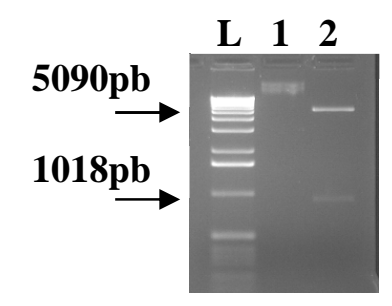

Figura 46: Clivagem do plasmídio pETcERBB2_26. Clivagem do clone pETcERBB2_26 com as enzimas NheI e XhoI. L-marcador 1Kb, 1-pETcERBB2_26 não digerido e 2-pETcERBB2_26 digerido.

O clone pETcERBB2_26 apresentou banda próxima a 1018pb (tamanho esperado de 909pb) indicando a presença do inserto cERBB2. A partir dos resultados obtidos com as clivagens, o clone 26 que apresentava o plasmídio recombinante pETcERBB2 foi analisado por sequenciamento utilizando-se os oligonucleotídeos T7p e T7t para confirmação da clonagem (Figura 47).

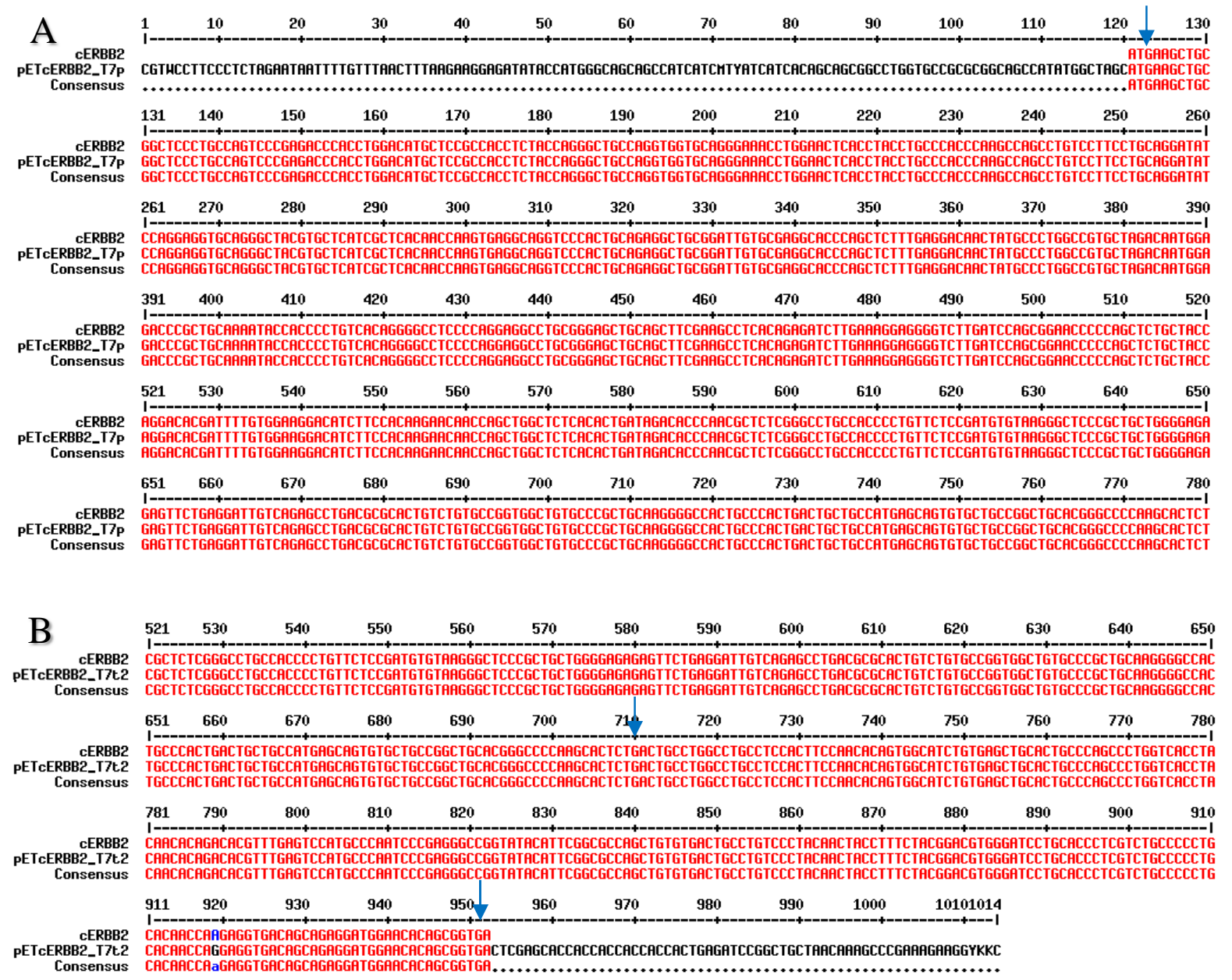

Figura 47: Sequenciamento do clone pETcERBB2_26. Alinhamento da sequência cERBB2 com o clone pETcERBB2_26 sequenciado com os oligonucleotídeos T7p (A) e T7t (B); em destaque (setas), o códon de iniciação da tradução da proteína cERBB2, o início da sequência que não é encontrada no sequenciamento anterior e o códon de terminação da tradução. 
O sequenciamento com os dois oligonucleotídeos confirmou a clonagem e, juntamente com a análise do eletroferograma, demonstrou a sequência correta do pETcERBB2_26.

\subsubsection{Clonagem do gene MAGE no vetor pET28a}

A clonagem do gene MAGE no vetor pET e a seleção do plasmídio recombinante foram realizadas pela empresa Farmacore Biotechnology Ltd. utilizando-se o molde e os oligonucleotídeos descritos no materiais e métodos. O clone pETMAGE selecionado foi sequenciado utilizando-se os oligonucleotídeos T7p e T7t para confirmação da clonagem (Figura 48).

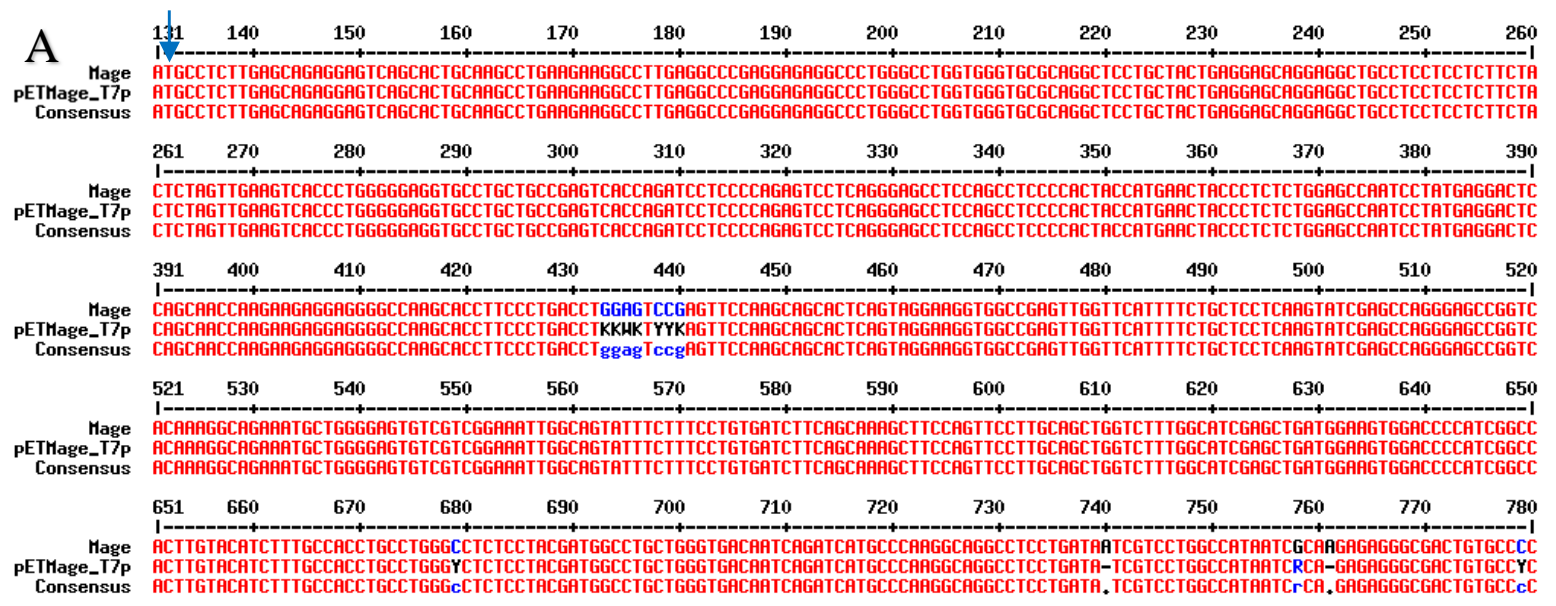

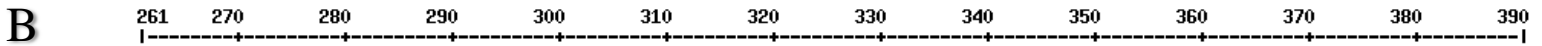

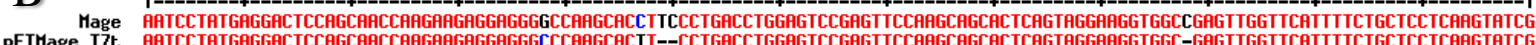
pETMage_t7t
Consensus

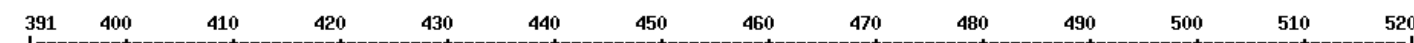

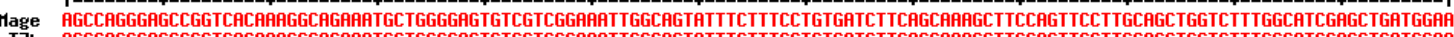
PE
Consensus

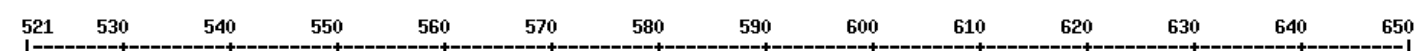

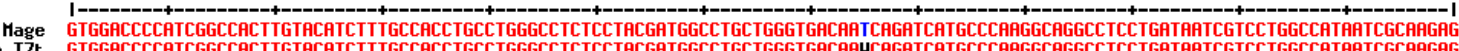

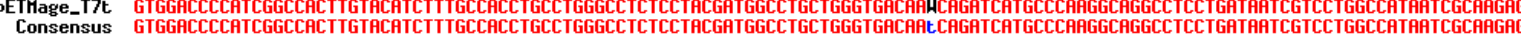

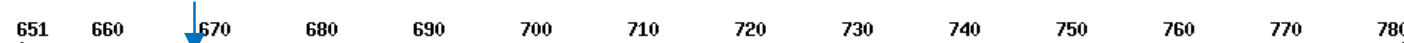

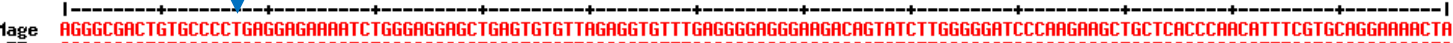

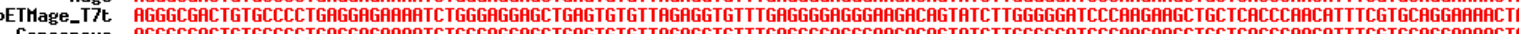

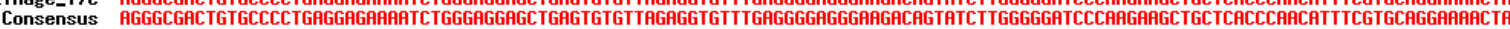

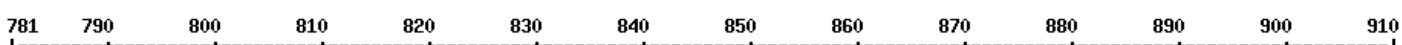

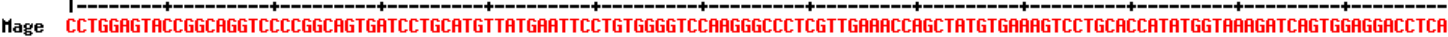
PETMage_t7t CCTGGAGTACCGGCAGGTCCCCGGCAGTGATCCTGCATGTTATGAPTTCCTGTGGGGTCCAAGGGCCCTCGTTGAPACCAGCTATGTGAPAGTCCTGCACCATATGGTAPAGATCAGTGGAGGACCTCAC

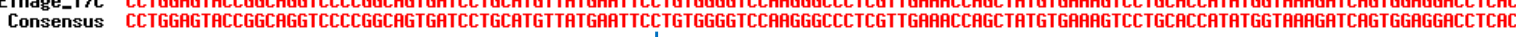

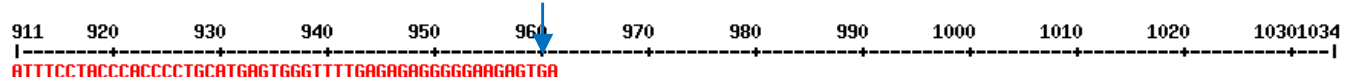

Mage ATTTCCTACCCACCCCTGCATGAGGGGGTTTTGAGGGGGGGGGAAGAGTGA

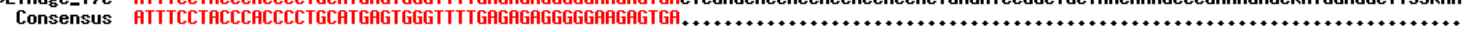

Figura 48: Sequenciamento do clone pETMAGE. Alinhamento da sequência MAGE com o clone pETMAGE sequenciado com os oligonucleotídeos T7p (A) e T7t (B); em destaque (setas), o códon de iniciação da tradução da proteína MAGE, o início da sequência que não é encontrada no sequenciamento anterior e o códon de terminação da tradução.

O sequenciamento com os dois oligonucleotídeos confirmou a clonagem e demonstrou a sequência correta do pETMAGE. 


\subsubsection{Clonagem do gene GLEA no vetor pET}

O fragmento GLEA foi clonado no plasmídio pET por meio de uma reação de ligação, cujo produto foi posteriormente transformado em células E. coli Top10. A seleção do plasmídio recombinante pETGLEA foi feita pela PCR de 8 grupos contendo 5 colônias cada. A reação foi realizada com os oligonucleotídeos T7p e GLEA_2Rseq (Figura 49).
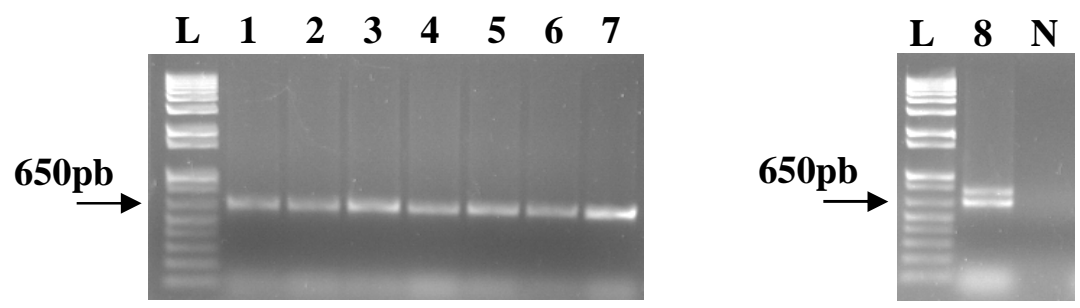

Figura 49: PCR de colônia da ligação pET + GLEA. PCR de 8 grupos de colônias da ligação pET + GLEA com os oligonucleotídeos T7p e GLEA_2Rseq. L-marcador 1Kb Plus, 1 ao 8-PCR dos 8 grupos e N-negativo.

Todos os grupos apresentaram uma banda de amplificação de aproximadamente $650 \mathrm{pb}$ (tamanho esperado de 660pb). A partir do resultado acima, foram realizadas a extração e clivagem dos cinco plasmídios do grupo 7 com as enzimas NheI e XhoI (Figura 50).

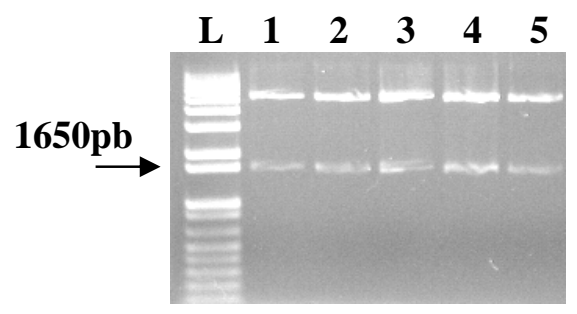

Figura 50: Clivagem dos plasmídios pETGLEA. Clivagem dos 5 plasmídios pETGLEA com as enzimas NheI e XhoI. L-marcador $1 \mathrm{~Kb}$ Plus e 1 ao 5-Clivagem dos clones pVAXGLEA_1 a 5.

Todos os clones pETGLEA apresentaram fragmento de aproximadamente 1650pb quando clivados com as enzimas NheI e XhoI (tamanho esperado de 1642pb), indicando a presença do inserto GLEA no interior do pET.

A partir dos resultados obtidos com a PCR e clivagem, o plasmídio recombinante pETGLEA_3 foi analisado por sequenciamento utilizando-se os oligonucleotídeos T7p, Glea_1Sseq e T7t para confirmação da clonagem (Figura 51). 


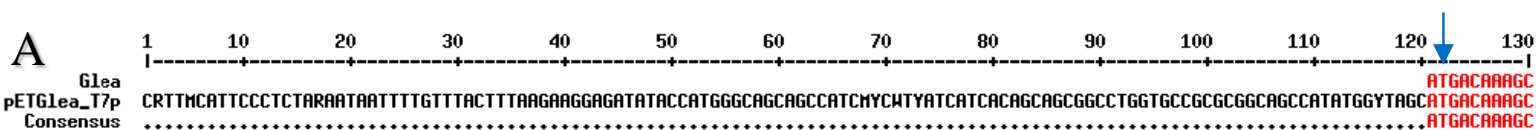

$\begin{array}{llllllllllll}131 & 140 & 150 & 160 & 170 & 180 & 190 & 200 & 210 & 220 & 230 & 240 \\ 250 & 260\end{array}$

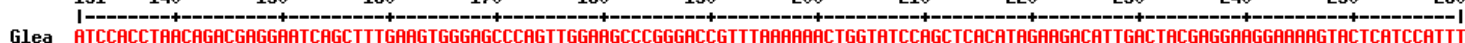

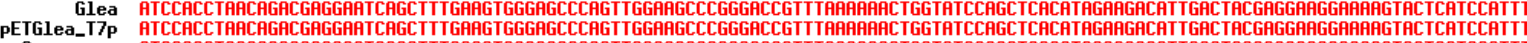

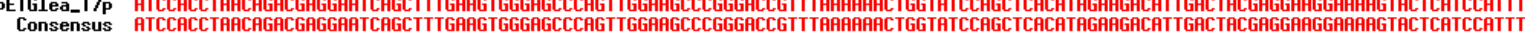

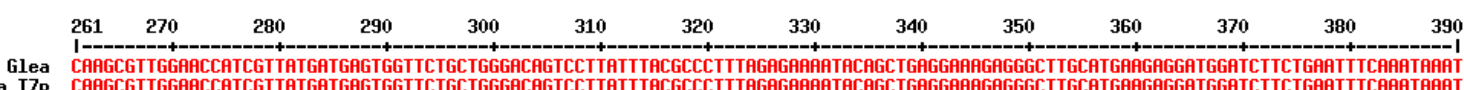

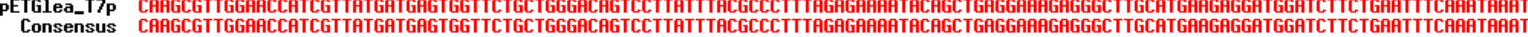

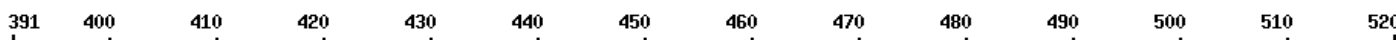

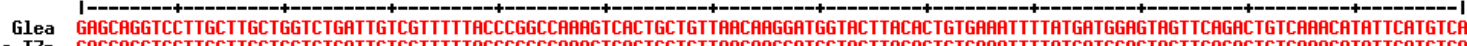
PETGlea_T7p GAGCAGGiCC

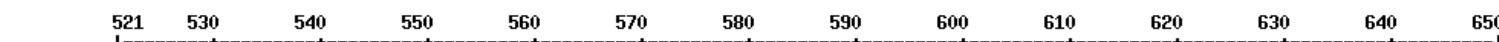

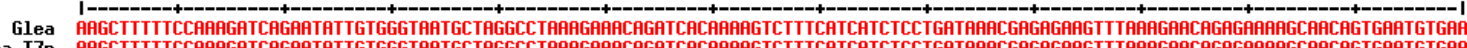

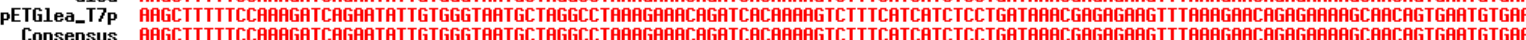

B

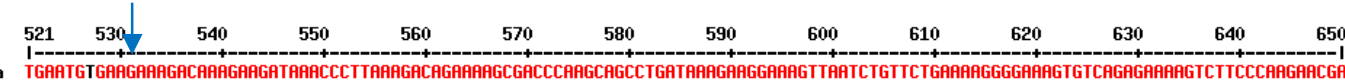

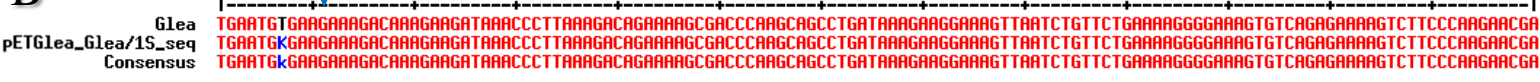

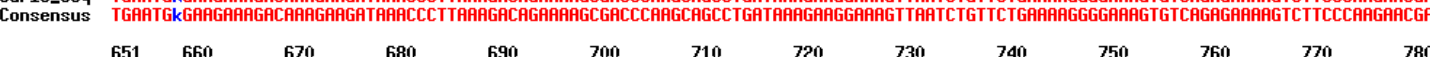

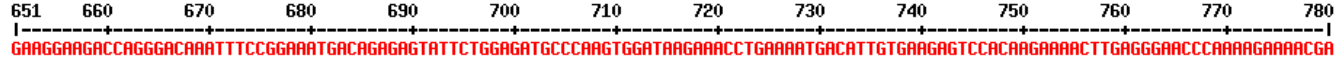

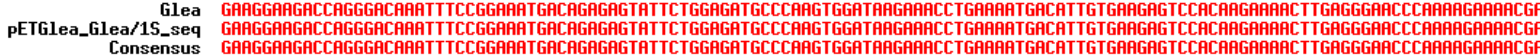

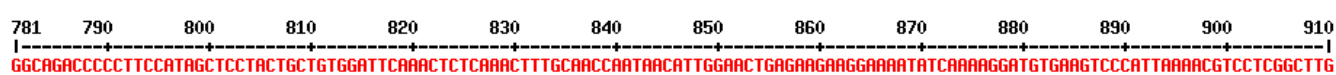

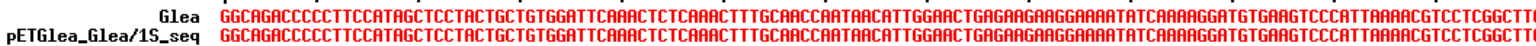

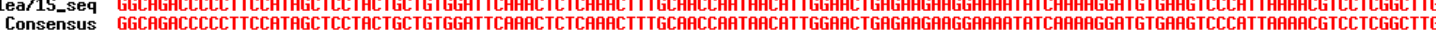

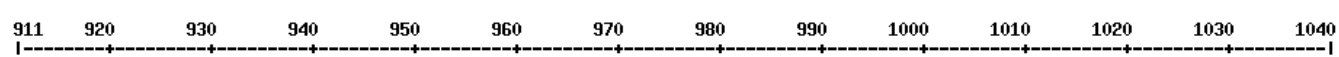

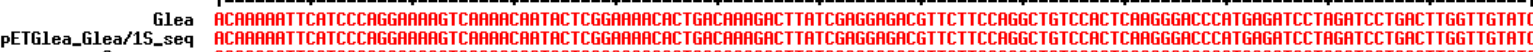

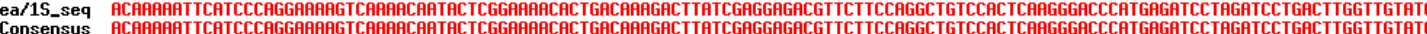

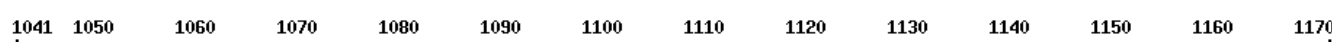

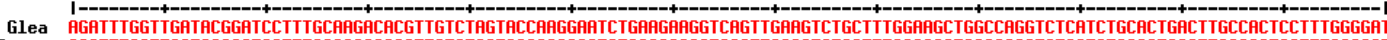

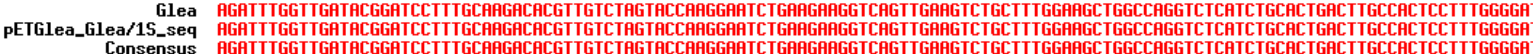

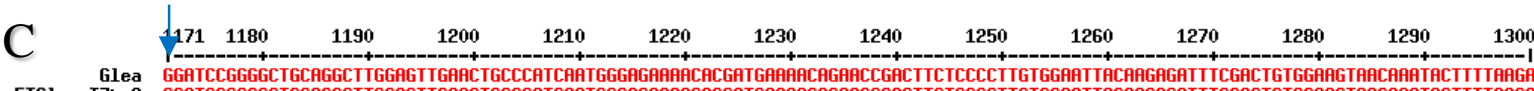

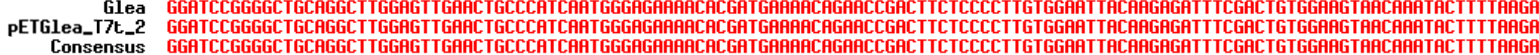

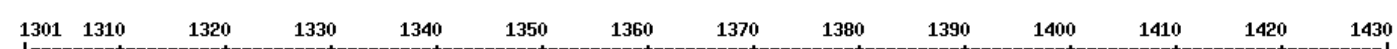

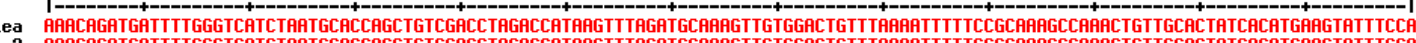

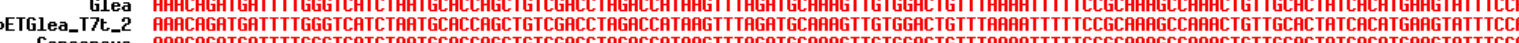

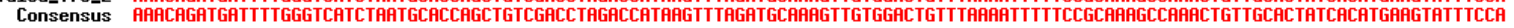

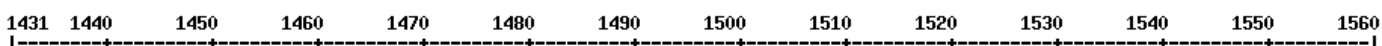

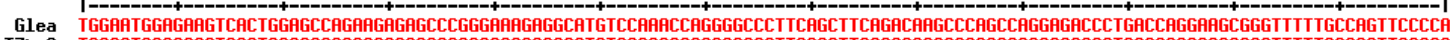

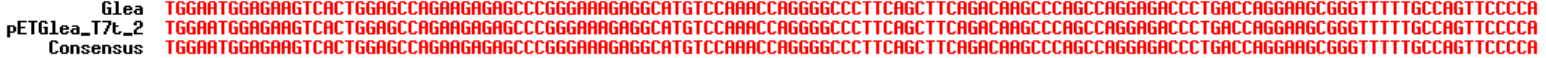

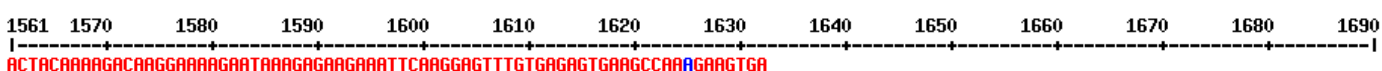

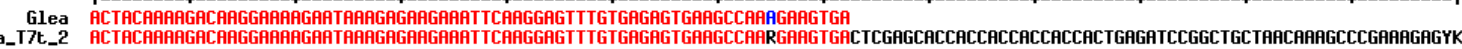

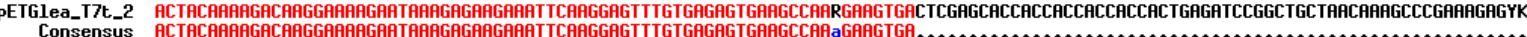

Figura 51: Sequenciamento do clone pETGLEA_3. Alinhamento da sequência GLEA com o clone pETGLEA_3 sequenciado com o primer T7p (A), Glea1Sseq (B) e T7t (C); em destaque (setas), o códon de iniciação da tradução da proteína GLEA, o início da sequência que não é encontrada no sequenciamento anterior e o códon de terminação da tradução.

O sequenciamento com os três oligonucleotídeos confirmou a clonagem e, juntamente com a análise do eletroferograma, demonstrou a sequência correta do pETGLEA_3. 


\subsubsection{Clonagem do gene hsp70 no vetor pET}

O fragmento hsp70 foi clonado no plasmídeo pET por meio de uma reação de ligação, cujo produto foi posteriormente transformado em células E. coli Top10. A seleção do plasmídio recombinante pEThsp70 foi feita inicialmente pela PCR de 8 grupos contendo 5 colônias cada (nomeados de 9 a 16). A reação foi realizada com os oligonucleotídeos T7p e Hsp70_2Rseq (Figura 52).
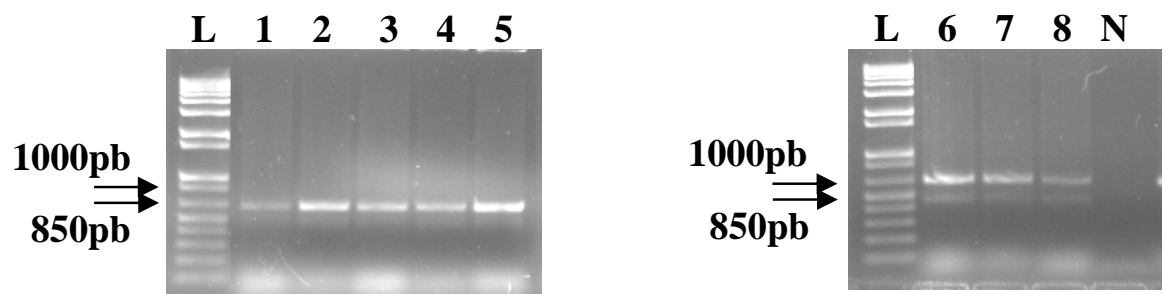

Figura 52: PCR de colônia da ligação pET + hsp70. PCR de 8 grupos de colônias da ligação pET + hsp70 com os oligonucleotídeos T7p e hsp70_Rseq. L-marcador 1Kb Plus, 1 ao 8-PCR dos 8 grupos (nomeados de 9 a 16) e N-negativo.

Todos os grupos apresentaram banda de amplificação de aproximadamente $650 \mathrm{pb}$ (tamanho esperado de 656pb) indicando a presença do fragmento hsp70. A partir do resultado acima, foram realizadas a extração e clivagem com as enzimas NheI e XhoI dos cinco plasmídios do grupo 13 (nomeados de 6 a 10). A digestão foi analisada em gel de agarose $1 \%$ (Figura 53):
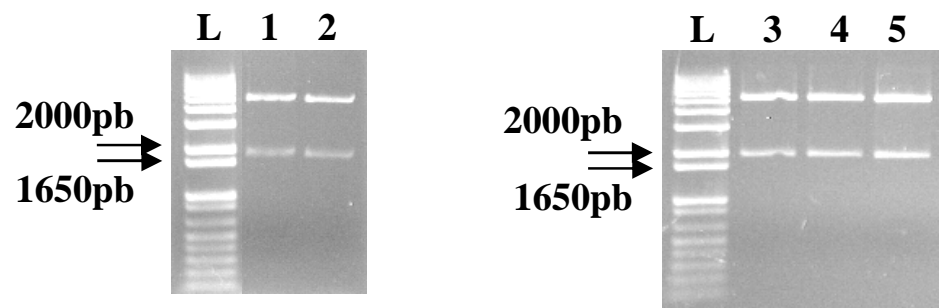

Figura 53: Clivagem dos plasmídios pEThsp70. Clivagem dos clones pEThsp70 com as enzimas NheI e XhoI. L-marcador $1 \mathrm{~Kb}$ Plus e 1 ao 5-clones pEThsp70_6 a 10 digeridos.

Todos os clones pEThsp70 apresentaram fragmento entre 1650-2000 após a clivagem (tamanho esperado de $1937 \mathrm{pb}$ ) indicando a presença do fragmento hsp70 no interior do pET.

A partir dos resultados obtidos com a PCR e análise de restrição, o plasmídio recombinante pEThsp70_9 foi analisado por sequenciamento utilizando-se os oligonucleotídeos T7p, Hsp70_1Sseq e T7t para confirmação da clonagem (Figura 54). 


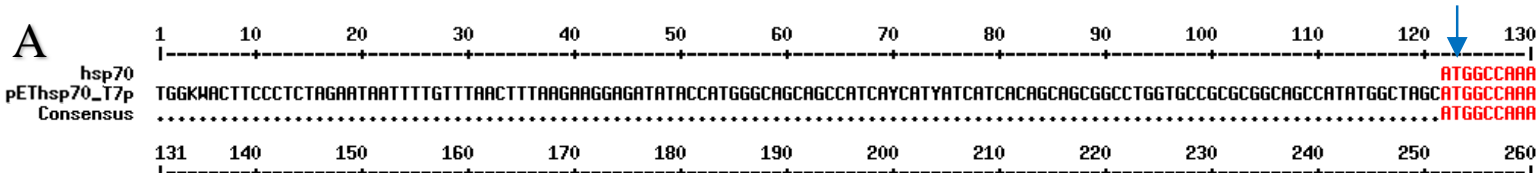

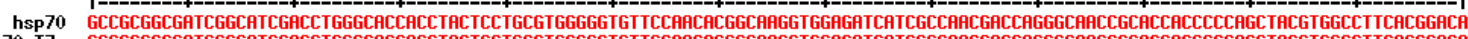

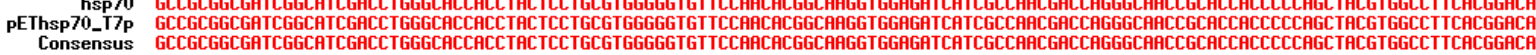

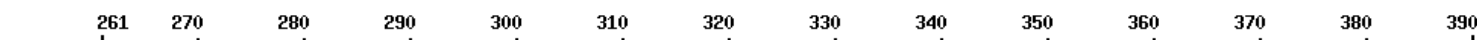

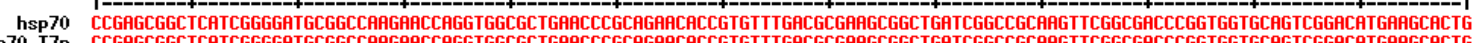

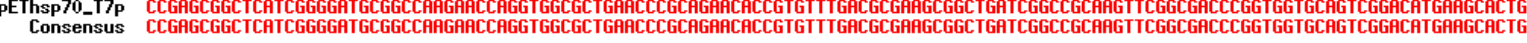

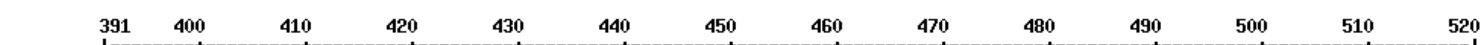

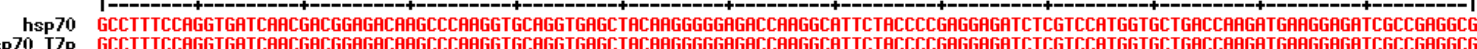

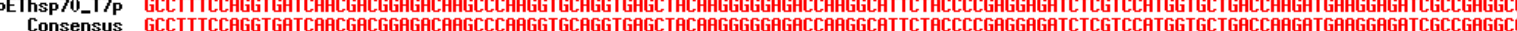

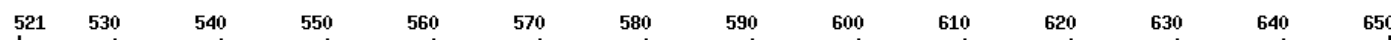

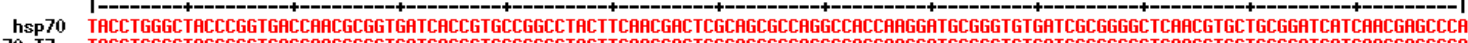
pEThsp70_t7p TACCTGGGCTACCCGGTGACCAACGCGGTGATCACCGTGCCGGCCTACTTCAACGACTCGCAGCGCCAGGCCACCAAGGATGCGGGTGTGATCGCGGGGCTCAACGTGCTGCGGATCATCAACGAGCCCA
Consensus

B

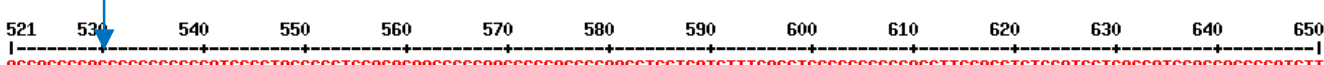

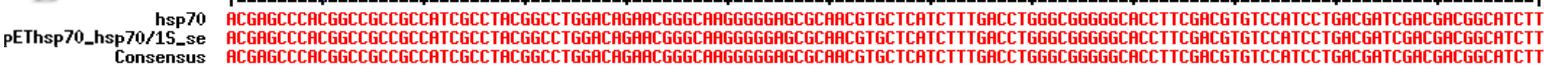

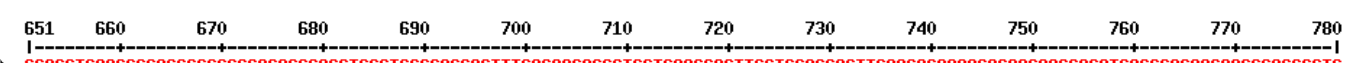

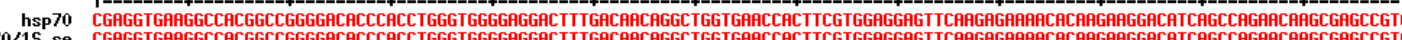
pEThsp70_hsp70/15_se
Consensus

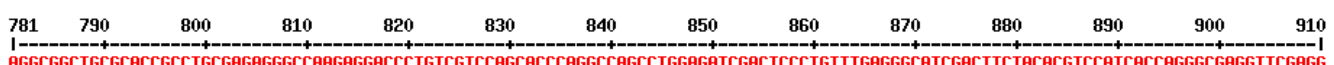

hsp70 AgGCGGCTGCGCACCGCCTGCGAGHGGGCCHAGAGGACCCTGTCGTCCAGCACCCAGGCCAGCCTGGAGATCGACTCCCTGTTTGAGGGCATCGACTTCTACACGTCCATCACCAGGGCGAGGTTCGAG pEThsp70_hsp70/15_se
Consensus

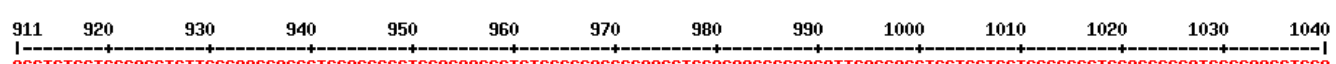

hsp70 AGCTGTGCTCCGACCTGTTCCGAAGCACCCTGGAGCCCGTGGAGAAGGCTCTGCGCGACGCCARGCTGGACAAGGCCCAGATTCACGACCTGGTCCTGGTCGGGGGCTCCACCCGCATCCCCAAGGTGCA PEThsp70_hsp70/15_se AGCTGTGCTCCGACCTGTTCCGAAGCACCCTGGAGCCCGTGGAGAAGGCTCTGCGCGACGCCAAGCTGGACAAGGCCCAGATTCACGACCTGGGTCCTGGTCGGGGGCTCCACCCGCATCCCCAAGGTGCA
Consensus

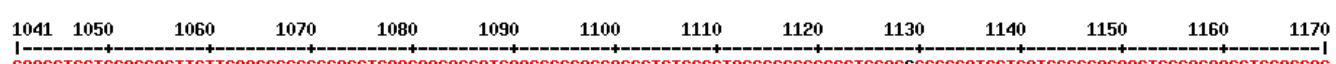

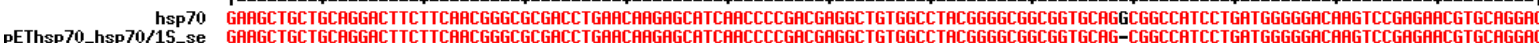
70/15_se GAAGCTGCTGCAGGACTTCTTCAACGGGCGCGACCTGAACAAGAGCATCAACCCCGACGAGGCTGTGGCCTACGGGGCGGCGGTGCAG-CGGCCATCCTGATGGGGGACAAGTCCGAGAACGTGCAGGAC
Consensus

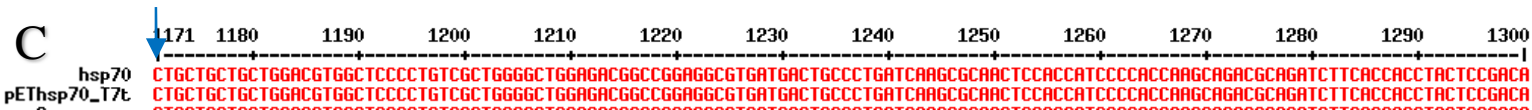

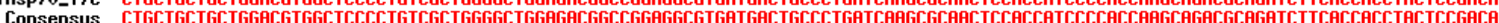

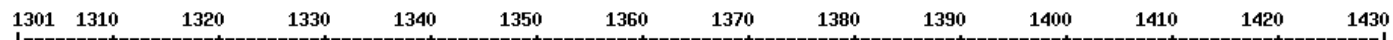

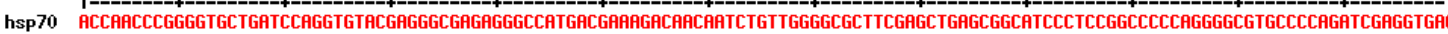

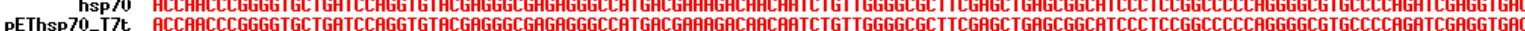

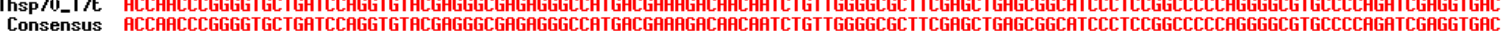

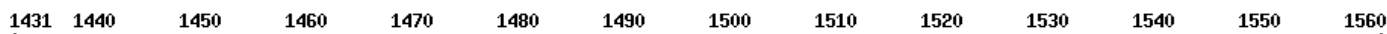

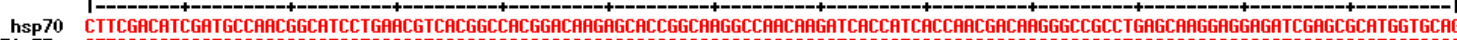
pEThsp70_t7t CTTCGACATCGATGCCABCGGCATCCTGABCGTCACGGCCACGGACPAG

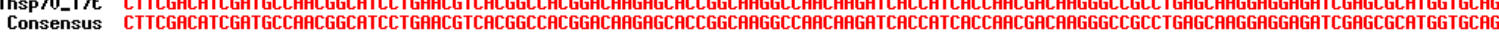

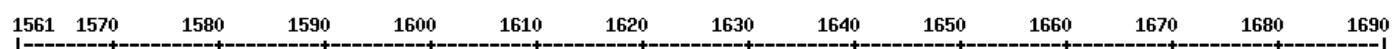

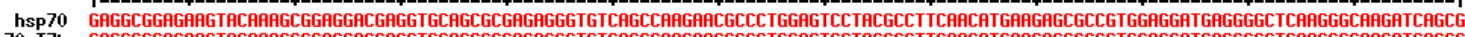
pEThsp70_T7t GAGGCGGAGAAGTACAAAGCGGAGGACGAGGTGCAGCGCGAGAGGGTGTCAGCCAAGAACGCCCTGGAGTCCTACGCCTTCAACATGAAGAGCGCCGTGGAGGATGAGGGGCTCAAGGGCAAGATCAGCG
Consensus

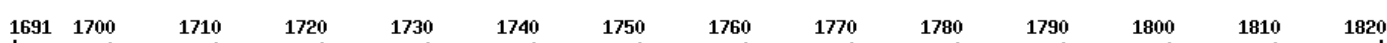

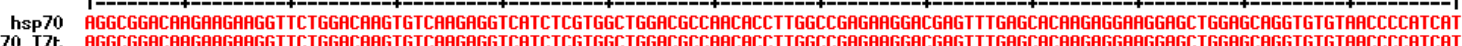

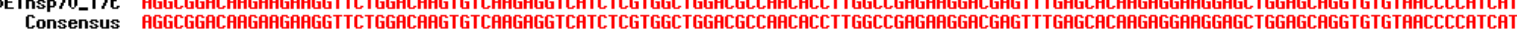

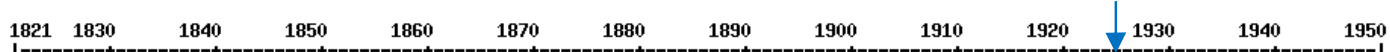

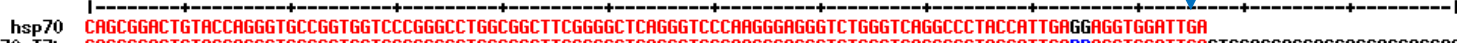
PEThsp70_T7t CAGCGGACTGTCCCAGGGGCCGG

Figura 54: Sequenciamento do clone pEThsp70_9. Alinhamento da sequência hsp70 com o clone pEThsp70_9 sequenciado com os oligonucleotídeos T7p (A), Hsp70_1Sseq (B) e T7t (C); em destaque (setas), o códon de iniciação da tradução da proteína hsp70, o início da sequência que não é encontrada no sequenciamento anterior e o códon de terminação da tradução. 
O sequenciamento confirmou a clonagem e, juntamente com a análise do eletroferograma, demonstrou a sequência correta do pEThsp70.

\subsubsection{Clonagem do gene gp96 no vetor pcDNA3.3}

\subsubsection{Amplificação do gene gp96}

O gene gp96 foi amplificado utilizando-se os iniciadores T7p e gp96pET28a e o molde pETgp96 (Anexo 5). A amplificação foi analisada em gel de agarose 1\% (Figura 55):

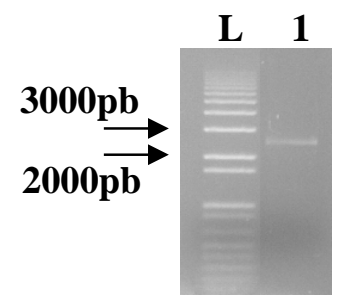

Figura 55: Amplificação do gene gp96 para a clonagem no pcDNA. L-marcador 1 Kb Plus e 1-gp96.

O gene foi amplificado de forma correta como demonstrado pela banda de tamanho $2517 \mathrm{pb}$. O fragmento foi clonado diretamente no vetor pcDNA e transformados em células $E$. coli Top10.

\subsubsection{Clonagem do gene gp96 no vetor pcDNA}

A seleção do plasmídio recombinante pcDNAgp96 foi feita inicialmente pela PCR de 10 colônias realizada com os oligonucleotídeos T7p e gp96pET_R (Figura 56).
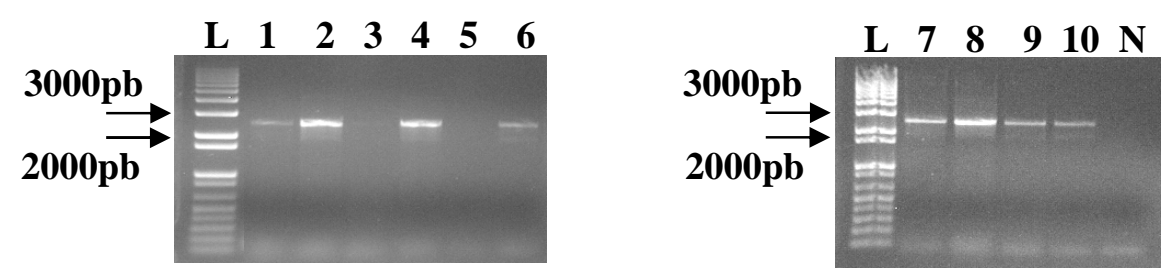

Figura 56: PCR de colônia da ligação pcDNA + gp96. PCR de 10 colônias da ligação pcDNA + gp96 com os oligonucleotídeos T7p e gp96pET_R. L-marcador 1Kb Plus, 1 ao 10-PCR das 10 colônias e N-negativo.

As colônias 1, 2, 4, 6, 7, 8, 9 e 10 apresentaram fragmento entre 2000-3000pb (tamanho esperado de 2393pb) indicando a presença do fragmento gp96. Os plasmídios das colônias 2, 4, 7, 8, 9 e 10 foram extraídos e submetidos a uma nova PCR com os oligonucleotídeos CMV e gp96pET_R (Figura 57) que indicam a presença e direção do fragmento no interior do vetor. 

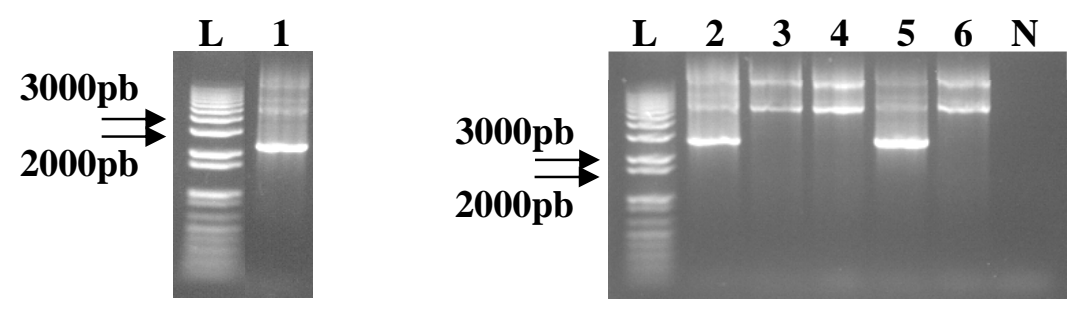

Figura 57: PCR de colônia dos plasmídios pcDNAgp96. PCR dos 6 plasmídios extraídos com os oligonucleotídeos CMV e gp96pET_R. L-marcador 1Kb Plus, 1 ao 6-PCR dos plasmídios 2, 4, 7, 8, 9 e 10 e Nnegativo.

Os plasmídios 2, 4 e 9 apresentaram fragmento entre 2000-3000pb (tamanho esperado de $2677 \mathrm{pb}$ ) indicando a presença e direção correta do fragmento gp96. A partir dos resultados obtidos com as PCRs, o plasmídio recombinante pcDNAgp96_9 foi analisado por sequenciamento utilizando-se os oligonucleotídeos CMV, gp96_1Sseq, gp96_3Sseq e TK para confirmação da clonagem (Figura 58).

A

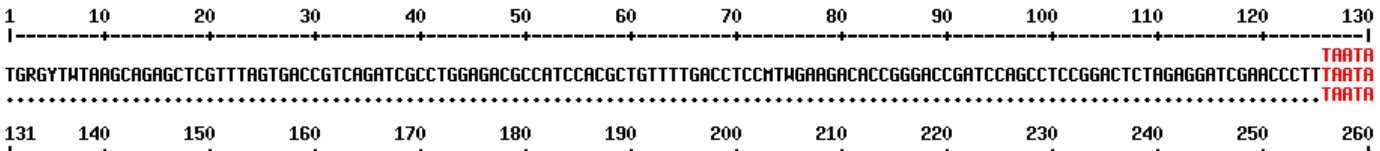

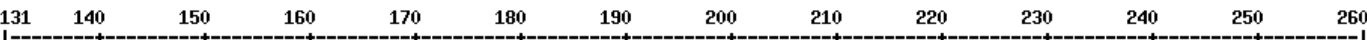

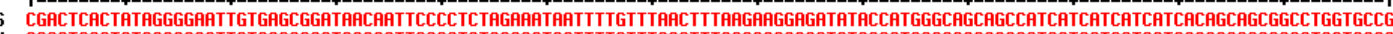

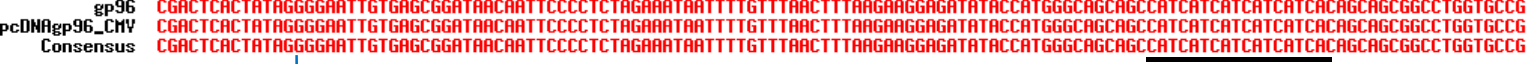

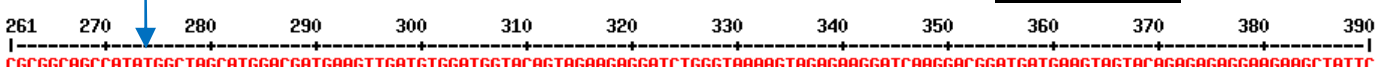

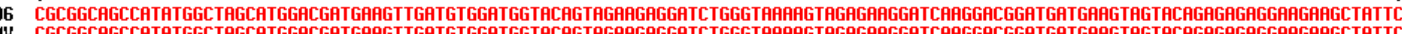

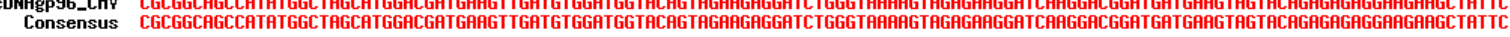

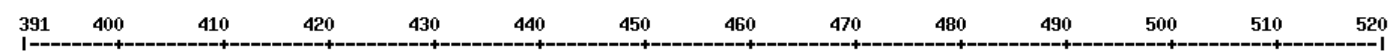

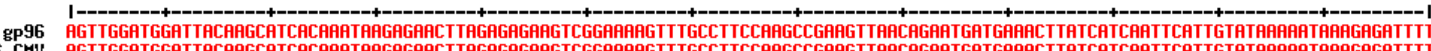

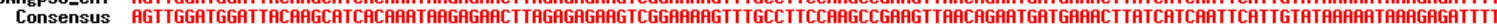

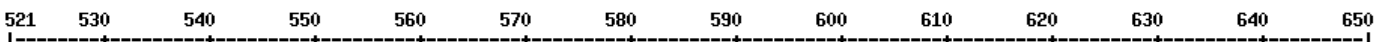

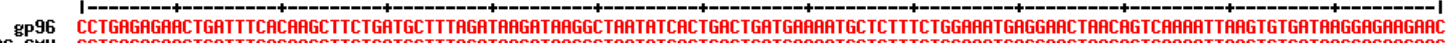

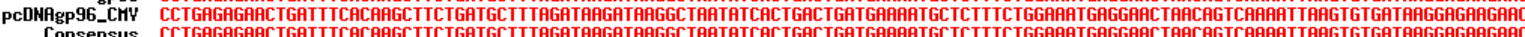
Consensus CCTGGGARC

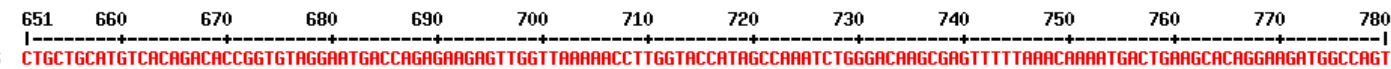

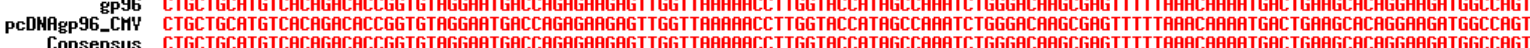

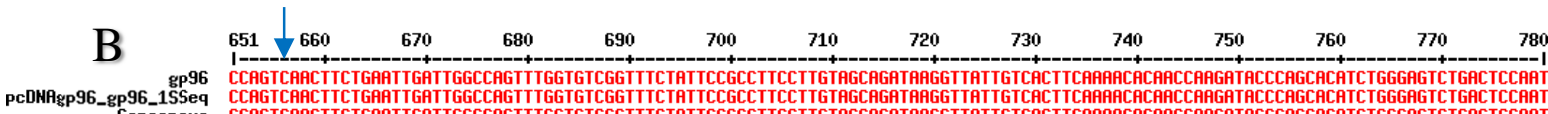

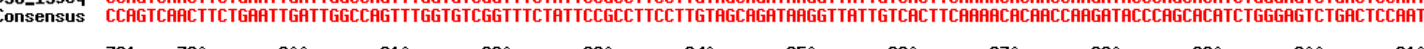

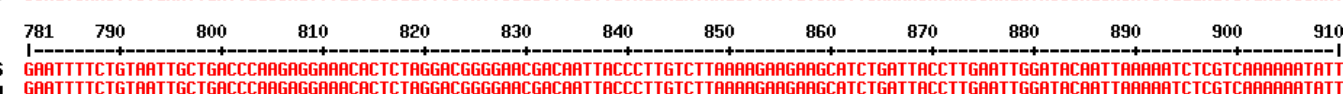

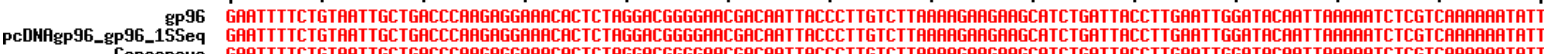

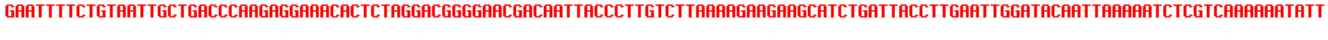

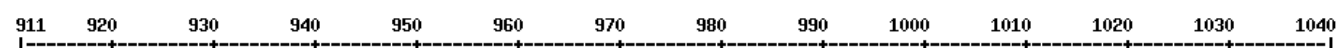

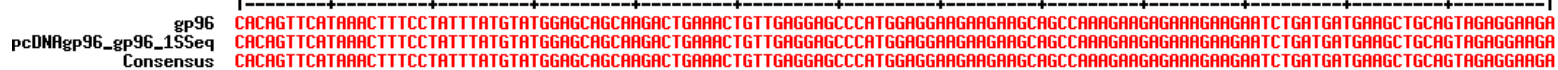

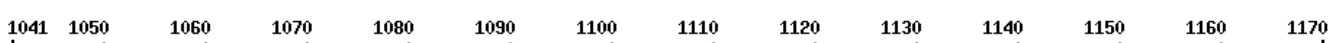

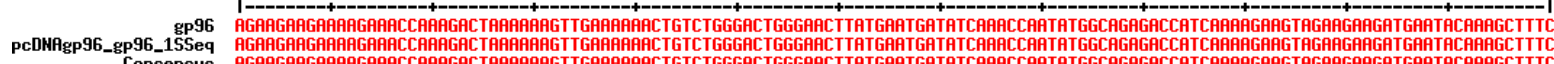

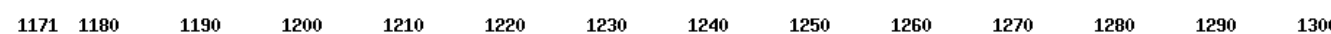

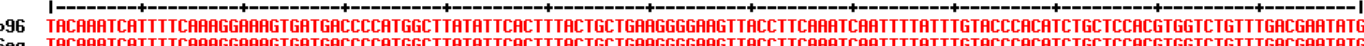

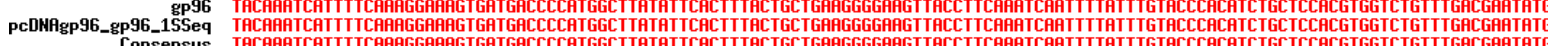

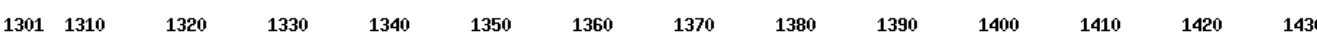

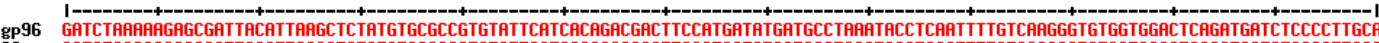

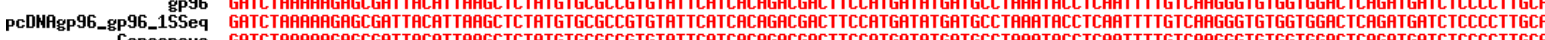




\begin{tabular}{|c|c|c|c|c|c|c|c|c|c|c|c|c|c|c|}
\hline & 1301 & 1310 & 1320 & 1330 & 1340 & 1350 & 1360 & 1370 & 1380 & 1390 & 1400 & 1410 & 1420 & 1430 \\
\hline $\begin{array}{r}\text { gp96 } \\
\text { PcDNAgp96_gp96_35Seq } \\
\text { Consensus }\end{array}$ & \multicolumn{14}{|c|}{ 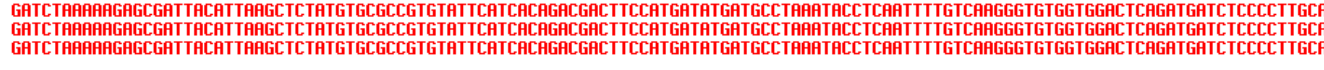 } \\
\hline & 1431 & 1440 & 1450 & 1460 & 1470 & 1480 & 1490 & 1500 & 1510 & 1520 & 1530 & 1540 & 1550 & 1560 \\
\hline $\begin{array}{r}\text { gp96 } \\
\text { PcDNAgp96_gp96_35Seq } \\
\text { Consensus }\end{array}$ & \multicolumn{14}{|c|}{ 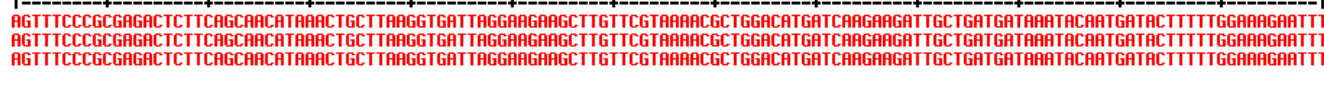 } \\
\hline & 1561 & 1570 & 1580 & 1590 & 1600 & 1610 & 1620 & 1630 & 1640 & 1650 & 1660 & 1670 & 1680 & 1690 \\
\hline $\begin{array}{r}\text { gp96 } \\
\text { PcDNAgp96_gp96_35Seq } \\
\text { Consensus }\end{array}$ & \multicolumn{14}{|c|}{ 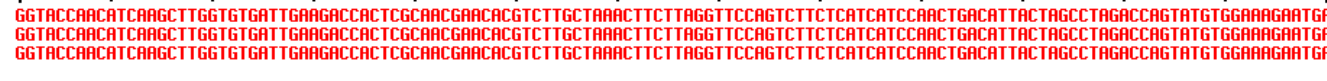 } \\
\hline & 1691 & 1700 & 1710 & 1720 & 1730 & 1740 & 1750 & 1760 & 1770 & 1780 & 1790 & 1800 & 1810 & 1820 \\
\hline $\begin{array}{r}\text { gp96 } \\
\text { pcDNAgp96_gp96_35Seq } \\
\text { Consensus }\end{array}$ & \multicolumn{14}{|c|}{ 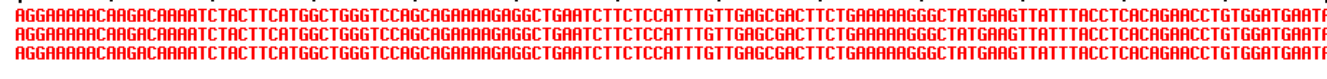 } \\
\hline & 1821 & 1830 & 1840 & 1850 & 1860 & 1870 & 1880 & 1890 & 1900 & 1910 & 1920 & 1930 & 1940 & 1950 \\
\hline $\begin{array}{r}\text { gp96 } \\
\text { pcDNAgp96_gp96_35Seq } \\
\text { Consensus }\end{array}$ & & & & & & & & & & & & & & $\begin{array}{l}\text { CTCTG } \\
\text { CTCTG } \\
\text { CTCTG }\end{array}$ \\
\hline
\end{tabular}

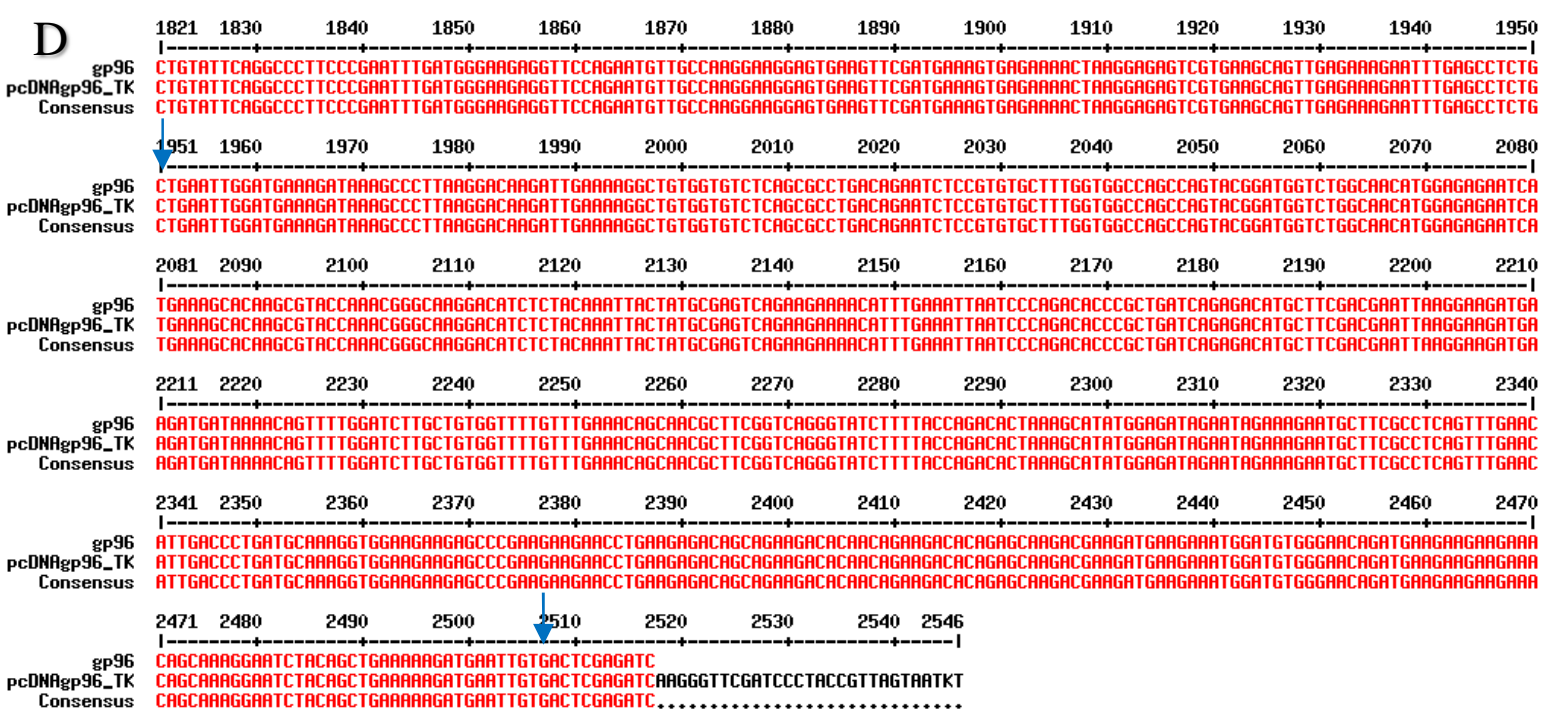

Figura 58: Sequenciamento do clone pcDNAgp96_9. Alinhamento da sequência gp96 com o clone pcDNAgp96_9 sequenciado com os oligonucleotídeos CMV (A), gp96_1Sseq (B), gp96_3Sseq (C) e TK (D); em destaque, a cauda de histidina (sublinhado), o códon de iniciação da tradução da proteína gp96 (seta), o início da sequência que não é encontrada no sequenciamento anterior (seta) e o códon de terminação da tradução (seta).

O sequenciamento confirmou a clonagem e demonstrou a sequência correta do pcDNAgp96_9.

\subsection{Expressão e purificação das proteínas recombinantes}

\subsubsection{Expressão e purificacão das proteínas EGFRvIII, cERBB2, MAGE, GLEA e}

\section{Hsp70 produzidas em $E$. coli}

\subsubsection{Expressão e purificação das proteínas EGFRvIII e cERBB2}

A expressão, o teste de solubilidade e a purificação das proteínas recombinantes EGFRvIII e cERBB2 foram analisados em SDS-PAGE a 10\% (Figura 59): 

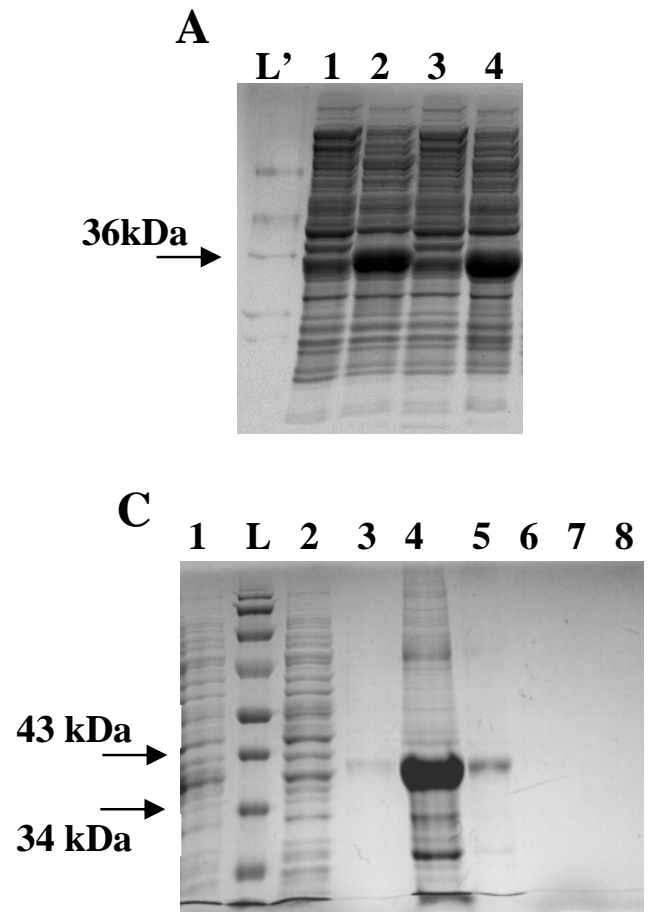

B

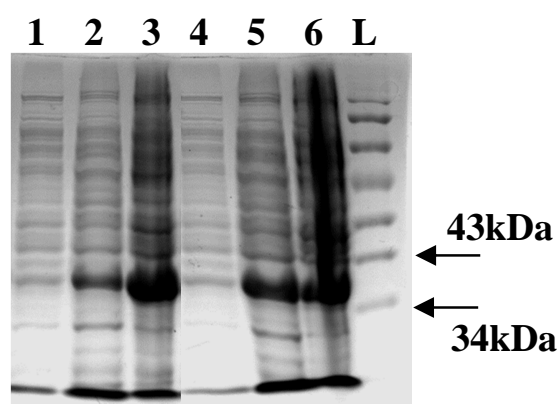

D
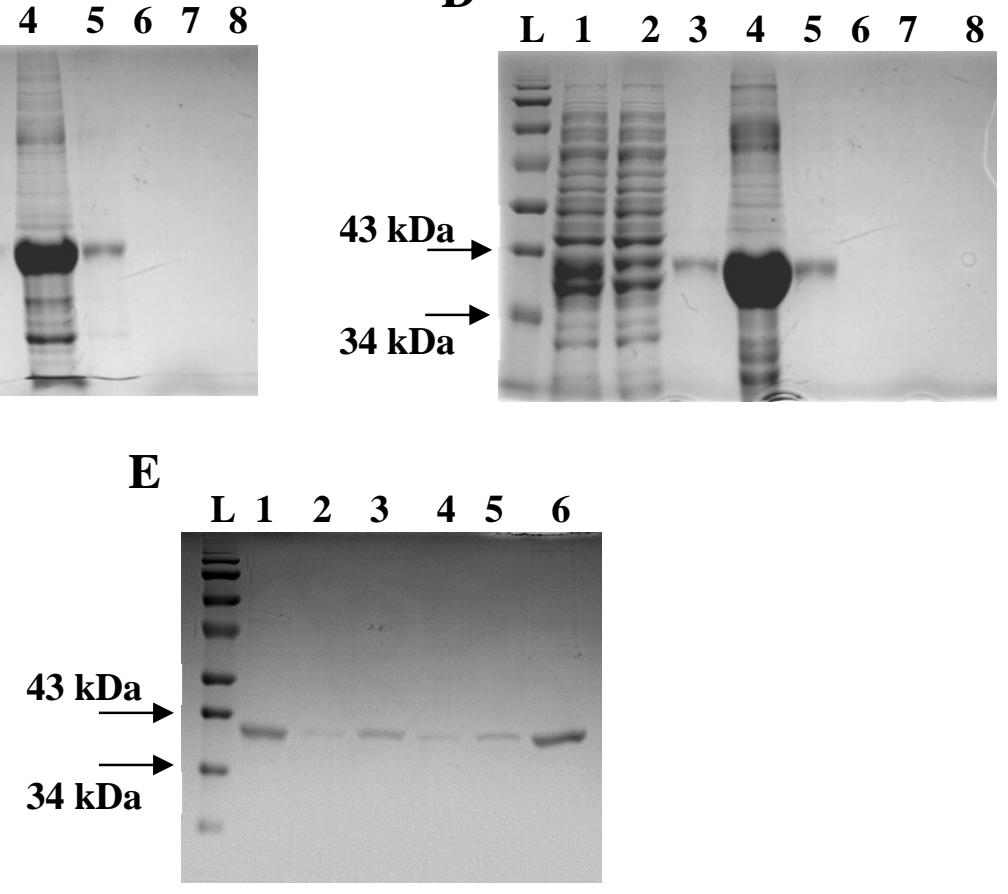

Figura 59: Expressão, teste de solubilidade e purificação das proteínas recombinantes EGFRvIII e CERBB2. L e L'-marcadores de peso molecular [PageRuler Prestained Protein Ladder - Fermentas e Molecular Weight Marker (M.W. 14,000-66,000) - Sigma, respectivamente]. A) Expressão das proteínas EGFRvIII (1 e 2) e cERBB2 (3 e 4), 1 e 3-não induzido (sem adição de IPTG); 2 e 4-16 horas após indução com IPTG. B) Teste de solubilidade das proteínas EGFRvIII (1, 2 e 3) e cERBB2 (4, 5 e 6), 1 e 4-sobrenadante 1 (sem adição de ureia); 2 e 5-sobrenadante 2 (com adição de ureia); 3 e 6-sedimento celular (precipitado). C e D) Purificação das proteínas EGFRvIII e cERBB2 respectivamente, 1-sobrenadante 2; 2-fração não ligada (eluato); 3-lavagem (com 50mM de imidazol); 4-eluição 1; 5-eluição 2; 6-eluição 3; 7-eluição 4; 8-eluição 5 (todas eluições com 500mM de imidazol). E) Frações das proteínas EGFRvIII (1, 2 e 3) e cERBB2 (4, 5 e 6) após diálise e concentração.

Ambas as proteínas EGFRvIII e cERBB2 foram expressas após aproximadamente 16 horas de indução com IPTG, como é visto na figura A, pela presença das bandas de expressão próximas a 36kDa, condizente com o peso das proteínas EGFRvIII, 35,7kDa (324 aas) e cERBB2, 35,5kDa (323 aas). Após a expressão, foi realizado o teste de solubilidade, o precipitado celular foi ressuspendido em tampão de sonicação sem agente desnaturante (ureia), sonicado e separado em sedimento e sobrenadante (1). O sedimento foi novamente 
ressuspendido e separado em precipitado e sobrenadante (2), no entanto, nessa fase já com tampão contendo ureia. $\mathrm{O}$ teste de solubilidade foi realizado para verificar se a proteína era expressa na forma solúvel ou em corpos de inclusão. Como demonstrado na figura $\mathrm{B}$, ambas as proteínas solubilizaram um pouco na presença de ureia (sobrenadante 2), mas a maior parte delas permaneceu insolúvel no sedimento celular.

As proteínas foram, então, purificadas por cromatografia de afinidade, sob condições desnaturantes, sendo eluídas com 500mM de imidazol nas frações 1 e 2 (Figura 59C e D). Uma maior quantidade de proteína foi obtida na fração 1 , juntamente com um grande rastro de outras bandas que pode ser degradação da própria proteína ou proteínas contaminantes. As frações 1 e 2 de cada proteína foram dialisadas para retirada do imidazol e ureia. Como as proteínas precipitaram após diálise, as frações foram centrifugadas para separação do precipitado e sobrenadante. As proteínas presentes no sobrenadante foram concentradas (Figura 59E) para serem utilizadas na imunização de camundongos e produção de anticorpos, e nos ensaios de imunogenicidade.

\subsubsection{Expressão e purificação da proteína MAGE}

A expressão, o teste de solubilidade e a purificação da proteína recombinante MAGE foram analisados em SDS-PAGE a 10\% (Figura 60): 

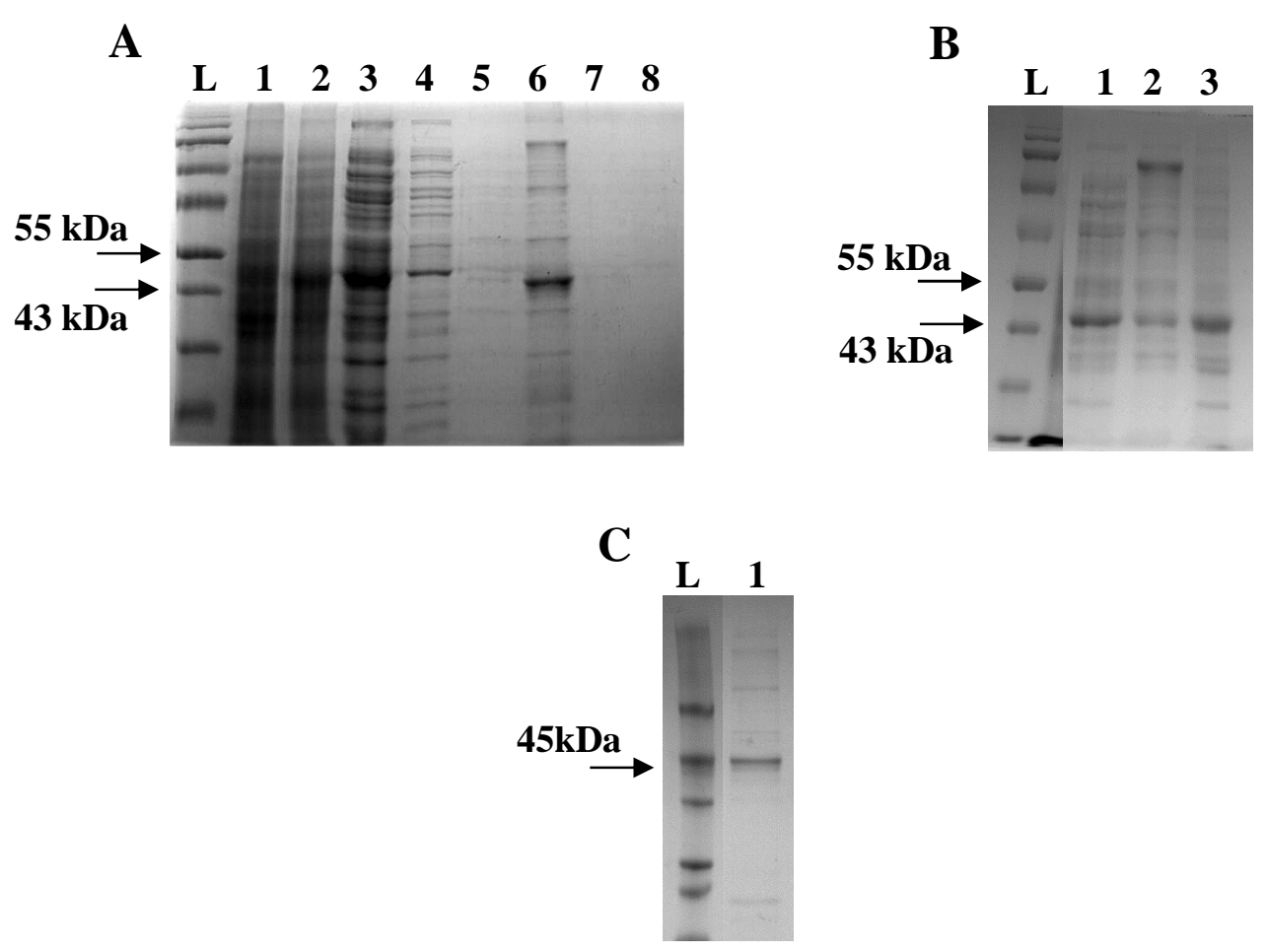

Figura 60: Expressão, teste de solubilidade e purificação da proteína recombinante MAGE. L-marcador. A) Expressão, teste de solubilidade e purificação da proteína MAGE, 1-não induzido; 2-4 horas após indução com IPTG; 3-sobrenadante 1 (sem ureia); 4- eluato/lavagem (com 50mM de imidazol) (coletados juntos); 5eluição 1; 6-eluição 2; 7-eluição 3; 8-eluição 4 (todas eluições com 500mM de imidazol). B) Teste de solubilidade, 1-sobrenadante 1; 2-sobrenadante 2 (com ureia); 3-sedimento celular. C) Fração da proteína MAGE após diálise e concentração.

A proteína MAGE foi expressa após 4 horas de indução com IPTG, como é visto na figura A, pela presença da banda de expressão entre 55 e 43kDa. A proteína expressa apresenta um tamanho maior que o predito de $37,2 \mathrm{kDa}$ (337 aas). Após a expressão, foi realizado o teste de solubilidade (Figuras 60A e B), com tampão de sonicação sem ureia e em condições desnaturantes para verificar a solubilidade da proteína. Como demonstrado na figura $\mathrm{B}$, a proteína MAGE estava presente em maior quantidade no sobrenadante $1 \mathrm{e}$ precipitado.

A proteína foi, então, purificada a partir do sobrenadante 1 por cromatografia de afinidade, sendo eluída com 500mM de imidazol principalmente na fração 2 (Figura 60A). Junto com a proteína MAGE apareceram outras bandas que podem ser contaminantes e um pouco de proteína degradada. Essa fração foi dialisada para retirada do imidazol e posteriormente concentrada (Figura 60C) para ser utilizada na imunização de camundongos e produção de anticorpos, e nos ensaios de imunogenicidade. 


\subsubsection{Expressão e purificação da proteína GLEA}

A expressão, o teste de solubilidade e a purificação da proteína recombinante GLEA foram analisados em SDS-PAGE a 10\% (Figura 61):

A
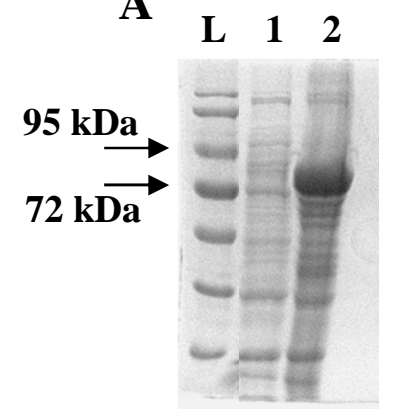

$\begin{array}{llll}\text { B } & \text { L } & 1 & \mathbf{2}\end{array}$

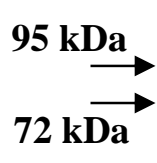

D
$\begin{array}{lllll}L & 1 & 2 & 3 & 4\end{array}$

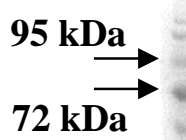

$\mathbf{E}$

L $\quad 1$

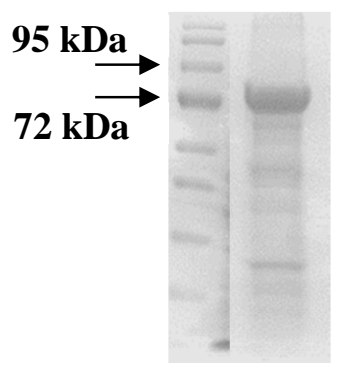

Figura 61: Expressão, teste de solubilidade e purificação da proteína recombinante GLEA. L-marcador. A) Expressão da proteína GLEA, 1-não induzido; 2-4 horas após indução com IPTG. B) Teste de solubilidade, 1-precipitado; 2-sobrenadante 1 (sem ureia). C) Teste de solubilidade, 1-precipitado; 2-sobrenadante 2 (com ureia). D) Purificação da proteína GLEA, 1-eluato; 2-lavagem (com 50mM de imidazol); 3-eluição 1; 4-eluição 2 (todas eluições com 500mM de imidazol). E) Proteína GLEA após diálise.

A proteína GLEA foi expressa após 4 horas de indução com IPTG, como é visto na figura 61A, pela presença da banda de expressão entre 72 e $95 \mathrm{kDa}$, tamanho próximo ao da proteína de $64,4 \mathrm{kDa}$ (566aas). Após a expressão, foi realizado o teste de solubilidade com tampão de sonicação sem ureia (Figura 61B) e em condições desnaturantes (Figura 61C) para verificar a solubilidade da proteína. Como demonstrado nas figuras 61B e C, a proteína GLEA estava presente no sobrenadante 2 e precipitado após a adição de ureia.

A proteína foi purificada do sobrenadante 2 por cromatografia de afinidade, sendo eluída com 500mM de imidazol na fração 1 (Figura 61D) juntamente com um grande rastro de outras bandas que pode ser degradação da própria proteína ou contaminantes. Essa fração foi dialisada para retirada do imidazol e ureia. Como a proteína GLEA precipita após diálise, a fração foi centrifugada para separação do precipitado e sobrenadante (Figura 61E). O sobrenadante foi utilizado na imunização de camundongos e produção de anticorpos, e nos ensaios de imunogenicidade. 


\subsubsection{Expressão e purificação da proteína Hsp70}

A expressão, o teste de solubilidade e a purificação da proteína recombinante Hsp70 foram analisados em SDS-PAGE a 10\% (Figura 62):
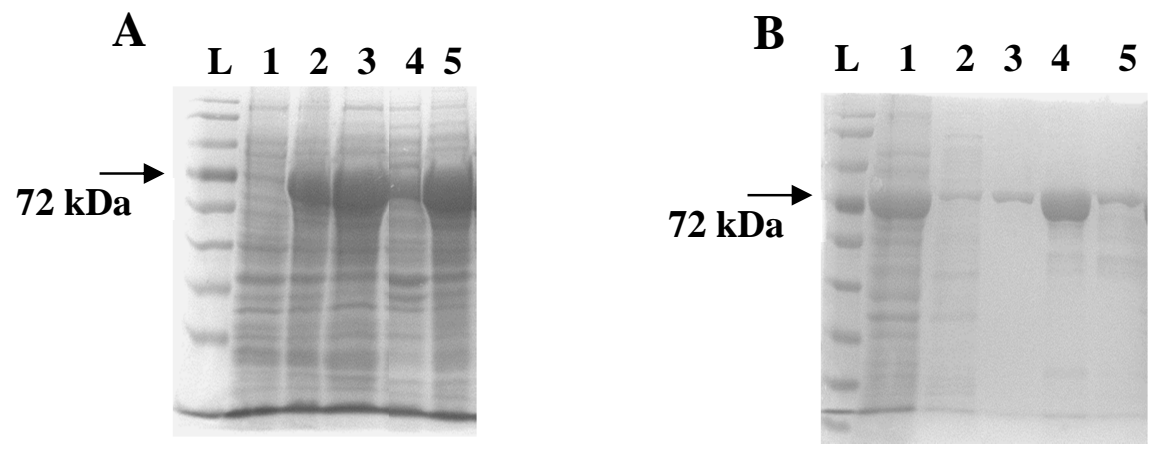

Figura 62: Expressão, Teste de solubilidade e Purificação da proteína recombinante Hsp70. L-marcador. A) Expressão e teste de solubilidade da proteína Hsp70, 1-não induzido; 2-16 horas após indução com IPTG; 3sobrenadante 1 (sem ureia); 4-precipitado; 5-sobrenadante 2 (com ureia). B) Purificação da proteína Hsp70, 1eluato; 2-lavagem 1; 3-lavagem 2 (com 50mM de imidazol); 4-eluição 1 (com 150mM de imidazol); 5-eluição 2 (com 250mmM de imidazol).

A proteína Hsp70 foi expressa após 16 horas de indução com IPTG, como é visto na figura $62 \mathrm{~A}$, pela presença da banda de expressão próxima a $72 \mathrm{kDa}$, condizente com o tamanho da proteína de $72,5 \mathrm{kDa}$ (664 aas). Após a expressão, foi realizado o teste de solubilidade com tampão de sonicação sem ureia e em condições desnaturantes (Figura 62A) para verificar a solubilidade da proteína. Como demonstrado na figura 62A, a proteína hsp70 estava presente em ambos os sobrenadante ( 1 e 2 ) e em pequena quantidade no precipitado.

A proteína foi purificada do sobrenadante 1 por cromatografia de afinidade, sendo eluída principalmente na fração $1 \mathrm{com} 150 \mathrm{mM}$ de imidazol e em menor quantidade na fração 2 (250mM de imidazol) (Figura 62B). Ambas as frações foram dialisadas para retirada do imidazol e utilizadas na imunização de camundongos para produção de anticorpos.

\subsubsection{Expressão e purificacão da proteína gp96 em células HEK}

A primeira expressão da proteína gp96 em HEK, chamada de teste, foi realizada com menor quantidade de células, DNA e PEI e foi coletada após 72 horas da transfecção. No momento da coleta as células possuíam uma concentração $1 \times 10^{6}$ células $/ \mathrm{mL}$ e eficiência de transfecção de 98,2\% medida pela taxa de transfecção com o plasmídio pGFP. Esse vetor foi utilizado na concentração de $1 \%$ em comparação ao pcDNAgp96 e a taxa de transfecção para esse plasmídio foi de 9,82\%. Dois sobrenadantes foram obtidos após a expressão da proteína gp96, um após a lise celular feita por congelamento e descongelamento das células em PBS 
(sobrenadante 1) e outro ressuspendendo o precipitado obtido após a lise em tampão com ureia (sobrenadante 2). Ambos sobrenadantes foram purificados e a purificação da proteína recombinante gp96 foi analisada em SDS-PAGE a 10\% (Figura 63):
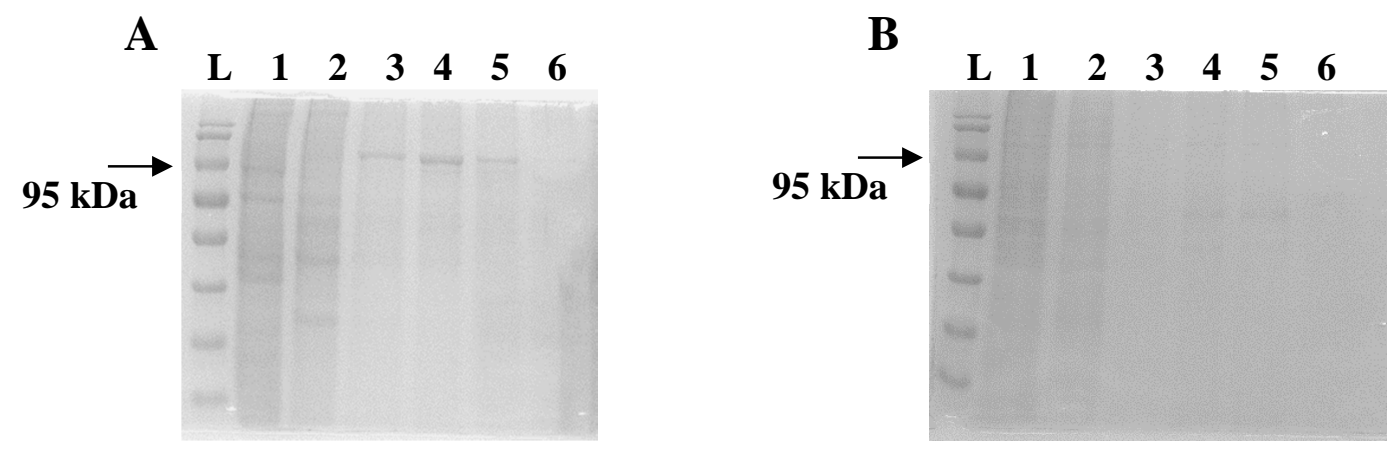

Figura 63: Purificação da proteína recombinante gp96. L-marcador. A) Purificação da proteína gp96 a partir do sobrenadante 1 (PBS), 1-eluato; 2-lavagem (50mM de imidazol); 3-eluição 1; 4-eluição 2; 5-eluição 3; 6eluição 4. B) Purificação da proteína gp96 a partir do sobrenadante 2 (tampão com ureia), 1-eluato; 2-lavagem (50mM de imidazol); 3-eluição 1; 4-eluição 2; 5-eluição 3; 6-eluição 4.

A proteína gp96 foi purificada a partir do sobrenadante 1 (PBS) por cromatografia de afinidade como é visto na figura $63 \mathrm{~A}$, pela presença de uma banda próxima a $95 \mathrm{kDa}$, condizente com o tamanho da proteína de $92,8 \mathrm{kDa}$ (806 aas). A proteína foi eluída nas frações 1,2 e 3 com $500 \mathrm{mM}$ de imidazol. Todas as frações foram dialisadas para retirada do imidazol e concentradas.

Após a confirmação de que a proteína gp96 era expressa em células HEK pelo protocolo teste, uma nova metodologia foi utilizada com maior quantidade de células, DNA e PEI. Nessa metodologia as células crescem por um determinado tempo no spinner, mantendo sempre uma concentração entre $3 \times 10^{5}-1 \times 10^{6}$ células $/ \mathrm{mL}$. A viabilidade durante 0 crescimento foi mantida entre 97 e $98 \%$ e o volume final do cultivo foi de $700 \mathrm{~mL}$. No dia da transfecção, a viabilidade era de $94 \%$ e no dia da coleta, $70 \%$ com concentração de $1,1 \times 10^{6}$ células/mL. A eficácia da transfecção foi de 33,3\% medida pela taxa de transfecção com o plasmídio pGFP. A purificação foi realizada com o sobrenadante 1 e avaliada em SDSPAGE (Figura 64): 

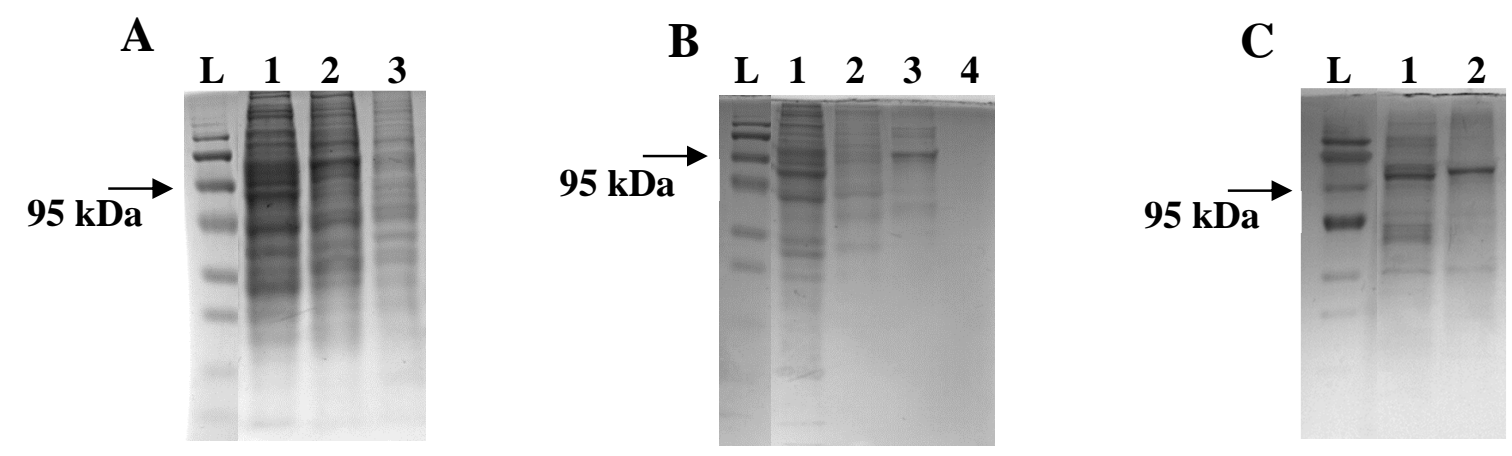

Figura 64: Solubilidade e Purificação da proteína recombinante gp96. L-marcador. A) Solubilidade da proteína gp96, 1-sobrenadante 1 (PBS); 2-sobrenadante 2 (com ureia); 3-precipitado. B) Purificação da proteína gp96 a partir do sobrenadante 1, 1-eluato; 2-lavagem (50mM de imidazol); 3-eluição 1; 4-eluição 2. C) Proteína gp96 após purificação, 1-proteína purificada em B após diálise; 2-proteína da purificação anterior dialisada e concentrada.

A expressão da proteína gp96 não foi possível de ser avaliada nos sobrenadantes e precipitado como é visto na figura 64A. A confirmação da expressão só foi possível após a purificação. A proteína gp96 foi purificada a partir do sobrenadante 1 (PBS) por cromatografia de afinidade como é visto na figura 64B, pela presença de uma banda próxima a $95 \mathrm{kDa}$. A proteína foi eluída na fração $1 \mathrm{com} 500 \mathrm{mM}$ de imidazol. Essa fração foi dialisada para retirada do imidazol (Figura 64C) e concentrada para utilização na imunização de camundongos.

Todas as proteínas purificadas (EGFRvIII, cERBB2, MAGE, GLEA, Hsp70 e gp96) foram avaliadas quanto a presença de endotoxinas (dados não mostrados), demonstrando níveis inferiores aos requeridos para materiais utilizados como injetáveis (Tuomela, Stanescu e Krohn, 2005). As proteínas recombinantes foram, então, utilizadas na produção de anticorpos policlonais em camundongos para serem utilizados na caracterização das vacinas de DNA construídas. Além disso, as proteínas EGFRvIII, cERBB2, MAGE e GLEA foram utilizadas nos ensaios de imunogenicidade.

\subsection{Caracterização das vacinas de DNA}

\subsubsection{Análise de restricão e dosagem de endotoxinas nas vacinas de DNA}

Os plasmídios pVAXgDEGFRvIII, pVAXgDcERBB2, pVAXgDMAGE, pVAXgDGLEA, pVAXgp96, pVAXEGFRvIII, pVAXcERBB2, pVAXMAGE, pVAXGLEA e pVAXhsp70 foram purificados, quantificados e caracterizados pela clivagem com a enzima NheI (Figura 65). 


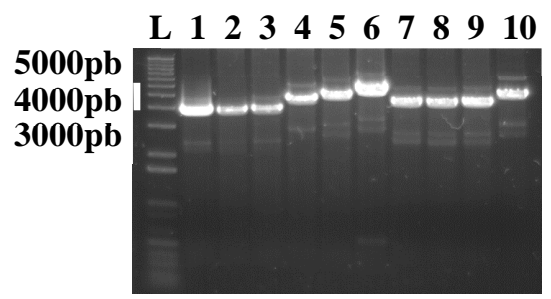

Figura 65: Clivagem das vacinas de DNA. Clivagem das vacinas de DNA com a enzima NheI. L-marcador $1 \mathrm{~Kb}$ Plus, 1 ao 10-vacinas pVAXEGFRvIII, pVAXcERBB2, pVAXMAGE, pVAXGLEA, pVAXhsp70, pVAXgp96, pVAXgDEGFRvIII, pVAXgDcERBB2, pVAXgDMAGE e pVAXgDGLEA digeridas.

As vacinas pVAXEGFRvIII, pVAXcERBB2, pVAXMAGE, pVAXGLEA, pVAXhsp70, pVAXgp96, pVAXgDEGFRvIII, pVAXgDcERBB2, pVAXgDMAGE e pVAXgDGLEA foram corretamente caracterizadas pelos fragmentos, 3820pb, 3817pb, $3859 \mathrm{pb}, 4546 \mathrm{pb}, 4840 \mathrm{pb}, 5266 \mathrm{pb}, 4357 \mathrm{pb}, 4357 \mathrm{pb}, 4399 \mathrm{pb}$ e $5086 \mathrm{pb}$, respectivamente, que representam o tamanho do vetor mais o inserto.

Além disso, elas foram avaliadas quanto à presença de endotoxinas (dados não mostrados) demonstrando níveis inferiores aos requeridos para materiais utilizados como injetáveis $(<0,01$ unidades de endotoxinas/ $\mu \mathrm{g}$ de DNA).

\subsubsection{Transfeccão das células HEK com as vacinas de DNA}

Para detecção da transcrição e tradução das proteínas codificadas pelas vacinas de DNA, pVAXgDEGFRvIII, pVAXgDcERBB2, pVAXgDMAGE, pVAXgDGLEA, pVAXgp96, pVAXEGFRvIII, pVAXcERBB2, pVAXMAGE, pVAXGLEA, pVAXhsp70, células eucarióticas HEK foram transfectadas. A eficiência na transfecção dessas células foi avaliada pela utilização do plasmídio pGFP (Figura 66).
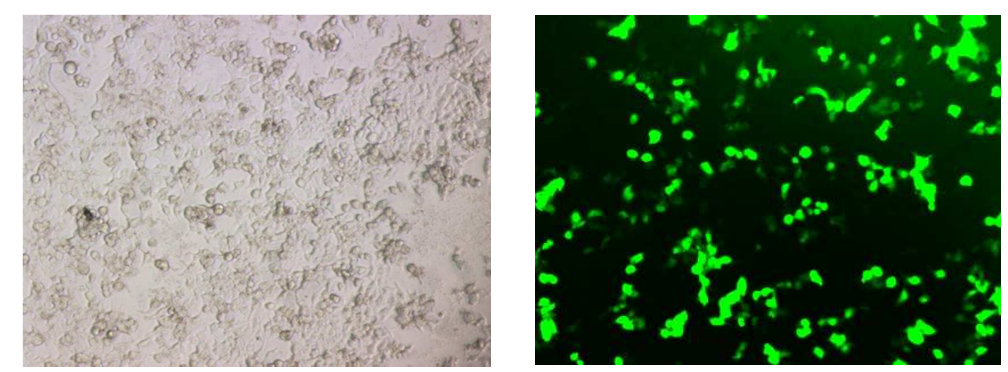

Figura 66: Transfecção de células HEK com pGFP. Células HEK transfectadas com o plasmídio pGFP após 24 horas. A esquerda células em campo claro e a direita, vista em microscopia de fluorescência.

Como é visto na figura 66, a transfecção foi eficiente o que pode ser aferido também para as transfecções com as construções vacinais. 


\subsubsection{Transcrição do RNA mensageiro}

As células HEK após 24 horas de transfecção com as construções vacinais foram utilizadas na extração de RNA. A detecção dos transcritos (Figura 67) codificados pelas vacinas foi realizada de forma indireta a partir do cDNA obtido pela transcrição reversa do RNA.

A

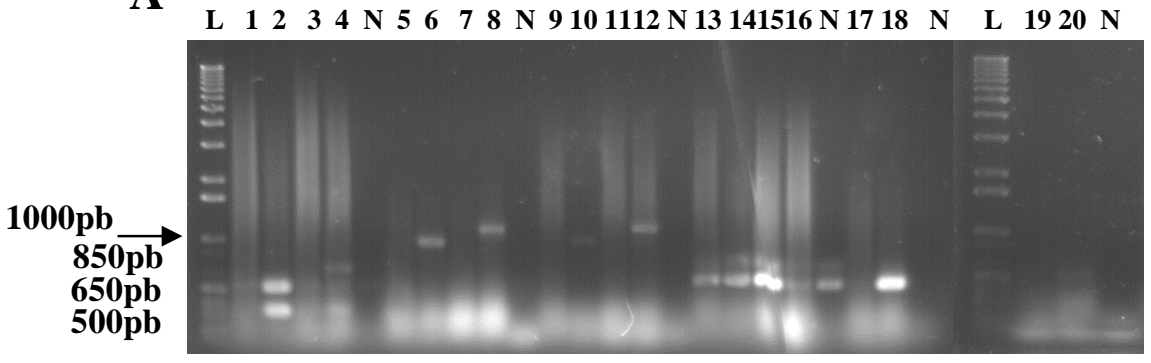

B

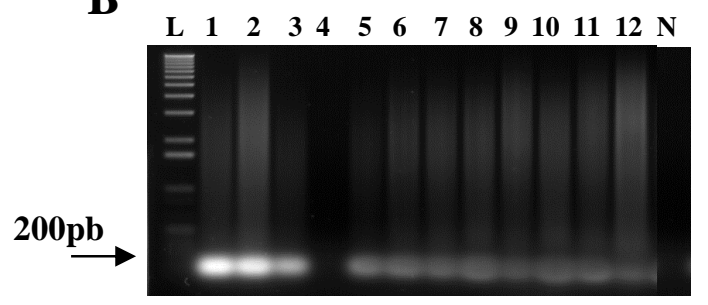

Figura 67: Detecção dos transcritos codificados pelas vacinas de DNA. Avaliação da presença do RNA mensageiro dos genes codificados pelas vacinas de DNA (A) e do gene GAPDH (B). L-marcador $1 \mathrm{~Kb}$. A) 1 ao 4-amplificação utilizando os oligonucleotídeos T7p e Mage_RSeq; 5 ao 8-T7p e EGFR_RSeq; 9 ao 12-T7p e cERBB2_RSeq; 13 ao 16-T7p e Glea_RSeq; 17 e 18-T7p e gp96_RSeq; 19 e 20-T7p e hsp70_RSeq. 1, 5, 9, 13, 17 e 19-amplificação utilizando os cDNAs feitos a partir dos RNAs extraídos das células HEK transfectada com pVAX; 3, 7, 11 e 15-pVAXgD; 2-pVAXMAGE; 4-pVAXgDMAGE; 6-pVAXEGFRvIII; 8-pVAXgDEGFRvIII; 10-pVAXcERBB2; 12-pVAXgDcERBB2; 14-pVAXGLEA; 16-pVAXgDGLEA; 18-pVAXgp96 e 20pVAXhsp70; N-controle negativo. B) 1 a 12-amplificação utilizando-se os oligonucleotídeos GAPDH sense e antisense e os cDNAs feitos a partir dos RNAs extraídos das células HEK transfectada com pVAX, pVAXMAGE, pVAXEGFRvIII, pVAXcERBB2, pVAXGLEA, pVAXgp96, pVAXhsp70, pVAXgD, pVAXgDMAGE, pVAXgDEGFRvIII, pVAXgDcERBB2 e pVAXGLEA.

A amplificação utilizando os oligonucleotídeos T7p e os específicos de cada gene para verificar a presença dos transcritos nas células HEK transfectadas com as construções vacinais revelou bandas de tamanhos esperados, 527pb, 686pb, 953pb, 1100pb, 993pb, $1168 \mathrm{pb}, 545 \mathrm{pb}, 704 \mathrm{pb}, 540 \mathrm{pb}, 541 \mathrm{pb}$ nas transfecções com as vacinas, pVAXMAGE, pVAXgDMAGE, pVAXEGFRvIII, pVAXgDEGFRvIII, pVAXcERBB2, pVAXgDcERBB2, pVAXGLEA, pVAXgDGLEA, pVAXgp96 e pVAXhsp70, respectivamente. Além disso, nenhuma banda foi vista nos controles negativos. Para todas as células transfectadas, com exceção das células transfectadas com pVAXcERBB2, obteve-se a amplificação do gene GAPDH (178pb), como controle positivo do experimento. 


\subsubsection{Tradução das proteínas (western blot)}

Células HEK, após 24 horas de transfecção, foram coletadas e avaliadas por western blot quanto à expressão das proteínas codificadas pelas vacinas utilizando-se os anticorpos policlonais de cada proteína (Figura 68).
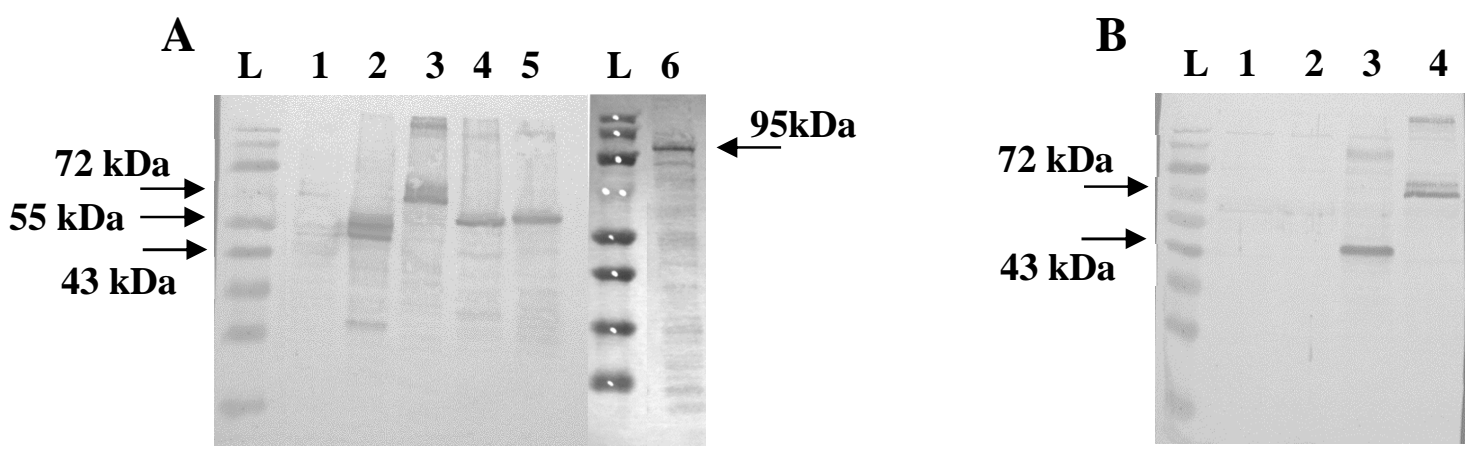

$\mathbf{C}$ $\begin{array}{llllll}\text { L } & 1 & 2 & 3 & 4 & 5\end{array}$

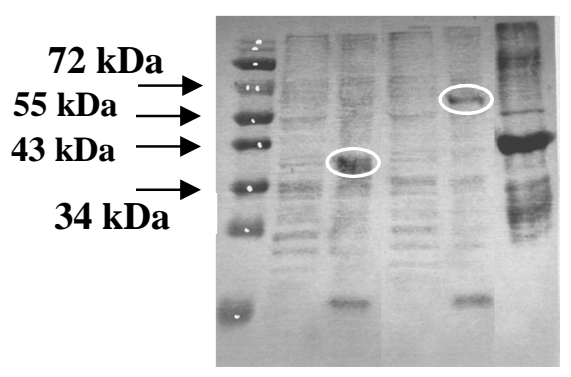

D

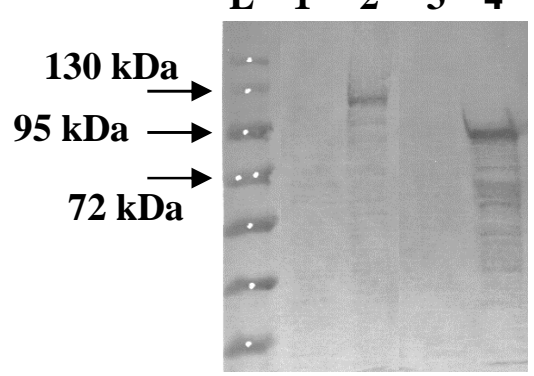

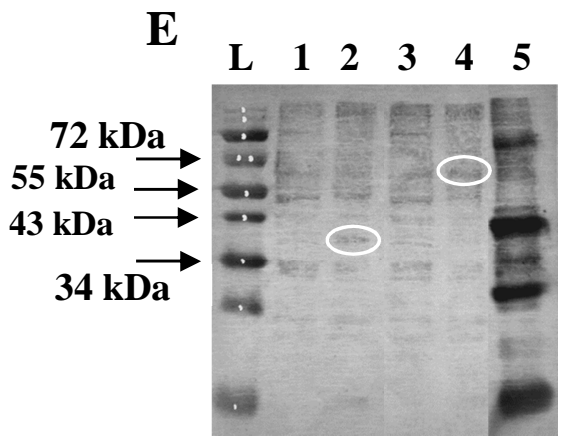
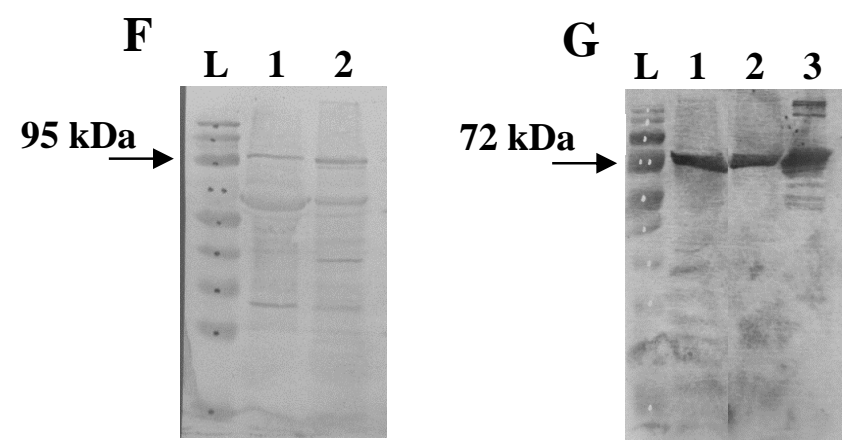

Figura 68: Expressão das proteínas codificadas pelas vacinas de DNA. Células HEK foram transfectadas com as vacinas de DNA e após 24 horas foram avaliadas com relação à expressão das proteínas codificadas pelos vetores vacinais por western blot. L-marcador. A) western blot utilizando anti-gD, células transfectadas com, 1-pVAX; 2-pVAXgD; 3-pVAXgDMAGE; 4-pVAXgDEGFRvIII; 5-pVAXgDcERBB2; 6pVAXgDGLEA. B) Anti-MAGE, células transfectadas com 1-pVAX; 2-pVAXgD; 3-pVAXMAGE; 4pVAXgDMAGE. C) Anti-cERBB2, células transfectadas com 1-pVAX; 2- pVAXcERBB2; 3- pVAXgD; 4pVAXgDcERBB2; 5-proteína recombinante cERBB2 produzida em E. coli. D) Anti-GLEA, células transfectadas com 1-pVAXgD; 2-pVAXgDGLEA; 3- pVAX; 4-pVAXGLEA. E) Anti-EGFRvIII, células transfectadas com 1-pVAX; 2-pVAXEGFRvIII; 3-pVAXgD; 4-pVAXgDEGFRvIII; 5-proteína recombinante EGFRvIII produzida em E. coli. F) Anti-grp94, células transfectadas com 1-pVAX; 2-pVAXgp96. G) AntiHsp70, células transfectadas com 1-pVAX; 2-pVAXhsp70; 3-proteína recombinante Hsp70 produzida em $E$. coli. 
As células HEK transfectadas com os plasmídios pVAXgD, pVAXgDMAGE, pVAXgDcERBB2, pVAXgDGLEA e pVAXgDEGFRvIII, expressaram as proteínas gD, gDMAGE, gDcERBB2, gDGLEA e gDEGFRvIII de tamanhos 43,3kDa (394 aas), 54kDa (494 aas), 52,4kDa (480 aas), $81,3 \mathrm{kDa}$ (723 aas) e 52,4kDa (480 aas) respectivamente, como visto na figura 68A com anti-gD. A proteína gDMAGE também foi revelada com antiMAGE, assim como a proteína MAGE sozinha, de 34,7kDa (314 aas) expressa nas células transfectadas com pVAXMAGE (Figura 68B). As proteínas gDMAGE e MAGE expressaram em tamanhos maiores que o esperado como já havia sido visto na expressão da MAGE (sem a gD) em E. coli.

As proteínas gDcERBB2 e cERBB2 de 33kDa (300 aas) foram reveladas com anticERBB2 (Figura 68C). Com anti-GLEA (Figura 68D) foi possível verificar a expressão das proteínas gDGLEA e GLEA de 62kDa (543 aas). Ambas em tamanhos maiores que o esperado, o que também já havia sido visto na expressão da GLEA (sem a gD) em E. coli. As proteínas gDEGFRvIII e EGFRvIII de 33,2kDa (301 aas) foram reveladas com anti-EGFRvIII (Figura 68E). As células transfectadas apenas com o vetor $\mathrm{pVAX}$ e pVAXgD foram utilizadas como controle dos experimentos. O controle positivo, com a proteína purificada, também foi utilizado em alguns dos western blots.

As proteínas gp96 e Hsp70 de tamanhos 90,3kDa (783 aas) e 70kDa (641 aas) foram detectadas nas células HEK transfectadas com os plasmídios pVAXgp96 e pVAXhsp70 assim como no controle negativo, células transfectadas somente com o vetor $\mathrm{pVAX}$, como visto nas figuras 68F e 68G, respectivamente. Como a gp96 e a Hsp70 são proteínas humanas, presente nas células HEK, não foi possível determinar se as vacinas codificaram as proteínas recombinantes.

\subsection{Experimentos de Imunogenicidade}

\subsubsection{Avaliação da resposta imunológica}

Após a construção e caracterização das vacinas de DNA, foi realizada a imunização de camundongos para avaliação da imunogenicidade dessas construções. A resposta imunológica desencadeada pelas vacinas de DNA foi avaliada pela produção de anticorpos contra os antígenos utilizados, no soro dos camundongos imunizados, e pela caracterização do perfil 
das células $\mathrm{T}$ provenientes do baço dos animais imunizados. Para essas avaliações foram utilizadas as proteínas purificadas GLEA, EGFRvIII, cERBB2 e MAGE.

\section{Primeiro Protocolo}

O primeiro protocolo foi realizado apenas com um antígeno tumoral (GLEA) e com todas as proteínas imunomoduladoras, para determinar qual dessas moléculas seria mais eficiente na indução da resposta imunológica específica contra o antígeno tumoral. Os animais foram imunizados com as seguintes vacinas: $p V A X$ / pVAXGLEA / pVAXgDGLEA / pVAXGLEA + pVAXhsp65 / pVAXGLEA + pVAXhsp70 / pVAXGLEA + pVAXgp96.

OBS.: No primeiro experimento desse protocolo foram incluídos os grupos pVAX + pVAXGLEA e pVAX + pVAXgDGLEA como controles, pois os grupos imunizados com pVAXGLEA + pVAXHsps receberam maior quantidade do vetor pVAX. Nos dois experimentos desse protocolo foi utilizada a vacina pVAXhsp65, desenvolvida pelo nosso grupo, em combinação com o plasmídio pVAXGLEA.

\subsubsection{Avaliação da resposta imunológica humoral (primeiro protocolo)}

A presença de anticorpos anti-GLEA foi avaliada no soro dos animais vacinados, após 20 dias da última imunização (Figura 69). 


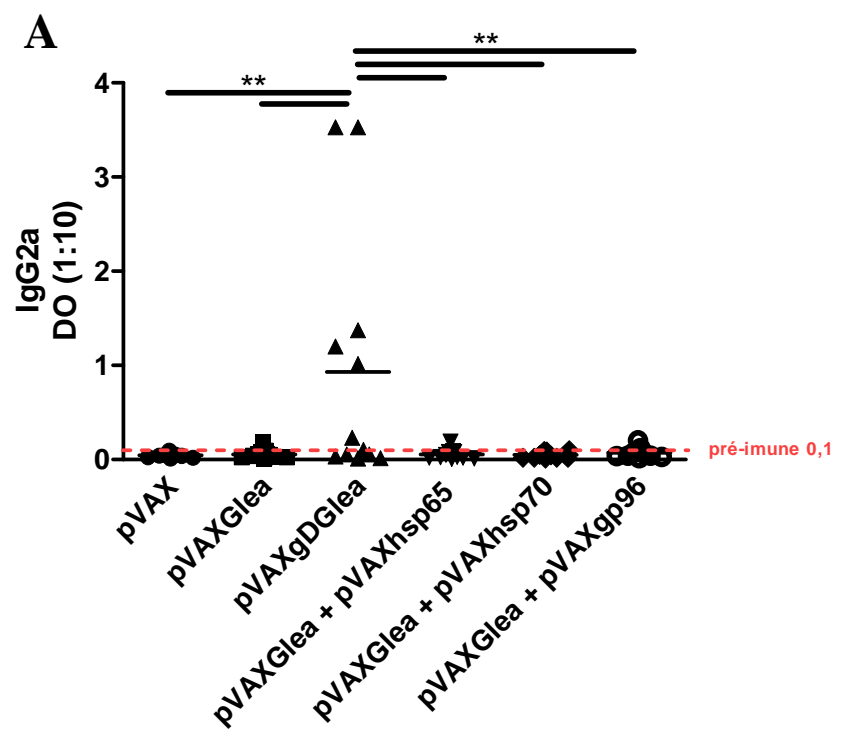

B

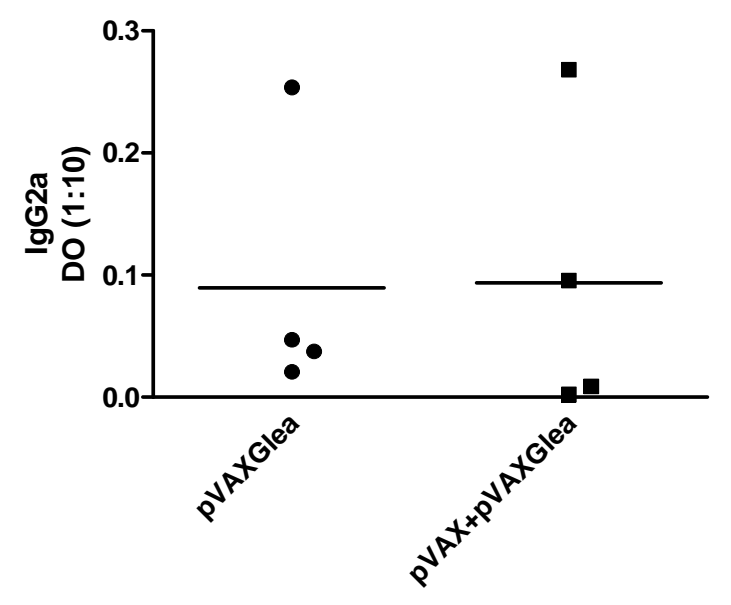

C

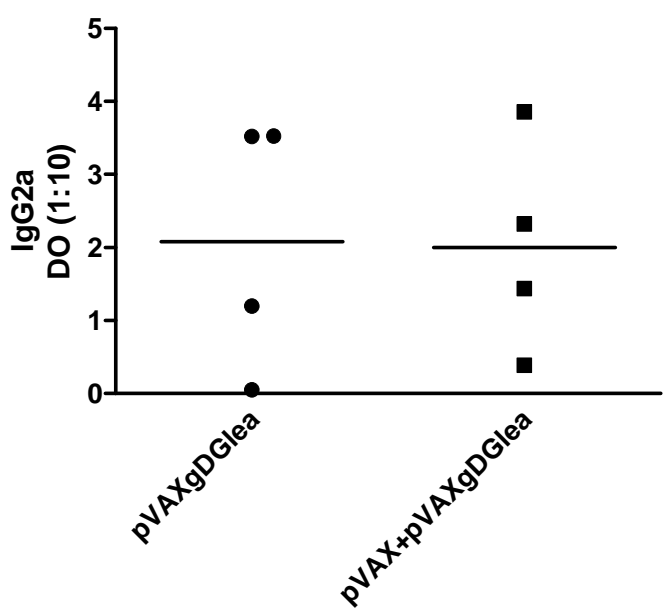

Figura 69: Produção de anticorpos anti-GLEA. O soro dos animais imunizados com três doses de 100 $\mu \mathrm{g}$ de cada DNA foi coletado após 20 dias da última dose e avaliado quanto a presença de anticorpos do subtipo IgG2a anti-GLEA. A) Resultado dos dois experimentos realizados para esse protocolo (12 animais); a linha tracejada indica a média da DO de seis animais antes da imunização (pré-imune) [DO (1:10), 0,1]. A análise estatística foi realizada por ANOVA com o teste de múltipla comparação de Tukey, ** p<0,01. B e C) Resultado de um experimento com 4 animais. A análise estatística foi realizada por teste $t, p<0,05$.

Como é visto na figura 69A, a vacina pVAXgDGLEA foi a única capaz de induzir, em alguns animais, a produção de anticorpos do subtipo IgG2a anti-GLEA. A quantidade de anticorpos produzidos pelos animais imunizados com pVAXgDGLEA foi estatisticamente diferente dos demais grupos. $\mathrm{O}$ grupo controle representado pelos animais imunizados com pVAX também não foi capaz de induzir resposta humoral contra a proteína GLEA. Dois outros grupos controles foram adicionados no primeiro experimento desse protocolo e a 
dosagem de anticorpos realizada no soro desses animais. Os animais dos grupos pVAXGLEA e pVAX + pVAXGLEA não produziram níveis significativos de anticorpos anti-GLEA (Figura 69B) e os camundongos imunizados com pVAXgDGLEA e pVAX + pVAXgDGLEA produziram mesma quantidade desse anticorpo (Figura 69C). Os grupos pVAX + pVAXGLEA e pVAX + pVAXgDGLEA foram utilizados como um controle do experimento uma vez que os animais imunizados com pVAXGLEA + pVAXhsp recebem o dobro do vetor pVAX. Anticorpos do subtipo IgG1 anti-GLEA não foram detectados nos grupos avaliados.

\subsubsection{Avaliação da resposta imunológica celular (primeiro protocolo)}

\subsection{Dosagem de citocinas}

A produção das citocinas IFN- $\gamma$ (Figura 70), IL-5, IL-10 (Figura 71), IL-6 (Figura 72) e IL-12 foram avaliadas no sobrenadante da cultura de células do baço, dos animais imunizados, após estímulo ex vivo de 48 horas com ConA ou com a proteína recombinante GLEA. As células foram obtidas 20 dias após a última imunização. As citocinas foram quantificadas por ELISA no sobrenadante das culturas. Como controle negativo foi utilizado sobrenadante de células não estimuladas. 
A

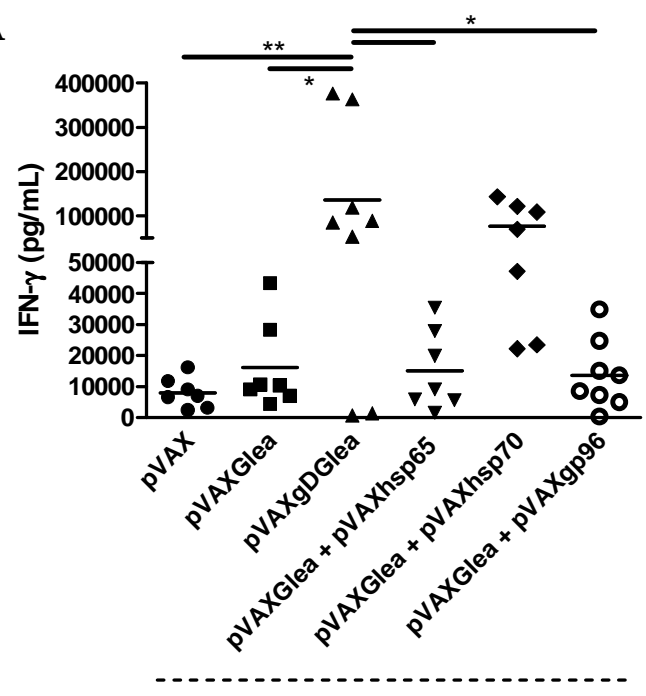

Estímulo: GLEA

B

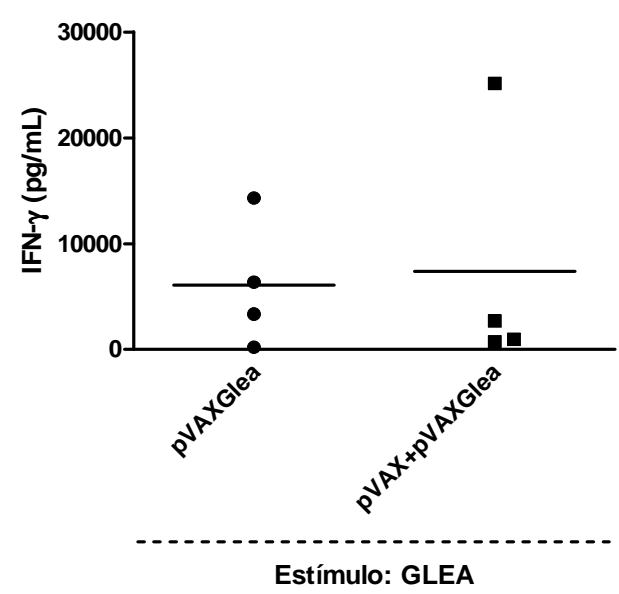

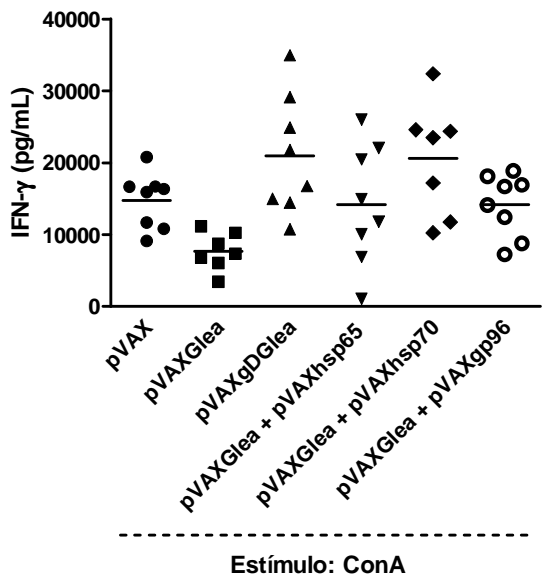

C

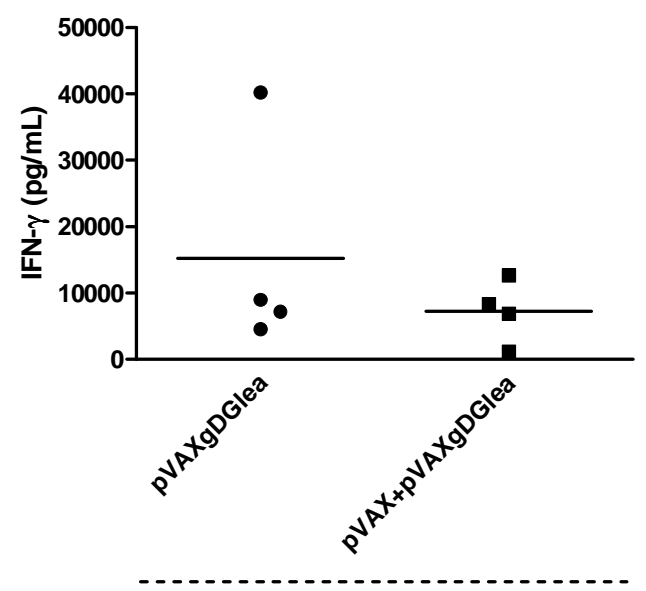

Estímulo: GLEA

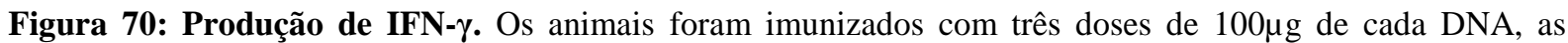
células do baço foram obtidas 20 dias após a última imunização e estimuladas ex vivo por 48 horas. A produção de IFN- $\gamma$ foi quantificada por ELISA no sobrenadante da cultura. A) Resultado do segundo experimento realizado para o primeiro protocolo (8 animais); a análise estatística foi realizada por ANOVA com o teste de múltipla comparação de Tukey, * $\mathrm{p}<0,05, * * \mathrm{p}<0,01$; gráfico maior, cultura estimulada com a proteína recombinante GLEA, gráfico menor, cultura estimulada com ConA. B e C) Resultado de um experimento com 4 animais. A análise estatística foi realizada por teste t, $\mathrm{p}<0,05$. Os níveis basais de IFN- $\gamma$, quando quantificáveis, nas células não estimuladas foram descontados de ambos os estímulos.

As células quando estimuladas com ConA produzem altos níveis de IFN- $\gamma$ (Figura 70A, gráfico menor) independente da vacina utilizada na imunização. As células dos animais imunizados com as diferentes vacinas quando estimuladas com a proteína recombinante 
GLEA produziram IFN- $\gamma$ (Figura 70A, gráfico maior). No entanto, os níveis mais altos dessa citocina foram vistos apenas nas células dos animais vacinados com pVAXgDGLEA e pVAXGLEA + pVAXhsp70 e somente os níveis de IFN- $\gamma$ produzidos pelas células dos animais imunizados com pVAXgDGLEA são diferentes estatisticamente dos níveis de IFN- $\gamma$ observados nos outros grupos, exceto pVAXGLEA + pVAXhsp70. Os grupos pVAXGLEA e pVAX + pVAXGLEA (Figura 70B) não apresentaram diferenças na produção de IFN- $\gamma$, bem como os grupos pVAXgDGLEA e pVAX + pVAXgDGLEA (Figura 70C). 
A

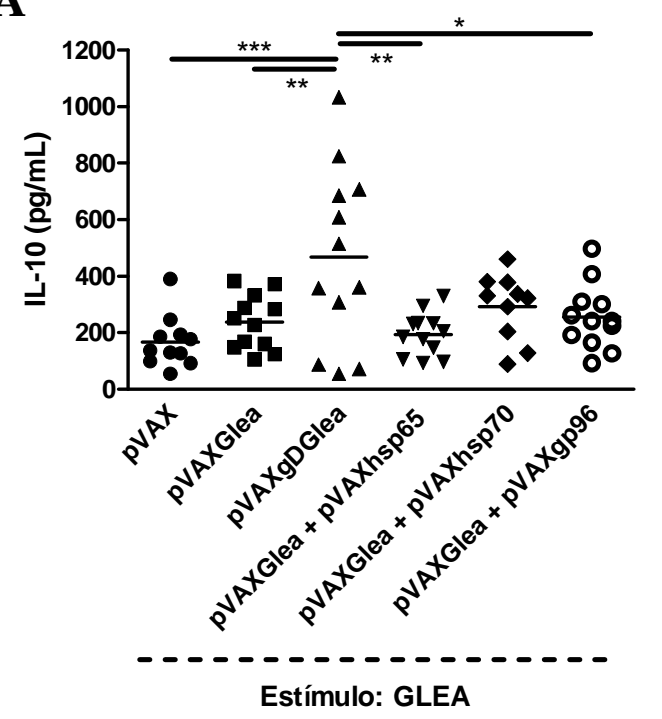

B

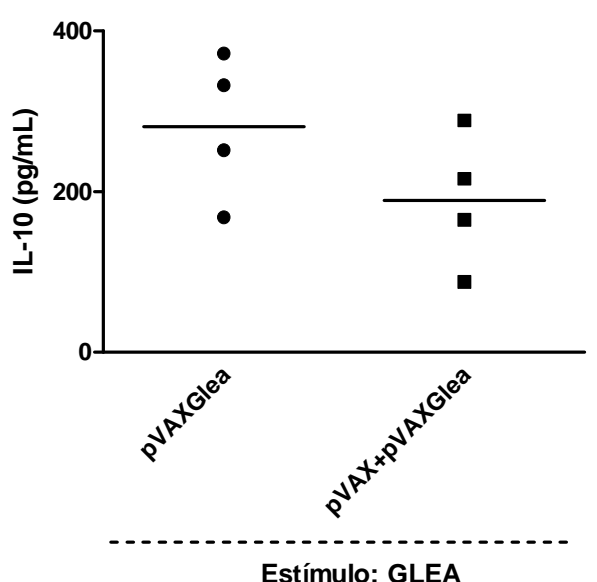

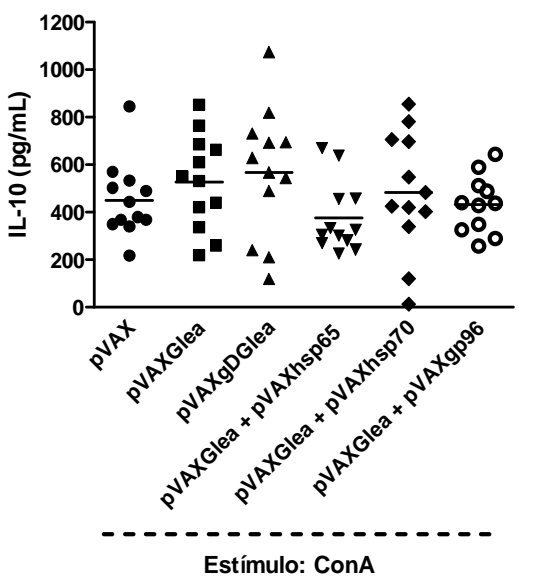

C

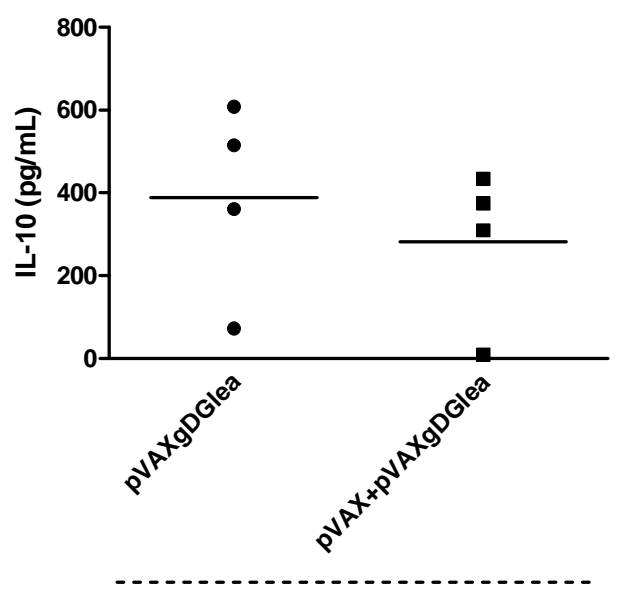

Estímulo: GLEA

Figura 71: Produção de IL-10. Os animais foram imunizados com três doses de $100 \mu \mathrm{g}$ de cada DNA, as células do baço foram obtidas 20 dias após a última imunização e estimuladas ex vivo por 48 horas. A produção da citocina IL-10 foi quantificada por ELISA no sobrenadante da cultura. A) Resultado dos dois experimentos realizados para esse protocolo (12 animais); a análise estatística foi realizada por ANOVA com o teste de múltipla comparação de Tukey, * $\mathrm{p}<0,05$, ** $\mathrm{p}<0,01$, ***p<0,001; gráfico maior, cultura estimulada com a proteína recombinante GLEA, gráfico menor, cultura estimulada com ConA. B e C) Resultado de um experimento com 4 animais. A análise estatística foi realizada por teste $t, p<0,05$. Os níveis basais de IL-10, quando quantificáveis, nas células não estimuladas foram descontados de ambos os estímulos.

As células quando estimuladas com ConA produzem IL-10 (Figura 71A, gráfico menor) independente da vacina utilizada na imunização. As células dos animais imunizados com as diferentes vacinas quando estimuladas com a proteína recombinante GLEA também 
produziram IL-10 (Figura 71A, gráfico maior). Os níveis mais altos dessa citocina foram vistos nas células dos animais vacinados com pVAXgDGLEA e pVAXGLEA + pVAXhsp70, mas somente os níveis de IL-10 produzidos pelas células dos animais imunizados com pVAXgDGLEA são diferentes estatisticamente dos níveis de IL-10 observados nos outros grupos, exceto pVAXGLEA + pVAXhsp70. Os grupos pVAXGLEA e pVAX + pVAXGLEA (Figura 71B) não apresentaram diferenças na produção de IL-10, bem como os grupos pVAXgDGLEA e pVAX + pVAXgDGLEA (Figura 71C). 
A

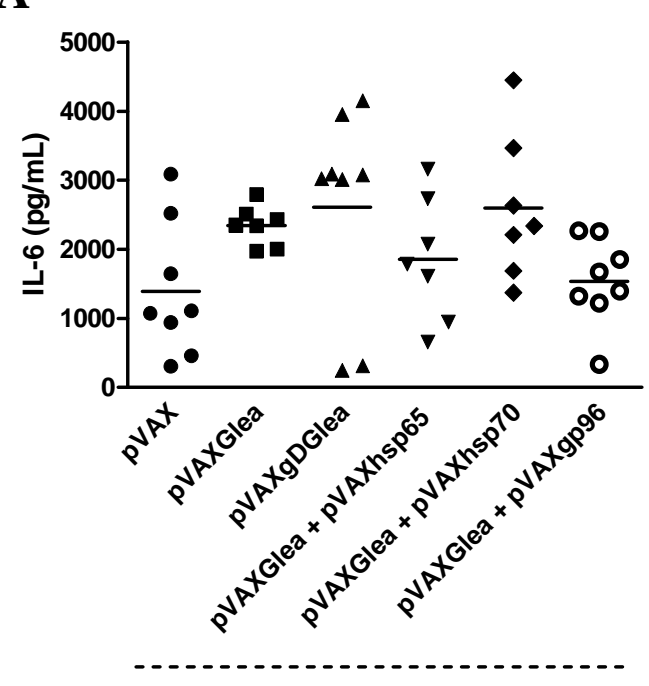

Estímulo: GLEA

B

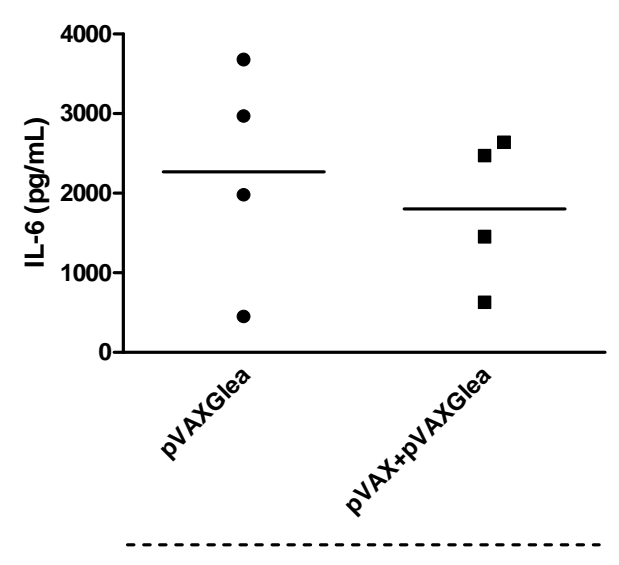

Estímulo: GLEA

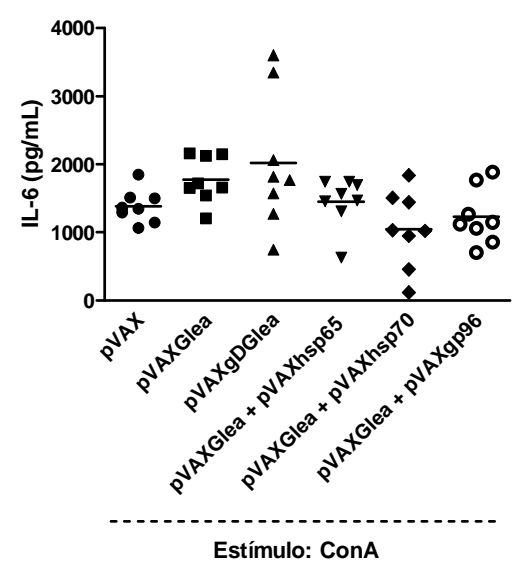

C

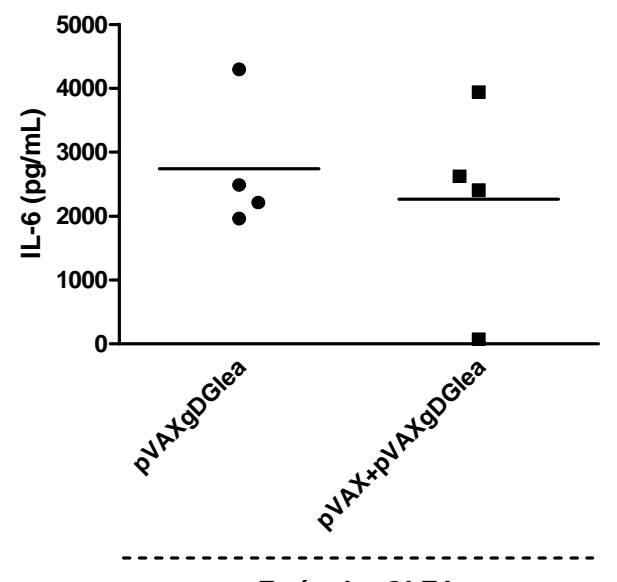

Estímulo: GLEA

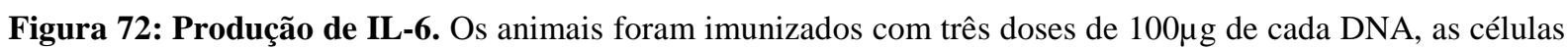
do baço foram obtidas 20 dias após a última imunização e estimuladas ex vivo por 48 horas. A produção de IL-6 foi quantificada por ELISA no sobrenadante da cultura. A) Resultado do segundo experimento realizado para o primeiro protocolo ( 8 animais); a análise estatística foi realizada por ANOVA com o teste de múltipla comparação de Tukey, $\mathrm{p}<0,05$; gráfico maior, cultura estimulada com a proteína recombinante GLEA, gráfico menor, cultura estimulada com ConA. B e C) Resultado de um experimento com 4 animais. A análise estatística foi realizada por teste $t, p<0,05$. Os níveis basais de IL-6, quando quantificáveis, nas células não estimuladas foram descontados de ambos os estímulos.

As células quando estimuladas com ConA (Figura 72A, gráfico menor) ou com a proteína recombinante GLEA (Figura 72A, gráfico maior) produzem IL-6 independente da vacina utilizada na imunização. Os grupos pVAXGLEA e pVAX + pVAXGLEA (Figura 72B) não apresentaram diferenças na produção de IL-6, bem como os grupos pVAXgDGLEA e pVAX + pVAXgDGLEA (Figura 72C). 
As células quando estimuladas com ConA produzem IL-5 (dados não mostrados) independente da vacina utilizada na imunização, assim como nas demais citocinas avaliadas. Ao contrário, os níveis de IL-12 não foram detectáveis na presença desse estímulo. As citocinas IL-5 e IL-12 não foram detectadas quando as células foram estimuladas com a proteína GLEA.

\subsection{Proliferação de linfócitos $T$}

A produção da citocina IL-2 também foi avaliada no sobrenadante da cultura de células do baço dos animais imunizados após estímulo ex vivo de 48 horas com ConA ou com a proteína recombinante GLEA. Essa citocina, por ser um fator de crescimento para células T, foi utilizada para inferir sobre a proliferação dessas células após o estímulo específico. As células foram obtidas 20 dias após a última imunização. A citocina foi quantificada por ELISA no sobrenadante das culturas. Como controle negativo foi utilizado sobrenadante de células não estimuladas.

O sobrenadante das células do baço dos animais imunizados com as diferentes construções vacinais quando estimuladas com ConA apresentava a citocina IL-2 independente da vacina utilizada (dados não mostrados). Entretanto, o sobrenadante dessas mesmas células estimuladas com a proteína GLEA não apresentou níveis detectáveis de IL-2.

\subsection{Fenótipo celular}

O fenótipo das células estimuladas ex vivo com ConA ou com a proteína recombinante GLEA após 48 horas foi analisado por citometria de fluxo. As células, obtidas 20 dias após a última imunização, foram estimuladas e avaliadas com relação à expressão dos marcadores de superfície celular CD4, CD8, CD44 e CD62L (Figuras 73 e 74). Células não estimuladas foram utilizadas como controle negativo. 

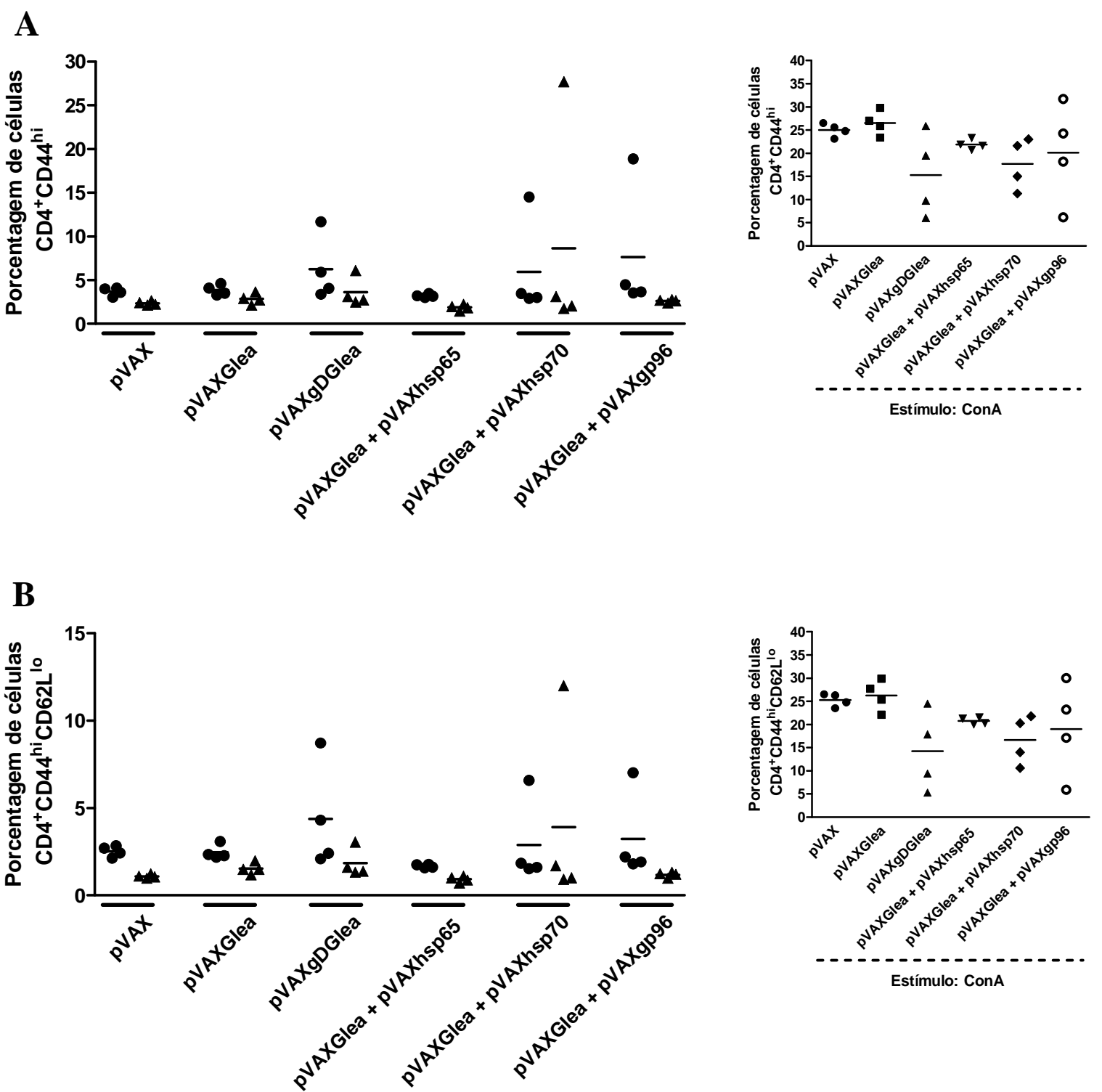

Figura 73: Porcentagem de células CD4 ativadas e de memória efetora. Os animais foram imunizados com três doses de $100 \mu \mathrm{g}$ de cada DNA, as células do baço foram obtidas 20 dias após a última imunização e estimuladas ex vivo por 48 horas. O fenótipo das células estimuladas foi determinado pela marcação com antiCD4, anti-CD44 e anti-CD62L e pela analise por citometria de fluxo. Resultado do segundo experimento realizado para esse protocolo (4 animais). A análise estatística foi realizada por ANOVA com o teste de múltipla comparação de Tukey, $\mathrm{p}<0,05$. Gráfico maior, células provenientes da cultura sem estímulo (•) ou estimulada com a proteína recombinante GLEA $(\boldsymbol{\Delta})$, gráfico menor, células provenientes da cultura estimulada com ConA. A) Porcentagem de células $\mathrm{CD} 4$ ativadas $\left(\mathrm{CD} 4^{+} \mathrm{CD} 44^{\mathrm{hi}}\right)$. B) Porcentagem de células CD4 de memória efetora $\left(\mathrm{CD} 4{ }^{+} \mathrm{CD} 44^{\mathrm{hi}} \mathrm{CD} 62 \mathrm{~L}^{\mathrm{lo}}\right)$. Os dois fenótipos foram avaliados dentro da gate de linfócitos; hi = high/lo = low. 

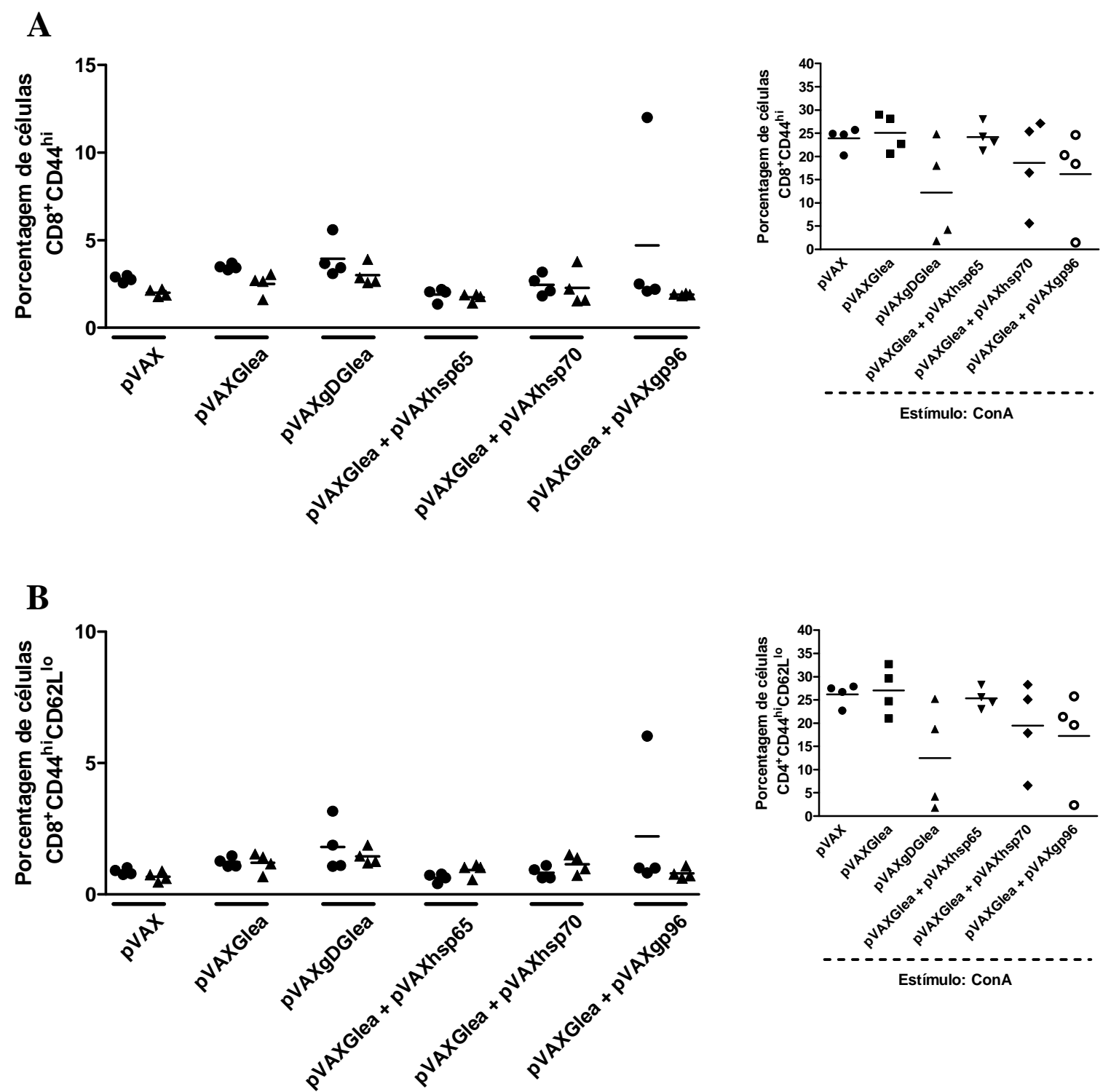

Figura 74: Porcentagem de células CD8 ativadas e de memória efetora. Os animais foram imunizados com três doses de $100 \mu \mathrm{g}$ de cada DNA, as células do baço foram obtidas 20 dias após a última imunização e estimuladas ex vivo por 48 horas. O fenótipo das células estimuladas foi determinado pela marcação com antiCD8, anti-CD44 e anti-CD62L e pela analise por citometria de fluxo. Resultado do segundo experimento realizado para esse protocolo (4 animais). A análise estatística foi realizada por ANOVA com o teste de múltipla comparação de Tukey, $\mathrm{p}<0,05$. Gráfico maior, células provenientes da cultura sem estímulo (•) ou estimulada com a proteína recombinante GLEA $(\boldsymbol{\Delta})$, gráfico menor, células provenientes da cultura estimulada com ConA. A) Porcentagem de células $\mathrm{CD} 8$ ativadas $\left(\mathrm{CD} 8^{+} \mathrm{CD} 44^{\mathrm{hi}}\right)$ B) Porcentagem de células CD8 de memória efetora $\left(\mathrm{CD} 8{ }^{+} \mathrm{CD} 44^{\mathrm{hi}} \mathrm{CD}^{2} \mathrm{~L}^{\mathrm{lo}}\right)$. Os dois fenótipos foram avaliados dentro da gate de linfócitos; hi = hight/lo = low.

A cultura quando estimulada com ConA apresentou alta porcentagem de células CD4 (Figura 73A, gráfico menor) e CD8 ativadas $\left(C D 44^{\text {hi }}\right.$ ) (Figura 74A, gráfico menor) e de memória efetora $\left(\mathrm{CD} 44^{\mathrm{hi}} \mathrm{CD} 62 \mathrm{~L}^{\mathrm{lo}}\right.$ ) (Figuras 73B e 74B, gráficos menores) independente da vacina utilizada na imunização. Já na cultura estimulada com a proteína recombinante GLEA 
a porcentagem dessas células foi bem menor e sem diferenças com relação as células não estimuladas (Figuras 73A e B, 74A e B gráficos maiores).

\section{Segundo protocolo}

O segundo protocolo foi realizado com os outros antígenos tumorais (EGFRvIII, cERBB2 e MAGE) e apenas com as proteínas gD e Hsp70. Os animais imunizados com as seguintes vacinas: pVAX / pVAXEGFR / pVAXgDEGFR / pVAXEGFR + pVAXhsp70 / pVAXcERBB2 / pVAXgDcERBB2 / pVAXcERBB2 + pVAXhsp70 / pVAXMAGE / pVAXgDMAGE / pVAXMAGE + pVAXhsp70.

\subsubsection{Avaliação da resposta imunológica humoral (segundo protocolo)}

A presença de anticorpos anti-EGFRvIII (Figura 75A), anti-cERBB2 (Figura 75B) e anti-MAGE (Figura 75C) foi avaliada no soro dos animais vacinados, após 20 dias da última imunização. 
A

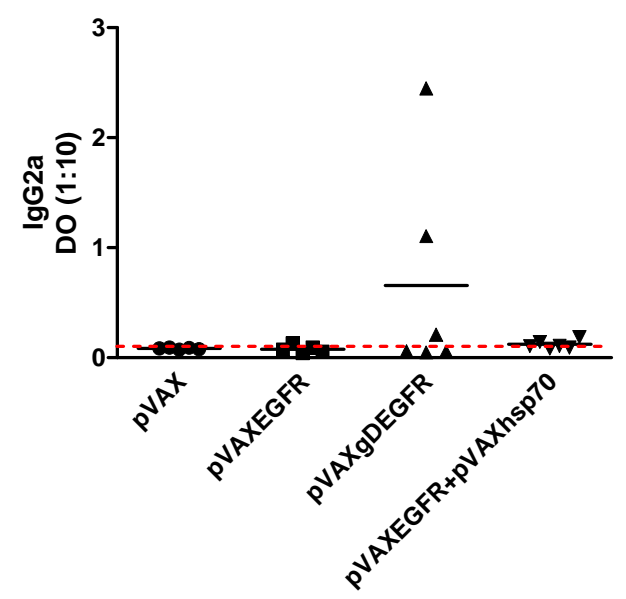

B

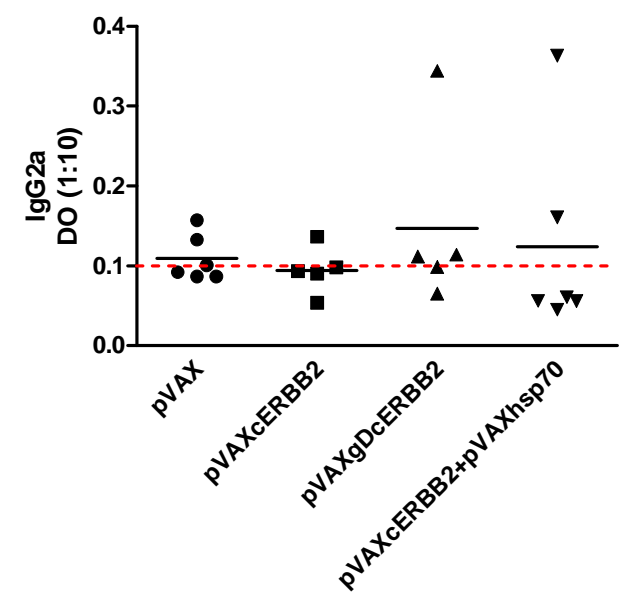

C

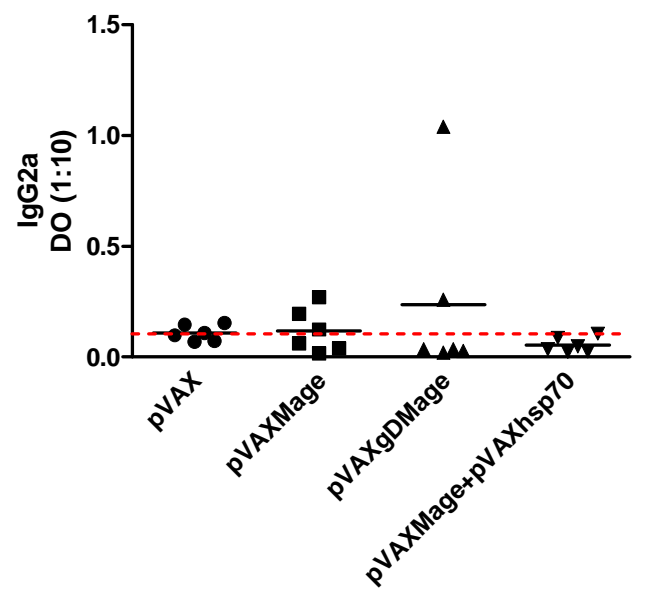

Figura 75: Produção de anticorpos anti-EGFRvIII, anti-cERBB2 e anti-MAGE. O soro dos animais imunizados com três doses de $100 \mu \mathrm{g}$ de cada DNA foi coletado após 20 dias da última dose e avaliado quanto a presença de anticorpos do subtipo IgG2a. Resultado do primeiro experimento realizado para o segundo protocolo (6 animais); a linha tracejada indica a média da DO de seis animais antes da imunização (pré-imune) [DO (1:10), 0,1]. A análise estatística foi realizada por ANOVA com o teste de múltipla comparação de Tukey, p<0,05. A) Anticorpos anti-EGFRvIII. B) Anticorpos anti-cERBB2. C) Anticorpos anti-MAGE. EGFR = EGFRvIII.

A figura 75 mostra que poucos animais foram capazes de produzir anticorpos contra as proteínas expressas pelas vacinas. A maioria produziu níveis semelhantes aos animais controles, pré-imune e animais vacinados com pVAX. Apenas dois animais do grupo pVAXgDEGFRvIII (Figura 75A) e um do pVAXgDMAGE (Figura 75C) foram capazes de induzir a produção de anticorpos do subtipo IgG2a anti-EGFRvIII e anti-MAGE, respectivamente. Anticorpos do subtipo IgG1 contra as proteínas expressas pelas vacinas não foram detectados nos grupos avaliados. 


\subsubsection{Avaliação da resposta imunológica celular (segundo protocolo)}

\subsection{Dosagem de citocinas}

A produção das citocinas IFN- $\gamma$ (Figura 76), IL-5, IL-10 (Figura 77), IL-6 (Figura 78)

e IL-12 foram avaliadas no sobrenadante da cultura de células do baço, dos animais imunizados, após estímulo ex vivo de 48 horas com ConA ou com as proteínas recombinantes EGFRvIII, cERBB2 e MAGE. As células foram obtidas 20 dias após a última imunização. As citocinas foram quantificadas por ELISA no sobrenadante das culturas. Como controle negativo foi utilizado sobrenadante de células não estimuladas 
$\mathbf{A}$

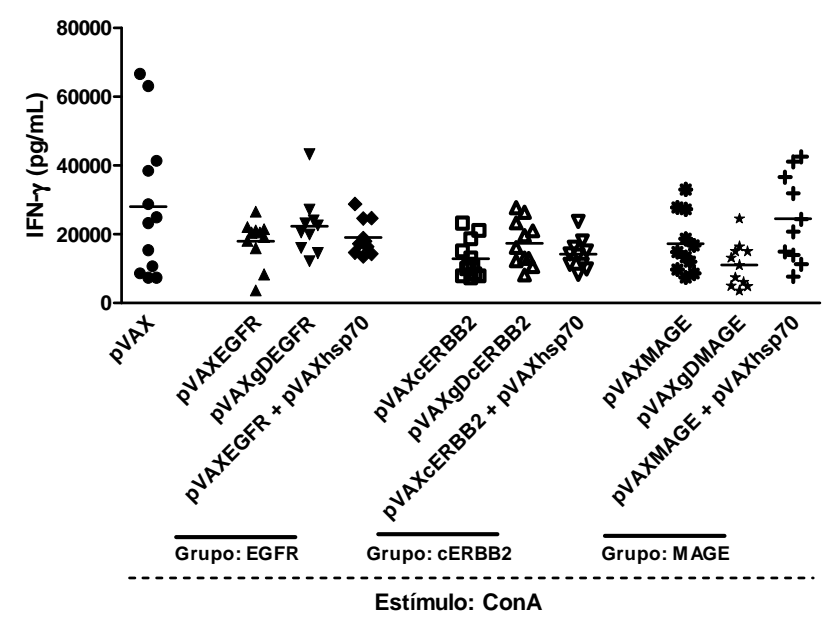

B

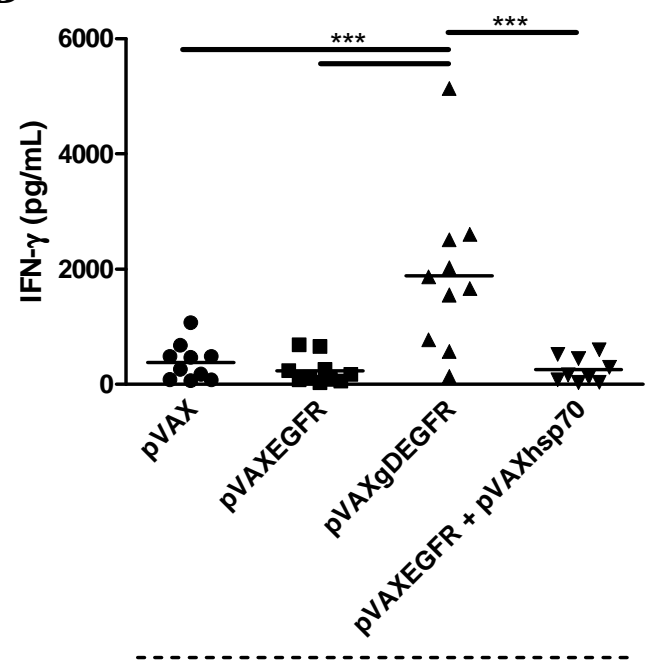

Estímulo: EGFR

D

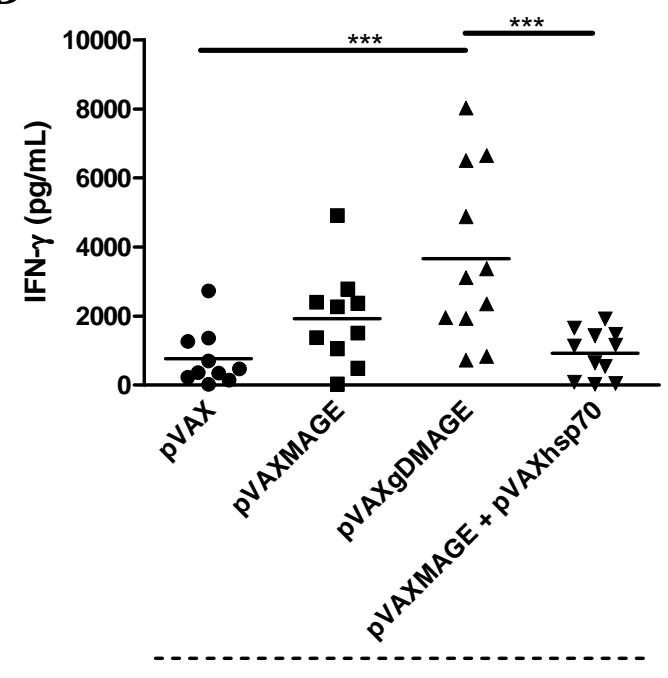

Estímulo: MAGE
C

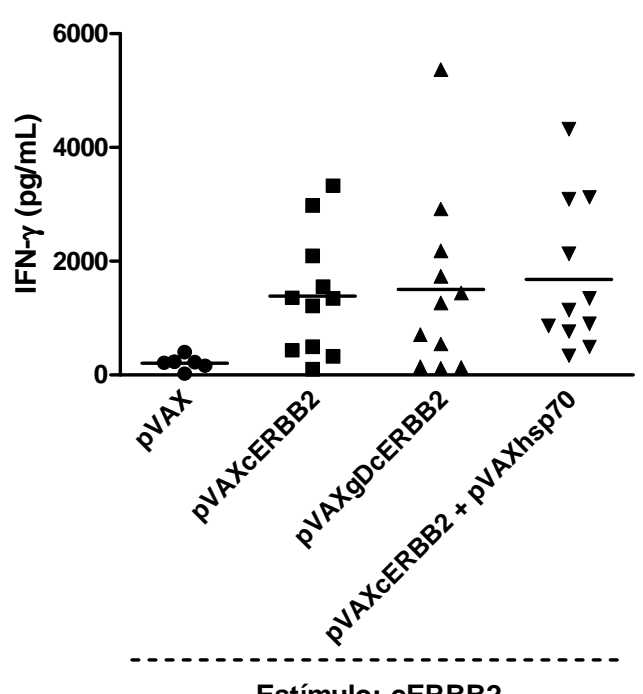

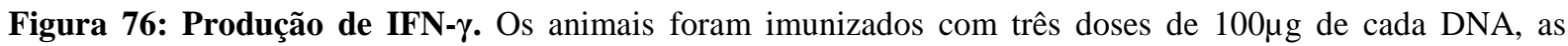
células do baço foram obtidas 20 dias após a última imunização e estimuladas ex vivo por 48 horas. A produção de IFN- $\gamma$ foi quantificada por ELISA no sobrenadante da cultura. Resultado dos dois experimentos realizados para esse protocolo (12 animais); a análise estatística foi realizada por ANOVA com o teste de múltipla comparação de Tukey, $* * *$ p $<0,001$. A) Células estimuladas com ConA. B) Células estimuladas com a proteína recombinante EGFRvIII. C) Células estimuladas com a proteína recombinante cERBB2. D) Células estimuladas com a proteína recombinante MAGE. Os níveis basais de IFN- $\gamma$, quando quantificáveis, nas células não estimuladas foram descontados dos estímulos ConA, EGFRvIII, cERBB2 e MAGE. EGFR = EGFRvIII.

As células dos animais vacinados quando estimuladas com ConA produzem altos níveis de IFN- $\gamma$ (Figura 76A) independente da vacina utilizada na imunização. As células dos animais imunizados com as vacinas pVAXEGFRvIII e pVAXEGFRvIII + pVAXhsp70, bem como as células dos animais vacinados com pVAX, quando estimuladas com a proteína 
recombinante EGFRvIII produziram níveis baixíssimos de IFN- $\gamma$ e as células dos animais imunizados com pVAXgDEGFR (Figura 76B) produziram maior quantidade dessa citocina, sendo diferente estatisticamente dos demais grupos.

As células dos grupos imunizados com as diferentes vacinas contendo o gene que codifica a proteína cERBB2 produziram níveis aumentados de IFN- $\gamma$ (Figura 76C) quando estimuladas com a proteína recombinante cERBB2, no entanto, sem diferenças estatísticas entre esses grupos e em relação ao grupo controle pVAX.

Já as células dos animais imunizados com as diferentes vacinas contendo o gene que codifica a proteína MAGE produziram níveis aumentados de IFN- $\gamma$ quando estimuladas com a proteína recombinante MAGE (Figura 76D) em comparação ao grupo pVAX, cujas células produziram pequena quantidade dessa citocina. No entanto, apenas a quantidade produzida pelas células do grupo pVAXgDMAGE foram significativamente maiores em comparação as células dos grupos controle e pVAXMAGE + pVAXhsp70. 
$\mathbf{A}$

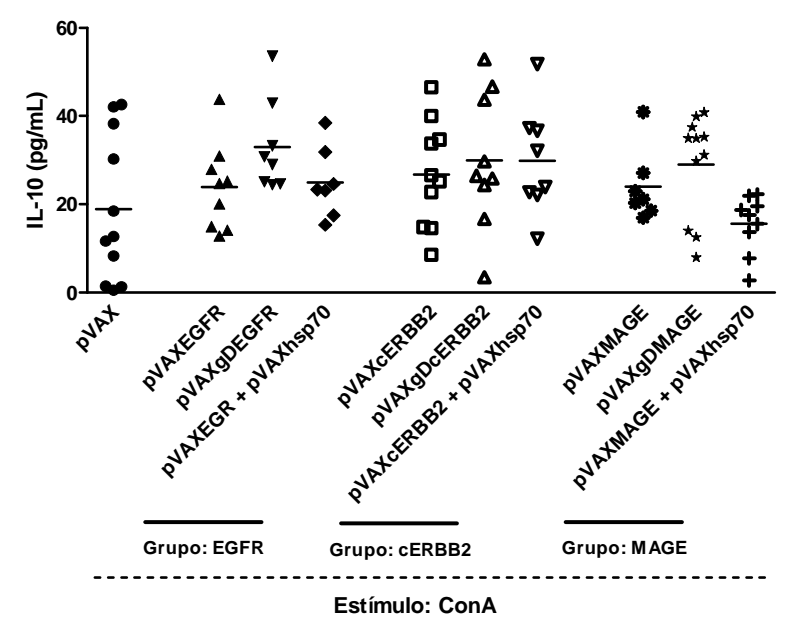

C

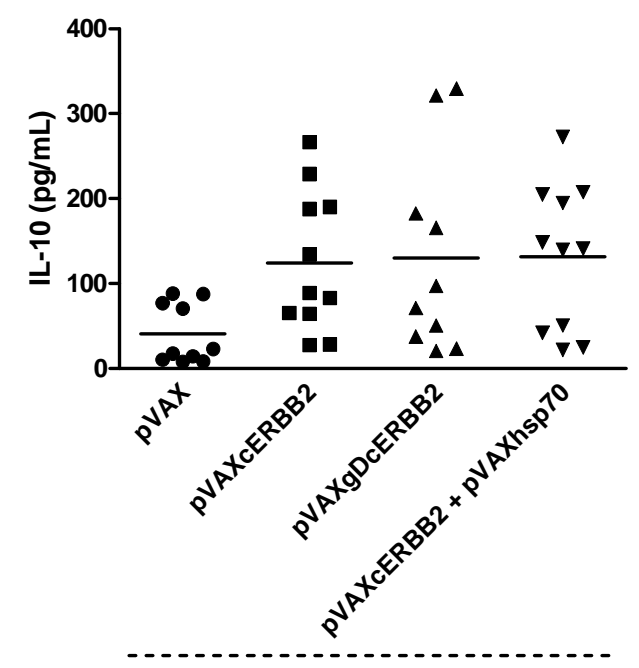

Estímulo: cERBB2
B

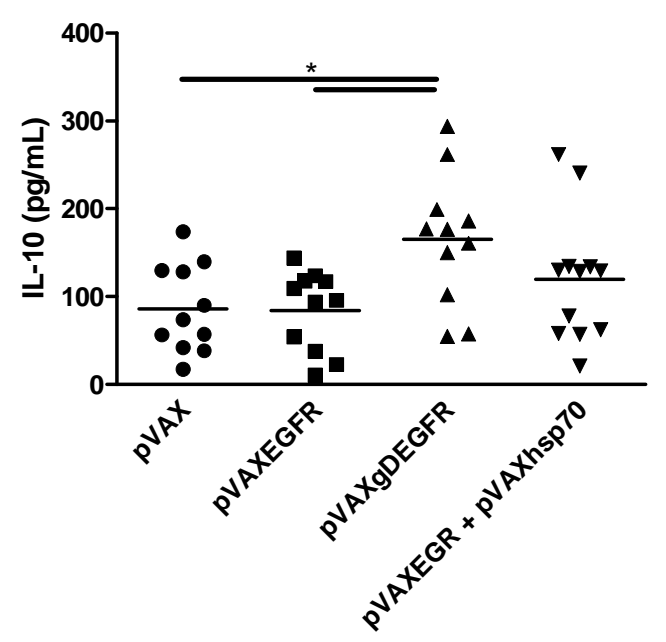

Estímulo: EGFR

D

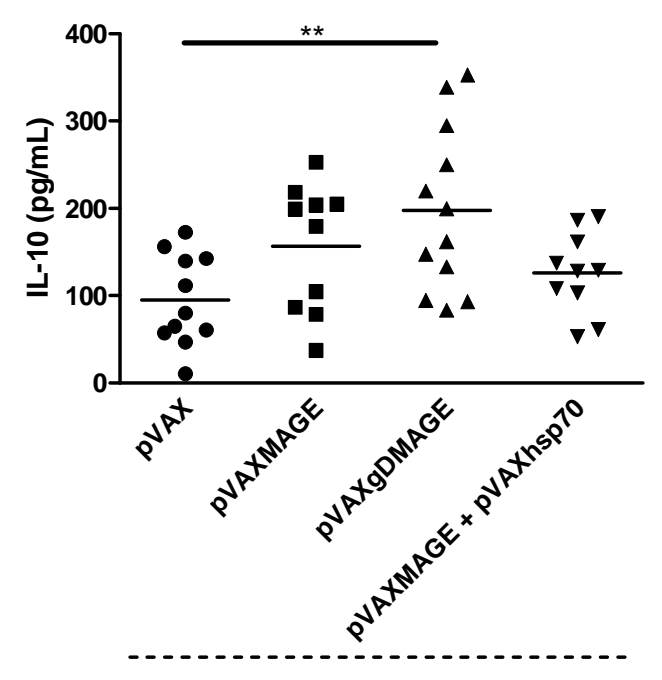

Estímulo: MAGE

Figura 77: Produção de IL-10. Os animais foram imunizados com três doses de 100 $\mu$ g de cada DNA, as células do baço foram obtidas 20 dias após a última imunização e estimuladas ex vivo por 48 horas. A produção de IL-10 foi quantificada por ELISA no sobrenadante da cultura. Resultado dos dois experimentos realizados para esse protocolo (12 animais); a análise estatística foi realizada por ANOVA com o teste de múltipla comparação de Tukey, ${ }^{*} \mathrm{p}<0,05, * * \mathrm{p}<0,01$. A) Células estimuladas com ConA. B) Células estimuladas com a proteína recombinante EGFRvIII. C) Células estimuladas com a proteína recombinante cERBB2. D) Células estimuladas com a proteína recombinante MAGE. Os níveis basais de IL-10, quando quantificáveis, nas células não estimuladas foram descontados dos estímulos ConA, EGFRvIII, cERBB2 e MAGE. EGFR = EGFRvIII.

As células dos animais vacinados quando estimuladas com ConA produzem pouquíssima quantidade de IL-10 (Figura 77A) independente da vacina utilizada na imunização. As células dos animais imunizados com as diferentes vacinas contendo o gene 
que codifica a proteína EGFRvIII, bem como as células dos animais vacinados com pVAX, quando estimuladas com a proteína recombinante EGFRvIII produziram IL-10, sendo apenas o grupo pVAXgDEGFRvIII (Figura 77B) diferente estatisticamente dos grupos pVAX e pVAXEGFRvIII.

As células dos grupos imunizados com as diferentes vacinas contendo o gene que codifica a proteína cERBB2 produziram níveis maiores de IL-10 que as células do grupo controle (Figura 77C) quando estimuladas com a proteína recombinante cERBB2, no entanto, sem diferenças estatísticas entre os grupos.

As células dos animais imunizados com as diferentes vacinas contendo o gene que codifica a proteína MAGE e as células do grupo controle, pVAX, também produziram IL-10 quando estimuladas com a proteína recombinante MAGE (Figura 77D). No entanto, a quantidade produzida pelas células do grupo pVAXgDMAGE foram significativamente maiores em comparação as células do grupo controle. 
A

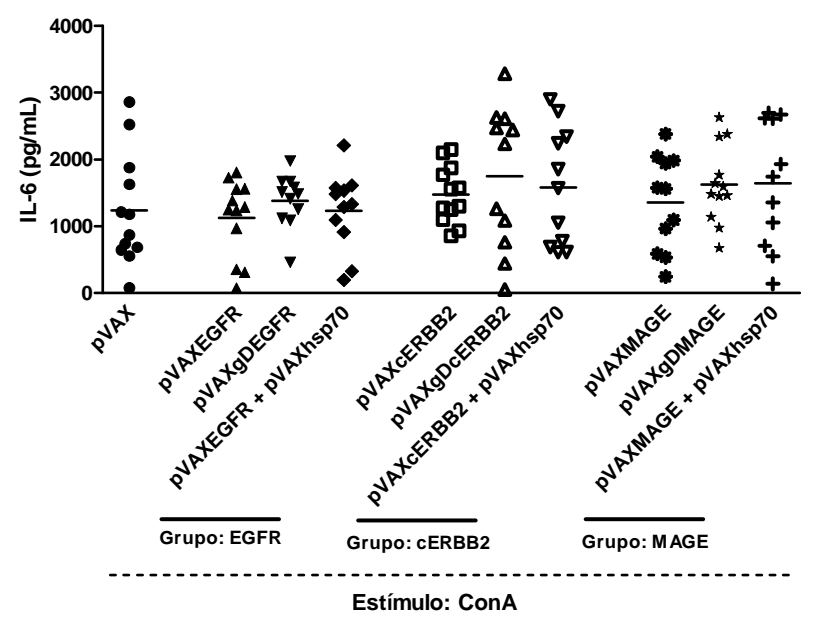

C

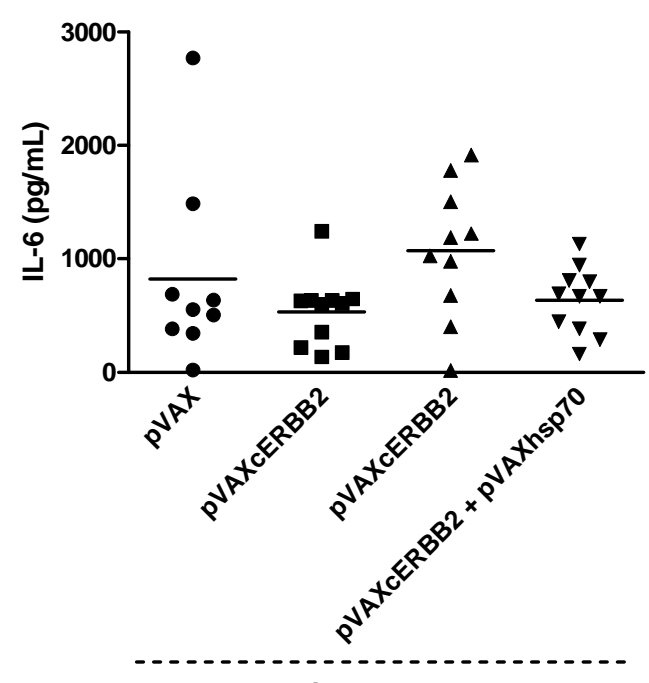

B

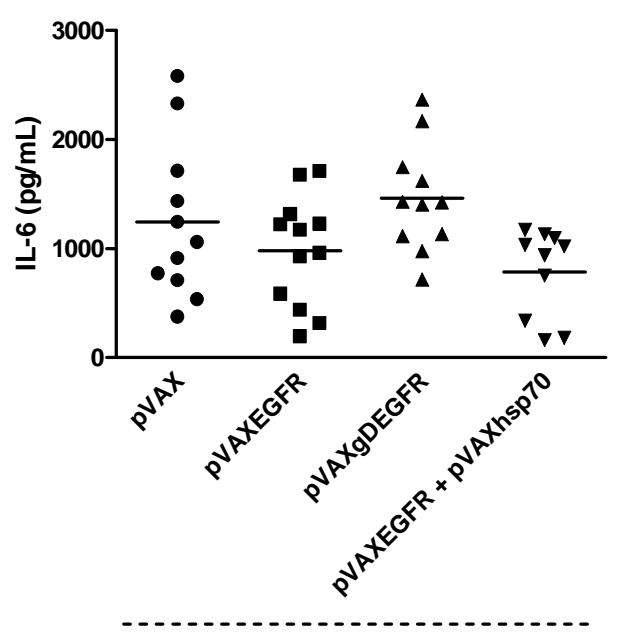

Estímulo: EGFR

D

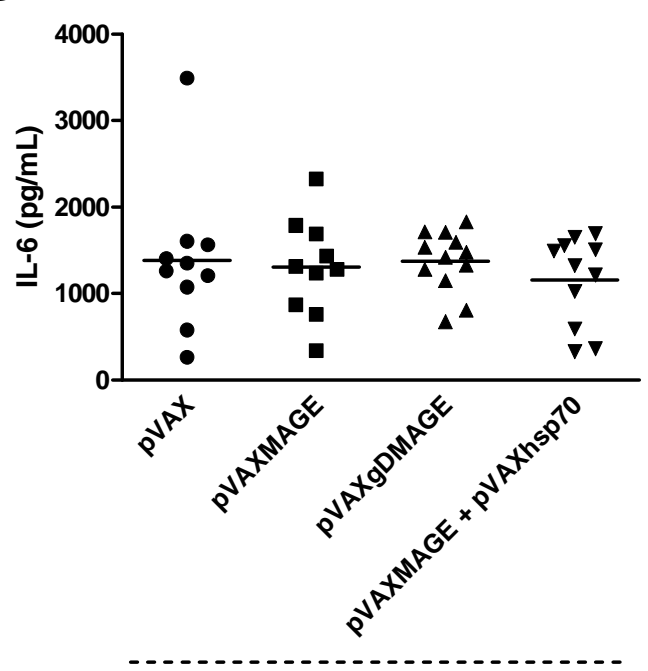

Estímulo: MAGE

Figura 78: Produção de IL-6. Os animais foram imunizados com três doses de 100 $\mu$ ge cada DNA, as células do baço foram obtidas 20 dias após a última imunização e estimuladas ex vivo por 48 horas. A produção de IL-6 foi quantificada por ELISA no sobrenadante da cultura. Resultado dos dois experimentos realizados para esse protocolo (12 animais); a análise estatística foi realizada por ANOVA com o teste de múltipla comparação de Tukey, p $<0,05$. A) Células estimuladas com ConA. B) Células estimuladas com a proteína recombinante EGFRvIII. C) Células estimuladas com a proteína recombinante cERBB2. D) Células estimuladas com a proteína recombinante MAGE. Os níveis basais de IL-6, quando quantificáveis, nas células não estimuladas foram descontados dos estímulos ConA, EGFRvIII, cERBB2 e MAGE. EGFR = EGFRvIII. 
As células dos animais vacinados quando estimuladas com ConA produzem IL-6 (Figura 78A) independente da vacina utilizada na imunização. As células dos animais imunizados com as diferentes vacinas incluindo o vetor pVAX, quando estimuladas com a proteína recombinante específica produziram IL-6 em quantidades semelhantes (Figura 78B, C e D), sem diferenças estatísticas entre os grupos.

As células quando estimuladas com ConA produzem IL-5 (dados não mostrados) independente da vacina utilizada na imunização, assim como nas demais citocinas avaliadas. Ao contrário, os níveis de IL-12 não foram detectáveis na presença desse estímulo. As citocinas IL-5 e IL-12 não foram detectadas quando as células foram estimuladas com as proteínas EGFRvIII, cERBB2 e MAGE.

\subsection{Proliferacão de linfócitos $T$}

A produção da citocina IL-2 (fator de crescimento para células T) também foi avaliada no sobrenadante da cultura de células do baço dos animais imunizados após estímulo ex vivo com ConA ou com as proteínas recombinantes EGFRvIII, cERBB2 e MAGE. No entanto, o tempo de coleta do sobrenadante após o estímulo foi de 24 horas. As células foram obtidas 20 dias após a última imunização. A citocina foi quantificada por ELISA no sobrenadante das culturas. Como controle negativo foi utilizado sobrenadante de células não estimuladas.

O sobrenadante das células do baço dos animais imunizados com as diferentes construções vacinais quando estimuladas com ConA continha a citocina IL-2 independente da vacina utilizada (dados não mostrados). Entretanto, o sobrenadante dessas mesmas células estimuladas com as proteínas recombinantes não apresentou níveis detectáveis de IL-2.

\subsection{Fenótipo celular}

O fenótipo das células estimuladas ex vivo com ConA ou com as proteínas recombinantes após 24 horas foi analisado por citometria de fluxo. As células, obtidas 20 dias após a última imunização, foram estimuladas e avaliadas com relação à expressão dos marcadores de superfície celular CD4, CD8, CD44 e CD62L (Figuras 79 a 84). Células não estimuladas foram utilizadas como controle negativo. 

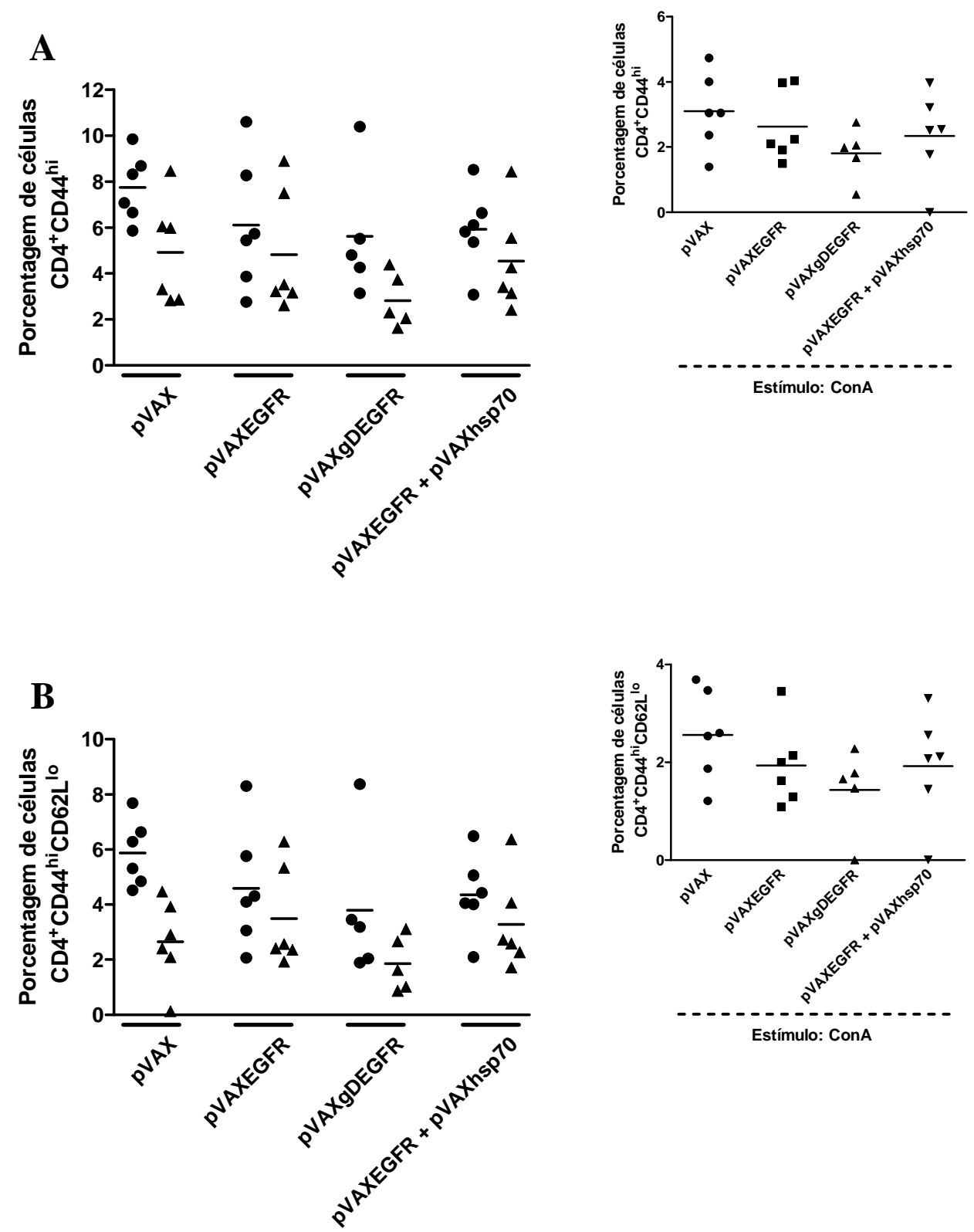

Figura 79: Porcentagem de células CD4 ativadas e de memória efetora nos grupos EGFR. Os animais foram imunizados com três doses de $100 \mu \mathrm{g}$ de cada DNA, as células do baço foram obtidas 20 dias após a última imunização e estimuladas ex vivo por 24 horas. O fenótipo das células estimuladas foi determinado pela marcação com anti-CD4, anti-CD44 e anti-CD62L e pela analise por citometria de fluxo. Resultado do segundo experimento realizado para esse protocolo (6 animais). A análise estatística foi realizada por ANOVA com o teste de múltipla comparação de Tukey, $\mathrm{p}<0,05$. Gráfico maior, células provenientes da cultura sem estímulo (•) ou estimulada com a proteína recombinante EGFRvIII $(\boldsymbol{\Delta})$, gráfico menor, células provenientes da cultura estimulada com ConA. A) Porcentagem de células CD4 ativadas (CD4 ${ }^{+}$CD44 $\left.{ }^{\text {hi }}\right)$ B) Porcentagem de células CD4 de memória efetora $\left(\mathrm{CD} 4{ }^{+} \mathrm{CD} 44^{\mathrm{hi}} \mathrm{CD} 62 \mathrm{~L}^{\mathrm{lo}}\right)$. Os dois fenótipos foram avaliados dentro da gate de linfócitos; hi = high/lo = low. EGFR = EGFRvIII. 

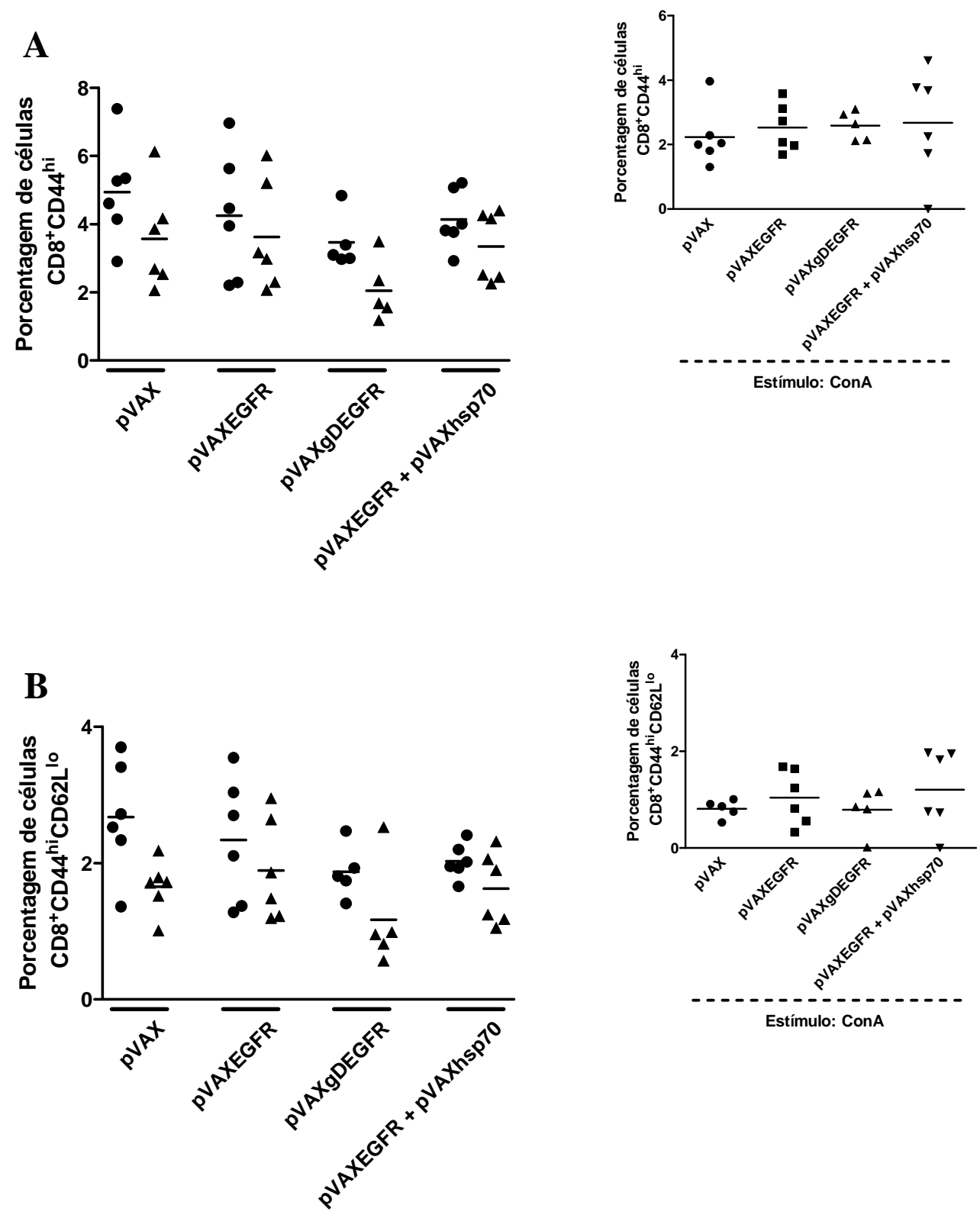

Figura 80: Porcentagem de células CD8 ativadas e de memória efetora nos grupos EGFR. Os animais foram imunizados com três doses de $100 \mu \mathrm{g}$ de cada DNA, as células do baço foram obtidas 20 dias após a última imunização e estimuladas ex vivo por 24 horas. O fenótipo das células estimuladas foi determinado pela marcação com anti-CD8, anti-CD44 e anti-CD62L e pela analise por citometria de fluxo. Resultado do segundo experimento realizado para esse protocolo (6 animais). A análise estatística foi realizada por ANOVA com o teste de múltipla comparação de Tukey, $\mathrm{p}<0,05$. Gráfico maior, células provenientes da cultura sem estímulo (•) ou estimulada com a proteína recombinante EGFRvIII $(\boldsymbol{\Delta})$, gráfico menor, células provenientes da cultura estimulada com ConA. A) Porcentagem de células CD8 ativadas $\left(C D 8^{+}\right.$CD44 $\left.\left.{ }^{\mathrm{hi}}\right) \mathbf{B}\right)$ Porcentagem de células CD8 de memória efetora $\left(\mathrm{CD} 8{ }^{+} \mathrm{CD} 44^{\mathrm{hi}} \mathrm{CD} 62 \mathrm{~L}^{\mathrm{lo}}\right)$. Os dois fenótipos foram avaliados dentro da gate de linfócitos; hi = high/lo = low. EGFR = EGFRvIII.

A cultura quando estimulada com ConA apresentou pequena porcentagem de células CD4 e CD8 ativadas (CD44 ${ }^{\mathrm{hi}}$ ) (Figuras 79A e 80A, gráficos menores) e de memória efetora $\left(\mathrm{CD} 44^{\mathrm{hi}} \mathrm{CD} 62 \mathrm{~L}^{\mathrm{lo}}\right.$ ) (Figura 79B e 80B, gráficos menores) para todos os grupos analisados. A 
cultura estimulada com a proteína recombinante EGFRvIII também apresentou pequena porcentagem dessas células e sem diferenças com relação as células não estimuladas (Figuras 79 e 80 , gráficos maiores).
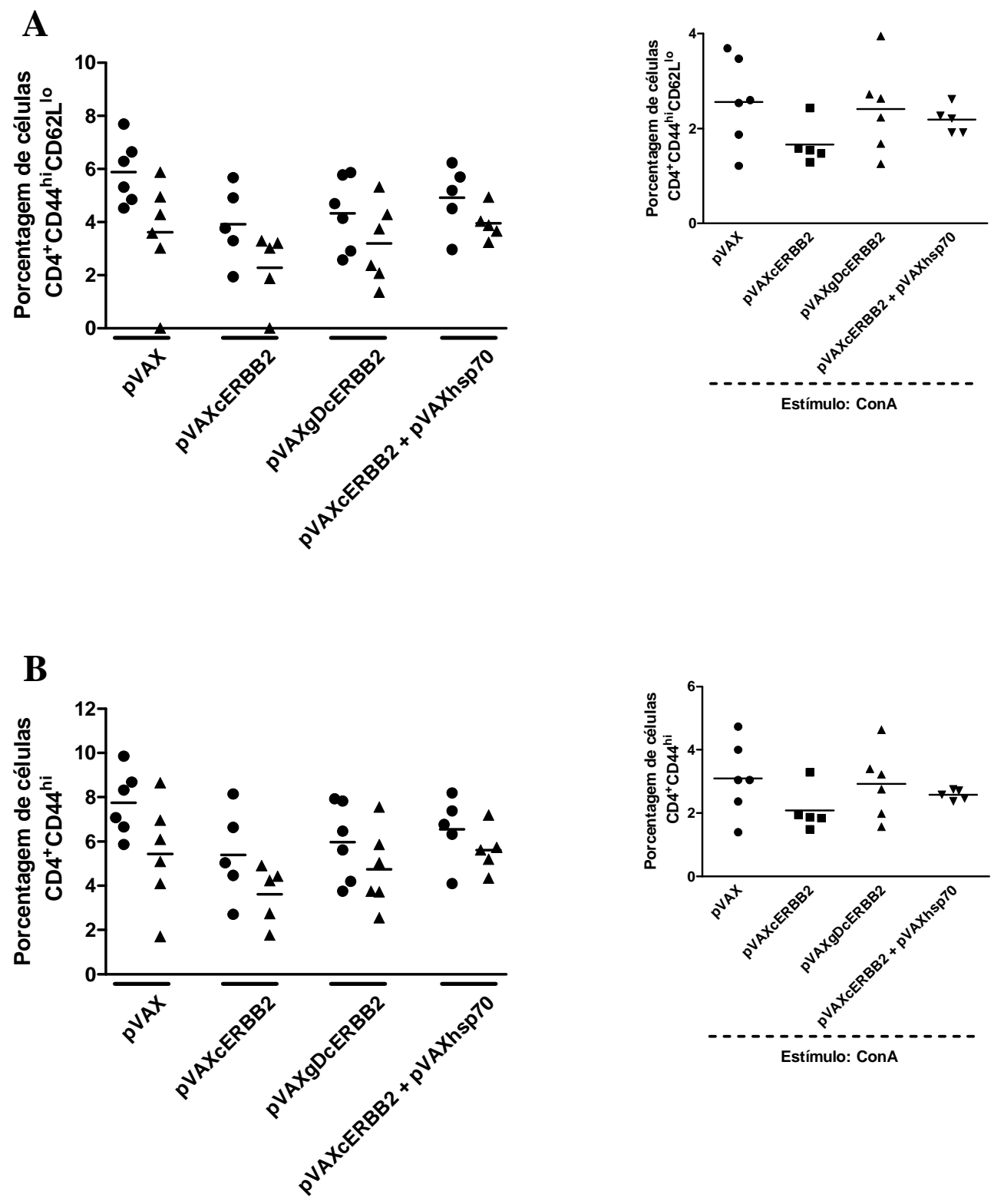

Figura 81: Porcentagem de células CD4 ativadas e de memória efetora nos grupos cERBB2. Os animais foram imunizados com três doses de $100 \mu \mathrm{g}$ de cada DNA, as células do baço foram obtidas 20 dias após a última imunização e estimuladas ex vivo por 24 horas. O fenótipo das células estimuladas foi determinado pela marcação com anti-CD4, anti-CD44 e anti-CD62L e pela analise por citometria de fluxo. Resultado do segundo experimento realizado para esse protocolo (6 animais). A análise estatística foi realizada por ANOVA com o teste de múltipla comparação de Tukey, $\mathrm{p}<0,05$. Gráfico maior, células provenientes da cultura sem estímulo (•) ou estimulada com a proteína recombinante cERBB2 $(\boldsymbol{\Delta})$, gráfico menor, células provenientes da cultura estimulada com ConA. A) Porcentagem de células CD4 ativadas (CD4 $\left.\left.{ }^{+} \mathrm{CD} 44^{\mathrm{hi}}\right) \mathbf{B}\right)$ Porcentagem de células CD4 de memória efetora $\left(\mathrm{CD} 4{ }^{+} \mathrm{CD} 44^{\mathrm{hi}} \mathrm{CD} 62 \mathrm{~L}^{\mathrm{lo}}\right)$. Os dois fenótipos foram avaliados dentro da gate de linfócitos; hi = high/lo = low. 

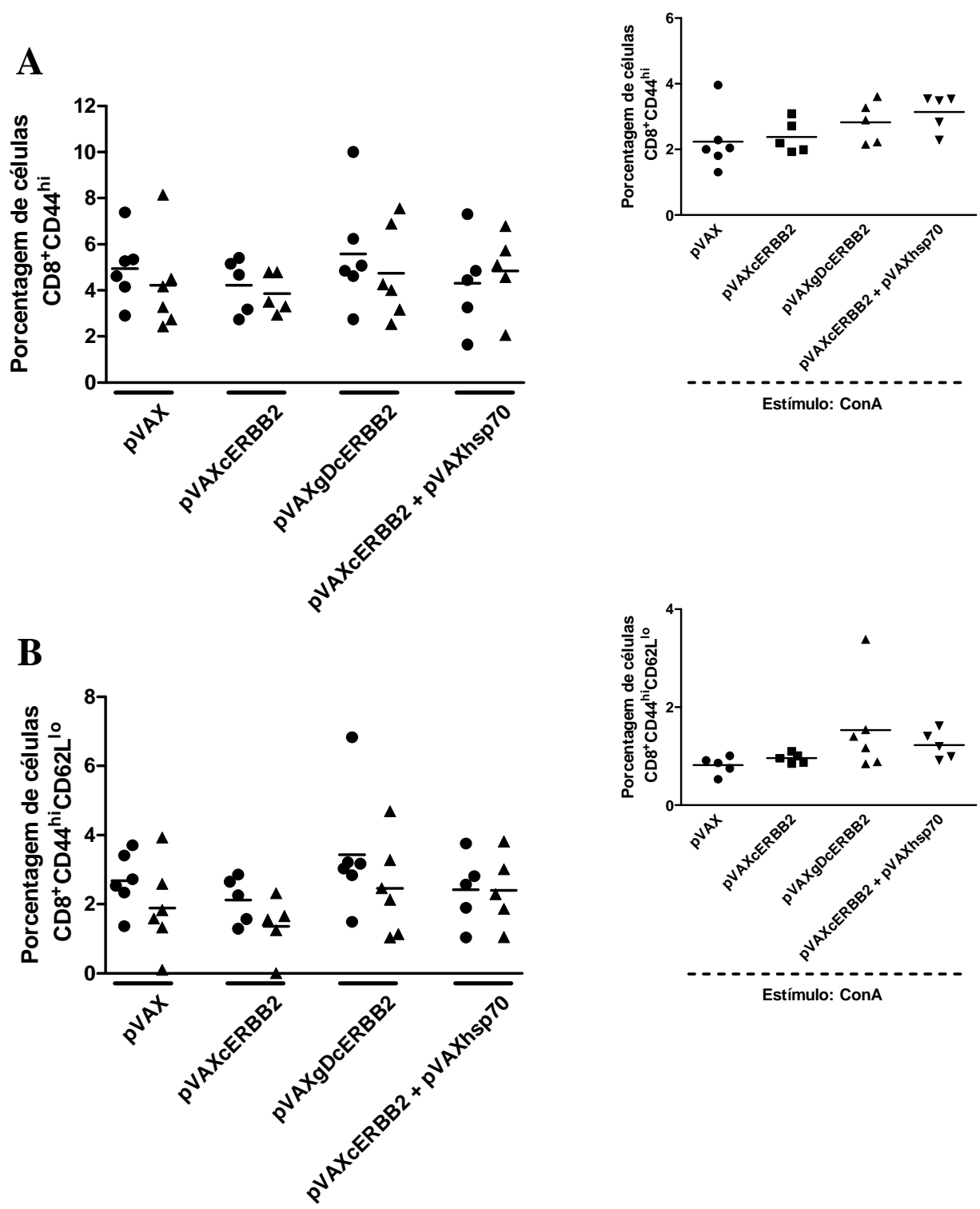

Figura 82: Porcentagem de células CD8 ativadas e de memória efetora nos grupos cERBB2. Os animais foram imunizados com três doses de $100 \mu \mathrm{g}$ de cada DNA, as células do baço foram obtidas 20 dias após a última imunização e estimuladas ex vivo por 24 horas. O fenótipo das células estimuladas foi determinado pela marcação com anti-CD8, anti-CD44 e anti-CD62L e pela analise por citometria de fluxo. Resultado do segundo experimento realizado para esse protocolo (6 animais). A análise estatística foi realizada por ANOVA com o teste de múltipla comparação de Tukey, $\mathrm{p}<0,05$. Gráfico maior, células provenientes da cultura sem estímulo $(\bullet)$ ou estimulada com a proteína recombinante $\operatorname{cERBB} 2(\mathbf{\Lambda})$, gráfico menor, células provenientes da cultura estimulada com ConA. A) Porcentagem de células CD8 ativadas (CD8 $\left.{ }^{+} \mathrm{CD} 44^{\text {hi }}\right)$ B) Porcentagem de células CD8 de memória efetora $\left(\mathrm{CD} 8{ }^{+} \mathrm{CD} 44^{\mathrm{hi}} \mathrm{CD} 62 \mathrm{~L}^{\mathrm{lo}}\right)$. Os dois fenótipos foram avaliados dentro da gate de linfócitos; hi $=$ high/lo $=$ low.

A cultura quando estimulada com ConA apresentou pequena porcentagem de células CD4 e CD8 ativadas (CD44 ${ }^{\text {hi }}$ (Figura 81A e 82A, gráficos menores) e de memória efetora $\left(\mathrm{CD} 44^{\text {hi }} \mathrm{CD}^{2} \mathrm{~L}^{\text {lo }}\right.$ ) (Figura 81B e 82B, gráficos menores) para todos os grupos analisados. A 
cultura estimulada com a proteína recombinante cERBB2 também apresentou pequena porcentagem dessas células e sem diferenças com relação as células não estimuladas (Figuras 81 e 82 , gráficos maiores).
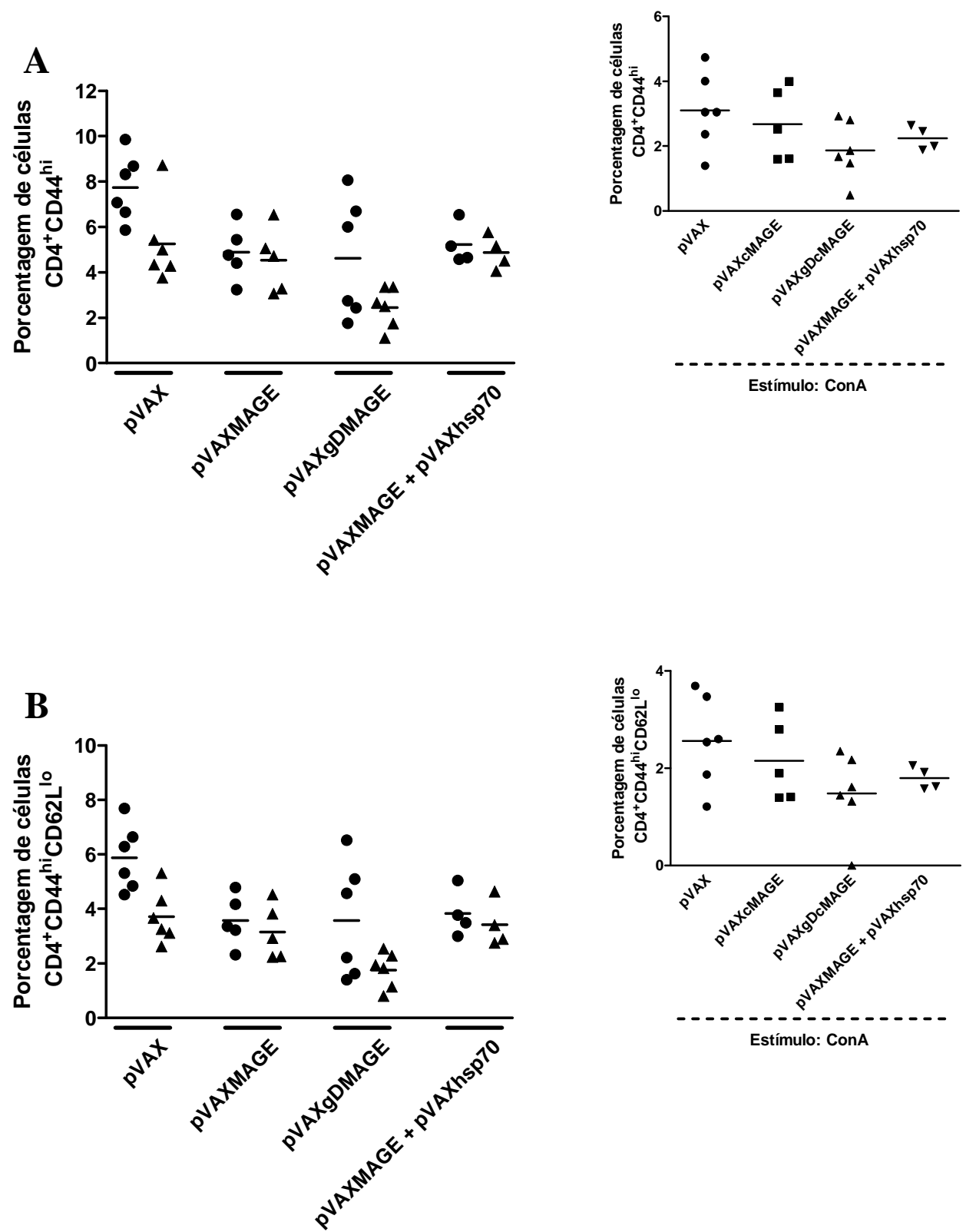

Figura 83: Porcentagem de células CD4 ativadas e de memória efetora nos grupos MAGE. Os animais foram imunizados com três doses de $100 \mu \mathrm{g}$ de cada DNA, as células do baço foram obtidas 20 dias após a última imunização e estimuladas ex vivo por 24 horas. O fenótipo das células estimuladas foi determinado pela marcação com anti-CD4, anti-CD44 e anti-CD62L e pela analise por citometria de fluxo. Resultado do segundo experimento realizado para esse protocolo (6 animais). A análise estatística foi realizada por ANOVA com o teste de múltipla comparação de Tukey, $\mathrm{p}<0,05$. Gráfico maior, células provenientes da cultura sem estímulo $(\bullet)$ ou estimulada com a proteína recombinante $\operatorname{MAGE}(\boldsymbol{\Delta})$, gráfico menor, células provenientes da cultura estimulada com ConA. A) Porcentagem de células CD4 ativadas (CD4 $\left.4^{+} \mathrm{CD} 44^{\text {hi }}\right)$ B) Porcentagem de células CD4 de memória efetora $\left(\mathrm{CD} 4{ }^{+} \mathrm{CD} 44{ }^{\mathrm{hi}} \mathrm{CD} 62 \mathrm{~L}^{\mathrm{lo}}\right)$. Os dois fenótipos foram avaliados dentro da gate de linfócitos; hi = high/lo = low. 

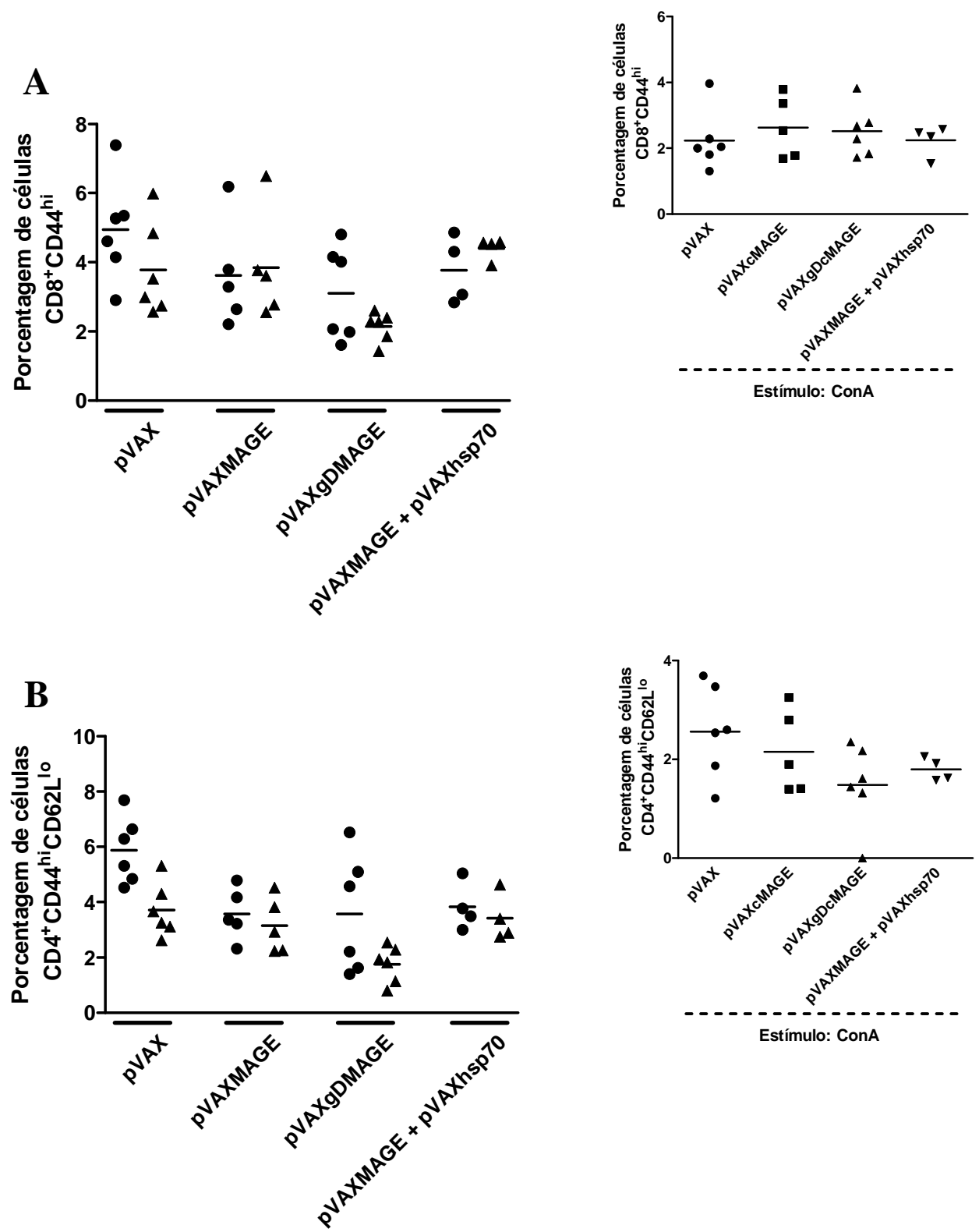

Figura 84: Porcentagem de células CD8 ativadas e de memória efetora nos grupos MAGE. Os animais foram imunizados com três doses de $100 \mu \mathrm{g}$ de cada DNA, as células do baço foram obtidas 20 dias após a última imunização e estimuladas ex vivo por 24 horas. O fenótipo das células estimuladas foi determinado pela marcação com anti-CD8, anti-CD44 e anti-CD62L e pela analise por citometria de fluxo. Resultado do segundo experimento realizado para esse protocolo (6 animais). A análise estatística foi realizada por ANOVA com o teste de múltipla comparação de Tukey, $\mathrm{p}<0,05$. Gráfico maior, células provenientes da cultura sem estímulo $(\bullet)$ ou estimulada com a proteína recombinante MAGE $(\boldsymbol{\Delta})$, gráfico menor, células provenientes da cultura estimulada com ConA. A) Porcentagem de células CD8 ativadas $\left(C D 8^{+} C D 44^{\text {hi }}\right)$ B) Porcentagem de células CD8 de memória efetora $\left(\mathrm{CD} 8{ }^{+} \mathrm{CD} 44^{\mathrm{hi}} \mathrm{CD} 62 \mathrm{~L}^{\mathrm{lo}}\right)$. Os dois fenótipos foram avaliados dentro da gate de linfócitos; hi = high/lo = low.

A cultura quando estimulada com ConA apresentou pequena porcentagem de células CD4 e CD8 ativadas (CD44hi) (Figuras 83A e 84A, gráficos menores) e de memória efetora 
$\left(\mathrm{CD} 44^{\text {hi }} \mathrm{CD} 62 \mathrm{~L}^{\text {lo }}\right.$ ) (Figura 83B e 84B, gráficos menores) para todos os grupos analisados. A cultura estimulada com a proteína recombinante MAGE também apresentou pequena porcentagem dessas células e sem diferenças com relação às células não estimuladas (Figura 83 e 84 , gráficos maiores).

Como resultado, então, dos experimentos de imunogenicidade realizados em camundongos, cujo objetivo era avaliar o tipo de resposta induzido pelas vacinas de DNA, obtivemos um padrão de resposta Th1, com produção de IFN- $\gamma$ e IL-10 pelas células reestimuladas, no grupo vacinado com pVAXgDGLEA. A imunização com pVAXGLEA + pVAXhsp70 também induziu células produtoras de IFN- $\gamma$ e IL-10 após o re-estímulo, embora em menor proporção, mas nos levou a utilizar a proteína imunomoduladora Hsp70, além da $\mathrm{gD}$, nas demais imunizações. As vacinas pVAXgDEGFRvIII e pVAXgDMAGE também induziram o mesmo padrão de resposta com produção de IFN- $\gamma$ e IL-10 pelas células reestimuladas. A resposta de anticorpos foi pequena nesses grupos e não foi possível caracterizar as células de memória com os marcadores de superfície utilizados. 


\subsection{DISCUSSÃO}

A terapia tumoral com tratamentos localizados como a radioterapia é altamente efetiva em destruir um grande número de células no tumor primário, no entanto, não trata metástase e não assegura a eliminação de uma recorrência. É nesse contexto, então, de tumores pequenos, câncer disseminado e reaparecimento de células tumorais que a imunoterapia contra os tumores é mais efetiva. Essas características já são suficientes para indicar que ambas as terapias sejam trabalhadas juntas, entretanto, a terapia localizada tem atraído ainda mais o uso da imunoterapia, por destruir o tumor de forma a criar um ambiente imunogênico (Reits et al., 2006; Lugade et al., 2008). Os grandes desafios agora para os imunologistas de tumores são: determinar melhor todos os mecanismos da resposta imunológica que podem contribuir para uma resposta protetora e, aprimorar esses mecanismos efetores por meio de estratégias que sejam específicas contra os tumores. Para o GBM os desafios são ainda maiores devido à grande heterogeneidade genética desse tumor e o microambiente altamente imunossupressor que o torna um tumor com um dos piores prognósticos e invariavelmente fatal.

Nesse contexto, então, da necessidade de integrar diferentes terapias para o tratamento do GBM, superando os desafios da heterogeneidade e supressão, o objetivo desse trabalho foi a construção de vacinas de DNA contendo os genes EGFRvIII, cERBB2, MAGE e GLEA que codificam antígenos tumorais de GBM e os genes das proteínas imunomoduladoras gD, hsp70 e gp96 capazes de ativar a resposta imunológica inata, importante no direcionamento da resposta adaptativa contra as proteínas tumorais. O intuito é desenvolver uma imunoterapia eficiente para tratar o GBM de vários pacientes juntamente com as terapias convencionais. Acredita-se que o desenvolvimento de uma resposta imunológica específica contra os antígenos tumorais pode resultar em uma resposta contra o tumor que proteja de uma recorrência.

A proposta foi, então, construir as vacinas separadas, cada uma contendo um dos genes citados acima, e nos testes de imunogenicidade combiná-las usando um antígeno e uma proteína imunomoduladora. A única exceção foi com relação ao gene que codifica a gD que foi fusionado separadamente a cada antígeno para construção das vacinas contendo essa proteína. Trabalhos que utilizam essa proteína para ativar o sistema imunológico fusionam os antígenos de interesse em seu interior, na forma de vacinas de DNA (Lásaro et al., 2003; Lasaro et al., 2005; Lasaro et al., 2008; Rios, 2009; Diniz et al., 2010). 
Inicialmente quando se propõe um projeto de desenvolvimento de vacinas é preciso pensar que elas serão testadas e que o resultado desse teste precisa ser avaliado/medido. A avaliação, na maioria das vezes, precisa ocorrer primeiro em um modelo de imunogenicidade para verificar se as vacinas são capazes de desencadear uma resposta imunológica ou em um modelo experimental da doença, no qual se avalia se a vacina foi capaz de proteger ou tratar a doença. No caso de avaliar a imunogenicidade desencadeada por vacinas, que é um dos objetivos desse trabalho, é necessário, após a vacinação, fazer um segundo estímulo (reestímulo ou desafio) com o antígeno da vacina para verificar se ela foi eficaz em gerar moléculas e células protetoras específicas a esse antígeno. Dessa forma, além da construção das vacinas de DNA com os antígenos tumorais, foi preciso produzir as proteínas tumorais, a partir dos genes citados acima, para serem utilizadas como re-estímulo.

Entretanto, as proteínas tumorais foram produzidas não somente para serem utilizadas como um segundo estímulo, mas também para serem empregadas na imunização de camundongos para a produção de anticorpos contra elas. Isso porque uma das caracterizações das vacinas de DNA construídas é avaliar se o gene presente nelas codifica a proteína de interesse e para isso são utilizados anticorpos específicos contra a proteína. Assim, como também foram construídas as vacinas contendo os genes gp96 e hsp70, foi necessária a produção dessas proteínas para posterior caracterização das vacinas de DNA. Elas não foram utilizadas como re-estímulo, pois a resposta que se quer avaliar é contra os antígenos tumorais, mas foram usadas na produção de anticorpos.

Nesse contexto, como os genes, EGFRvIII, cERBB2, MAGE, GLEA e gp96, seriam usados na construção das diversas vacinas e dos vetores de expressão foi preciso combinar os objetivos em uma única estratégia para desenvolver o projeto. O primeiro passo foi escolher o sistema de expressão das moléculas de interesse. O sistema inicialmente escolhido foi o de produção dos antígenos tumorais e das proteínas imunomoduladoras na levedura K. lactis. Nesse sistema o gene que codifica a proteína de interesse pode ser clonado após a sequência de um peptídeo sinal no vetor pKLAC1 (Anexo 1), o que direciona a proteína de fusão expressa para o caminho secretório da levedura. A proteína sofre ação de proteases no retículo endoplasmático e complexo de golgi, resultando na secreção da proteína no meio de cultura, sem o peptídeo sinal. A expressão da proteína é regulada pelo forte promotor K. lactis LAC4 e, como a inserção no genoma da levedura é por recombinação homóloga, pode haver inclusão de mais de uma cópia da sequência da proteína de fusão, o que aumentaria ainda mais a expressão da molécula de interesse. 
Esse sistema de expressão é interessante pela grande quantidade de proteína expressa na forma secretada, mas, é ainda mais importante, pela expressão de proteínas na ausência de LPS, um componente da parede celular de bactérias gram-negativas como a E. coli, muito utilizada na expressão de proteínas recombinantes. Proteínas ou qualquer molécula contaminada com LPS podem ter sua imunogenicidade alterada, pois essa endotoxina é reconhecida pelo receptor TLR4 (Kawai e Akira, 2011) presente na superfície de células do sistema imunológico. O TLR4 pode sinalizar por dois caminhos distintos, um culmina na

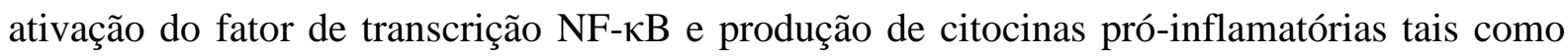
TNF- $\alpha$ e IL-6 (Takeuchi e Akira, 2010) e o outro, sinalizando via o fator de transcrição IRF3, com consequente produção de IFNs do tipo I, o que ocorre quando o complexo receptor-LPS é internalizado dentro de endossomos (Kawai e Akira, 2011).

No entanto, apesar das vantagens desse sistema, as modificações pós-traducionais realizadas nas proteínas produzidas em levedura podem diferir daquelas dos organismos eucariotos superiores. As glicoproteínas, por exemplo, apresentam carboidratos ligados aos resíduos de serina ou treonina (O-glicosilação) e/ou aos resíduos de asparagina (Nglicosilação) (David L. Nelson, 2002) e podem apresentar grandes diferenças dependendo do organismo que as produzem. A glicosilação realizada pela maquinaria celular das leveduras consiste principalmente de cadeias formadas por manoses (Kukuruzinska, Bergh e Jackson, 1987), diferentemente das encontradas em organismos eucariotos superiores que são compostas por uma variedade de monossacarídeos (David L. Nelson, 2002). As manoses adicionadas nos resíduos de asparagina (N-glicosilação) podem variar de 9 a 200 resíduos, ao contrário, nos resíduos de serina ou treonina as cadeias são pequenas, normalmente não excedem 5 resíduos de manose (Kukuruzinska, Bergh e Jackson, 1987). Dessa forma, é interessante a retirada desses pontos de $\mathrm{N}$-glicosilação, que pode ser feita por mutação na sequência de nucleotídeos ou utilizando-se endoglicosidases que retiram carboidratos inteiros da glicoproteína. Além da eliminação das $\mathrm{N}$-glicosilações, é também importante a retirada do peptídeo sinal das proteínas que apresentem essa sequência, uma vez que o sistema escolhido na expressão das proteínas de interesse já disponibiliza esse domínio, como discutido acima.

Diante disso, os antígenos tumorais e as proteínas imunomoduladoras foram avaliados com relação à presença de peptídeo sinal e N-glicosilação. A sequência de aminoácidos das moléculas escolhidas para esse projeto foram obtidas no GenBank (NCBI) e avaliada utilizando-se os programas SignalP 3.0 Server e NetNGlyc 1.0 Server. Apenas a proteína gp96 apresentava peptídeo sinal que foi removido e as proteínas EGFRvIII, cERBB2, GLEA 
e gp96 apresentavam sítios de N-glicosilação que foram modificados na sequência de nucleotídeos, também obtida no GenBank. Todas as modificações foram realizadas in silico. A sequência de aminoácidos da proteína $\mathrm{gD}$ não foi modificada para não alterar sua função, mesmo porque ela não seria usada na expressão da proteína, apenas para construção das vacinas de DNA. A sequência de nucleotídeos da Hsp70 foi cedida já sintetizada pela empresa Farmacore Biotecnologia Ltda.

Após as modificações nas sequências de nucleotídeos dos genes EGFRvIII, cERBB2, MAGE e GLEA para retirada das N-glicosilações, elas foram inseridas no interior da sequência gênica da $\mathrm{gD}$, uma das proteínas imunomoduladoras utilizadas nesse trabalho para a construção das vacinas de DNA. A gD apresenta sítios únicos de restrição para as enzimas PvuII e ApaI onde podem ser inseridos fragmentos que codificam até 300 aminoácidos, sem interferência com seu transporte e ancoramento na membrana (Watson et al., 1982). A sequência de nucleotídeo dos antígenos tumorais foi inserida entre os sítios PvuII e ApaI com a retirada da porção central da $\mathrm{gD}, 642 \mathrm{pb}$ (214 aas, do aa 54 ao 267).

Como nenhum fragmento maior que 300 aas havia sido inserido no interior da $\mathrm{gD}$, apenas os 300 aas iniciais das proteínas EGFRvIII e cERBB2, ou seja, os 900pb iniciais dos genes foram utilizados na construção das vacinas de DNA. Como essas proteínas são utilizadas apenas como antígenos, acredita-se que 300 aas contenham muitos epitopos que possam ser reconhecidos por células específicas. Na proteína EGFRvIII, o fragmento utilizado inclui o peptídeo PEPvIII, utilizado em triagens clínicas (Heimberger et al., 2006; Sampson et al., 2008). A proteína MAGE foi utilizada inteira, pois apresentava apenas 314 aas e a proteína GLEA, com 543 aas, também foi usada de forma completa, na tentativa de verificar se é possível inserir fragmentos maiores no interior da $\mathrm{gD}$ e por ser um antígeno específico de gliomas. Isso não foi adotado para as proteínas EGFRvIII, de 918 aas e cERBB2, de 1225 aas, por serem sequências muito grandes que poderiam interferir com as funções da gD. Assim, obtivemos as sequências gDEGFRvIII, gDcERBB2, gDMAGE, gDGLEA e gp96 (não fusionada a gD) modificadas in silico.

Essas sequências seriam, então, sintetizadas in vitro, utilizadas na construção das vacinas de DNA no vetor pVAX1 e usadas como molde para obtenção dos genes EGFRvIII, cERBB2, MAGE, GLEA e gp96 para expressão em levedura. Como as mesmas sequências seriam usadas para ambas as construções, das vacinas e vetores de expressão, a retirada das $\mathrm{N}$-glicosilações causou uma preocupação quanto ao prejuízo na função de cada proteína nas 
vacinas de DNA, uma vez que as modificações pós-traducionais podem ser importantes no papel dessas moléculas. No entanto, as únicas proteínas certamente glicosiladas são a EGFRvIII que é uma variante da EGFR que possui 10 domínios extracelulares glicosilados (Wu et al., 2006) e a gp96 que é uma glicoproteína. Como a EGFRvIII seria usada apenas como antígeno, a preocupação ficou focada na gp96 cuja função seria importante no desenvolvimento da resposta imunológica.

Outra preocupação foi com relação aos epitopos das proteínas tumorais que poderiam ser modificados pela troca de aminoácidos para que a glicosilação não ocorresse (asparagina pela glutamina). As moléculas de MHC apresentam especificidade muito ampla na ligação com peptídeos e interagem com diferentes antígenos que possuem características estruturais comuns (Abul K. Abbas, 2005). A ligação peptídeo-MHC ocorre por meio de interações nãocovalentes entre os aminoácidos das duas moléculas e as cadeias laterais presentes nesses aminoácidos também podem participar da interação (Abul K. Abbas, 2005). Como a mudança foi entre aminoácidos de mesma característica (polar neutro) e estrutura semelhante, não acreditamos que a ligação peptídeo-MHC fosse prejudicada.

No entanto, o reconhecimento dos antígenos pelo TCR é regulado por uma fina especificidade (Abul K. Abbas, 2005). Acredita-se que as células T distinguem diversos antígenos baseadas apenas na diferença de poucos aminoácidos (Abul K. Abbas, 2005). Além disso, poucos resíduos do peptídeo são responsáveis pela especificidade no reconhecimento do antígeno (Abul K. Abbas, 2005). Dessa forma, apesar de poucas alterações na composição de cada antígeno tumoral, é possível que a mudança nos aminoácidos interfira no reconhecimento do fragmento que contem a modificação.

O vetor pVAX1, que seria utilizado no desenvolvimento das vacinas de DNA, foi construído segundo as normas da FDA (Food and Drugs Administration). Esse plasmídio apresenta o promotor do citomegalovírus humano (CMV), para eficiente expressão em células de mamíferos; sinais de poliadenilação, para eficiente terminação da transcrição; sinais de poliadenilação do RNA mensageiro e o gene de resistência ao antibiótico canamicina para seleção em E. coli. No entanto, é um vetor transcricional, desenhado para expressão de genes que contenham sua própria sequência Kozak, que é uma sequência consenso, reconhecida pelo ribossomo como o sítio inicial da tradução da proteína (Kozak, 1990). Dessa forma, além dessa sequência, os fragmentos precisavam conter seu próprio stop códon e sítios 
reconhecidos por enzimas de restrição compatíveis com o sítio de múltipla clonagem do vetor pVAX.

Assim, as sequências gDEGFRvIII, gDcERBB2, gDMAGE, gDGLEA e gp96 foram avaliadas com relação a presença da sequência Kozak e do stop códon que foram acrescentados, quando ausentes, juntamente com os sítios de enzimas de restrição no início e final de cada fragmento para clonagem no pVAX. Após todas as modificações descritas acima, as sequências foram sintetizadas in vitro e clonadas no vetor pBluescript II SK (pBSK) pela empresa Epoch Biolabs gerando os plasmídios pBSKgDEGFRvIII, pBSKgDcERBB2, pBSKgDMAGE, pBSKgDGLEA e pBSKgp96.

Esses plasmídios foram clivados e os fragmentos gDEGFRvIII, gDcERBB2, gDMAGE, gDGLEA e gp96 clonados no vetor pVAX utilizando-se técnicas de biologia molecular. As enzimas escolhidas para essa montagem foram NheI e XbaI que poderiam ser usadas para todos os fragmentos e para o plasmídio pVAX e cujos sítios foram inseridos nas sequências como descrito no parágrafo acima. No entanto, a clivagem com essas enzimas geram sitos coesivos que podem promover a ligação do plasmídio sem o inserto de interesse. Dessa forma, antes de qualquer clonagem e após a clivagem do vetor pVAX, foi necessária a desfosforilação desse plasmídio que consiste na retirada dos grupos fosfatos das extremidades 5' do DNA impedindo que essa molécula se ligue sozinha.

As clonagens no vetor pVAX resultaram na construção das vacinas pVAXgDEGFRvIII, pVAXgDcERBB2, pVAXgDMAGE, pVAXgDGLEA e pVAXgp96. A confirmação das clonagens foi realizada por PCR e análise de restrição. Foram utilizados oligonucleotídeos e enzimas que pudessem confirmar a presença e direção do inserto uma vez que as extremidades coesivas das enzimas utilizadas permitem a clonagem em qualquer direção. Em seguida, foi realizado o sequenciamento de um clone de cada vacina de DNA construída para confirmação da clonagem. O sequenciamento confirmou as clonagens, mas erros foram observados nas sequências, alguns foram corrigidos com a análise do eletroferograma, no entanto, como essas sequências foram sintetizadas e não amplificadas, não houve uma preocupação maior. Acredita-se que alguns erros podem ocorrer devido aos vários parâmetros que influenciam a reação de sequenciamento, purificação do DNA, excesso ou falta de material, corrente, temperatura entre outros.

As vacinas pVAXgDEGFRvIII, pVAXgDcERBB2, pVAXgDMAGE e pVAXgDGLEA já apresentavam em sua constituição o antígeno tumoral e uma proteína 
imunomoduladora, no entanto, como a proposta era utilizar as proteínas de choque térmico gp96 e Hsp70 também como moduladores da resposta imunológica aos antígenos, vetores contendo apenas os antígenos tumorais foram construídos para serem combinados a elas.

Os plasmídios pBSKgDEGFRvIII, pBSKgDcERBB2, pBSKgDMAGE, pBSKgDGLEA e pBSKhsp70 (cedido pela empresa Farmacore Biotecnologia Ltda.) foram usados, então, como molde nas novas construções, juntamente com oligonucleotídeos específicos para cada antígeno. Os oligonucleotídeos continham os sítios das enzimas escolhidas para clonagem, NheI e XbaI, a sequência Kozac, o stop códon e parte do gene para amplificação correta das sequências EGFRvIII, cERBB2, MAGE, GLEA e hsp70. Após as amplificações, os fragmentos foram digeridos e purificados diretamente sem avaliação em gel de agarose, pois a clivagem de produtos de PCR elimina fragmentos muito pequenos cuja diferença entre o fragmento não digerido e digerido não é possível de ser avaliada. As sequências EGFRvIII, cERBB2, MAGE, GLEA e hsp70 clivadas foram ligadas ao plasmídio pVAX, sem a presença da sequência da $\mathrm{gD}$, e as clonagens confirmadas por PCR, análise de restrição e sequenciamento.

O sequenciamento confirmou as clonagens, no entanto, erros nas sequências pVAXEGFRvIII e pVAXhsp70 foram observados. Na vacina pVAXEGFRvIII houve a perda de uma trinca de bases no início do gene (e consequentemente de um aminoácido) e a mudança da trinca seguinte, no entanto, a ordem de leitura da proteína após o erro não foi alterada. A sequência correta seria metionina, leucina, ácido glutâmico, acido glutâmico, lisina, lisina, glicina e a sequência modificada ficou, metionina, leucina, ácido glutâmico, acido glutâmico, acido glutâmico, glicina. Na vacina pVAXhsp70 o final do gene apresentou problemas no sequenciamento deixando dúvidas quanto ao stop códon. O oligonucleotídeo BGH hibridiza muito próximo do final do gene, prejudicando o sequenciamento dessa região.

A alteração na proteína EGFRvIII parece mais problemática, pois foi identificada em duas análises feitas por sequenciamento e ela altera um epitopo importante da proteína EGFRvIII (PEPvIII) utilizado em estudos clínicos (Heimberger et al., 2006; Sampson et al., 2008). A presença do stop códon no final do gene da Hsp70 clonado no vetor pVAX pode ser confirmado pela expressão correta dessa proteína em células transfectadas com a vacina pVAXhsp70. Apesar dos problemas encontrados, as clonagens no vetor pVAX sem a sequência da gD resultaram na construção das vacinas pVAXEGFRvIII, pVAXcERBB2, pVAXMAGE, pVAXGLEA e pVAXhsp70. 
O próximo passo do projeto era, então, caracterizar as vacinas de DNA construídas, pVAXgDEGFRvIII, pVAXgDcERBB2, pVAXgDMAGE, pVAXgDGLEA, pVAXgp96, pVAXEGFRvIII, pVAXcERBB2, pVAXMAGE, pVAXGLEA e pVAXhsp70 com relação à expressão das proteínas codificadas por elas. No entanto, para fazer essa avaliação foi preciso obter anticorpos que as reconhecessem. Para tanto, antes de conseguir os anticorpos, foi, então, necessária a produção heteróloga destas proteínas.

Como descrito no início da discussão, o sistema escolhido inicialmente foi a expressão em $K$. lactis devido às vantagens desse sistema de expressão, que confere grande quantidade da proteína na forma secretada sem LPS. Novamente os vetores pBSKgDEGFRvIII, pBSKgDcERBB2, pBSKgDMAGE, pBSKgDGLEA e pBSKgp96 foram usados como molde juntamente com oligonucleotídeos específicos para cada gene. Os oligonucleotídeos apresentavam os sítios das enzimas escolhidas para a clonagem no vetor pKLAC, XhoI e KpnI (BglII, para gp96), uma sequência que codifica o sítio de clivagem para retirada do peptídeo sinal, uma cauda de histidina para purificação das proteínas, um stop códon e parte do gene para amplificação correta das sequências EGFRvIII, cERBB2, MAGE, GLEA e gp96. As sequências amplificadas foram clivadas, clonadas e confirmadas por PCR, análise de restrição e sequenciamento (Anexo 1).

Dessa forma, obtivemos os vetores, pKLACEGFRvIII, pKLACcERBB2, pKLACMAGE, pKLACGLEA e pKLACgp96. Iniciamos os testes de expressão em $K$. lactis com o plasmídio pKLACgp96 que foi utilizado na transformação das leveduras segundo dois protocolos diferentes, o indicado pelo fabricante (K. lactis Protein Expression kit) e por eletroporação. Alguns clones foram testados para expressão da proteína gp96, no entanto, tivemos dificuldades com o sistema de produção da proteína, que foi expressa em pequena quantidade, sendo necessária a precipitação da proteína com ácido tricloroacético (TCA) ou a concentração do meio de cultura onde ela foi secretada. A proteína precipitada com TCA se mostrou difícil de ser solubilizada e, a concentrada, ainda precisou ser purificada, pois componentes do meio de cultura eram concentrados juntamente com a proteína. Apesar das alternativas, houve grande dificuldade em obtermos a proteína em quantidade adequada e pura (Anexo 2).

Assim, outros sistemas de expressão surgiram como alternativa, e novos vetores de expressão foram construídos utilizando-se os plasmídios pcDNA e pET. O pET é um vetor plasmidial usado na expressão de proteínas em E. coli, um sistema simples e bem padronizado 
de expressão de proteínas recombinantes, no entanto, por ser um sistema procarioto não confere modificações pós-traducionais e as proteínas precisam ser avaliadas quanto à presença de LPS. Esse vetor apresenta o promotor T7, para eficiente expressão em bactéria, possui uma sequência de nucleotídeos que codifica uma cauda de histidina no N- e/ou Cterminal para facilitar a purificação da proteína recombinante e o gene de resistência ao antibiótico canamicina. O sistema pET é uma poderosa ferramenta de expressão de proteínas em E. coli que podem representar 50\% do total de proteínas, após poucas horas de indução.

Os vetores pBSKgDEGFRvIII, pBSKgDcERBB2, pBSKgDMAGE, pBSKgDGLEA, pBSKgp96 e pBSKhsp70 foram utilizados como molde na amplificação dos fragmentos EGFRvIII, cERBB2, MAGE, GLEA, gp96 (Anexo 5) e hsp70 para a clonagem no plasmídio pET. Nos oligonucleotídeos foram inseridos apenas os sítios das enzimas usadas na clonagem, NheI e XhoI e a porção inicial e final dos genes. Como o vetor pET é um plasmídio traducional já apresenta um sítio de ligação ribossomal para correta tradução das proteínas. As sequências amplificadas foram clivadas, clonadas e confirmadas por PCR, análise de restrição e sequenciamento.

Todas as proteínas foram expressas por meio desse sistema, exceto a proteína gp96, para a qual foi construído um novo vetor utilizando-se o plasmídio pcDNA, utilizado na expressão de proteínas em células de mamíferos. Nesse sistema, as proteínas são expressas na ausência de LPS e podem apresentar modificações pós-traducionais. O pcDNA é constituído pelo promotor $\mathrm{CMV}$, apresenta sinais de poliadenilação para eficiente terminação da transcrição, poliadenilação do RNA mensageiro e o gene de resistência ao antibiótico ampicilina para seleção em E. coli. Esse vetor se apresenta na forma linearizada com o nucleotídeo timina nas extremidades, permitindo rápida clonagem de produtos de PCR amplificados com enzimas que coloquem o nucleotídeo adenina nas extremidades do gene de interesse. Dessa forma, foi utilizado como molde o vetor pETgp96 (Anexo 5) e oligonucleotídeos que mantivessem a cauda de histidina no início do gene, juntamente com a sequência de reconhecimento do ribossomo para tradução da proteína, e o stop códon no final. A clonagem foi confirmada por PCR, análise de restrição e sequenciamento.

A partir dos vetores de expressão construídos, pETEGFRvIII, pETcERBB2, pETMAGE, pETGLEA, pEThsp70 e pcDNAgp96, foi realizada a expressão das proteínas recombinantes. As proteínas EGFRvIII, cERBB2, MAGE, GLEA e Hsp70 foram expressas em E. coli sob diferentes condições, de forma a produzir maior quantidade de cada uma delas. As variáveis utilizadas foram tempo, temperatura e concentração do indutor. As proteínas expressas a $37^{\circ} \mathrm{C}$ foram induzidas por 4 horas enquanto aquelas obtidas a $30^{\circ} \mathrm{C}$ foram 
produzidas por um tempo de aproximadamente 16 horas. Longos períodos de indução requerem diminuição da temperatura para que a bactéria cresça devagar, produza a proteína e não consuma todos os nutrientes do meio, necessários a sua sobrevivência. A quantidade de IPTG foi fixada em $0,2 \mathrm{mM}$ ou $0,5 \mathrm{mM}$ para não prejudicar a expressão da proteína com excesso de indutor.

Todas as proteínas foram expressas em quantidades suficientes para dar prosseguimento aos demais experimentos e, em seguida, foram avaliadas quanto à solubilidade. No processo de expressão de proteínas recombinantes em E. coli muitas vezes as proteínas ficam insolúveis devido à formação de agregados proteicos inativos conhecidos como corpos de inclusão (Baneyx e Mujacic, 2004; Jevsevar et al., 2005). Isso ocorre devido ao dobramento incorreto da proteína ocasionado pela maquinaria procariota não possuir mecanismos de modificações pós-traducionais; devido aos fortes promotores; e a alta quantidade de indutor utilizado, fazendo com que a expressão exceda $50 \%$ do total das proteínas bacterianas (Baneyx e Mujacic, 2004; Jevsevar et al., 2005). Dessa forma, a proteína fica indisponível para a purificação sendo necessária a desnaturação.

A avaliação da solubilidade das proteínas EGFRvIII, cERBB2 e GLEA mostrou que elas foram expressas na forma insolúvel, provavelmente por terem sido produzidas em grandes quantidades, serem proteínas de genes humanos e no caso do EGFRvIII e cERBB2 pode ser ainda, devido a essas proteínas serem de membrana. Apesar das proteínas EGFRvIII e cERBB2 terem sido produzidas em menor temperatura $\left(30^{\circ} \mathrm{C}\right)$ com relação à proteína GLEA $\left(37^{\circ} \mathrm{C}\right)$, o que resultaria em uma expressão mais lenta, não favoreceu a solubilidade dessas moléculas. Dessa forma, foi necessário solubilizar o precipitado com adição de ureia que rompe as interações hidrofóbicas. Mesmo com adição de 8M desse agente desnaturante, parte das proteínas permaneceu na fração insolúvel. Já as proteínas MAGE e Hsp70 foram expressas na forma solúvel, com parte permanecendo no sedimento celular. A adição de ureia na fração insolúvel foi capaz de solubilizar a maior parte da Hsp70, mas não toda MAGE, que ainda permaneceu no precipitado.

Após a expressão e solubilização das proteínas, elas foram purificadas por cromatografia de afinidade. Essas proteínas foram expressas em fusão com uma cauda de histidina (6 aminoácidos histidina) o que facilita a purificação. Esse aminoácido apresenta o grupo imidazol que possui afinidade ao níquel imobilizado na coluna cromatográfica, dessa forma, as proteínas ficam retidas na coluna e são eluídas utilizando-se diferentes concentrações de imidazol. Os resultados mostraram que a purificação por cromatografia de 
afinidade foi eficiente em purificar todas as proteínas, mas junto com elas apareceram outras bandas, que podem ser degradação ou agregados da própria proteína purificada ou proteínas contaminantes.

Proteínas purificadas do sobrenadante solúvel, sem agentes desnaturantes, como a MAGE e Hsp70, normalmente apresentam mais contaminantes, os nossos resultados mostraram que as proteínas EGFRvIII, cERBB2 e GLEA purificadas sob condições desnaturantes foram as que apresentaram mais bandas contaminantes, dessa forma, acredita-se que muitos desses fragmentos sejam proteína degradada ou agregada. No entanto, esse não foi um fator limitante e as frações contendo as proteínas de interesse foram dialisadas para retirada da ureia e/ou imidazol. Um fator crítico na purificação das proteínas recombinantes foi a precipitação de grande parte das proteínas EGFRvIII, cERBB2 e GLEA após a retirada da ureia, mesmo que de forma gradual.

Apesar da precipitação, foi possível obter uma pequena quantidade das proteínas EGFRvIII e cERBB2 no sobrenadante. Essa fração solúvel foi concentrada para ser usada nos ensaios de imunogenicidade e a imunização de camundongos, para produção de anticorpos policlonais, foi feita com o precipitado. A proteína GLEA, após precipitar, estava em maior quantidade no sobrenadante do que as outras proteínas descritas acima, o que possibilitou o uso na imunogenicidade e na imunização. As proteínas MAGE e Hsp70 foram obtidas solúveis após a diálise, pois todo o processo de purificação foi sem adição de agente desnaturante, dessa forma, puderam ser utilizadas no experimento de imunogenicidade e na imunização de camundongos, respectivamente.

A proteína gp96, ao contrário de todas as outras, foi expressa em células HEK utilizando-se o vetor pcDNAgp96. Essa proteína também foi expressa em fusão com uma cauda de histidina podendo ser purificada por cromatografia de afinidade. Os resultados mostraram que a gp96 foi purificada pela adição de imidazol juntamente com outras bandas que podem ser proteínas contaminantes. A proteína foi dialisada, mas devido à pequena quantidade obtida com esse sistema de expressão, não foi suficiente para induzir a produção de anticorpos policlonais em camundongos. Assim, obtivemos as proteínas EGFRvIII, cERBB2 e GLEA para serem usadas nos experimentos de imunogenicidade e imunização e as proteínas MAGE e Hsp70, usada apenas na imunogenicidade e imunização, respectivamente.

Um resultado inesperado foi a obtenção da proteína MAGE em um tamanho maior, com aproximadamente $45 \mathrm{kDa}$, sendo o predito de 37,2kDa (337aas). No entanto, já havia sido 
demonstrado por Kocher e colaboradores (1995), que expressaram a proteína MAGE-3 e produziram anticorpos contra ela, um tamanho maior que o predito tanto para a proteína recombinante expressa (aproximadamente 50kDa), como para a proteína nativa (aproximadamente $48 \mathrm{kDa}$ ) localizada intracelularmente em linhagens celulares de melanoma. Como a proteína não apresenta modificações pós-traducionais, os autores sugerem que o tamanho alterado pode ser devido à composição de aminoácidos ricos em resíduos ácidos que alteram o perfil eletroforético da proteína. Resultados semelhantes foram obtidos com a proteína GLEA cujo tamanho predito é de $64,4 \mathrm{kDa}$, mas se revelou com tamanho próximo a $72 \mathrm{kDa}$.

As proteínas EGFRvIII, cERBB2, MAGE, GLEA e Hsp70 assim como todas as construções vacinais (vacinas de DNA) foram produzidas em E. coli, e uma das principais preocupações com relação à imunização com vacinas de DNA ou proteínas vindas desse organismo é a contaminação com LPS, como discutido anteriormente. Dessa forma, todas as vacinas de DNA e as proteínas expressas foram quantificadas em relação ao LPS, demonstrando a pureza de todos os DNAs e a presença de níveis aceitáveis, em todas as proteínas, para testes in vivo de acordo com a Farmacopéia Européia que preconiza o limite de contaminação por endotoxina de 5UE/kg peso corpóreo/hora (Tuomela, Stanescu e Krohn, 2005). As proteínas foram, então, utilizadas na imunização de camundongos para obtenção de anticorpos policlonais anti-EGFRvIII, anti-cERBB2, anti-GLEA e anti-Hsp70.

Após a obtenção dos anticorpos policlonais, as construções vacinais pVAXgDEGFRvIII, pVAXgDcERBB2, pVAXgDMAGE, pVAXgDGLEA, pVAXgp96, pVAXEGFRvIII, pVAXcERBB2, pVAXMAGE, pVAXGLEA e pVAXhsp70 foram avaliadas em relação à formação dos transcritos (RNA mensageiro) e da proteína codificadas por elas em células HEK transfectadas. Essa avaliação é de extrema importância nas construções de vacinas de DNA visto que resultados negativos podem ser devido a construções que não codificam proteínas. Algumas construções podem ser realizadas fora da sua fase aberta de leitura resultando na ausência de expressão ou produção de proteínas diferentes da nativa. A fase aberta de leitura correta pode ser confirmada por sequenciamento como já descrito anteriormente e pela detecção específica das proteínas expressas.

Os transcritos apresentaram os tamanhos esperados para a combinação de oligonucleotídeos utilizada, confirmando a síntese do RNA mensageiro a partir das construções vacinais. As proteínas codificadas por elas foram detectadas por western blot, a 
MAGE e a GLEA sozinhas ou em combinação com a gD apresentaram um tamanho maior que o esperado, o que já havia sido demonstrado na expressão dessas proteínas em E. coli. As proteínas gp96 e Hsp70 codificadas pelas vacinas de DNA não puderam ser caracterizadas nas transfecções, pois estão presentes nas células HEK que são células humanas e foram detectadas de forma cruzada em células $\mathrm{CHO}$ (Chinese hamster ovary) (dados não mostrados) também utilizada nos ensaios. No entanto, a expressão da proteína Hsp70 pode ser confirmada pela presença de anticorpos anti-Hsp70 em todos os animais vacinados com pVAXhsp70 (dados não mostrados).

As proteínas gDEGFRvIII e gDcERBB2 foram identificadas com anti-gD, ao contrário, quando foram analisadas usando anti-EGFRvIII e anti-cERBB2, respectivamente, juntamente com as proteínas sozinhas, EGFRvIII e cERBB2 apareceram com um sinal mais fraco e após um período maior de revelação. Isso pode ter ocorrido devido aos anticorpos terem sido produzidos para as proteínas precipitadas, cujos principais epitopos expostos podem ser diferentes daqueles expressos pelas proteínas das vacinas de DNA. Apesar disso, foi possível demonstrar que as vacinas pVAXgDEGFRvIII, pVAXgDcERBB2, pVAXgDMAGE, pVAXgDGLEA, pVAXEGFRvIII, pVAXcERBB2, pVAXMAGE e pVAXGLEA apresentaram seus fragmentos transcritos e traduzidos.

As construções vacinais, após toda caracterização possível, foram utilizadas na imunização de camundongos realizadas pela administração intramuscular de três doses com intervalo de 12 dias. Juntamente com as vacinas construídas foram utilizados o vetor pVAX como controle negativo e a vacina pVAXhsp65 (Anexos 7 e 8) desenvolvida em nosso laboratório e que já foi utilizada em ensaio clínico, em tumor de cabeça e pescoço demonstrando resultados encorajadores (Michaluart et al., 2008).

Apesar das críticas em relação à imunização intramuscular por ser um tecido "pobre" em células apresentadoras de antígenos, essa é uma rota muito utilizada, pois trabalhos demonstram a expressão do gene nos miócitos (Wolff et al., 1990) bem como em DCs (Casares et al., 1997) e macrófagos (Chattergoon et al., 1998), além da distribuição da vacina de DNA no sangue e vários outros tecidos, sendo, portanto, uma inoculação sistêmica (Winegar et al., 1996; Coelho-Castelo et al., 2006). Raz e colaboradores (1996) também demonstraram que a injeção intramuscular e intradérmica não variam no perfil da resposta imunológica desencadeada, mesmo a segunda sendo um sítio com maior número de DCs. 
Após 20 dias da última imunização foram realizados os ensaios para detecção da resposta induzida pelas vacinas. No primeiro protocolo foram testadas as vacinas contendo as proteínas imunomoduladoras em combinação com a vacina contendo o antígeno GLEA com intuito de definir qual imunomodulador induziria uma resposta imunológica eficaz para ser usado com os demais antígenos. Os grupos utilizados, então, no primeiro protocolo foram: pVAX; pVAXGLEA; pVAXgDGLEA; pVAXGLEA + pVAXhsp65; pVAXGLEA + pVAXhsp70; pVAXGLEA + pVAXgp96; pVAX + pVAXGLEA e pVAX + pVAXgDGLEA. Definido os dois melhores imunomoduladores, gD e Hsp70, o segundo protocolo foi realizado com os grupos: pVAX; pVAXEGFRvIII; pVAXgDEGFRvIII; pVAXEGFRvIII + pVAXhsp70; pVAXcERBB2; pVAXgDcERBB2; pVAXcERBB2 + pVAXhsp70; pVAXMAGE; pVAXgDMAGE e pVAXMAGE + pVAXhsp70.

O primeiro protocolo foi, ainda, importante não só para definir os imunomoduladores, mas também para definir se os grupos que receberam o dobro da quantidade do vetor pVAX $(\mathrm{pVAXGLEA}+\mathrm{pVAXhsp/gp})$ induziriam uma resposta melhor que os plasmídios pVAXGLEA e pVAXgDGLEA devido à presença de mais vetor. Essa é uma avaliação importante, visto que as sequências de DNA apresentam em sua própria constituição regiões que interagem com receptores presentes em APCs ativando essas células (Hemmi et al., 2000; Ishii et al., 2006; Takaoka et al., 2007). Dessa forma, foram adicionados os grupos pVAX + pVAXGLEA e pVAX + pVAXgDGLEA como controles no primeiro experimento. $\mathrm{O}$ resultado de todos os parâmetros avaliados (produção de anticorpos e citocinas) mostrou que a presença de mais vetor não interferiu na resposta desencadeada pelas vacinas.

O primeiro passo foi a avaliação da resposta imunológica humoral desencadeada pelas vacinas. A avaliação da produção de anticorpos específicos representa um importante indicador do padrão de resposta induzido pela vacinação. Uma vez que anticorpos IgG1 e IgG2a podem ser considerados marcadores dos padrões Th2 e Th1, respectivamente, essa avaliação pode ajudar a definir o fenótipo das células T induzidas na vacinação (Coffman et al., 1988).

Os resultados mostraram que apenas alguns animais vacinados com pVAXgDGLEA foram capazes de produzir anticorpos do subtipo IgG2a anti-GLEA. Isso também ocorreu, embora em menor proporção, para as vacinas pVAXgDEGFRvIII e pVAXgDMAGE. Algumas hipóteses não exclusivas foram levantadas e entre elas, a suposição de que as proteínas codificadas pelas vacinas sem gD são expressas no citoplasma das células 
"transfectadas" ficando inacessíveis ao reconhecimento pelas imunoglobulinas. No entanto, anticorpos contra a proteína Hsp70 foram detectados em todos os grupos de animais imunizados com essa vacina, independente do antígeno utilizado (dados não mostrados). Dessa forma, as proteínas sem a gD, apesar de serem produzidas intracelularmente, podem ser disponibilizadas fora das células, estando acessíveis ao reconhecimento pelos anticorpos.

Diante disso, é muito provável que outros eventos tenham ocorrido. Os animais imunizados com as vacinas de DNA codificando os antígenos junto com a gD induziram anticorpos contra epitopos conformacionais que não são encontrados nas proteínas expressas em E. coli utilizadas para detecção desses anticorpos; isso pode ter acontecido principalmente com as proteínas GLEA e EGFRvIII que foram desnaturadas no processo de purificação. Esse evento também pode ter ocorrido nos grupos de animais vacinados apenas com o antígeno tumoral ou com o antígeno tumoral e as proteínas HSPs. Entretanto, esses grupos também podem ter sido fracamente estimulados resultando na incapacidade de produzir anticorpos IgG específicos contra os antígenos tumorais.

De qualquer forma, esses resultados indicam que as vacinas pVAXgDGLEA, pVAXgDEGFRvIII e pVAXgDMAGE induziram um padrão de resposta Th1 nos animais que produziram anticorpos. Além de indicar o padrão de resposta, os anticorpos podem ser ferramentas importantes na eliminação do tumor pela ativação do complemento que promove lise celular e pela resposta de citotoxicidade mediada por anticorpo (ADCC, antibody dependent cellular cytotoxicity) (Abul K. Abbas, 2005). As células NK e outros leucócitos se ligam a células recobertas por anticorpos por meio de receptores Fc e destroem estas células pela liberação de seus grânulos, além disso, as células NK ativadas por esse mecanismo podem produzir citocinas como IFN- $\gamma$ (Abul K. Abbas, 2005). No caso das proteínas GLEA e MAGE que são intracelulares na célula tumoral, a resposta de anticorpos não seriam um fator preponderante na eliminação das células que as expressam. Ao contrário, células tumorais que expressam em sua superfície as proteínas EGFRvIII e cERBB2 poderiam ser reconhecidas por anticorpos sendo destruídas pelo mecanismo de ADCC e/ou ativação do complemento. Dessa forma, vacinas desenvolvidas contras essas proteínas seriam mais eficazes se induzissem anticorpos.

No entanto, o principal mecanismo de imunidade tumoral é a destruição mediada por células T CD8 ${ }^{+}$citotóxicas (Abul K. Abbas, 2005). Essas células são ativadas por APCs que apresentam antígenos tumorais via moléculas de MHC de classe I e moléculas co- 
estimuladoras, e também pelo auxílio das células T CD4 $4^{+}$(Abul K. Abbas, 2005). As APCs ativam células auxiliares $\mathrm{T} \mathrm{CD}^{+}$pela apresentação dos antígenos via MHC de classe II, estas células por sua vez podem fornecer citocinas como IL-2 que estimula a proliferação e diferenciação de células $\mathrm{T} \mathrm{CD}^{+}$ou podem expressar em sua superfície a molécula CD40L que interage com CD40 presente nas APCs tornando-as mais eficientes na ativação dos linfócitos citotóxicos (Abul K. Abbas, 2005). Além disso, as células T auxiliares podem secretar citocinas como TNF e IFN- $\gamma$ que podem aumentar à expressão de moléculas de MHC-I nas células tumorais e a sensibilidade destas células a lise por CTLs (Abul K. Abbas, 2005). O IFN- $\gamma$ também pode ativar a destruição das células tumorais pelos macrófagos (Abul K. Abbas, 2005). Provavelmente estas células podem destruir a célula tumoral pelos mesmos mecanismos que destroem organismos infectantes: liberação de enzimas lisossomais e de intermediários reativos do oxigênio e óxido nítrico (Abul K. Abbas, 2005). Além disso, os macrófagos também produzem TNF que destrói o tumor principalmente pela trombose de vasos sanguíneos tumorais (Abul K. Abbas, 2005).

Nesse contexto, as vacinas de DNA são principalmente conhecidas por desencadearem resposta de células $\mathrm{T} \mathrm{CD}^{+}$contra os antígenos codificados por elas. Isso ocorre, pois as proteínas são produzidas no citoplasma das células transfectadas e apresentadas via MHC-I (Ulmer et al., 1993; Corr et al., 1996; Ulmer et al., 1996; Liu, 2003). Entretanto, as vacinas de DNA também ativam linfócitos $\mathrm{T} \mathrm{CD}^{+}$, pois as células "transfectadas" podem produzir e eliminar a proteína, deixando-a disponível para as APCs que fagocitam e ativam células T $\mathrm{CD}^{+}$via moléculas de MHC-II (Liu, 2003; Kutzler e Weiner, 2008).

Dessa forma, o próximo passo foi avaliar, nos diferentes grupos vacinados, o tipo de linfócitos $\mathrm{T}$ induzido contra os antígenos tumorais por meio da dosagem de citocinas produzidas por eles. Como discutido anteriormente, a resposta de células $\mathrm{T}$ com produção da citocina IFN- $\gamma$ (padrão Th1) é fundamental para a defesa contra o tumor, entretanto, as células T podem se diferenciar em pelo menos quatro subtipos principais, Th1, Th2 (Mosmann et al., 1986), Th9 (Veldhoen et al., 2008) e Th17 (Harrington et al., 2005). A diferenciação depende do antígeno e das citocinas produzidas no microambiente e cada subtipo apresenta uma assinatura, composta principalmente por fatores de transcrição e citocinas que medeiam à função efetora específica de cada subtipo.

Nesse trabalho foram avaliadas as citocinas, IFN- $\gamma$, IL-2 e IL-12 características do padrão Th1; IL-5, padrão Th2; IL-6 com características inflamatórias e a citocina IL-10. A 
citocina IL-10 foi classificada inicialmente como derivada do padrão Th2 de resposta (Fiorentino, Bond e Mosmann, 1989), no entanto, é produzida por vários subtipos de células T $\mathrm{CD}^{+}$, macrófagos, DCs, células B, eosinófilos e mastócitos (Moore et al., 2001). A principal fonte de IL-10 são as células $\mathrm{T} \mathrm{CD}^{+}$reguladoras e sua principal função é regular a resposta Th1 inibindo a proliferação e produção de IL-2 (Taga e Tosato, 1992; De Waal Malefyt, Yssel e De Vries, 1993), mas principalmente pela interferência com a maturação das DCs e produção de IL-12 (citocina necessária para indução do padrão Th1) (Fiorentino, Zlotnik, Mosmann, et al., 1991; Fiorentino, Zlotnik, Vieira, et al., 1991; Moore et al., 2001).

As células $\mathrm{T}$ provenientes do baço dos animais imunizados com as diferentes vacinas de DNA foram estimuladas, e as citocinas produzidas por elas dosadas no sobrenadante da cultura. A ausência de estímulo foi utilizada como controle da produção basal das citocinas e o controle positivo foi realizado com ConA. Este estímulo foi capaz de ativar as células de todos os animais a produzirem IL-2, IL-5, IL-6, IL-10 e principalmente IFN- $\gamma$, independente da vacina utilizada para a imunização. Isso ocorre, pois a ConA é uma proteína polimérica derivada da planta Canavalia ensiforms que se liga a resíduos de açúcares nas glicoproteínas de superfície das células T, incluindo o TCR (receptor de célula T) e o CD3, provocando assim ativação inespecífica (Abul K. Abbas, 2005).

Já o estímulo específico de cada grupo foi realizado com as proteínas recombinantes, para avaliar se as imunizações foram eficientes em primar/estimular células $\mathrm{T}$ específicas ao antígeno codificado pela vacina. Esse estímulo permite analisar se células específicas de memória foram geradas, pois essas células permanecem no organismo e são ativadas rapidamente quando ocorre um novo contato com o antígeno. Essas respostas, além de serem mais rápidas, são de maior intensidade e mais eficazes (Abul K. Abbas, 2005). A ativação das células de memória leva a produção de citocinas que caracteriza o tipo de células induzidas pela vacinação. Os resultados mostraram que os animais vacinados com pVAXgDGLEA, pVAXgDEGFRvIII e pVAXgDMAGE apresentavam células específicas produtoras de IL-10 e grande quantidade de IFN- $\gamma$. Os animais vacinados com pVAXGLEA + pVAXhsp70 (primeiro protocolo) também apresentavam essas células específicas produtoras de IL-10 e IFN- $\gamma$ e, apesar da menor proporção, foi o que determinou a utilização da vacina pVAXhsp70 com os outros antígenos.

Esse resultado corrobora com o resultado de anticorpos na definição de um padrão de resposta com características Th1 induzido pelas vacinas pVAXgDGLEA, pVAXgDEGFRvIII 
e pVAXgDMAGE. No entanto, parece intrigante pela presença concomitante de INF- $\gamma$ e IL10, que poderia prejudicar esse padrão de resposta considerado essencial para a geração de uma resposta imunológica específica e duradoura contra as células tumorais. A produção desta citocina, em níveis significantes nos animais imunizados com as vacinas citadas acima, sugere uma produção por células $\mathrm{T}$ específicas, talvez as mesmas que produzem INF- $\gamma$. Alguns trabalhos vêm sugerindo que a citocina IL-10, além de ser produzida por células Treg para controlar a resposta das células Th1 de uma forma extrínseca, pode ser produzidas pela própria célula produtora de IFN- $\gamma$ realizando um controle intrínseco por feedback (O'garra e Vieira, 2007; Trinchieri, 2007).

Estudos mostram a existência de células Th1 IFN- $\gamma^{+} \mathrm{IL}-10^{+}$em pacientes infectados com Mycobacterium tuberculosis (M. tuberculosis) ou Leishmania visceralis e em pacientes com artrite reumatoide (Assenmacher, Schmitz e Radbruch, 1994; Jankovic et al., 2007). Um modelo de infecção com Toxoplasma gondii providenciou uma explicação funcional para a existência dessas células duplo positivas, produtoras de duas citocinas com efeitos biológicos contrários (Jankovic et al., 2007). Esse estudo sugere que a produção de IFN- $\gamma$ é necessária para eliminação do patógeno e a presença de IL-10 concomitante é fundamental para resolução da resposta inflamatória e prevenção de uma patologia tecidual. Essa mesma característica das citocinas IFN- $\gamma$ e IL-10 também já foi demonstrada pelo nosso grupo na profilaxia contra M. tuberculosis utilizando-se a vacina DNAhsp65 (Gonçalves et al., 2007). Isso seria fundamental na imunoterapia do GBM, pois a resposta Th1 é imprescindível para a eliminação do tumor, no entanto, essa resposta precisa ser bem regulada para prevenir o dano tecidual no ambiente cerebral.

Os dados da literatura também sugerem que as células Th1 IFN- $\gamma^{+} \mathrm{IL}-10^{+}$não representam uma linhagem, mas sim um ponto final de uma resposta efetora bem sucedida, um componente final do ciclo de vida da célula Th1 (Cope et al., 2011). Essa troca de perfil implicaria na produção de IFN- $\gamma$ e IL-10 pela mesma célula reconhecendo o mesmo antígeno. Isso corrobora com a produção de IL-10 pelos diferentes subtipos de células T auxiliares sob determinadas condições (Cope et al., 2011). Dessa forma, independente da fonte, a IL-10 é muito importante para controlar as respostas inflamatórias das células Th1 quando o estímulo foi eliminado.

No entanto, na imunologia de tumores, o papel da citocina IL-10 parece um pouco mais difícil de ser desvendado. Em geral, ela é considerada um agente imunossupressor de 
vários mecanismos envolvidos na resposta imunológica contra o tumor (Moore et al., 2001). Mais especificamente em gliomas, a IL-10 é caracterizada como uma molécula produzida pelas células tumorais para escapar da imunovigilância (Nitta et al., 1994). No entanto, em um trabalho com células $\mathrm{T}$ estimuladas com complexo autólogo de DCs-lisado tumoral de GBM foi observado atividade supressora contra células tumorais com produção não só de IFN- $\gamma$, mas de IL-10 (De Vleeschouwer et al., 2007). Além disso, a quantidade de IL-10 produzida na fase de estimulação e na fase efetora da resposta foi correlacionada com a atividade supressora (De Vleeschouwer et al., 2007). A persistente produção de IL-10 pelas células $\mathrm{T}$ estimuladas parece ser crítica para a subsequente supressão realizada por essas mesmas células efetoras Th1. Outros trabalhos apontam para a habilidade da IL-10 aumentar a imunidade antitumoral (Berman et al., 1996; Zheng et al., 1996) inclusive em modelo de glioma (Book et al., 1998). A IL-10 produzida por células T CD4 ${ }^{+}$também tem sido relacionada a funções anti-glioma in vivo (Segal, Glass e Shevach, 2002) e pode aumentar as funções de células NK e a citotoxicidade das células T CD8 ${ }^{+}$(Moore et al., 2001).

Dessa forma, a ação da citocina IL-10 parece um pouco incompreensível, mas tanto como reguladora quanto como promotora da imunidade tumoral pode ser importante e precisa ser investigada em cada modelo. Além do padrão Th1 de resposta com produção de IL-10, os resultados indicam que as vacinas contendo a proteína $\mathrm{gD}$ foram eficazes em induzir células de memória específicas aos diferentes antígenos em comparação as vacinas que expressam apenas os antígenos ou antígenos combinados as HSPs. Nossos resultados corroboram com os dados de Lasaro e colaboradores (2003, 2005 e 2008) e de Diniz e colaboradores (2010) que mostram claramente que vacinas de DNA construídas com a gD induzem maiores títulos de anticorpos e porcentagem de células $\mathrm{T} \mathrm{CD}^{+}$produtoras de IFN- $\gamma$ quando comparadas a vacinas que não apresentavam o gene dessa proteína.

Isso pode ser explicado pelo fato dessa proteína ser expressa na superfície das células "transfectadas" com as vacinas, podendo interagir com seu receptor HVEM presente em diferentes células do sistema imunológico (Montgomery et al., 1996). Lasaro e colaboradores (2011) demonstraram, em camundongos vacinados com AdgDE7, que o aumento no número de células T CD8 ${ }^{+}$específicas ao antígeno E7 do HPV-16 era dependente da interação gDHVEM. Essa interação pode levar a uma melhor ativação da imunidade inata com produção de IL-12 que induz o padrão Th1 de resposta (Medici et al., 2003; Pollara et al., 2004). Além disso, a gD pode interferir com o caminho inibitório HVEM-BTLA, responsável pela bloqueio na proliferação das células T (Cheung et al., 2005; Lasaro et al., 2008). 
Uma hipótese foi proposta para explicar porque as vacinas contendo as proteínas Hsp65, Hsp70 e gp96 quando combinadas as vacinas que expressam os antígenos não foram eficazes em induzir células de memória específicas aos diferentes antígenos. As proteínas Hsp65, Hsp70 e gp96 são proteínas intracelulares (gp96 mais especificamente se encontra no retículo endoplasmático) (Wei e Hendershot, 1996; Kampinga et al., 2009), no entanto, vários trabalhos demonstram que as proteínas Hsp70 e gp96 quando complexadas a peptídeos e disponibilizadas extracelularmente são capazes de ajudar na apresentação cruzada desses peptídeos para linfócitos T CD8 ${ }^{+}$(Udono e Srivastava, 1993; Srivastava, 2005; Murshid, Gong e Calderwood, 2008; 2010). Além disso, essas proteínas, inclusive a Hsp65, podem interagir com receptores de superfície presente nas células da imunidade inata induzindo a produção de citocinas e moléculas co-estimuladoras importantes na ativação da imunidade adaptativa (Basu et al., 2001; Becker, Hartl e Wieland, 2002; Vabulas, Wagner e Schild, 2002; Calderwood et al., 2007; Murshid, Gong e Calderwood, 2010; Souza, 2011).

Dessa forma, como as vacinas de antígenos e HSPs eram independentes (as moléculas não foram fusionadas) podem ter sido internalizadas por células diferentes. As HSPs podem ter interagido com receptores presentes na superfície de APCs que não apresentavam os antígenos tumorais. Assim, os antígenos podem ter sido disponibilizados em um ambiente pouco imunogênico. A gp96 pode ainda ter tido sua função prejudicada pela retirada do peptídeo sinal e mutação nos seus sítios de N-glicosilação, uma vez que essa é uma proteína regulada por glicose (Wei e Hendershot, 1996; Kampinga et al., 2009). Alguns trabalhos também indicam que a dose de HSPs está relacionada à imunidade ou supressão (Chandawarkar, Wagh e Srivastava, 1999). Apesar das proteínas expressas pelas vacinas de DNA serem disponibilizadas fora da célula como foi demonstrado pela presença de anticorpos contra a Hsp70, grande parte dos trabalhos que associam HSPs a antígenos tumorais, utilizam-nos na forma de complexos extracelulares. Portanto, a estratégia utilizada de vacinas separadas pode ter eliminado a grande vantagem de se utilizar HSPs com antígenos tumorais.

Um resultado intrigante foi a vacina $\mathrm{pVAXgDcERBB} 2$ que induziu células produtoras de IFN- $\gamma$ e IL-10 assim como os grupos pVAXcERBB2 e pVAXcERBB2 + pVAXhsp70, apesar de não haver diferenças significativas com o grupo controle. A proteína cERBB2 pode ter exercido alguma função estimuladora, além de ser um antígeno. Outro resultado inesperado foi a produção de altos níveis de IFN- $\gamma$ em todos os grupos estimulados com a proteína GLEA (inclusive o controle), apesar dos grupos pVAXgDGLEA e pVAXGLEA + pVAXhsp70 apresentarem maiores níveis. Isso pode indicar que a proteína ativou outras 
células de uma forma inespecífica a produzirem essa citocina como as células NK que secretam IFN- $\gamma$ em resposta ao reconhecimento de componentes desconhecidos ou em resposta a IL-12 (Abul K. Abbas, 2005).

Dessa forma, também dosamos IL-12 para tentar entender melhor a alta produção de IFN- $\gamma$ de forma inespecífica. Essa citocina é produzida por macrófagos e DCs ativados em resposta a estímulos microbianos e é responsável pela diferenciação de células $\mathrm{T} \mathrm{CD} 4^{+}$em células Th1 produtoras de IFN- $\gamma$ e por acentuar a resposta de células NK ativadas e CTLs (Abul K. Abbas, 2005). No re-estímulo (adição das proteínas recombinantes na cultura) não era esperado a produção de IL-12, uma vez que as proteínas são disponibilizadas sem nenhum estímulo adicional, somente para ativar células $\mathrm{T}$ já estimuladas (células de memória) que não precisam da ação dessa citocina, dessa forma, a presença dela poderia indicar uma ativação inespecífica das células da imunidade inata. No entanto, essa citocina não foi detectada no sobrenadante das culturas.

A ausência de IL-12 também sugere que a estimulação inespecífica não é de contaminação das proteínas com LPS. No entanto, outra citocina inflamatória (IL-6) foi dosada para confirmar esse resultado. A IL-6 tem sua ação na imunidade inata e adaptativa e é produzida por macrófagos, fibroblastos e outras células em resposta a estímulos microbianos (inclusive LPS) e a outras citocinas (Abul K. Abbas, 2005). Essa citocina foi detectada no sobrenadante das células estimuladas com a proteína GLEA independente da vacina utilizada. No entanto, também foi produzida pelas células estimuladas com as outras proteínas (EGFRvIII, cERBB2 e MAGE) em quantidades semelhantes, mas que não tinham essa produção acentuada de IFN- $\gamma$. Esses resultados indicam que a produção de IL-6 pode ser devido à presença de pequenas quantidades de LPS nas proteínas recombinantes, mas não está relacionada à produção inespecífica de IFN- $\gamma$. Dessa forma, essa produção pode ser devido à estimulação de células NK pela proteína GLEA.

A produção da citocina IL-2 também foi avaliada frente aos diferentes estímulos específicos uma vez que essa proteína é o fator de crescimento para linfócitos T estimulados por antígenos e responsável pela expansão clonal após o reconhecimento antigênico. A IL-2 é produzida por células $\mathrm{T} \mathrm{CD} 4^{+}$e em menor proporção por células $\mathrm{T} C D 8^{+}$. Essa citocina age principalmente nas mesmas células que a produziram (ação autócrina) (Abul K. Abbas, 2005). A avaliação realizada após 48 e 24 horas de estímulo não foi eficiente em detectar essa citocina que esperávamos encontrar nos grupos vacinados com pVAXgDAntígeno devido à 
presença de células específicas produtoras de IFN- $\gamma$ e IL-10. Seu pico de secreção ocorre entre 8 e 12 horas após a ativação (Abul K. Abbas, 2005), dessa forma, o resultado nos leva a acreditar que por ser um fator de crescimento de células $\mathrm{T}$ tenha sido completamente consumida.

Os resultados de produção de citocinas indicaram a presença de células de memória específicas nos grupos imunizados com as vacinas pVAXgDGLEA, pVAXgDEGFRvIII e pVAXgDMAGE, no entanto, também fomos avaliar a presença desses linfócitos $\mathrm{T}$ analisando diretamente as células estimuladas com o antígeno específico. A presença das células de memória é muito importante, pois em muitos casos o aumento no número dessas células está relacionado com aumento da proteção contra determinada doença (Badovinac e Harty, 2006).

Vários marcadores de superfície são utilizados para caracterizar as células de memória, CD27, CD44, CD62L, CD127 e CCR7 entre outros. Estudos sugerem que a expressão de moléculas de homing como o CD62L e o CCR7, que implicam na retenção das células nos órgãos linfoides secundários, podem ser usados para diferenciar os subtipos de memória, $\mathrm{CD} 62 \mathrm{~L}^{\mathrm{lo}} \mathrm{CCR} 7{ }^{\text {lo }}$ para memória efetora, e $\mathrm{CD} 62 \mathrm{~L}{ }^{\text {hi }} \mathrm{CCCR} 7{ }^{\mathrm{hi}}$, para memória central (Sallusto, Geginat e Lanzavecchia, 2004). Entretanto, trabalhos mais recentes sugerem que o fenótipo celular de superfície pode ser falho em caracterizar os atributos funcionais das células de memória (Badovinac e Harty, 2006). Dessa forma, muitas vezes é importante identificar as citocinas produzidas por essas populações celulares, além de caracterizar seus marcadores de superfície.

A maioria das células $\mathrm{T} \mathrm{CD}^{+}$após uma infecção aguda apresentam, além de marcadores de superfície para células efetoras, produção alta de IFN- $\gamma$, média de TNF- $\alpha$ e nenhuma produção de IL-2. Ao contrário, após a eliminação do antígeno, além do fenótipo de memória central na superfície, essas células apresentam alta produção de IFN- $\gamma$ e TNF- $\alpha$ e média de IL-2 (Sallusto, Geginat e Lanzavecchia, 2004; Badovinac e Harty, 2006) mostrando a importância em se analisar o estado funcional dos subtipos de memória, pois são essas características que determinarão a proteção.

Apesar da comum utilização dos marcadores de superfície CD62L e CCR7 para caracterizar essas células, os marcadores utilizados nesse trabalho foram o CD62L e o CD44, que também é um importante marcador na definição de células de memória. O receptor CD44 promove adesão nas células endoteliais e matriz extracelular e os linfócitos efetores/ativados apresentam alta expressão dessa molécula (Lesley, Hyman e Kincade, 1993; Abul K. Abbas, 
2005). O marcador CD62L é uma L-seleciona com função de reter os linfócitos naive e de memória nos órgãos linfoides periféricos (Rainer, 2002; Abul K. Abbas, 2005).

Como a vacinação gera células de memória e uma forma alternativa de definir essa população é sua expansão vigorosa após o re-estímulo (Badovinac e Harty, 2006), esperávamos verificar um aumento na população de células de memória efetora $\left(\mathrm{CD} 44^{\mathrm{hi}} \mathrm{CD} 62 \mathrm{~L}^{\mathrm{lo}}\right)$ ou mesmo de células ativadas $\left(\mathrm{CD} 44^{\mathrm{hi}}\right)$ após o re-estímulo com as proteínas específicas nos grupos imunizados com as construções vacinais que geraram resposta de citocinas. No entanto, os resultados não demonstraram a presença dessas células, que podem não ter sido caracterizadas com os marcadores adequados ou podem ter exercido suas funções como foi visto pela produção de citocinas e morrido. Além disso, alguns trabalhos mostram que células $\mathrm{T} \mathrm{CD}^{+}$de memória (geradas após mais de uma imunização) não expressam rapidamente o marcador CD62L, apesar de sustentada produção de granzima B e eficácia na proteção. E, apesar das células $\mathrm{T} \mathrm{CD}^{+}$de memória apresentarem robusta capacidade proliferativa, as estimulações sucessíveis podem provocar um declínio na proliferação indicando que essas células são capazes de sofrer sucessivas, mas finitas divisões (Masopust et al., 2006).

Lasaro e colaboradores (2011) também demonstraram que as células T CD8 ${ }^{+}$ específicas ao antígeno E7 em camundongos vacinados com uma construção contendo o antígeno e a proteína gD (AdgDE7) apresentavam os marcadores CD62L e CD44, mas sem diferenças com relação aos controles. Assim, apesar de não conseguirmos identificar a população de células de memória específica utilizando marcadores de superfície, a resposta funcional das células (produção de citocinas) indica a presença desses linfócitos $\mathrm{T}$ e a eficácia das vacinas pVAXgDGLEA, pVAXgDEGFRvIII e pVAXgDMAGE em gerar resposta celular. Os resultados demonstram, portanto, o potencial das três vacinas de DNA em gerar uma resposta imunológica do padrão Th1 com produção de IL-10 importante no combate ao tumor e no balanço da resposta imunológica. Os resultados apresentados nesse trabalho sugerem que as vacinas pVAXgDGLEA, pVAXgDEGFRvIII e pVAXgDMAGE podem ser utilizadas como uma nova estratégia na imunoterapia do GBM capaz de superar a heterogeneidade do tumor e o microambiente supressor.

Dessa forma, surge como perspectiva futura o teste dessas vacinas em estudos préclínicos e, principalmente em clínicos. Modelos animais de gliomas humanos existem principalmente em ratos baseados na transplantação intracerebral de tumores humanos em 
animais imuno-deficientes (nude) (Szatmári et al., 2006). Modelos murinos são usados com menor frequência, principalmente pela disponibilidade, mas um dos mais usados é o GL261, que pode ser incluído entre os tumores de crescimento mais agressivo e moderadamente imunogênico devido à presença de moléculas de MHC-I e do coestimulador B7 na superfície das células (Szatmári et al., 2006).

Um modelo ideal de glioma humano deve reproduzir as principais características desse tumor: crescimento infiltrativo, mas não metastático e pobre imunogenicidade (Szatmári et al., 2006). Entretanto, nenhum modelo disponível simula exatamente gliomas humanos de alto-grau, a maioria apresenta variação na imunogenicidade, crescimento e invasão (Szatmári et al., 2006). Além disso, pesquisas pré-clínicas em camundongos, com modelos tumorais de glioma são difíceis de serem realizadas quando se define antígenos presentes em GBM de humanos para serem utilizados na imunoterapia. As proteínas selecionadas podem não estar presentes no glioma utilizado como modelo, dificultando a avaliação da eficácia das vacinas.

Apesar das limitações com relação à extrapolação para humanos, o glioma GL261 é considerado hoje o padrão ouro para pesquisas com glioma (Maes e Van Gool, 2011). Desde os primeiros trabalhos com imunoterapia para glioma experimental no início dos anos 90, os pesquisadores têm investigado várias estratégias para tratar esse tipo tumoral: transferência adotiva de células, anticorpos, imunização com DCs, terapia gênica entre outras (Maes e Van Gool, 2011). O tratamento com anticorpos não consiste de moléculas específicas a antígenos de superfície, devido à falta de epitopos presentes em todas as células do glioma, dessa forma, essa terapia envolve aumentar a co-estimulação das células $\mathrm{T}$ e diminuir a imunossupressão no ambiente tumoral (Maes e Van Gool, 2011). A imunoterapia com DCs tem sido a mais utilizada, muitas vezes é combinada com citocinas e/ou outras terapias e tem demonstrado resultados promissores de proteção e imunidade duradoura (Maes e Van Gool, 2011).

Embora o mais comum seja o uso da célula tumoral inteira como fonte de antígenos na imunoterapia para gliomas murinos, alguns trabalhos selecionam apenas alguns antígenos como TRP-2 (tyrosinase-related protein-2) e gp100, que são antígenos associados ao melanoma, ou EphA2, demonstrando que essas moléculas juntamente com DCs, adjuvantes ou na forma de vacina de DNA podem induzir proteção em animais desafiados com células GL261 (O et al., 2003; Prins, Odesa e Liau, 2003; Ueda et al., 2009). Além disso, esses trabalhos demonstram que a proteção requer a participação de células $\mathrm{T} \mathrm{CD}^{+}$e $\mathrm{T}$ CD8 ${ }^{+}$e o 
envolvimento da molécula IFN- $\gamma$ (O et al., 2003; Prins, Odesa e Liau, 2003; Ueda et al., 2009). Esses resultados corroboram com a ideia de que as vacinas pVAXgDGLEA, pVAXgDEGFRvIII e pVAXgDMAGE podem ser eficazes no combate ao GBM uma vez que elas induzem o padrão Th1 de resposta imunológica.

As vacinas podem, então, ser testadas no modelo GL261 se esses antígenos estiverem presentes nesse tumor, mas podem ainda, de uma forma mais direta, ser estudadas em ensaios clínicos. Como os pacientes com GBM são submetidos à cirurgia para retirada máxima do tumor, existe a possibilidade de avaliação quanto à expressão dos antígenos tumorais no GBM retirado. Como as proteínas EGFRvIII, MAGE e GLEA são proteínas encontradas em GBM, e até mesmo a proteína cERBB2, é importante estudar a presença dessas moléculas em pacientes com a neoplasia, para verificar a possibilidade de usar esses antígenos na forma de vacina de DNA na imunoterapia. Esse trabalho abre as portas para a utilização de uma nova estratégia na imunoterapia do GBM ainda não utilizada: vacinas de DNA, mais de um antígeno e a glicoproteína D. A avaliação do tumor de cada paciente pode definir os antígenos, conduzindo a uma terapia mais eficiente e provavelmente mais individualizada ou para pequenos grupos de indivíduos com GBMs de características semelhantes. 


\subsection{CONCLUSÃO}

» Todas as vacinas de DNA, exceto a pVAXEGFRvIII, foram corretamente construídas;

» As proteínas EGFRvIII, cERBB2, MAGE, GLEA e Hsp70 foram obtidas em quantidades suficientes para realização dos experimentos;

» Anticorpos policlonais contra as proteínas recombinantes foram produzidos;

» As vacinas de DNA foram corretamente caracterizadas in vitro, exceto as vacinas pVAXhsp70 e pVAXgp96;

» As vacinas pVAXgDEGFRvIII, pVAXgDMAGE e pVAXgDGLEA foram capazes de ativar células específicas aos antígenos tumorais e desencadear um perfil Th1 de resposta imunológica;

» As vacinas pVAXgDEGFRvIII, pVAXgDMAGE e pVAXgDGLEA foram capazes de ativar células específicas aos antígenos tumorais produtoras de IL-10;

» As vacinas de DNA contendo apenas os antígenos tumorais não foram eficazes em induzir resposta imunológica;

»A estratégia de combinar as vacinas de DNA contendo os antígenos tumorais com as vacinas de DNA contendo as HSPs em vetores separados não foi bem sucedida. 


\subsection{REFERÊNCIAS BIBLIOGRÁFICAS}

ABUL K. ABBAS, A. H. L. Imunologia Celular e Molecular. Rio de Janeiro: Elsevier, 2005.

ALLEN, J. et al. Recombinant interferon beta: a phase I-II trial in children with recurrent brain tumors. J Clin Oncol, v. 9, n. 5, p. 783-8, May 1991. ISSN 0732-183X. Disponível em: < http://www.ncbi.nlm.nih.gov/pubmed/2016620 >.

ANALYSIS, C. F. B. S., Disponível em: < http://www.cbs.dtu.dk/services/NetNGlyc/ >.

ANDERSSON, U. et al. Epidermal growth factor receptor family (EGFR, ErbB2-4) in gliomas and meningiomas. Acta Neuropathol, v. 108, n. 2, p. 135-42, Aug 2004. ISSN 0001-6322. Disponível em: < http://www.ncbi.nlm.nih.gov/pubmed/15148612 >.

. A comprehensive study of the association between the EGFR and ERBB2 genes and glioma risk. Acta Oncol, v. 49, n. 6, p. 767-75, Aug 2010. ISSN 1651-226X. Disponível em: < http://www.ncbi.nlm.nih.gov/pubmed/20446891 >.

ANIDO, J. et al. TGF- $\beta$ Receptor Inhibitors Target the CD44(high)/Id1(high) Glioma-Initiating Cell Population in Human Glioblastoma. Cancer Cell, v. 18, n. 6, p. 655-68, Dec 2010. ISSN 1878-3686. Disponível em: < http://www.ncbi.nlm.nih.gov/pubmed/21156287 >.

ANUMANTHAN, A. et al. Cloning of BY55, a novel Ig superfamily member expressed on NK cells, CTL, and intestinal intraepithelial lymphocytes. J Immunol, v. 161, n. 6, p. 2780-90, Sep 1998. ISSN 0022-1767. Disponível em: 〈 http://www.ncbi.nlm.nih.gov/pubmed/9743336 >.

ARDON, H. et al. Integration of autologous dendritic cell-based immunotherapy in the primary treatment for patients with newly diagnosed glioblastoma multiforme: a pilot study. J Neurooncol, v. 99, n. 2, p. 261-72, Sep 2010. ISSN 1573-7373. Disponível em: < http://www.ncbi.nlm.nih.gov/pubmed/20146084 >.

ASSENMACHER, M.; SCHMITZ, J.; RADBRUCH, A. Flow cytometric determination of cytokines in activated murine $\mathrm{T}$ helper lymphocytes: expression of interleukin-10 in interferon-gamma and in interleukin-4-expressing cells. Eur J Immunol, v. 24, n. 5, p. 1097-101, May 1994. ISSN 0014-2980. Disponível em: < http://www.ncbi.nlm.nih.gov/pubmed/7910138 >.

BADOVINAC, V. P.; HARTY, J. T. Programming, demarcating, and manipulating CD8+ T-cell memory. Immunol Rev, v. 211, p. 67-80, Jun 2006. ISSN 0105-2896. Disponível em: < http://www.ncbi.nlm.nih.gov/pubmed/16824118 >.

BAILEY, R., 2012. Disponível em: < <http://biology.about.com/od/anatomy/a/aa032808a.htm $>$.Disponível em: < http://blustein.tripod.com/>>.

BANEYX, F.; MUJACIC, M. Recombinant protein folding and misfolding in Escherichia coli. Nat Biotechnol, v. 22, n. 11, p. 1399-408, Nov 2004. ISSN 1087-0156. Disponível em: < http://www.ncbi.nlm.nih.gov/pubmed/15529165 >. 
BARCELLOS-HOFF, M. H. et al. Therapeutic targets in malignant glioblastoma microenvironment. Semin Radiat Oncol, v. 19, n. 3, p. 163-70, Jul 2009. ISSN 1532-9461. Disponível em: < http://www.ncbi.nlm.nih.gov/pubmed/19464631 >.

BASU, S. et al. CD91 is a common receptor for heat shock proteins gp96, hsp90, hsp70, and calreticulin. Immunity, v. 14, n. 3, p. 303-13, Mar 2001. ISSN 1074-7613. Disponível em: < http://www.ncbi.nlm.nih.gov/pubmed/11290339 >.

BATRA, S. K. et al. Epidermal growth factor ligand-independent, unregulated, cell-transforming potential of a naturally occurring human mutant EGFRvIII gene. Cell Growth Differ, v. 6, n. 10, p. 1251-9, Oct 1995. ISSN 1044-9523. Disponível em: < http://www.ncbi.nlm.nih.gov/pubmed/8845302 $>$.

BECKER, T.; HARTL, F. U.; WIELAND, F. CD40, an extracellular receptor for binding and uptake of Hsp70-peptide complexes. J Cell Biol, v. 158, n. 7, p. 1277-85, Sep 2002. ISSN 0021-9525. Disponível em: < http://www.ncbi.nlm.nih.gov/pubmed/12356871 >.

BEHIN, A. et al. Primary brain tumours in adults. Lancet, v. 361, n. 9354, p. 323-31, Jan 2003. ISSN 0140-6736. Disponível em: < http://www.ncbi.nlm.nih.gov/pubmed/12559880 >.

BELANICH, M. et al. Retrospective study of the correlation between the DNA repair protein alkyltransferase and survival of brain tumor patients treated with carmustine. Cancer Res, v. 56, n. 4, p. 783-8, Feb 1996. ISSN 0008-5472. Disponível em: < http://www.ncbi.nlm.nih.gov/pubmed/8631014 >.

BELLI, F. et al. Vaccination of metastatic melanoma patients with autologous tumor-derived heat shock protein gp96-peptide complexes: clinical and immunologic findings. J Clin Oncol, v. 20, n. 20, p. 4169-80, Oct 2002. ISSN 0732-183X. Disponível em: < http://www.ncbi.nlm.nih.gov/pubmed/12377960 >.

BERMAN, R. M. et al. Systemic administration of cellular IL-10 induces an effective, specific, and long-lived immune response against established tumors in mice. J Immunol, v. 157, n. 1, p. 231-8, Jul 1996. ISSN 0022-1767. Disponível em: 〈 http://www.ncbi.nlm.nih.gov/pubmed/8683120 >.

BIGNER, S. H. et al. Characterization of the epidermal growth factor receptor in human glioma cell lines and xenografts. Cancer Res, v. 50, n. 24, p. 8017-22, Dec 1990. ISSN 0008-5472. Disponível em: < http://www.ncbi.nlm.nih.gov/pubmed/2253244 >.

BINDER, R. J.; SRIVASTAVA, P. K. Essential role of CD91 in re-presentation of gp96-chaperoned peptides. Proc Natl Acad Sci U S A, v. 101, n. 16, p. 6128-33, Apr 2004. ISSN 0027-8424. Disponível em: < http://www.ncbi.nlm.nih.gov/pubmed/15073331 >.

BIOLABS, N. E., Disponível em: < http://tools.neb.com/NEBcutter2/ >. 
BODMER, J. L.; SCHNEIDER, P.; TSCHOPP, J. The molecular architecture of the TNF superfamily. Trends Biochem Sci, v. 27, n. 1, p. 19-26, Jan 2002. ISSN 0968-0004. Disponível em: < http://www.ncbi.nlm.nih.gov/pubmed/11796220 >.

BOGDAHN, U. et al. Targeted therapy for high-grade glioma with the TGF- $\beta 2$ inhibitor trabedersen: results of a randomized and controlled phase IIb study. Neuro Oncol, v. 13, n. 1, p. 132-42, Jan 2011. ISSN 1523-5866. Disponível em: < http://www.ncbi.nlm.nih.gov/pubmed/20980335 >.

BOLHASSANI, A. et al. Enhanced immunogenicity of HPV16E7 accompanied by Gp96 as an adjuvant in two vaccination strategies. Vaccine, v. 26, n. 26, p. 3362-70, Jun 2008. ISSN 0264-410X. Disponível em: < http://www.ncbi.nlm.nih.gov/pubmed/18471945 >.

BONAVIA, R. et al. Heterogeneity maintenance in glioblastoma: a social network. Cancer Res, v. 71, n. 12, p. 4055-60, Jun 2011. ISSN 1538-7445. Disponível em: < http://www.ncbi.nlm.nih.gov/pubmed/21628493 >.

BOOK, A. A. et al. IL-10 gene transfer to intracranial 9L glioma: tumor inhibition and cooperation with IL-2. J Neuroimmunol, v. 92, n. 1-2, p. 50-9, Dec 1998. ISSN 0165-5728. Disponível em: < http://www.ncbi.nlm.nih.gov/pubmed/9916879 >.

BRADFORD, M. M. A rapid and sensitive method for the quantitation of microgram quantities of protein utilizing the principle of protein-dye binding. Anal Biochem, v. 72, p. 248-54, May 1976. ISSN 0003-2697. Disponível em: < http://www.ncbi.nlm.nih.gov/pubmed/942051 >.

BRANDES, A. A. et al. Glioblastoma in adults. Crit Rev Oncol Hematol, v. 67, n. 2, p. 139-52, Aug 2008. ISSN 1040-8428. Disponível em: < http://www.ncbi.nlm.nih.gov/pubmed/18394916 >.

BRENNAN, C. et al. Glioblastoma subclasses can be defined by activity among signal transduction pathways and associated genomic alterations. PLoS One, v. 4, n. 11, p. e7752, 2009. ISSN 19326203. Disponível em: < http://www.ncbi.nlm.nih.gov/pubmed/19915670 >.

BUCKNER, J. C. et al. Phase II evaluation of recombinant interferon alpha and BCNU in recurrent glioma. J Neurosurg, v. 82, n. 3, p. 430-5, Mar 1995. ISSN 0022-3085. Disponível em: < http://www.ncbi.nlm.nih.gov/pubmed/7861221 >.

BUKAU, B.; HORWICH, A. L. The Hsp70 and Hsp60 chaperone machines. Cell, v. 92, n. 3, p. 35166, Feb 1998. ISSN 0092-8674. Disponível em: < http://www.ncbi.nlm.nih.gov/pubmed/9476895 >.

CAI, G. et al. CD160 inhibits activation of human CD4+ T cells through interaction with herpesvirus entry mediator. Nat Immunol, v. 9, n. 2, p. 176-85, Feb 2008. ISSN 1529-2916. Disponível em: < http://www.ncbi.nlm.nih.gov/pubmed/18193050 >.

CALDERWOOD, S. K. et al. Cell surface receptors for molecular chaperones. Methods, v. 43, n. 3, p. 199-206, Nov 2007. ISSN 1046-2023. Disponível em: < http://www.ncbi.nlm.nih.gov/pubmed/17920516 >. 
CALZASCIA, T. et al. Homing phenotypes of tumor-specific CD8 T cells are predetermined at the tumor site by crosspresenting APCs. Immunity, v. 22, n. 2, p. 175-84, Feb 2005. ISSN 1074-7613. Disponível em: < http://www.ncbi.nlm.nih.gov/pubmed/15723806 >.

CARFÍ, A. et al. Herpes simplex virus glycoprotein D bound to the human receptor HveA. Mol Cell, v. $8, \quad$ n. 1, p. 169-79, Jul 2001. ISSN 1097-2765. Disponível em: < http://www.ncbi.nlm.nih.gov/pubmed/11511370 >.

CARPENTER, G.; COHEN, S. Epidermal growth factor. J Biol Chem, v. 265, n. 14, p. 7709-12, May 1990. ISSN 0021-9258. Disponível em: 〈 http://www.ncbi.nlm.nih.gov/pubmed/2186024 >.

CASARES, S. et al. Antigen presentation by dendritic cells after immunization with DNA encoding a major histocompatibility complex class II-restricted viral epitope. J Exp Med, v. 186, n. 9, p. 1481-6, Nov 1997. ISSN 0022-1007. Disponível em: < http://www.ncbi.nlm.nih.gov/pubmed/9348305 >.

CHANDAWARKAR, R. Y.; WAGH, M. S.; SRIVASTAVA, P. K. The dual nature of specific immunological activity of tumor-derived gp96 preparations. J Exp Med, v. 189, n. 9, p. 1437-42, May 1999. ISSN 0022-1007. Disponível em: < http://www.ncbi.nlm.nih.gov/pubmed/10224283 >.

CHATTERGOON, M. A. et al. Specific immune induction following DNA-based immunization through in vivo transfection and activation of macrophages/antigen-presenting cells. J Immunol, v. 160 , n. 12, p. 5707-18, Jun 1998. ISSN 0022-1767. Disponível em: < http://www.ncbi.nlm.nih.gov/pubmed/9637479 >.

CHEUNG, T. C. et al. Evolutionarily divergent herpesviruses modulate $\mathrm{T}$ cell activation by targeting the herpesvirus entry mediator cosignaling pathway. Proc Natl Acad Sci U S A, v. 102, n. 37, p. 13218-23, Sep 2005. ISSN 0027-8424. Disponível em: < http://www.ncbi.nlm.nih.gov/pubmed/16131544 >.

CHOI, B. D. et al. EGFRvIII-targeted vaccination therapy of malignant glioma. Brain Pathol, v. 19, n. 4, p. 713-23, Oct 2009. ISSN 1750-3639. Disponível em: < http://www.ncbi.nlm.nih.gov/pubmed/19744042 >.

CHOMEZ, P. et al. An overview of the MAGE gene family with the identification of all human members of the family. Cancer Res, v. 61, n. 14, p. 5544-51, Jul 2001. ISSN 0008-5472. Disponível em: < http://www.ncbi.nlm.nih.gov/pubmed/11454705 >.

COELHO-CASTELO, A. A. et al. Tissue distribution of a plasmid DNA encoding Hsp65 gene is dependent on the dose administered through intramuscular delivery. Genet Vaccines Ther, v. 4, p. 1, 2006. ISSN 1479-0556. Disponível em: < http://www.ncbi.nlm.nih.gov/pubmed/16445866 >.

COFFMAN, R. L. et al. The role of helper T cell products in mouse B cell differentiation and isotype regulation. Immunol Rev, v. 102, p. 5-28, Feb 1988. ISSN 0105-2896. Disponível em: < http://www.ncbi.nlm.nih.gov/pubmed/2966762 >. 
COLOMBO, F. et al. Combined HSV-TK/IL-2 gene therapy in patients with recurrent glioblastoma multiforme: biological and clinical results. Cancer Gene Ther, v. 12, n. 10, p. 835-48, Oct 2005. ISSN 0929-1903. Disponível em: < http://www.ncbi.nlm.nih.gov/pubmed/15891772 >.

CONNOLLY, S. A. et al. Structure-based mutagenesis of herpes simplex virus glycoprotein D defines three critical regions at the gD-HveA/HVEM binding interface. J Virol, v. 77, n. 14, p. 8127-40, Jul 2003. ISSN 0022-538X. Disponível em: < http://www.ncbi.nlm.nih.gov/pubmed/12829851 >.

CONRY, R. M. et al. Safety and immunogenicity of a DNA vaccine encoding carcinoembryonic antigen and hepatitis B surface antigen in colorectal carcinoma patients. Clin Cancer Res, v. 8, n. 9, p. 2782-7, Sep 2002. ISSN 1078-0432. Disponível em: < http://www.ncbi.nlm.nih.gov/pubmed/12231517 >.

COPE, A. et al. The Th1 life cycle: molecular control of IFN- $\gamma$ to IL-10 switching. Trends Immunol, v. 32, n. 6, p. 278-86, Jun 2011. ISSN 1471-4981. Disponível em: < http://www.ncbi.nlm.nih.gov/pubmed/21531623 >.

CORR, M. et al. Gene vaccination with naked plasmid DNA: mechanism of CTL priming. J Exp Med, v. 184, n. 4, p. 1555-60, Oct 1996. ISSN 0022-1007. Disponível em: < http://www.ncbi.nlm.nih.gov/pubmed/8879229 >.

DAVID L. NELSON, M. M. C. Lehninger Princípios de Bioquímica. São Paulo: SARVIER, 2002.

DAVIES, D. C. Blood-brain barrier breakdown in septic encephalopathy and brain tumours. J Anat, v. 200, n. 6, p. 639-46, Jun 2002. ISSN 0021-8782. Disponível em: < http://www.ncbi.nlm.nih.gov/pubmed/12162731 >.

DE VLEESCHOUWER, S. et al. Persistent IL-10 production is required for glioma growth suppressive activity by Th1-directed effector cells after stimulation with tumor lysate-loaded dendritic cells. J Neurooncol, v. 84, n. 2, p. 131-40, Sep 2007. ISSN 0167-594X. Disponível em: < http://www.ncbi.nlm.nih.gov/pubmed/17361330 >.

DE WAAL MALEFYT, R.; YSSEL, H.; DE VRIES, J. E. Direct effects of IL-10 on subsets of human CD4+ T cell clones and resting T cells. Specific inhibition of IL-2 production and proliferation. $\mathbf{J}$ Immunol, v. 150, n. 11, p. 4754-65, Jun 1993. ISSN 0022-1767. Disponível em: < http://www.ncbi.nlm.nih.gov/pubmed/7684412 >.

DINIZ, M. O. et al. Immune responses and therapeutic antitumor effects of an experimental DNA vaccine encoding human papillomavirus type 16 oncoproteins genetically fused to herpesvirus glycoprotein D. Clin Vaccine Immunol, v. 17, n. 10, p. 1576-83, Oct 2010. ISSN 1556-679X. Disponível em: < http://www.ncbi.nlm.nih.gov/pubmed/20739505 >.

DUNN, G. P.; OLD, L. J.; SCHREIBER, R. D. The immunobiology of cancer immunosurveillance and immunoediting. Immunity, v. 21, n. 2, p. 137-48, Aug 2004. ISSN 1074-7613. Disponível em: < http://www.ncbi.nlm.nih.gov/pubmed/15308095 >. 
EHRHART, E. J. et al. Latent transforming growth factor beta1 activation in situ: quantitative and functional evidence after low-dose gamma-irradiation. FASEB J, v. 11, n. 12, p. 991-1002, Oct 1997. ISSN 0892-6638. Disponível em: < http://www.ncbi.nlm.nih.gov/pubmed/9337152 >.

EKSTRAND, A. J. et al. Genes for epidermal growth factor receptor, transforming growth factor alpha, and epidermal growth factor and their expression in human gliomas in vivo. Cancer Res, v. 51, n. 8 , p. 2164-72, Apr 1991. ISSN 0008-5472. Disponível em: < http://www.ncbi.nlm.nih.gov/pubmed/2009534 >.

EL ANDALOUSSI, A.; LESNIAK, M. S. An increase in CD4+CD25+FOXP3+ regulatory T cells in tumor-infiltrating lymphocytes of human glioblastoma multiforme. Neuro Oncol, v. 8, n. 3, p. 234-43, Jul 2006. ISSN 1522-8517. Disponível em: < http://www.ncbi.nlm.nih.gov/pubmed/16723631 >.

ENCR. European Network of Cancer Registries. Eurocim version 4.0. European incidence database V2.2 (1999). Lyon 2001.

ESCHENBURG, G. et al. DNA vaccination: using the patient's immune system to overcome cancer. Clin Dev Immunol, v. 2010, p. 169484, 2010. ISSN 1740-2530. Disponível em: < http://www.ncbi.nlm.nih.gov/pubmed/21197271 >.

FARZANEHPOUR, M. et al. HSP70 modified response against HPV based tumor. Eur Rev Med Pharmacol Sci, v. 17, n. 2, p. 228-34, Jan 2013. ISSN 1128-3602. Disponível em: < http://www.ncbi.nlm.nih.gov/pubmed/23377813 >.

FIORENTINO, D. F.; BOND, M. W.; MOSMANN, T. R. Two types of mouse T helper cell. IV. Th2 clones secrete a factor that inhibits cytokine production by Th1 clones. J Exp Med, v. 170, n. 6, p. 2081-95, Dec 1989. ISSN 0022-1007. Disponível em: < http://www.ncbi.nlm.nih.gov/pubmed/2531194 >.

FIORENTINO, D. F. et al. IL-10 inhibits cytokine production by activated macrophages. J Immunol, v. 147, n. 11, p. 3815-22, Dec 1991. ISSN 0022-1767. Disponível em: < http://www.ncbi.nlm.nih.gov/pubmed/1940369 >.

IL-10 acts on the antigen-presenting cell to inhibit cytokine production by Th1 cells. $\mathbf{J}$ Immunol, v. 146, n. 10, p. 3444-51, May 1991. ISSN 0022-1767. Disponível em: < http://www.ncbi.nlm.nih.gov/pubmed/1827484 >.

FISCHER, U. et al. Glioma-expressed antigen 2 (GLEA2): a novel protein that can elicit immune responses in glioblastoma patients and some controls. Clin Exp Immunol, v. 126, n. 2, p. 206-13, Nov 2001. ISSN 0009-9104. Disponível em: < http://www.ncbi.nlm.nih.gov/pubmed/11703362 >.

FURNARI, F. B. et al. Malignant astrocytic glioma: genetics, biology, and paths to treatment. Genes Dev, v. 21, n. 21, p. 2683-710, Nov 2007. ISSN 0890-9369. Disponível em: < http://www.ncbi.nlm.nih.gov/pubmed/17974913 >. 
FÄRKKILÄ, M. et al. Randomised, controlled study of intratumoral recombinant gamma-interferon treatment in newly diagnosed glioblastoma. Br J Cancer, v. 70, n. 1, p. 138-41, Jul 1994. ISSN $0007-$ 0920. Disponível em: < http://www.ncbi.nlm.nih.gov/pubmed/8018525 >.

GAVRIELI, M. et al. Characterization of phosphotyrosine binding motifs in the cytoplasmic domain of B and T lymphocyte attenuator required for association with protein tyrosine phosphatases SHP-1 and SHP-2. Biochem Biophys Res Commun, v. 312, n. 4, p. 1236-43, Dec 2003. ISSN 0006-291X. Disponível em: < http://www.ncbi.nlm.nih.gov/pubmed/14652006 >.

GILBOA, E. The makings of a tumor rejection antigen. Immunity, v. 11, n. 3, p. 263-70, Sep 1999. ISSN 1074-7613. Disponível em: < http://www.ncbi.nlm.nih.gov/pubmed/10514004 >.

GOLDMANN, J. et al. T cells traffic from brain to cervical lymph nodes via the cribroid plate and the nasal mucosa. J Leukoc Biol, v. 80, n. 4, p. 797-801, Oct 2006. ISSN 0741-5400. Disponível em: < http://www.ncbi.nlm.nih.gov/pubmed/16885505 >.

GONZALEZ, L. C. et al. A coreceptor interaction between the CD28 and TNF receptor family members B and T lymphocyte attenuator and herpesvirus entry mediator. Proc Natl Acad Sci U S A, v. 102, n. 4, p. 1116-21, Jan 2005. ISSN 0027-8424. Disponível em: < http://www.ncbi.nlm.nih.gov/pubmed/15647361 >.

GONÇALVES, E. D. et al. Improve protective efficacy of a TB DNA-HSP65 vaccine by BCG priming. Genet Vaccines Ther, v. 5, p. 7, 2007. ISSN 1479-0556. Disponível em: < http://www.ncbi.nlm.nih.gov/pubmed/17714584 >.

GURUNATHAN, S.; KLINMAN, D. M.; SEDER, R. A. DNA vaccines: immunology, application, and optimization*. Annu Rev Immunol, v. 18, p. 927-74, 2000. ISSN 0732-0582. Disponível em: < http://www.ncbi.nlm.nih.gov/pubmed/10837079 >.

GUSTAFSON, M. P. et al. Systemic immune suppression in glioblastoma: the interplay between CD14+HLA-DRlo/neg monocytes, tumor factors, and dexamethasone. Neuro Oncol, v. 12, n. 7, p. 631-44, Jul 2010. ISSN 1523-5866. Disponível em: < http://www.ncbi.nlm.nih.gov/pubmed/20179016 $>$.

GUY, B. The perfect mix: recent progress in adjuvant research. Nat Rev Microbiol, v. 5, n. 7, p. 50517, Jul 2007. ISSN 1740-1534. Disponível em: 〈 http://www.ncbi.nlm.nih.gov/pubmed/17558426 >.

HARRINGTON, L. E. et al. Interleukin 17-producing CD4+ effector T cells develop via a lineage distinct from the T helper type 1 and 2 lineages. Nat Immunol, v. 6, n. 11, p. 1123-32, Nov 2005. ISSN 1529-2908. Disponível em: < http://www.ncbi.nlm.nih.gov/pubmed/16200070 >.

HEGI, M. E. et al. MGMT gene silencing and benefit from temozolomide in glioblastoma. N Engl J Med, v. 352, n. 10, p. 997-1003, Mar 2005. ISSN 1533-4406. Disponível em: < http://www.ncbi.nlm.nih.gov/pubmed/15758010 >. 
HEIMBERGER, A. et al. Tumor-specific peptide vaccination in newly-diagnosed patients with GBM. J Clin Oncol: Abstrat 2529 p. 2006.

HEIMBERGER, A. B.; SAMPSON, J. H. Immunotherapy coming of age: what will it take to make it standard of care for glioblastoma? Neuro Oncol, v. 13, n. 1, p. 3-13, Jan 2011. ISSN 1523-5866. Disponível em: < http://www.ncbi.nlm.nih.gov/pubmed/21149252 >.

HEISEL, S. M. et al. Increased seroreactivity to glioma-expressed antigen 2 in brain tumor patients under radiation. PLoS One, v. 3, n. 5, p. e2164, 2008. ISSN 1932-6203. Disponível em: < http://www.ncbi.nlm.nih.gov/pubmed/18478111 >.

HEMMI, H. et al. A Toll-like receptor recognizes bacterial DNA. Nature, v. 408, n. 6813, p. 740-5, Dec 2000. ISSN 0028-0836. Disponível em: < http://www.ncbi.nlm.nih.gov/pubmed/11130078 >.

HENSON, J. W. Treatment of glioblastoma multiforme: a new standard. Arch Neurol, v. 63, n. 3, p. 337-41, Mar 2006. ISSN 0003-9942. Disponível em: < http://www.ncbi.nlm.nih.gov/pubmed/16533960 >.

HUMPHREY, P. A. et al. Anti-synthetic peptide antibody reacting at the fusion junction of deletionmutant epidermal growth factor receptors in human glioblastoma. Proc Natl Acad Sci U S A, v. 87, n. 11, p. 4207-11, Jun 1990. ISSN 0027-8424. Disponível em: < http://www.ncbi.nlm.nih.gov/pubmed/1693434 >.

HUNG, K. et al. The central role of CD4(+) T cells in the antitumor immune response. J Exp Med, v. 188, n. 12, p. 2357-68, Dec 1998. ISSN 0022-1007. Disponível em: < http://www.ncbi.nlm.nih.gov/pubmed/9858522 >.

HURCHLA, M. A. et al. B and T lymphocyte attenuator exhibits structural and expression polymorphisms and is highly Induced in anergic CD4+ T cells. J Immunol, v. 174, n. 6, p. 3377-85, Mar 2005. ISSN 0022-1767. Disponível em: < http://www.ncbi.nlm.nih.gov/pubmed/15749870 >.

HUSSAIN, S. F.; HEIMBERGER, A. B. Immunotherapy for human glioma: innovative approaches and recent results. Expert Rev Anticancer Ther, v. 5, n. 5, p. 777-90, Oct 2005. ISSN 1744-8328. Disponível em: < http://www.ncbi.nlm.nih.gov/pubmed/16221048 >.

ISHII, K. J. et al. A Toll-like receptor-independent antiviral response induced by double-stranded Bform DNA. Nat Immunol, v. 7, n. 1, p. 40-8, Jan 2006. ISSN 1529-2908. Disponível em: < http://www.ncbi.nlm.nih.gov/pubmed/16286919 >.

JACKSON, C. et al. Challenges in immunotherapy presented by the glioblastoma multiforme microenvironment. Clin Dev Immunol, v. 2011, p. 732413, 2011. ISSN 1740-2530. Disponível em: < http://www.ncbi.nlm.nih.gov/pubmed/22190972 >.

JANKOVIC, D. et al. Conventional T-bet(+)Foxp3(-) Th1 cells are the major source of hostprotective regulatory IL-10 during intracellular protozoan infection. J Exp Med, v. 204, n. 2, p. 273 83, Feb 2007. ISSN 0022-1007. Disponível em: < http://www.ncbi.nlm.nih.gov/pubmed/17283209 >. 
JAROS, E. et al. Prognostic implications of p53 protein, epidermal growth factor receptor, and Ki-67 labelling in brain tumours. Br J Cancer, v. 66, n. 2, p. 373-85, Aug 1992. ISSN 0007-0920. Disponível em: < http://www.ncbi.nlm.nih.gov/pubmed/1503912 >.

JEVSEVAR, S. et al. Production of nonclassical inclusion bodies from which correctly folded protein can be extracted. Biotechnol Prog, v. 21, n. 2, p. 632-9, 2005 Mar-Apr 2005. ISSN 8756-7938. Disponível em: < http://www.ncbi.nlm.nih.gov/pubmed/15801811 >.

JOCKHECK-CLARK, A. R. et al. Re-examination of CD91 function in GRP94 (glycoprotein 96) surface binding, uptake, and peptide cross-presentation. J Immunol, v. 185, n. 11, p. 6819-30, Dec 2010. ISSN 1550-6606. Disponível em: < http://www.ncbi.nlm.nih.gov/pubmed/21048103 >.

JOHNSON, L. A.; SAMPSON, J. H. Immunotherapy approaches for malignant glioma from 2007 to 2009. Curr Neurol Neurosci Rep, v. 10, n. 4, p. 259-66, Jul 2010. ISSN 1534-6293. Disponível em: < http://www.ncbi.nlm.nih.gov/pubmed/20424975 >.

KAMPINGA, H. H. et al. Guidelines for the nomenclature of the human heat shock proteins. Cell Stress Chaperones, v. 14, n. 1, p. 105-11, Jan 2009. ISSN 1355-8145. Disponível em: < http://www.ncbi.nlm.nih.gov/pubmed/18663603 >.

KAWAI, T.; AKIRA, S. Toll-like receptors and their crosstalk with other innate receptors in infection and immunity. Immunity, v. 34, n. 5, p. 637-50, May 2011. ISSN 1097-4180. Disponível em: < http://www.ncbi.nlm.nih.gov/pubmed/21616434 >.

KAYE, J. CD160 and BTLA: LIGHTs out for CD4+ T cells. Nat Immunol, v. 9, n. 2, p. 122-4, Feb 2008. ISSN 1529-2916. Disponível em: < http://www.ncbi.nlm.nih.gov/pubmed/18204424 >.

KESARI, S. Understanding glioblastoma tumor biology: the potential to improve current diagnosis and treatments. Semin Oncol, v. 38 Suppl 4, p. S2-10, Dec 2011. ISSN 1532-8708. Disponível em: < http://www.ncbi.nlm.nih.gov/pubmed/22078644 >.

KIKUCHI, T. et al. Vaccination of glioma patients with fusions of dendritic and glioma cells and recombinant human interleukin 12. J Immunother, v. 27, n. 6, p. 452-9, 2004 Nov-Dec 2004. ISSN 1524-9557. Disponível em: < http://www.ncbi.nlm.nih.gov/pubmed/15534489 >.

KIM, J. J. et al. Molecular and immunological analysis of genetic prostate specific antigen (PSA) vaccine. Oncogene, v. 17, n. 24, p. 3125-35, Dec 1998. ISSN 0950-9232. Disponível em: < http://www.ncbi.nlm.nih.gov/pubmed/9872328 >.

KOZAK, M. Downstream secondary structure facilitates recognition of initiator codons by eukaryotic ribosomes. Proc Natl Acad Sci U S A, v. 87, n. 21, p. 8301-5, Nov 1990. ISSN 0027-8424. Disponível em: < http://www.ncbi.nlm.nih.gov/pubmed/2236042 >.

KRIEG, A. M. et al. CpG DNA induces sustained IL-12 expression in vivo and resistance to Listeria monocytogenes challenge. J Immunol, v. 161, n. 5, p. 2428-34, Sep 1998. ISSN 0022-1767. Disponível em: < http://www.ncbi.nlm.nih.gov/pubmed/9725240 >. 
KRIEG, C. et al. B and T lymphocyte attenuator regulates CD8+ T cell-intrinsic homeostasis and memory cell generation. Nat Immunol, v. 8, n. 2, p. 162-71, Feb 2007. ISSN 1529-2908. Disponível em: < http://www.ncbi.nlm.nih.gov/pubmed/17206146 >.

KUKURUZINSKA, M. A.; BERGH, M. L.; JACKSON, B. J. Protein glycosylation in yeast. Annu Rev Biochem, v. 56, p. 915-44, 1987. ISSN 0066-4154. Disponível em: < http://www.ncbi.nlm.nih.gov/pubmed/3304149 >.

KUNISAWA, J.; SHASTRI, N. Hsp90alpha chaperones large C-terminally extended proteolytic intermediates in the MHC class I antigen processing pathway. Immunity, v. 24, n. 5, p. 523-34, May 2006. ISSN 1074-7613. Disponível em: < http://www.ncbi.nlm.nih.gov/pubmed/16713971 >.

KURAMOTO, T. Detection of MAGE-1 tumor antigen in brain tumor. Kurume Med J, v. 44, n. 1, p. 43-51, 1997. ISSN 0023-5679. Disponível em: < http://www.ncbi.nlm.nih.gov/pubmed/9154761 >.

KUTZLER, M. A.; WEINER, D. B. DNA vaccines: ready for prime time? Nat Rev Genet, v. 9, n. 10, p. 776-88, Oct 2008. ISSN 1471-0064. Disponível em: < http://www.ncbi.nlm.nih.gov/pubmed/18781156 >.

LAEMMLI, U. K. Cleavage of structural proteins during the assembly of the head of bacteriophage T4. Nature, v. 227, n. 5259, p. 680-5, Aug 1970. ISSN 0028-0836. Disponível em: < http://www.ncbi.nlm.nih.gov/pubmed/5432063 >.

LASARO, M. O. et al. Anti-tumor DNA vaccines based on the expression of human papillomavirus16 E6/E7 oncoproteins genetically fused with the glycoprotein D from herpes simplex virus-1. Microbes Infect, v. 7, n. 15, p. 1541-50, Dec 2005. ISSN 1286-4579. Disponível em: < http://www.ncbi.nlm.nih.gov/pubmed/16213178 >.

Active immunotherapy combined with blockade of a coinhibitory pathway achieves regression of large tumor masses in cancer-prone mice. Mol Ther, v. 19, n. 9, p. 1727-36, Sep 2011. ISSN 1525-0024. Disponível em: < http://www.ncbi.nlm.nih.gov/pubmed/21587210 >.

Targeting of antigen to the herpesvirus entry mediator augments primary adaptive immune responses. Nat Med, v. 14, n. 2, p. 205-12, Feb 2008. ISSN 1546-170X. Disponível em: < http://www.ncbi.nlm.nih.gov/pubmed/18193057>.

LEDWITH, B. J. et al. Plasmid DNA vaccines: assay for integration into host genomic DNA. Dev Biol (Basel), v. 104, p. 33-43, 2000. ISSN 1424-6074. Disponível em: < http://www.ncbi.nlm.nih.gov/pubmed/11713822 >.

LESLEY, J.; HYMAN, R.; KINCADE, P. W. CD44 and its interaction with extracellular matrix. Adv Immunol, v. 54, p. 271-335, 1993. ISSN 0065-2776. Disponível em: < http://www.ncbi.nlm.nih.gov/pubmed/8379464 >. 
LEV, A. et al. The exception that reinforces the rule: crosspriming by cytosolic peptides that escape degradation. Immunity, v. 28, n. 6, p. 787-98, Jun 2008. ISSN 1097-4180. Disponível em: < http://www.ncbi.nlm.nih.gov/pubmed/18549799 >.

LIAU, L. M. et al. Treatment of a patient by vaccination with autologous dendritic cells pulsed with allogeneic major histocompatibility complex class I-matched tumor peptides. Case Report. Neurosurg Focus, v. 9, n. 6, p. e8, 2000. ISSN 1092-0684. Disponível em: < http://www.ncbi.nlm.nih.gov/pubmed/16817691 >.

LIMA, D. S. Avaliação da Vacina DNA-hsp65 na Indução de Auto-Agressão Tecidual. 2006. Imunologia Básica e Aplicada, FMRP-USP, Ribeirão Preto.

LINDQUIST, S.; CRAIG, E. A. The heat-shock proteins. Annu Rev Genet, v. 22, p. 631-77, 1988. ISSN 0066-4197. Disponível em: < http://www.ncbi.nlm.nih.gov/pubmed/2853609 >.

LIU, M. A. DNA vaccines: a review. J Intern Med, v. 253, n. 4, p. 402-10, Apr 2003. ISSN 09546820. Disponível em: < http://www.ncbi.nlm.nih.gov/pubmed/12653868 >.

LOCKSLEY, R. M.; KILLEEN, N.; LENARDO, M. J. The TNF and TNF receptor superfamilies: integrating mammalian biology. Cell, v. 104, n. 4, p. 487-501, Feb 2001. ISSN 0092-8674. Disponível em: < http://www.ncbi.nlm.nih.gov/pubmed/11239407 >.

LOW, L. et al. DNA vaccination with electroporation induces increased antibody responses in patients with prostate cancer. Hum Gene Ther, v. 20, n. 11, p. 1269-78, Nov 2009. ISSN 1557-7422. Disponível em: < http://www.ncbi.nlm.nih.gov/pubmed/19619001 >.

LUGADE, A. A. et al. Radiation-induced IFN-gamma production within the tumor microenvironment influences antitumor immunity. J Immunol, v. 180, n. 5, p. 3132-9, Mar 2008. ISSN 0022-1767. Disponível em: < http://www.ncbi.nlm.nih.gov/pubmed/18292536 >.

LÁSARO, M. O. et al. Antibody-inducing properties of a prototype bivalent herpes simplex virus/enterotoxigenic Escherichia coli DNA vaccine. FEMS Immunol Med Microbiol, v. 35, n. 1, p. 25-31, Jan 2003. ISSN 0928-8244. Disponível em: < http://www.ncbi.nlm.nih.gov/pubmed/12589954 $>$.

MAEDA, M. et al. Murine CD160, Ig-like receptor on NK cells and NKT cells, recognizes classical and nonclassical MHC class I and regulates NK cell activation. J Immunol, v. 175, n. 7, p. 4426-32, Oct 2005. ISSN 0022-1767. Disponível em: < http://www.ncbi.nlm.nih.gov/pubmed/16177084 >.

MAES, W.; VAN GOOL, S. W. Experimental immunotherapy for malignant glioma: lessons from two decades of research in the GL261 model. Cancer Immunol Immunother, v. 60, n. 2, p. 153-60, Feb 2011. ISSN 1432-0851. Disponível em: < http://www.ncbi.nlm.nih.gov/pubmed/21120655 >.

MANAM, S. et al. Plasmid DNA vaccines: tissue distribution and effects of DNA sequence, adjuvants and delivery method on integration into host DNA. Intervirology, v. 43, n. 4-6, p. 273-81, 2000. ISSN 0300-5526. Disponível em: < http://www.ncbi.nlm.nih.gov/pubmed/11251382 >. 
MARSTERS, S. A. et al. Herpesvirus entry mediator, a member of the tumor necrosis factor receptor (TNFR) family, interacts with members of the TNFR-associated factor family and activates the transcription factors NF-kappaB and AP-1. J Biol Chem, v. 272, n. 22, p. 14029-32, May 1997. ISSN 0021-9258. Disponível em: < http://www.ncbi.nlm.nih.gov/pubmed/9162022 >.

MASOPUST, D. et al. Stimulation history dictates memory CD8 T cell phenotype: implications for prime-boost vaccination. J Immunol, v. 177, n. 2, p. 831-9, Jul 2006. ISSN 0022-1767. Disponível em: 〈 http://www.ncbi.nlm.nih.gov/pubmed/16818737 >.

MASSA, C.; MELANI, C.; COLOMBO, M. P. Chaperon and adjuvant activity of hsp70: different natural killer requirement for cross-priming of chaperoned and bystander antigens. Cancer Res, v. 65, n. 17 , p. 7942-9, Sep 2005. ISSN 0008-5472. Disponível em: < http://www.ncbi.nlm.nih.gov/pubmed/16140966 >.

MASSON, F. et al. Brain microenvironment promotes the final functional maturation of tumorspecific effector CD8+ T cells. J Immunol, v. 179, n. 2, p. 845-53, Jul 2007. ISSN 0022-1767. Disponível em: < http://www.ncbi.nlm.nih.gov/pubmed/17617575 >.

MAYER, M. P.; BUKAU, B. Hsp70 chaperones: cellular functions and molecular mechanism. Cell Mol Life Sci, v. 62, n. 6, p. 670-84, Mar 2005. ISSN 1420-682X. Disponível em: < http://www.ncbi.nlm.nih.gov/pubmed/15770419>.

MEDICI, M. A. et al. Protection by herpes simplex virus glycoprotein D against Fas-mediated apoptosis: role of nuclear factor kappaB. J Biol Chem, v. 278, n. 38, p. 36059-67, Sep 2003. ISSN 0021-9258. Disponível em: 〈 http://www.ncbi.nlm.nih.gov/pubmed/12844494 >.

MICHALUART, P. et al. Phase I trial of DNA-hsp65 immunotherapy for advanced squamous cell carcinoma of the head and neck. Cancer Gene Ther, v. 15, n. 10, p. 676-84, Oct 2008. ISSN 14765500. Disponível em: < http://www.ncbi.nlm.nih.gov/pubmed/18535616 >.

MINCHEFF, M. et al. Naked DNA and adenoviral immunizations for immunotherapy of prostate cancer: a phase I/II clinical trial. Eur Urol, v. 38, n. 2, p. 208-17, Aug 2000. ISSN 0302-2838. Disponível em: < http://www.ncbi.nlm.nih.gov/pubmed/10895014 >.

MONTGOMERY, R. I. et al. Herpes simplex virus-1 entry into cells mediated by a novel member of the TNF/NGF receptor family. Cell, v. 87, n. 3, p. 427-36, Nov 1996. ISSN 0092-8674. Disponível em: < http://www.ncbi.nlm.nih.gov/pubmed/8898196 >.

MOORE, K. W. et al. Interleukin-10 and the interleukin-10 receptor. Annu Rev Immunol, v. 19, p. 683-765, 2001. ISSN 0732-0582. Disponível em: < http://www.ncbi.nlm.nih.gov/pubmed/11244051 $>$.

MOSMANN, T. R. et al. Two types of murine helper T cell clone. I. Definition according to profiles of lymphokine activities and secreted proteins. J Immunol, v. 136, n. 7, p. 2348-57, Apr 1986. ISSN 0022-1767. Disponível em: 〈 http://www.ncbi.nlm.nih.gov/pubmed/2419430 >. 
MRASS, P.; WENINGER, W. Immune cell migration as a means to control immune privilege: lessons from the CNS and tumors. Immunol Rev, v. 213, p. 195-212, Oct 2006. ISSN 0105-2896. Disponível em: < http://www.ncbi.nlm.nih.gov/pubmed/16972905 >.

MURSHID, A.; GONG, J.; CALDERWOOD, S. K. Heat-shock proteins in cancer vaccines: agents of antigen cross-presentation. Expert Rev Vaccines, v. 7, n. 7, p. 1019-30, Sep 2008. ISSN 1744-8395. Disponível em: < http://www.ncbi.nlm.nih.gov/pubmed/18767951 >.

Heat shock protein 90 mediates efficient antigen cross presentation through the scavenger receptor expressed by endothelial cells-I. J Immunol, v. 185, n. 5, p. 2903-17, Sep 2010. ISSN 15506606. Disponível em: < http://www.ncbi.nlm.nih.gov/pubmed/20686127 >.

NISHIKAWA, R. et al. A mutant epidermal growth factor receptor common in human glioma confers enhanced tumorigenicity. Proc Natl Acad Sci U S A, v. 91, n. 16, p. 7727-31, Aug 1994. ISSN 00278424. Disponível em: < http://www.ncbi.nlm.nih.gov/pubmed/8052651 >.

NITTA, T. et al. Selective expression of interleukin-10 gene within glioblastoma multiforme. Brain Res, v. 649, n. 1-2, p. 122-8, Jun 1994. ISSN 0006-8993. Disponível em: < http://www.ncbi.nlm.nih.gov/pubmed/7953624 >.

$\mathrm{O}$, I. et al. A DNA vaccine expressing tyrosinase-related protein-2 induces T-cell-mediated protection against mouse glioblastoma. Cancer Gene Ther, v. 10, n. 9, p. 678-88, Sep 2003. ISSN 0929-1903. Disponível em: < http://www.ncbi.nlm.nih.gov/pubmed/12944987 >.

O'GARRA, A.; VIEIRA, P. T(H)1 cells control themselves by producing interleukin-10. Nat Rev Immunol, v. 7, n. 6, p. 425-8, Jun 2007. ISSN 1474-1733. Disponível em: < http://www.ncbi.nlm.nih.gov/pubmed/17525751 >.

OHGAKI, H.; KLEIHUES, P. Genetic pathways to primary and secondary glioblastoma. Am J Pathol, v. 170, n. 5, p. 1445-53, May 2007. ISSN 0002-9440. Disponível em: < http://www.ncbi.nlm.nih.gov/pubmed/17456751 >.

OKADA, H. et al. Immunotherapeutic approaches for glioma. Crit Rev Immunol, v. 29, n. 1, p. 142, 2009. ISSN 1040-8401. Disponível em: < http://www.ncbi.nlm.nih.gov/pubmed/19348609 >.

ORGANIZATION WWH. International Statistical Classification of Diseases and Related Health Problems. Geneva 1992.

PACHTER, J. S.; DE VRIES, H. E.; FABRY, Z. The blood-brain barrier and its role in immune privilege in the central nervous system. J Neuropathol Exp Neurol, v. 62, n. 6, p. 593-604, Jun 2003. ISSN 0022-3069. Disponível em: < http://www.ncbi.nlm.nih.gov/pubmed/12834104 >.

PARDOLL, D. M. Inducing autoimmune disease to treat cancer. Proc Natl Acad Sci U S A, v. 96, n. 10, p. 5340-2, May 1999. ISSN 0027-8424. Disponível em: < http://www.ncbi.nlm.nih.gov/pubmed/10318881 >. 
PELIZON, A. C. et al. Genetic vaccine for tuberculosis (pVAXhsp65) primes neonate mice for a strong immune response at the adult stage. Genet Vaccines Ther, v. 5, p. 12, 2007. ISSN 1479-0556. Disponível em: < http://www.ncbi.nlm.nih.gov/pubmed/18047644 >.

PHILLIPS, H. S. et al. Molecular subclasses of high-grade glioma predict prognosis, delineate a pattern of disease progression, and resemble stages in neurogenesis. Cancer Cell, v. 9, n. 3, p. 157-73, Mar 2006. ISSN 1535-6108. Disponível em: < http://www.ncbi.nlm.nih.gov/pubmed/16530701 >.

PLAUTZ, G. E. et al. T cell adoptive immunotherapy of newly diagnosed gliomas. Clin Cancer Res, v. 6, n. 6, p. 2209-18, Jun 2000. ISSN 1078-0432. Disponível em: < http://www.ncbi.nlm.nih.gov/pubmed/10873070 >.

POLLARA, G. et al. Herpes simplex virus type-1-induced activation of myeloid dendritic cells: the roles of virus cell interaction and paracrine type I IFN secretion. J Immunol, v. 173, n. 6, p. 4108-19, Sep 2004. ISSN 0022-1767. Disponível em: < http://www.ncbi.nlm.nih.gov/pubmed/15356161 >.

PRINS, R. M.; ODESA, S. K.; LIAU, L. M. Immunotherapeutic targeting of shared melanomaassociated antigens in a murine glioma model. Cancer Res, v. 63, n. 23, p. 8487-91, Dec 2003. ISSN 0008-5472. Disponível em: < http://www.ncbi.nlm.nih.gov/pubmed/14679014 >.

PUPA, S. M. et al. Prevention of spontaneous neu-expressing mammary tumor development in mice transgenic for rat proto-neu by DNA vaccination. Gene Ther, v. 8, n. 1, p. 75-9, Jan 2001. ISSN 0969-7128. Disponível em: < http://www.ncbi.nlm.nih.gov/pubmed/11402305 >.

QIU, B. et al. IL-10 and TGF- $\beta 2$ are overexpressed in tumor spheres cultured from human gliomas. Mol Biol Rep, v. 38, n. 5, p. 3585-91, Jun 2011. ISSN 1573-4978. Disponível em: < http://www.ncbi.nlm.nih.gov/pubmed/21088899 >.

QUATTROCCHI, K. B. et al. Pilot study of local autologous tumor infiltrating lymphocytes for the treatment of recurrent malignant gliomas. J Neurooncol, v. 45, n. 2, p. 141-57, 1999. ISSN 0167594X. Disponível em: < http://www.ncbi.nlm.nih.gov/pubmed/10778730 >.

RAINER, T. H. L-selectin in health and disease. Resuscitation, v. 52, n. 2, p. 127-41, Feb 2002. ISSN 0300-9572. Disponível em: < http://www.ncbi.nlm.nih.gov/pubmed/11841880 >.

RASCHER, G. et al. Extracellular matrix and the blood-brain barrier in glioblastoma multiforme: spatial segregation of tenascin and agrin. Acta Neuropathol, v. 104, n. 1, p. 85-91, Jul 2002. ISSN 0001-6322. Disponível em: < http://www.ncbi.nlm.nih.gov/pubmed/12070669 >.

RAZ, E. et al. Preferential induction of a Th1 immune response and inhibition of specific IgE antibody formation by plasmid DNA immunization. Proc Natl Acad Sci U S A, v. 93, n. 10, p. 5141 5, May 1996. ISSN 0027-8424. Disponível em: < http://www.ncbi.nlm.nih.gov/pubmed/8643542 >.

REIS E SOUSA, C. Dendritic cells in a mature age. Nat Rev Immunol, v. 6, n. 6, p. 476-83, Jun 2006. ISSN 1474-1733. Disponível em: < http://www.ncbi.nlm.nih.gov/pubmed/16691244 >. 
REITS, E. A. et al. Radiation modulates the peptide repertoire, enhances MHC class I expression, and induces successful antitumor immunotherapy. J Exp Med, v. 203, n. 5, p. 1259-71, May 2006. ISSN 0022-1007. Disponível em: < http://www.ncbi.nlm.nih.gov/pubmed/16636135 >.

RIOS, W. M. Construção de uma vacina de DNA bivalente para tuberculose expressando a proteína gD do HSV-1 e os epítopos da Hsp65 micobacteriana. 2009. Imunologia Básica e Aplicada, FMRP-USP, Ribeirão Preto.

RIVOLTINI, L. et al. Human tumor-derived heat shock protein 96 mediates in vitro activation and in vivo expansion of melanoma- and colon carcinoma-specific T cells. J Immunol, v. 171, n. 7, p. 346774, Oct 2003. ISSN 0022-1767. Disponível em: < http://www.ncbi.nlm.nih.gov/pubmed/14500642 >.

ROLLE, C. E.; SENGUPTA, S.; LESNIAK, M. S. Challenges in clinical design of immunotherapy trials for malignant glioma. Neurosurg Clin N Am, v. 21, n. 1, p. 201-14, Jan 2010. ISSN 1558-1349. Disponível em: < http://www.ncbi.nlm.nih.gov/pubmed/19944979 >.

ROONEY, I. A. et al. The lymphotoxin-beta receptor is necessary and sufficient for LIGHT-mediated apoptosis of tumor cells. J Biol Chem, v. 275, n. 19, p. 14307-15, May 2000. ISSN 0021-9258. Disponível em: < http://www.ncbi.nlm.nih.gov/pubmed/10799510 >.

SAIKALI, S. et al. Expression of nine tumour antigens in a series of human glioblastoma multiforme: interest of EGFRvIII, IL-13Ralpha2, gp100 and TRP-2 for immunotherapy. J Neurooncol, v. 81, n. 2, p. 139-48, Jan 2007. ISSN 0167-594X. Disponível em: < http://www.ncbi.nlm.nih.gov/pubmed/17004103 >.

SALLUSTO, F.; GEGINAT, J.; LANZAVECCHIA, A. Central memory and effector memory T cell subsets: function, generation, and maintenance. Annu Rev Immunol, v. 22, p. 745-63, 2004. ISSN 0732-0582. Disponível em: < http://www.ncbi.nlm.nih.gov/pubmed/15032595 >.

SAMBROOK, J., FRITSCH, E.F., MANIATIS, T. Molecular Cloning: a laboratory manual. New York: <st1:place w:st="on"><st1:placename w:st="on">Cold <st1:placetype w:st="on">Spring $<$ st1:placetype w:st="on">Harbor Laboratory Press, 1989.

SAMPSON, J. H. et al. Tumor-specific immunotherapy targeting the EGFRvIII mutation in patients with malignant glioma. Semin Immunol, v. 20, n. 5, p. 267-75, Oct 2008. ISSN 1044-5323. Disponível em: 〈 http://www.ncbi.nlm.nih.gov/pubmed/18539480 >.

SANTOS JÚNIOR, R. R. et al. Immune modulation induced by tuberculosis DNA vaccine protects non-obese diabetic mice from diabetes progression. Clin Exp Immunol, v. 149, n. 3, p. 570-8, Sep 2007. ISSN 0009-9104. Disponível em: < http://www.ncbi.nlm.nih.gov/pubmed/17590177 >.

SANTOS-JUNIOR, R. R. et al. Immunomodulation and protection induced by DNA-hsp65 vaccination in an animal model of arthritis. Hum Gene Ther, v. 16, n. 11, p. 1338-45, Nov 2005. ISSN 1043-0342. Disponível em: < http://www.ncbi.nlm.nih.gov/pubmed/16259568 >. 
SASAKI, M. et al. MAGE-E1, a new member of the melanoma-associated antigen gene family and its expression in human glioma. Cancer Res, v. 61, n. 12, p. 4809-14, Jun 2001. ISSN 0008-5472. Disponível em: < http://www.ncbi.nlm.nih.gov/pubmed/11406556 >.

SCHALK, J. A. et al. Preclinical and clinical safety studies on DNA vaccines. Hum Vaccin, v. 2, n. 2, p. 45-53, 2006 Mar-Apr 2006. ISSN 1554-8600. Disponível em: < http://www.ncbi.nlm.nih.gov/pubmed/17012886 >.

SCHIFF, D.; BATCHELOR, T., $2010 . \quad$ Disponível em: < 〈http://www.uptodate.com/contents/classification-of-brain-tumors > >.

SEDY, J. R. et al. B and T lymphocyte attenuator regulates T cell activation through interaction with herpesvirus entry mediator. Nat Immunol, v. 6, n. 1, p. 90-8, Jan 2005. ISSN 1529-2908. Disponível em: < http://www.ncbi.nlm.nih.gov/pubmed/15568026 >.

SEGAL, B. M.; GLASS, D. D.; SHEVACH, E. M. Cutting Edge: IL-10-producing CD4+ T cells mediate tumor rejection. J Immunol, v. 168, n. 1, p. 1-4, Jan 2002. ISSN 0022-1767. Disponível em: $<$ http://www.ncbi.nlm.nih.gov/pubmed/11751938 $>$.

SEROT, J. M. et al. Ultrastructural and immunohistological evidence for dendritic-like cells within human choroid plexus epithelium. Neuroreport, v. 8, n. 8, p. 1995-8, May 1997. ISSN 0959-4965. Disponível em: < http://www.ncbi.nlm.nih.gov/pubmed/9223091 >.

SOUZA, P. R. M. D. Modulação de células dendríticas com a proteína de choquetérmico de 65 kDa. 2011. Imunologia Básica e Aplicada, FMRP-USP, Ribeirão Preto.

SRIVASTAVA, P. K. Immunotherapy for human cancer using heat shock protein-peptide complexes. Curr Oncol Rep, v. 7, n. 2, p. 104-8, Mar 2005. ISSN 1523-3790. Disponível em: < http://www.ncbi.nlm.nih.gov/pubmed/15717943 >.

SRIVASTAVA, P. K.; MAKI, R. G. Stress-induced proteins in immune response to cancer. Curr Top Microbiol Immunol, v. 167, p. 109-23, 1991. ISSN 0070-217X. Disponível em: < http://www.ncbi.nlm.nih.gov/pubmed/1711433 >.

STEITZ, J. et al. Genetic immunization of mice with human tyrosinase-related protein 2: implications for the immunotherapy of melanoma. Int J Cancer, v. 86, n. 1, p. 89-94, Apr 2000. ISSN 0020-7136. Disponível em: < http://www.ncbi.nlm.nih.gov/pubmed/10728600 >.

STOSCHECK, C. M.; KING, L. E. Functional and structural characteristics of EGF and its receptor and their relationship to transforming proteins. J Cell Biochem, v. 31, n. 2, p. 135-52, 1986. ISSN 0730-2312. Disponível em: < http://www.ncbi.nlm.nih.gov/pubmed/3015991 >.

STUPP, R. et al. Radiotherapy plus concomitant and adjuvant temozolomide for glioblastoma. $\mathbf{N}$ Engl J Med, v. 352, n. 10, p. 987-96, Mar 2005. ISSN 1533-4406. Disponível em: < http://www.ncbi.nlm.nih.gov/pubmed/15758009 >. 
SUL, J.; FINE, H. A. Malignant gliomas: new translational therapies. Mt Sinai J Med, v. 77, n. 6, p. 655-66, 2010 Nov-Dec 2010. ISSN 1931-7581. Disponível em: < http://www.ncbi.nlm.nih.gov/pubmed/21105127 >.

SZATMÁRI, T. et al. Detailed characterization of the mouse glioma 261 tumor model for experimental glioblastoma therapy. Cancer Sci, v. 97, n. 6, p. 546-53, Jun 2006. ISSN 1347-9032. Disponível em: < http://www.ncbi.nlm.nih.gov/pubmed/16734735 >.

TABATABAI, G. et al. Irradiation and hypoxia promote homing of haematopoietic progenitor cells towards gliomas by TGF-beta-dependent HIF-1alpha-mediated induction of CXCL12. Brain, v. 129, n. Pt 9, p. 2426-35, Sep 2006. ISSN 1460-2156. Disponível em: < http://www.ncbi.nlm.nih.gov/pubmed/16835250 >.

TAGA, K.; TOSATO, G. IL-10 inhibits human T cell proliferation and IL-2 production. J Immunol, v. $148, \quad$ n. 4, p. 1143-8, Feb 1992. ISSN 0022-1767. Disponível em: < http://www.ncbi.nlm.nih.gov/pubmed/1737931 >.

TAGAWA, S. T. et al. Phase I study of intranodal delivery of a plasmid DNA vaccine for patients with Stage IV melanoma. Cancer, v. 98, n. 1, p. 144-54, Jul 2003. ISSN 0008-543X. Disponível em: $<$ http://www.ncbi.nlm.nih.gov/pubmed/12833467 >.

TAKAOKA, A. et al. DAI (DLM-1/ZBP1) is a cytosolic DNA sensor and an activator of innate immune response. Nature, v. 448, n. 7152, p. 501-5, Jul 2007. ISSN 1476-4687. Disponível em: < http://www.ncbi.nlm.nih.gov/pubmed/17618271 >.

TAKEUCHI, O.; AKIRA, S. Pattern recognition receptors and inflammation. Cell, v. 140, n. 6, p. 805-20, Mar 2010. ISSN 1097-4172. Disponível em: < http://www.ncbi.nlm.nih.gov/pubmed/20303872 >.

TAMADA, K. et al. Modulation of T-cell-mediated immunity in tumor and graft-versus-host disease models through the LIGHT co-stimulatory pathway. Nat Med, v. 6, n. 3, p. 283-9, Mar 2000. ISSN 1078-8956. Disponível em: 〈 http://www.ncbi.nlm.nih.gov/pubmed/10700230 >.

TAMURA, Y. et al. Immunotherapy of tumors with autologous tumor-derived heat shock protein preparations. Science, v. 278, n. 5335, p. 117-20, Oct 1997. ISSN 0036-8075. Disponível em: < http://www.ncbi.nlm.nih.gov/pubmed/9311915 >.

THÉRIAULT, J. R.; ADACHI, H.; CALDERWOOD, S. K. Role of scavenger receptors in the binding and internalization of heat shock protein 70. J Immunol, v. 177, n. 12, p. 8604-11, Dec 2006. ISSN 0022-1767. Disponível em: < http://www.ncbi.nlm.nih.gov/pubmed/17142759 >.

TRINCHIERI, G. Interleukin-10 production by effector T cells: Th1 cells show self control. J Exp Med, v. 204, n. 2, p. 239-43, Feb 2007. ISSN 0022-1007. Disponível em: < http://www.ncbi.nlm.nih.gov/pubmed/17296790 >. 
TUOMELA, M.; STANESCU, I.; KROHN, K. Validation overview of bio-analytical methods. Gene Ther, v. 12 Suppl 1, p. S131-8, Oct 2005. ISSN 0969-7128. Disponível em: < http://www.ncbi.nlm.nih.gov/pubmed/16231045 >.

UDONO, H.; SRIVASTAVA, P. K. Heat shock protein 70-associated peptides elicit specific cancer immunity. J Exp Med, v. 178, n. 4, p. 1391-6, Oct 1993. ISSN 0022-1007. Disponível em: < http://www.ncbi.nlm.nih.gov/pubmed/8376942 >.

UEDA, R. et al. Systemic inhibition of transforming growth factor-beta in glioma-bearing mice improves the therapeutic efficacy of glioma-associated antigen peptide vaccines. Clin Cancer Res, v. 15, n. 21, p. 6551-9, Nov 2009. ISSN 1078-0432. Disponível em: < http://www.ncbi.nlm.nih.gov/pubmed/19861464 >.

ULMER, J. B. et al. Generation of MHC class I-restricted cytotoxic T lymphocytes by expression of a viral protein in muscle cells: antigen presentation by non-muscle cells. Immunology, v. 89, n. 1, p. 59-67, Sep 1996. ISSN 0019-2805. Disponível em: < http://www.ncbi.nlm.nih.gov/pubmed/8911141 $>$.

Heterologous protection against influenza by injection of DNA encoding a viral protein. Science, v. 259, n. 5102, p. 1745-9, Mar 1993. ISSN 0036-8075. Disponível em: < http://www.ncbi.nlm.nih.gov/pubmed/8456302 >.

UNITED STATES CANCER STATISTICS. National Program of Cancer Registries.

VABULAS, R.; WAGNER, H. Toll-like receptor-dependent activation of antigen presenting cells byHsp60, Gp96 and Hsp70. Molecular Chaperones \& CellSignalling, p. 113-133, 2005.

VABULAS, R. M. et al. HSP70 as endogenous stimulus of the Toll/interleukin-1 receptor signal pathway. J Biol Chem, v. 277, n. 17, p. 15107-12, Apr 2002. ISSN 0021-9258. Disponível em: < http://www.ncbi.nlm.nih.gov/pubmed/11842086 >.

VABULAS, R. M.; WAGNER, H.; SCHILD, H. Heat shock proteins as ligands of toll-like receptors. Curr Top Microbiol Immunol, v. 270, p. 169-84, 2002. ISSN 0070-217X. Disponível em: < http://www.ncbi.nlm.nih.gov/pubmed/12467251 >.

VAULEON, E. et al. Overview of cellular immunotherapy for patients with glioblastoma. Clin Dev Immunol, v. 2010, 2010. ISSN 1740-2530. Disponível em: < http://www.ncbi.nlm.nih.gov/pubmed/20953324 >.

VELDHOEN, M. et al. Transforming growth factor-beta 'reprograms' the differentiation of T helper 2 cells and promotes an interleukin 9-producing subset. Nat Immunol, v. 9, n. 12, p. 1341-6, Dec 2008. ISSN 1529-2916. Disponível em: < http://www.ncbi.nlm.nih.gov/pubmed/18931678 >.

WATANABE, N. et al. BTLA is a lymphocyte inhibitory receptor with similarities to CTLA-4 and PD-1. Nat Immunol, v. 4, n. 7, p. 670-9, Jul 2003. ISSN 1529-2908. Disponível em: < http://www.ncbi.nlm.nih.gov/pubmed/12796776 >. 
WATSON, R. J. et al. Herpes simplex virus type-1 glycoprotein D gene: nucleotide sequence and expression in Escherichia coli. Science, v. 218, n. 4570, p. 381-4, Oct 1982. ISSN 0036-8075. Disponível em: < http://www.ncbi.nlm.nih.gov/pubmed/6289440 $>$.

WEI, J.; HENDERSHOT, L. M. Protein folding and assembly in the endoplasmic reticulum. EXS, v. 77, p. 41-55, 1996. ISSN 1023-294X. Disponível em: < http://www.ncbi.nlm.nih.gov/pubmed/8856968 >.

WEIDE, B. et al. Plasmid DNA- and messenger RNA-based anti-cancer vaccination. Immunol Lett, v. $115, \quad$ n. $1, \quad$ p. 33-42, Jan 2008. ISSN 0165-2478. Disponível em: < http://www.ncbi.nlm.nih.gov/pubmed/18006079 >.

WELLER, R. O.; ENGELHARDT, B.; PHILLIPS, M. J. Lymphocyte targeting of the central nervous system: a review of afferent and efferent CNS-immune pathways. Brain Pathol, v. 6, n. 3, p. 275-88, Jul 1996. ISSN 1015-6305. Disponível em: < http://www.ncbi.nlm.nih.gov/pubmed/8864284 >.

WEN, P. Y.; KESARI, S. Malignant gliomas in adults. N Engl J Med, v. 359, n. 5, p. 492-507, Jul 2008. ISSN 1533-4406. Disponível em: < http://www.ncbi.nlm.nih.gov/pubmed/18669428 >.

WINEGAR, R. A. et al. Determination of tissue distribution of an intramuscular plasmid vaccine using PCR and in situ DNA hybridization. Hum Gene Ther, v. 7, n. 17, p. 2185-94, Nov 1996. ISSN 1043-0342. Disponível em: < http://www.ncbi.nlm.nih.gov/pubmed/8934232 >.

WOLFF, J. A. et al. Direct gene transfer into mouse muscle in vivo. Science, v. 247, n. 4949 Pt 1, p. 1465-8, Mar 1990. ISSN 0036-8075. Disponível em: < http://www.ncbi.nlm.nih.gov/pubmed/1690918 $>$.

WU, S. L. et al. Dynamic profiling of the post-translational modifications and interaction partners of epidermal growth factor receptor signaling after stimulation by epidermal growth factor using Extended Range Proteomic Analysis (ERPA). Mol Cell Proteomics, v. 5, n. 9, p. 1610-27, Sep 2006. ISSN 1535-9476. Disponível em: < http://www.ncbi.nlm.nih.gov/pubmed/16799092 >.

YAMANAKA, R. Cell- and peptide-based immunotherapeutic approaches for glioma. Trends Mol Med, v. 14, n. 5, p. 228-35, May 2008. ISSN 1471-4914. Disponível em: < http://www.ncbi.nlm.nih.gov/pubmed/18403264 >.

YANG, I. et al. The role of microglia in central nervous system immunity and glioma immunology. $\mathbf{J}$ Clin Neurosci, v. 17, n. 1, p. 6-10, Jan 2010. ISSN 1532-2653. Disponível em: < http://www.ncbi.nlm.nih.gov/pubmed/19926287 >.

YU, J. S. et al. Vaccination of malignant glioma patients with peptide-pulsed dendritic cells elicits systemic cytotoxicity and intracranial T-cell infiltration. Cancer Res, v. 61, n. 3, p. 842-7, Feb 2001. ISSN 0008-5472. Disponível em: < http://www.ncbi.nlm.nih.gov/pubmed/11221866 >. 
ZHENG, L. M. et al. Interleukin-10 inhibits tumor metastasis through an NK cell-dependent mechanism. J Exp Med, v. 184, n. 2, p. 579-84, Aug 1996. ISSN 0022-1007. Disponível em: < http://www.ncbi.nlm.nih.gov/pubmed/8760811 >. 


\section{ANEXO}

Anexo 1.0 - Clonagem dos genes EGFRvIII, cERBB2, MAGE, GLEA e gp96 no vetor pKLAC

Os plasmídios pBSKgDEGFRvIII, pBSKgDcERBB2, pBSKgDMAGE, pBSKgDGLEA e pBSKgp96 também foram utilizados na amplificação dos genes EGFRvIII, cERBB2, MAGE, GLEA e gp96 para posterior clonagem no vetor pKLAC e expressão na levedura $K$. lactis.

\subsection{Amplificacão e clivagem dos genes EGFRvIII, cERBB2, MAGE, GLEA e gp96}

Os genes EGFRvIII, cERBB2, MAGE, GLEA e gp96 foram amplificados para a clonagem no vetor pKLAC utilizando-se como molde os plasmídios pBSKgDEGFRvIII, pBSKgDcERBB2, pBSKgDMAGE, pBSKgDGLEA e pKBSKgp96 e os seguintes iniciadores:

EGFRvIIIS_pKLAC: 5'CTACTCGAGAAAAGAATGCTGGAGGAAAAGAAAG 3'

EGFRvIIIR_pKLAC: 5 `CGGGGTACCTCA GTGGTGGTGGTGGTGGTGGCAGTGGGGGCCGTCAATG 3`

ERBB2pKLAC_S: 5'CTACTCGAGAAAAGAATGAAGCTGCGGCTCCC 3'

ERBB2pKLAC_R: 5'CGGGGTACCTCA $G T G G T G G T G G T G G T G G T G C C G C T G T G T T C C A T C C T C$ 3'

MagepKLAC_S: 5'CTACTCGAGAAAAGAATGCCTCTTGAGCAGAG 3'

MagepKLAC_R: 5'CGGGGTACCTCAGTGGTGGTGGTGGTGGTGCTCTTCCCCCTCTCTC 3'

GleapKLAC_S: 5'CTACTCGAGAAAAGAATGACAAAGCATCCACC 3'

GleapKLAC_R: 5'CGGGGTACCTCAGTGGTGGTGGTGGTGGTGCTTCTTTGGCTTCACTC 3'

Gp96pKLAC_S: 5'CTACTCGAGAAAAGAATGGACGATGAAGTTGATG 3'

Gp96pKLAC_R: 5'GGAAGATCTTCAGTGGTGGTGGTGGTGGTGCAATTCATCTTTTTCAGC 3'

Nos oligonucleotídeos $\mathrm{S}$ foram incluídos um sítio de ancoragem (em cinza), o sítio da enzima XhoI (região sublinhada), uma sequência que codifica o sítio de clivagem da enzima KEX (AAAAGA) para retirada do peptídeo sinal e a porção inicial do gene (aproximadamente 18 bases) e nos oligonucleotídeos R, a porção final do gene, uma cauda de histidina (em itálico), um stop códon (em negrito), o sítio da enzima KpnI ou BglII (para gp96) (região sublinhada) e um sítio de ancoragem (em cinza).

$\mathrm{Na}$ reação de amplificação, além dos $0,1 \mu \mathrm{M}$ de cada oligonucleotídeo foi utilizado 100-150ng do molde, 0,2mM de cada dNTPs, tampão $1 \mathrm{X}$ e 5 unidade da enzima High fidelity; a reação foi feita em $100 \mu \mathrm{L}$ finais utilizando-se o programa VAC (1 minuto de 
extensão para a amplificação dos genes EGFRvIII, cERBB2 e MAGE e 2 minutos para a amplificação dos genes GLEA e gp96). Os produtos das amplificações foram analisados em gel de agarose $1 \%$ (Figura 1) e purificados utilizando-se o Wizard SV Gel and PCR Clean-Up System.
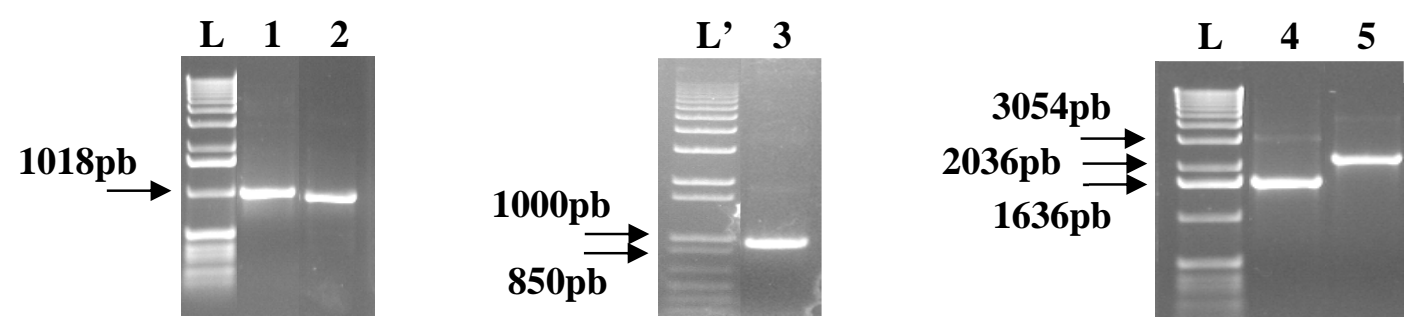

Figura 1: Amplificação dos genes EGFRvIII, cERBB2, MAGE, GLEA e gp96 para a clonagem no pKLAC. L, L'-marcador $1 \mathrm{~Kb}$ e $1 \mathrm{~Kb}$ Plus, respectivamente, 1-MAGE, 2-cERBB2, 3-EGFRvIII, 4-GLEA e 5gp96.

Os cinco genes foram amplificados de forma correta revelando bandas de tamanhos esperados, MAGE, 987pb, cERBB2, 945pb, EGFRvIII, 948pb, GLEA, 1674pb e gp96, $2394 \mathrm{pb}$. Esses genes foram clivados com as enzimas XhoI e KpnI (ou BglII para gp96) para a clonagem no vetor pKLAC clivado com as mesmas enzimas: 2,4 $\mathrm{g}$ de cada gene foram clivados com 4 unidades de cada enzima, juntamente com tampão 1X em um volume final de $60-70 \mu \mathrm{L}$ por aproximadamente 16 horas a $37^{\circ} \mathrm{C}$. Os fragmentos clivados foram diretamente purificados utilizando-se o Wizard SV Gel and PCR Clean-Up System.

\subsection{Clivagem do vetor pKLAC}

O plasmídio pKLAC (Figura 2) $(3,84 \mu \mathrm{g})$ foi digerido com 6 unidades das enzimas XhoI e KpnI e 2,4 $\mathrm{g}$ desse mesmo vetor foram digeridos com 4 unidades das enzimas XhoI e BglII, juntamente com tampão FastDigest $1 \mathrm{X}$ em um volume final de $80 \mu \mathrm{L}$ e $60 \mu \mathrm{L}$, respectivamente, a $37^{\circ} \mathrm{C}$, overnight. A digestão foi analisada em gel de agarose $1 \%$ (Figura 3) e os vetores digeridos com as diferentes enzimas foram desfosforilados com 1 unidade da enzima CIAP (Invitrogen) a $37^{\circ} \mathrm{C}$ por 5 minutos. Em seguida os plasmídios foram purificados utilizando-se o Wizard SV Gel and PCR Clean-Up System. 


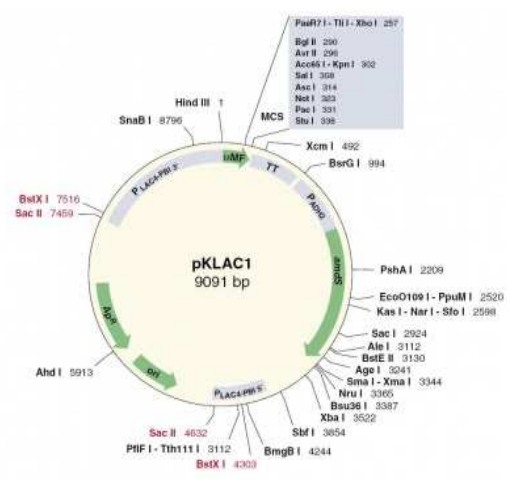

Figura 2: Plasmídio pKLAC. Vetor utilizado nas construções dos vetores de expressão.

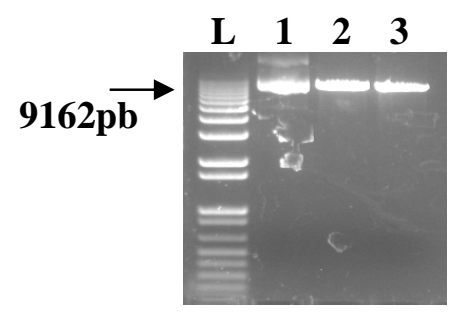

Figura 3: Clivagem do vetor pKLAC. L-marcador $1 \mathrm{~Kb}, 1$-pKLAC não digerido, 2-pKLAC clivado com as enzimas XhoI e KpnI e 3-pKLAC clivado com as enzimas XhoI e BglII.

$\mathrm{O}$ vetor pKLAC clivado foi visualizado por uma única banda que indica seu tamanho de 9091pb. Esse vetor foi purificado para posterior ligação com os fragmentos EGFRvIII, cERBB2, MAGE, GLEA e gp96.

\subsection{Clonagem do gene EGFRvIII no vetor pKLAC}

O fragmento EGFRvIII clivado com as enzimas XhoI e KpnI, obtido como descrito no item 1.1, foi clonado no plasmídio pKLAC, clivado com as mesmas enzimas (item 1.2), pela reação de ligação feita a temperatura ambiente por 1 hora, utilizando-se 120ng do fragmento, 60ng do vetor, tampão da enzima $1 \mathrm{X}$ e 1 unidade da T4 DNA ligase em um volume final de $10 \mu \mathrm{L}$. Todo volume da ligação foi utilizado na transformação de células de E. coli Top10 competentes que foram plaqueadas em meio LB ágar suplementado com ampicilina.

A seleção do plasmídio recombinante pKLACEGFRvIII foi feita por uma PCR de 13 colônias individuais, diluídas em água estéril e nomeadas de 40 a 52. A reação foi realizada com $5 \mu \mathrm{L}$ da mistura de água + bactérias como molde, $0,1 \mu \mathrm{M}$ de cada oligonucleotídeo (pKLACseq_S** e EGFRvIII_Rseq), 0,2mM de cada dNTPs, tampão 1X, 1,5mM de $\mathrm{MgCl}_{2}$ e 1 unidade da enzima Taq DNA polimerase em um volume final de $20 \mu \mathrm{L}$ (programa VAC). O produto da PCR foi analisado em gel de agarose 1\% (Figura 4): 
pKLACseq_S: 5’'GAAGAAGCCTTGATTGGA 3’

**O oligonucleotídeo pKLACseq_S hibridiza no vetor pKLAC.
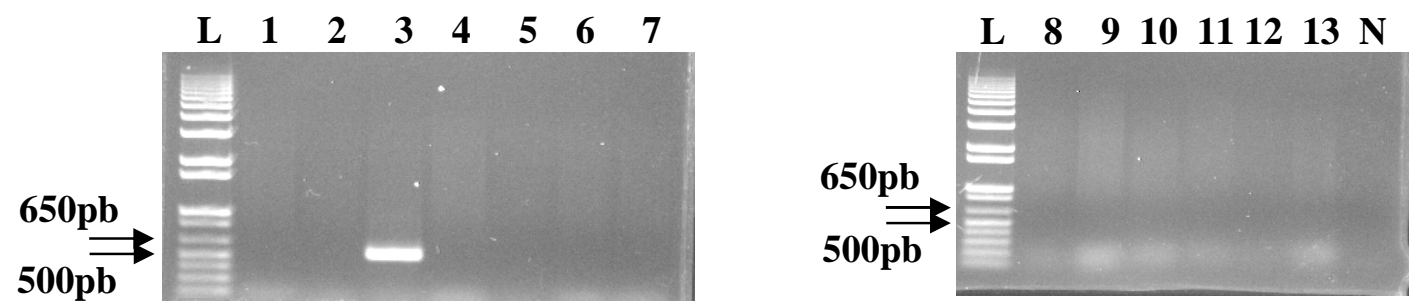

Figura 4: PCR de colônia da ligação pKLAC + EGFRvIII. PCR das 13 colônias da ligação pKLAC + EGFRvIII com os oligonucleotídeos pKLACsense e EGFRvIII_Rseq. L-marcador 1Kb Plus, 1 ao 10-PCR das 13 colônias, nomeadas de 40 a 52 e N-negativo.

Apenas o clone pKLACEGFRvIII_42 apresentou o fragmento EGFRvIII na direção correta demonstrada no gel pelo fragmento entre 500-650pb (548pb). A partir desse resultado, foram realizadas a extração e clivagem do plasmídio da colônia 42. A reação de clivagem foi feita com 320ng do plasmídio, 0,5 unidade das enzimas XhoI e KpnI, tampão FastDigest $1 \mathrm{X}$ em um volume final de $20 \mu \mathrm{L}$, overnight a $37^{\circ} \mathrm{C}$. A digestão foi analisada em gel de agarose $1 \%$ (Figura 5):

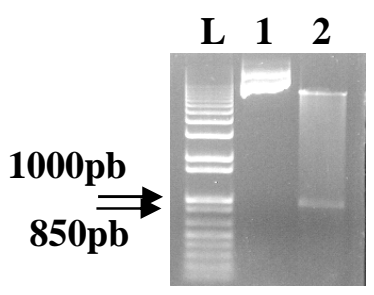

Figura 5: Clivagem do plasmídio pKLACEGFRvIII. Clivagem do clone pVAXEGFRvIII_42 com as enzimas XhoI e KpnI. L-marcador 1Kb Plus, 1-pKLACEGFRvIII_42 não digerido e 2-pKLACEGFRvIII_42 digerido.

O clone pKLACEGFRvIII_42 liberou um fragmento entre 850-1000pb (936pb) após a clivagem, indicando a presença do fragmento EGFRvIII no interior do vetor.

A partir dos resultados obtidos com a PCR e a análise de restrição, o clone 42 que apresentava o plasmídio recombinante pKLACEGFRvIII foi analisado por sequenciamento utilizando-se os oligonucleotídeos pKLACseq_S e pKLACseq_R para confirmação da clonagem (Figura 6).

pKLACseq_R: 5' TTATCGCACAAGACAATC 3' 


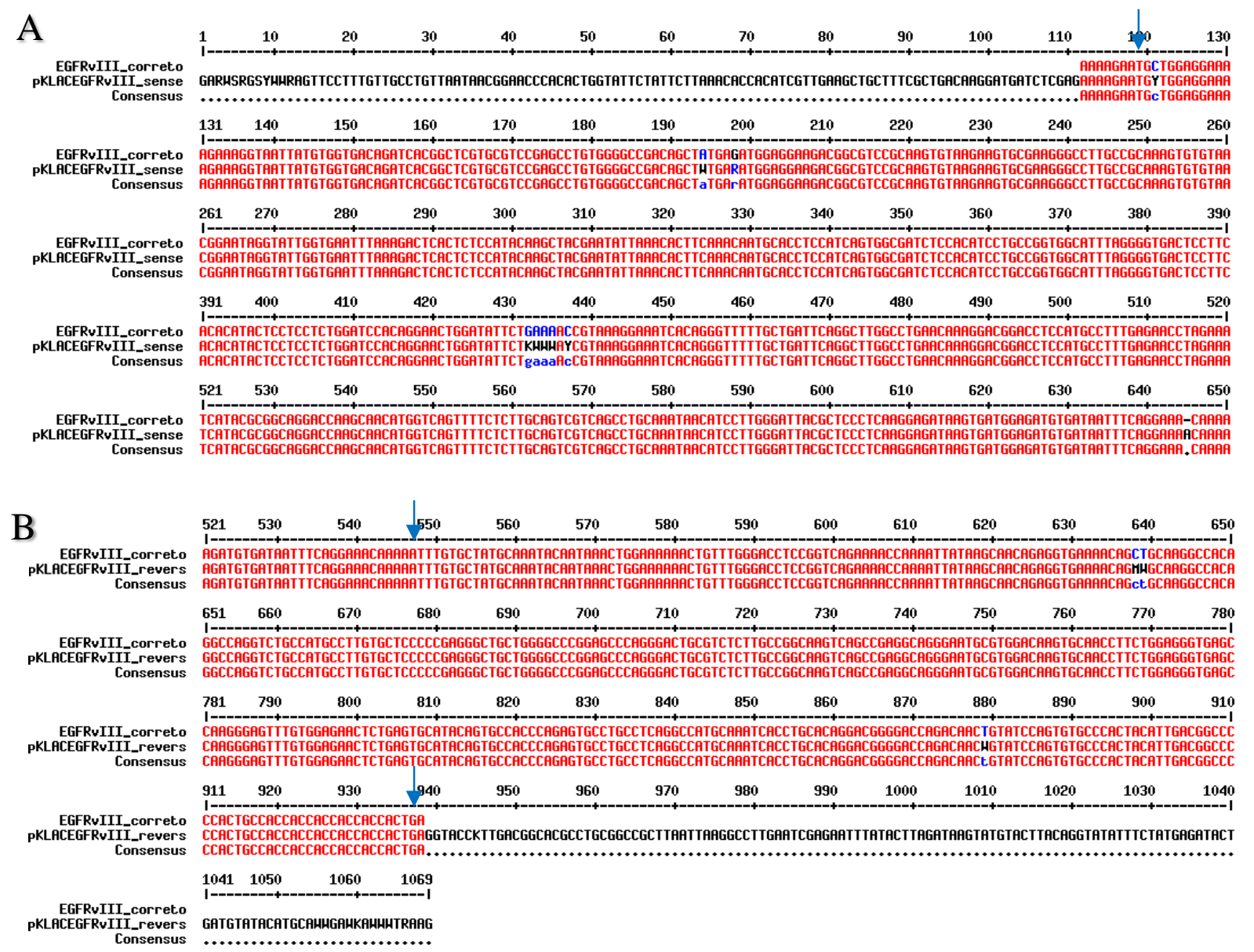

Figura 6: Sequenciamento do clone pKLACEGFR_42. Alinhamento da sequência EGFRvIII com o clone pKLACEGFRvIII_42 sequenciado com os oligonucleotídeos pKLACseq_S (A) e pKLACseq_R (B); em destaque (seta), o códon de iniciação da tradução da proteína EGFRvIII, o início da sequência que não é encontrada no sequenciamento anterior e o códon de terminação da tradução.

O sequenciamento e a análise do eletroferograma confirmaram a clonagem e a sequência correta da gene clonado.

\subsection{Clonagem do gene cERBB2 no vetor $\mathrm{PKLAC}$}

O fragmento cERBB2 clivado com as enzimas XhoI e KpnI, obtido como descrito no item 1.1, foi clonado no plasmídio pKLAC, clivado com as mesmas enzimas (item 1.2), pela reação de ligação feita a temperatura ambiente por 1 hora, utilizando-se 60ng do fragmento, 120ng do vetor, tampão da enzima 1X e 1 unidade da T4 DNA ligase em um volume final de $10 \mu \mathrm{L}$. Todo volume da ligação foi utilizado na transformação de células de E. coli Top10 competentes que foram plaqueadas em meio LB ágar suplementado com ampicilina.

A seleção do plasmídio recombinante pKLACcERBB2 foi feita por uma PCR de 6 grupos contendo 5 colônias cada, diluídas em água estéril. Cada reação foi realizada com $5 \mu \mathrm{L}$ 
da mistura de água + bactérias como molde, $0,1 \mu \mathrm{M}$ de cada oligonucleotídeo (pKLACseq_S e cERBB2_Rseq), 0,2mM de cada dNTPs, tampão $1 \mathrm{X}, 1,5 \mathrm{mM}$ de $\mathrm{MgCl}_{2}$ e 1 unidade da enzima Taq DNA polimerase em um volume final de $20 \mu \mathrm{L}$ (programa VAC). O produto da PCR foi analisado em gel de agarose 1\% (Figura 7):

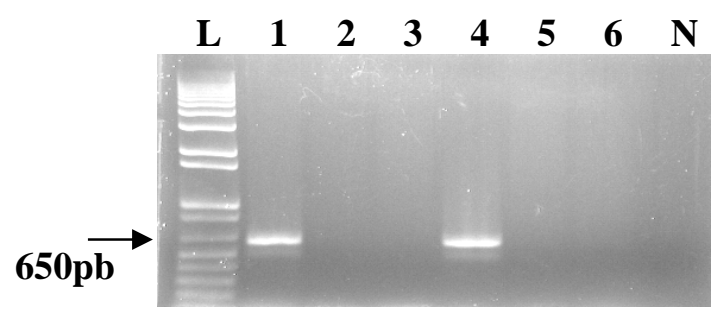

Figura 7: PCR de colônia da ligação pKLAC + cERBB2. PCR dos 6 grupos das colônias da ligação pKLAC + cERBB2 com os oligonucleotídeos pKLACseq_S e cERBB2_Rseq. L-marcador 1Kb Plus, 1 ao 6-PCR dos 6 grupos e N-negativo.

Os grupos 1 e 4 apresentaram banda de amplificação próxima a 650pb (tamanho esperado de $611 \mathrm{pb}$ ) indicando a presença do fragmento cERBB2 na direção correta.

A partir desse resultado, foi realizada a extração dos plasmídios dos dois grupos. Esses plasmídios foram submetidos a uma reação de clivagem, na qual 720ng de cada plasmídio foram digeridos com 0,5 unidade das enzimas XhoI e KpnI, tampão FastDigest 1X em uma reação final de $20 \mu \mathrm{L}$, overnight a $37^{\circ} \mathrm{C}$. A digestão foi analisada em gel de agarose $1 \%$ (Figura 8):

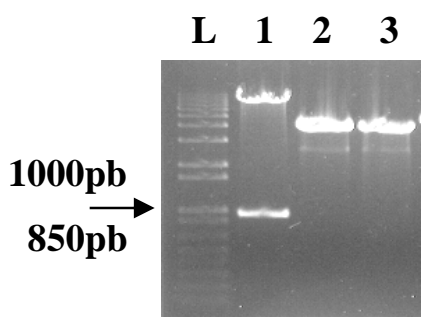

Figura 8: Clivagem dos plasmídios pKLACcERBB2. Clivagem dos plasmídios pKLACcERBB2 com as enzimas XhoI e KpnI. L-marcador 1Kb Plus e 1 ao 3-pKLACcERBB2_8, 9 e 10 digeridos.

O clone pKLACcERBB2_8 apresentou fragmento entre 850-1000pb (tamanho esperado de 933pb) após a clivagem, indicando a presença do fragmento cERBB2 no interior do vetor. A clivagem dos outros plasmídios também foi analisada em gel de agarose, no entanto, apareceu apenas um rastro e não foi repetida, pois obtivemos o clone 8 como recombinante.

A partir dos resultados obtidos com a PCR e a análise de restrição, o clone 8 que apresentava o plasmídio recombinante pKLACcERBB2 foi analisado por sequenciamento 
utilizando-se os oligonucleotídeos pKLACseq_S e pKLACseq_R para confirmação da clonagem (Figura 9).

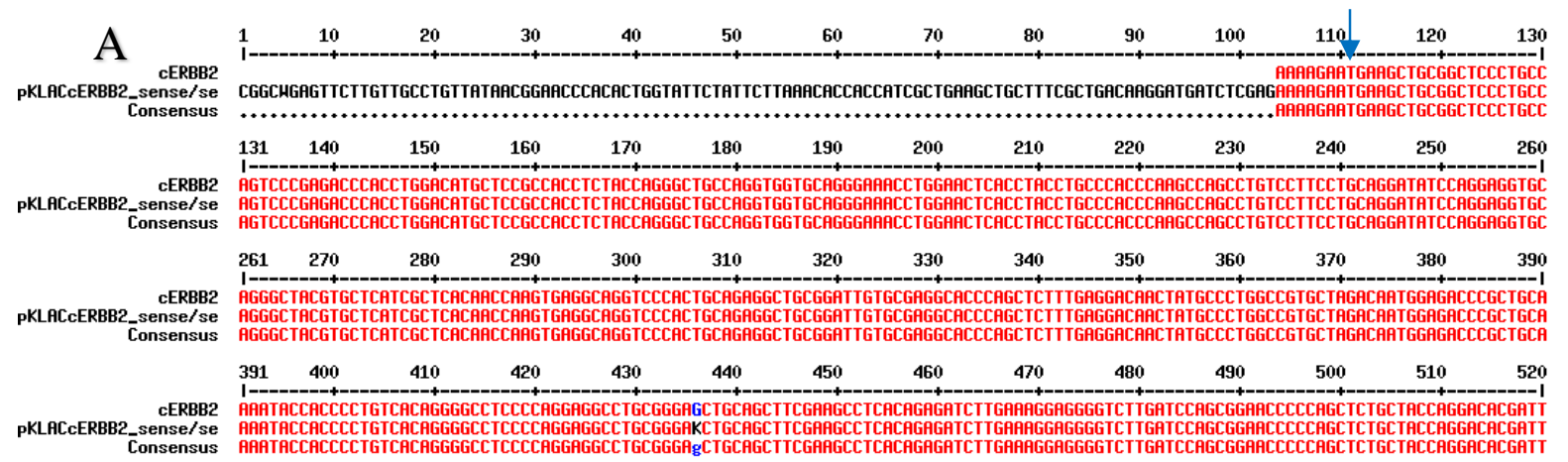

\begin{tabular}{|c|c|c|c|c|c|c|c|c|c|c|c|c|c|c|}
\hline B & 391 & 400 & 410 & 20 & 430 & 440 & 450 & 460 & 470 & 480 & 490 & 500 & 510 & 520 \\
\hline $\begin{array}{r}\text { cERBB2 } \\
\text { PKLAC.cERBB2_reverse/ } \\
\text { Consensus }\end{array}$ & \multicolumn{14}{|c|}{ 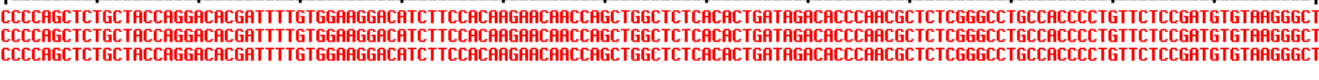 } \\
\hline & 521 & 530 & 540 & 550 & 560 & 570 & 580 & 590 & 600 & 610 & 620 & 630 & 640 & 650 \\
\hline $\begin{array}{r}\text { cERBB2 } \\
\text { PKLACcERBB2_reverse/ } \\
\text { Consensus }\end{array}$ & \multicolumn{14}{|c|}{ 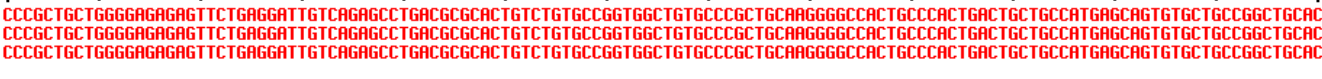 } \\
\hline & 651 & 660 & 670 & 680 & 690 & 700 & 710 & 720 & 730 & 740 & 750 & 760 & 770 & 780 \\
\hline $\begin{array}{r}\text { cERBB2 } \\
\text { PKLACcERBB2_reverse/ } \\
\text { Consensus }\end{array}$ & \multicolumn{14}{|c|}{ 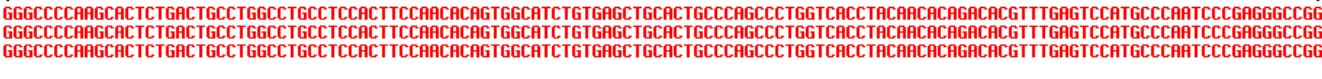 } \\
\hline & 781 & 790 & 800 & 810 & 820 & 830 & 840 & 850 & 860 & 870 & 880 & 890 & 900 & 910 \\
\hline $\begin{array}{r}\text { cERBB2 } \\
\text { PKLACcERBB2_reverse/ } \\
\text { Consensus }\end{array}$ & \multicolumn{14}{|c|}{ 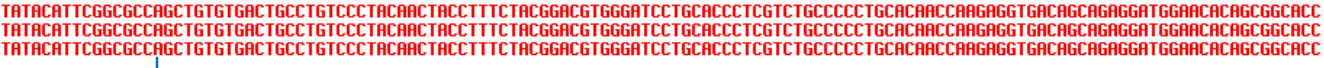 } \\
\hline & 911 & 920 & 930 & 940 & 950 & 960 & 970 & 980 & 990 & 1000 & 1010 & 1020 & 1030 & 1040 \\
\hline
\end{tabular}

Figura 9: Sequenciamento do clone pKLACcERBB2_8. Alinhamento da sequência cERBB2 com o clone pKLACcERBB2_8 sequenciado com os oligonucleotídeos pKLACseq_S (A) e pKLACseq_R (B); em destaque (setas), o códon de iniciação da tradução da proteína cERBB2, o início da sequencia que não é encontrada no sequenciamento anterior e o códon de terminação da tradução.

O sequenciamento confirmou a clonagem e a análise do eletroferograma confirmou a sequência correta do gene cERBB2 no vetor pKLAC.

\subsection{Clonagem do gene MAGE no vetor PKLAC}

O fragmento MAGE clivado com as enzimas XhoI e KpnI, obtido como descrito no item 1.1, foi clonado no plasmídio pKLAC, clivado com as mesmas enzimas (item 1.2), pela reação de ligação feita a temperatura ambiente por 1 hora, utilizando-se 60ng do fragmento, 120ng do vetor, tampão da enzima 1X e 1 unidade da T4 DNA ligase em um volume final de $10 \mu \mathrm{L}$. Todo volume da ligação foi utilizado na transformação de células de E. coli Top10 competentes que foram plaqueadas em meio LB ágar suplementado com ampicilina.

A seleção do plasmídio recombinante pKLACMAGE foi feita por uma PCR de 6 grupos contendo 5 colônias cada, diluídas em água estéril. A reação foi realizada com $5 \mu \mathrm{L}$ da 
mistura de água + bactérias como molde, $0,1 \mu \mathrm{M}$ de cada oligonucleotídeo (pKLACseq_S e MAGE_Rseq), 0,2mM de cada dNTPs, tampão 1X, 1,5mM de $\mathrm{MgCl}_{2}$ e 1 unidade da enzima Taq DNA polimerase em um volume final de $20 \mu \mathrm{L}$ (programa VAC). O produto da PCR foi analisado em gel de agarose $1 \%$ (Figura 10):

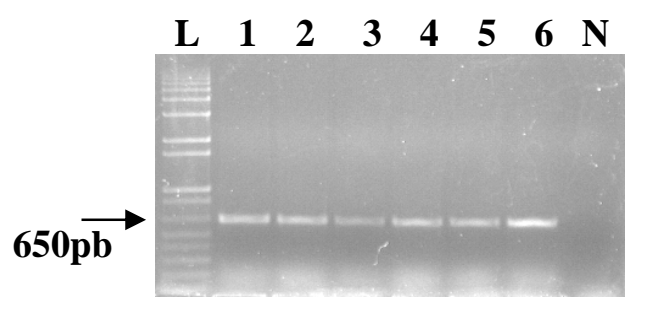

Figura 10: PCR de colônia da ligação pKLAC + MAGE: PCR dos 6 grupos das colônias da ligação pKLAC + MAGE com os oligonucleotídeos pKLACseq_S e MAGE_Rseq. L-marcador 1Kb Plus, 1 ao 6-PCR dos 6 grupos e N-negativo.

Todos os grupos apresentaram banda de amplificação próxima a 650pb (tamanho esperado de 633pb), indicando a presença do fragmento MAGE na direção correta. A partir desse resultado, foi realizada a extração dos plasmídios dos dois grupos de colônias. Esses plasmídios foram submetidos a uma reação de clivagem, na qual $1 \mu \mathrm{g}$ de cada plasmídio foram digeridos com 0,5 unidade das enzimas XhoI e KpnI, tampão FastDigest $1 \mathrm{X}$ em uma reação final de $20 \mu \mathrm{L}$, overnight a $37^{\circ} \mathrm{C}$. A digestão foi analisada em gel de agarose $1 \%$ (Figura 11 ):
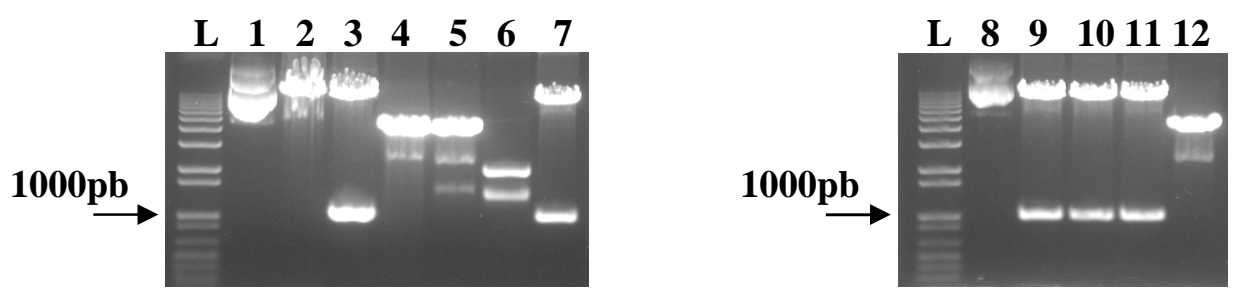

Figura 11: Clivagem dos plasmídios pKLACMAGE. Clivagem dos plasmídios pKLACMAGE com as enzimas XhoI e KpnI. L-marcador 1Kb Plus, 1 e 8-pKLACMAGE_1 e 7 não digerido, respectivamente, 2 ao 7 e 9 ao 12-pKLACMAGE_1 a 10 digeridos.

Os clones pKLACMAGE_2, 6, 7, 8 e 9 apresentaram fragmento próximo a 1000pb (tamanho esperado de $975 \mathrm{pb}$ ) após a clivagem, indicando a presença do fragmento MAGE no interior do vetor.

A partir dos resultados obtidos com a PCR e a análise de restrição, o clone 7 que apresentava o plasmídio recombinante pKLACMAGE foi analisado por sequenciamento utilizando-se os oligonucleotídeos pKLACseq_S, e pKLACseq_R para confirmação da clonagem (Figura 12). 


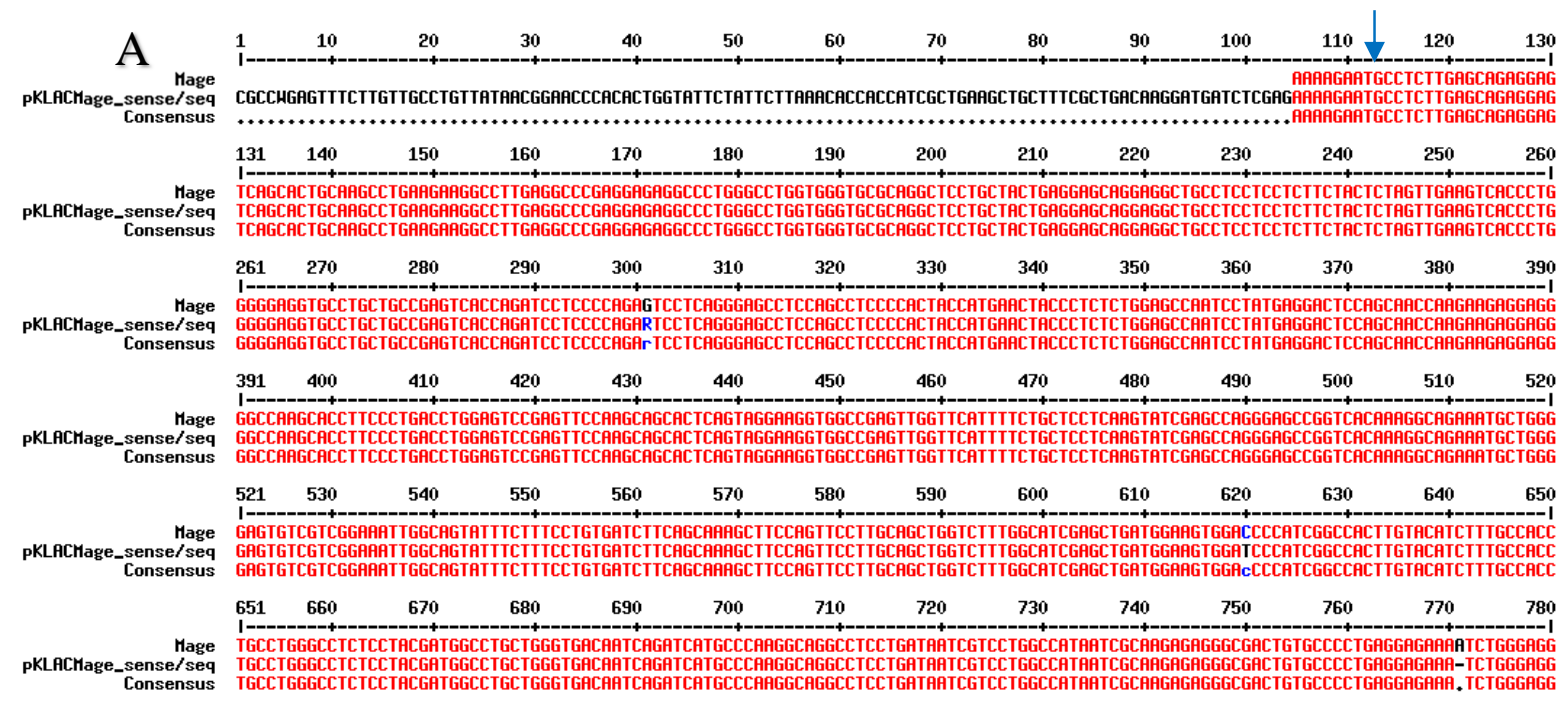

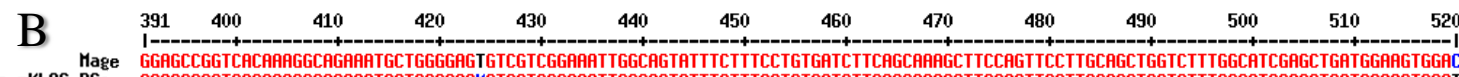

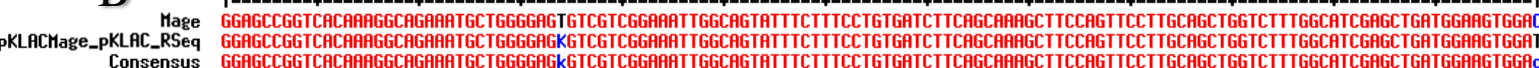

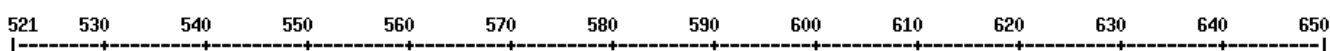

Mage сСС pKLACHage_pKLAC_RSeq CCCATCGGCCACTTGTACATCTTTGCCACCTGCCTGGGCCTCTC-TACGATGGCCTGCTGGGTGACARTCAGATCATGCCCAAGGCAGGCCTCCTGATARTCGTCCTGGCCATHATCGCARGAGAGGGCC

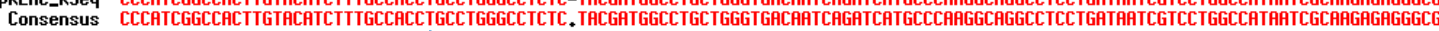

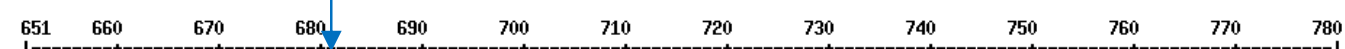

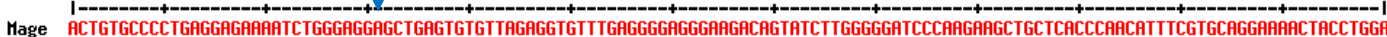

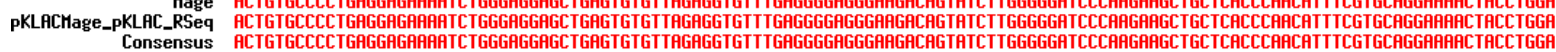

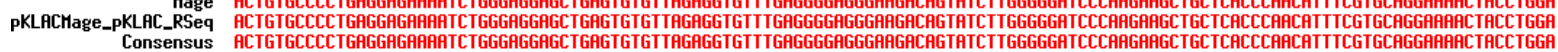

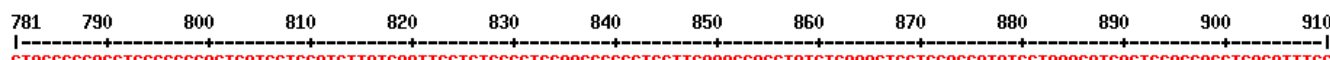

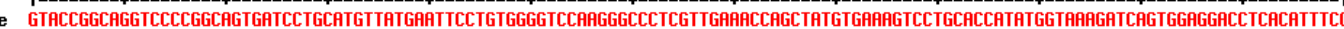

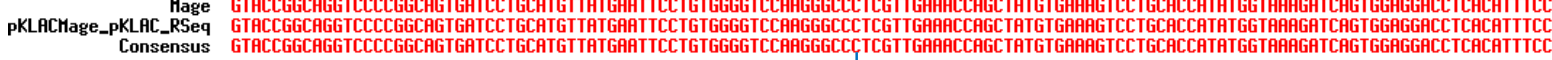

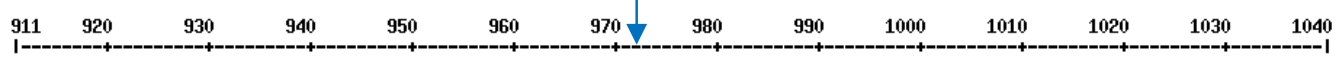

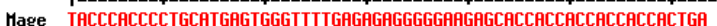

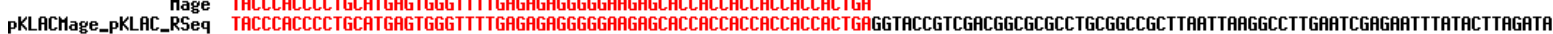

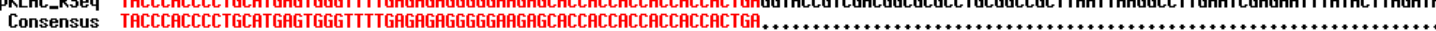

Figura 12: Sequenciamento do clone pKLACMAGE_7. Alinhamento da sequência MAGE com o clone pKLACMAGE_7 sequenciado com os oligonucleotídeos pKLACseq_S (A) e pKLACseq_R (B); em destaque (seta), o códon de iniciação da tradução da proteína MAGE, o início da sequência que não é encontrada no sequenciamento anterior e o códon de terminação da tradução.

O sequenciamento confirmou a clonagem e a análise do eletroferograma confirmou que o $\mathrm{R}$ e um $\mathrm{G}$ e que o T é um T, apesar da mudança nesse códon, de GAC para GAT, não há mudança no aminoácido codificado que permanece sendo um ácido aspártico. Todos os outros erros foram corrigidos sempre no outro sequenciamento confirmando que o gene clonado estava correto.

\subsection{Clonagem do gene GLEA no vetor pKLAC}

O fragmento GLEA clivado com as enzimas XhoI e KpnI, obtido como descrito no item 1.1, foi clonado no plasmídio pKLAC, clivado com as mesmas enzimas (item 1.2), pela reação de ligação feita a temperatura ambiente por 1 hora, utilizando-se 80ng do fragmento, 
120ng do vetor, tampão da enzima $1 \mathrm{X}$ e 1 unidade da T4 DNA ligase em um volume final de $10 \mu \mathrm{L}$. Todo volume da ligação foi utilizado na transformação de células de E. coli Top10 competentes que foram plaqueadas em meio LB ágar suplementado com ampicilina.

A seleção do plasmídio recombinante pKLACGLEA foi feita por uma PCR de 6 grupos contendo 5 colônias cada, diluídas em água estéril. A reação foi realizada com $5 \mu \mathrm{L}$ da mistura de água + bactérias como molde, $0,1 \mu \mathrm{M}$ de cada oligonucleotídeo (pKLACseq_S e GLEA_2Rseq), 0,2mM de cada dNTPs, tampão 1X, 1,5mM de $\mathrm{MgCl}_{2}$ e 1 unidade da enzima Taq DNA polimerase em um volume final de $20 \mu \mathrm{L}$ (programa VAC). O produto da PCR foi analisado em gel de agarose $1 \%$ (Figura 13):

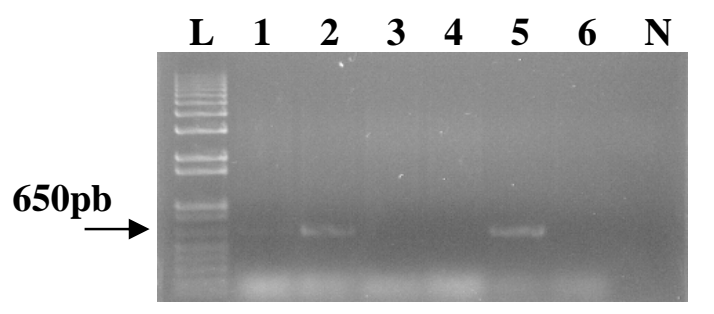

Figura 13: PCR de colônia da ligação pKLAC + GLEA. PCR dos 6 grupos das colônias da ligação pKLAC + GLEA com os oligonucleotídeos pKLACseq_S e GLEA_2Rseq. L-marcador 1Kb Plus, 1 ao 6-PCR dos 6 grupos e N-negativo.

Os grupos 2 e 5 apresentaram banda de amplificação próxima a 650pb (tamanho esperado de 651pb) indicando a presença do fragmento GLEA na direção correta. A partir desse resultado, foi realizada a extração dos plasmídios dos dois grupos de colônias. Esses plasmídios foram submetidos a uma reação de clivagem, na qual 720ng de cada plasmídio foram digeridos com 0,5 unidade das enzimas XhoI e KpnI, tampão FastDigest 1X em uma reação final de $20 \mu \mathrm{L}$, overnight a $37^{\circ} \mathrm{C}$. A digestão foi analisada em gel de agarose $1 \%$ (Figura 14):
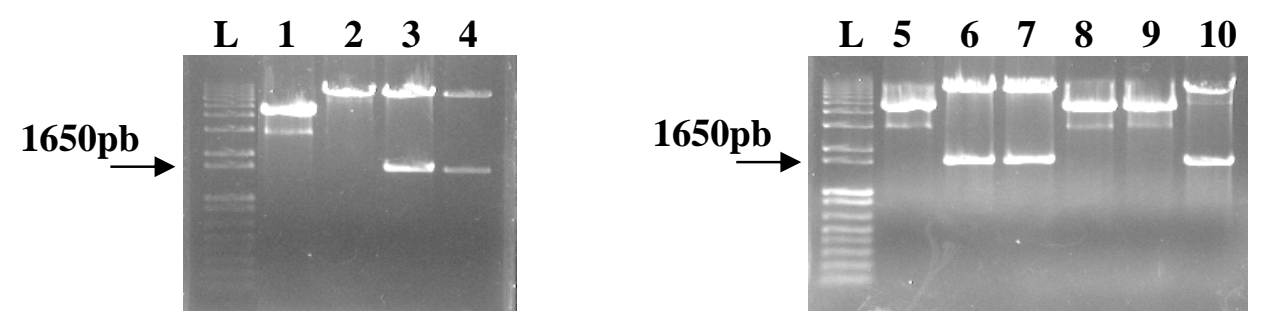

Figura 14: Clivagem dos plasmídios pKLACGLEA. Clivagem dos plasmídios pKLACGLEA com as enzimas XhoI e KpnI. L-marcador 1Kb Plus e 1 ao 10-pKLACGLEA_1 a 10 digeridos.

Os clones pKLACGLEA_3, 4, 6, 7 e 10 apresentaram fragmento próximo a 1650pb (tamanho esperado de 1662pb) após a clivagem, indicando a presença do fragmento GLEA no interior do vetor. 
A partir dos resultados obtidos com a PCR e a análise de restrição, o plasmídio recombinante pKLACGLEA_6 foi analisado por sequenciamento utilizando-se os oligonucleotídeos pKLACseq_S, Glea_1Sseq e Glea_3Sseq para confirmação da clonagem (Figura 15).

\begin{tabular}{|c|c|c|c|c|c|c|c|c|c|c|c|c|c|c|}
\hline \multirow{3}{*}{ A } & 1 & 10 & 20 & 30 & 40 & 50 & 60 & 70 & 80 & 90 & 100 & $110 \mathrm{~L}$ & 120 & 130 \\
\hline & \multicolumn{14}{|c|}{ 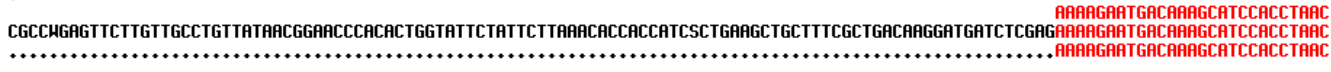 } \\
\hline & 131 & 140 & 150 & 160 & 170 & 180 & 190 & 200 & 210 & 220 & 230 & 240 & 250 & $\begin{array}{r}260 \\
-\end{array}$ \\
\hline 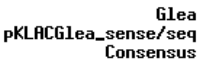 & \multicolumn{14}{|c|}{ 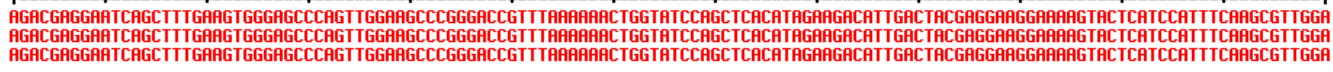 } \\
\hline & 261 & 270 & 280 & 290 & 300 & 310 & 320 & 330 & 340 & 350 & 360 & 370 & 380 & 390 \\
\hline $\begin{array}{r}\begin{array}{r}\text { Glea } \\
\text { PKLACGlea_sens/seq } \\
\text { Consensus }\end{array} \\
\text { PKans }\end{array}$ & \multicolumn{14}{|c|}{ 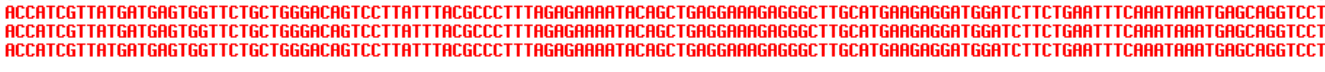 } \\
\hline & 391 & 400 & 410 & 420 & 430 & 440 & 450 & 460 & 470 & 480 & 490 & 500 & 510 & 520 \\
\hline $\begin{array}{r}\text { Glea } \\
\text { PKLACGlea_sense/seq } \\
\text { Consensus }\end{array}$ & \multicolumn{14}{|c|}{ 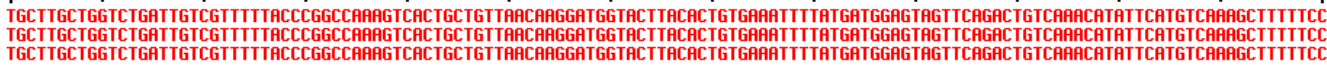 } \\
\hline & 521 & 530 & 540 & 550 & 560 & 570 & 580 & 590 & 600 & 610 & 620 & 630 & 640 & 650 \\
\hline 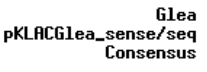 & \multicolumn{14}{|c|}{ 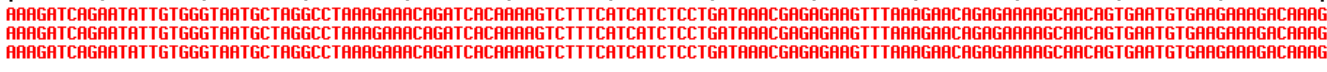 } \\
\hline & 651 & 660 & 670 & 680 & 690 & 700 & 710 & 720 & 730 & 740 & 750 & 760 & 770 & 780 \\
\hline
\end{tabular}

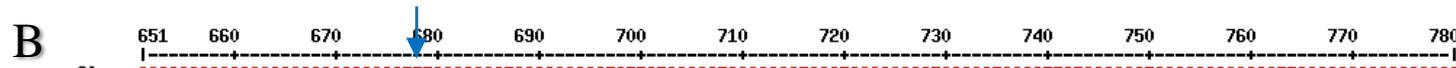

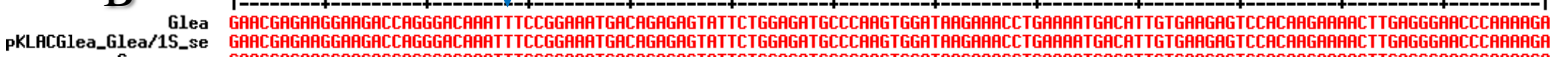

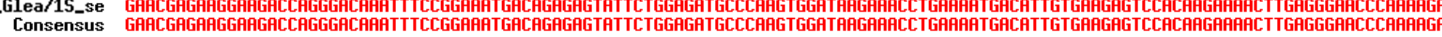

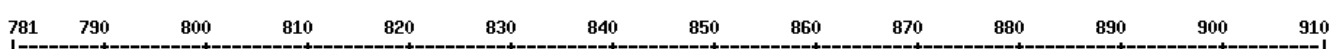

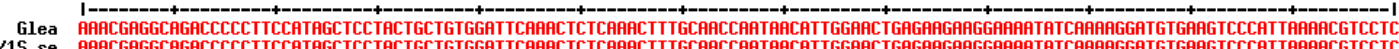

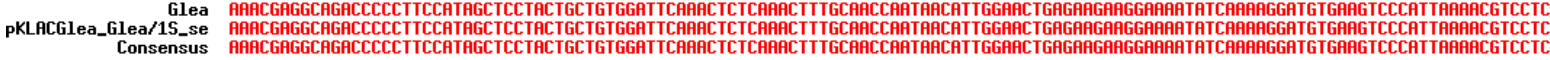

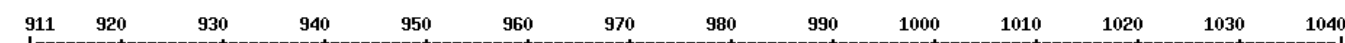

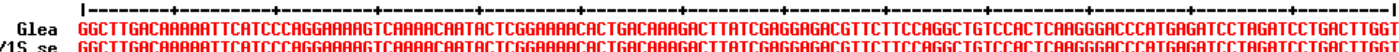

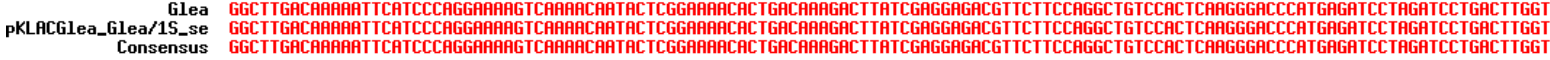

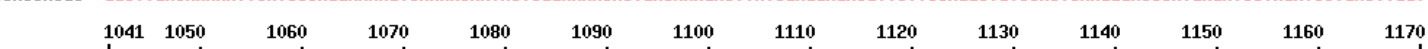

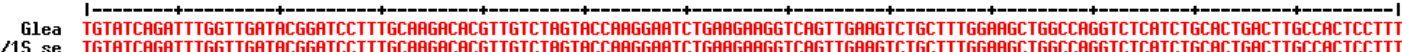

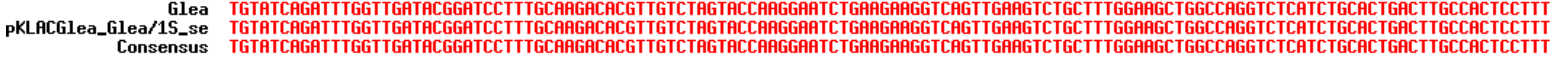

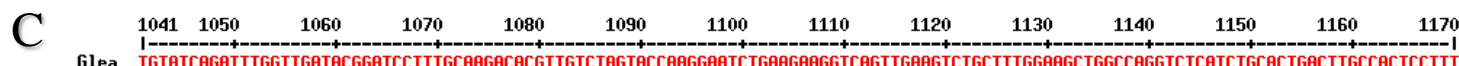

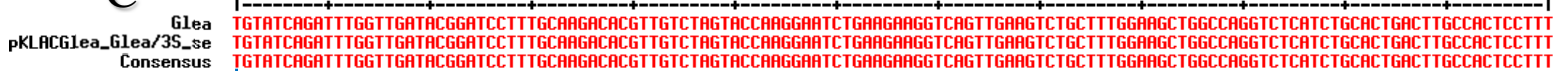
$1171 \quad 1180 \quad 1190 \quad 1200 \quad 1210 \quad 1220 \quad 1230 \quad 1240 \quad 1250 \quad 1260 \quad 1270 \quad 1280 \quad 1290 \quad 1300$

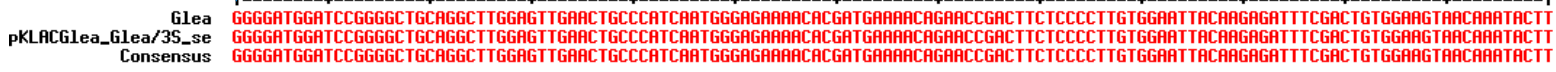

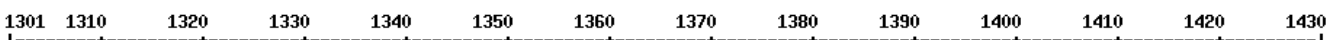

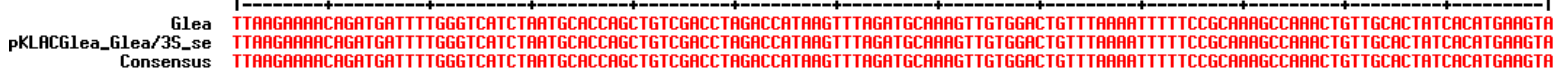

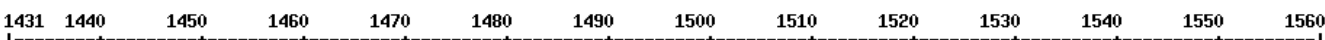

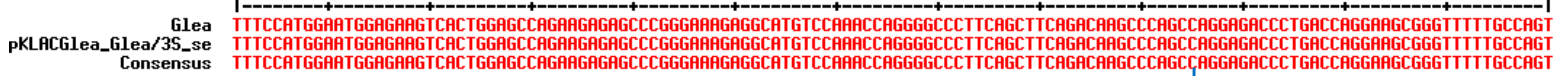

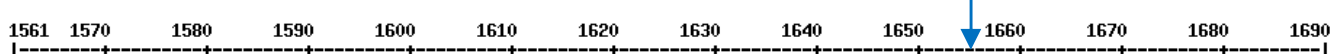

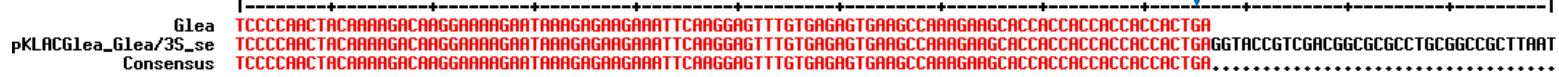

Figura 15: Sequenciamento do clone pKLACGLEA_6: Alinhamento da sequência GLEA com o clone pKLACGLEA_6 sequenciado com os oligonucleotídeos pKLACseq_S (A), Glea_1SSeq (B) e Glea_3SSeq (C); em destaque (setas), o códon de iniciação da tradução da proteína GLEA, o início da sequência que não é encontrada no sequenciamento anterior e o códon de terminação da tradução. 
O sequenciamento confirmou a clonagem e a sequência correta do fragmento GLEA clonado no vetor pKLAC.

\subsection{Clonagem do gene gp96 no vetor $\mathrm{pKLAC}$}

O fragmento gp96 clivado com as enzimas XhoI e BglII, obtido como descrito no item 1.1, foi clonado no plasmídio pKLAC, clivado com as mesmas enzimas (item 1.2), pela reação de ligação feita a temperatura ambiente por 1 hora, utilizando-se 48ng do fragmento, 120ng do vetor, tampão da enzima 1X e 1 unidade da T4 DNA ligase em um volume final de $10 \mu \mathrm{L}$. Todo volume da ligação foi utilizado na transformação de células de E. coli Top10 competentes que foram plaqueadas em meio LB ágar suplementado com ampicilina.

A seleção do plasmídio recombinante pKLACgp96 foi feita por uma PCR de 6 grupos contendo 5 colônias cada, diluídas em água estéril. A reação foi realizada com $5 \mu \mathrm{L}$ da mistura de água + bactérias como molde, $0,1 \mu \mathrm{M}$ de cada oligonucleotídeo (pKLACseq_S e gp96_2Rseq), 0,2mM de cada dNTPs, tampão 1X,1,5mM de $\mathrm{MgCl}_{2}$ e 1 unidade da enzima Taq DNA polimerase em um volume final de $20 \mu \mathrm{L}$ (programa VAC). O produto da PCR foi analisado em gel de agarose $1 \%$ (Figura 16):

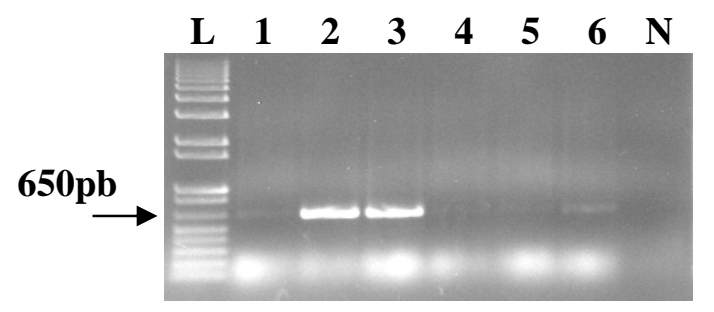

Figura 16: PCR de colônia da ligação pKLAC + gp96. PCR dos 6 grupos das colônias da ligação pKLAC + gp96 com os oligonucleotídeos pKLACseq_S e gp96_2Rseq. L-marcador 1Kb Plus, 1 ao 6-PCR dos 6 grupos e N-negativo.

Os grupos 2 e 3 apresentaram banda de amplificação próxima a 650pb (tamanho esperado de 646pb) indicando a presença do fragmento gp96 no vetor pKLAC. A partir desse resultado, foi realizada a extração dos plasmídios desses dois grupos de colônias que apresentaram banda de amplificação do tamanho esperado. Esses plasmídios foram submetidos a uma reação de clivagem, na qual 720ng de cada plasmídio foram digeridos com 0,5 unidade das enzimas XhoI e BglII, tampão FastDigest $1 \mathrm{X}$ em uma reação final de $20 \mu \mathrm{L}$, overnight a $37^{\circ} \mathrm{C}$. A digestão foi analisada em gel de agarose $1 \%$ (Figura 17): 

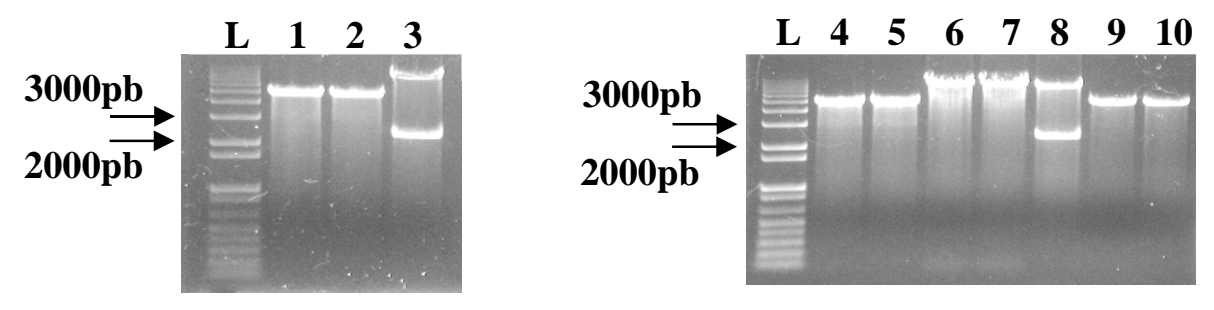

Figura 17: Clivagem dos plasmídios pKLACgp96. Clivagem dos plasmídios pKLACgp96 com as enzimas XhoI e BglII. L-marcador 1Kb Plus e 1 ao 10-pKLACgp96_1 a 10 digeridos.

Os clones pKLACgp96_3 e 8 apresentaram fragmento entre 2000-3000pb (tamanho esperado de 2382pb) após a clivagem, indicando a presença do fragmento gp96 no interior do vetor.

A partir dos resultados obtidos com a PCR e a análise de restrição, o plasmídio recombinante pKLACgp96_3 foi analisado por sequenciamento utilizando-se os oligonucleotídeos pKLACseq_S, gp96_1Sseq, gp96_3Sseq, gp96_4Sseq e pKLACseq_R para confirmação da clonagem (Figura 18).

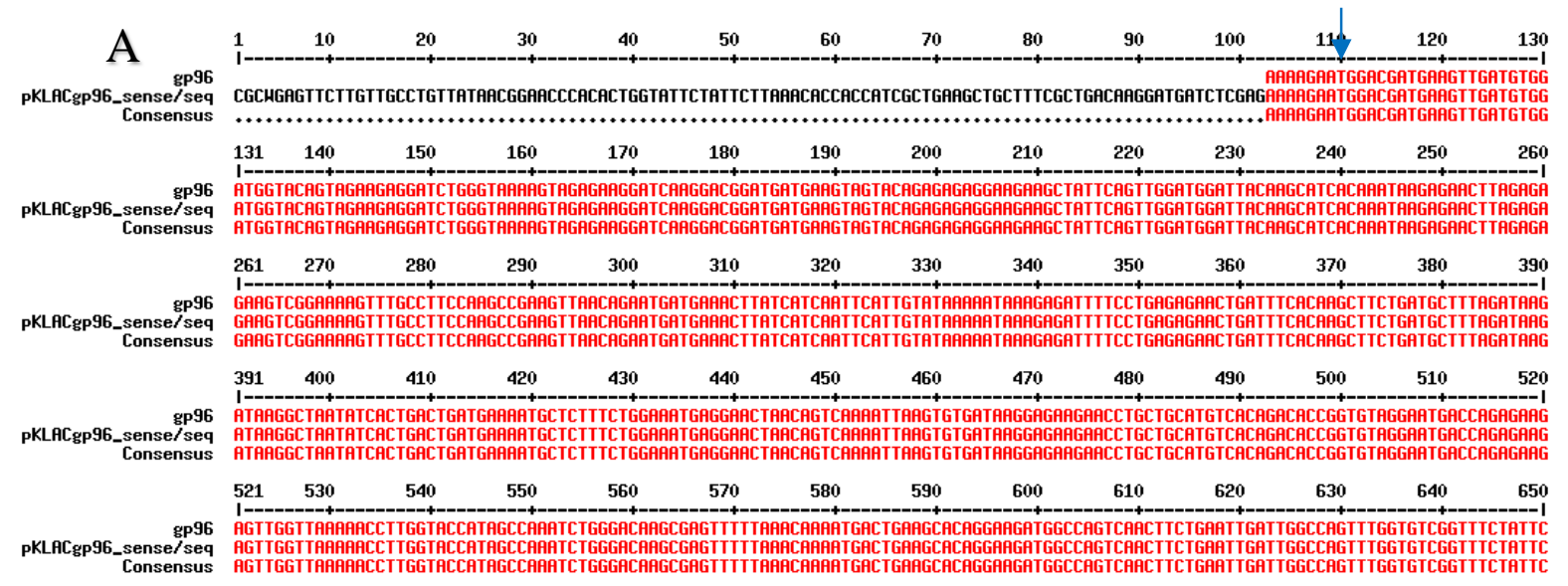

B 521

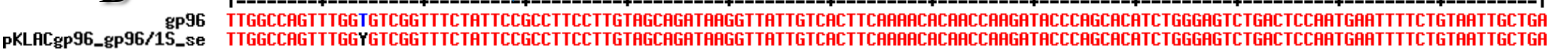

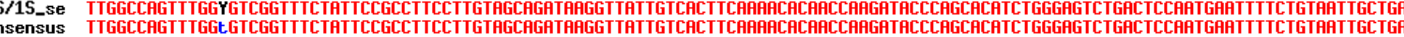

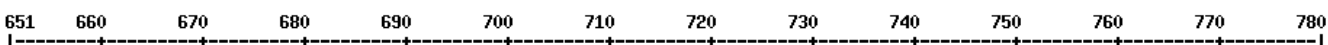

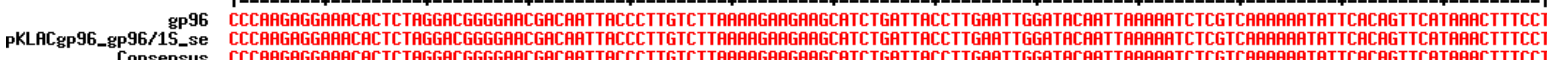

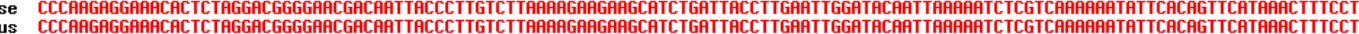

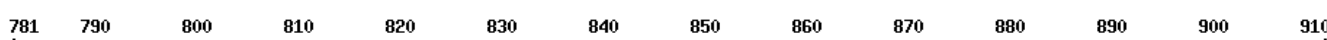

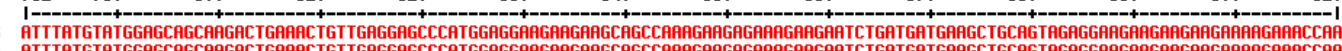

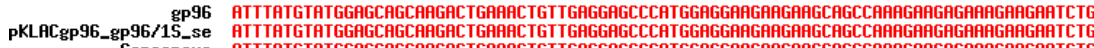

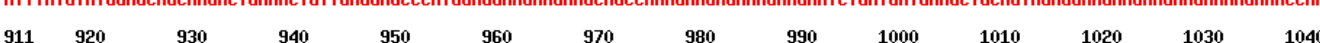

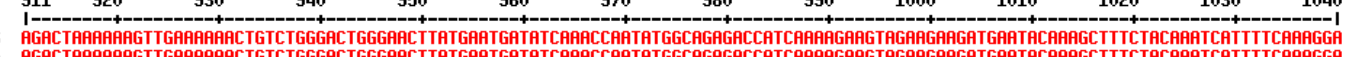
pKLACgP96_gp96/15_se

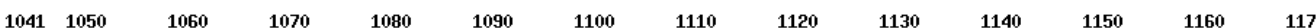

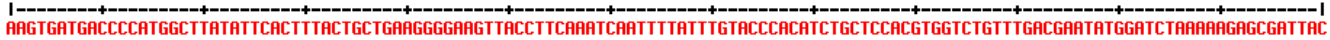
pKLACgP96_gp96/15_se

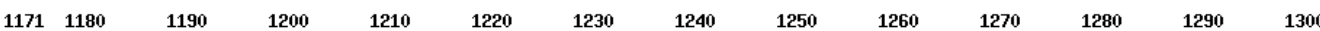

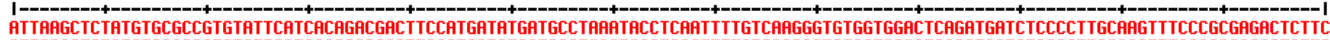

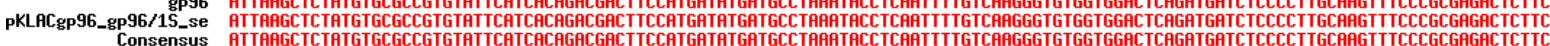




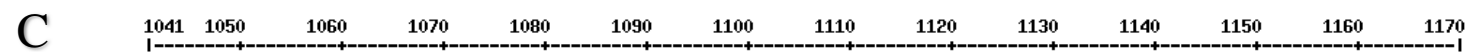

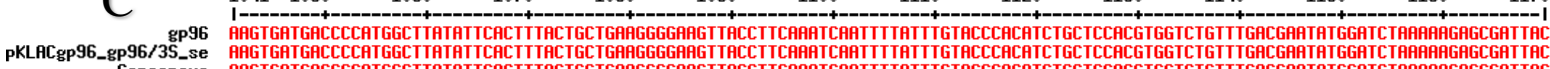

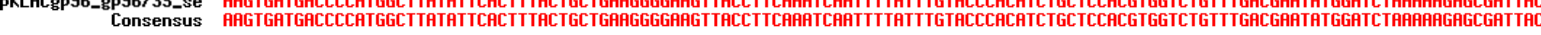

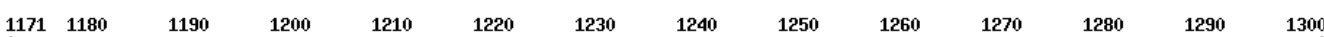

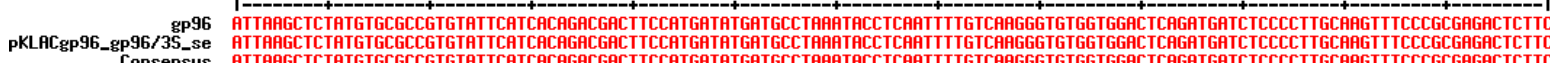

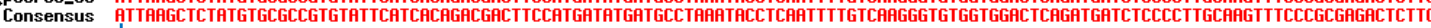

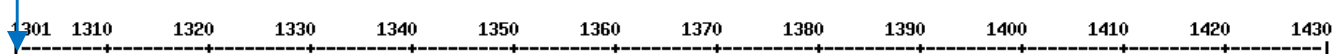

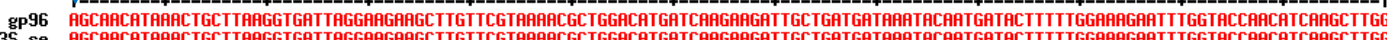

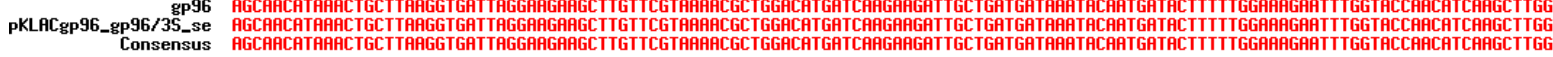

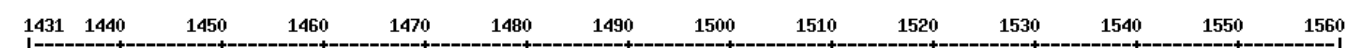
gP96
pKLAC PKLACgP96_Ep96/35_se
Consensus

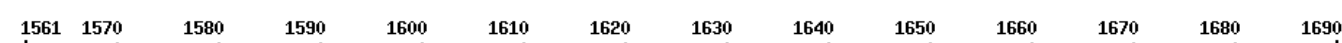

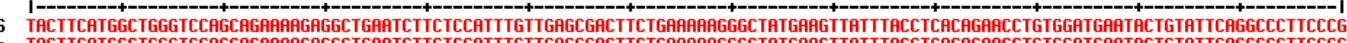

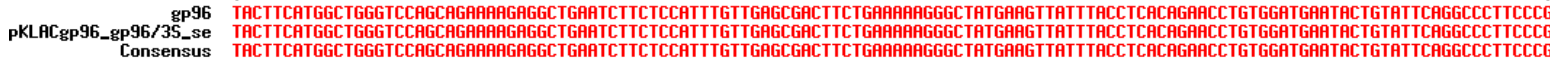

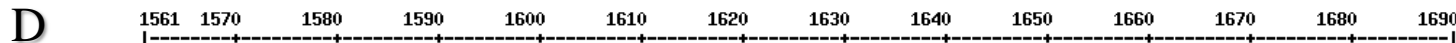
pkL g9

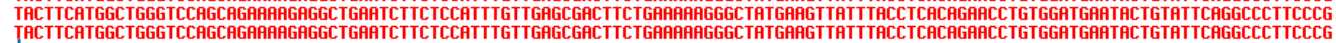

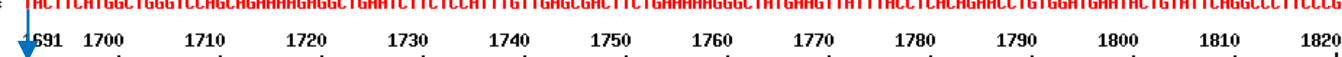

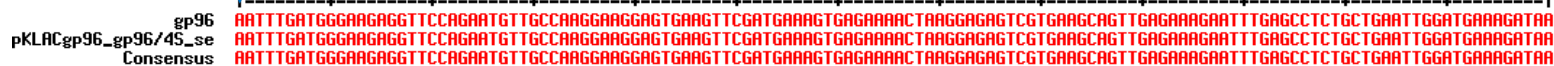

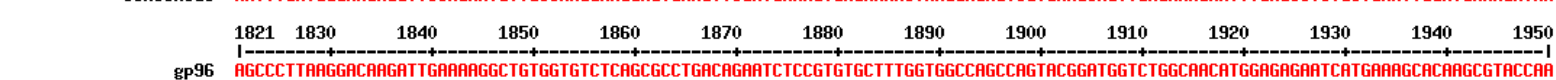

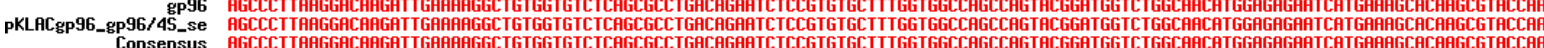

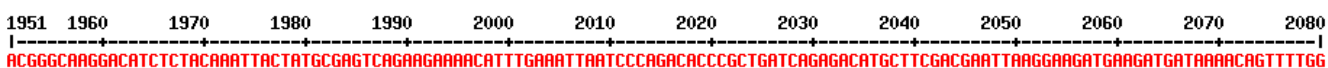

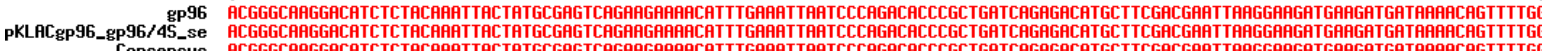

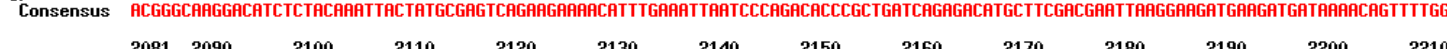

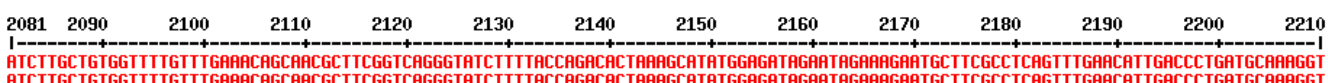

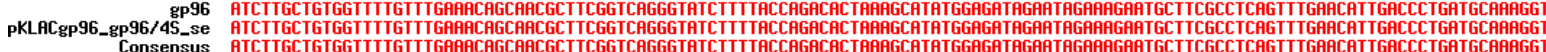

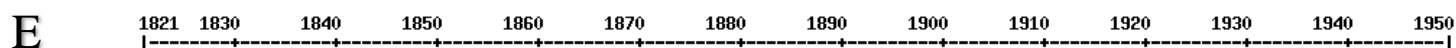
pKLACgP96_reverse/se f96 96_reverse/se
Consensus

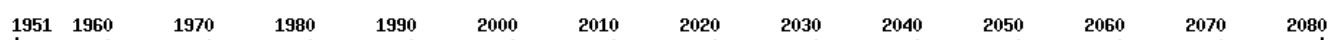

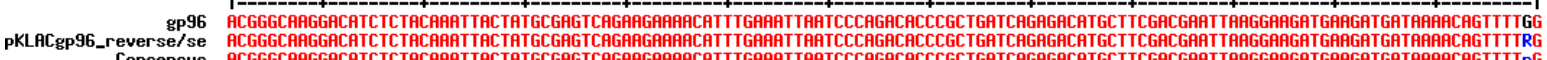

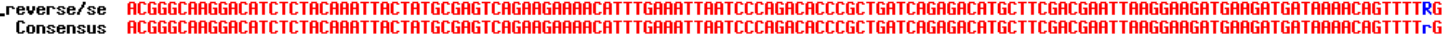

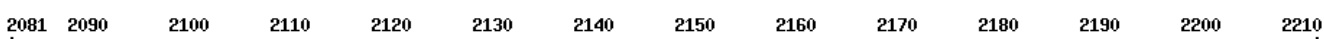

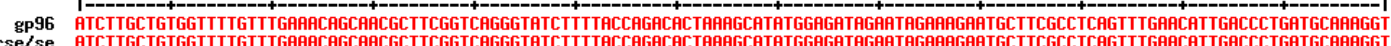

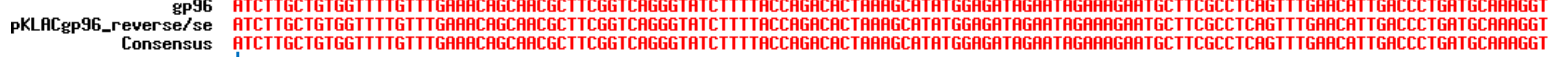

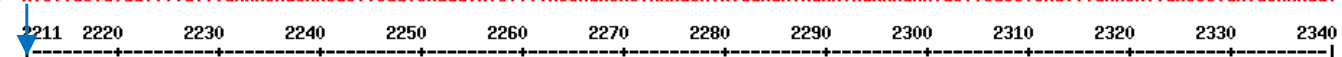

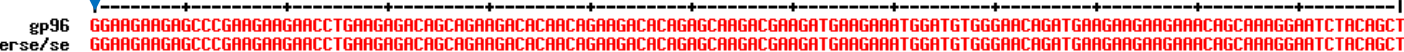

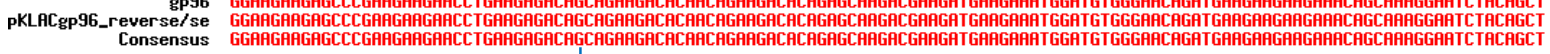

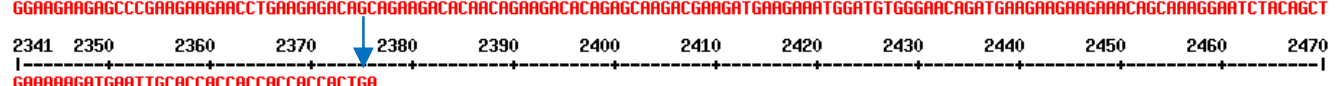

gP96 GARARAGATGGATTGCACCACCACС

PKLACgP96_reverse/se GAFAFGG

Figura 18: Sequenciamento do clone pKLACgp96_3. Alinhamento da sequência gp96 com o clone pKLACgp96_3 sequenciado com os oligonucleotídeos pKLACseq_S (A), gp96_1SSeq (B), gp96_3SSeq (C), gp96_4SSeq (D) e pKLACseq_R (E); em destaque (setas), o códon de iniciação da tradução da proteína gp96, o início da sequência que não é encontrada no sequenciamento anterior e o códon de terminação da tradução.

O sequenciamento e a análise do eletroferograma confirmaram a clonagem e a sequência correta do fragmento gp96 clonado no vetor pKLAC. 


\section{Anexo 2.0 - Expressão da proteína gp96 em K. lactis e purificação}

\subsection{Clivagem do plasmídio pKLACgp96}

Após a confirmação da clonagem do gene gp96 no plasmídio pKLAC por sequenciamento, esse plasmídio foi clivado com a enzima SacII (Fermentas) para linearização e posterior transformação na levedura $K$. lactis.

A reação foi realizada a $37^{\circ} \mathrm{C}$ por aproximadamente 16 horas com $2,1 \mu \mathrm{g}$ do plasmídio pKLACgp96_3, tampão B 1X e 30 unidades da enzima em um volume final de $60 \mu \mathrm{L}$. A digestão foi analisada em gel de agarose $1 \%$ (Figura 1):

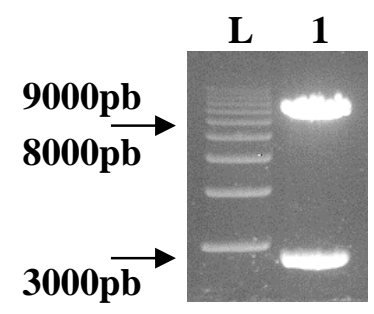

Figura 1: Clivagem do plasmídio pKLACgp96_3. Clivagem do plasmídio pKLACgp96_3 com a enzimas SacII. L-marcador 1Kb Plus e 1-pKLACgp96_3 digerido.

O clone pKLACgp96_3 digerido apresentou dois fragmentos, um entre 8000-9000pb e outro próximo a 3000pb indicando clivagem correta (tamanhos esperados de 2827 e $8646 \mathrm{pb}$ ). $\mathrm{O}$ vetor pKLAC contendo qualquer gene de interesse precisa ser linearizado com a enzima SacII (ou BstxI) para que ocorra a integração do fragmento de interesse no locus Lac4 do genoma da levedura. $\mathrm{O}$ fragmento maior contém o gene que será inserido e o menor uma porção do plasmídio que não é importante na recombinação.

Os fragmentos foram purificados juntos utilizando-se o kit Wizard SV Gel and PCR Clean-Up System e usados na transformação de células K. lactis GG799 competentes segundo instruções do K. lactis Protein Expression kit. As leveduras transformadas foram plaqueadas em meio YCB ágar contendo $5 \mathrm{mM}$ de acetamida e incubadas por 4 dias a $30^{\circ} \mathrm{C}$. Colônias brancas grandes formadas na placa foram estriadas em Agar novo e crescidas por dois dias na mesma condição.

\section{$\underline{2.2}$ Expressão da proteína gp96 em K. lactis}

Vários clones foram testados para expressão da proteína gp96 em K. lactis seguindo as instruções do kit. Amostras diárias durante 6 dias foram retiradas da cultura e analisadas em SDS-PAGE. Em nenhum dos clones foi detectada a expressão da proteína gp96. A partir 
desse resultado, novo protocolo de transformação foi realizado, $2 \mu \mathrm{g}$ do DNA linearizado foi adicionado às células competentes e a mistura adicionada em uma cubeta de eletroporação pré-esfriada em gelo; as células foram eletroporadas a 1,5KV, 25F e 2000hm, adicionou-se imediatamente após a eletroporação $1 \mathrm{~mL}$ de Sorbitol a $1 \mathrm{M}$ gelado e a cubeta foi incubada no gelo por 10 minutos; adicionou-se $1 \mathrm{~mL}$ de YPGlu e transferiu-se a mistura para um falcon de $15 \mathrm{~mL}$, as células foram incubadas por 30 minutos a $30^{\circ} \mathrm{C}$ sob agitação, centrifugadas por 2 minutos a 4000g (Eppendorf 5402), lavadas com $1 \mathrm{~mL}$ de água estéril, centrifugadas novamente, ressuspendidas em $100 \mu \mathrm{L}$ de água e plaqueadas em YCB ágar suplementado com $5 \mathrm{mM}$ de acetamida. Após 4 dias de incubação a $30^{\circ} \mathrm{C}$, as colônias brancas grandes foram estriadas em nova placa e incubadas por 2 dias nas mesmas condições.

\subsection{Deteccão da integracão do gene de interesse gp96 nas células K. lactis}

Após o segundo protocolo de transformação 27 colônias foram testadas por duas reações de PCR para detecção da integração do fragmento de interesse e da presença de múltiplas cópias desse fragmento no genoma da levedura. As reações foram realizadas seguindo as instruções do kit e analisadas em gel de agarose $1 \%$ (Figuras 2 e 3):
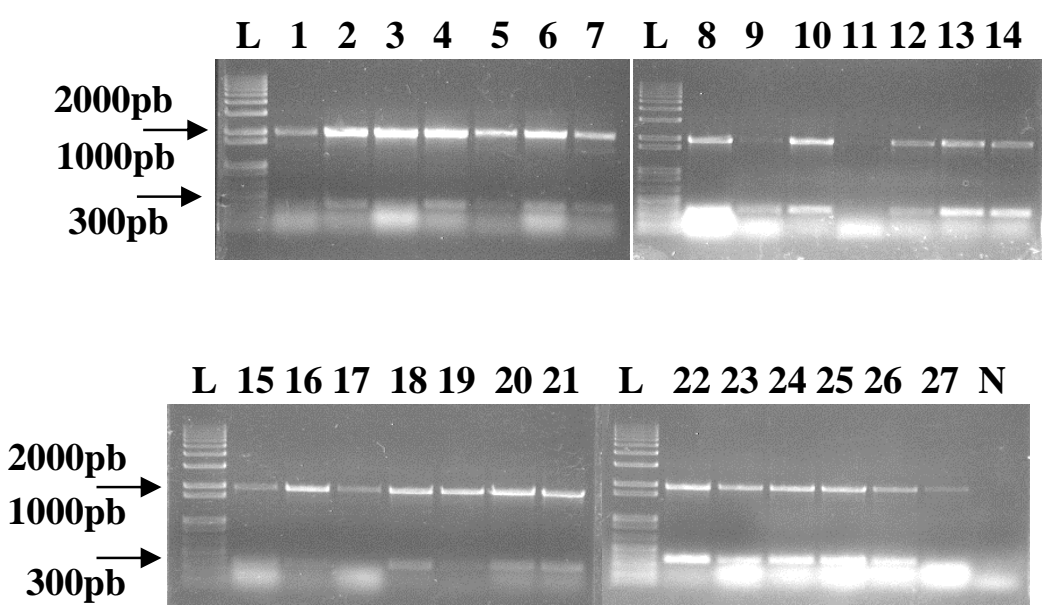

Figura 2: PCR das leveduras transformadas para detectar integração no genoma. PCR utilizando-se os oligonucleotídeos 1 e 2 disponibilizados pelo kit para detecção da integração do fragmento de interesse no genoma da levedura $K$. lactis transformada. L-marcador $1 \mathrm{~Kb}$ Plus, 1 ao 27 -colônias da transformação K. lactis + o fragmento contendo o gene da gp96 e N-negativo. 

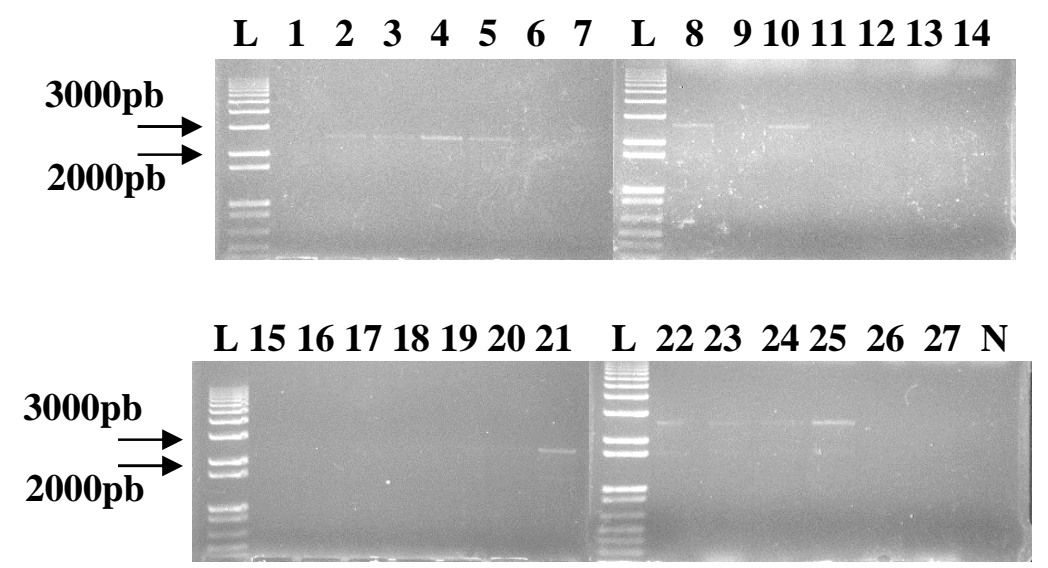

Figura 3: PCR das leveduras transformadas para detectar múltiplas cópias no genoma. PCR utilizando-se os oligonucleotídeos 2 e 3 disponibilizados pelo kit para detecção da integração de múltiplas cópias do fragmento de interesse no genoma da levedura $K$. lactis transformada. L-marcador $1 \mathrm{~Kb}$ Plus, 1 ao 27-colônias da transformação K. lactis + o fragmento contendo o gene da gp96 e N-negativo.

Como demonstrado na figura 2, todas as colônias, exceto a 11, apresentaram uma banda próxima a 2000pb indicando a presença de um fragmento de interesse no genoma da levedura (tamanho esperado de 1900pb). No entanto, apenas as colônias 2, 3, 4, 5, 8, 10, 21, 22, 23, 24 e 25 apresentaram banda entre 2000 e 3000pb, como mostra a figura 3, indicando presença de múltiplas cópias (tamanho esperado de 2300pb). A partir desses resultados, duas colônias, 4 e 21, foram utilizadas nos novos testes.

\section{$\underline{2.4}$ Novas expressões da proteína gp96 em $K$. lactis e purificacão}

Conforme instruções do kit, as colônias 4 e 21 foram crescidas em 400mL de meio YPGal, após 72 horas foram centrifugadas por 30 minutos a $2465 \mathrm{~g}, 4^{\circ} \mathrm{C}$ (Centrifuge $5810 \mathrm{R}$ ) e o sobrenadante armazenado a $4^{\circ} \mathrm{C}$. Uma pequena fração do sobrenadante foi usada em dois testes para verificar a expressão da proteína gp96. Um volume de apenas $600 \mu \mathrm{L}$ foi purificado utilizando-se uma coluna HisSpinTrap (GE Healthcare) seguindo as instruções do fabricante (teste 1). Um volume maior, $30,4 \mathrm{~mL}$ foi precipitado com $7,6 \mathrm{~mL}$ de TCA $100 \%$ (teste 2). Após a adição do TCA, a amostra foi incubada por 10 minutos a $4{ }^{\circ} \mathrm{C}$, centrifugada por 5 minutos a $20598 \mathrm{~g}, 4^{\circ} \mathrm{C}$ (Avanti ${ }^{\mathrm{TM}} 30$ Centrifuge) e lavada três vezes com $2 \mathrm{~mL}$ de acetona. Após a última centrifugação nas mesmas condições, o precipitado foi mantido a temperatura ambiente para secar e foi ressuspendido em $1 \mathrm{~mL}$ de salina. Os testes foram analisados por western blot (Figura 4): 
A

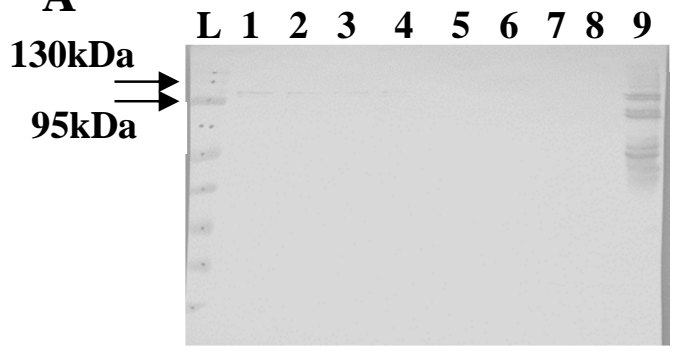

B

130kDa

L $1 \begin{array}{lllllllll}1 & 2 & 3 & 4 & 5 & 6 & 7 & 8 & 9\end{array}$

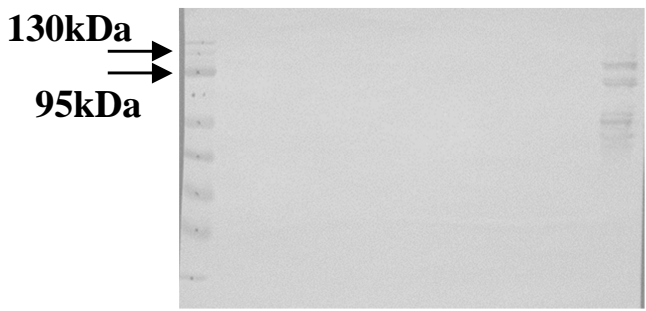

Figura 4: Western blot dos testes de purificação da proteína gp96 expressa em $K$. lactis. As amostras das purificações utilizando-se a coluna HisSpinTrap e TCA foram analisadas utilizando-se o protocolo de western blot já descrito nos materiais e métodos e o anticorpo primário anti-His (Ms Ab 6xHistag ${ }^{\circledR}$ AD1.1.10, Abcam) diluído 1:2000. A) Purificação da gp96 expressa utilizando-se a colônia 4. B) Purificação da gp96 expressa utilizando-se a colônia 21. L-marcador, 1-sobrenadante da expressão, 2 ao 4-eluatos (fração não ligada), 5 ao 7 eluições, 8-sobrenadante após precipitação com TCA e 9-precipitado solubilizado.

A proteína gp 96 foi detectada no sobrenadante da cultura 4, bem como nas frações do eluato da purificação utilizando-se a coluna de afinidade, o que significou que a proteína não estava ficando presa a coluna. Essa proteína também foi detectada após a precipitação com TCA juntamente com outras bandas que podem ser proteínas contaminantes ou degradação (Figura 4A). Na purificação da proteína gp96 expressa a partir da colônia 21 a detecção só foi possível após precipitação com TCA (Figura 4B).

A partir desse resultado, foi realizada a concentração do sobrenadante da cultura 4 (aproximadamente 370mL) em cartucho UFP-3-C-4X2MA, 3000NMWC (Amersham Bioscience). No volume final do concentrado (aproximadamente $100 \mathrm{~mL}$ ) foi adicionado mesmo volume de PBS e a concentração realizada novamente para ocorrer a troca do meio de cultura por PBS, esse procedimento foi realizado três vezes. A proteína concentrada foi analisada em SDS-PAGE 10\% (Figura 5):

$\begin{array}{lllll}L & 1 & 2 & 3 & 4\end{array}$

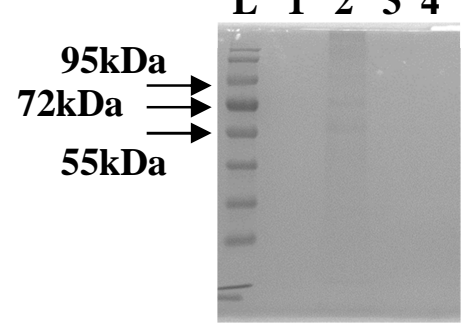

Figura 5: Concentração da proteína gp96 expressa em $K$. lactis. O sobrenadante da cultura 4 foi concentrado. L-marcador, 1-descarte do que passa pelos poros do cartucho, 2-fração concentrada, 3 e 4-frações da lavagem do cartucho. 
Como observado na figura 5 a fração concentrada apresentou três bandas nos tamanhos próximos a 95, 72 e 55kDa. Como a proteína é expressa em fusão com uma cauda de histidina, a fração concentrada foi purificada por cromatografia de afinidade segundo protocolo usado para purificação das proteínas MAGE e Hsp70 com exceção do tampão de equilíbrio que foi PBS. A proteína apareceu nas frações do eluato, lavagem e muito pouco no eluído 1. As eluições 1, 2 e 3 foram concentradas, mas pouquíssima proteína foi detectada (dados não documentados).

Outras duas novas culturas foram realizadas com o clone 4 em volumes maiores, em uma delas, uma fração foi precipitada com TCA e como foi detectada a proteína gp96, o restante da cultura foi purificada por cromatografia de afinidade. A outra cultura foi concentrada novamente. A purificação e a concentração foram analisadas em SDS-PAGE (Figura 6):

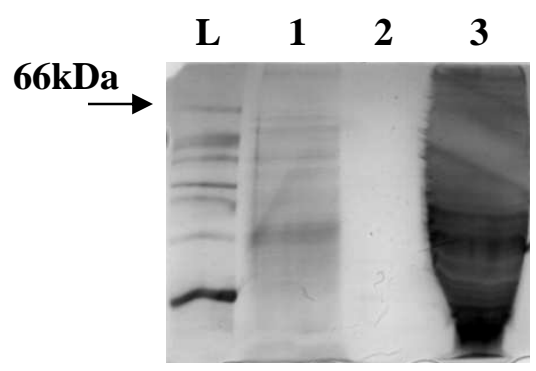

Figura 6: Purificação e concentração da proteína gp96 expressa em $K$. lactis. O sobrenadante de uma das culturas foi purificado, L-marcador, 1-eluato e 2-eluído. O sobrenadante da outra cultura foi concentrado, 3fração concentrada.

Como observado na figura 6 nenhuma das alternativas de obtenção da proteína gp96 foi bem sucedida, a proteína pode não estar sendo expressa ou ter sido produzida em pequena quantidade. A alternativa de concentrar não foi viável, pois várias substâncias presentes no meio de cultura parecem interferir. Diante desses resultados, a estratégia de produção de qualquer uma das proteínas em $K$. lactis foi abandonada. 


\section{Anexo 3.0 - Clonagem dos genes EGFRvIII, cERBB2, MAGE e GLEA no vetor pcDNA3.3}

Os genes EGFRvIII, cERBB2, MAGE e GLEA também foram clonados no vetor pcDNA3.3 para expressão das proteínas em células HEK.

\subsection{Amplificacão dos genes EGFRvIII, cERBB2, MAGE e GLEA}

Os genes EGFRvIII, cERBB2, MAGE e GLEA foram amplificados para a clonagem no vetor pcDNA utilizando-se como molde os plasmídios pKLACEGFRvIII, pKLACERBB2, pBSKMAGE (cedido pela empresa Farmacore Biotechnology Ltd.) e pKLACGLEA e os seguintes iniciadores: EGFRvIIIpVAX_S e EGFRvIIIpKLAC_R; cERBB2pVAX_S e cERBB2pKLAC_R; MAGEpVAX_S e MAGEpKLAC_R e GLEApVAX_S e GLEApKLAC_R. Para essas construções foram utilizados oligonucleotídeos já desenhados e moldes já construídos de forma a respeitar a presença da sequência Kozac no início do gene e uma cauda de histidina na porção C-terminal juntamente com um stop códon.

Na reação de amplificação, além dos $0,1 \mu \mathrm{M}$ de cada oligonucleotídeo foi utilizado 100-150ng do molde, 0,2mM de cada dNTPs, tampão $1 \mathrm{X}$ e 5 unidade da enzima High fidelity; a reação foi feita em $100 \mu \mathrm{L}$ finais utilizando o programa VAC (1'30'” de extensão e TM de $50^{\circ} \mathrm{C}$ ). Após a amplificação, 2,5 unidades da enzima Taq DNA polimerase foi adicionada e a reação incubada a $72^{\circ} \mathrm{C}$ por 10 minutos para adição de adeninas nas extremidades dos fragmentos amplificados. Os produtos das amplificações foram analisados em gel de agarose $1 \%$ (Figura 1):
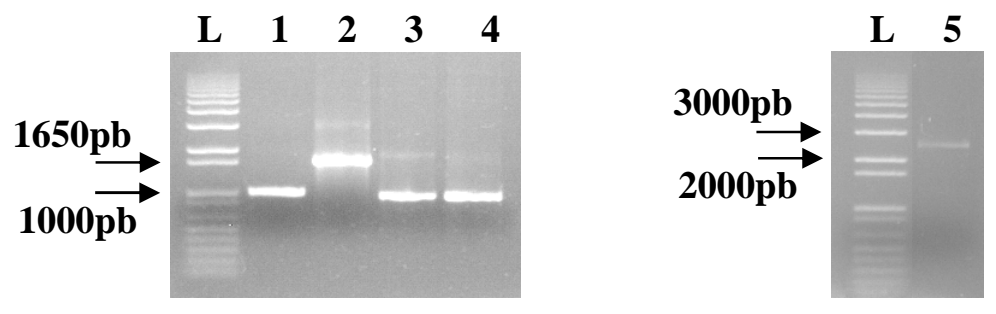

Figura 1: Amplificação dos genes para a clonagem no pcDNA. L-marcador $1 \mathrm{~Kb}$ Plus, 1-MAGE, 2-GLEA, 3EGFRvIII e 4-cERBB2.

Todos os genes foram amplificados de forma correta revelando bandas de tamanhos esperados, MAGE, 986pb, GLEA, 1673pb, EGFRvIII, 947pb e cERBB2, 944pb.

Todos os fragmentos foram clonados diretamente no vetor pcDNA isoladamente segundo as instruções do kit. Na reação de ligação utilizou-se $2 \mu \mathrm{L}$ da reação de amplificação do EGFRvIII ( $2 \mu \mathrm{L}$ do cERBB2, $3 \mu \mathrm{L}$ do MAGE e $3 \mu \mathrm{L}$ do GLEA), $0,5 \mu \mathrm{L}$ do vetor pcDNA, $1 \mu \mathrm{L}$ da solução salina (disponibilizada pelo kit) em um volume final de $6 \mu \mathrm{L}$. Essa reação foi 
incubada por 30 minutos a temperatura ambiente e utilizada na transformação de células de $E$. coli Top10 competentes que foram plaqueadas em meio LB ágar suplementado com ampicilina.

\subsection{Clonagem do gene EGFRvIII no vetor pcDNA}

Após a transformação, a seleção do plasmídio recombinante pcDNAEGFRvIII foi feita realizando-se uma PCR de 20 colônias individuais diluídas em $20 \mu \mathrm{L}$ de água estéril. A reação foi realizada com $5 \mu \mathrm{L}$ da mistura de água + bactérias como molde, $0,1 \mu \mathrm{M}$ de cada oligonucleotídeo (CMV sense e EGFRvIIIpKLAC_R), 0,2mM de cada dNTPs, tampão 1X, $1,5 \mathrm{mM}$ de $\mathrm{MgCl}_{2}$ e 1 unidade da enzima Taq DNA polimerase em um volume final de $20 \mu \mathrm{L}$ (programa VAC, TM $50^{\circ} \mathrm{C}$ e extensão de 2'30'). O produto da PCR foi analisado em gel de agarose $1 \%$ (Figura 2):
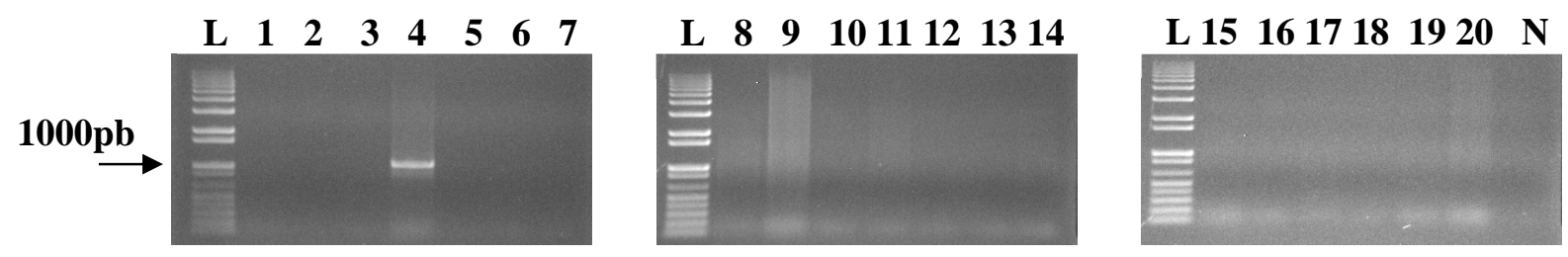

Figura 2: PCR de colônia da ligação pcDNA + EGFRvIII. PCR de 20 colônias da ligação pcDNA + EGFRvIII com os oligonucleotídeos CMV e EGFRvIIIpKLAC_R. L-marcador 1Kb Plus, 1 ao 20-PCR das 20 colônias, $\mathrm{N}$-negativo.

Apenas a colônia pcDNAEGFRvIII_4 apresentou fragmento próximo a 1000pb (tamanho esperado de $1107 \mathrm{pb}$ ). A partir do resultado obtido, o plasmídio recombinante pcDNAEGFRvIII_4 foi analisado por sequenciamento utilizando-se os oligonucleotídeos CMV e TK para confirmação da clonagem (Figura 3).

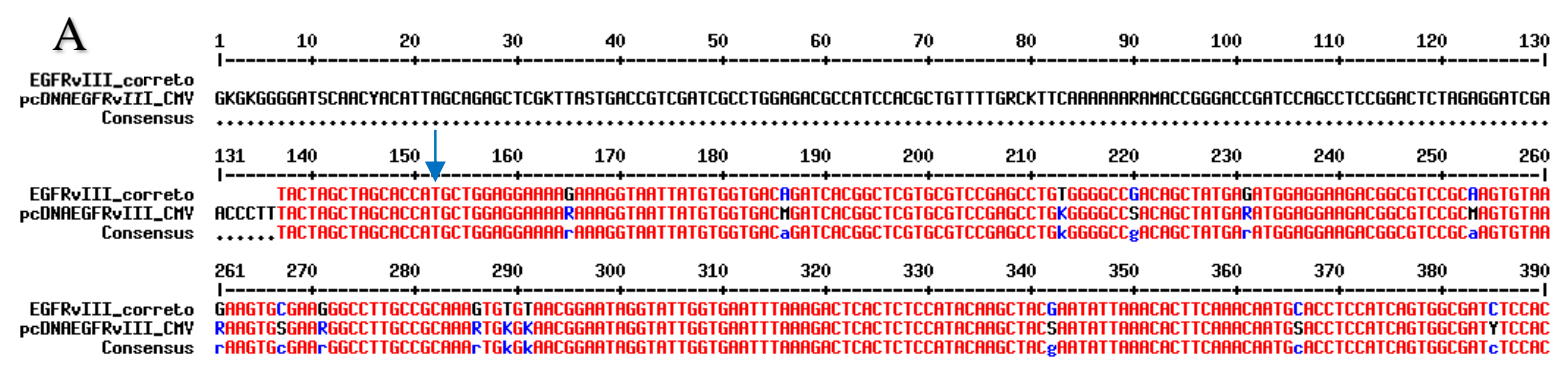




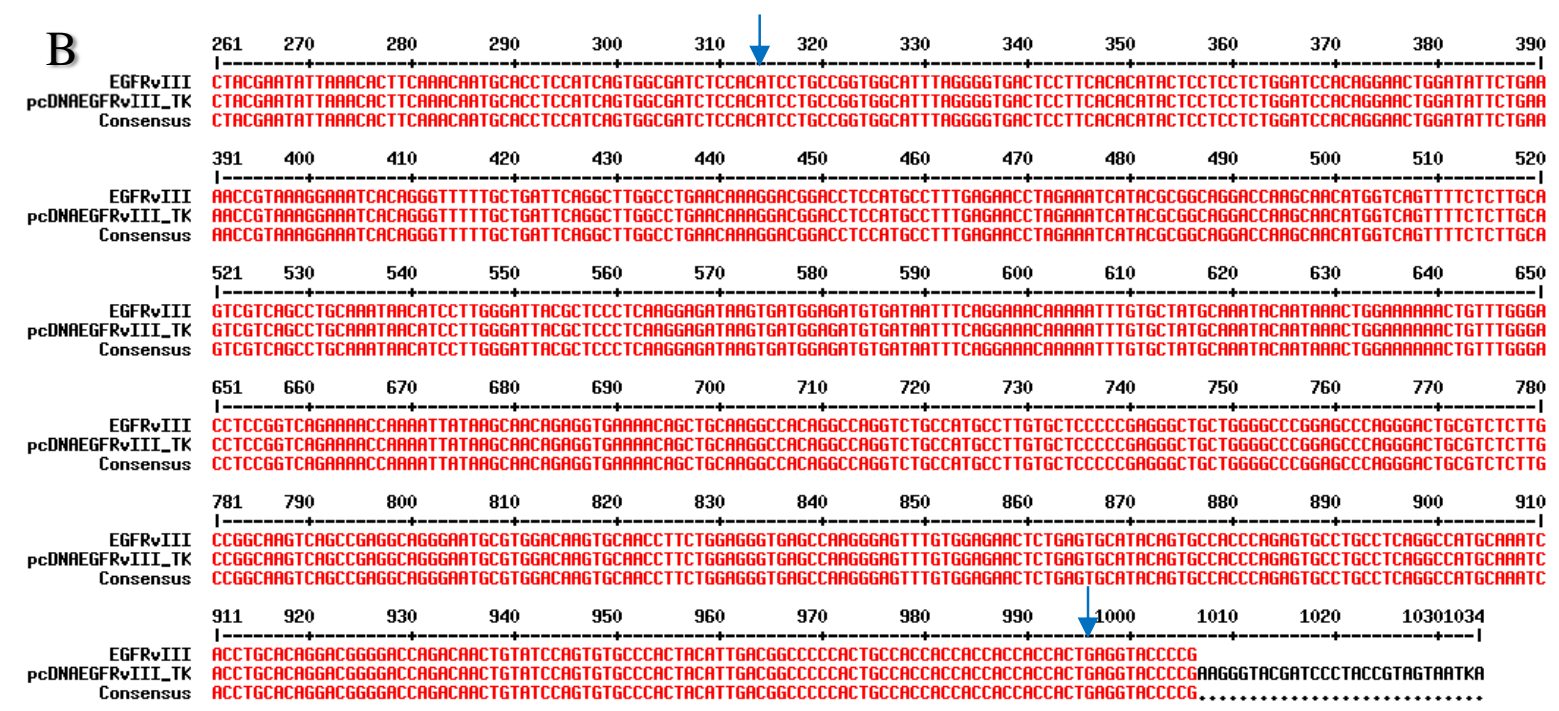

Figura 3: Sequenciamento do clone pcDNAEGFRvIII_4. Alinhamento da sequência EGFRvIII com o clone pcDNAEGFRvIII_4 sequenciado com o oligonucleotídeo CMV (A) e TK (B); em destaque (seta), o códon de iniciação da tradução da proteína EGFRvIII, o início da sequência que não é encontrada no sequenciamento anterior e o códon de terminação da tradução.

O sequenciamento confirmou a clonagem e o eletroferograma confirmou que as bases estavam corretas, indicando sequência correta do pcDNAEGFRvIII_4.

\subsection{Clonagem do gene cERBB2 no vetor pcDNA}

Após a transformação, a seleção do plasmídio recombinante pcDNAcERBB2 foi feita realizando-se uma PCR de 6 grupos com 5 colônias cada diluídas em $50 \mu \mathrm{L}$ de água estéril. A reação foi realizada com $5 \mu \mathrm{L}$ da mistura de água + bactérias como molde, $0,1 \mu \mathrm{M}$ de cada oligonucleotídeo (cERBB2pVAX_S e cERBB2pKLAC_R), 0,2mM de cada dNTPs, tampão 1X, 1,5mM de $\mathrm{MgCl}_{2}$ e 1 unidade da enzima Taq DNA polimerase em um volume final de $20 \mu \mathrm{L}$ (programa $\mathrm{VAC}, \mathrm{TM} 50^{\circ} \mathrm{C}$ e extensão de 2'30')' O produto da PCR foi analisado em gel de agarose $1 \%$ (Figura 4 ):

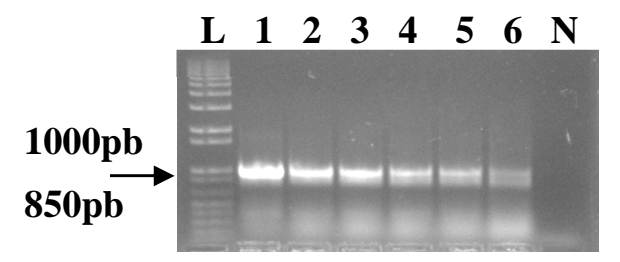

Figura 4: PCR de colônia da ligação pcDNA + cERBB2. PCR dos 6 grupos da ligação pcDNA + cERBB2 com os oligonucleotídeos cERBB2pVAX_S e cERBB2pKLAC_R. L-marcador 1Kb Plus, 1 ao 6-PCR dos grupos de 1 a 6 e N-negativo.

Todos os grupos apresentaram fragmento entre 850-1000pb (tamanho esperado de $944 \mathrm{pb}$ ) indicando a presença do fragmento cERBB2. A partir desse resultado, foi realizada a 
extração de 10 plasmídios de dois grupos que foram submetidos a uma nova PCR com 75ng de cada plasmídio como molde e os oligonucleotídeos CMV e cERBB2pKLAC_R (Figura 5):
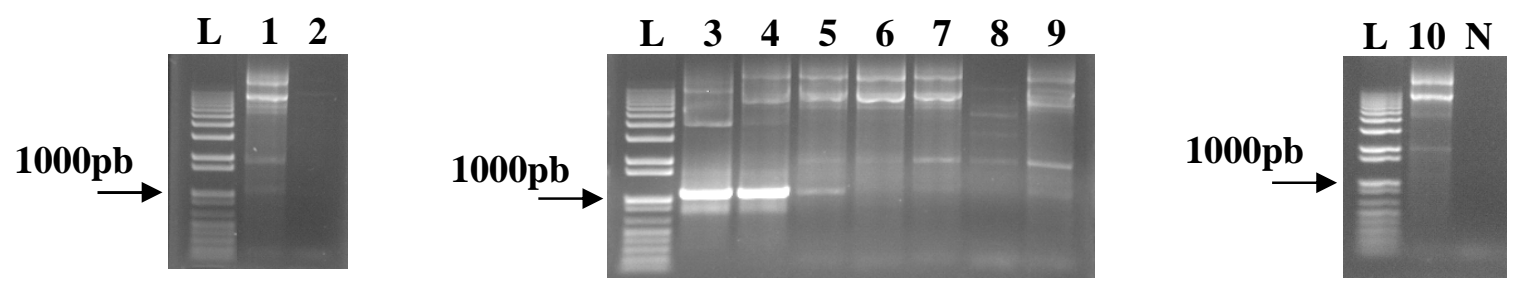

Figura 5: PCR dos plasmídios da ligação pcDNA + cERBB2. PCR de 10 plasmídios da ligação pcDNA + cERBB2 com os oligonucleotídeos CMV e cERBB2pKLAC_R. L-marcador 1Kb Plus, 1 ao 10-PCR dos 10 plasmídios e N-negativo.

Os clones pcDNAcERBB2_3 e 4 apresentaram fragmento próximo a 1000pb (tamanho esperado de $1104 \mathrm{pb}$ ) indicando a presença e direção correta do fragmento cERBB2. A partir dos resultados obtidos com as PCRs, o plasmídio recombinante pcDNAcERBB2_3 foi sequenciado para confirmação da clonagem. Três sequenciamentos foram realizados, mas não foi possível confirmar a clonagem correta por essa metodologia, pois os arquivos apresentam problemas.

\subsection{Clonagem do gene MAGE no vetor pcDNA}

Após a transformação, a seleção do plasmídio recombinante pcDNAMAGE foi feita realizando-se uma PCR de 13 grupos com 5 colônias cada diluídas em $50 \mu \mathrm{L}$ de água estéril. A reação foi realizada com $5 \mu \mathrm{L}$ da mistura de água + bactérias como molde, $0,1 \mu \mathrm{M}$ de cada oligonucleotídeo (CMV e MAGEpKLAC_R), 0,2mM de cada dNTPs, tampão 1X, 1,5mM de $\mathrm{MgCl}_{2}$ e 1 unidade da enzima Taq DNA polimerase em um volume final de $20 \mu \mathrm{L}$ (programa VAC, TM $50^{\circ} \mathrm{C}$ e extensão de 2 minutos). $\mathrm{O}$ produto da PCR foi analisado em gel de agarose $1 \%$ (Figura 6):
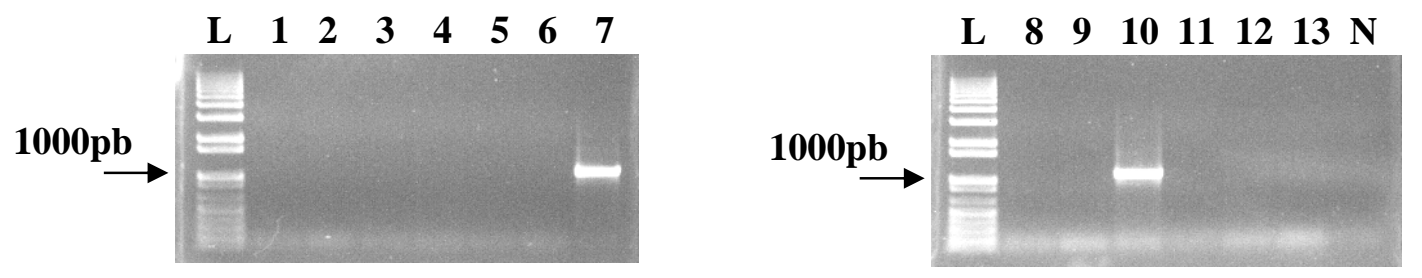

Figura 6: PCR de colônia da ligação pcDNA + MAGE. PCR de 13 grupos de 5 colônias da ligação pcDNA + MAGE com os oligonucleotídeos CMV e MAGEpKLAC_R. L-marcador 1Kb Plus, 1 ao 13-PCR dos 13 grupos e N-negativo.

Os grupos 7 e 10 apresentaram fragmento próximo a 1000pb (tamanho esperado de $1146 \mathrm{pb}$ ) indicando a presença do fragmento MAGE na direção correta. A partir desse resultado, foi realizada a extração dos plasmídios das colônias dos dois grupos e uma nova 
PCR como a descrita acima utilizando-se 150ng de cada plasmídio como molde e 1 minuto de extensão. A PCR foi analisada em gel de agarose (Figura 7):
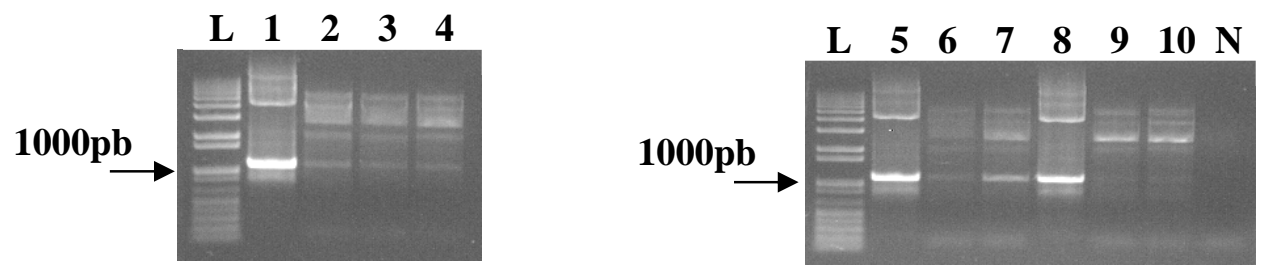

Figura 7: PCR dos plasmídios da ligação pcDNA + MAGE. PCR de 10 plasmídios extraídos da ligação pcDNA + MAGE com os oligonucleotídeos CMV e MAGEpKLAC_R. L-marcador 1Kb Plus, 1 ao 10-PCR dos 10 plasmídios e N-negativo.

Os clones pcDNAMAGE_1, 5, 7 e 8 apresentaram fragmento próximo a 1000pb (tamanho esperado de 1146pb) indicando a presença do fragmento MAGE na direção correta.

A partir dos resultados obtidos com as PCRs, o plasmídio recombinante pcDNAMAGE_1 foi analisado por sequenciamento utilizando-se os oligonucleotídeos CMV e TK para confirmação da clonagem (Figura 8).

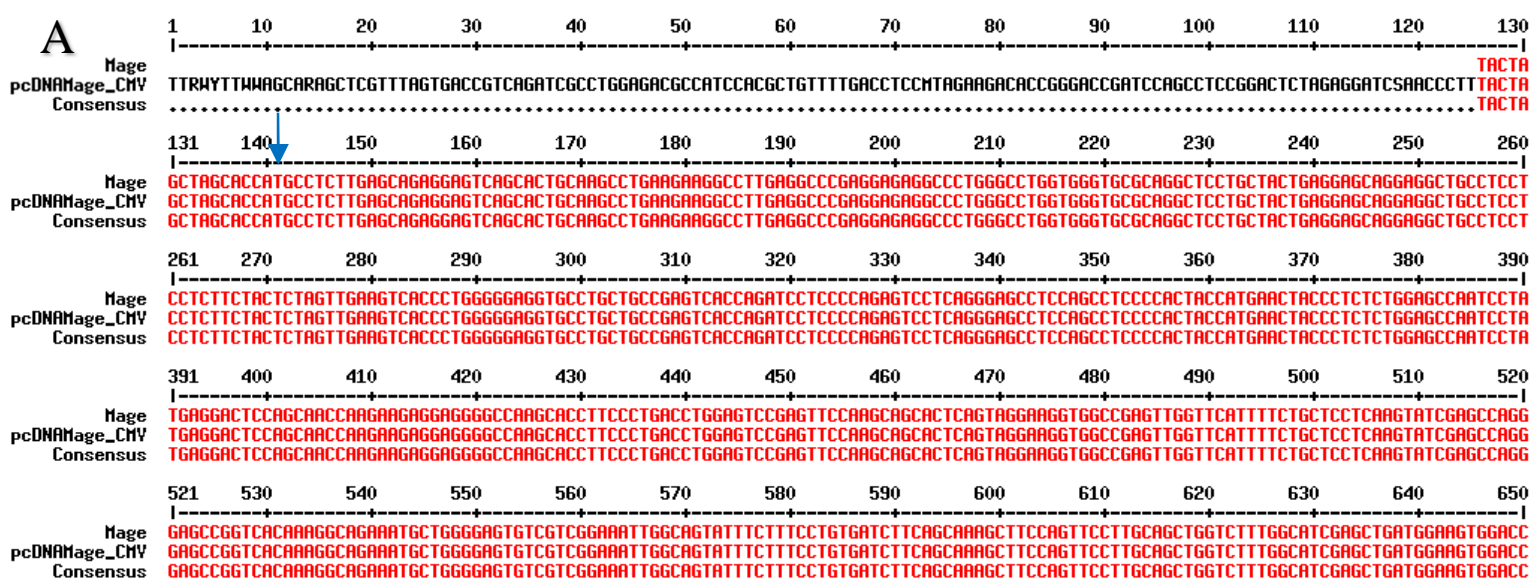

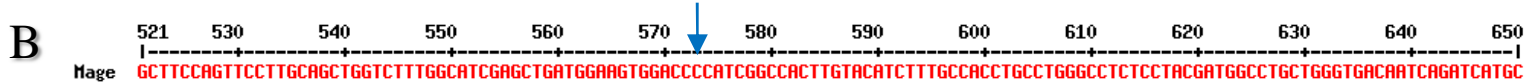

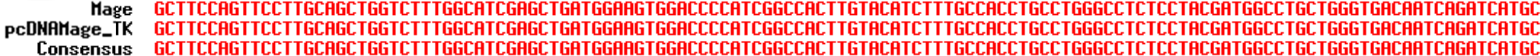

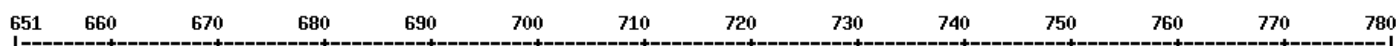

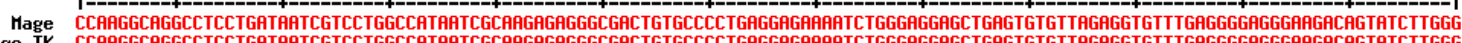

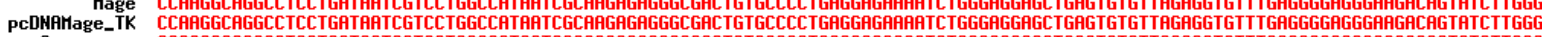

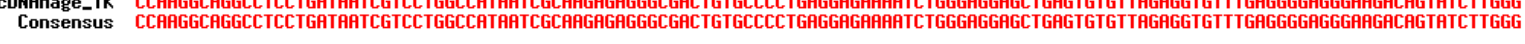

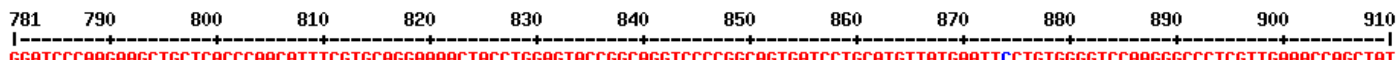

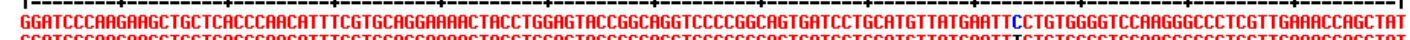
pcDNAMage_TK
Consensus

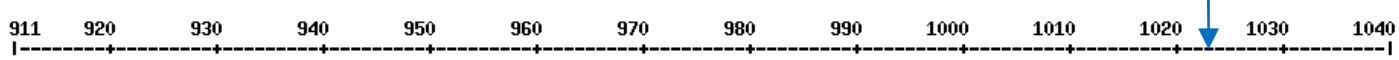

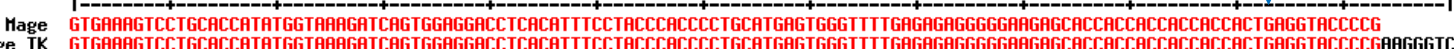

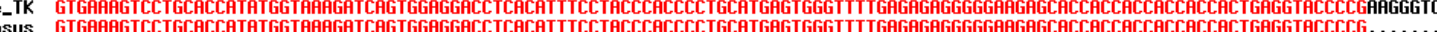

Figura 8: Sequenciamento do clone pcDNAMAGE_1. Alinhamento da sequência MAGE com o clone pcDNAMAGE_1 sequenciado com o primer CMV (A) e TK (B); em destaque (seta), o códon de iniciação da tradução da proteína MAGE, o início da sequência que não é encontrada no sequenciamento anterior e o códon de terminação da tradução. 
O sequenciamento e a análise do eletroferograma indicaram a presença de uma mutação (troca do $\mathrm{C}$ pelo $\mathrm{T}$ ) (vista em subsequentes sequenciamentos) que modifica o aminoácido de Prolina para Serina.

\subsection{Clonagem do gene GLEA no vetor pcDNA}

Após a transformação a, seleção do plasmídio recombinante pcDNAGLEA foi feita realizando-se uma PCR de 13 grupos com 5 colônias cada diluídas em $50 \mu \mathrm{L}$ de água estéril. A reação foi realizada com $5 \mu \mathrm{L}$ da mistura de água + bactérias como molde, $0,1 \mu \mathrm{M}$ de cada oligonucleotídeo (GLEApVAX_S e GLEApKLAC_R), 0,2mM de cada dNTPs, tampão 1X, $1,5 \mathrm{mM}$ de $\mathrm{MgCl}_{2}$ e 1 unidade da enzima Taq DNA polimerase em um volume final de $20 \mu \mathrm{L}$ (programa VAC, $\mathrm{TM} 50^{\circ} \mathrm{C}$ e extensão de 2 minutos). O produto da PCR foi analisado em gel de agarose $1 \%$ (Figura 9):
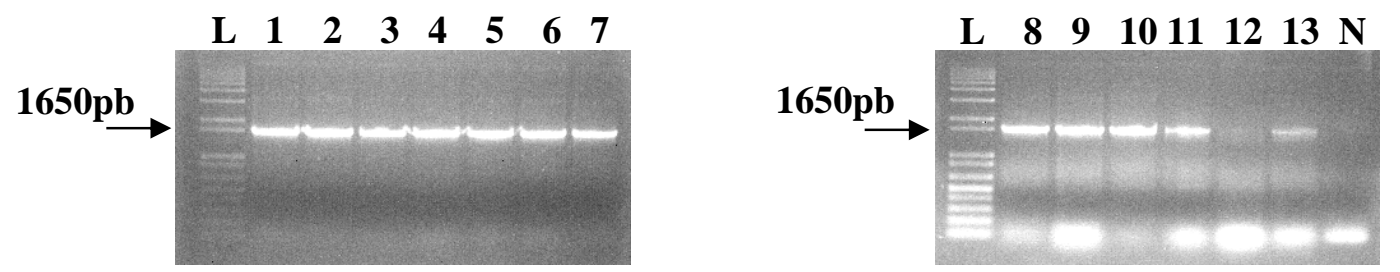

Figura 9: PCR de colônia da ligação pcDNA + GLEA. PCR de 13 grupos de 5 colônias da ligação pcDNA + GLEA com os oligonucleotídeos GLEApVAX_S e GLEApKLAC_R. L-marcador 1Kb Plus, 1 ao 13-PCR dos 13 grupos e N-negativo.

Todos os grupos, exceto o 12, apresentaram fragmento próximo a 1650pb (tamanho esperado de $1673 \mathrm{pb}$ ) indicando a presença do fragmento GLEA. A partir desse resultado, foi realizada a extração dos plasmídios das colônias de três grupos (grupos 3, 9 e 14). Os plasmídios foram submetidos a clivagem (900ng de cada plasmídio) com 0,5 unidade das enzimas PmeI $^{* *}$ e HindIII**, tampão OPA $1 \mathrm{X}$ em uma reação final de $20 \mu \mathrm{L}$ a $37^{\circ} \mathrm{C}$ por 5 horas (Figura 10).

**A enzima PmeI digere o plasmídio e a HindIII o inserto, sendo possível avaliar a presença do fragmento e sua direção.

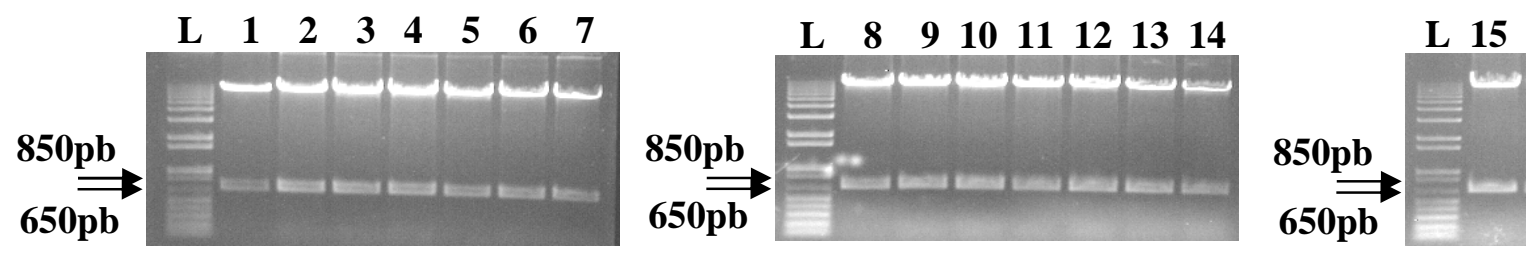

Figura 10: Clivagem dos plasmídios pcDNAGLEA: Clivagem dos clones pcDNAGLEA com as enzimas PmeI e HindIII. L-marcador $1 \mathrm{~Kb}$ Plus e 1 ao 15-clones pcDNAGLEA digeridos. 
Todos os plasmídios liberaram um fragmento entre 650-850pb, o que não era o tamanho esperado para clonagem na direção correta ou invertida, outra digestão foi realizada com as enzimas XbaI (que também cliva o plasmídeo) e HindIII, mas o mesmo resultado foi obtido, um fragmento que não condizia com a presença do gene na direção correta ou invertida. Dessa forma, selecionamos um clone (clone 5) para análise por sequenciamento utilizando-se os oligonucleotídeos CMV, GLEA_1Sseq, GLEA_2RSeq e GLEA_3Sseq para confirmação da clonagem (Figura 11).

\begin{tabular}{|c|c|c|c|c|c|c|c|c|c|c|c|c|c|c|}
\hline \multirow[b]{2}{*}{$\begin{array}{r}\text { Glea } \\
\text { Pc:DNAGlea_1SSeq } \\
\text { Consensus }\end{array}$} & 391 & 400 & 410 & 420 & 430 & 440 & 450 & 460 & 470 & 480 & 490 & 500 & 510 & \\
\hline & \multicolumn{14}{|c|}{ 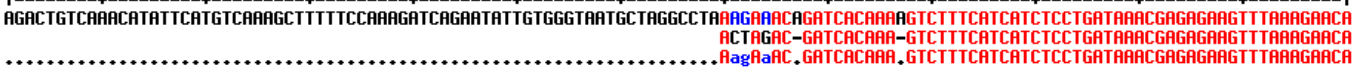 } \\
\hline & 521 & 530 & 540 & 550 & 560 & 570 & 580 & 590 & 600 & 610 & 620 & 630 & 640 & \\
\hline $\begin{array}{r}\text { Glea } \\
\text { PcDNAGlea_15Seq } \\
\text { Consensus }\end{array}$ & \multicolumn{14}{|c|}{ 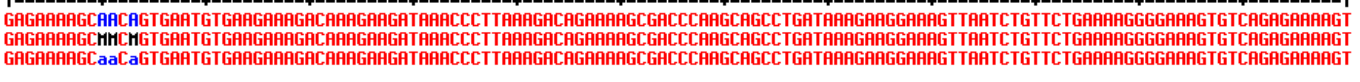 } \\
\hline & 651 & 660 & 670 & 680 & 690 & 700 & 710 & 720 & 730 & 740 & 750 & 760 & 770 & \\
\hline $\begin{array}{r}\text { Glea } \\
\text { PcDNAGlea_1SSeq } \\
\text { Consensus }\end{array}$ & \multicolumn{14}{|c|}{ 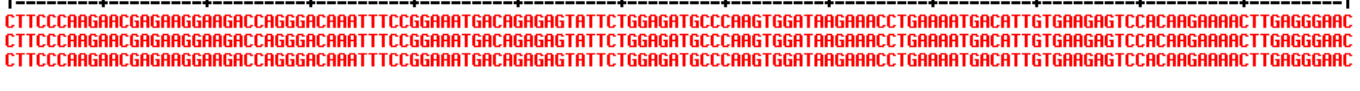 } \\
\hline & 781 & 790 & 800 & 810 & 820 & 830 & 840 & 850 & 860 & 870 & 880 & 890 & 900 & \\
\hline $\begin{array}{r}\text { Glea } \\
\text { PcDNAGlea_1SSeq } \\
\text { Consensus }\end{array}$ & \multicolumn{14}{|c|}{ 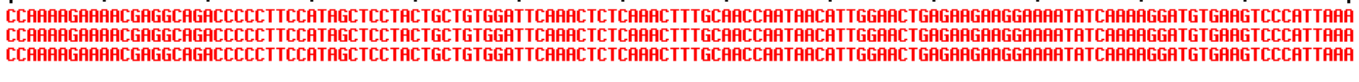 } \\
\hline & 911 & 920 & 930 & 940 & 950 & 960 & 970 & 980 & 990 & 1000 & 1010 & 1020 & 1030 & 104 \\
\hline $\begin{array}{r}\text { Glea } \\
\text { PcDNAGlea_1SSeq } \\
\text { Consensus }\end{array}$ & \multicolumn{14}{|c|}{ 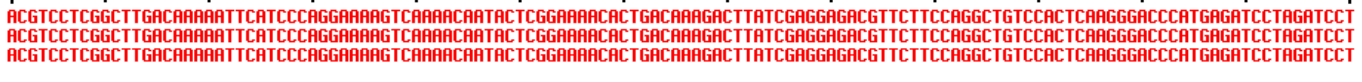 } \\
\hline & 1041 & 1050 & 1060 & 1070 & 1080 & 1090 & 1100 & 1110 & 1120 & 1130 & 1140 & 1150 & 1160 & \\
\hline $\begin{array}{r}\text { Glea } \\
\text { DNAGlea_1SSeq } \\
\text { Consensus }\end{array}$ & & & & & & & & & & & & & & \\
\hline
\end{tabular}

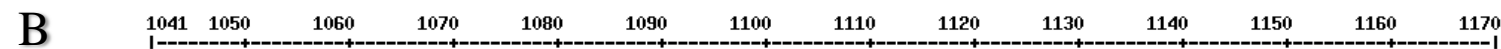

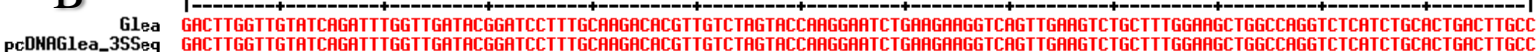

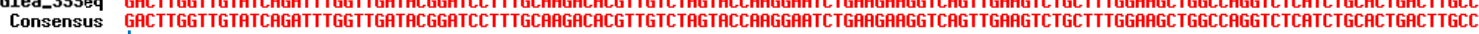

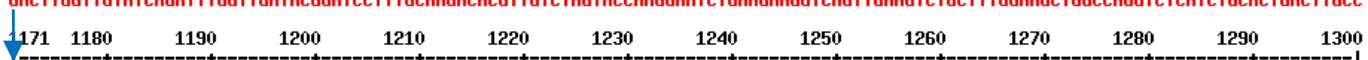

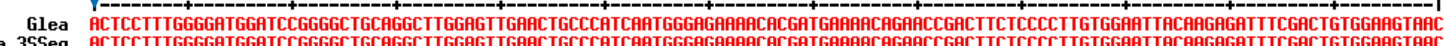

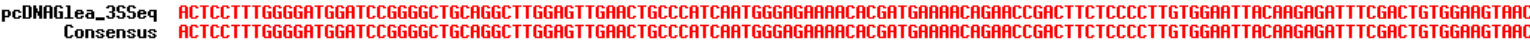

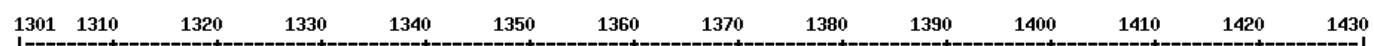

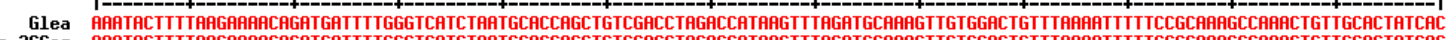

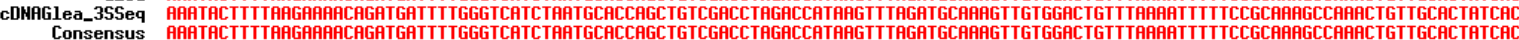

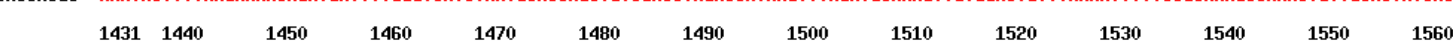

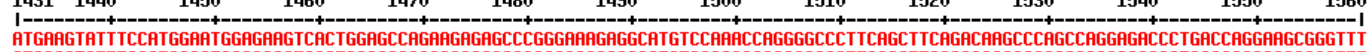

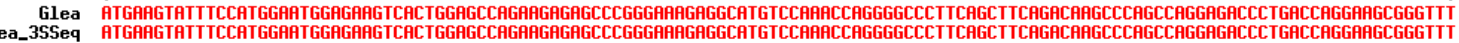

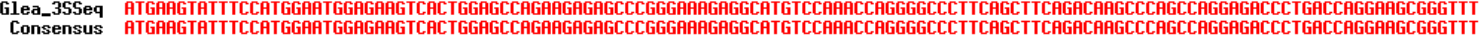

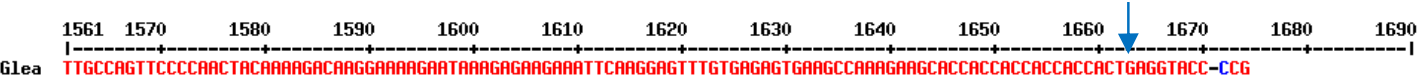

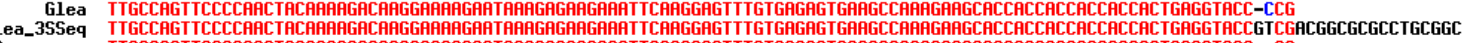

Consensus TTGCCAGTTCCC A

Figura 11: Sequenciamento do clone pcDNAGLEA_5. Alinhamento da sequência GLEA com o clone pcDNAGLEA_5 sequenciado com o Oligonucleotídeo Glea_1Sseq (A) e Glea_3Sseq (B); em destaque (seta), o início da sequência que não é encontrada no sequenciamento anterior e o códon de terminação da tradução.

O sequenciamento só foi possível com os oligonucleotídeos GLEA_1Sseq e GLEA_3Sseq, os outros iniciadores utilizados parecem anelar em uma região inespecífica. Dessa forma, só foi possível visualizar que o clone apresenta a sequência GLEA, mas não, se toda a sequência estava correta. 


\section{Anexo 4.0 - Expressão das proteínas EGFRvIII, cERBB2, MAGE e GLEA em HEK}

Os vetores pcDNAEGFRvIII, pcDNAcERBB2, pcDNAMAGE e pcDNAGLEA foram utilizados na transfecção de células HEK para teste da expressão das proteínas recombinantes.

\subsection{Transfeccão das células HEK com os vetores de expressão}

As células $\mathrm{HEK}$ foram transfectadas com $\mathrm{CaCl}_{2}$ segundo protocolo descrito no item 4.6.2.2 do materiais e métodos. As células foram coletadas após 24 horas da transfecção e avaliadas por western blot como descrito no item 4.6.2.2.2 do materiais e métodos, utilizandose o anticorpo anti-HisTag na diluição 1:3000 para detecção das proteínas expressas pelos vetores (Figura 1). Algumas variações também foram realizadas, como a transfecção utilizando-se o reagente JetPrime (Polyplus transfection SA) segundo as instruções do

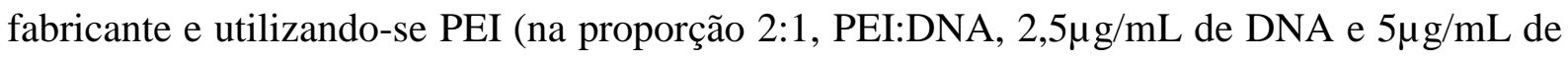
PEI) com coleta das células após 72 horas da transfecção.

\section{$\begin{array}{llllllll}\text { L } & 1 & 2 & 3 & 4 & 5 & 6 & 7\end{array}$}

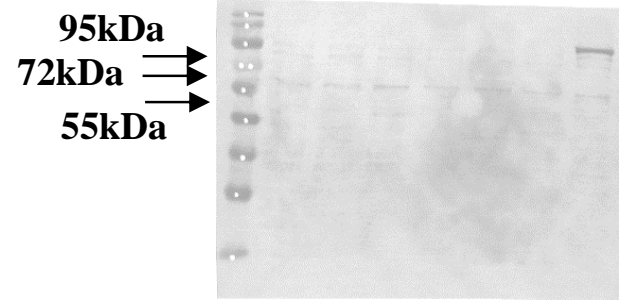

Figura 1: Expressão das proteínas codificadas pelos vetores construídos com pcDNA. Células HEK foram transfectadas com os vetores pcDNAEGFRvIII, pcDNAcERBB2, pcDNAMAGE e pcDNAGLEA e após 24 horas foram avaliadas quanto a expressão das proteínas codificadas pelos plasmídios por western blot com antiHisTag. L-marcador; 1- células não transfectadas; células transfectadas com 2-pVAX; 3-pcDNAMAGE; 4pcDNAEGFRvIII; 5-pcDNAcERBB2; 6-pcDNAGLEA e 7-pcDNAgp96.

Em nenhuma das condições utilizadas houve expressão das proteínas de interesse, dessa forma, essa estratégia não pode ser utilizada para expressão das proteínas recombinantes EGFRvIII, cERBB2, MAGE e GLEA. 


\section{Anexo 5.0 - Clonagem do gene gp96 no vetor pET}

O plasmídio pBSKgp96 também foi utilizado para amplificação do gene gp96 para posterior clonagem no vetor pET e expressão E. coli.

\subsection{Amplificacão e clivagem do gene gp96}

O gene gp96 foi amplificado para a clonagem no vetor pET utilizando-se como molde o plasmídio pBSKgp96 e os seguintes iniciadores:

\section{Gp96pET28a_S: 5'TACTAGCTAGCATGGACGATGAAGTTGATG 3'}

\section{Gp96pET28a_R: 5'GATCTCGAGTCACAATTCATCTTTTTCAGC 3'}

No oligonucleotídeo $\mathrm{S}$ foi incluído um sítio de ancoragem (em cinza), o sítio da enzima NheI (região sublinhada) e a porção inicial do gene (aproximadamente 18 bases) e no oligonucleotídeo R foi inserido a porção final do gene, um stop códon (em negrito), o sítio da enzima XhoI (região sublinhada) e um sítio de ancoragem (em cinza).

$\mathrm{Na}$ reação de amplificação, além dos $0,1 \mu \mathrm{M}$ de cada oligonucleotídeo foi utilizado 100ng do molde, 0,2mM de cada dNTPs, tampão $1 \mathrm{X}$ e 5 unidade da enzima High fidelity; a reação foi feita em $100 \mu \mathrm{L}$ finais utilizando o programa VAC (2 minutos de extensão). O produto da amplificação foi analisado em gel de agarose $1 \%$ e purificado utilizando-se o Wizard SV Gel and PCR Clean-Up System (Figura 1).

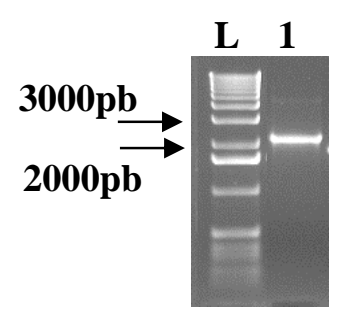

Figura 1: Amplificação do gene gp96 para a clonagem no pET. L-marcador 1Kb e 1-gp96.

O gene gp96 foi amplificado de forma correta $(2517 \mathrm{pb})$, foi purificado e clivado com as enzimas NheI e XhoI: $2,4 \mu \mathrm{g}$ do gene foi clivado com 4 unidades de cada enzima, juntamente com tampão FastDigest $1 \mathrm{X}$ em um volume final de 60-70 $\mu \mathrm{L}$ por aproximadamente 16 horas a $37^{\circ} \mathrm{C}$. O fragmento clivado foi diretamente purificado utilizando-se o Wizard SV Gel and PCR Clean-Up System.

\subsection{Clonagem do gene gp96no vetor $\mathrm{pET}$}

O fragmento gp96 clivado com as enzimas NheI e XhoI, como descrito anteriormente, foi clonado no plasmídio pET, clivado com as mesmas enzimas, como descrito no materiais e métodos, pela reação de ligação, feita a temperatura ambiente por 1 hora, utilizando-se 150ng 
do inserto gp96, 50ng do vetor pET, tampão da enzima $1 \mathrm{X}$ e 0,5 unidade da T4 DNA ligase em um volume final de $10 \mu \mathrm{L}$. Todo volume da ligação foi utilizado na transformação de células de E. coli Top10 competentes que foram plaqueadas em meio LB ágar suplementado com canamicina.

A seleção do plasmídio recombinante pETgp96 foi feita por uma PCR de colônias com 8 grupos contendo 5 colônias cada. As bactérias foram diluídas em $50 \mu \mathrm{L}$ de água estéril e a reação realizada com $5 \mu \mathrm{L}$ da mistura de água + bactérias como molde, $0,1 \mu \mathrm{M}$ de cada oligonucleotídeo (T7p e gp96_2Rseq), 0,2mM de cada dNTPs, tampão 1X, 1,5mM de $\mathrm{MgCl}_{2}$ e 1 unidade da enzima Taq DNA polimerase em um volume final de $20 \mu \mathrm{L}$ (programa VAC). O produto da PCR foi analisado em gel de agarose $1 \%$ (Figura 2):
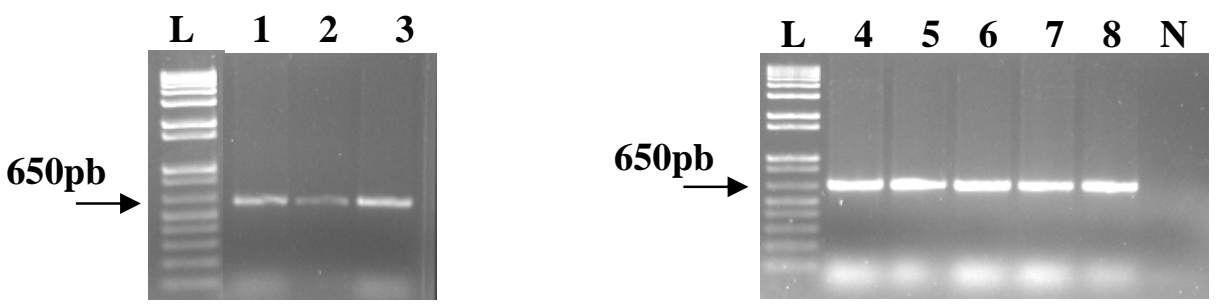

Figura 2: PCR de colônia da ligação pET + gp96. PCR de 8 grupos de colônias da ligação pET + gp96 com os oligonucleotídeos T7p e gp96_2Rseq. L-marcador 1Kb Plus, 1 ao 8-PCR dos 8 grupos e N-negativo.

Todos os grupos apresentaram uma banda de amplificação de aproximadamente 650pb (tamanho esperado de 655pb) indicando a presença do fragmento gp96. A partir desse resultado, foi realizada a extração dos 5 plasmídios do grupo 6, nomeados de 11 a 15 . Esses plasmídios foram submetidos a uma reação de clivagem: 360ng de cada plasmídio foram digeridos com 0,5 unidade das enzimas NheI $^{* *}$ e XhoI**, tampão $1 \mathrm{X}$ em uma reação final de $20 \mu \mathrm{L}$ a $37^{\circ} \mathrm{C}$ por 3 horas e 30 minutos. A digestão foi analisada em gel de agarose $1 \%$ (Figura 3):

**As enzimas NheI e XhoI flanqueiam o inserto gp96 sendo possível avaliar a presença dele pelo fragmento liberado.
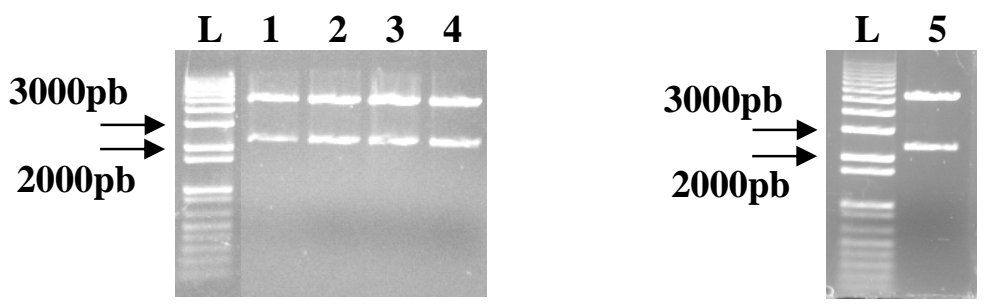

Figura 3: Clivagem dos plasmídios pETgp96. Clivagem dos clones pETgp96 com as enzimas NheI e XhoI. Lmarcador 1Kb Plus e 1 ao 5-clones pETgp96_11 a 15 digeridos. 
Todos os clones pETgp96 apresentaram fragmento entre 2000-3000pb (tamanho esperado de 2358pb) indicando a presença do fragmento gp96 no interior do pET.

A partir do resultado obtido com a análise de restrição, o plasmídio recombinante pETgp96_13 foi analisado por sequenciamento utilizando-se os oligonucleotídeos T7p, gp96_1SSeq, gp96_3SSeq e gp96_4SSeq para confirmação da clonagem (Figura 4).
A 1 $20 \quad 30$ $40 \quad 50$ $60 \quad 70$ $80 \quad 90$ $100 \quad 110 \quad 120 \quad 130$

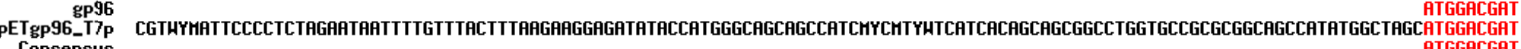

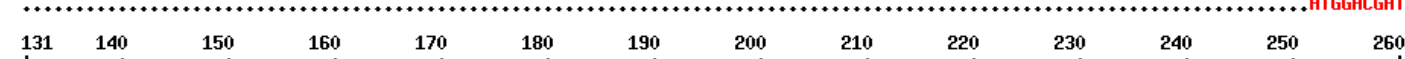

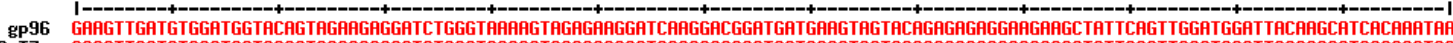 PETgP96_-17 G GAAG

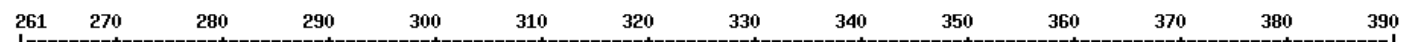

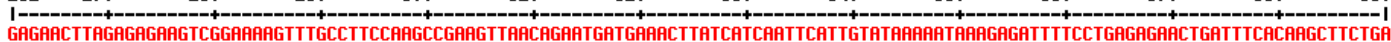

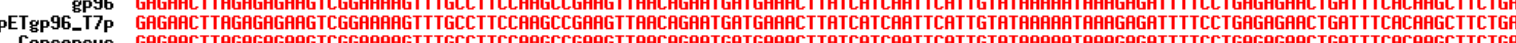

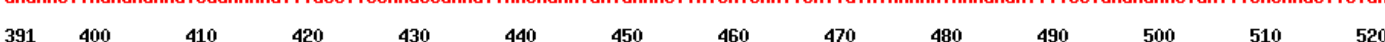

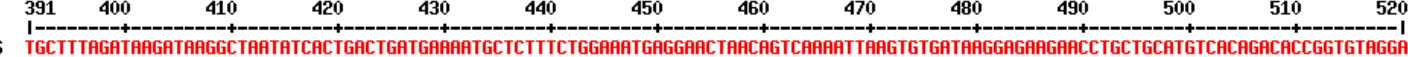

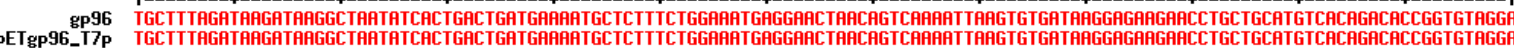

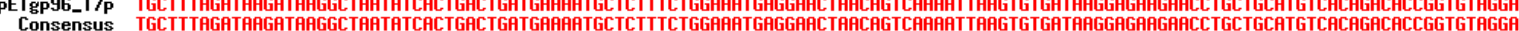

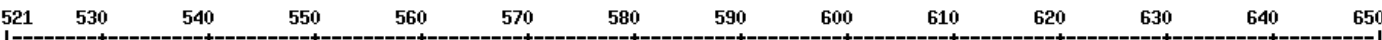

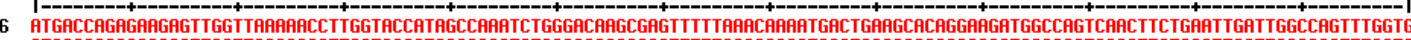

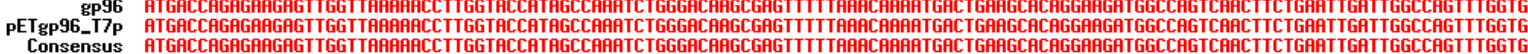

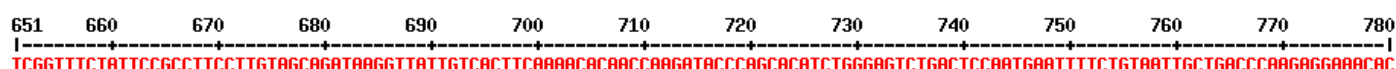

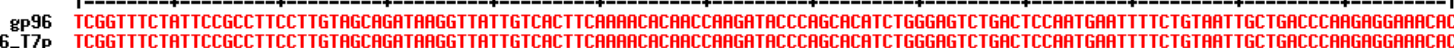

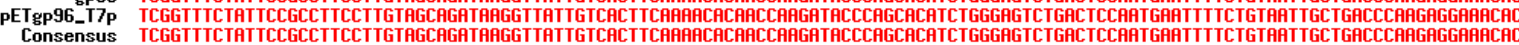

B

PETgP96_gp96/15_seq $651 \quad 66 \frac{6}{16} \quad 670 \quad 680$

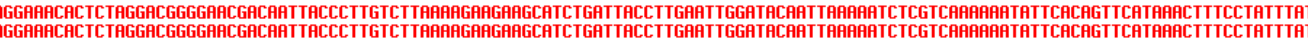

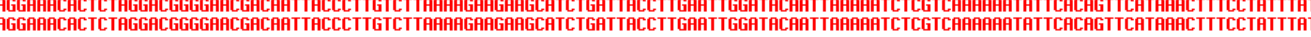

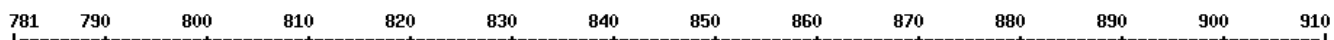

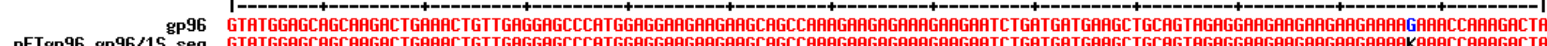
pETgp96_gp96/15_seq
Consensus

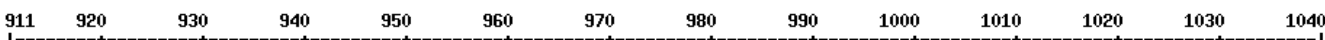

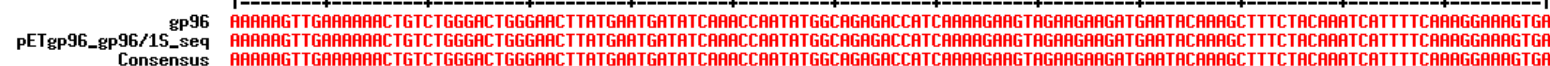

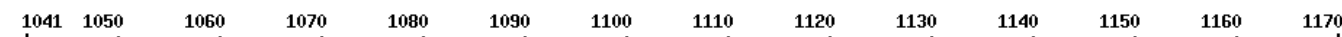

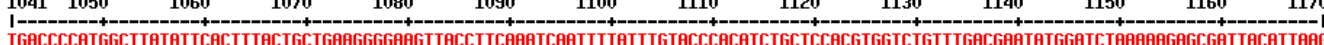

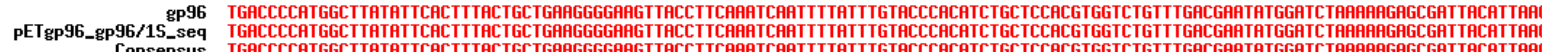

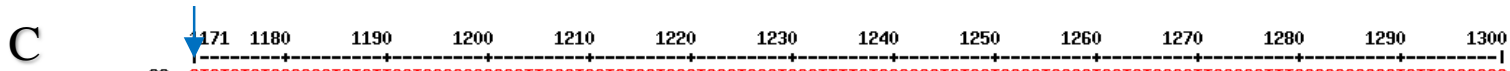
gP96 CTCTATGTGCGCCGTGTATTCATCACAGACGACTTCCATGATPTGATGCCTAAPTACCTCAATTTTGTCAAGGGTGTGGTGGACTCAGATGATCTCCCCTTGCAAGTTTCCCGCGAGACTCTTCAGCARC CTCTATGTGCGCCGTGTATTCATCACAGACGACTTCCATGATATGATGCCTAARTACCTCAATTTTGTCAAGGGTGTGGTGGACTCAGATGATCTCCCCTTGCAAGTTTCCCGCGAGACTCTTCAGCAAC
CTCTATGTGCGCCGTGTATTCATCACAGACGACTTCCATGATATGATGCCTAAATACCTCAATTTTGTCAAGGGTGTGGTGGACTCAGATGATCTCCCCTTGCAAGTTTCCCGCGAGACTCTTCAGCAAC

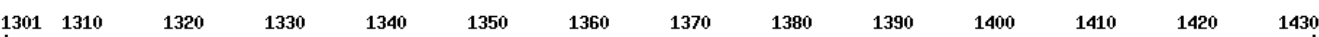

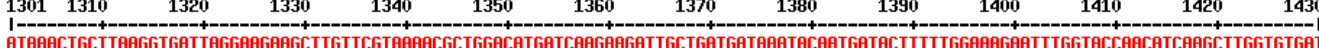

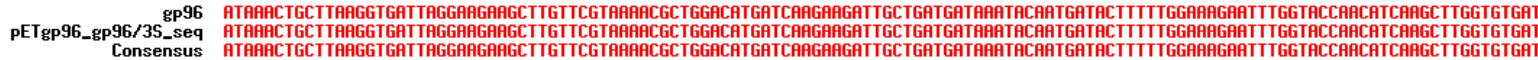

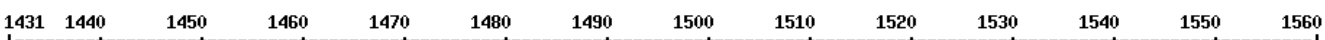

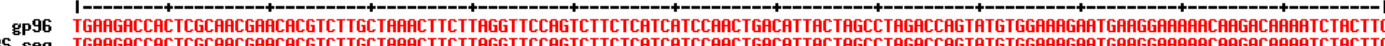

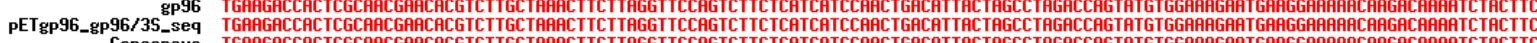

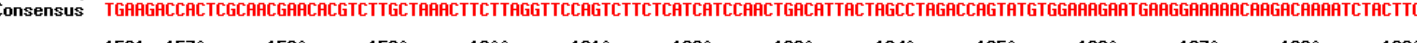

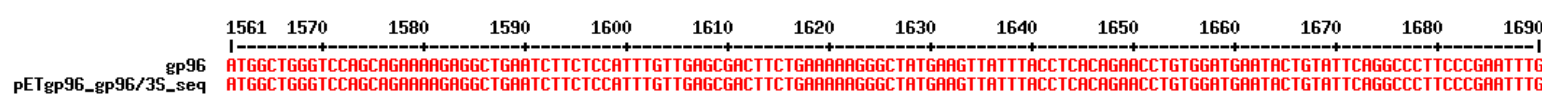

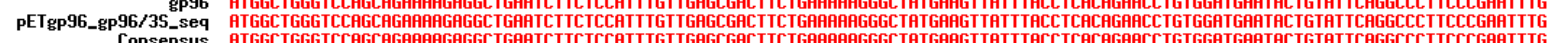




\begin{tabular}{|c|c|c|c|c|c|c|c|c|c|c|c|c|c|c|}
\hline 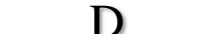 & 691 & 1700 & 1710 & 1720 & 1730 & 1740 & 1750 & 1760 & 1770 & 1780 & 1790 & 1800 & 1810 & 1820 \\
\hline $\begin{array}{r}\text { pETgP96_gp96/4S_seq } \\
\text { Consensus }\end{array}$ & \multicolumn{14}{|c|}{ 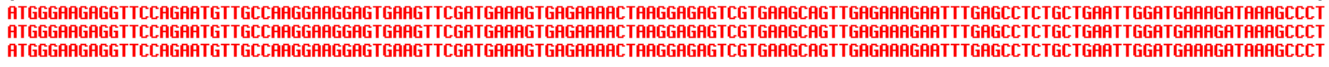 } \\
\hline & 1821 & 1830 & 1840 & 1850 & 1860 & 1870 & 1880 & 1890 & 1900 & 1910 & 1920 & 1930 & 1940 & 1950 \\
\hline $\begin{array}{r}\text { pETgP96_gp96/4S_seq } \\
\text { Consensus }\end{array}$ & \multicolumn{14}{|c|}{ 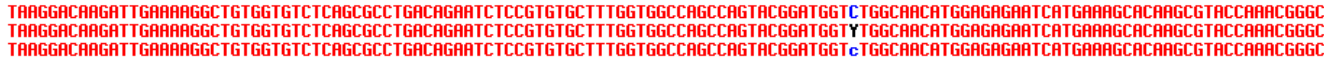 } \\
\hline & 1951 & 1960 & 1970 & 1980 & 1990 & 2000 & 2010 & 2020 & 2030 & 2040 & 2050 & 2060 & 2070 & 2080 \\
\hline $\begin{array}{r}\text { gp96 } \\
\text { pETgp96_gp96/4S_seq } \\
\text { Consensus }\end{array}$ & \multicolumn{14}{|c|}{ 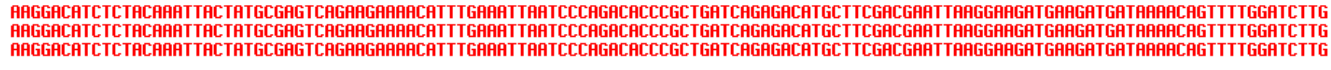 } \\
\hline & 2081 & 2090 & 2100 & 2110 & 2120 & 2130 & 2140 & 2150 & 2160 & 2170 & 2180 & 2190 & 2200 & 2210 \\
\hline $\begin{array}{r}\text { gPT6 } \\
\text { pETgP96_gp96/4S_seq } \\
\text { Consensus }\end{array}$ & \multicolumn{14}{|c|}{ 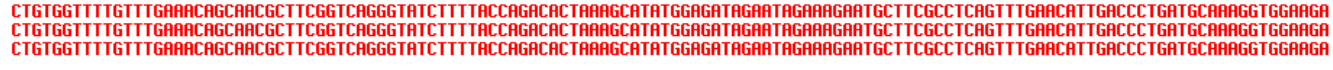 } \\
\hline & 2211 & 2220 & 2230 & 2240 & 2250 & 2260 & 2270 & 2280 & 2290 & 2300 & 2310 & 2320 & 2330 & 2340 \\
\hline $\begin{array}{r}\text { gP96 } \\
\text { PETgP96_gp96/4S_seq } \\
\text { Consensus }\end{array}$ & \multicolumn{14}{|c|}{ 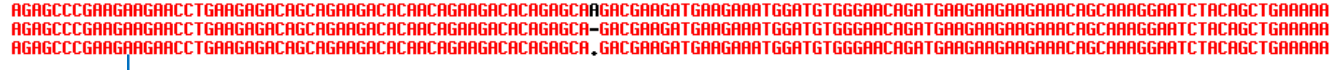 } \\
\hline & 2341 & 2350 & 2360 & 2370 & 2380 & 2390 & 2400 & 2410 & 2420 & 2430 & 2440 & 2450 & 24 & \\
\hline
\end{tabular}

Figura 4: Sequenciamento do clone pETgp96_13. Alinhamento da sequência gp96 com o clone pETgp96_13 sequenciado com os oligonucleotídeos T7p (A), gp96_1Sseq (B), gp96_3Sseq (C) e gp96_4Sseq (D); em destaque (setas), o códon de iniciação da tradução da proteína gp96, o início da sequência que não é encontrada no sequenciamento anterior e o códon de terminação da tradução.

O sequenciamento e a análise do eletroferograma comprovaram a sequência correta do clone pETgp96_13. 
Anexo 6.0 - Expressão da proteína gp96 em E. coli

O vetor pETgp96 foi utilizado na transformação de células E. coli BL21 para teste da expressão da proteína recombinante gp96.

\subsection{Expressão da proteína gp96 em $E$. coli}

Uma colônia de células E. coli BL21 transformada com pETgp96 foi utilizada na expressão teste da proteína gp 96 a $37^{\circ} \mathrm{C}$ por 2 , 4 e overnight de indução com $0,2 \mathrm{mM}$ de IPTG. A expressão foi analisada em SDS-PAGE 10\% (Figura 1):

\section{$\begin{array}{llllll}L & 1 & 2 & 3 & 4\end{array}$}

$95 \mathrm{kDa}$

Figura 1: Expressão da proteína recombinante gp96. L-marcador; 1-não induzido; 2-2 horas após indução com IPTG; 3-4 horas após indução com IPTG e 4-overnight após indução com IPTG.

A proteína gp96 não foi expressa em nenhum dos tempos após a indução com IPTG. Outras condições foram testadas, como a expressão a $30^{\circ} \mathrm{C}$ e a utilização da linhagem Rosetta, no entanto, não foi detectada a expressão da proteína recombinante, dessa forma, outra estratégia foi desenvolvida para expressão dessa proteína. 


\section{Anexo 7.0 - Gel de agarose da caracterização do vetor pVAX e da vacina pVAXhsp65.}

A produção e caracterização dessas construções vacinais foram realizadas da mesma forma que as outras vacinas, exceto pela clivagem realizada com a enzima BamHI (Invitrogen). L-marcador de $1 \mathrm{~Kb}, 1-\mathrm{pVAX}$ não digerido, 2-pVAX clivado com a enzima BamHI, 3-pVAXhsp65 não digerido e 4-pVAXhsp65 clivado com a enzima BamHI. Ambos os plasmídios apenas linearizam com a clivagem, pelo tamanho podemos caracterizar o pVAX de 3000pb e o pVAXhsp65 de 6000pb (3000pb do vetor + 3000pb do inserto hsp65).

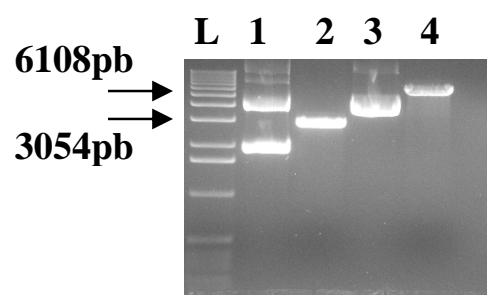

\section{Anexo 8.0 - Caracterização da vacina pVAXhsp65 por western blot.}

Western blot utilizando o anticorpo anti-Vac1 (específico para epitopos da proteína Hsp65) para confirmar a expressão da proteína Hsp65 codificada pela vacina pVAXhsp65. Lmarcador, 1-células HEK transfectadas com pVAXhsp65, 2-células HEK transfectadas com pVAX. O western blot revelou a banda da proteína Hsp65 $(56,89 \mathrm{kDa})$ no sedimento e sobrenadante celulares.

\section{L $\quad 1 \quad 2$}

$55 \mathrm{kDa}$ 


\title{
Anexo 9.0 - Manuscrito para publicação
}

\section{D glicoprotein from herpes simplex vírus-1 enhances secondary adaptive immune responses to glioblastoma tumoral antigens in DNA vaccine strategy}

Wendy Martin Rios, Jeanne Blanco de Molfetta, Izaíra Tincani Brandão, Ana Paula Masson, Rosiane Peripato, Idalete da Silva, Rodrigo Ferracine Rodrigues, Rogério Silva Rosada, Patrícia Rodrigues Marques de Souza and Celio Lopes Silva.

The Center for Tuberculosis Research, Department of Biochemistry and Immunology, School of Medicine of Ribeirão Preto - University of São Paulo, Brazil.

E-mail: wendy@usp.br

\begin{abstract}
Glioblastoma multiforme (GBM) is a recurrent and fatal cancer. EGFRvIII, MAGE-3 and GLEA-2 are antigens found in this highly heterogeneous tumor and absent in normal tissue. New therapies are required because conventional therapy is not able to prevent recurrence. Vaccination, as alternative immunotherapy, can be a good choice due to induction of longlasting and specific immune response. However, an efficient vaccine against tumors requires induction of strong cellular response. Thus, it is necessary to combine tumor antigens to adjuvant molecules. In this study, we construct DNA vaccines encoding GBM tumor antigens fused glycoprotein $\mathrm{D}(\mathrm{gD})$ from HSV-1 and evaluable their immunogenicity in C57BL/6 mice. The proteins were correctly expressed by DNA vaccines. We compared the immune response induced by only tumor antigen and tumor antigen-gD combination. The vaccines that combine tumor antigen-gD induced stronger cellular immune response with IFN- $\gamma$ and IL-10 production. DNA vaccination including tumor antigen and gD induced Th1 response. We concluded that this strategy could be an effective approach to GBM immunotherapy together with conventional therapy.
\end{abstract}

\section{Introduction}

Glioblastoma multiforme (GBM) (WHO grade IV astrocytoma) is the most common and malignant primary brain cancer in adults (Kleihues, Louis et al., 2002). Despite multimodal treatment with maximal surgical resection followed by temozolomide and radiation (Stupp, Mason et al., 2005; Stupp, Hegi et al., 2009) the prognosis for patients with GBM remains poor with a median survival of less than 15 months. One great challenge in advancing GBM therapy is the complexity of the GBM microenvironment (Charles, Holland et al., 2011). The characteristic features of this disease include uncontrolled cellular proliferation, diffuse infiltration, tendency for necrosis, significant angiogenesis, resistance to apoptosis and tumor heterogeneity (Furnari, Fenton et al., 2007). Furthermore, profound immunosuppression is present in patients with GBM (Kesari, 2011) and a recent study reported by Wei and colleagues (Wei, Barr et al., 2010) showed that cancer cells may contribute in many of the immunosuppressive features of GBM. Effective therapies, therefore, 
must not only be directly cytotoxic to a molecularly diverse population of tumor cells (Phillips, Kharbanda et al., 2006), but must also overcome the protumorigenic properties of the GBM microenvironment.

Thus, researches have actively focused on testing new therapeutic approaches, including immunotherapy. Immunotherapy is a particularly attractive approach to cancer treatment as it affords the advantages of cellular specificity and the potential for generating long-term immune surveillance against cancer cells (Jackson, Ruzevick et al., 2011). Furthermore, the change of the concept that the central nervous system (CNS) is immunologically privileged (Pachter, De Vries et al., 2003) has generated enthusiasm for a potential role for immunotherapy in GBM. The first and main line of active defense for the brain is constituted by specialized and resident cells, called microglia. (Vauleon, Avril et al., 2010). These cells migrate toward inflammatory zones and, after activation, acquire phagocytic properties and synthesize several types of cytokines and chemokines enabling the recruitment of other immune cells (Tambuyzer, Ponsaerts et al., 2009). Also, macrophages and dendritic cells (DCs) can act as powerful antigen-presenting cells (APCs) in the CNS (Serot, Foliguet et al., 1997; Hussain e Heimberger, 2005). Some studies showed that antigens originating within the CNS are drained in the cerebrospinal fluid to nasal and cervical lymph nodes where adaptive immune reactions are initiated (Weller, Engelhardt et al., 1996; Goldmann, Kwidzinski et al., 2006). Moreover, subpopulations of activated $\mathrm{T}$ cells expressing particular phenotype, with overexpression of $\alpha 4 / \beta 7$ integrins, exhibit tropism for the brain and cross the blood-brain barrier (BBB) (Calzascia, Masson et al., 2005). Taken together, these findings represent the evolution of the knowledge about the interactions between the CNS and the immune system and strengthen the idea that immunotherapy can be a great weapon in the GBM treatment.

Immunotherapy provides the advantage of long-term specific immune response that can prevent GBM recurrence. But, the selection of good antigens constitutes a big challenge yet. Nonetheless, many antigens associated with GBM have been described. EGFRvIII, the most common and well-characterized variant of the type I epidermal growth factor receptor (EGFR), was first identified in primary human GBM. This variant form is constitutively active form and its expression confers tumorigenic properties to the cell (Nishikawa, Ji et al., 1994; Batra, Castelino-Prabhu et al., 1995). Clinical trials has been performed with a 14-mer derived-peptide EGFRvIII, the PEPvIII (Humphrey, Wong et al., 1990), conjugated to KLH (keyhole limpet hemocyanin) pulsed in DCs or not (Heimberger, Hussain et al., 2006; Sampson, Archer et al., 2008; Schmittling, Archer et al., 2008; Sampson, Archer et al., 2009). 
Results showed that this strategy can induce antigen-specific cellular and humoral immune responses and increase in patient's median survival (Schmittling, Archer et al., 2008; Sampson, Archer et al., 2009).

The MAGE-3 (melanoma antigen gene), another antigen, is member of the MAGE family of "cancer-germline" genes (Chomez, De Backer et al., 2001), which are expressed in many tumors (Gaugler, Van Den Eynde et al., 1994; Weynants, Lethé et al., 1994). Chi et al. (1997) showed MAGE-3 mRNA was present in 33\% of GBMs analyzed and absent in normal tissue (Chi, Merchant et al., 1997). Other researchers have identified MAGE-3 peptides recognized by $\mathrm{CD}^{+} \mathrm{T}$ cells of individuals with or without cancer (Chaux, Vantomme et al., 1999; Zhang, Chaux et al., 2003) indicating that this antigen may be target of an immune response. GLEA-2 (glioma-expressed antigen 2) was identified in a GBM cDNA library. This is also an interesting GBM antigen because it can induce immune response in more than $43 \%$ of the GBM patients (Fischer, Struss et al., 2001). Furthermore, patients undergoing radiotherapy may increase the frequency of the autologous antibody against GLEA-2 antigen (Heisel, Ketter et al., 2008).

Although all these characteristics indicate that these antigens could be good targets for GBM immunotherapy, the immunogenicity of protein antigens is usually limited. For these reasons, they must be combined with other substances in order to achieve the desired response. In this sense, the genetic fusion of D glycoprotein $(\mathrm{gD})$ from herpes simplex virus-1 (HSV-1) to tumor antigens in DNA vaccines have been proposed as the effective adjuvant (Lasaro, Diniz et al., 2005; Lasaro, Tatsis et al., 2008; Diniz, Lasaro et al., 2010). HSV-1 gD, a structural component of the virus envelope that is essential for virus entry into hosts cells (Highlander, Sutherland et al., 1987), was the first HVEM (herpesvirus entry mediator) ligand described (Montgomery, Warner et al., 1996). Interaction between HVEM and gD actives type I IFNs and IL-12 production by DCs (Medici, Sciortino et al., 2003; Pollara, Jones et al., 2004). Furthermore, this interaction can interrupt the HVEM-BTLA (B and T-lymphocyte attenuator) inhibitory pathway (Lasaro, Tatsis et al., 2008) responsible for the inhibition of the lymphocytes proliferation (Gavrieli, Watanabe et al., 2003; Gonzalez, Loyet et al., 2005; Sedy, Gavrieli et al., 2005).

Thus, supported by these studies and using the same rational, here we show that DNA vaccines expressing GBM tumor antigens as fusion proteins within HSV-1 gD induced markedly cellular immune response. The DNA vaccines induced specific memory $\mathrm{T}$ cells that after secondary stimulus produced IFN- $\gamma$ and IL-10. These cytokines are important to tumor destruction and inflammatory response control, respectively. Thus, the DNA vaccines strategy 
represents a promising alternative in the GBM immunotherapy combined conventional therapy.

\section{Materials and methods}

\subsection{Construction of DNA vaccines}

The coding sequence of EGFRvIII, MAGE-3 (MAGE) and GLEA-2 (GLEA) protein (accession numbers NM_005228, NM_005362.3, AF258787, respectively) without their stop codons were fused to the gD nucleotide sequence in silico. The fusion was made between two unique sites (PvuII and ApaI) presents into the $\mathrm{gD}$ (Cohen, Wilcox et al., 1988). This fusion results in the withdrawal of the gD central portion with 214 amino acids. As EGFRvIII sequence was very large, only the initial 900 base pairs (bp) were utilized in the assembly. The gDEGFRvIII, gDMAGE, gDGLEA fragments were constructed by Epoch Biolabs (Missouri, TX) and cloned into the pBluescript II SK vector (pBSK). The pBSKgDEGFRvIII, pBSKgDMAGE and pBSKgDGLEA plasmids were cleaved with NheI and XbaI restriction enzymes, whose sites were respectively included in the start and end of the all fragments. The cleaved gDEGFRvIII, gDMAGE, gDGLEA fragments were cloned into the pVAX1 (pVAX) (Invitrogen) vector. As pVAX is a transcription plasmid, all the fragments had already the Kozak sequence (ACCATG) (Kozak, 1990). Cloning were confirmed by restriction enzyme digestion, polymerase chain reaction (PCR) and DNA sequencing.

The pBSKgDEGFRvIII, pBSKgDMAGE and pBSKgDGLEA plasmids were also used as template to EGFRvIII, MAGE and GLEA amplification. Reactions were carried out using the following primers:

Forward

EGFRpVAX_S: 5'TACTAGCTAGCACCATGCTGGAGGAAAAGAAAGGTAATTATGTGGTGACAGATCACG 3' MAGEPVAX_S: 5'TACTAGCTAGCACCATGCCTCTTGAGCAGAG 3'

GLEApVAX_S: 5'TACTAGCTAGCACCATGACAAAGCATCCACC 3'

Reverse

EGFRpVAX_R: 5' ATTCTAGATCAGCAGTGGGGGCCGTC 3'

MAGEpVAX_R: 5'ATTCTAGATCACTCTTCCCССТCTC 3'

GLEApVAX_R: 5'ATTCTAGATCACTTCTTTGGCTTCAC 3' 
In forward primers, bold fragment represents Kozak sequence and NheI restriction site is underlined; in reverse primers, bold fragment represents stop codon and XbaI restriction site is underlined. The conditions for PCR were as follows: a 100 $\mu \mathrm{L}$ PCR-mixture comprised of 100-150ng of template; $0,2 \mathrm{mM}$ of each deoxynucleoside triphosphates (dNTPs, Invitrogen); 0,1mM of each primer and 5 units of High fidelity PCR enzyme mix (Fermentas, Thermo Scientific). The following amplification program was used: $94^{\circ} \mathrm{C}, 5 \mathrm{~min} ; 24$ cycles of $94^{\circ} \mathrm{C}, 1 \mathrm{~min} ; 48^{\circ} \mathrm{C}, 1 \mathrm{~min} ; 72^{\circ} \mathrm{C}, 1 \mathrm{~min}$ (GLEA, $2 \mathrm{~min}$ ) and final step of $72^{\circ} \mathrm{C}, 10 \mathrm{~min}$. The amplified EGFRvIII, MAGE and GLEA were cleaved with NheI and XbaI restriction enzymes and cloned into the pVAX without gD. Cloning were confirmed by restriction enzyme digestion, PCR and DNA sequencing.

Large-scale purification of DNA vaccines, pVAXgDEGFRvIII, pVAXgDMAGE, pVAXgDGLEA, pVAXEGFRvIII, pVAXMAGE and pVAXGLEA was conducted by ionexchange chromatography with an Endofree plasmid Giga kit (QIAGEN) according to the manufacturer's instructions. DNA vaccines were quantified by spectrophotometry (Nanodrop $1000^{\mathrm{TM}}$, Thermo Scientific) and analyzed for the endotoxin presence with QCL-100 LAL kit (Cambrex) according to the manufacturer's instructions.

\subsection{Construction of expression vectors}

The pBSKgDEGFRvIII, pBSKgDMAGE and pBSKgDGLEA plasmids were used as template to EGFRvIII, MAGE and GLEA amplification. Reactions were carried out using the following primers:

Forward

EGFRpET28a_S:5'TACTAGCTAGCATGCTGGAGGAAAAGAAAG 3'

MAGEpET28a_S: 5'TACTAGCTAGCATGCCTCTTGAGCAGAG 3'

GLEApET28a_S: 5'TACTAGCTAGCATGACAAAGCATCCACC 3'

Reverse

EGFRpET28a_R: 5'GATCTCGAGTCAGCAGTGGGGGCCGTC 3'

MAGEpET28a_R: 5'GATCTCGAGTCACTCTTCCCCCTCTCTC 3'

GLEAPET28a_R: 5'GATCTCGAGTCACTTCTTTGGCTTCAC 3'

In forward primers, underline fragment represents NheI restriction site; in reverse primers, bold fragment represents stop codon and XhoI restriction site is underlined. The conditions for PCR were as follows: a 100 $\mu \mathrm{L}$ PCR-mixture comprised of 100-150ng of 
template; $0,2 \mathrm{mM}$ of each dNTP; $0,1 \mathrm{mM}$ of each primer and 5 units of High fidelity PCR enzyme mix. The amplification program was the same as described above. The amplified EGFRvIII, MAGE and GLEA were cleaved with NheI and XhoI restriction enzymes and cloned into the pET28a vector (pET) (Novagen). Cloning were confirmed by restriction enzyme digestion, PCR and DNA sequencing.

\subsection{Expression and purification of the recombinant proteins}

The EGFRvIII, MAGE and GLEA fragments were cloned into the pET, which encodes the N-terminal 6XHis-tag. The E. coli BL21 and Rosetta strains were transformed with the pETEGFRvIII, pETMAGE, pETGLEA plasmids. For the production of the recombinant protein (EGFRvIII, MAGE or GLEA), the transformed bacteria were grown at $37^{\circ} \mathrm{C}$ in $\mathrm{LB}$ broth supplemented with $50 \mu \mathrm{g} / \mathrm{mL}$ kanamycin to an optical density of $0,5-0,6$ at $600 \mathrm{~nm}\left(\mathrm{OD}_{600}=0,5-0,6\right)$ and protein expression was induced with 0,5mM IPTG (Invitrogen) at $30^{\circ} \mathrm{C}$ for overnight (MAGE was induced with $0,5 \mathrm{mM}$ IPTG at $37^{\circ} \mathrm{C}$ for about 4 hours and GLEA was induced with $0,2 \mathrm{mM}$ IPTG at $37^{\circ} \mathrm{C}$ for about 4 hours). The cell pellets were collected, analyzed in SDS-PAGE 10\% (Laemmli, 1970) by Coomassie Blue staining (Pierce, Thermo Scientific) and used for protein purification.

Recombinant proteins were purified by affinity chromatography on Ni-NTA (GE Healthcare) resin using 6XHis-tag according to the manufacturer's protocol and analyzed in SDS-PAGE $10 \%$ by Coomassie Blue staining. The EGFRvIII and GLEA recombinant proteins were purified under denaturing conditions (8M urea) and MAGE, under native condition. The purified protein fractions were dialyzed against PBS, concentrated in GE Healthcare Vivaspin and quantified by the Bradford procedure (Pierce, Thermo Scientific) (Bradford, 1976). As EGFRvIII and GLEA proteins precipitated after dialysis, they were centrifuged and supernatants used in the assays.

\subsection{Production of antibodies against recombinant proteins}

Female BALB/c mice at 6-8 weeks of age from Animal Breeding Center of the School of Medicine of Ribeirão Preto-University of São Paulo were used in this protocol. All procedures involving handling and killing of animals were performed according to approved protocols in accordance with recommendations for the proper use and care of laboratory animals at the School of Medicine of Ribeirão Preto-University of São Paulo (number 082/2009). Three mice were immunized subcutaneously at the back with 50 $\mu$ g of recombinant 
protein (MAGE or GLEA) (or protein precipitated, EGRFvIII) emulsified with Freund's incomplete adjuvant (Gibco) at the ratio of 1:1 (oil:aqueous phase) given 3 times in 12 days intervals. Mice were sacrificed and bled by cardiac puncture 20 days after last immunization. Sera were obtained from the whole blood samples, pooled and used in the DNA vaccines characterization.

\subsection{DNA vaccines characterization}

HEK293 cells were cultivated in 24-well culture plates (Corning) at concentration of 2 x $10^{5}$ cells per well in $1 \mathrm{~mL}$ of DMEN medium (Gibco) supplemented with 10\% FBS (Gibco) and $1 \%$ penicillin/streptomycin (Gibco) and incubated for 24 hours at $37^{\circ} \mathrm{C}$ in an atmosphere of $5 \% \mathrm{CO}_{2}$. Next, cells were transfected with 500ng of DNA vaccine and $\mathrm{CaCl}_{2}$ according to the protocol described by Kingston et al. and incubated again (Kingston, Chen et al., 2001). Negative control was performed with pVAX vector. After 24 hours, transfected cells were harvested, washed with PBS, lysed with RIPA buffer and evaluated by western blot.

Cell samples were analysed by SDS-PAGE 10\%, transferred onto nitrocellulose membrane (Life Technologies). The membrane was blocked with PBS supplemented with $0,05 \%$ tween (PBS-T) and 2\% bovin serum albumin (BSA, INLAB) for 2 hours at room temperature and then reacted with anti-gD (1:20000, kindly provided by Luis Carlos de Souza Ferreira) or sera (item 2.4) containing anti-recombinant protein antibody (1:1000) (antiEGFRvIII, MAGE or GLEA) overnight at $4^{\circ} \mathrm{C}$. After three washes with PBS-T, the membrane was incubated with anti-mouse IgG-HRP (1:5000, Molecular Probes) for 1 hour at room temperature. The immunoreactive protein bands were visualized using peroxidase substrate, 3, 3'-diaminobenzidine (DAB, Vector Peroxydase Substrate Kit).

\subsection{Mice immunization}

Groups of 8 to 12 female C57BL/6 mice at 6-8 weeks of age from the same Animal Breeding Center received the DNA vaccines (pVAXgDEGFRvIII, pVAXgDMAGE, pVAXgDGLEA, pVAXEGFRvIII, pVAXMAGE and pVAXGLEA) given 3 times by intramuscular route in 12 days intervals. The control group was immunized with pVAX vector. Each dose of $100 \mu \mathrm{g}$ of DNA was divided in two $50 \mu \mathrm{L}$ aliquot and applied into the tibialis anterior muscle of each hind limb.

\subsection{Assessment of humoral and cellular immune responses}

Twenty days after last immunization, mice were bled by retro-orbital plexus and sera were obtained from the whole blood samples. Then, mice were sacrificed and the spleens 
were removed. Cell suspension was obtained from the spleen macerated. Cells were treated for 2 min with $2 \mathrm{~mL}$ ACK buffer to lyse red blood cells, washed with PBS and suspended in RPMI medium 1640 (Sigma) supplemented with 10\% FBS, 1\% penicillin/streptomycin, $30 \mu \mathrm{g} / \mathrm{mL}$ polymyxin B (P-4932, Sigma), $10 \mu \mathrm{g} / \mathrm{mL}$ Gentamicin (Gibco) and $50 \mu \mathrm{M} 2-$ mercaptoethanol (Sigma). Then, $5 \times 10^{6}$ cells per well were cultured in $1 \mathrm{~mL}$ of medium in the presence of $20 \mu \mathrm{g} / \mathrm{mL}$ of EGFRvIII, MAGE or GLEA recombinant proteins for 48 hours at $37^{\circ} \mathrm{C}$ in an atmosphere of $5 \% \mathrm{CO}_{2}$. Positive and negative controls were performed with $40 \mu \mathrm{g} / \mathrm{ml}$ of concanavalin A (ConA) (Sigma) and only medium, respectively.

Sera from vaccinated mice were tested for the presence of IgG1 and IgG2a antibodies against recombinant protein by ELISA. Briefly, 96-microwell plates (Maxisorb, Nunc) were coated with $100 \mu \mathrm{L}$ of coating buffer $\left(\mathrm{Na}_{2} \mathrm{CO}_{3}\right.$ at $15 \mathrm{mM}$ and $\mathrm{NaHCO}_{3}$ at $35 \mathrm{mM}$, pH 9,6) containing $5 \mu \mathrm{g} / \mathrm{mL}$ of recombinant protein and incubated overnight at $4{ }^{\circ} \mathrm{C}$. Next, after washing with PBS-T, plates were blocked with $200 \mu \mathrm{L}$ of PBS-T containing 10\% FBS (block solution) for 1 hour at $37^{\circ} \mathrm{C}$. After washing, $100 \mu \mathrm{L}$ of serum samples diluted (1:10) in block solution were added to the plates, incubated for 2 hours at $37^{\circ} \mathrm{C}$ and washed. Next, $100 \mu \mathrm{L}$ of biotinylated anti-IgG1 (A85-1) or anti-IgG2a (R19-15) (BD Bioscience) diluted 1:1000 in block solution were added and the plates were incubated for 1 hour at $37^{\circ} \mathrm{C}$. Then, the plates were washed and incubated with $100 \mu \mathrm{L}$ of 1:1000 dilution of streptavidin-biotin-horseradish peroxidase (Vector) for $30 \mathrm{~min}$ at room temperature. Detection was done with $100 \mu \mathrm{L}$ of TMB substrate (BD Bioscience). After $30 \mathrm{~min}$ at room temperature, the enzyme reaction was stopped by $50 \mu \mathrm{L}$ of $16 \%$ sulfuric acid and the absorbance was measured at 490 and $570 \mathrm{~nm}$.

Production of cytokines was also evaluated in supernatants of cell cultures by ELISA. Briefly, 96-microwell plates were coated with $100 \mu \mathrm{L}$ of coating buffer $\left(\mathrm{Na}_{2} \mathrm{HPO}_{4}\right.$ at $0,1 \mathrm{M}$, $\mathrm{pH} 9,0)$ containing capture antibody [IFN- $\gamma(\mathrm{R} 4-6 \mathrm{~A} 2)$ and IL-5 (TRFK5) at $1 \mu \mathrm{g} / \mathrm{mL}$; IL-10 (JES5-2A5) at $2 \mu \mathrm{g} / \mathrm{mL}$ (BD Biosciences) and incubated overnight at $4^{\circ} \mathrm{C}$. After washing with PBS-T, plates were blocked with $200 \mu \mathrm{L}$ of block solution for 1-2 hours at room temperature. After washing, $100 \mu \mathrm{L}$ of supernatants samples were added to plates, incubated overnight at $4^{\circ} \mathrm{C}$ and washed. Next, $100 \mu \mathrm{L}$ of biotin-labeled secondary antibody [IFN- $\gamma$ (XGM1.2) and IL-5 (TRFK4) at 0,5 $\mu \mathrm{g} / \mathrm{mL}$; IL-10 (SXC-1) at $1 \mu \mathrm{g} / \mathrm{mL}$ (BD Biosciences) diluted in block solution were added and the plates were incubated for 1 hour at room temperature. Then, plates were washed and incubated with $100 \mu \mathrm{L}$ dilution of streptavidinbiotin-horseradish peroxidase (IFN- $\gamma, 1: 500$; IL-10 and IL-5, 1:1000) for $30 \mathrm{~min}$ at room temperature. Detection was done with $100 \mu \mathrm{L}$ of TMB substrate. After $30 \mathrm{~min}$ at room 
temperature, the enzyme reaction was stopped by $50 \mu \mathrm{L} 16 \%$ sulfuric acid and the absorbance was measured at 490 and $570 \mathrm{~nm}$.

\subsection{Statistical analysis}

Comparisons were performed by ANOVA with Tukey test a posteriori using GraphPad Prism 4.02 version software (GraphPad Software, San Diego, CA, USA). Statistical significance was attributed to $\mathrm{p}$ values $<0.05$.

\section{Results}

\subsection{Construction of DNA vaccines}

Restriction analyses (Fig. 1) and sequencing (data not shown) confirmed that DNA vaccines were correctly constructed. As showed in figure 1, pVAXgDEGFRvIII, pVAXgDMAGE, pVAXgDGLEA, pVAXEGFRvIII, pVAXMAGE and pVAXGLEA constructions presented sizes matching the vector associated to the insert: 4357bp, 4399bp, 5086bp, 3820bp, 3859bp and 4546bp, respectively.

\subsection{Expression and purification of the recombinant proteins}

The EGFRvIII, MAGE and GLEA fragments were inserted into E. coli expression vector, pET, and the recombinant proteins were expressed and analyzed in SDS-PAGE 10\% (Fig 2A). The recombinant EGFRvIII, MAGE and GLEA proteins migrated around 36, 43 and $72 \mathrm{kDa}$ in SDS-PAGE. The MAGE and GLEA proteins showed larger molecular mass than expected (37 and 64kDa, respectively). The recombinant EGFRvIII, MAGE and GLEA proteins were purified by affinity chromatography and analyzed in SDS-PAGE 10\% (Fig. 2B). The recombinant proteins were used to vaccinate mice, to antibody production and to immunogenicity assays.

\subsection{DNA vaccines characterization}

To verify whether DNA vaccines could express the expected proteins, HEK293 cells were transiently transfected with the constructions. One day later, extract cell was obtained and the proteins were detected by western blot with the appropriate antibodies (Fig. 3). Extract from cells transfected with the empty pVAX vector failed to bind gD, EGFRvIII, MAGE and GLEA-specific antibodies. The anti-gD antibody stained extracts from cells transfected with vaccines expressing the gDEGFRvIII, gDMAGE and gDGLEA fusion proteins (Fig. 3A). Cells transfected with pVAXgDEGFRvIII and pVAXEGFRvIII were 
stained by anti-EGFRvIII antibody specific to the corresponding tumor antigen (Fig. 3B). Extracts from cells transfected with the pVAXgDMAGE and pVAXMAGE were stained by anti-MAGE antibody (Fig. 3C) and extracts from cells transfected with the pVAXgDGLEA and pVAXGLEA were stained by anti-GLEA antibody (Fig. 3D). Collectively, these results demonstrate that the proteins encoded by the DNA vaccines were correctly expressed by the cellular machinery.

\subsection{Assessment of humoral and cellular immune responses}

The presence of specific IgG2a antibodies against EGFRvIII, MAGE and GLEA was determined by ELISA 20 days after the last immunization. The production of specific IgG2a antibodies was inconsistent for pVAXgDEGFRvIII (Fig. 4A) and pVAXgDMAGE (Fig. 4B) groups. Only the pVAXgDGLEA group produced high level of specific IgG2a antibodies (Fig. 4C). Specific IgG1 antibodies were not detected in any group.

To characterize antigen-specific cell-mediated response, spleen cells were obtained 20 days after the last immunization and stimulated ex vivo with the recombinant proteins or ConA as positive control. The negative control was performed with not stimulated cells. The production of the cytokines by stimulated cells was quantified by ELISA in the culture supernatants. IFN- $\gamma$ (Fig. 5) and IL-10 (Fig. 6) production were significantly higher in groups pVAXgDEGFRvIII (Fig 5A and 6A), pVAXgDMAGE (Fig 5B and 6B) and pVAXgDGLEA (Fig 5C and 6C) as compared with the others groups. IL-5 production was not detect for any group.

\section{Discussion}

Despite multimodal treatment with maximal surgical resection followed by temozolomide and radiation, GBM remains a recurrent and fatal cancer (Stupp, Mason et al., 2005; Stupp, Hegi et al., 2009). In this sense, immunotherapy combined to the conventional therapy can be a good alternative to treat this disease, providing the advantage of induce a long-term specific immune response that could prevent the GBM recurrence. An effective vaccine for cancer should elicit not only the humoral response, but also the cellular response. However, it has been reported that vaccines containing only antigens can elicit inefficient cellular response. Thus, antigens need to be combined with an efficient adjuvant or delivery system which can be used in humans. In this context, we developed DNA vaccines codifying GBM antigens fused a gD from HSV-1.

Previous observations have indicated that $\mathrm{gD}$ can enhance the immunogenicity of DNA vaccines when the antigens are fused to gD (Lásaro, Alves et al., 2003; Lasaro, Diniz et 
al., 2005; Lasaro, Tatsis et al., 2008; Diniz, Lasaro et al., 2010). Antigen and secondary signals are required for activation of adaptive immune response. Secondary signals are delivered by co-stimulatory molecules and the $\mathrm{gD}$ can perform this function when interacts with HVEM receptor and actives type I IFNs and IL-12 production by DCs (Medici, Sciortino et al., 2003; Pollara, Jones et al., 2004). Lasaro et al. (2008) also suggested that the secondary signal can come of the blockade of HVEM inhibitory pathway by targeting the BTLA binding site with $\mathrm{gD}$.

Ours results indicated that DNA vaccines were constructed correctly and analysis of transfected HEK293 confirmed that the proteins were expressed by DNA vaccines. We also expressed the EGFRvIII, MAGE and GLEA proteins in E. coli and purified by affinity chromatography to use them in immunogenicity assays. The MAGE and GLEA recombinant proteins showed larger molecular mass than expected, what had already been demonstrated by Kocher et al. (1995). The authors showed that the MAGE protein, recombinant or native in melanoma cells, presented larger than expected. As the MAGE protein does not show posttranslational modifications, the authors suggested that the size can be changed due to amino acid composition. The prevalence of amino acid rich in acidic residues can alter the electrophoresis pattern of the protein. The amino acid composition may also explain the increased size of the GLEA protein, which also does not undergo post-translational modifications when expressed in E. coli.

DNA vaccines are an attractive tool for antigen-specific immunotherapy. In this study, DNA vaccines codifying only tumor antigens presented low immunogenicity. Mice immunized with pVAXEGFRvIII, pVAXMAGE and pVAXGLEA did not presented relevant humoral or cellular immune responses. Many studies have shown that DNA vaccines can stimulate both humoral and cellular immune responses (Conry, Curiel et al., 2002; Liu, 2003; Tagawa, Lee et al., 2003). However, most of the protein produced by DNA immunization is not capable by itself of priming an immune response and it is necessary enhance the potency of genetic vaccination (Mincheff, Tchakarov et al., 2000; Pavlenko, Roos et al., 2004; Low, Mander et al., 2009). Satisfying this condition, the pVAXgDEGFRvIII, pVAXgDMAGE and pVAXgDGLEA vaccines enconding the tumor antigens and adjuvant $\mathrm{gD}$ protein were able to induce the cellular immune response, despite small humoral response.

Analysis of the cellular immune response showed significant differences between groups. To evaluate the production of cytokines, cells were stimulated with recombinant proteins. IFN- $\gamma$ production in the supernatant of spleen cells from mice vaccinated with 
pVAXgDEGFRvIII, pVAXgDMAGE and pVAXgDGLEA were significantly higher than that one verified to the others groups. It indicates that tumor antigens associated to $\mathrm{gD}$ drives $\mathrm{T}$ cell response towards a Th1-type profile of immune response. $\mathrm{gD}$ immunomodulatory effects were also demonstrated in other studies with DNA vaccines codifying E5, E6 and E7 tumor antigens fused to $\mathrm{gD}$. Mice immunized with these DNA vaccines presented markedly increased the specific $\mathrm{CD}^{+} \mathrm{T}$ cells (Lasaro, Diniz et al., 2005; Lasaro, Tatsis et al., 2008; Diniz, Lasaro et al., 2010). The immune effects of these vaccines might be dependent on the structural integrity of the gD-HVEM receptor-binding domains. For all vaccination strategies, cell-mediated immune response and IFN- $\gamma$ production have been considered to be essential for the generation of a long-lasting specific immune response against tumor cells.

In addition, spleen cells from mice vaccinated with pVAXgDEGFRvIII, pVAXgDMAGE and pVAXgDGLEA stimulated with recombinant proteins produced significantly higher levels of IL-10 than mice vaccinated with the other constructions. The role of IL-10 in tumor immunology is contradictory. IL-10 was initially classified as a Th2derived cytokine (Fiorentino, Bond et al., 1989), but it is produced by a range of $\mathrm{CD}^{+} \mathrm{T}$ cell subsets, as well as macrophages, DCs, B cells, eosinophils and mast cells (Moore, De Waal Malefyt et al., 2001). In general, IL-10 is considered to be an immune suppressive molecule (Akdis e Blaser, 2001; Moore, De Waal Malefyt et al., 2001). In glioma cancer, IL-10 is characterized as one of the immune suppressive molecule produced by the cancer cells to escape immune response (Nitta, Hishii et al., 1994). However, several other reports documented the ability of IL-10 to augment the immune response against the tumor (Berman, Suzuki et al., 1996; Zheng, Ojcius et al., 1996; Groux, Cottrez et al., 1999), including glioma models (Book, Fielding et al., 1998). IL-10 producing $\mathrm{CD}^{+}{ }^{+} \mathrm{T}$ cells have been shown to present anti-glioma functions in vivo (Segal, Glass et al., 2002). Moreover, T cells primed against GBM tumor cells by autologous DC loaded with GBM tumor cell lysate acquired a Th1 profile and the capacity to produce IL-10 (De Vleeschouwer, Spencer Lopes et al., 2007). This production was correlated with anti-tumor T cell activity (De Vleeschouwer, Spencer Lopes et al., 2007). Furthermore, IL-10 enhances the function of NK cells and cytotoxic $\mathrm{CD}^{+} \mathrm{T}$ cells (Moore, De Waal Malefyt et al., 2001).

On the other hand, a recent concept suggests that Th1 cells themselves are source of IL-10 that controls immune responses - i.e., Th1 effector responses are regulated through a negative feedback loop via the co-induction of IL-10 in addition to IFN- $\gamma$ in the same cells (O'garra e Vieira, 2007; Trinchieri, 2007). Cells producing IL-10 can develop from IFN- $\gamma^{+}$ Th1 cells that have received appropriate signals to switch into regulatory IL-10-secreting 
cells, representing the 'endpoint' of a successful effector response - a cell-intrinsic component of the life cycle of a Th1 cell (Cope, Le Friec et al., 2011). Such a switch would have the advantage of producing $\mathrm{T}$ cells that express an effector cytokine, while, at the same time, induce a regulatory cytokine, following recognition of the same antigen (Cope, Le Friec et al., 2011). The two roles of IL-10, favoring or controlling the immune response, are important to the tumor destruction as well as to the control of the immune response that should not cause damage to normal tissue.

In summary, this study indicates the potential value of DNA vaccination using codelivery of tumor antigens plus gD. DNA vaccination using tumor antigens and $\mathrm{gD}$ revealed specific IFN- $\gamma$ and IL-10 responses. gD was able to stimulate cell-mediated immunity which is considered essential to tumor combating. Finally, this study provides an additional immunotherapy to be used together conventional therapy in GBM treatment.

\section{References}

AKDIS, C. A.; BLASER, K. Mechanisms of interleukin-10-mediated immune suppression. Immunology, v. 103, n. 2, p. 131-6, Jun 2001. ISSN 0019-2805. Disponível em: < http://www.ncbi.nlm.nih.gov/pubmed/11412299 >.

BATRA, S. K. et al. Epidermal growth factor ligand-independent, unregulated, cell-transforming potential of a naturally occurring human mutant EGFRvIII gene. Cell Growth Differ, v. 6, n. 10, p. 1251-9, Oct 1995. ISSN 1044-9523. Disponível em: < http://www.ncbi.nlm.nih.gov/pubmed/8845302 $>$.

BERMAN, R. M. et al. Systemic administration of cellular IL-10 induces an effective, specific, and long-lived immune response against established tumors in mice. J Immunol, v. 157, n. 1, p. 231-8, Jul 1996. ISSN 0022-1767. Disponível em: 〈 http://www.ncbi.nlm.nih.gov/pubmed/8683120 〉.

BOOK, A. A. et al. IL-10 gene transfer to intracranial 9L glioma: tumor inhibition and cooperation with IL-2. J Neuroimmunol, v. 92, n. 1-2, p. 50-9, Dec 1998. ISSN 0165-5728. Disponível em: < http://www.ncbi.nlm.nih.gov/pubmed/9916879 >.

BRADFORD, M. M. A rapid and sensitive method for the quantitation of microgram quantities of protein utilizing the principle of protein-dye binding. Anal Biochem, v. 72, p. 248-54, May 1976. ISSN 0003-2697. Disponível em: < http://www.ncbi.nlm.nih.gov/pubmed/942051 >.

CALZASCIA, T. et al. Homing phenotypes of tumor-specific CD8 $\mathrm{T}$ cells are predetermined at the tumor site by crosspresenting APCs. Immunity, v. 22, n. 2, p. 175-84, Feb 2005. ISSN 1074-7613. Disponível em: < http://www.ncbi.nlm.nih.gov/pubmed/15723806 >. 
CHARLES, N. A. et al. The brain tumor microenvironment. Glia, v. 59, n. 8, p. 1169-80, Aug 2011. ISSN 1098-1136. Disponível em: < http://www.ncbi.nlm.nih.gov/pubmed/21446047 >.

CHAUX, P. et al. Identification of MAGE-3 epitopes presented by HLA-DR molecules to CD4(+) T lymphocytes. J Exp Med, v. 189, n. 5, p. 767-78, Mar 1999. ISSN 0022-1007. Disponível em: < http://www.ncbi.nlm.nih.gov/pubmed/10049940>.

CHI, D. D. et al. Molecular detection of tumor-associated antigens shared by human cutaneous melanomas and gliomas. Am J Pathol, v. 150, n. 6, p. 2143-52, Jun 1997. ISSN 0002-9440. Disponível em: < http://www.ncbi.nlm.nih.gov/pubmed/9176405 >.

CHOMEZ, P. et al. An overview of the MAGE gene family with the identification of all human members of the family. Cancer Res, v. 61, n. 14, p. 5544-51, Jul 2001. ISSN 0008-5472. Disponível em: 〈 http://www.ncbi.nlm.nih.gov/pubmed/11454705 >.

COHEN, G. H. et al. Expression of herpes simplex virus type 1 glycoprotein D deletion mutants in mammalian cells. J Virol, v. 62, n. 6, p. 1932-40, Jun 1988. ISSN 0022-538X. Disponível em: < http://www.ncbi.nlm.nih.gov/pubmed/2452897 >.

CONRY, R. M. et al. Safety and immunogenicity of a DNA vaccine encoding carcinoembryonic antigen and hepatitis B surface antigen in colorectal carcinoma patients. Clin Cancer Res, v. 8, n. 9, p. 2782-7, Sep 2002. ISSN 1078-0432. Disponível em: < http://www.ncbi.nlm.nih.gov/pubmed/12231517 >.

COPE, A. et al. The Th1 life cycle: molecular control of IFN- $\gamma$ to IL-10 switching. Trends Immunol, v. 32, n. 6, p. 278-86, Jun 2011. ISSN 1471-4981. Disponível em: < http://www.ncbi.nlm.nih.gov/pubmed/21531623 >.

DE VLEESCHOUWER, S. et al. Persistent IL-10 production is required for glioma growth suppressive activity by Th1-directed effector cells after stimulation with tumor lysate-loaded dendritic cells. J Neurooncol, v. 84, n. 2, p. 131-40, Sep 2007. ISSN 0167-594X. Disponível em: < http://www.ncbi.nlm.nih.gov/pubmed/17361330>.

DINIZ, M. O. et al. Immune responses and therapeutic antitumor effects of an experimental DNA vaccine encoding human papillomavirus type 16 oncoproteins genetically fused to herpesvirus glycoprotein D. Clin Vaccine Immunol, v. 17, n. 10, p. 1576-83, Oct 2010. ISSN 1556-679X. Disponível em: < http://www.ncbi.nlm.nih.gov/pubmed/20739505 >. 
FIORENTINO, D. F.; BOND, M. W.; MOSMANN, T. R. Two types of mouse T helper cell. IV. Th2 clones secrete a factor that inhibits cytokine production by Th1 clones. J Exp Med, v. 170, n. 6, p. 2081-95, Dec 1989. ISSN 0022-1007. Disponível em: < http://www.ncbi.nlm.nih.gov/pubmed/2531194 >.

FISCHER, U. et al. Glioma-expressed antigen 2 (GLEA2): a novel protein that can elicit immune responses in glioblastoma patients and some controls. Clin Exp Immunol, v. 126, n. 2, p. 206-13, Nov 2001. ISSN 0009-9104. Disponível em: < http://www.ncbi.nlm.nih.gov/pubmed/11703362 >.

FURNARI, F. B. et al. Malignant astrocytic glioma: genetics, biology, and paths to treatment. Genes Dev, v. 21, n. 21, p. 2683-710, Nov 2007. ISSN 0890-9369. Disponível em: < http://www.ncbi.nlm.nih.gov/pubmed/17974913 >.

GAUGLER, B. et al. Human gene MAGE-3 codes for an antigen recognized on a melanoma by autologous cytolytic T lymphocytes. J Exp Med, v. 179, n. 3, p. 921-30, Mar 1994. ISSN 0022-1007. Disponível em: < http://www.ncbi.nlm.nih.gov/pubmed/8113684 >.

GAVRIELI, M. et al. Characterization of phosphotyrosine binding motifs in the cytoplasmic domain of B and T lymphocyte attenuator required for association with protein tyrosine phosphatases SHP-1 and SHP-2. Biochem Biophys Res Commun, v. 312, n. 4, p. 1236-43, Dec 2003. ISSN 0006-291X. Disponível em: < http://www.ncbi.nlm.nih.gov/pubmed/14652006 >.

GOLDMANN, J. et al. T cells traffic from brain to cervical lymph nodes via the cribroid plate and the nasal mucosa. J Leukoc Biol, v. 80, n. 4, p. 797-801, Oct 2006. ISSN 0741-5400. Disponível em: < http://www.ncbi.nlm.nih.gov/pubmed/16885505 >.

GONZALEZ, L. C. et al. A coreceptor interaction between the CD28 and TNF receptor family members B and T lymphocyte attenuator and herpesvirus entry mediator. Proc Natl Acad Sci U S A, v. 102 , n. 4, p. 1116-21, Jan 2005. ISSN 0027-8424. Disponível em: < http://www.ncbi.nlm.nih.gov/pubmed/15647361 >.

GROUX, H. et al. A transgenic model to analyze the immunoregulatory role of IL-10 secreted by antigen-presenting cells. J Immunol, v. 162, n. 3, p. 1723-9, Feb 1999. ISSN 0022-1767. Disponível em: 〈http://www.ncbi.nlm.nih.gov/pubmed/9973435 >.

HEIMBERGER, A. et al. Tumor-specific peptide vaccination in newly-diagnosed patients with GBM. J Clin Oncol: Abstrat 2529 p. 2006. 
HEISEL, S. M. et al. Increased seroreactivity to glioma-expressed antigen 2 in brain tumor patients under radiation. PLoS One, v. 3, n. 5, p. e2164, 2008. ISSN 1932-6203. Disponível em: < http://www.ncbi.nlm.nih.gov/pubmed/18478111 >.

HIGHLANDER, S. L. et al. Neutralizing monoclonal antibodies specific for herpes simplex virus glycoprotein D inhibit virus penetration. J Virol, v. 61, n. 11, p. 3356-64, Nov 1987. ISSN 0022538X. Disponível em: 〈 http://www.ncbi.nlm.nih.gov/pubmed/2444713 >.

HUMPHREY, P. A. et al. Anti-synthetic peptide antibody reacting at the fusion junction of deletionmutant epidermal growth factor receptors in human glioblastoma. Proc Natl Acad Sci U S A, v. 87, n. 11, p. 4207-11, Jun 1990. ISSN 0027-8424. Disponível em: < http://www.ncbi.nlm.nih.gov/pubmed/1693434 >.

HUSSAIN, S. F.; HEIMBERGER, A. B. Immunotherapy for human glioma: innovative approaches and recent results. Expert Rev Anticancer Ther, v. 5, n. 5, p. 777-90, Oct 2005. ISSN 1744-8328. Disponível em: < http://www.ncbi.nlm.nih.gov/pubmed/16221048 >.

JACKSON, C. et al. Challenges in immunotherapy presented by the glioblastoma multiforme microenvironment. Clin Dev Immunol, v. 2011, p. 732413, 2011. ISSN 1740-2530. Disponível em: < http://www.ncbi.nlm.nih.gov/pubmed/22190972 >.

KESARI, S. Understanding glioblastoma tumor biology: the potential to improve current diagnosis and treatments. Semin Oncol, v. 38 Suppl 4, p. S2-10, Dec 2011. ISSN 1532-8708. Disponível em: < http://www.ncbi.nlm.nih.gov/pubmed/22078644 >.

KINGSTON, R. E.; CHEN, C. A.; OKAYAMA, H. Calcium phosphate transfection. Curr Protoc Immunol, v. Chapter 10, p. Unit 10.13, May 2001. ISSN 1934-368X. Disponível em: < http://www.ncbi.nlm.nih.gov/pubmed/18432676 >.

KLEIHUES, P. et al. The WHO classification of tumors of the nervous system. J Neuropathol Exp Neurol, v. 61, n. 3, p. 215-25; discussion 226-9, Mar 2002. ISSN 0022-3069. Disponível em: < http://www.ncbi.nlm.nih.gov/pubmed/11895036 >.

KOZAK, M. Downstream secondary structure facilitates recognition of initiator codons by eukaryotic ribosomes. Proc Natl Acad Sci U S A, v. 87, n. 21, p. 8301-5, Nov 1990. ISSN 0027-8424. Disponível em: < http://www.ncbi.nlm.nih.gov/pubmed/2236042 >.

LAEMMLI, U. K. Cleavage of structural proteins during the assembly of the head of bacteriophage T4. Nature, v. 227, n. 5259, p. 680-5, Aug 1970. ISSN 0028-0836. Disponível em: < http://www.ncbi.nlm.nih.gov/pubmed/5432063 >. 
LASARO, M. O. et al. Anti-tumor DNA vaccines based on the expression of human papillomavirus16 E6/E7 oncoproteins genetically fused with the glycoprotein D from herpes simplex virus-1. Microbes Infect, v. 7, n. 15, p. 1541-50, Dec 2005. ISSN 1286-4579. Disponível em: < http://www.ncbi.nlm.nih.gov/pubmed/16213178 >.

Targeting of antigen to the herpesvirus entry mediator augments primary adaptive immune responses. Nat Med, v. 14, n. 2, p. 205-12, Feb 2008. ISSN 1546-170X. Disponível em: < http://www.ncbi.nlm.nih.gov/pubmed/18193057 >.

LIU, M. A. DNA vaccines: a review. J Intern Med, v. 253, n. 4, p. 402-10, Apr 2003. ISSN 09546820. Disponível em: < http://www.ncbi.nlm.nih.gov/pubmed/12653868 >.

LOW, L. et al. DNA vaccination with electroporation induces increased antibody responses in patients with prostate cancer. Hum Gene Ther, v. 20, n. 11, p. 1269-78, Nov 2009. ISSN 1557-7422. Disponível em: < http://www.ncbi.nlm.nih.gov/pubmed/19619001 >.

LÁSARO, M. O. et al. Antibody-inducing properties of a prototype bivalent herpes simplex virus/enterotoxigenic Escherichia coli DNA vaccine. FEMS Immunol Med Microbiol, v. 35, n. 1, p. 25-31, Jan 2003. ISSN 0928-8244. Disponível em: < http://www.ncbi.nlm.nih.gov/pubmed/12589954 $>$.

MEDICI, M. A. et al. Protection by herpes simplex virus glycoprotein D against Fas-mediated apoptosis: role of nuclear factor kappaB. J Biol Chem, v. 278, n. 38, p. 36059-67, Sep 2003. ISSN 0021-9258. Disponível em: < http://www.ncbi.nlm.nih.gov/pubmed/12844494 >.

MINCHEFF, M. et al. Naked DNA and adenoviral immunizations for immunotherapy of prostate cancer: a phase I/II clinical trial. Eur Urol, v. 38, n. 2, p. 208-17, Aug 2000. ISSN 0302-2838. Disponível em: < http://www.ncbi.nlm.nih.gov/pubmed/10895014 >.

MONTGOMERY, R. I. et al. Herpes simplex virus-1 entry into cells mediated by a novel member of the TNF/NGF receptor family. Cell, v. 87, n. 3, p. 427-36, Nov 1996. ISSN 0092-8674. Disponível em: < http://www.ncbi.nlm.nih.gov/pubmed/8898196 >.

MOORE, K. W. et al. Interleukin-10 and the interleukin-10 receptor. Annu Rev Immunol, v. 19, p. 683-765, 2001. ISSN 0732-0582. Disponível em: < http://www.ncbi.nlm.nih.gov/pubmed/11244051 $>$.

NISHIKAWA, R. et al. A mutant epidermal growth factor receptor common in human glioma confers enhanced tumorigenicity. Proc Natl Acad Sci U S A, v. 91, n. 16, p. 7727-31, Aug 1994. ISSN 00278424. Disponível em: < http://www.ncbi.nlm.nih.gov/pubmed/8052651 >. 
NITTA, T. et al. Selective expression of interleukin-10 gene within glioblastoma multiforme. Brain Res, v. 649, n. 1-2, p. 122-8, Jun 1994. ISSN 0006-8993. Disponível em: < http://www.ncbi.nlm.nih.gov/pubmed/7953624 >.

O'GARRA, A.; VIEIRA, P. T(H)1 cells control themselves by producing interleukin-10. Nat Rev Immunol, v. 7, n. 6, p. 425-8, Jun 2007. ISSN 1474-1733. Disponível em: < http://www.ncbi.nlm.nih.gov/pubmed/17525751 >.

PACHTER, J. S.; DE VRIES, H. E.; FABRY, Z. The blood-brain barrier and its role in immune privilege in the central nervous system. J Neuropathol Exp Neurol, v. 62, n. 6, p. 593-604, Jun 2003. ISSN 0022-3069. Disponível em: < http://www.ncbi.nlm.nih.gov/pubmed/12834104 >.

PAVLENKO, M. et al. A phase I trial of DNA vaccination with a plasmid expressing prostatespecific antigen in patients with hormone-refractory prostate cancer. Br J Cancer, v. 91, n. 4, p. 68894, Aug 2004. ISSN 0007-0920. Disponível em: < http://www.ncbi.nlm.nih.gov/pubmed/15280930 >.

PHILLIPS, H. S. et al. Molecular subclasses of high-grade glioma predict prognosis, delineate a pattern of disease progression, and resemble stages in neurogenesis. Cancer Cell, v. 9, n. 3, p. 157-73, Mar 2006. ISSN 1535-6108. Disponível em: < http://www.ncbi.nlm.nih.gov/pubmed/16530701 >.

POLLARA, G. et al. Herpes simplex virus type-1-induced activation of myeloid dendritic cells: the roles of virus cell interaction and paracrine type I IFN secretion. J Immunol, v. 173, n. 6, p. 4108-19, Sep 2004. ISSN 0022-1767. Disponível em: < http://www.ncbi.nlm.nih.gov/pubmed/15356161 >.

SAMPSON, J. H. et al. Tumor-specific immunotherapy targeting the EGFRvIII mutation in patients with malignant glioma. Semin Immunol, v. 20, n. 5, p. 267-75, Oct 2008. ISSN 1044-5323. Disponível em: < http://www.ncbi.nlm.nih.gov/pubmed/18539480 >.

. An epidermal growth factor receptor variant III-targeted vaccine is safe and immunogenic in patients with glioblastoma multiforme. Mol Cancer Ther, v. 8, n. 10, p. 2773-9, Oct 2009. ISSN 1538-8514. Disponível em: < http://www.ncbi.nlm.nih.gov/pubmed/19825799 >.

SCHMITTLING, R. J. et al. Detection of humoral response in patients with glioblastoma receiving EGFRvIII-KLH vaccines. J Immunol Methods, v. 339, n. 1, p. 74-81, Nov 2008. ISSN 0022-1759. Disponível em: < http://www.ncbi.nlm.nih.gov/pubmed/18775433 >.

SEDY, J. R. et al. B and T lymphocyte attenuator regulates T cell activation through interaction with herpesvirus entry mediator. Nat Immunol, v. 6, n. 1, p. 90-8, Jan 2005. ISSN 1529-2908. Disponível em: 〈http://www.ncbi.nlm.nih.gov/pubmed/15568026 >. 
SEGAL, B. M.; GLASS, D. D.; SHEVACH, E. M. Cutting Edge: IL-10-producing CD4+ T cells mediate tumor rejection. J Immunol, v. 168, n. 1, p. 1-4, Jan 2002. ISSN 0022-1767. Disponível em: $\langle$ http://www.ncbi.nlm.nih.gov/pubmed/11751938 $>$.

SEROT, J. M. et al. Ultrastructural and immunohistological evidence for dendritic-like cells within human choroid plexus epithelium. Neuroreport, v. 8, n. 8, p. 1995-8, May 1997. ISSN 0959-4965. Disponível em: < http://www.ncbi.nlm.nih.gov/pubmed/9223091 >.

STUPP, R. et al. Effects of radiotherapy with concomitant and adjuvant temozolomide versus radiotherapy alone on survival in glioblastoma in a randomised phase III study: 5-year analysis of the EORTC-NCIC trial. Lancet Oncol, v. 10, n. 5, p. 459-66, May 2009. ISSN 1474-5488. Disponível em: 〈 http://www.ncbi.nlm.nih.gov/pubmed/19269895 >.

. Radiotherapy plus concomitant and adjuvant temozolomide for glioblastoma. N Engl J Med, v. 352, n. 10 , p. 987-96, Mar 2005. ISSN 1533-4406. Disponível em: < http://www.ncbi.nlm.nih.gov/pubmed/15758009 >.

TAGAWA, S. T. et al. Phase I study of intranodal delivery of a plasmid DNA vaccine for patients with Stage IV melanoma. Cancer, v. 98, n. 1, p. 144-54, Jul 2003. ISSN 0008-543X. Disponível em: < http://www.ncbi.nlm.nih.gov/pubmed/12833467 >.

TAMBUYZER, B. R.; PONSAERTS, P.; NOUWEN, E. J. Microglia: gatekeepers of central nervous system immunology. J Leukoc Biol, v. 85, n. 3, p. 352-70, Mar 2009. ISSN 1938-3673. Disponível em: < http://www.ncbi.nlm.nih.gov/pubmed/19028958 >.

TRINCHIERI, G. Interleukin-10 production by effector T cells: Th1 cells show self control. J Exp Med, v. 204, n. 2, p. 239-43, Feb 2007. ISSN 0022-1007. Disponível em: < http://www.ncbi.nlm.nih.gov/pubmed/17296790 >.

VAULEON, E. et al. Overview of cellular immunotherapy for patients with glioblastoma. Clin Dev Immunol, v. 2010, 2010. ISSN 1740-2530. Disponível em: < http://www.ncbi.nlm.nih.gov/pubmed/20953324 >.

WEI, J. et al. Glioma-associated cancer-initiating cells induce immunosuppression. Clin Cancer Res, v. 16, n. 2, p. 461-73, Jan 2010. ISSN 1078-0432. Disponível em: < http://www.ncbi.nlm.nih.gov/pubmed/20068105 >.

WELLER, R. O.; ENGELHARDT, B.; PHILLIPS, M. J. Lymphocyte targeting of the central nervous system: a review of afferent and efferent CNS-immune pathways. Brain Pathol, v. 6, n. 3, p. 275-88, Jul 1996. ISSN 1015-6305. Disponível em: < http://www.ncbi.nlm.nih.gov/pubmed/8864284 >. 
WEYNANTS, P. et al. Expression of mage genes by non-small-cell lung carcinomas. Int J Cancer, v. 56, n. 6, p. 826-9, Mar 1994. ISSN 0020-7136. Disponível em: < http://www.ncbi.nlm.nih.gov/pubmed/8119772 >.

ZHANG, Y. et al. A MAGE-3 peptide presented by HLA-DR1 to CD4+ T cells that were isolated from a melanoma patient vaccinated with a MAGE-3 protein. J Immunol, v. 171, n. 1, p. 219-25, Jul 2003. ISSN 0022-1767. Disponível em: < http://www.ncbi.nlm.nih.gov/pubmed/12817001 >.

ZHENG, L. M. et al. Interleukin-10 inhibits tumor metastasis through an NK cell-dependent mechanism. J Exp Med, v. 184, n. 2, p. 579-84, Aug 1996. ISSN 0022-1007. Disponível em: < http://www.ncbi.nlm.nih.gov/pubmed/8760811 >. 


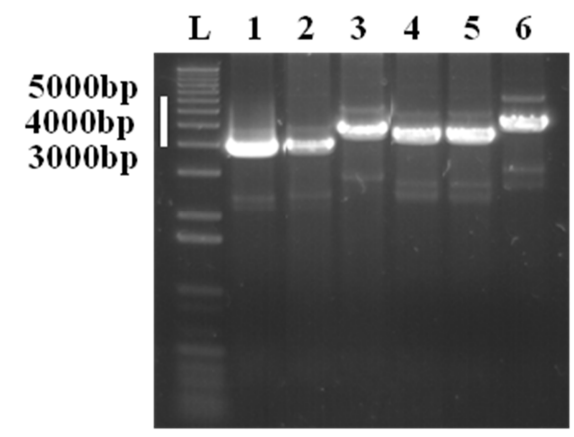

Figure 1: Digestion of DNA vaccines. Large-scale purification of DNA vaccines, pVAXEGFRvIII (1), pVAXMAGE (2), pVAXGLEA (3), pVAXEgDGFRvIII (4), pVAXgDMAGE (5) and pVAXGLEA (6) was conducted with Endofree plasmid Giga kit. DNA vaccines were quantified by spectrophotometry and digested with NheI restriction enzyme used in the cloning. L-1Kb Plus DNA Ladder (Invitrogen). 

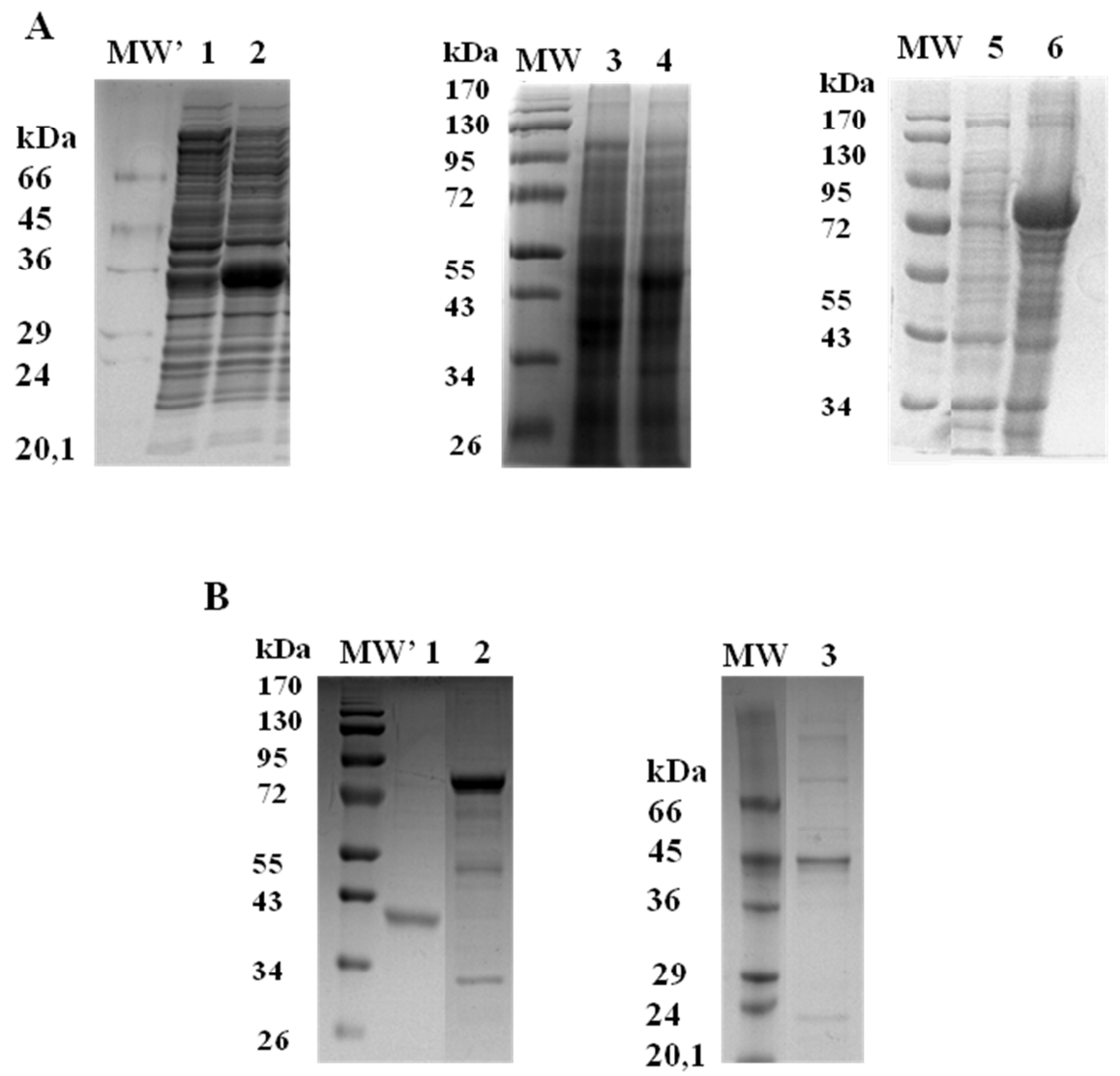

Figure 2: Expression and purification of recombinant proteins. The EGFRvIII, MAGE and GLEA recombinant proteins were produced in E. coli BL21 and Rosetta strains (A) and purified by affinity chromatography using Ni-NTA resin (B). MW-PageRuler Prestained Protein Ladder (Fermentas, Thermo Scientific) and MW'-Molecular Weight Marker (M.W. 14,000-66,000, Sigma). A) 1-bacterial extract before EGFRvIII induction by IPTG, 2bacterial extract after overnight induction by $0,5 \mathrm{mM}$ IPTG; 3-bacterial extract before MAGE induction by IPTG, 4-bacterial extract after 4 hours induction by $0,5 \mathrm{mM}$ IPTG; 5-bacterial extract before GLEA induction by IPTG, 6-bacterial extract after 4 hours induction by $0,2 \mathrm{mM}$ IPTG. B) 1-EGFRvIII recombinant protein purified from bacterial lysate under denaturing conditions (8M urea); 2-GLEA recombinant protein purified from bacterial lysate under denaturing conditions (8M urea); 3-MAGE recombinant protein purified from bacterial lysate under native conditions. 
A

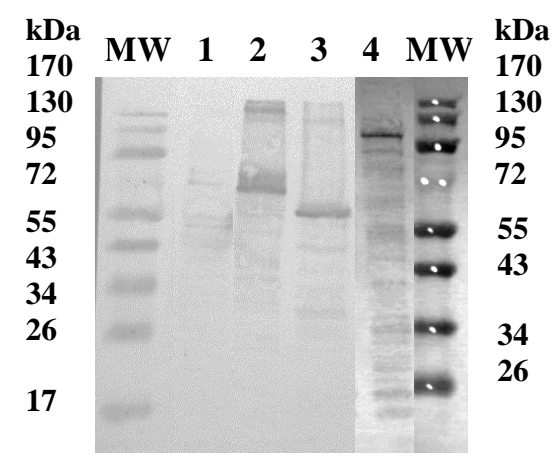

C

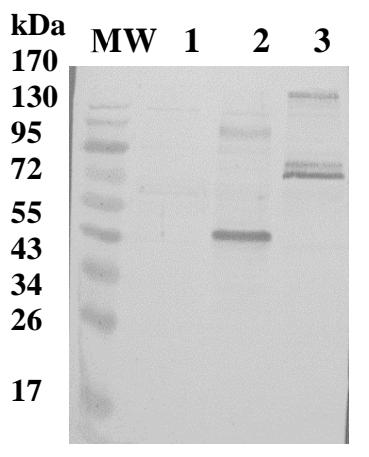

B

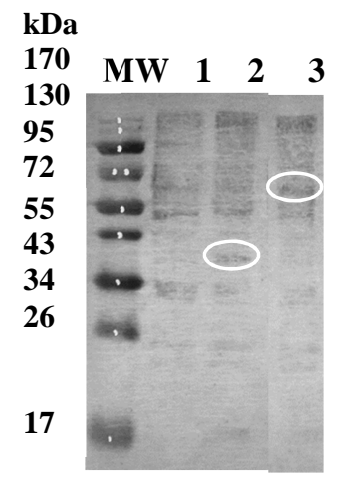

D

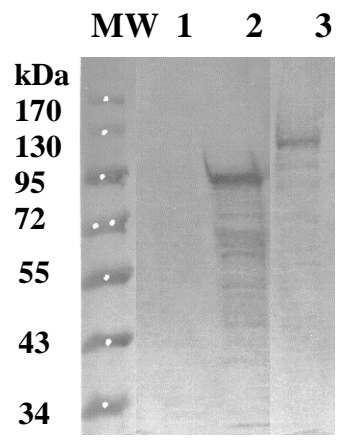

Figure 3: DNA vaccines characterization. HEK293 cells were transfected with DNA vaccines, harvested after 24 hours and evaluated by western blot using anti-gD (A) or sera containing anti-MAGE (B), anti-EGFRvIII (C) or anti-GLEA (D). Negative control was performed with empty pVAX vector. MW-PageRuler Prestained Protein Ladder. A) Western blot using anti-gD antibody, 1-cell extract of $\mathrm{pVAX}$ transfection, 2-cell extract of pVAXgDMAGE transfection, 3-cell extract of pVAXgDEGFRvIII transfection, 4- cell extract of pVAXgDGLEA transfection. B) Western blot using anti-EGFRvIII antibody, 1-cell extract of pVAX transfection, 2-cell extract of pVAXEGFRvIII transfection, 3-cell extract of pVAXgDEGFRvIII transfection. C) Western blot using anti-MAGE antibody, 1-cell extract of pVAX transfection, 2-cell extract of pVAXMAGE transfection, 3-cell extract of pVAXgDMAGE transfection. D) Western blot using anti-GLEA antibody, 1-cell extract of pVAX transfection, 2-cell extract of pVAXGLEA transfection, 3-cell extract of pVAXgDGLEA transfection. In $\mathbf{B}$, the circles showed EGFRvIII and gDEGFRvIII proteins. 

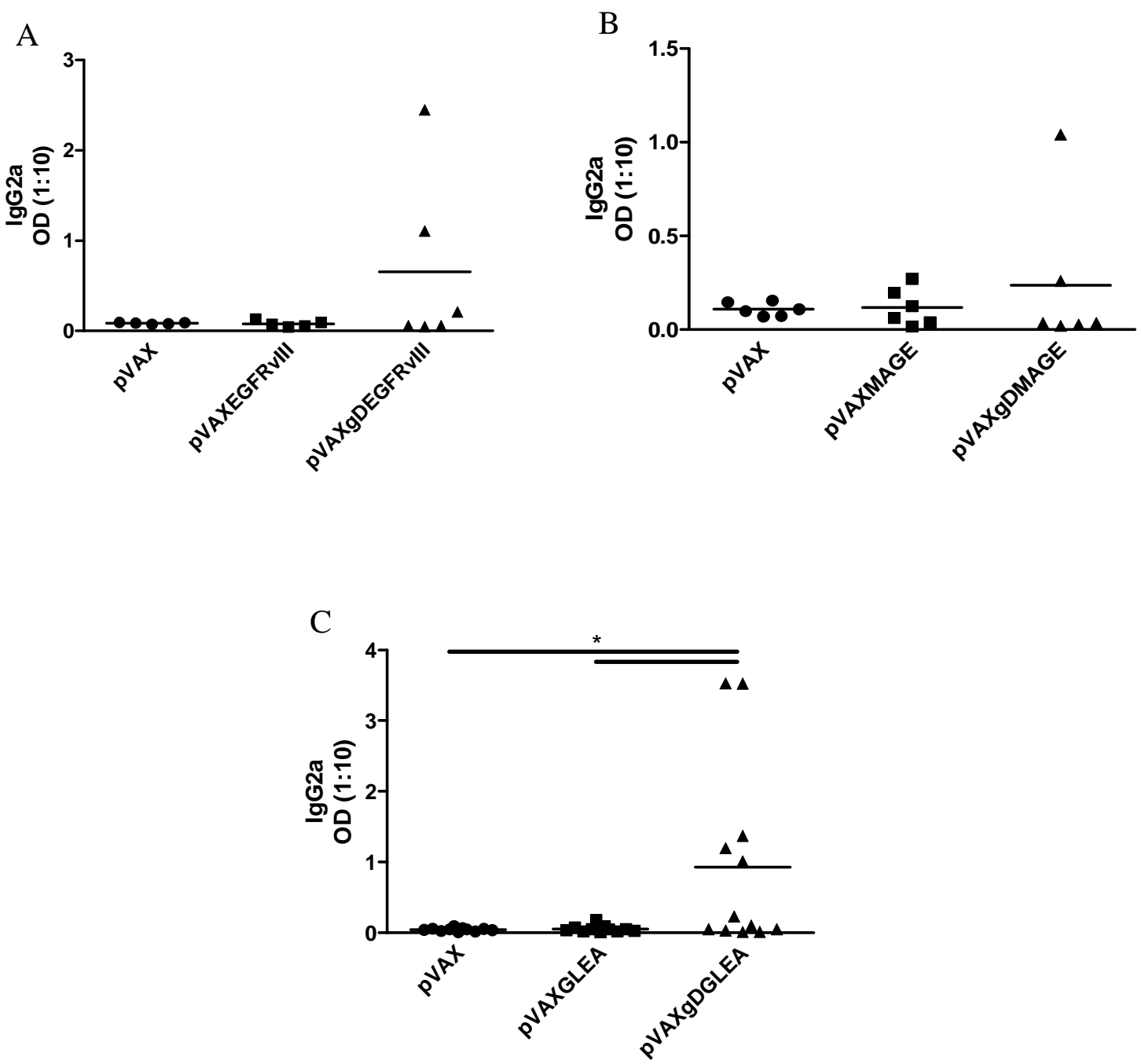

Figure 4: Humoral immune response induced by DNA vaccines. Sera from vaccinated mice with three doses of $100 \mu \mathrm{g}$ of DNA vaccines were collected 20 days after the last immunization and tested for the presence of $\mathrm{IgG} 2 \mathrm{a}$ antibodies against recombinant proteins by ELISA. A) Anti-EGFRvIII detection, data from one experiment (6 mice per group). B) AntiMAGE detection, representative data from one experiment (6 mice per group). C) AntiGLEA detection, data from two experiments (12 mice per group). ${ }^{*} p<0.05$, one-way ANOVA and Tukey post test. 

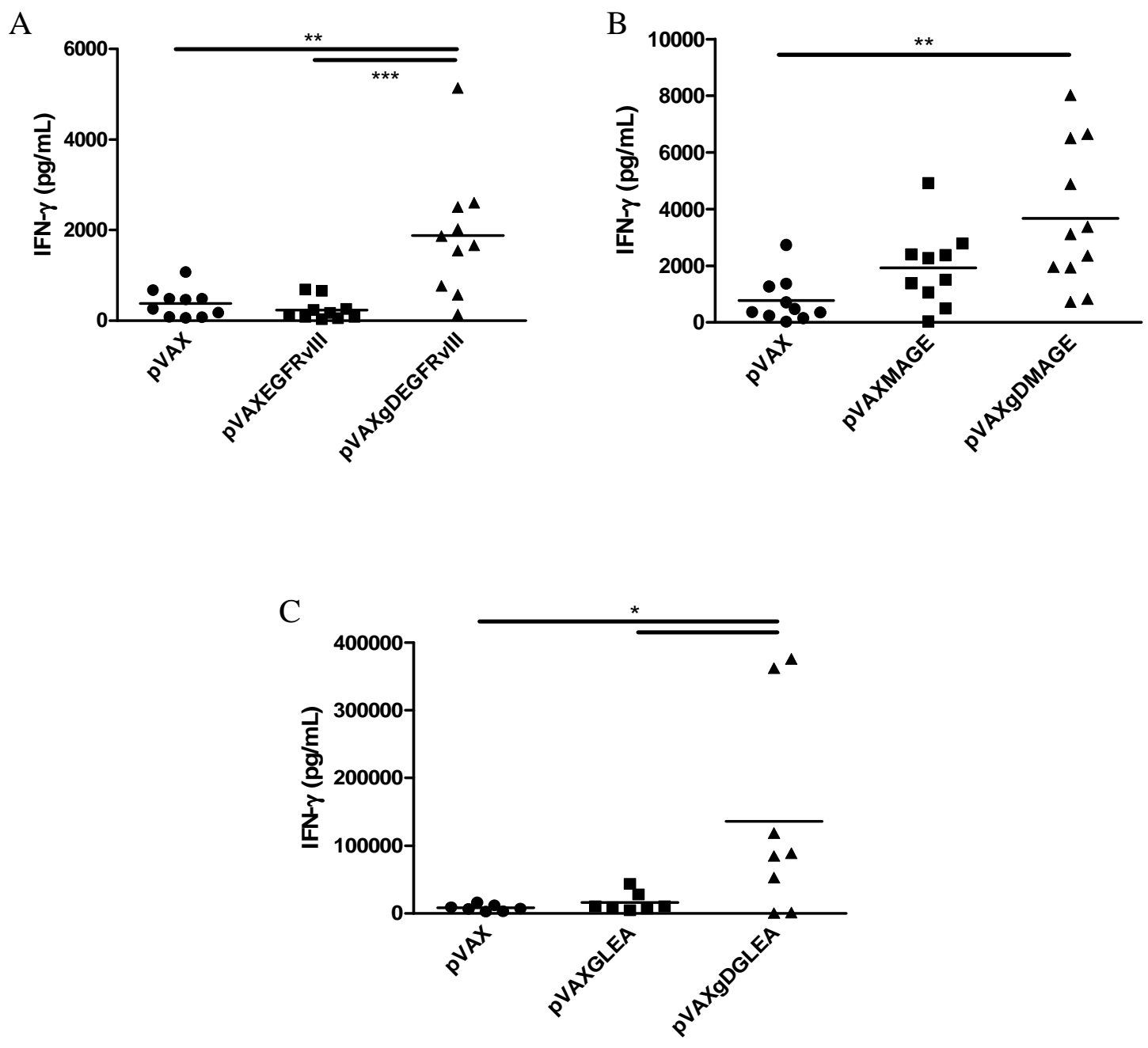

Figure 5: Assessment of cellular immune response induced by DNA vaccines through the measurement of IFN- $\gamma$ production. Mice were vaccinated with three doses of $100 \mu \mathrm{g}$ of DNA vaccines, spleen cells were collected 20 days after the last immunization and stimulated ex vivo for 48 hours. The IFN- $\gamma$ production was quantified in the culture supernatants by ELISA. A) Culture stimulated with EGFRvIII protein, data from two experiments (12 mice per group). B) Culture stimulated with MAGE protein, data from two experiments (12 mice per group). C) Culture stimulated with GLEA protein, data from one experiment (8 mice per group). The differences in the cellular responses were determined by one-way ANOVA and Tukey post test. $* \mathrm{p}<0.05, * * \mathrm{p}<0.01, * * * \mathrm{p}<0.001$. Negative control was performed without any stimulus and, if detected, cytokine production was discounted for data tabulation of other stimuli. Positive control was performed using ConA as polyclonal stimulus. 

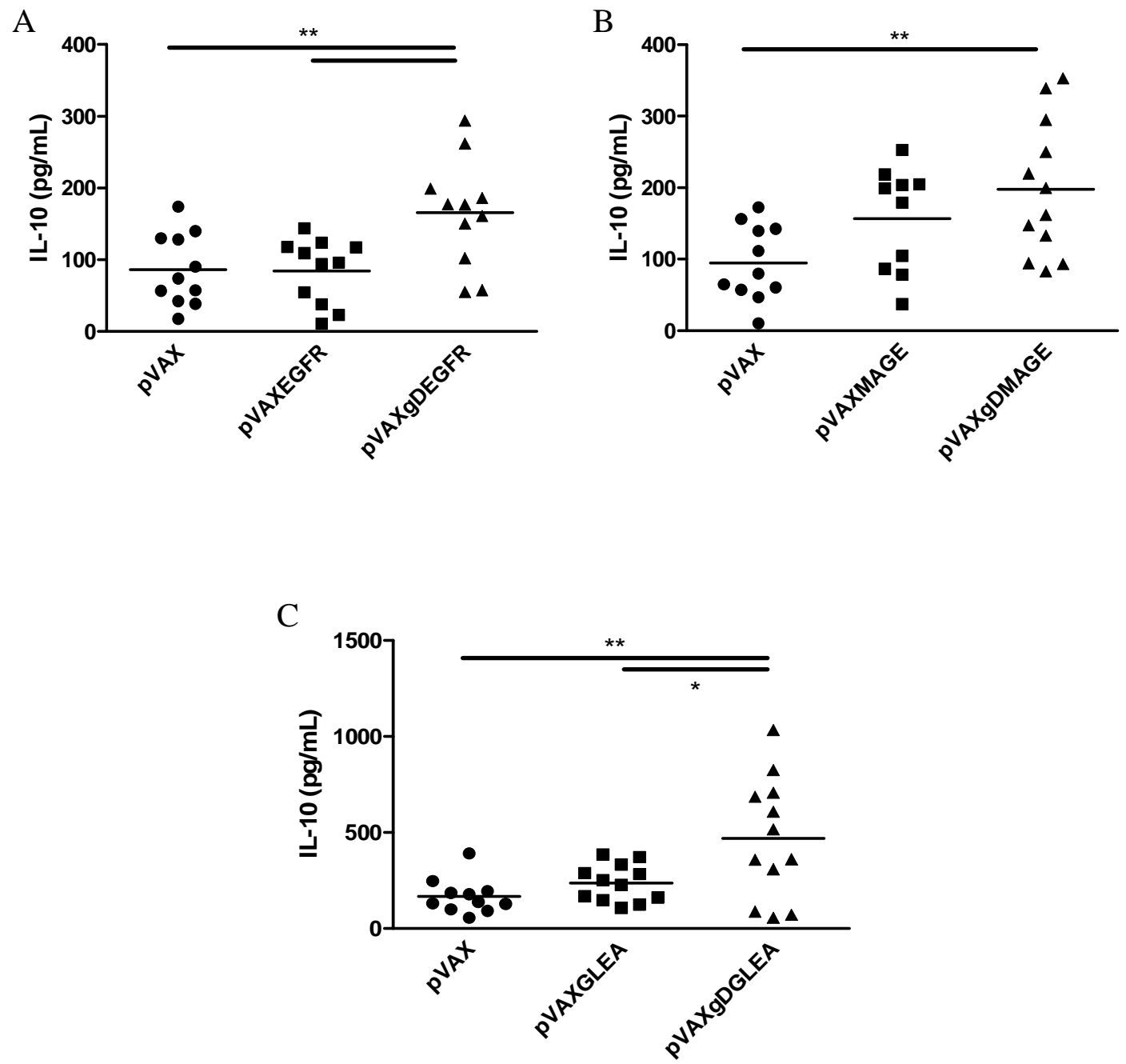

Figure 6: Assessment of cellular immune response induced by DNA vaccines through the measurement of IL-10 production. Mice were vaccinated with three doses of $100 \mu \mathrm{g}$ of DNA vaccines, spleen cells were collected 20 days after the last immunization and stimulated ex vivo for 48 hours. IL-10 production was quantified in the culture supernatants by ELISA. A) Culture stimulated with EGFRvIII protein, data from two experiments (12 mice per group). B) Culture stimulated with MAGE protein, data from two experiments (12 mice per group). C) Culture stimulated with GLEA protein, data from two experiments (12 mice per group). The differences in the cellular responses were determined by one-way ANOVA and Tukey post test. $* \mathrm{p}<0.05, * * \mathrm{p}<0.01$. Negative control was performed without any stimulus and, if detected, cytokine production was discounted for data tabulation of other stimuli. Positive control was performed using ConA as polyclonal stimulus. 